Universidade de São Paulo

Faculdade de Educação

Programa de Pós-Graduação em Educação

Tese de Doutorado

\title{
O Ensino de Cálculo: \\ Dificuldades de Natureza Epistemológica
}

\author{
Wanderley Moura Rezende
}

Tese apresentada como exigência parcial para obtenção do Título de Doutor em Educação - Área de Ensino de Ciências e Matemática, sob a orientação do Prof. Dr. Nílson José Machado

São Paulo

maio/2003 

"É apenas por faltar algum degrau aqui e ali, por descuido, em nosso caminho para o Cálculo Diferencial [e Integral], que este último não é coisa tão simples quanto um soneto de Mr. Solomon Seesaw". 



\section{Dedicatória}

A Jesus Cristo,

Luz e Sabedoria da humanidade;

Aos meus pais Jorgílio e Renée,

Exemplos de carinho e dedicação:

À minha esposa Fatima,

Companheira de todas as horas:

Aos meus filhos Mariana e Pedro,

Realizações plenas do meu projeto de vida. 



\section{Agradecimentos}

\section{Agradeço}

Em primeiro lugar, a Deus, pela vida e pela oportunidade desse momento.

Ao Professor Nilson, pelo exemplo, dedicação e amizade fraterna; suas atitudes, tanto profissionais quanto aquelas de convívio pessoal, tornaram-se modelos para o meu caminhar.

Aos membros da douta Banca de Qualificação, Professora Elza Gomide e Professor Luiz Carlos Menezes, pelas valiosas sugestões e contribuições para a realização deste trabalho.

Aos professores do Programa de Pós-Graduação em Educação da USP pela hospitalidade e pela generosidade no ensinamento de seus conhecimentos.

À amiga Marisa, pela paciente leitura crítica deste trabalho $e$, acima de tudo, pelo carinho e pela amizade fraterna.

Aos colegas do Programa de Pós-Graduação em Educação da USP, em especial ao grupo do Seminário de Epistemologia e Didática, pelas valiosas trocas de idéias e pelo convívio fraternal.

Aos meus familiares e amigos, pelo carinho e pelo aconchego emocional. Aos colegas da UFF, pelo incentivo e apoio à realização deste trabalho.

À Pró-Reitoria de Pesquisa da UFF, pela atenção, presteza e eficiência de seus funcionários.

À CAPES, pelo apoio financeiro a este trabalho. 



\section{Resumo}

São notórias e bem evidentes as dificuldades de aprendizagem no ensino de Cálculo. Algumas tentativas de resolver, ou pelo menos, amenizar, este problema têm sido realizadas tanto no campo pedagógico quanto no âmbito da pesquisa. Muitas dessas ações, inseridas no próprio contexto do ensino superior de Cálculo, partem do pressuposto que essas dificuldades de aprendizagem são de natureza psicológica, internas ao sujeito aprendiz. No entanto, contrariando esta tendência, esta pesquisa pretende mostrar que parte significativa dos problemas de aprendizagem "do atual" ensino de Cálculo é de natureza essencialmente epistemológica, está além dos métodos e das técnicas de ensino, sendo inclusive anterior ao seu próprio tempo de realização.

Diante disto, foram imaginadas duas ações inter-relacionadas, dois mapeamentos que visam ao levantamento e entendimento dessas dificuldades de natureza epistemológica no ensino de Cálculo: um mapeamento conceitual do Cálculo e de suas idéias e procedimentos básicos; em seguida, munido desses elementos, realizou-se efetivamente o mapeamento das dificuldades supracitadas.

Assim, a partir do entrelaçamento dos fatos históricos e pedagógicos, e tendo como pano de fundo as dualidades essenciais e os mapas conceituais do Cálculo, foram explicitados e consubstanciados cinco macro-espaços de dificuldades de aprendizagem de natureza epistemológica, cinco eixos que estruturam o ensino de Cálculo, a saber: o eixo discreto/contínuo: o eixo variabilidade/permanência: 
- eixo finito/infinito: o eixo local/global: e 0 eixo sistematização/construção.

Nesse esforço filosófico, foram estabelecidas relações entre os macro-espaços determinados com os mapas históricos e conceituais do Cálculo, e destes com o ensino de matemática em todos os níveis. Então, pôde-se perceber, em essência, um único lugar-matriz das dificuldades de aprendizagem de natureza epistemológica do ensino de Cálculo: o da omissão/evitação das idéias básicas e dos problemas construtores do Cálculo no ensino de Matemática em sentido amplo. Isto posto, para romper com 0 isolamento semântico, a subestimação da relevância das idéias $e$ dos instrumentos característicos do Cálculo, propõem-se algumas intervenções didáticas relativas ao ensino básico de Matemática e ao ensino do próprio Cálculo. O que se pretende com isso é possibilitar ao Cálculo exercer no campo pedagógico a mesma função integradora que ele realizou no âmbito científico, no processo de construção do conhecimento matemático.

Palavras-chave: Cálculo; Epistemologia; Ensino; Mapas de relevância; Dificuldades de aprendizagem; História do Cálculo. 


\section{Resumen}

Son perceptibles y bastante evidentes las dificultades de aprendizaje en la enseñanza de Cálculo. Algunos intentos de resolver o por lo menos amenizar este problema son realizados tanto en el campo pedagógico como en el ámbito de la investigación. Muchas de esas acciones, inseridas en el propio contexto de la enseñanza superior de Cálculo, parten de la premisa de que tales dificultades tienen naturaleza psicológica, internas al sujeto aprendiz. Sin embargo, contrariando esta tendencia, esta investigación pretende enseñar que gran parte de los problemas de aprendizaje "de la actual" enseñanza de Cálculo es de naturaleza esencialmente epistemológica, se encuentra más adelante de los métodos y de las técnicas de enseñanza, siendo incluso anterior a su propio tiempo de realización.

Delante de esto, se imaginaron dos acciones interrelacionadas, dos mapeamentos que buscan la identificación y el entendimiento de esas dificultades de naturaleza epistemológica en la enseñanza de Cálculo: un mapeamento conceptual del Cálculo y de sus ideas y procedimientos básicos; en seguida, teniendo como instrumentos esos elementos, se realizó efectivamente el mapeamento de dichas dificultades.

Así, a partir del enlace entre hechos históricos y pedagógicos, y teniendo como base las dualidades esenciales y los mapas conceptuales del Cálculo, se explicitaron y se fundieron cinco macro espacios de dificultades de aprendizaje de naturaleza epistemológica, cinco ejes que estructuran la enseñanza de Cálculo, a saber: el eje 
discreto/continuo; el eje variabilidad/permanencia; el eje finito/infinito; el eje local/global; $y$ el eje sistematización/ construcción.

En ese esfuerzo filosófico se establecieron relaciones entre los macro espacios determinados con los mapas históricos y conceptuales del Cálculo y de estos con la enseñanza de matemáticas en todos los niveles. Entonces, se pudo percibir, en esencia, la existencia de uno sólo lugar de origen para las dificultades de naturaleza epistemológica de la enseñanza de Cálculo: el de la omisión/evitación de las ideas básicas y de los problemas constructores del Cálculo en la enseñanza de Matemáticas en su amplio sentido.

De esta manera, para romper con el aislamiento semántico, la subestimación de la relevancia de las ideas y de los instrumentos característicos del Cálculo, se proponen algunas intervenciones didácticas relativas a la enseñanza básica de Matemáticas y en la propia enseñanza de Cálculo. Lo que se pretende con esto es posibilitar al Cálculo ejercer en el campo pedagógico la misma función de integración que él ha realizado en el ámbito científico, en el proceso de construcción del conocimiento matemático.

Palabras-llave: Cálculo; Epistemología; Enseñanza; Mapas de relevancia; Dificultades de aprendizaje; Historia del Cálculo. 


\section{Abstract}

The difficulties in learning Calculus are noticeable and quite evident. Some attempts to solve, or at least, soften, this problem have been made both in the pedagogical field and in the scope of the research. Many of these actions, within the context of a higher teaching of Calculus itself, assume that such difficulties in learning are of a psychological nature, internal to the learner. However, contrary to this tendency, this research intends to show that a significant part of the problems of learning the "current" teaching of Calculus is of a nature essentially epistemological, it is beyond the methods and the techniques of teaching, being also prior to its own time of realization.

With that in mind, there were imagined two actions interrelated, two mappings which aim the rising and understanding of these difficulties of an epistemological nature in the teaching of Calculus: a conceptual mapping of Calculus and of its ideas and basic procedures; next, having these instruments, the mapping of the previously mentioned difficulties was effectively done.

Thus, from the interlacement of the historical and pedagogical facts, and having as background the essential dualities and the conceptual maps of Calculus, there were clarified and consubstantiated five macro spaces of the difficulties in learning of an epistemological nature, five axes which structure the teaching of Calculus, namely: the axis discreet/continuous: the axis 
variability/permanence; the axis finite/infinite; the axis local/global; and the axis systematization/construction.

In this philosophical endeavour there were established relations between the macro spaces determined by the historical and conceptual maps of Calculus, and from these with the teaching of mathematics in all levels. Therefore, one can notice, essentially, a single point of origin in the difficulties in the learning of an epistemological nature in the teaching of Calculus: the omission/avoidance of the basic ideas and the construction problems of Calculus in the teaching of mathematics in an ample sense.

So, to break up with the semantic isolation, the underestimation of the relevance of the ideas and of the instruments characteristics of Calculus, some didactic interventions are proposed in the field of the basic teaching of Mathematics and in the teaching of Calculus itself. What is expected from this is to allow Calculus to have in the pedagogical field the same function of integration that it had in the scientific field, in the process of building the mathematical knowledge.

Key-words: Calculus; Epistemology; Teaching: Maps of relevance; Difficulties in learning; History of Calculus. 


\section{Indice}

1. O Problema ...................................................... 01

2. Ensino de Cálculo: Crise ou Catástrofe?..... 06

2.1. A normalidade do ensino de Cálculo........................ 08

2.2. As soluções "normais" para o ensino de Cálculo.... 15

2.2.1. No contexto pedagógico.................................. 15

2.2.2. No âmbito da pesquisa.................................... 19

2.3. Sobre a "cegueira" dos outros................................. $\quad 30$

3. O encaminhamento desta Pesquisa................ 36

3.1. Premissas e princípios norteadores da pesquisa 36

3.1.1. O ensino de Cálculo é imprescindível........... 36

3.1.2. A toda prática didática subjaz uma concepção epistemológica ..................................... 38

3.1.3. É preciso transcender o espaço-tempo local do ensino de Cálculo 
3.2. Objetivos

3.3. A metodologia

49

3.3.1. Da dicotomia qualitativo-quantitativo à idéia de mapa.

3.3.2. O mapa como instrumento metodológico .....

53

3.3.3. A construção dos mapas históricos e conceituais do Cálculo e das dificuldades de aprendizagem de natureza epistemológica do seu ensino

59

4. Uma cartografia simbólica do Cálculo.......... 66

4.1. O que é o Cálculo? Uma visão preliminar

68

4.2. A escala histórica: a evolução dos conceitos básicos do Cálculo.

4.2.1. O prelúdio (do séc. VI a.C. ao séc. III a.C.) 85

4.2.2. A transição para a Europa medieval

114

4.2.3. Prenúncio do Cálculo. 136

4.2.4. A invenção do Cálculo. 187

4.2.5. O período de indecisão 218

4.2.5.1. A revisão crítica dos métodos infinitesimais. 
4.2.5.2. A passagem do Cálculo para a Análise.

4.2.6. O desenvolvimento da Análise (Real): a solução standard da fundamentação do Cálculo Diferencial e Integral

4.2.7. O desenvolvimento da Análise Não-

Standard de Robinson: a solução não-standard do Cálculo Infinitesimal.

4.3. A escala filosófica: os mapas conceituais do Cálculo

5. Uma cartografia simbólica do ensino de

Cálculo 305

5.1. Algumas visões preliminares sobre o ensino de Cálculo 305

5.2. Um mapeamento das dificuldades de natureza epistemológica do ensino de Cálculo

5.2.1. O macro-espaço da dualidade discreto/contínuo

5.2.2. O macro-espaço da dualidade variabilidade/permanência.

5.2.3. O macro-espaço da dualidade finito/infinito. 
5.2.4. O macro-espaço da dualidade oposição local/global.

5.2.5. O macro-espaço da dualidade sistematização/construção.

5.3. Mapa espectral das dificuldades de natureza epistemológica do ensino de Cálculo.

6. Considerações finais. 401

Bibliografia. 443

Anexos 


\section{O ENSINO DE CÁLCULO: \\ DIFICULDADES DE NATUREZA EPISTEMOLÓGICA}

\section{O Problema}

Muito se fala, muito se tem dito no meio acadêmico, a respeito do "fracasso no ensino de Cálculo". Creio, no entanto, que, se investigarmos a origem histórica de tal "fracasso", verificaremos que este tem início desde o momento em que se começa a ensinar Cálculo. É bem verdade que, com a "massificação" ${ }^{1}$ do ensino superior, os dados estatísticos têm dado mais evidência à tão propalada crise no ensino de Cálculo. Barufi (1999), em sua tese de doutorado, nos revela alguns dados alarmantes dessa crise: o índice de não-aprovação em cursos de Cálculo Diferencial e Integral oferecidos, por exemplo, aos alunos da Escola Politécnica da USP, no período de 1990 a 1995, varia de 20\% a $75 \%$, enquanto que no universo dos alunos do Instituto de Matemática e Estatística o menor índice não é inferior a 45\% - isto é, não se aprova mais do que 55\% em uma turma de Cálculo.

No que diz respeito à UFF, instituição onde leciono, os índices de não-aprovação são bem mais catastróficos do que os levantados por Barufi, na USP. O gráfico a seguir descreve essa realidade a partir de

\footnotetext{
${ }^{1}$ Talvez o termo usado aqui não seja muito apropriado uma vez que, apesar de se aumentar o número de vagas no ensino superior, os vestibulares universitários continuam cumprindo o seu papel "elitista".
} 
um levantamento efetuado com base em dados disponíveis ${ }^{2}$ relativos ao período de 1996 a 2000.

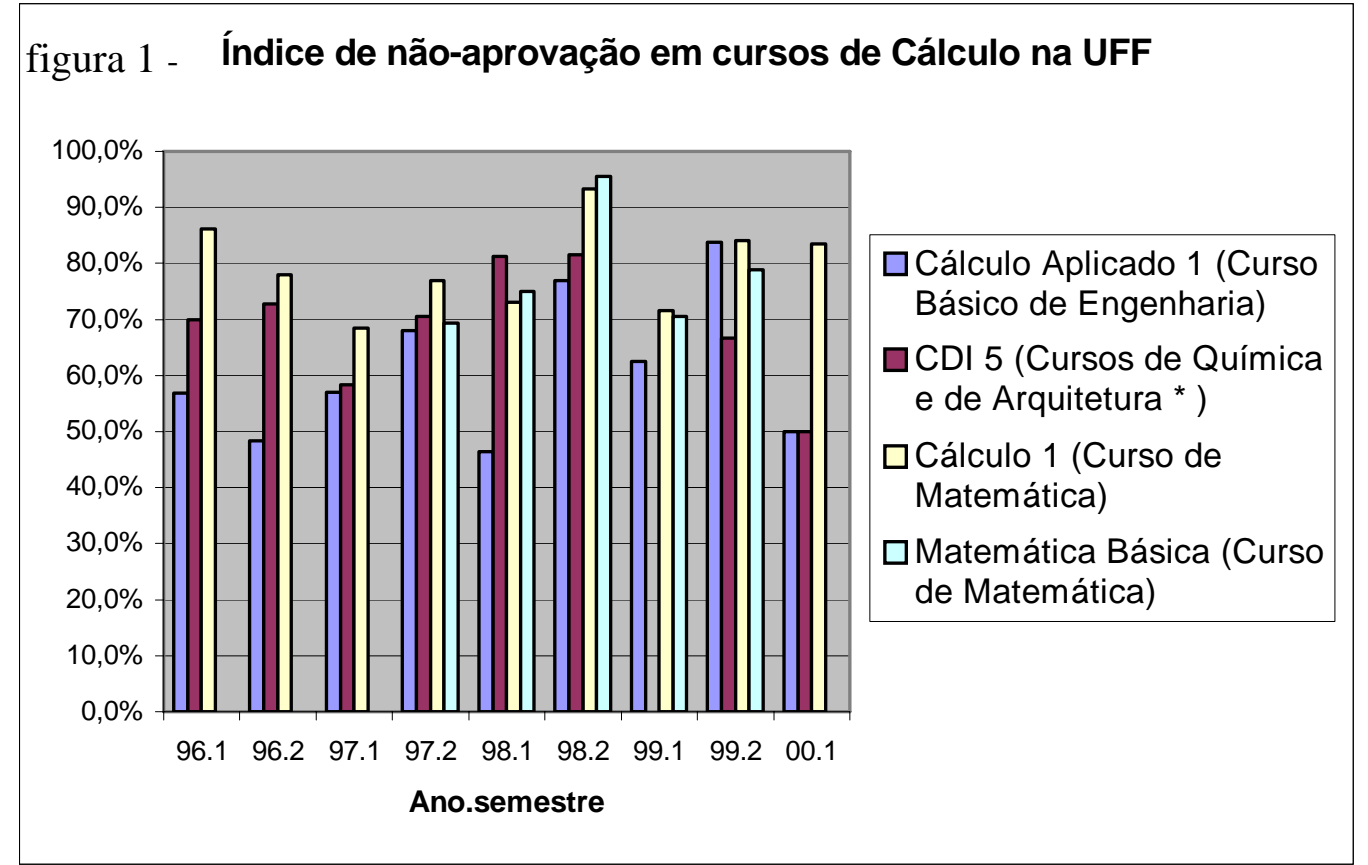

$\mathrm{Na}$ UFF, a variação do índice de não-aprovação se encontra na faixa de $45 \%$ a $95 \%$, sendo que, para o Curso de Matemática, este não é inferior a $65 \%$. Ainda no que tange aos dados do gráfico, gostaria de esclarecer dois pontos que permanecem tácitos sob a cortina dos índices apresentados: primeiro, que a partir de 1998 a disciplina de Cálculo Diferencial e Integral 5 não faz mais parte da grade curricular do cur-

\footnotetext{
${ }^{2}$ Não dispomos de alguns dados referentes à Matemática Básica, no $1^{0}$ semestre de 2000, e Cálculo Diferencial e Integral 5, no $1^{\underline{0}}$ semestre de 1999 - tal fato justifica-se pelo não recebimento, na secretaria do departamento, dos relatórios dos docentes e coordenadores responsáveis por estas disciplinas nos períodos destacados. Cabe ressaltar entretanto que a ausência da coluna de Matemática Básica nos períodos anteriores a 97.2 justifica-se pelo fato deste semestre ter sido o primeiro em que tal disciplina começou a ser lecionada para os alunos do curso de Matemática / Niterói da UFF, como disciplina obrigatória e efetiva da grade curricular. O objetivo de se introduzir esta disciplina na grade curricular do curso básico de Matemática / Niterói da UFF era de reforçar e dar um "embasamento" à cadeira de Cálculo. Pelo gráfico, pode-se perceber que tal meta não se cumpriu e mais, que a disciplina de Matemática Básica tornou-se um outro "tormento" para o estudante de matemática.
} 
So de Arquitetura; e, por último, que a disciplina de Matemática Básica, introduzida na grade curricular do curso de Matemática / Niterói da UFF a partir do segundo semestre de 1997, tem por objetivo auxiliar e dar um "embasamento" à disciplina de Cálculo 1. O relato desses dois fatos serve para dar a dimensão exata da gravidade do problema do ensino de Cálculo. Excluir o Cálculo de sua grade curricular ou criar disciplinas subsidiárias para o seu ensino representam, sem dúvida, indícios de que o tal problema já atinge limites próximo do insuportável.

Tal situação de desconforto com relação ao ensino de Cálculo não é local e nem característica exclusiva da UFF; é geral e tem provocado por parte de outras instituições atitudes inusitadas. Na USP, por exemplo, como nos relata Barufi (1999), as disciplinas de Cálculo Diferencial e Integral oferecidas para os cursos de Matemática e Arquitetura passam a ser anuais a partir de 1993, contrapondo-se ao padrão da periodicidade semestral das demais disciplinas. Levando-se em conta a tradição de excelência, pelo menos em termos nacionais, das Instituições aqui reportadas, há de se preocupar, e muito, com o "fracasso do ensino de Cálculo".

Engana-se quem pensa que tal problema é cultural e que se justifica pela condição sócio-econômica da sociedade brasileira. A situação do ensino de Cálculo nos países "desenvolvidos" não é muito diferente, visto que trabalhos sobre esse tema têm sido publicados e recebido merecido destaque por parte da literatura especializada internacional. David Tall ${ }^{3}$, por exemplo, tem sido um dos principais articuladores da área de pesquisa "pensamento matemático avançado", cujas questões

\footnotetext{
${ }^{3}$ Professor da Universidade de Londres e pesquisador em Educação Matemática, com vários artigos e livros publicados sobre o tema citado.
} 
giram em torno das dificuldades encontradas nas aprendizagens dos conceitos básicos do Cálculo, tendo a psicologia cognitiva como pano de fundo para as suas análises epistemológicas.

Outro exemplo internacional desta inquietação foi o movimento em prol da reforma do ensino de Cálculo, iniciado na década de 80 , e que ficou conhecido por "Calculus Reform" (ou Cálculo Reformado). Tal movimento teve como elemento deflagrador um polêmico documento do famoso matemático Peter Lax, que atacava os cursos de Cálculo da época.

Segundo seus precursores, o "Calculus Reform" tem como características básicas: o uso de tecnologia, isto é, software computacional e calculadoras gráficas, tanto para o aprendizado de conceitos e teoremas como para a resolução de problemas; o ensino via a "Regra dos Três", isto é, todos os tópicos e todos os problemas devem ser abordados numérica, geométrica e analiticamente; grande preocupação, ou pretensão, em mostrar a aplicabilidade do Cálculo através de exemplos reais e com dados referenciados; tendência a exigir pouca competência algébrica por parte dos alunos, suprindo essa falta com o treinamento no uso de Sistemas de Computação Algébrica ${ }^{4}$.

Um reflexo deste movimento nas universidades brasileiras já começa a ser percebido através do crescente número de trabalhos com esse perfil e apresentados recentemente nos Encontros Nacionais de Educação Matemática.

Diante da problemática aqui apresentada emergem algumas questões interessantes: Seria realmente o curso de Cálculo imprescin-

\footnotetext{
4 Mais informações sobre este movimento pode ser obtido na homepage pessoal www.mat.ufrqs.br/ portosil/calculo.html do professor J. P. Silveira.
} 
dível para alguns destes cursos de ensino superior? E qual é a razão de tantas reprovações? Onde reside a dificuldade? No processo de aprendizagem? No aluno, isto é, na "falta de base" do aluno? Ou estaria esta dificuldade no próprio professor, ou na metodologia de ensino, ou ainda, na estrutura curricular do ensino de matemática que não dá o suporte que esta disciplina mereceria? Antes, porém, de esboçarmos qualquer tentativa de respostas para estas perguntas, discorreremos, nos parágrafos seguintes, e com mais detalhes, sobre a tal "crise" no ensino de Cálculo, sua "normalidade" e algumas "soluções normais" apresentadas para a mesma no campo pedagógico e no âmbito da pesquisa. 


\section{Ensino de Cálculo: Crise ou Catástrofe?}

A palavra "crise", derivada das palavras latina "crisis" e grega "krísis", significa etimologicamente "alteração e desequilíbrio repentino", "estado de dúvida e incerteza", "tensão" e "conflito". Já a palavra "catástrofe", do francês "catastrophe", deriva do latim "catastrophe" e este do grego "katastrophe", que quer dizer "acontecimento lastimoso ou funesto", "grande desgraça".

Assim, a partir do significado etimológico das palavras, poderíamos dizer inicialmente que o ensino de Cálculo está em crise e prestes a se tornar catástrofe (se já não se tornou em algumas instituições). Mas vamos com calma: nem toda crise deflagra ou resulta em uma catástrofe - já nos dizia, prudentemente, o físico e epistemólogo Thomas Kuhn (1989). Apesar da crise, é possível vislumbrar, no ensino de Cálculo em particular, algum senso de "normalidade" nas suas realizações. Além disso, René Thom (1985), ao desenvolver a sua "teoria das catástrofes", procura dar um outro sentido, mais "positivo", ao próprio termo "catástrofe". Não podemos ignorar esses fatos em nossos julgamentos.

Ao dar a sua interpretação da "estrutura" das revoluções científicas, T. Kuhn (1989) define o seu conceito de "crise" científica no próprio sentido etimológico do termo. Todas as crises (científicas), segundo o autor, se iniciam com o obscurecimento de um paradigma e o conseqüente relaxamento das regras que orientam a pesquisa normal. Acrescenta ainda que as crises podem terminar de três maneiras (e não apenas uma, como uma mente imprudente poderia pensar): algumas 
vezes a ciência normal acaba revelando-se capaz de tratar o problema que provoca crise; em outras ocasiões o problema resiste até mesmo a novas abordagens aparentemente radicais - nesse caso, os cientistas podem concluir que nenhuma solução para o problema poderá surgir no estado atual da área de estudo; ou, finalmente, a crise pode terminar com a emergência de um novo candidato a paradigma e com uma subseqüente batalha por sua aceitação.

Já R. Thom (1985), em um contexto bem diferente do de T. Kuhn, amplia e procura dar um significado mais positivo à idéia de "catástrofe". O autor da "Teoria das Catástrofes" diferencia, então, o seu conceito de "catástrofe" do conceito de "crise" de T. Kuhn. Para Thom uma "catástrofe" (no seu sentido mais amplo) é um "fenômeno bem visivel", uma "descontinuidade observável", enquanto que a "crise", pelo contrário, pode estar latente, imperceptível. Acrescenta ainda que a "crise", em geral, manifesta-se apenas através de uma perturbação quantitativa (e não qualitativa) de um processo de regulação. Assim, a crise anuncia freqüentemente a catástrofe, que é precedida pela crise e às vezes até por ela provocada.

No entanto, para nos posicionarmos a respeito do ensino de Cálculo, não há necessidade de um aprofundamento das divergências teóricas dos dois autores supracitados. Pode-se dizer simplesmente que 0 "ensino de Cálculo" está em crise, em estado latente, dissimulado por algumas ações paliativas, apesar da evidência catastrófica ("catástro$f e^{\prime \prime}$ aqui, no sentido comum do termo) dos seus resultados finais. O que se precisa fazer então é torná-lo "catástrofe", no sentido positivo de Thom, para que se possa dar, de fato, um salto qualitativo para a solu- 
ção desse problema. Só que para isso aconteça, será preciso romper com algumas barreiras "normais" do ensino de Cálculo.

\subsection{A normalidade do ensino de Cálculo}

Ao analisar os textos didáticos usualmente empregados num curso inicial de Cálculo, Barufi (1999) detectou a predominância da seqüência de "Cauchy-Weierstrass" na organização didática dos seus conteúdos programáticos. Esta seqüência, consagrada no século XIX como a grande resposta às questões de Berkeley, consiste, basicamente, em fundamentar os conceitos básicos do Cálculo Diferencial e Integral nas noções de limite e número real. Assim, primeiro define-se formalmente o conceito de limite ${ }^{5}$, em seguida define-se continuidade, derivada e integral de uma função, nessa ordem, e a partir da noção de limite. "Limite-Continuidade-Derivada-Integral", a seqüência de Cauchy-Weierstrass, é, com muito mais propriedade, a seqüência didática da maioria dos textos de Análise. Tal fato será posteriormente nosso objeto de discussão, por ora, cabe registrar apenas que esta sequiência didática é também a que prevalece na realização dos cursos de Cálculos de nossas universidades.

Outra característica dessa normalidade do ensino de Cálculo é a predominância do "pseudo-rigor" na apresentação dos conteúdos do Cálculo. Certos resultados são assumidos a partir de suas evidências

\footnotetext{
${ }^{5}$ Surge aqui a principal contribuição de Weierstrass, já que a definição de limite de Cauchy ainda era impregnada de idéias metafísicas.
} 
empíricas/intuitivas - como, por exemplo, o teorema do valor intermediário ${ }^{6}$ ou que "toda função real contínua é integrável em um intervalo fechado da reta real" -, e outros são demonstrados com certo rigor. É notório que nem todos os resultados do Cálculo podem ou devem ser demonstrados em um curso inicial de Cálculo - os citados acima são exemplos desta situação. Mas a questão que se coloca aqui não é tão somente o que pode e deve ser demonstrado, mas, também, qual o nível de rigor aceitável nesse contexto. Newton e Leibniz também foram rigorosos quando desenvolveram o Cálculo - menos rigorosos do que Cauchy e Weierstrass, é verdade, mas foram rigorosos e produziram matemática de primeira linha. Por outro lado, o próprio Cauchy admitia em seu Cálculo idéias intuitivas de limite e de continuidade, e não possuía uma fundamentação dos números reais independente da noção de limite e muito menos uma teoria de medida que permitisse colocar 0 seu conceito de integração em bases mais "sólidas". Tal fato só ocorrerá mais adiante na escola alemã. Essa fundamentação gradativa das idéias básicas do Cálculo em bases cada vez mais "sólidas" dá origem, historicamente, ao que chamamos hoje a Análise. Assim, discussões dessa natureza desembocam, inevitavelmente, em terrenos comuns do Cálculo e da Análise. Surge então uma questão natural que emerge desse emaranhado de questionamentos: Qual seria o divisor de águas do Cálculo para a Análise? O que é próprio do Cálculo? E o que é próprio da Análise? Voltaremos a essa discussão num momento posterior deste trabalho. Vejamos agora o caso específico da operação de limite, que é, sem dúvida, um conceito desse território comum.

\footnotetext{
${ }^{6}$ Teorema do valor intermediário: Seja f contínua em [a,b] e $m$ um valor real entre f(a) e f(b). Então existe c em (a,b) tal que $f(c)=m$. Em outras palavras: uma função contínua em um interva-
} 
Por se tratar de uma idéia fundamental, onde todas as demais noções do Cálculo se encontram alicerçadas, é inevitável que surjam questões a respeito do nível de compreensão que se deseja desta operação. O autor desta pesquisa, por exemplo, em sua dissertação de mestrado - em (Rezende, 1994) -, observou que ainda que se dê ênfase à definição formal de limite num curso inicial de Cálculo, a idéia que permanece, reforçada inclusive pelo próprio professor, é a desta noção enquanto um "processo de aproximação", isto é, "uma grandeza é o limite de outra quando esta se aproxima da primeira tanto quanto se queira" - esta é, aliás, a idéia da definição intuitiva de limite de Cauchy. Assim, como se pode perceber, a apresentação de limite em suas bases formais é uma clara evidência do uso do "pseudo-rigor" no curso de Cálculo.

Ainda no que toca ao uso de demonstrações em um curso de Cálculo, outra questão, mais profunda e anterior às que foram colocadas acima, diz respeito à "real necessidade" destas para a compreensão $e$ desenvolvimento dos resultados básicos do Cálculo. O que se está pondo em discussão aqui não é a relevância da demonstração para a construção do conhecimento matemático, mas sim, o seu uso exclusivo para se atingir a compreensão ou essência de um resultado matemático.

Hegel (1992), por exemplo, em sua crítica à matemática, reconhece o valor da demonstração na construção do conhecimento matemático:

"Quanto às verdades matemáticas, não se pode considerar geômetra quem saiba de cor, exteriormente, os teoremas de Euclides, sem saber as demonstrações, sem conhecê-los interiormente. Também será considerado insatisfatório o

lo fechado [a,b] assume todos os valores intermediários entre f(a) e f(b). 
conhecimento da relação de Pitágoras se esta for adquirida a partir da medida de muitos triângulos"

Por outro lado, Hegel nos alerta para o fato de que:

"(...) a essencialidade da demonstração ainda não tem, no conhecimento matemático, a significação e a natureza que fariam dela um momento do próprio resultado, mas, em tal resultado, esse momento foi ultrapassado e desapareceu ..."

Hegel acrescenta ainda que "o movimento da demonstração matemática não pertence ao conteúdo do objeto, mas é uma operação exterior à coisa". Bachelard (1991) ratifica esta posição. Segundo ele "a matemática não é serena e cristalina e nem feita de construtividade dedutiva de índole cartesiana-euclidiana". De fato, o resultado matemático transcende o momento exato da demonstração. A demonstração é apenas uma justificação lógica da validade do resultado, e muitas vezes não carrega em si a idéia que permitiu intuí-lo. Esta dicotomia entre o significado lógico de um resultado matemático e o seu sentido, apesar de não ser uma questão específica do ensino de Cálculo, é de suma importância para o esclarecimento de outra característica "normal" do mesmo: a prevalência do significado lógico sobre o sentido dos resultados do Cálculo.

Segundo Baldino (1998), o "matemático-professor" 7 insiste em priorizar o significado lógico dos resultados em relação aos seus sentidos. É nesse contexto que devemos interpretar a afirmação do professor Baldino de que "o critério de verdade da matemática é sintático, e não semântico". O matemático-professor satisfaz seu ego matemático ao reproduzir as demonstrações dos resultados no quadro de

\footnotetext{
${ }^{7}$ Expressão usada pelo prof. Baldino para fazer referência aos professores de matemática do curso superior que não largam o "ranço matemático".
} 
giz. Acredita de forma alienada que, com a realização da demonstração, o significado do resultado estará garantido. Faz isso tentando convencer o aluno da verdade de seu enunciado, não percebendo que muitas vezes tal procedimento é tão desnecessário quanto inútil. Baldino (1998) nos relata em seu texto uma experiência, verídica ou não (isto realmente não importa), que fortalece sua argumentação.

Um professor, ao terminar a demonstração de que "se uma função $f$ possui derivada nula em todos os pontos de um intervalo aberto I então é constante em I", vê-se interpelado por um aluno que lhe faz a seguinte pergunta:

A _ "Professor, o que o senhor tá querendo mostrar é que um objeto que tem velocidade nula, não se move, e portanto, sua posição permanece constante?"

O professor depois de meditar algum tempo, responde, meio desorientado:

P_ "Sim... é isso mesmo."

Então, o aluno dá o golpe final:

A _ "E precisa?"

E precisa? Realmente não precisa. Este exemplo caracteriza bem o que se quer dizer com o "sentido" ou "essência" de um resultado matemático. No exemplo destacado, o aluno assimila o sentido do resultado proposto, ignorando e desprezando a demonstração esboçada pelo professor. Seria ótimo se a maioria dos nossos alunos de Cálculo se comportassem tal como o aluno ideal imaginado por Baldino, mas, seria melhor ainda se nossos professores fizessem esse tipo de reflexão e percebessem que nem sempre a demonstração revela, por si pró- 
pria, a essência do resultado; que existem outros caminhos para se alcançar à compreensão de uma proposição ou conceito matemático.

Fato curioso, e também compreensivel, é que quanto aos resultados num curso de Cálculo para os quais o matemático-professor não realiza uma demonstração, ele encontra uma saída: postula-os, assumeos como verdadeiros e segue o seu treinamento da sintaxe matemática.

Assim, com base nas questões aqui discutidas, podemos, ainda que de modo prematuro, e em consonância com o professor Baldino, tirar como uma diretriz para o ensino de Cálculo, ou de qualquer outra área do conhecimento matemático, que se priorize e busque sempre a essência dos resultados matemáticos.

No entanto, nem tudo no ensino "normal" de Cálculo são "demonstrações". Isto, em geral, é tarefa do professor. Ao aluno, cabe a exaustiva tarefa de fazer exercícios. Para isso existem as intermináveis e concorridas listas de exercícios ${ }^{8}$ de Cálculo. Surge assim um primeiro conflito pedagógico entre o que se pede e o que se faz: se nas aulas propriamente ditas o que prevalece são as demonstrações, nas avaliações o que se pede em geral é a técnica, os cálculos de limites, de derivadas, de antiderivadas e integrais. Ocorre desse modo uma outra característica normal do ensino de Cálculo: a prevalência da técnica sobre o significado.

Em nossa dissertação de mestrado, (Rezende, 1994), observamos que para os alunos de Cálculo (e professores também) as dificuldades de aprendizagem relacionadas a operação de limite estão associadas muito mais às suas dificuldades em manipulações algébricas ( $f a-$

\footnotetext{
${ }^{8}$ Tal instrumento didático é considerado imprescindível em um curso de Cálculo, tanto na opinião dos professores quanto dos alunos.
} 
toração de polinômios, relações trigonométricas, simplificações algébricas, "produtos notáveis", etc.) do que à sua interpretação analítica. Assim, no contexto do ensino de Cálculo, pode-se dizer que a noção de limite de funções está mais caracterizada, portanto, como uma operação algébrica do que como uma operação analítica. Esta "algebrização" exacerbada da operação de limite caracteriza bem o que queremos dizer com a "prevalência da técnica sobre o significado". Exercícios de técnicas de derivação e integração também preponderam sobre os exercícios de natureza conceitual.

Isto posto, ou seja, colocados os traços da "normalidade" da crise do ensino de Cálculo, resta-nos ver então quais têm sido os encaminhamentos normais para o problema. A fim de facilitar a nossa exposição, subdividiremos o conjunto dessas soluções "normais" em dois grupos quanto à natureza das circunstâncias que a produziram. Consideraremos, portanto, apenas duas classes: aquela que representa o cotidiano escolar, o contexto pedagógico, o corpo-a-corpo da sala de aula, e aquela que se constitui pelo universo das pesquisas já desenvolvidas e com resultados já publicados sobre o tema proposto. 


\subsection{As soluções "normais" para o ensino de Cálculo}

\subsubsection{No contexto pedagógico}

A produção de listas de exercícios é sem dúvida a solução "normal" mais usual em nossas universidades: já faz parte da tradição de um curso de Cálculo a presença de extensas listas de exercícios, com gabarito, para que os alunos possam realizar o seu "treinamento" com segurança. A tal lista tem ainda o papel de prenunciar o contexto em que se dará a avaliação, fato, aliás, que muito interessa aos estudantes, e que poderá, inclusive, ser usado por eles em um momento futuro, numa contra-argumentação de uma "questão da prova" que fuja aos parâmetros da lista.

Outra solução "normal" diz respeito ao uso de computadores em trabalhos complementares ou mesmo em atividades na sala de aula. São inúmeros os exemplos de instituições universitárias que vêm implementando laboratórios de informática como apoio às disciplinas de matemática. No IM-UFF, por exemplo, foram construídos, recentemente, com verbas de programas institucionais ${ }^{9}$, um laboratório de computadores, para apoio às atividades de ensino das disciplinas do curso graduação em Matemática, e uma sala de aula informatizada para a realização de aulas de Cálculo Aplicado 1, para alunos do curso de engenharia. Cabe ressaltar que as dificuldades de aprendizagem em Cálculo e a necessidade de "modernizar" o seu ensino constam como as principais justificativas para a implementação desses projetos. Apesar

\footnotetext{
${ }^{9}$ Os programas institucionais que possibilitaram tal empreendimento foram, respectivamente, o PROIN e o PRODENGE.
} 
do laboratório de computadores ser destinado a todas as disciplinas do curso de graduação de matemática, é a disciplina de Cálculo que tem mais usufruído desse espaço.

Assim como na UFF, temos tido outros exemplos de investimentos dessa natureza. Todos com o argumento da "modernidade" do seu ensino, como se "modernidade" fosse o valor maior e condição suficiente para a solução dos problemas de aprendizagem. Não há nada mais insensato do que "modernizar" a ignorância - a ignorância dos reais problemas de aprendizagem do Cálculo. O que precisamos fazer não são projetos para o "uso de computadores" no ensino de Cálculo, e sim, projetos para o ensino de Cálculo. O foco deve ser o Cálculo e o seu ensino, e não o "uso de computadores". Primeiro, será necessário que se defina o que (nós professores) queremos com o ensino de Cálculo, qual - seu papel no ensino superior; isto é, questões pertinentes ao Cálculo e ao seu ensino, para, aí sim, num momento oportuno, definir qual a contribuição que este valioso instrumento da inteligência - o computador - possa vir a dar para este projeto. Do contrário, estaremos, como já havíamos dito, apenas "modernizando" nossa ignorância a respeito das questões essenciais a respeito do ensino de Cálculo.

Outro instrumento "normal" bastante usual nas instituições de ensino superior para o enfrentamento dos resultados catastróficos no ensino de Cálculo é a realização de cursos "preparatórios" para um curso inicial de Cálculo. É o caso, por exemplo, dos cursos de "Cálculo Zero", "Pré-Cálculo", "Matemática Básica", já tão familiares no nosso meio acadêmico. Tais cursos, independentemente do nome que tenham, têm como meta principal resolver o problema da "falta de base" do aluno, ponto aliás que parece consensual entre os professores de Cálculo. 
Com a finalidade de resolver a tão propalada "falta de base", ensina-se, costumeiramente, nesses cursos, toda aquela parte da matemática básica necessária à realização técnica do Cálculo: polinômios, fatoração, relações e identidades trigonométricas, funções reais usuais (modulares, polinomiais, exponenciais, logarítmicas e trigonometrias), produtos notáveis, simplificações e cálculos algébricos em geral etc. É verdade que falta tudo isto ao nosso aluno recém-egresso do ensino médio. Mas também é verdade que a tal "falta de base" não é um problema específico do ensino de Cálculo. A "base" que falta aqui, para o ensino de Cálculo, também faz falta para o ensino de outras disciplinas do curso superior, e nem por isso os seus resultados são tão catastróficos como os do Cálculo.

No caso particular da UFF, o curso recebe o nome de Matemática Básica e tornou-se, como já dissemos, disciplina obrigatória da grade curricular do curso de Matemática / Niterói da UFF a partir do segundo semestre de 1997. Os resultados finais desta disciplina se encontram registrados no gráfico da figura 1 (p. 2). Vale a pena retornar ao gráfico para avaliar alguns dados relativos a esta disciplina e o cumprimento de seus objetivos.

Note, por exemplo, que a disciplina Matemática Básica não atinge sua principal meta que é o de reduzir o quantitativo de nãoaprovados em Cálculo 1 (o índice de não-aprovados permanece na faixa de 70 a $90 \%$, chegando a ultrapassar a barreira dos $90 \%$ no segundo semestre de 1998). Note ainda que os resultados de Matemática Básica são bem parecidos com os de Cálculo 1, o que dá a falsa impressão de que o problema de Cálculo está condicionado realmente pela "falta de base" do aluno. O que não é verdade. $O$ que se pode concluir tão 
somente, a partir desses resultados, é o que todos já sabiam: que os alunos de matemática carecem de uma formação "básica" de matemáti$c a, e$ que os professores da disciplina não conseguiram resolver tal problema. O campo semântico das noções básicas do Cálculo tem muito mais a ver com as noções de "infinito", de "infinitésimos", de "variáveis", do que com "fatoração de polinômios", "relações trigonométricas", "cálculos algébricos" etc. É bem verdade que o conhecimento destes últimos auxilia na árdua tarefa de calcular limites (derivadas, integrais etc), mas é exatamente aí que se coloca a nossa primeira questão fundamental: Qual é o curso de Cálculo que se quer? Aquele em que prevalece a técnica? Ou aquele em que se busca a construção dos significados? Quando se fala de "falta de base", de que "base"se está falando?

Na tentativa de amenizar a situação catastrófica dos resultados de Cálculo, alguns professores de Cálculo, conscientes da deficiente formação matemática dos seus alunos, têm procurado evitar os sintomas de "base" no processo de avaliação; isto é, procuram evitar manipulações algébricas exacerbadas, relações trigonométricas pouco conhecidas ou usadas pelos estudantes etc. Assim, em vez de pedir ao aluno que calcule a derivada da função $f(x)=\sec (\operatorname{arctg} x)$, por exemplo, pede que ele calcule a derivada de $g(x)=\operatorname{sen}(2 x)$. Poderíamos enumerar ainda outros exemplos desses sintomas de evitação dos problemas de "base". Em vez disso, preferimos avaliar essa atitude do professor. É salutar a sua tentativa de amenizar os problemas de "base" em prol da avaliação da parte específica do Cálculo. Afinal, a regra da cadeia pode ser avaliada com qualquer uma das expressões acima. Não se tra- 
ta aqui de colocar uma questão mais fácil com o intuito de "facilitar a prova" ou "melhorar a média da prova". Até porque, do ponto de vista do Cálculo, as duas questões têm o mesmo grau de dificuldade e estão avaliando o mesmo assunto: a derivada da composição de duas funções reais. O que se quer com a escolha da segunda função é avaliar, de forma mais simples e direta, o conteúdo específico do Cálculo. No entanto, fica aqui um alerta: ambas as questões apresentadas fazem menção tão somente à parte técnica do cálculo de derivadas.

\subsubsection{No âmbito da pesquisa}

Os computadores estão aí, é verdade, e não há como ignorá-los. Já fazem parte do nosso cotidiano, seja nos bancos, nos supermercados ou lojas comerciais, no ambiente de nosso trabalho, ou mesmo em nossas casas. As escolas, de qualquer grau de ensino, sejam elas públicas ou privadas, já começam a incorporar este valioso instrumento em seus ambientes administrativos e pedagógicos. A utilização dos computadores é inevitável e irreversível. $O$ uso dos computadores como ferramenta didática tem aparecido com frequiência nas pesquisas sobre o ensino de Cálculo. A questão que se apresenta então não é se "se deve usar ou não o computador para o ensino de Cálculo", mas "como" e "quando" usar esta ferramenta. Além disso, não podemos perder de vista que o computador, assim como qualquer outra máquina, possui suas limitações, sejam estas de naturezas técnicas ou mesmo pedagógicas. Portanto, ao trabalharmos com tal instrumento, precisamos, assim como os cientistas em seus laboratórios de pesquisa, ter a noção exata 
do seu uso, de sua finalidade, de suas potencialidades e limitações. Todas essas variáveis aqui apresentadas em relação ao uso do computador estão dimensionadas então por uma meta maior e exterior ao próprio uso do computador. No nosso caso específico, a "meta maior", ou meIhor, o nosso projeto deve ser o "ensino de Cálculo", logo, a questão que se põe é: "Como e quando o computador pode colaborar com o ensino de Cálculo?" Assim colocada, diríamos que a resposta para esta questão é então outra questão, de caráter mais fundamental: Qual é o projeto de Ensino de Cálculo que se tem, ou que se quer?

$\mathrm{Na}$ década de 80, como mencionamos anteriormente, surge um movimento em prol da reforma do ensino de Cálculo - o "Calculus Reform" - em que se sugere a introdução de novas tecnologias. Um reflexo deste movimento pode-se perceber na "revolução" literária dos novos livros didáticos de Cálculo, perpassados pelos preceitos dessa nova abordagem. Assim, através das leituras feitas destes livros, começa-se a assimilar e introduzir nas universidades brasileiras essa "nova" forma de se ensinar Cálculo. Entretanto, penso que toda e qualquer reestruturação do ensino de Cálculo que não seja fruto de uma análise epistemológica profunda deste estará condenada ao fracasso. Serão obras de "maquiagem", onde se disfarçam as aparências, mas se mantém as raízes, isto é, as causas reais do fracasso. O que se precisa fazer é uma reflexão de natureza epistemológica, séria e realista, sobre o ensino de Cálculo. E é esta, sem dúvida, a principal contribuição que este projeto pretende trazer.

Outro encaminhamento para essa problemática tem sido dado no âmbito das ciências cognitivas. D. Tall, conforme já observado neste trabalho, é um dos principais articuladores da área de pesquisa "Pen- 
samento Matemático Avançado". Os pesquisadores desta área procuram interpretar e justificar as dificuldades de aprendizagem no domínio da psicologia cognitiva. Dão ênfase em suas análises "epistemológicas" a um processo psicológico de imaginação (imaginação significa tão somente $o$ ato psicológico de criar imagens) e fazem dos "conceitosimagem" ou "concepções espontâneas" os elementos básicos de suas teorias. No caso específico do ensino de Cálculo, procuram estudar, por exemplo, como os alunos concebem a operação de limite. Identificam com isso um enorme distanciamento entre os "conceitos-imagens" dos estudantes e os "conceitos científicos" propriamente ditos. A aprendizagem, para eles, é um processo de realizar aproximações sucessivas, a partir dos "conceitos-imagens", até alcançar o "conceito científico" 10 .

Quanto às noções de "conceitos-imagem" e "concepções espontâneas", pode-se observar em Rezende (1994) um alerta para essa associação indevida que fazem os pesquisadores dos termos "conceito" $e$ "imagem". Ao tratar a problemática da aprendizagem do "conceito" de limite em termos de "conceito-imagem" (tal como definiram), Davis e Vinner (1986) empregam a palavra "conceito" no sentido psicológico. Pretendem fazer a união de algo lógico e objetivo (conceito) com algo sensivel e subjetivo (imagem). Não justificam tal procedimento e ficam apenas nessa "vontade" que é a solução construtivista para a questão epistemológica. $O$ "conceito" deles de "conceito-imagem" é fruto

\footnotetext{
${ }^{10}$ Denominam por “conhecimento científico” o conhecimento "pronto” já construído e formalizado, sendo, desta forma, o conceito-imagem uma interpretação "espontânea” do aprendiz, produzida por processos psicológicos, quando este interage com o dito conhecimento científico.
} 
do processo de "imaginação formal" ${ }^{11}$, própria da concepção construtivista, e que ignora o papel do inconsciente no processo cognitivo. É nesse sentido que podemos afirmar que esta concepção de "conceitoimagem" é incompleta inclusive do ponto de vista psicológico.

Por outro lado, G. Frege (1978) procura estudar a lógica, isolando a variável lingüística, e fundamentando o seu trabalho a partir do "pensamento não-expresso". Ao definir "conceito", Frege, que era matemático, segue uma linha puramente lógica. Faz isso porque trabalha com lógica formal demonstrativa e não com a razão social, psicológica, de valores pessoais e polissêmicos. Quer com isto chegar com precisão e rigor ao significado do termo "conceito". Para Frege, conceito é uma "função monádica", isto é, de um só argumento. A resposta está referida ao ponto de vista lógico e não psicológico. A função tomada separadamente é incompleta, tem necessidade de ser saturada. Por exemplo: consideremos o conceito "homem". Neste caso, a função monádica é "... é homem". Observe:

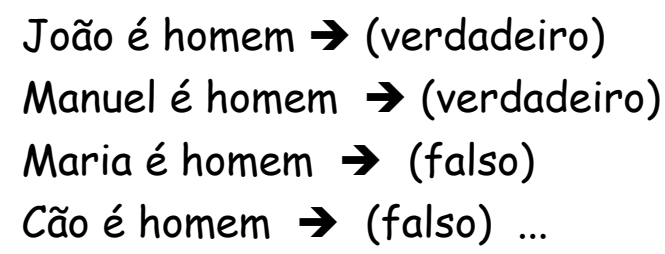

$O$ valor da função para o elemento João é verdadeiro, para o elemento Maria é falso, e assim por diante. O conceito "homem" é obtido então pela saturação da função monádica dada. Note que não podemos representar (ou imaginar) o homem. Tudo que existe é singular.

\footnotetext{
${ }^{11}$ Termo usado por Bachelard (1991) para fazer referência ao processo consciente de representar imagens da realidade. Bachelard com isso pretende contrapor este "tipo" de imaginação, própria das teorias construtivistas, com o seu conceito de "imaginação material".
} 
O conceito ou idéia é abstrato. João é tão somente o nome de um homem.

Vejamos agora um exemplo em matemática. Consideremos o conceito de "múltiplo de 3". Neste caso, a função monádica é: "x é múltiplo de 3". Note, assim como no exemplo anterior, que, por exemplo, 12 é um múltiplo de 3, mas não o múltiplo de 3 . O conceito "múltiplo de 3" deve ser construído e não pode ser representado mentalmente. Mais precisamente, o conceito "múltiplo de 3" é uma unidade lógica (uma operação mental) que precisa ser construída. Note, através desses exemplos, que o assunto aqui discutido é muito mais profundo do que uma questão simples e superficial de linguagem. É uma questão de aprofundarmos a discussão do que o "conceito" efetivamente é.

Ainda no campo da psicologia, mas imergindo nos mares da psicanálise, alguns pesquisadores têm relacionado o problema da aprendizagem ao campo do "desejo". Baseados principalmente nas teorias de Freud e Lacan, procuram fazer da psicanálise uma ferramenta para suas análises epistemológicas. O foco desta análise, como não poderia deixar de ser é o "sujeito aprendente", seus desejos.

"O desejo do homem é o desejo do Outro (...) [É] de ver funcionar toda uma cadeia no nivel do desejo do Outro que o desejo do sujeito se constitui. Quanto ao objeto do desejo Lacan esclarece (...) o objeto do desejo é a causa do desejo, e esse objeto causa do desejo é o objeto da pulsão - quer dizer, o objeto em torno do qual gira a pulsão (...) o desejo faz seu contorno, na medida em que é dele que se trata na pulsão".

(apud Cabral, 1992)

A partir deste recorte que fez da teoria lacaniana, Cabral (1992) nos coloca a seguinte questão: Qual é o propósito dos alunos, com dificuldades especiais, em relação ao curso de Cálculo? Esta é realmente uma questão interessante, mas não é, certamente, uma 
questão esclarecedora dos problemas de aprendizagem no ensino de Cálculo.

Com efeito, um aluno "normal" (ou "real" se assim preferirem) não tem, em geral, a perspicácia necessária para discernir as reais causas de seus problemas de aprendizagem em relação a um curso de Cálculo, quanto mais para ter "propósitos" em relação a esta disciplina. Fato que pode ser confirmado, na dissertação da própria pesquisadora, pelas justificativas dadas pelos próprios alunos entrevistados para as suas dificuldades de aprendizagem em relação ao Cálculo. Vejamos então os seus argumentos:

- Têm "problemas" intelectuais para aprender.

- Falta de base, porque são oriundos de uma escola pública.

- Não estudam o suficiente.

- Aprender é uma questão de preparo ou treino.

- Pertencem a uma classe economicamente carente, sem recursos.

- Engano na escolha do curso, talvez fosse diferente mais tarde.

- Já trabalham e nada do que é ensinado tem aplicação ou ligação.

- As aulas são monótonas.

- O professor não demonstra segurança na matéria.

- O professor se esforça mas não expõe bem.

É interessante observar também aqui o que dizem os professores:

- Aprender é querer aprender, e os alunos não querem.

- É falta de base, porque a situação em que se encontram os ensinos básico e secundário está cada vez pior.

- Os alunos entram imaturos, são muito novos para escolherem o que querem.

- Aprender Matemática é uma questão de talento, é inato.

Como se pode perceber, pelos próprios dados da pesquisadora, não são apenas os alunos que carecem de lucidez para enfrentar a problemática do ensino de Cálculo: os professores também. Assim, esperar essa lucidez de um aluno "com dificuldade especial" em relação ao 
Cálculo não me parece uma atitude muito esclarecedora em relação ao problema específico do ensino de Cálculo. Além disso, este aluno, "com dificuldade especial", é apenas uma "vítima", que carrega consigo, de forma inconsciente, as marcas de um processo que começou e já estava definido antes mesmo que assistisse à sua primeira aula de Cálculo.

Ao analisar os dados obtidos do seu levantamento inicial, Cabral (1992) isolou três formas de conceber o propalado fracasso do ensino e da aprendizagem de Matemática:

- convicção sobre o fracasso da didática:

- convicção sobre o fracasso da pedagogia e

- conviç̧ão sobre distúrbios do aluno.

Baseado nesses fatos a autora infere que as soluções ou abordagens propostas, via de regra, são executadas em separado:

- Tratamento da didática. Segue-se a linha da engenharia didática, projetos de ensino, classes-pilotos, classes-experimentais.

- Tratamento da psicopedagogia. Seguem-se as linhas que abordam o indivíduo na sua afetividade primária, nas suas emoções, segundo as suas motivações e estágios cognitivos ou condicionamentos de comportamentos (...).

- Em caso considerado como de extrema gravidade, o tratamento terapêutico proposto por clínica ou consultório psicanalíticos, essencialmente fora da escola (...) é procurado para explicar e controlar alguns tipos de distúrbios (neurastenias, histerias, etc.) que o sujeita apresenta (...).

Assim, seguindo os parâmetros da pesquisadora, poderíamos dizer que o nosso projeto de pesquisa pertenceria ao âmbito do "tratamento da epistemologia". Preferimos, no entanto, evitar o caráter "separatista" apresentado pela autora a respeito dos "tratamentos" apresentados para a solução do problema do ensino de Cálculo. A nossa pesquisa, por exemplo, situa-se, na verdade, nas "pontes" que interligam os terrenos da epistemologia e da didática, tal como sugere N. J. Machado (1995), em seu texto "Epistemologia e Didática". Segundo o 
autor, "a toda prática didática subjaz uma concepção epistemológica". No próprio ato da prática didática se revela uma concepção de conhecimento que precisa ser explicitada para que se possa fazer então uma reflexão de natureza epistemológica. Essa é, de fato, uma das grandes apostas deste trabalho.

Ainda no âmbito das "pontes" que interligam a epistemologia e a didática, o professor Baldino (1998) tem realizado com justeza severas críticas à "epistemologia clássica" ${ }^{12}$. Segundo o professor, do ponto de vista da "epistemologia clássica", o ser humano adquire conhecimentos à medida que este sujeito (cognoscente) e um objeto (de conhecimento) entram em relação. Segundo uns, é o conhecimento que impõe suas propriedades ao sujeito. Segundo outros, é o sujeito que age sobre o objeto. Há ainda quem põe a ênfase no processo de interação. Observa entretanto que todas as vertentes da "epistemologia clássica" nos falam de "aquisição" de conhecimento. Ao propor então uma "nova concepção epistemológica", clarifica e diferencia dois termos que são utilizados de forma indistinguível pela "epistemologia clássica": "aquisição" e "produção" de conhecimento. Em sua nova concepção epistemológica "não há transmissão nem comunicação de conhecimentos; há, sim, produção de significados na dialética do sujeito e do outro, sob as circunstâncias que a instituição determina". O sujeito aprende porque fala, e não porque presta atenção. "O significado", afirma o professor, "é uma função do ouvinte", e que, portanto, é uma produção conjunta do falante e do outro. O que se precisa fazer então é colocar o aluno na posição de falante para que este possa refletir criticamente a sua

\footnotetext{
${ }^{12} \mathrm{O}$ autor usa o termo "epistemologia clássica" para fazer referência às teorias interacionistas clássicas.
} 
forma de pensar. O aluno precisa "falar mais", e o professor "falar menos e ouvir mais". No ensino tradicional vigente é reservado ao aluno o papel de mero espectador: "o professor ensina mostrando e o aluno aprende vendo". Torna-se então imprescindível a inversão desses papéis.

Assim, a fim de possibilitar uma prática didática coerente com sua "nova concepção epistemológica", Baldino propõe uma nova pedagogia com base no regime de "assimilação solidária". Mais detalhes dessa proposta podem ser vistos nas referências (Cabral, 1992 e 1998) e (Baldino, 1999). Não cabe aqui analisar os entremeios dessa proposta, até porque não é nesse contexto em que se realizará nossa pesquisa. $\mathrm{Na}$ verdade, as raízes da reflexão epistemológica a que nos referimos em nosso projeto estão fincadas, como já observamos, muito mais nos terrenos da filosofia e história da ciência do que da psicopedagogia.

Ainda no âmbito da didática têm sido sugeridas mudanças na sequiência do conteúdo programático. Alguns alegam razões históricas para as mudanças, outros sustentam sua posição com base em argumentos de natureza epistemológica. Dentre todas estas, aquela que, sem dúvida, foge aos parâmetros "normais" do ensino de Cálculo, é a que sugere a construção de suas noções básicas a partir da noção de infinitesimal. Tanto Baldino (1998) quanto Oliveira (1993) partilham desta linha de pensamento. Percebem-se, no entanto, diferenças significativas em suas idéias propostas. Enquanto Oliveira faz uma "apologia ao ensino da Análise Não-Standard", Baldino sugere que se desenvolva propriamente uma espécie de Cálculo Infinitesimal, muito mais próximo do Cálculo de Leibniz do que da Análise Não-Standard de Robson. Usa a Análise Não-Standard apenas como um aparato crítico e 
político de suas posições epistemológicas e ações de ensino. A proposta do professor é Cálculo: Cálculo Infinitesimal, e não Análise NãoStandard. Esta reflexão a respeito desta dicotomia limite $X$ infinitesimal é outro ponto que não pode ser ignorado em nossas análises futuras.

Outra linha de pesquisa, no campo da epistemologia, é aquela que procura interpretar as dificuldades de aprendizagem no ensino de Cálculo em termos de obstáculos epistemológicos de certos conceitos do Cálculo. Sierpinska (1987), Cornu (1983) e Rezende (1994) são exemplos de trabalhos nessa linha de pesquisa. O foco dessas análises epistemológicas tem sido o conceito de limite. Sierpinska, por exemplo, desenvolveu uma pesquisa histórico-experimental onde propôs uma classificação de obstáculos epistemológicos relativos ao "conceito" de limite. Fez isto baseado na propriedade da dualidade dos obstáculos epistemológicos. Dualidade aí, compreendida pelas dimensões cognitivas e sociais dos obstáculos epistemológicos. Cabe-nos, entretanto, ressaltar que, apesar de Sierpinska ter desenvolvido sua pesquisa em termos de obstáculos epistemológicos, ela não os investigou dentro do processo histórico da construção da operação de limite - assim como Bachelard sugere que se faça. Sierpinska restringiu sua pesquisa ao nível pedagógico. Tal tarefa foi executada, entretanto, por B. Cornu (1983) em sua tese de doutorado. Uma análise crítica e detalhada desses trabalhos pode ser estudada na dissertação de mestrado do autor desta tese (Rezende, 1994). 
É preciso deixar claro que não se contesta aqui a ferramenta epistemológica ${ }^{13}$ utilizada nos trabalhos desses pesquisadores, mas 0 seu foco: a operação de limite. Em que sentido as dificuldades de aprendizagem em relação à operação de limite interferem na aprendizagem dos demais conceitos do Cálculo? Teria a operação de limite algum "grau" de responsabilidade pelo fracasso do ensino de Cálculo? Em que "medida" queremos que nossos estudantes universitários façam uso da noção de limite em um curso inicial de Cálculo? Como Leibniz ou Newton usavam? Como Cauchy? Ou, como Weierstrass?

${ }^{13}$ Os obstáculos epistemológicos de Bachelard. 


\subsection{Sobre a "cegueira" dos outros}

Certa vez, Kierkegaard disse com muita sensatez a seguinte frase a respeito da dicotomia subjetividade $x$ objetividade:

"A maioria das pessoas são subjetivas a respeito de si próprias e objetivas algumas vezes terrivelmente objetivas - a respeito dos outros".

(apud Santos, 2000, p.17)

Ao realizar sua crítica à "razão indolente", Santos (2000) soube tirar proveito das palavras do grande mestre e, com humildade, soube reconhecer o inevitável "dilema da cegueira": da cegueira dos outros, e, por que não dizer, da nossa própria cegueira:

"(...) A cegueira dos outros, em especial dos outros do passado, é tão recorrente quanto fácil de identificar. Mas se é assim, seja o que for que dissermos hoje sobre a cegueira dos outros será visto no futuro como sinal da nossa própria cegueira. Este dilema pode ser formulado da seguinte forma: se somos cegos, porque vemos tão facilmente a cegueira dos outros e por que razão é tão difícil aceitar a própria cegueira? Por que julgamos ver plenamente o que só vemos parcialmente? E se assim é, de que vale sequer ver?"

(Santos, 2000, p.226)

Assim, como o sociólogo Boaventura Santos, temos "consciência de nossa própria cegueira", que somos forçados a exercer, enquanto procuramos desvelar a "cegueira dos outros". Mas, compreendemos, por outro lado, e, a fim de clarificar e explicitar os objetivos de nossa pesquisa, que a tal "arrogante" tarefa é tão necessária quanto inevitável. É preciso correr esse risco. Relacionamos, então, a seguir, alguns indicadores de tal "cegueira". 


\section{> A não-especificidade das questões abordadas}

Em primeiro lugar, penso que em muitos dos encaminhamentos das pesquisas sobre o ensino de Cálculo existe um grande desvio: tratam de questões que não são específicas do ensino de Cálculo. O fato de um estudante "querer ou não aprender", ou de haver um "distanciamento" ou "inversões de papéis" na relação professor-aluno no momento da aprendizagem dos conteúdos do Cálculo, ou mesmo sobre o "uso ou não de computadores em sala de aula", não são questões específicas do ensino de Cálculo. São questões relevantes, mas, como já dissemos, não são específicas do ensino de Cálculo - poderiam estar relacionadas à atividade de ensino de qualquer outro tipo de conhecimento, e não, especificamente, do Cálculo.

\section{$>$ caráter local e imediato das pesquisas.}

Um outro equívoco é o caráter local e imediato de certas pesquisas: procura-se a solução no próprio processo de ensino desenvolvido. Parte-se das estruturas atuais do Cálculo e do aluno sem se preocupar com as suas razões históricas. Muda-se a forma de ensinar de Cálculo, mas não a essência. Preocupa-se com o como, e não com o por quê, com - quê, e pra quê ensinar Cálculo?

Ao contrário do que se pensa em geral, pode-se afirmar que parte significativa dos problemas de aprendizagem "do atual" ensino de Cálculo está "fora" dele e é "anterior" inclusive ao seu próprio tempo de execução. Não se trata apenas da tão propalada "falta de base"dos estudantes, como afirma a grande maioria dos nossos colegas professores. A "base" à que fazem referência (polinômios, trigonometria, 
função, operações algébricas etc) também faz falta em outras áreas do ensino superior de matemática - e novamente aí, se comete o "desvio" da não-especificidade -; e nem por isso os resultados são tão catastróficos. Assim, ao invés de se fazer menção a uma "falta de base" dos estudantes, o que se precisa fazer, de fato, é estabelecer os conceitos básicos e necessários para se aprender as idéias básicas do Cálculo.

$\mathrm{Na}$ verdade, o que se sente falta no ensino de matemática em geral é de uma "preparação" para o ensino de Cálculo. Alguns problemas clássicos do Cálculo são evitados, ou simplesmente ignorados, ou ainda tratados de forma superficial pelos professores no ensino médio e fundamental. Fala-se, por exemplo, de funções crescentes, mas não se estuda o "quanto" estas crescem. Apresentam-se de forma "ritualística" alguns resultados do Cálculo - como a área do círculo, "transformação de dízimas periódicas em frações" etc. - sem um real enfrentamento dessas questões.

Curioso é observar aqui que se, por um lado, no processo histórico de construção do conhecimento matemático, o Cálculo potencializa áreas fundamentais como a geometria e a aritmética, além de ser o principal responsável pelo desenvolvimento e organização do próprio conhecimento matemático, no campo pedagógico, resta-lhe apenas o papel de "grande vilão" no ensino superior. O Cálculo aparece aí como uma disciplina isolada, temida pelos alunos que sequer vêem uma relação do aprendizado de suas idéias básicas com sua formação ou mesmo com as demais disciplinas da grade curricular do seu curso. É comum ouvirmos de um professor de matemática dos ensinos fundamental e médio o argumento de que não haveria necessidade de ter estudado 
Cálculo na universidade, uma vez que não precisaria ensinar tal coisa no ensino fundamental ou no ensino médio. É, realmente, lamentável que "tal coisa" não seja ensinada de fato em etapas anteriores do ensino de matemática. Não da forma como é ensinado no curso superior, estanque e dissociado de sua função potencializadora, mas como parte integrante e fundamental para a construção das idéias matemáticas e, por que não dizer, para a própria formação do cidadão.

No mundo de hoje, não basta perceber o crescimento/ decrescimento de uma função, mas determinar precisamente o quanto esta está crescendo/decrescendo. "A gente não quer só comida, a gente quer comida, diversão e arte" ${ }^{14}$. Isso mesmo, com o desenvolvimento das relações econômicas e sociais, tornando-se estas cada vez mais complexas, faz-se necessário e urgente uma revisão e ampliação das metas da "formação básica para o exercício pleno da cidadania".

\section{$>$ psicologismo das análises epistemológicas}

Outro desvio que se pode perceber no desenvolvimento das pesquisas diz respeito à submissão da análise das questões de naturezas epistemológicas ao domínio da psicologia. Este "psicologismo" das análises epistemológicas, com raízes no construtivismo, tem dado ênfase ao par sujeito-aprendente/objeto do conhecimento em detrimento de outro par, não menos importante: professor/conhecimento.

\footnotetext{
${ }^{14}$ Frase retirada da música "Comida”, de Arnaldo Antunes, Marcelo Fromer e Sérgio Britto, e lançada pelo conjunto Titãs, em 1987.
} 


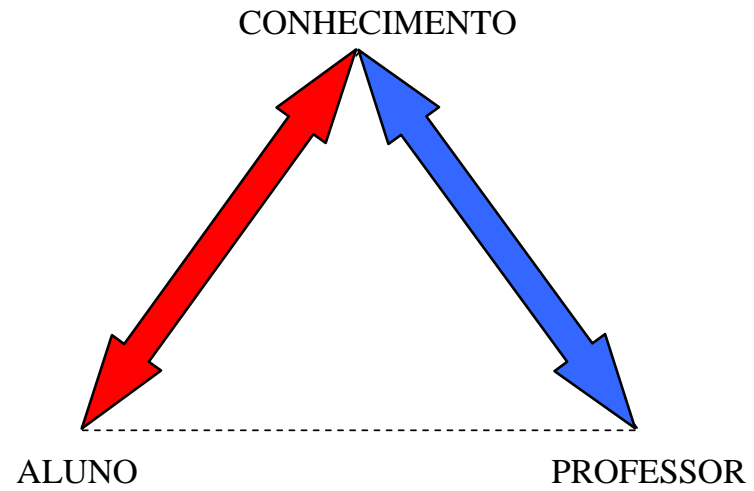

figura 2 - Triângulo fundamental das análises epistemológicas

Usando a alegoria geométrica acima para representar as relações fundamentais entre os três elementos essenciais (ProfessorConhecimento-Aluno) de qualquer processo de ensino-aprendizagem, poderíamos dizer que as análises epistemológicas das recentes pesquisas sobre o ensino de Cálculo têm se caracterizado majoritariamente pela centralidade no par Aluno/Conhecimento e, pelo esquecimento total do eixo Professor/Conhecimento.

De fato, é preciso que se chame à responsabilidade os professores de Cálculo para que estes possam explicitar e refletir as concepções epistemológicas (nem sempre as deles próprias) que perpassam suas ações docentes. Afinal, não cabe ao professor o comando (ou orientação) do processo ensino-aprendizagem? Esta reflexão de natureza epistemológica é, sem dúvida, uma das principais metas deste trabaIho.

Ainda com respeito à alegoria do triângulo, note que o eixo Professor-Aluno, apesar de muito comentado nas pesquisas sobre o ensino de Cálculo, não é do âmbito específico do mesmo. A ênfase que se pre- 
tende dar nesta pesquisa é exatamente sobre as questões de natureza epistemológica e específica do ensino de Cálculo. 


\section{O encaminhamento desta Pesquisa}

Ao falarmos da "cegueira dos outros" é compreensivel que tenha sobressaído muito mais o que "não pretendemos fazer" do que aquilo que realmente queremos com esta pesquisa. Assim, antes de se anunciar de forma sintética o seu objetivo, faz-se necessário traçar em linhas gerais as premissas que dão sustentação a esta pesquisa.

\subsection{Premissas e princípios norteadores da pesquisa}

\subsubsection{O ensino de Cálculo é imprescindível}

Segundo H. P. Greenspan e D. J. Benney (1973), "(..) o Cálculo é o maior triunfo da civilização e tem sido o suporte do progresso cientifico e tecnológico desde sua criação (...)". Essa característica do Cálculo como "suporte" para o progresso da ciência e para o desenvolvimento de novas tecnologias é sem dúvida o argumento mais usado no meio acadêmico quando se quer justificar o seu caráter de imprescindibilidade. Em nossa argumentação pretendemos ir além.

Willcox et alii (1971), ampliando o universo de relações do Cálculo do nível da ciência e tecnologia para o "mundo real", nos fala que "a importância do Cálculo deriva da potência e beleza intrínsecas de suas idéias e dos muitos e variados contatos entre essas idéias e o "mundo real"' - mas o que se quer dizer aqui com "mundo real"? 
Bem, não sabemos o que pensam os autores, mas podemos tirar proveito dessa situação para explicitar o que pensamos dessa relação entre o Cálculo e o "mundo real". Ao considerarmos a expressão "mundo real" usada pelos autores pretendemos ultrapassar o "mundo" natural, isto é, da ciência, e o "mundo" da produção de tecnologias. O sentido que se quer dar leva em conta a complexidade das relações cotidianas do cidadão. É neste contexto da cidadania, que pretendemos discutir agora o caráter de imprescindibilidade do Cálculo.

Com efeito: o Cálculo é imprescindível para a formação do cidadão. Resolução de problemas de juros ou de crescimento de população (ou do aumento do custo de vida, da dívida externa etc.), cálculos de velocidades ou de taxas de variações de outras grandezas, interpretações de gráficos de funções reais, resolução de problemas de otimização (de áreas, de orçamentos domésticos etc.) são habilidades cada vez mais requisitadas para o exercício pleno da cidadania em uma sociedade de crescente complexidade.

Outro aspecto notável no Cálculo diz respeito ao seu caráter integrador do próprio conhecimento matemático: o Cálculo é imprescindível para o desenvolvimento e organização interna da matemática e suas diversas áreas específicas. Numa linguagem alegórica diríamos que, se a geometria e a aritmética formam a "base" do conhecimento matemático, o Cálculo representa a sua "espinha dorsal", isto é, é o domínio de conhecimento da matemática que dá sustentação e realiza as diversas interfaces entre as outras áreas do próprio conhecimento matemático. Assim, ensinar matemática - seja em que grau de ensino for -, sem levar em conta as idéias básicas do Cálculo, será sempre um 
ensino realizado "com lacunas". Lacunas estas que só serão preenchidas à medida que forem explicitadas as idéias básicas do Cálculo.

\subsubsection{A toda prática didática subjaz uma concep- ção epistemológica}

A frase citada acima é sem dúvida o grande postulado deste trabalho. Sua simplicidade não tira o mérito de sua importância. As idéias básicas da teoria da relatividade e do conceito de continuidade também foram consideradas banais por seus respectivos autores ${ }^{15}$, mas ninguém, em sã consciência, ousa questionar a relevância dessas teorias para o desenvolvimento da ciência e da matemática.

A simplicidade da frase supracitada reside em sua evidência prática: quando se ensina algo, se ensina, obviamente, balizado por alguma concepção de conhecimento, esteja esta clara ou não para o docente que executa a ação didática. Machado (1995) explicita algumas representações de conhecimento que têm influenciado majoritariamente a prática docente; são elas:

> A representação empirista do conhecimento como um "balde". O conhecimento aqui é um bem passível de acumulação. Fala-se neste caso de "aquisição de conhecimento". Esta "aquisição" de conhecimento pode ser medida, e quantificada numericamente pelas já tão conhecidas, e igualmente temidas pelos alunos, "provas" de conteúdo.

\footnotetext{
${ }^{15}$ O físico Einstein e o matemático Dedekind, respectivamente.
} 
A representação cartesiana de conhecimento. A metáfora usada aqui, para representar o conhecimento, é a idéia de "cadei$a^{\prime \prime}$, isto é, uma sequiência lógica de conteúdos que parte das idéias mais simples para as mais complexas. O regime de "seriação escolar" e os "pré-requisitos" disciplinares são exemplos da influência deste modelo de conhecimento nos sistemas escolares. Cabe aqui ressaltar que o modelo cartesiano é tido como paradigma do conhecimento matemático pela grande parte dos professores desta disciplina. Representações alegóricas do conhecimento matemático como "uma escada", ou, "uma pirâmide", ou mesmo, como "uma linha espiral", são as interpretações majoritárias entre os professores, e mesmo os alunos de matemática 16.

Apesar de mostrar com clareza as diferenças entre as concepções "baldista" e cartesiana de conhecimento, Machado (1995) ressalta que as ações docentes são, em geral, híbridas e muitas vezes contraditórias. Poderíamos dizer que a grande maioria dos docentes é predominantemente cartesiana na hora de planejar, organizar e executar as ações de ensino, e "baldista" na hora de realizar suas avaliações. Esta hibridez presente em suas atitudes, que chegam, muitas vezes, a ser contraditórias com os seus discursos (em geral, mais progressistas que as próprias atitudes), demonstra a inconsistência das mesmas. Assim, a fim de se modificar o cenário didático do ensino de Cálculo (não só do Cálculo, mas de toda a Matemática), faz-se urgente uma reflexão de natureza epistemológica do próprio Cálculo e do seu ensino.

\footnotetext{
${ }^{16}$ Tal fato pode ser observado na dissertação de mestrado de Rezende (1994).
} 
Para contrapor às duas representações citadas, Machado apresenta uma concepção alternativa de conhecimento: o conhecimento enquanto rede. "Construir o conhecimento" significa aqui "enredar", "tecer", enfim, a teia do conhecimento.

A fim de uma melhor elucidação deste modelo vejamos uma explicação de M. Serres para esta representação de conhecimento:

"Imaginemos um diagrama em rede, desenhado num espaço de representação. Ele é formado, num dado instante (pois veremos que ele representa qualquer estado de uma situação móvel) por uma pluralidade de pontos (extremos) ligados entre si por uma pluralidade de ramificaçôes (caminhos). Cada ponto representa ou uma tese, ou um elemento efetivamente definivel de um conjunto determinado. Cada via é representativa de uma ligação ou de uma relação entre duas ou mais teses, ou de um fluxo de determinação entre dois ou mais elementos desta situação empírica. Quando dizemos determinação, entendemos por isso relação ou ação em geral: pode ser uma analogia, uma dedução, uma influência, uma oposição, uma reação $e$ assim sucessivamente. Por definição, nenhum ponto é privilegiado em relação a um outro, nem univocamente subordinado a qualquer um; cada um possui o seu próprio poder (eventualmente variável com o decorrer do tempo), a sua zona de incidência, ou ainda a sua força determinante original. Por conseguinte, ainda que alguns possam ser idênticos entre si na generalidade são diferentes. O mesmo se passa com os caminhos, que transportam os fluxos de determinações diferentes e variáveis com o tempo. Existe, enfim, uma reciprocidade profunda entre as interseções e os caminhos, ou, melhor dizendo, uma dualidade. Um extremo pode ser considerado a interseção de duas ou mais vias (uma tese pode constituir-se da interseção de uma multiplicidade de relaçôes ou um elemento de situação surgir subitamente da confluência de várias determinaşões): correlativamente, um caminho pode ser visto como uma determinação constituída a partir da correspondência entre duas interseções preconcebidas (relação de quaisquer duas teses, interação de duas situaçôes, etc.). Trata-se pois de uma rede, de um diagrama o mais irregular possivel onde podemos fazer variar até ao máximo a diferenciação interna. Uma rede regular, de encruzilhadas idênticas e com caminhos concorrentes, paralelas, perpendiculares entre si assim como equivalentes, seria um caso particular desta rede "escalena". Ou, se desejarmos, sendo dada uma rede regular, basta distinguir as suas interseções e os seus caminhos, aze-los variar o necessário para obter o modelo que propomos".

(apud Machado, 1995, p.138-139)

Note que na "rede" não existe nenhum caminho "logicamente" necessário: o mais curto. A menor distância entre dois pontos pode, eventualmente, ser mais difícil ou menos interessante que um outro 
mais longo. Além disso, a rede está em permanente estado de mudança. Nesse sentido, o aspecto temporal elucidado na fala de M. Serres é fundamental para a mobilidade essencial e interna dos nós.

Algumas das dimensões mais representativas de tal imagem metafórica foram sublinhadas por Machado; quais sejam:

- a caracterização dos significados como feixes de relações;

- a diversidade das relações constitutivas de cada feixe;

- a dualidade objetos/relações;

- a não-linearidade na articulação dos nós/significados;

- a não-existência de caminhos necessários ligando dois nós quaisquer:

- a permanente abertura das transformações.

Entre as interpretações de "rede", aquela que melhor se ajusta a nossa concepção de conhecimento é a de hipertexto de Lévy (1993). Etimologicamente, a palavra "texto" aproxima-se de textura, tecer. Em latim, "textus" significa tecido. Lévy elabora a noção de "hipertexto" para referir-se aos mundos de significações. A imensa rede dos universos mentais, ou mais geralmente, dos universos de significações, constitui um hipertexto. Para caracterizar o hipertexto, Lévy recorre a seis princípios conformadores: 
1. Princípio da Metamorfose: "A rede hipertextual está em constante transformação e renegociação. Ela pode permanecer estável durante certo tempo, mas esta estabilidade é em si mesma fruto de um trabalho. Sua extensão, sua composição e seu desenho estão permanentemente em jogo para os atores envolvidos, sejam eles humanos, palavras, imagens, traços de imafens ou de contexto, objetos técnicos, componentes destes objetos, etc." (p. 25).

2. Princípio de Heterogeneidade: "Os nós e as conexões de uma rede hipertextual são heterogêneos. Na memória serão encontradas imagens, sons, palavras, diversas sensações, modelos, etc., e as conexões serão lógicas, afetivas, etc. Na comunicação, as mensagens serão multimídias, multimodais, analógicas, digitais, etc. O processo sóciotécnico colocará em jogo pessoas, grupos, artefatos, forças naturais de todos os tamanhos, com todos os tipos de associações que pudermos imaginar entre estes elementos." (p.25).

3. Princípio de multiplicidade e de encaixe das escalas (ou da fractalidade): "O hipertexto se organiza de modo "fractal", ou seja, qualquer nó ou conexão, quando analisado, pode revelar-se como sendo composto por toda uma rede, e assim por diante, indefinidamente, ao longo da escala dos graus de precisão. Em algumas circunstâncias críticas, há efeitos que podem propagar-se de uma escala a outra: a interpretação de uma vírgula em um texto (elemento de uma microrrede de documentos), caso se trate de um tratado internacional, pode repercutir na vida de milhões de pessoas (na escala da macrorrede social)". (p. 25-6). 
4. Princípio da Exterioridade: "A rede não possui unidade orgânica, nem motor interno. Seu crescimento e sua diminuição, sua composição e sua recomposição permanente dependem de um exterior indeterminado: adição de novos elementos, conexões com outras redes, excitação de elementos terminais (captadores), etc. Por exemplo, para a rede semântica de uma pessoa escutando um discurso, a dinâmica dos estudos de ativação resulta de uma fonte externa de palavras e imagens. Na constituição da rede sóciotécnica intervêm 0 tempo todo elementos novos que não Ihe pertenciam no instante anterior: elétrons, micróbios, raios $X$, macromoléculas, etc." ( $p .26)$.

5. Princípio de Topologia: "Nos hipertextos, tudo funciona por proximidade, por vizinhança. Neles, o curso dos acontecimentos é uma questão de topologia, de caminhos. Não há espaço universal homogêneo onde haja forças de ligação e separação, onde as mensagens poderiam circular livremente. Tudo que se desloca deve utilizar-se da rede hipertextual tal como ela se encontra, ou então será obrigado a modifica-la. A rede não está no espaço, ela é o espaço." (p. 26). A noção de distância precisa ser compreendida em sentido topológico.

6. Princípio de Mobilidade dos Centros: "A rede não tem centro, ou melhor, possui permanentemente diversos centros que são como pontas luminosas perpetuamente móveis, saltando de um nó a outro, trazendo ao redor de si uma ramificação infinita de pequenas raízes, de rizomas, finas linhas brancas esboçando por um instante um mapa qualquer com detalhes delicados, e depois correndo para desenhar mais à frente outras paisagens do sentido." (p. 26). 
Nesse sentido, o Cálculo é uma grande rede que interage com várias outras redes: o próprio conhecimento matemático; a física e as ciências naturais de um modo geral; as ciências sociais e econômicas; o desenvolvimento de novas tecnologias etc. O "ensino de Cálculo", por outro lado, está relacionado a outras variedades de redes, além daquelas que o Cálculo naturalmente está interligado. Acrescentam a estas: as ciências cognitivas, a epistemologia, a educação etc. A tessitura dessas redes não tem fronteiras, não tem costuras, e está em permanente estado de transformação. Os feixes que estabelecem esta conexão temporária se modificam à medida que se façam novas imersões na rede. O uso de novas tecnologias (calculadoras gráficas / computadores), por exemplo, tem modificado bastante a estrutura atual do próprio Cálculo, revelando novos centros de interesse, relegando outros a um segundo plano, ou modificando a forma, ou mesmo o sentido, de um determinado tópico ensinado. É o caso, por exemplo, da revitalização de processos numéricos em cálculos de integrais e da estimativa de erros em cálculos aproximados da variação de determinadas grandezas - fatos que eram ignorados ou the atribuíam menor importância em épocas anteriores aos computadores.

Isto posto, convém observar que o hipertexto como paradigma para o conhecimento constitui-se como uma valiosa ferramenta para as nossas análises epistemológicas do Cálculo e do seu ensino. Navegar por hipertextos será preciso. E para o ato de navegar em si, mapas precisarão ser construídos: mapas conceituais, mapas de disciplinas e conteúdos programáticos, mapas de obstáculos epistemológicos, mapas de objetivos educacionais, mapas históricos, mapas sócio-políticos, etc. 
A idéia de mapa torna-se então um instrumento metodológico indispensável para a realização desta pesquisa. Voltaremos a este tema num ponto mais adiante deste trabalho, quando estivermos discutindo mais propriamente a metodologia desta pesquisa. Passemos então à nossa próxima premissa.

\subsection{3. É preciso transcender o espaço-tempo local do ensino de Cálculo}

A idéia de que a origem das dificuldades no ensino de Cálculo encontra-se em outros contextos que transcendem o seu próprio espaço-tempo local é, sem dúvida, a grande aposta desta pesquisa. Não se trata, como já observamos, de "falta de base" ou de outra razão tópica, mas da falta de condições globais efetivas para uma iniciação consciente ao Cálculo.

É necessário explicitar a natureza integradora do Cálculo na constituição do próprio conhecimento matemático, tal como efetivamente ocorreu no curso da História.

Se a Aritmética e a Geometria provêem a Matemática de seus elementos constituintes estáticos, é apenas com o Cálculo que a variabilidade e o movimento podem ser incorporados à arquitetura do conhecimento matemático, mesmo no ensino médio e fundamental. Precisamos, enfim, permitir ao Cálculo desempenhar o seu papel fundamen- 
tal tanto na construção e organização do conhecimento matemático quanto na formação desta nova demanda de cidadão. 


\subsection{Objetivos}

Assim, à luz das idéias discutidas aqui, podemos enunciar, enfim, o objetivo desta pesquisa:

Mapear as dificuldades de natureza epistemológica do ensino de Cálculo, procurando interpretá-las em diversas escalas e contextos. $O$ que se busca aqui, a partir de uma cartografia simbólica do ensino de cálculo, é uma compreensão do que o Cálculo é, e o que ele representa para a formação do cidadão e para a arquitetura do próprio conhecimento matemático. Acreditamos que, ao explicitar nos ensinos médio e fundamental de matemática as idéias fundamentais e imprescindíveis do Cálculo, estaremos contribuindo para diluir as dificuldades supracitadas no ensino de matemática como um todo, além de diminuir a sobrecarga e a responsabilidade de um curso de Cálculo inicial no ensino superior.

Diante da complexidade do seu objetivo geral, pensou-se no desenvolvimento da pesquisa em três etapas: uma inicial, em que se realizaria um estudo da evolução histórica das idéias e procedimentos básicos do Cálculo; uma posterior, em que mapear-se-ia as dificuldades de aprendizagem de natureza epistemológica no ensino de Cálculo; e, uma última, em que se proporia finalmente ações de natureza pedagógicas para o ensino de Cálculo em sentido amplo. 
Vislumbradas essas três etapas de desenvolvimento da pesquisa, pode-se extrair do seu objetivo geral os seguintes objetivos específicos:

- construir mapas históricos-conceituais das idéias básicas do Cálculo;

- construir mapas, em pequena escala, das dificuldades de aprendizagem de natureza epistemológica do ensino de Cálculo, de modo a ter uma visão mais global do problema em questão:

- elaborar diretrizes de ensino de natureza epistemológica para a emersão e participação efetiva das idéias do Cálculo no processo de construção do conhecimento matemático tanto no ensino superior como, principalmente, no ensino básico. 


\subsection{A metodologia}

\subsubsection{Da dicotomia qualitativo-quantitativo à idéia de mapa}

É notória a predominância da abordagem qualitativa - seja ela histórica, descritiva, participante ou de natureza etnográfica etc. - na grande maioria das atuais pesquisas em educação. Assim, dizer que este trabalho se desenvolve através de uma abordagem qualitativa, acreditamos, acrescenta muito pouco à idéia que o leitor possa ter a respeito da metodologia de pesquisa aqui utilizada.

Ratificando esse nosso ponto de vista, André (1995) destaca em seu texto o desgaste do termo "pesquisa qualitativa" e sugere, por conseguinte, "uma revisão do caráter tão amplo e genérico" dessa expressão. E é nessa "revisão do caráter tão amplo e genérico", que a autora se propõe a fazer, que pretendemos precisar, de modo inicial, o nosso referencial metodológico. Acompanhemos de perto o pensamento da professora.

Segundo André, a abordagem qualitativa de pesquisa surge em oposição a uma visão empiricista de ciência, no final do século XIX, quando os cientistas sociais começam a questionar "se o método das ciências físicas e naturais deveria continuar servindo como modelo para o estudo dos fenômenos sociais" (André 1995, p.16). Assim, podese dizer que a abordagem qualitativa "busca a interpretação em lugar da mensuração, a descoberta da constatação, valoriza a indução e as- 
sume que fatos e valores estão intimamente relacionados, tornando-se inaceitável uma postura neutra do pesquisador" (André, 1995, p.17).

$\mathrm{Na}$ década de oitenta, a abordagem qualitativa tornou-se muito popular entre os pesquisadores da área de educação, inclusive os brasileiros. Apesar da hegemonia das abordagens qualitativas, André identificou diferentes interpretações do significado do termo "qualitativo": uns identificam "pesquisa qualitativa" com pesquisa fenomenológica, outros, como sinônimo de etnográfico, ou, além disso, como um grande guarda-chuva que abarca inclusive os estudos clínicos. A pesquisadora identifica ainda, "em outro extremo", um sentido bem popularizado de pesquisa qualitativa, identificando-a como aquela que não envolve números, isto é, na qual qualitativo é sinônimo de não-quantitativo.

O uso do termo "pesquisa quantitativa" para identificar uma perspectiva positivista de ciência é, conforme observou André, no mínimo reducionista: "associar quantificação com positivismo é perder de vista que quantidade e qualidade estão intimamente relacionadas" (André, 1995, p.24). E é principalmente por esta razão que a pesquisadora sugere uma revisão do caráter tão amplo e genérico do termo "pesquisa qualitativa":

Eu reservaria os termos qualitativo e quantitativo para diferenciar técnicas de coleta ou, até melhor, para designar o tipo de dado obtido, e utilizaria denominações mais precisas para determinar o tipo de pesquisa realizada: histórica, descritiva, participante, etnográfica, fenomenológica etc.

(André, 1995, p.24-25)

E acrescenta: 
Se num determinado momento [final do século XIX] foi até interessante utilizar o termo qualitativo para identificar uma perspectiva de conhecimento que se contrapunha ao positivismo, esse momento parece estar superado.

(...) Porém, a necessidade agora é ir além, ultrapassar a dicotomia qualitativaquantitativa e tentar encontrar respostas para as inúmeras questões com que nos defrontamos diariamente, entre as quais podemos citar: $O$ que caracteriza um trabalho científico? O que diferencia o conhecimento científico de outros tipos de conhecimento? Quais os critérios para se julgar uma boa pesquisa? O que se pode se considerar como válido e confiável na pesquisa? Como deve ser tratada a problemática da generalização? Qual o papel da teoria da pesquisa? Como articular o micro e o macrossocial? Como trabalhar a subjetividade na pesquisa? Quais as formas mais apropriadas de análise de dados qualitativos?

- grifo nosso - (André, 1995, p.25)

Não minimizando as questões que a pesquisadora levantou no parágrafo anterior - todas pertinentes ao âmbito do tema proposto -, mas procurando dar direção e sentido à nossa discussão metodológica, colocamos outra questão fundamental: qual deve ser a relação entre o instrumental metodológico da pesquisa com o conhecimento estudado e produzido no seu próprio âmbito? Para dar início a nossa reflexão, é interessante observar, conforme nos revelou André (veja grifo acima), que a abordagem qualitativa tenha se apresentado como "uma perspectiva de conhecimento que se contrapunha ao positivismo". Mas qual, ou melhor, quais são essas "perspectivas de conhecimento"? Creio que esteja realmente ai (ou, pelo menos deveria estar), nas "perspectivas de conhecimento" do autor da pesquisa, o motor e o elemento diferencial da metodologia que deverá empregar em seu trabalho, visto que a forma como irá desenvolver o seu trabalho perpassa, ainda que tacitamente, a atitude que o pesquisador tem em relação ao conhecimento.

Este vínculo entre a ação metodológica e a atitude epistemológica do pesquisador deve então ser explicitada para que a opção metodológica possa ter consistência e não ser apenas o fruto de interinfluên- 
cias do meio acadêmico. Por outro lado, temos consciência de que este "vínculo epistemológico", aqui pretendido, possa ser questionado por certos pesquisadores em função da natureza de sua pesquisa. No entanto, em se tratando de uma pesquisa de natureza epistemológica, cremos que o instrumental metodológico desta tese se cria no próprio "vínculo" que se estabelece com a atitude epistemológica assumida: o conhecimento como rede.

Assim, em consonância com as idéias acima e com o paradigma de conhecimento aqui assumido, encontramos, na idéia de "mapa" desenvolvida em (Santos, 2000), o elemento metodológico imprescindível para a realização desta tese. Em verdade, ao assumirmos o conhecimento como rede, e iniciarmos a nossa investigação das dificuldades de natureza epistemológica do ensino de Cálculo, será preciso elaborar mapas que possam nos guiar e que nos permitam penetrar e compreender a complexa malha que envolve o tema proposto. As raízes dessas dificuldades identificadas no processo didático da disciplina de Cálculo podem ser muito mais profundas do que aparentam ser. Será preciso, muitas vezes, visitarmos outros cenários, mudar de escala, e fazermos uso do "princípio de multiplicidade e de encaixe das escalas (ou da fractalidade)" da própria rede para que se possa entender o significado de um de seus nós ou feixe de relações. Antes porém de explicitarmos como faremos uso de tão valioso instrumento no desenvolvimento de nossa pesquisa, faz-se necessário que destaquemos alguns pontos fundamentais a seu respeito. 


\subsubsection{O mapa como instrumento metodológico}

"(..) é uma ironia suprema que os mapas,
apesar de serem uma das metáforas culturais mais comuns,
estejam ainda longe de ocupar o lugar que merecem na história das mentalidades".
Josef Konvitz
"E o esplendor dos mapas,
caminho abstrato para a imaginação concreta,
Letras e riscos irregulares abrindo para a maravilha".

Fernando Pessoa

Boaventura Santos (2000, p.200), a partir das citações das epígrafes acima, procura dar início ao desenvolvimento a sua "cartografia simbólica" do Direito. Recorrendo à cartografia, fonte original da idéia de mapa, Santos procura promover, na verdade, sua "cartografia simbólica" (ou sociologia cartográfica) como o instrumento de análise não apenas do direito mas, fundamentalmente, do novo tipo de conhecimento que se anuncia, fruto da transição paradigmática da ciência moderna para o conhecimento pós-moderno. Esta "re-significação" da idéia de mapa no terreno da epistemologia, além de original, é, sem dúvida, uma das maiores contribuições de Santos às investigações do novo conhecimento paradigmático que se apresenta:

"Em vez da eternidade, temos a história; em vez do mecanicismo, a interpenetração, a espontaneidade e a auto-organização; em vez da reversibilidade, a irreversibilidade e a evolução; em vez da ordem, a desordem; em vez da necessidade, a criatividade e o acidente".

(Santos, 2000, p.71)

Assim, diante da complexidade da realidade, é preciso que se busquem os elementos relevantes para a sua compreensão. $O$ real não é o que é, mas o que se pensa que é. Não se trata de remeter a realidade ao campo da subjetividade, mas de realçar o caráter complexo do real. Segundo o sociólogo, a principal característica estrutural dos 
mapas reside em que, para desempenharem adequadamente as suas funções, estes têm inevitavelmente de distorcer a realidade (Santos, 2000, p.200). São três os mecanismos principais da ação de mapear: a escala, a projeção e a simbolização.

A escala é "a relação entre a distância no mapa e a correspondente distância do terreno" (Monmonier, 1981, p.41), e, como tal, implica uma decisão sobre o grau de pormenorização da representação. Quanto maior a escala, maior o grau de pormenorização do mapa. A maior escala, a de 1:1, corresponde ao mapa de Borges ${ }^{17}$. No entanto, tal escala, como nos revelou o próprio Borges, é tão grande quanto inútil. Como diz Muehrcke, "o que torna o mapa tão útil é o seu gênio da omissão, é o reduzir da realidade à sua essência" (apud Santos, 2000, p.201). A escala é, com efeito, um "esquecimento coerente" que deve ser levado a cabo coerentemente (Racine et al., 1982, p. 126). Mudar de escala significa mudar de fenômeno, e se torna muitas vezes necessária e indispensável para que se possa entender a complexidade do fato real. Sobrepor escalas é, sem dúvida, um exercício intelectual imprescindivel para a compreensão do significado de um conceito, de uma dificuldade de aprendizagem ou mesmo de um obstáculo epistemológico. Uma sobreposição inevitável e imprescindível para a realização desta tese é, por exemplo, a de mapas de dificuldades de aprendiza-

\footnotetext{
${ }^{17} \mathrm{O}$ "mapa de Borges" é uma metáfora criada pelo escritor argentino para se fazer uma reflexão "do rigor na ciência". No seu texto "Del rigor en la ciencia" - citado a seguir - o autor destaca a funcionalidade da ação de mapear: “.... Em aquel imperio, el Arte de la Cartografia logro tal Perfeccíon que el mapa de una sola Provincia ocupaba toda uma Ciudad, y el mapa del Imperio, toda uma Provincia. Con el tiempo, esos mapas Desmesurados no satisficieron y los Colegios de Cartógrafos levantaron un Mapa del Imperio, que tenía el tamaño del Imperio y coincidía puntualmente con él. Menos Adictasal Estúdio de la Cartografia, lãs Generaciones Siguientes entedieron que ese dilatado Mapa era Inútil y no sin Impiedad lo entregaron a las Inclemencias del Sol y d los Inviernos. En los desiertos Del Oeste perduram despezdadas Ruínas Del Mapa, habitadas por Animales y por Mendigos; en todo el País no hay otra reliquia de las Disciplinas Geográficas" (Borges, 1999, p.119).
} 
gem dos conteúdos programáticos da disciplina de Cálculo com os mapas de dificuldades de aprendizagem do próprio ensino básico de matemática. Cabe lembrar que a grande aposta desta pesquisa é que a origem das dificuldades de aprendizagem no ensino de Cálculo se encontra em outros contextos que transcendem o seu próprio espaçotempo local. Outra sobreposição interessante de ser realizada é, por exemplo, a de mapas históricos conceituais do Cálculo com os mapas de dificuldades de aprendizagem dos conteúdos programáticos da disciplina de Cálculo. Tais exercícios intelectuais, além de outros também interessantes, serão realizados no capítulo seguinte deste trabalho. Antes porém, é preciso que se diga que a escolha das escalas apropriadas está associada, sem dúvida, a outro mecanismo básico da ação de mapear: a projeção.

Com efeito, a escolha das escalas é determinada pela intenção daquele que elabora o mapa, em consonância com os seus interesses, suas metas, enfim, com o projeto original do autor. A projeção representa sempre um compromisso e cada tipo de projeção cria então um campo de representação no qual as formas e os graus de distorção têm lugar segundo regras conhecidas e precisas (Santos, 2000, p.203). A decisão sobre o tipo e o grau de distorção a privilegiar é condicionada muitas vezes por fatores técnicos, mas não deixa de ser baseada na ideologia do cartógrafo e no uso específico a que o mapa se destina. Assim, podemos assegurar que não existe neutralidade $e$ ingenuidade nas atitudes de mapear. Nesse sentido, podemos dizer que se, por um lado, a escala determina o grau de pormenorização desejado, a projeção faz o mesmo com o grau de distorção pretendido. 
As dificuldades de aprendizagem no ensino de Cálculo têm sido estudadas através de projeções de natureza psicológica do problema de aprendizagem de um ou mais conceitos específicos do Cálculo. A fonte de nossas ações de mapear é bem outra: a epistemologia. Nessa perspectiva, o aluno não aprende não é porque não possui "estruturas cognitivas" apropriadas ao desenvolvimento de determinados conceitos, mas, isto sim, porque ainda não construiu os nós e os feixes de relações de conhecimentos necessários para se estabelecer novas conexões e a incorporação de novos nós à rede já construída. A rota a ser seguida, nesse caso, não é a história individual e psicológica do aprendiz, mas a das redes de conhecimentos construídas pelo "sujeito normal" ${ }^{18}$ no processo didático e não as circunstâncias particulares de cada aprendiz em casos específicos. Sobrepor os mapas históricos e conceituais do Cálculo Diferencial e Integral e os mapas das dificuldades de aprendizagem no ensino de Cálculo nos permitirá visualizar o problema em questão numa perspectiva mais global. Confrontar os obstáculos epistemológicos relativos aos conceitos e procedimentos básicos do Cálculo com as dificuldades de natureza epistemológica do ensino de Cálculo é, sem dúvida, um dos principais exercícios intelectuais que esta tese se propõe a realizar. O que está em foco, repito, é o conhecimento ensinado e o conhecimento que o sujeito aprendiz dispõe para a aprendizagem e não as condições psico-cognitivas do sujeito aprendiz.

\footnotetext{
${ }^{18}$ Com a expressão "sujeito normal”, criada nesse parágrafo, queremos caracterizar o elemento abstrato e idealizado do aluno mediano de um curso "normal”, que é portador das dificuldades de aprendizagem usualmente identificada pelos professores no curso citado, mas, que, por outro lado, não apresenta nenhuma deficiência psíquica / linguística que o impeça de realizar o seu processo de aprendizagem. No caso específico do ensino de Cálculo, procuraremos caracterizar o "aluno normal” de um curso normal de Cálculo Diferencial e Integral no capítulo 5 desta tese.
} 
É nesse sentido que afirmamos que a projeção a ser usada em nossa ação de mapear é de natureza epistemológica.

A simbolização é o terceiro grande mecanismo da representação/distorção cartográfica da realidade. Diz respeito aos símbolos gráficos usados para assinalar os elementos e as características da realidade espacial selecionados. Assim, se a escala indica o "grau de pormenorização da realidade" e a projeção o "grau de distorção", a simbolização indica a "forma de representação" da mesma segundo a escala e a projeção realizada. Se a palavra-chave associada à projeção é projeto, a relacionada à escala é relevância, e à simbolização, é linguagem.

Assim, à medida que discorremos e aprofundamos mais a idéia de mapa como um instrumento metodológico, mais ele apresenta sua afinidade com o paradigma de conhecimento enquanto rede. Na discussão esboçada acima de cada mecanismo básico da ação de mapear, o conhecimento foi considerado enquanto rede $e$, curiosamente, foram considerados e citados alguns dos "princípios conformadores" do hipertexto de Levy. Esta feliz e formal coincidência do par redes/mapas só fortalece a nossa intenção de utilizarmos a idéia de mapa como o principal instrumento metodológico desta pesquisa. 

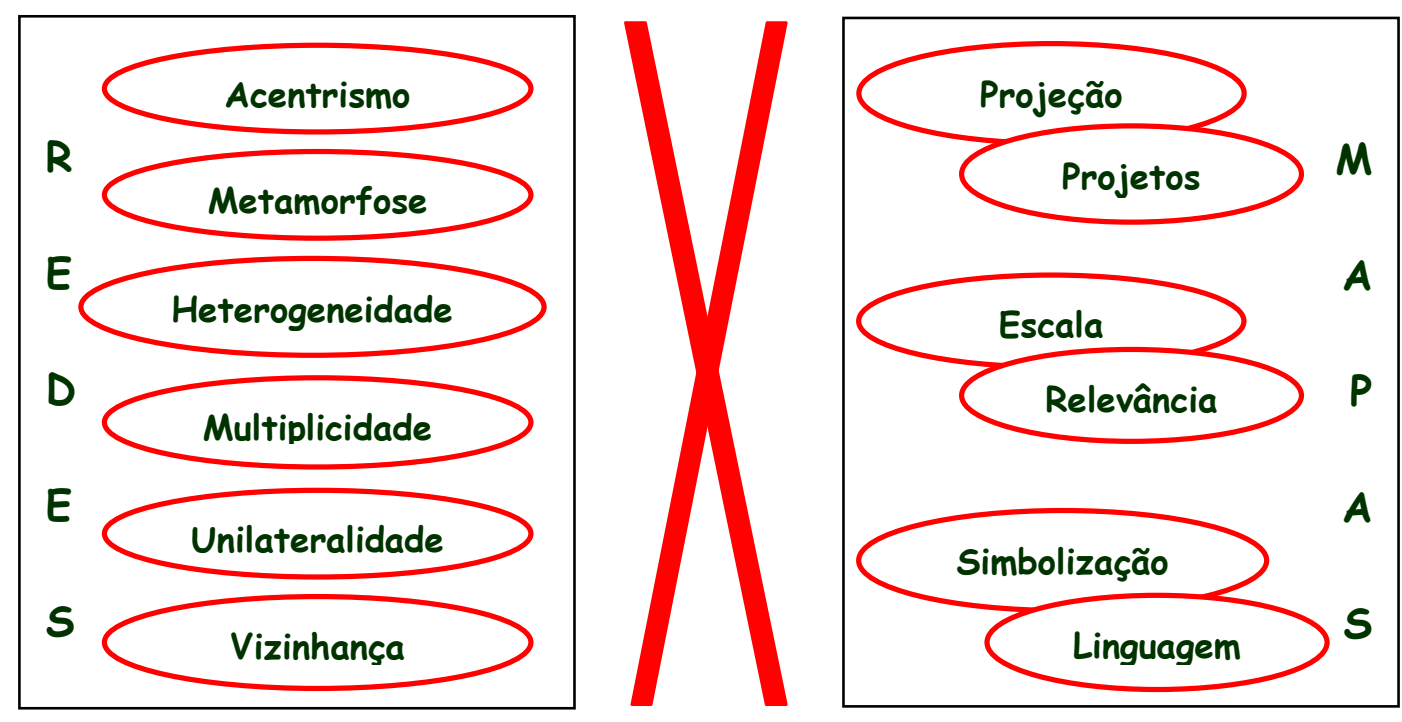

Apesar de recente, a abordagem cartográfica já tem sido alvo de críticas. A principal delas diz respeito a sua possivel semelhança com o formalismo analítico. Não vemos, assim como Boaventura Santos, esta dicotomia entre o formal e o informal, e, além disso, concordamos com o autor quando este afirma que "o quê" do acontecer só é susceptível de explicação enquanto "como" do acontecer:

A abordagem cartográfica parte do postulado de que os interesses grupais ou de classe fazem acontecer tudo mas não explicam nada. E isto porque a explicação nunca explica o que acontece mas antes o como acontece, ou, por outras palavras, porque "o quê" do acontecer só é susceptivel de explicação enquanto "como" do acontecer. As regras da escala, da projeção e da simbolização dirigem-se ao "como" do acontecer enquanto via única de acesso ao "quê" do acontecer. Uma abordagem deste tipo, atenta à mecânica terrestre das coisas, pode ser acusada de formalismo analítico. Julgo, no entanto, que o nosso século tem sido demasiadamente polarizado pela oposição formal/informal, tanto na ação social, como na análise científica, tanto na arte como na literatura. Agora que nos aproximamos do fim do século, é tempo de vermos o formal no informal e o informal no formal e não assumir posições dogmáticas a respeito da positividade ou negatividade de qualquer deles.

(Santos, 2000, p.223)

Com efeito, hoje se faz necessário cada vez mais "imaginar o mar nos cálices", assim como "saber imaginar os cálices no mar". Nesse sentido, a idéia de mapa, associada ao conhecimento enquanto rede, se 
apresenta como um valioso instrumento nessa nova perspectiva epistemológica:

Durkheim ensinou-nos que a consciência individual era um cálice demasiado pequeno para nele caber o néctar do conhecimento científico. (...) Hoje, é tão necessário saber imaginar o mar nos cálices, como saber imaginar os cálices no mar. Os mapas são talvez o objeto cujo desenho está mais estritamente vinculado ao uso que se lhes quer destinar. A incompletude estruturada dos mapas é a condição da criatividade com que nos movimentamos entre os seus pontos fixos. De nada valeria desenhar mapas se não houvesse viajantes para os percorrer.

(Santos, 2000, p.224)

Com certeza Santos, "de nada valeria desenhar mapas se não houvesse viajantes para os percorrer".

\subsubsection{A construção dos mapas históricos e concei- tuais do Cálculo e das dificuldades de aprendi- zagem de natureza epistemológica do seu ensino}

Tendo em vista o principal objetivo desta pesquisa - que é o mapeamento e a análise das dificuldades de natureza epistemológica do ensino de Cálculo - foram imaginados dois cenários distintos para as nossas reflexões: um inicial, relacionado ao próprio Cálculo, acerca do seu significado e do seu desenvolvimento histórico enquanto área própria do conhecimento matemático; e um outro, aí sim, relacionado ao ensino das idéias e procedimentos do Cálculo no âmbito do ensino de matemática.

No primeiro cenário o que se busca é determinar a essência do Cálculo, o fluxo evolutivo de suas idéias e procedimentos básicos, tendo como referência a visão de especialistas e historiadores da matemáti- 
ca. A revisão histórica que se propõe aqui permitirá observar com mais clareza o fluxo evolutivo das idéias fundamentais do Cálculo, bem como as suas dificuldades de precurso, "as causas de estagnação, e até de regressão". O que está em foco é o fluxo das idéias, de seus significados, como um conceito deu origem a outro, como está relacionado a outro. Há de se ressaltar que o esforço pretendido aqui é essencialmente de natureza epistemológica e tem como principal fonte inspiradora os estudos desenvolvidos por Bachelard (1996), La Formation de l'espirit scientifique (1938), sobre obstáculos epistemológicos.

"Quando se procuram as condições psicológicas do progresso da ciência, logo se chega à conviç̧ão de que é em termos de obstáculos que o problema do conhecimento científico deve ser colocado. Enão se trata de considerar obstáculos externos, como a complexidade e a fugacidade dos fenômenos, nem de incriminar a fragilidade dos sentidos e do espírito humano: é no âmago do próprio ato de conhecer que aparecem, por uma espécie de imperativo funcional, lentidões e conflitos. É ai que mostraremos as causas de estagnação e até de regressão, detectaremos causas de inércia às quais daremos o nome de obstáculos epistemológicos".

(Bachelard, 1996, p.17)

Assim, a partir da revisão histórica do desenvolvimento do Cálculo, teremos então elementos suficientes para realizar a construção, para cada idéia essencial do Cálculo, de um mapa histórico-conceitual de sua rede de significações. Conceitos como derivada, integral, limite, infinitésimo, função e variáve/merecerão destaques e atenção especial em nossa síntese histórica e epistemológica. Os dois primeiros são efetivamente as duas idéias fundamentais do Cálculo, e constituem, desde sua origem, os seus dois grandes eixos temáticos; os dois seguintes constituem seguramente as unidades construtoras dos procedimentos e idéias básicas do Cálculo; e os dois últimos são os principais responsáveis pelo desprendimento do Cálculo do estilo geométrico. 
Realizada a construção de mapas históricos e conceituais do Cálculo, teremos instrumentos que servirão de guia para as nossas futuras reflexões de natureza epistemológica acerca das dificuldades de aprendizagem no ensino de Cálculo. A ação de mapear essas dificuldades será, então, o resultado de uma viagem que faremos no segundo cenário (do ensino de Cálculo) munido, dentre outros instrumentos de análise, dos mapas histórico-conceituais do Cálculo construídos no primeiro momento.

Por outro lado, ao se pensar um planejamento para essa viagem, surgem algumas questões fundamentais e de natureza metodológica, que precisam ser esclarecidas a priori, como por exemplo: quais são as fontes e procedimentos de observações que adotaremos em nossa ação de mapear as dificuldades de aprendizagem de natureza epistemológica do ensino de Cálculo, isto é, onde efetivamente iremos buscar os fatos que irão motivar nossas interpretações e como estas serão realizadas? E, mais especificamente, quais são os critérios que adotaremos para a seleção das dificuldades de aprendizagem no ensino de Cálculo?

Mais uma vez recorreremos aqui à irreverência e maestria de Boaventura Santos. Ao discorrer sobre a "epistemologia do lixo", Santos (2000, p.239) faz severas críticas à poluição provocada pela ciência moderna:

Ao rejeitar todos os conhecimentos alternativos, a ciência moderna revelouse como uma produtora de lixo, condição que todos nós, - uns, poucos privilegiados habitantes da sociedade de consumo e outros, a esmagadora maioria, habitantes da sociedade da ideologia de consumo -, de igual modo partilhamos. Esta é, por sinal, uma dimensão mais da referida epistemologia do lixo, e mesmo de uma economia política simbólica de produção de resíduos na ciência moderna. Duas interrogações se impõem a este respeito: quanto lixo é preciso fazer para produzir conseqüências científicas? Quem sofre mais com a poluição daí resultante? 
Assim, em consonância com a "epistemologia do lixo" defendida por Boaventura Santos, reconhecemos a existência no ambiente acadêmico das pesquisas já produzidas em relação ao tema proposto nesta tese de um maravilhoso "lixão" ${ }^{19}$ constituído de inúmeras experiências e resultados acerca das "dificuldades de aprendizagem no ensino de Cálculo". Pesquisas como as de Cabral (1992 e 1998) e de Rezende (1994) (esta última, produzida no período de 1992 a 1994, é de nossa autoria) são exemplos do que estamos falando. Assim, não vimos necessidade da realização de uma outra pesquisa de campo para "embasar" as nossas investigações - entendemos que as experiências e resultados já produzidos pela academia, aliados à nossa própria experiência como professores de Cálculo, nos fornecem um elenco de dados suficientes para a nossa análise.

Ainda no que concerne à epistemologia do lixo, Santos (2000, p.238) revela-nos duas atitudes antagônicas em relação ao valor semântico do lixo:

Enquanto a Arqueologia é perita em identificar resíduos a fim de explicar a evolução de padrões de comportamentos, a Economia convencional é perita em identificá-los para os rejeitar como lixo. Não deixa de ser irônico que aquilo que os arqueólogos do século XXI vierem a descobrir a nosso respeito será revelado pelo lixo que deixamos (Deagan, 1989), uma circunstância que devia alertar-nos para o caráter situacional dos nossos resultados científicos, bem como para a relevância que Ihes atribuímos. Não é tão fácil rejeitar a epistemologia do lixo como o próprio lixo.

Nesse sentido, pode-se dizer que nossa atitude para com o "lixo acadêmico" está muito mais para a atitude do arqueólogo do que para a do economista convencional. Assim como para o arqueólogo, o "lixo" constitui efetivamente a nossa fonte de observações.

\footnotetext{
${ }^{19}$ Lixo no sentido positivo alinhavado por Santos
} 
Outro elemento que precisamos definir - já com o foco voltado para a justificativa dos critérios adotados para selecionar as dificuldades de aprendizagem no ensino de Cálculo - é nosso conceito de "aluno normal". Não se trata, certamente, de nenhum conceito estatístico, ao contrário, o seu universo se encontra, na verdade, nas lutas paradigmáticas travadas na academia e no ambiente pedagógico sobre o perfil que se tem do aluno de Cálculo. Assim, este conceito é uma abstração coletiva e uma idealização dos alunos de Cálculo que, de certa forma, participaram das pesquisas aqui mencionadas e das experiências didáticas no ensino de Cálculo dos autores aqui citados. Desse modo, divido com os demais autores e colegas a responsabilidade da produção dos dados relativos às dificuldades de aprendizagem do "aluno normal" de uma disciplina inicial de Cálculo. Assumo, no entanto, total e exclusiva responsabilidade pela seleção, análises e interpretações desses dados.

Gostaríamos de enfatizar, mais uma vez, que as dificuldades selecionadas aqui são de natureza epistemológica, não interessando aquelas de fundo emocional, de natureza psicológica, técnica, ou de qualquer outro tipo. Apesar de entender que algumas das pesquisas analisadas neste trabalho remetem o conceito de aprendizagem ao campo das teorias psicológicas da construção do conhecimento - as teorias psicocognitivas de aprendizagem - deixamos claro que esta não é a nossa forma de pensar: preferimos a interpretação deste conceito no terreno da epistemologia. 
Parafraseando Dewey, Machado (1995, p.34) traduz para nós o sentido exato daquilo que entendemos por aprender/compreender (o que para nós é a mesma coisa):

Compreender é apreender a significação... Apreender a significação de uma coisa, de um acontecimento ou situação é ver a coisa em suas relaçôes com outras coisas... Contrariamente, aquilo a que chamamos coisa bruta, a coisa sem sentido para nós, é algo cujas relações não foram apreendidas. (grifo nosso)

(Dewey, 1979, p.139 - apud Machado, 1995, p.35)

Com efeito, aprender alguma "coisd" é "ver a coisa em suas relações com outras coisas". A construção do conhecimento é um permanente entrelaçamento de significados onde a "coisd" a ser aprendida (ou apreendida) se tornará parte integrante da urdidura da nova rede de conhecimentos do aprendiz. As formas como isso se processa internamente no sujeito aprendiz não são de nossa competência e nem de nosso interesse neste trabalho, nem tampouco as interpretações de natureza psicológica do conceito de aprendizagem. A interpretação epistemológica do conceito de aprendizagem supracitada é efetivamente um dos pilares que dão sustentação ao nosso critério de seleção das dificuldades de aprendizagem - o elemento essencial das projeções nas nossas ações de mapear.

Assim, em consonância com nosso paradigma de conhecimento (rede) e com nosso instrumental metodológico (mapa), pode-se afirmar, grosso modo, que nossa pesquisa consiste de uma "viagem" pelo Cálculo e seu ensino, em cuja tripulação assumimos o papel de cartógrafo, procurando construir mapas históricos e/ou conceituais em diversas escalas e contextos das idéias do Cálculo e das dificuldades de aprendizagem de natureza epistemológica de seu ensino. O processo de simbolização a ser utilizada na confecção dos mapas é específico de cada ma- 
pa a ser construído e será explicitada com mais precisão no momento oportuno. 


\section{Uma cartografia simbólica do Cálculo}

O que é o Cálculo? Tentar responder a esta pergunta inspira dificuldades de mesma natureza das de tantas outras, já formuladas, mas não respondidas, como, por exemplo: o que é geometria? o que é matemática? o que é física? etc. Além das dificuldades de se tentar "isolar" determinada área do conhecimento - como se isto fosse possível - devemos ter em mente o caráter capcioso de perguntas dessa natureza: "o que é... ?". Por outro lado, entendemos que fazer esse tipo de questão é necessário para que se faça, durante a impossivel tarefa de respondê-la, uma reflexão profunda sobre aquilo de que se quer apreender o significado. Um belo exemplo desse salutar exercício filosófico é o conhecido trabalho de R. Courant \& H. Robbins (1967) sobre "O que é matemática?". Cautelosos com relação à amplidão da questão-título de sua obra, os autores afirmam que a única possibilidade de se alcançar a resposta para a pergunta proposta é a "experiência ativa na própria matemática":

"Tanto para eruditos quanto para leigos não é a filosofia, mas a experiência ativa na própria matemática que unicamente pode responder à questão: o que é matemática?"

Assim, com o objetivo de apreender o significado do Cálculo, consideraremos, de modo igual aos autores citados acima, a nossa "experiência ativa" 20 no Cálculo, mas, contrário aos mesmos, não abriremos mão do potencial crítico da filosofia. Entendemos que para buscar a essência do que seja o Cálculo, precisaremos muitas vezes lançar mão 
dos conhecimentos e procedimentos da filosofia - até porque a "experiência ativa" mostra, quase sempre, e tão somente, aquilo que é mais evidente: uma superficialidade aparente. Assim, para que se possa enxergar o Cálculo além da sua "própria" experiência "ativa", e transcender a "superficialidade aparente" dessa "experiência ativa", precisaremos estabelecer relações com outros campos do conhecimento, seja a física, a matemática - ou partes ${ }^{21}$ destas -, ou mesmo a própria filosofia e a história da ciência.

Nesse sentido, é indiscutível que o estudo do desenvolvimento histórico do Cálculo fornece subsídios que nos possibilitem apreender a essência do Cálculo, de suas idéias e procedimentos básicos. Além disso, tal revisão histórica fornecerá, conforme já foi dito no capítulo anterior, os elementos imprescindíveis a construção dos mapas históricos e conceituais das idéias e dos procedimentos básicos do Cálculo.

No entanto, antes de iniciarmos a nossa jornada histórica, é interessante que façamos um painel panorâmico do Cálculo e de suas idéias básicas. Tal painel, feita com base em opiniões de especialistas, "velhos" capitães que certamente já navegaram por esses mares, servirá como guia para as nossas investigações históricas e epistemológicas.

\footnotetext{
${ }^{20}$ Tentando evitar o caráter subjetivo do que seja ou não "ativa” na expressão citada pelos autores, procuramos caracterizar a nossa "experiência ativa" como a nossa experiência docente e de estudos sobre o Cálculo.

${ }^{21}$ A Geometria e a Análise, na Matemática, e a Mecânica, na Física, são exemplos do que está se afirmando aqui.
} 


\subsection{O que é o Cálculo? Uma visão preliminar}

Segundo Baron \& Boss (1985, v.1, p.1) é muito "mais fácil dizer o que o Cálculo faz do que dizer o que o Cálculo é". Justifica tal afirmação argumentando que, fora dos ambientes acadêmicos, aqueles que se preocupam com o cálculo infinitesimal, de uma maneira ou de outra, estão mais interessados em suas aplicações do que com sua essência. Não é esse o nosso caso, educadores matemáticos, que buscamos o entendimento do Cálculo, do seu papel no ensino de matemática e dos significados produzidos por ele. Reconhecer a dificuldade e o caráter capcioso da questão formulada é sensato, mas fugir a uma tentativa de resposta é, no mínimo, uma falta de compromisso com o objetivo tácito da questão que é a busca da essência do Cálculo. Longe de querermos encontrar a "resposta certa" - até porque temos consciência de que ela não existe, e, ainda que existisse, se modificaria com o avançar do próprio conhecimento científico como um todo -, o que pretendemos nesta seção é esboçar um desenho das idéias relativas ao que o Cálculo é, e não do que ele faz e é capaz de fazer. Entendemos que é através desse esforço coletivo, que buscaremos um entendimento comum a respeito da essência do Cálculo.

Antes de prosseguirmos em nossa discussão é interessante observar que muitos professores (alguns inclusive autores de livros didáticos de (álculo) circundam a questão, procurando - conforme citaram Baron e Boss - enumerar a relevância dos conceitos básicos do Cálculo ou suas principais aplicações. Outra confusão que às vezes se estabelece é a identificação do Cálculo, parte integrante do conhecimento 
científico, com o seu representante pedagógico: a disciplina de Cálculo. Tomaremos aqui o devido cuidado para não estabelecermos nenhuma confusão desse gênero, até porque a disciplina de Cálculo terá a sua devida atenção em outro momento deste trabalho, mais precisamente, na seção 5.1.

Morris Kline (1998, p.5), ao tentar estabelecer a "natureza do Cálculo" em seu livro "Calculus: an intuitive and physical approach", procura resgatar a origem etimológica da palavra "calculus". "Calculus", segundo o autor, vem da palavra latina para "pedregulho", que se associou à matemática por causa dos antigos matemáticos gregos de aproximadamente 600 a.C. que faziam aritmética com ajuda de pequenas pedras. É notório que o significado etimológico da palavra "calculus", assim como a matemática praticada pelos antigos gregos, está muito longe daquilo que entendemos hoje por "Cálculo", ou, mais precisamente, por "Cálculo Diferencial e Integral".

É indiscutível a relevância do Cálculo para o desenvolvimento do conhecimento científico. Morris Kline considera o Cálculo como "a criação matemática mais importante" do século XVII tanto para o desenvolvimento das ciências naturais quanto da própria matemática. Segundo o historiador, o Cálculo, assim com a geometria euclidiana, marca toda uma época do pensamento humano. "The Calculus", como se referem os anglo-saxões para diferenciá-lo de outros "cálculos", é, de fato, o cálculo por excelência. Poderíamos dizer mais: o Cálculo foi (e continua sendo) fundamental para a organização do próprio conhecimento matemático. Se a geometria e a aritmética representam a base, isto é, os pés, do corpo do conhecimento matemático, poderíamos dizer, metaforicamente, que o Cálculo representa a sua "espinha dorsal". 
Com efeito, sem a construção das idéias básicas do Cálculo, a geometria não passaria do cálculo de áreas e perímetros de regiões poligonais, e de volumes de figuras poliédricas, e a teoria dos números se restringiria ao domínio dos racionais. O Cálculo, historicamente, tomou emprestado da geometria e da aritmética, e também da física, alguns conceitos e problemas fundamentais, e desenvolveu novos instrumentos para solucioná-los, retornando sempre aos "conceitos envolvidos", em um nível superior de significação. O conjunto dos números reais e o conceito de função, junto com a geometria analítica, foram, sem dúvida, algumas das maiores reinvenções do Cálculo. É este caráter potencializador e integrador do Cálculo que o torna um elemento de organização, sustentação e criação imprescindível para a formação do próprio conhecimento matemático e científico.

Elogios à relevância do Cálculo, seja para a matemática, ou para a ciência em geral, é bastante costumeiro. Lazare Carnot, matemático francês do final do século XVIII e início do XIX, atribuiu ao Cálculo, em sua obra Reflexions, por exemplo, o título de "uma das revoluções mais rápidas e felizes" que já havia sido produzido na ciência até então. Entretanto, um destes elogios despertou nossa curiosidade por sua característica bem atípica em relação às demais. Nele, o autor estabelece uma relação entre a estrutura semântica do Cálculo e a boa "saúde" psíquica do ser humano: 
Não é exagero se dizer que o cálculo é um dos métodos mais estimulantes, mais criativos e estruturais da matemática. Há pouca dúvida de que a análise dos fundamentos da matemática, e sua revisão, foram sugeridas por um estudo dos métodos do cálculo. Ele é, estrutural e semanticamente, a "lógica" da razão e, como tal, pode ser dado fundamentalmente sem detalhes técnicos pelo presente Asistema e treinomento semântico, com a ajuda do Diferencial Estrutural.

(...)Ele [o cálculo] é o único método estrutural que pode se harmonizar com as ainda irreconciliáveis abstrações de ordens superiores e inferiores. Sem essa conciliação, em nosso atual nível de desenvolvimento, a razão é uma questão de sorte ainda bastante além do nosso controle consciente e educacional.

(Korzybski, 2000, p.574-575)

A explicação da tese levantada por Korzybski, bem como a dos conceitos de que faz uso em sua citação, fogem ao escopo desta tese. Não pretendemos aprofundar essa discussão de natureza psicológica da salutar influência da estrutura e do campo semântico do Cálculo na formação do "bom senso" do ser humano, mas discutiremos, isto sim, nas considerações finais desta tese, sobre o teor da abordagem nãostandard proposta pelo autor para o Cálculo. Sua abordagem infinitesimal, ou melhor, "indefinitesimal", é de extrema relevância para o desenvolvimento deste trabalho. Mas, conforme já dissemos, este assunto fica para um momento mais oportuno do nosso trabalho; por ora, voltemos à nossa discussão inicial em busca da essência do Cálculo.

A fim de lançar uma luz inicial em nossa discussão, formulamos as seguintes perguntas: Quais são os problemas que motivaram a construção das idéias e dos conceitos básicos do Cálculo? Quais são, afinal, tais idéias e conceitos fundamentais do Cálculo? E, precisamente, em que momento histórico o Cálculo se constituiu efetivamente como um domínio próprio do conhecimento matemático? Note que na última questão não estamos nos referindo à origem das idéias básicas do Cálculo, mas ao surgimento do próprio Cálculo como área do conhecimento matemático. Essas perguntas não apresentam respostas consensuais e 
estão intimamente relacionadas entre si, e todas elas estão associadas certamente à idéia que se tem do que seja o Cálculo.

Morris Kline (1998, p.VIII), por exemplo, no prefácio do seu livro "Calculus: an intuitive and physical approach", tomando o século XVII como marco da origem do Cálculo, destaca quatro classes de problemas que, em sua opinião, motivaram a criação deste "importante" campo do conhecimento matemático:

- problemas relacionados a movimentos; determinação de trajetórias e de velocidades instantâneas:

- determinação de tangentes a várias curvas;

- problemas de máximos e mínimos:

- comprimentos de curvas e áreas e volumes de figuras limitadas.

Procurando dar uma interpretação mais global das questões e idéias fundamentais relativas ao Cálculo, Machado (1998, p.148) procura sintetizá-las nas duas operações básicas dessa área do conhecimento matemático: a diferenciação (derivação) e a integração. Segundo o professor:

o Cálculo Diferencial e Integral trata de questôes relacionadas com a medida da rapidez com que as grandezas aumentam ou diminuem, os objetos se movem ou as coisas se transformam. Tratam também das questões envolvendo a interpretação de grandezas que variam continuamente como se variassem através de pequenos patamares onde se manteriam constantes, conduzindo a somas com um número cada vez maior de parcelas cada vez menores. A medida da rapidez de variação conduz à noção de derivada: o estudo das somas com muitas pequenas parcelas conduz à noção de integral. Ambas as noções têm que ver, em suma, com a aproximação de curvas por retas, ou de fenômenos não-lineares por descrições lineares, recurso fundamental em múltiplas e distintas situaçôes. O processo através do qual uma curva é aproximada por uma reta que lhe é tangente é a diferenciação ou derivação; a aproximação de curvas por retas como a que tem lugar, por exemplo, no cálculo de áreas, dá origem ao processo de integração. (grifo nosso). 
Machado, desta forma, reduz e enquadra as quatro categorias de problemas citadas por Kline em apenas duas centrais: o problema da variabilidade e o problema da multiplicidade, ou melhor, da "unidade na multiplicidade".

O estudo quantitativo de variabilidade foi desenvolvido pelos escolásticos no século XIV. A abordagem dos filósofos foi essencialmente dialética, mas representou do ponto de vista quantitativo um enorme avanço em relação à filosofia peripatética de Aristóteles e à dialética de Heráclito. Mas em que consiste medir essa variabilidade? Qual é o significado, por exemplo, do conceito de velocidade instantânea? O instrumento que usamos hoje para realizar esta medida é o conceito de derivada - depois de resolvido, o problema parece simples, mas os registros históricos mostram exatamente o contrário. Vejamos, por exemplo, o sentimento de angústia que este problema provocou em Santo Agostinho:

"Que meço eu, pergunto-te, Deus meu, quando digo ou aproximadamente: este tempo é mais longo que aquele, ou precisamente: este tempo é o dobro daquele? Meço o tempo, eu sei; mas não meço o futuro, que não existe ainda, não meço o presente, que não ocupa nenhum intervalo, não meço o passado, que já não existe. Mas que meço então? Talvez o tempo no ato de passar, e não já quando passou?"

Santo Agostinho, Livro XI das Confissóes, Pensadores (1999).

E foi certamente este "agarrar o instante fugaz", para usar a bela expressão do historiador de matemática Morris Kline, que se tornou, mais de um milênio depois de Santo Agostinho, o primeiro grande problema de Fermat e Pascal, de Newton e Leibniz, e que motivou a construção do cálculo diferencial. No entanto, o domínio completo da problemática levantada por Santo Agostinho só foi resolvido com a 
construção do atual conceito de derivada. Até a solução da questão, as aflições desse gênero perseguiram as grandes mentes que tentavam de todo modo compreender a natureza desse "tempo fugaz". Em grande parte da história do Cálculo - inclusive no período de sua "invenção", o século XVII -, esse "tempo fugaz" se refugiou nas noções de infinitésimos ou quantidades infinitamente pequenas. Por conta dessa associação, foram rotuladas como "fantasmas de quantidades desaparecidas" ou "coisas não-existentes", até que, numa etapa mais adiante do processo histórico, se associou aos conceitos de variável e de limite. Paralelamente a este processo, o procedimento de "medida" das variações instantâneas passou da idéia inicial de razão de quantidades infinitamente pequenas ou de últimas razões, no século XVII, ao cálculo de limite do quociente de duas quantidades variáveis que estabelecem entre si um certo tipo de relação a priori - o conceito de derivada, no século XIX. Cabe aqui ressaltar o importante papel que teve o conceito de função no processo de clarificação e fundamentação das idéias básicas do Cálculo. Este conceito, que hoje, junto com o conceito de número, se tornou um elemento fundamental da estrutura do próprio conhecimento matemático foi, de fato, um dos principais responsáveis pela solução do problema da medida instantânea de variação.

Isto posto, pode-se perceber que o problema da variabilidade é que motivou essencialmente a construção da noção de derivada - instrumento fundamental para o cálculo de velocidades instantâneas, de tangentes, de valores máximos e mínimos de funções reais, e para a solução de outros problemas do âmbito do cálculo diferencial. No entanto, um outro grupo de problemas - cálculo de comprimentos, de áreas, e de volumes de configurações curvilíneas - possibilitaram a de- 
finição de outro conceito fundamental do Cálculo: a integração. Todos esses problemas inspiradores da noção de integral, têm raízes no âmbito da segunda categoria de problemas levantados por Machado: o problema da "unidade na multiplicidade".

A origem desta outra categoria de problemas está relacionada com o surgimento e desenvolvimento da filosofia eleática, com destaque para Parmênides, o patriarca da escola, e Zenão, o seu pupilo rebelde. A perseguição da "unidade e a invariabilidade do mundo" é com certeza o postulado fundamental da explicação filosófica de Parmênides para os fenômenos da natureza. A influência desta perseguição eleática da "unidade na multiplicidade" no desenvolvimento do Cálculo pode ser observada, por exemplo, na aplicação do método de exaustão - método em que se procurava "exaurir" uma sequiência de áreas de polígonos inscritos (e/ou circunscritos) em um círculo com a meta de encontrar a área deste último. Os gregos, apesar de terem desenvolvido o método de exaustão, evitaram explicitamente o procedimento infinito, expulsando este para o mundo das "descobertas e intuições". Mas os filósofos escolásticos, inseridos em outra realidade histórica e científica, assumem o conceito de infinito, e a existência do elemento que traduz a "unidade" deste processo (no caso do cálculo da área do círculo, Nicolau de Cusa considera, sem nenhum constrangimento, o círculo como um polígono de infinitos lados). Novamente aqui, o conceito que possibilitará a clarificação e fundamentação desta outra idéia fundamental do Cálculo, a integração, é a operação de limite. Por outro lado, pode-se afirmar que em todas as tentativas de soluções dos problemas motivadores do cálculo integral a essência da idéia de integração tem raízes na busca "parmenidiana" do elemento unificador das 
múltiplas e consecutivas aproximações. Cabe ressaltar aqui, entretanto, que outro instrumento matemático foi importantíssimo para a construção da noção de integração: as séries infinitas.

Desde as séries desenvolvidas pelos escolásticos, no século XIV, até a soma de Riemann, no século XIX, este poderoso instrumento do Cálculo carregou dentro de si uma dualidade essencial para o desenvolvimento do Cálculo, mas cuja solução consideramos como objeto da Análise: estamos falando da dualidade contínuo/discreto.

Concordando com os demais autores sobre a origem do Cálculo 22, Boyer foi buscar, também na Grécia antiga, o fio condutor deste outro problema fundamental do Cálculo. Segundo o autor:

O Cálculo teve sua origem nas dificuldades lógicas encontradas pelos antigos matemáticos gregos em suas tentativas de expressar suas idéias intuitivas sobre razões ou proporcionalidades de linhas, que vagamente eles reconheciam como contínuas, em termos de números, que eles consideravam como discretos.

(Boyer, 1949, p.4)

Com efeito, essa dualidade contínuo/discreto, presente neste problema de medida, e não superado pelos matemáticos gregos, é realmente um dos elementos construtores e unificadores do Cálculo. Essa dualidade se manifesta, sem dúvida, em outros problemas importantes do Cálculo, inclusive naqueles mencionados por Kline e que foram aqui destacados. Afinal, quando aproximamos uma curva por uma sequiência de linhas poligonais para calcular o seu comprimento, ou uma região plana limitada por uma curva por uma exaustão de polígonos, quando pretendemos calcular a sua área etc., estamos fazendo, a priori, uma aproximação discreta (por uma seqüência de linhas poligonais, ou de

\footnotetext{
${ }^{22}$ Para ele o Cálculo se constituiu como domínio próprio através dos algoritmos desenvolvidos por Newton e Leibniz no século XVII.
} 
polígonos, ou de sólidos, conforme o caso) de uma representação contínua (a curva, a região plana, ou o sólido em questão). Na verdade, nas circunstâncias em que os procedimentos do Cálculo se tornam imprescindíveis, tal aproximação, além de discreta, é infinita. Nestes casos, a operação de limite, que é infinita, se faz necessária, esteja ela na sua versão intuitiva ou dissimulada na noção de infinitesimal. Acreditamos não ter opositores quando afirmamos que ambos os conceitos são com efeito aqueles essenciais do pensamento "analítico" 23 - a forma própria de pensar do Cálculo Diferencial e Integral.

Por outro lado, a idéia de infinitésimo sempre esteve associada, de alguma forma, à noção de infinito, seja ele resultado de um processo de divisão ad infinitum ou uma quantidade variável que tende a zero. Assim, ao assumirmos que as noções de limite e de infinitésimo são os conceitos essenciais do pensamento analítico, somos também obrigados a reconhecer que a noção de infinito é o principal agente dos procedimentos básicos do Cálculo.

É verdade que o conceito de infinito foi repudiado pela matemática grega, mas também é verdade que os gregos não resolveram o problema da medida e que as "quantidades infinitamente pequenas" sobreviveram clandestinamente nos métodos de "descobertas" 24 - fato nem sempre revelado pelos próprios matemáticos. A história do infinito confunde-se com a própria história do Cálculo. Na verdade ela supera

\footnotetext{
${ }^{23}$ Alguns autores que desenvolvem trabalhos na linha de pesquisa de "pensamento matemático avançado" denominam a forma própria de pensar do Cálculo de "pensamento diferencial". Prefiro a expressão "pensamento analítico" por razões históricas, visto que este modo de pensar próprio do Cálculo, desenvolvido por Newton e Leibniz no século XVII, teve sua origem nos métodos analíticos desenvolvidos por Fermat e Descartes.

${ }^{24}$ Um exemplo claro disso é o método mecânico de Arquimedes, que foi intensamente usado pelo matemático para descobrir resultados, mas renegado pelo próprio na hora de apresentar as suas demonstrações formais. Para este fim, o grande geômetra preferia usar o método de exaustão, o instrumento normal da época.
} 
esta última, e adentra pelo desenvolvimento da Análise. Assim, podese dizer que se, por um lado, a noção de infinito é fundamental para as construções dos procedimentos do Cálculo, a sua total assimilação não se esgota no próprio Cálculo. A relação do Cálculo com o conceito de infinito se estabelece no nível de sua "utilização": o Cálculo não teve, não tem, e nem deveria ter compromisso direto com a "fundamentação" desse conceito. Questões dessa natureza são objetos de outro domínio do conhecimento matemático: a Análise.

Assim, após essa reflexão inicial, acreditamos que as respostas às perguntas norteadoras já foram dadas. Começaremos pela última (Em que momento histórico o Cálculo se constituiu efetivamente como um domínio próprio do conhecimento matemático?), uma vez que nos parece mais consensual. A indicação do século XVII como resposta para a questão é uma unanimidade entre os autores selecionados - havendo pequenas discordâncias quanto às razões para essa indicação. Com efeito, antes desse século o Cálculo foi geometria, foi aritmética, foi filosofia natural ${ }^{25}$, mas não foi propriamente Cálculo Diferencial e Integral; e, depois do século XVIII, ele se confunde com o surgimento da Análise, momento em que os matemáticos estão mais preocupados com as questões relativas à fundamentação dos conceitos básicos do Cálculo do que com os problemas e métodos analíticos que de certa forma o constituíram. Este entrelaçamento do Cálculo com a Análise será feito num momento mais oportuno neste trabalho.

\footnotetext{
${ }^{25}$ Filosofia Natural era o campo da filosofia que se ocupava da ciência em geral: os problemas da física estão inseridos aí.
} 
Um outro argumento muito forte que justifica a citação do século XVII é a descoberta do Teorema Fundamental do Cálculo. Descoberto inicialmente por Torricelli, a primeira demonstração do teorema - essencialmente geométrica - foi dada por James Gregory, e por Barrow, em seguida. Mas foi somente com Newton e Leibniz, que o teorema funcionou como elo fundamental dos dois cálculos até então existentes: o cálculo diferencial, que se preocupava com os problemas de "tangentes" e "velocidades", e o cálculo integral, que se ocupava dos problemas de "quadraturas" e "cubaturas".

Quanto aos "conceitos fundamentais do Cálculo" entendemos que existe uma duplicidade de interpretações da questão provocada inicialmente pela ausência de um complemento para o "ser fundamental": fundamental "para quê"? Fundamental para a "significação lógica" do Cálculo? Ou, para a "construção semântica" de sua rede de significações? Assim, pelo desdobramento que fizemos da questão, percebe-se logo que a resposta dada perpassa, inevitavelmente, a atitude que o respondente tem em relação ao Cálculo, e por que não dizer, à própria matemática. Se, ao respondermos a questão dizemos que o conceito fundamental do Cálculo é a operação de limite, fica evidente, pela própria resposta dada, que estamos dando ênfase ao aspecto formal do Cálculo, ao seu significado lógico. $O$ argumento que se põe aqui, em geral, é que tanto a derivada, a integral e o conceito de diferencial são definidos em termos de limite; logo, ele é que é o conceito fundamental. Bem, a pensar assim, deveríamos dizer então que o conceito fundamental do Cálculo é o de número real, uma vez que a definição formal de limite de Weierstrass depende "logicamente" da noção de número real. Poderíamos, além disso, estender ainda mais essa cadeia lógica, 
até chegarmos, quem sabe, ao conceito que traduziria, enfim, a unidade lógica do Cálculo. Assim, de tão distante que ele possa estar da rede de significações do Cálculo, talvez possa ser também a unidade lógica de outros domínios do conhecimento matemático: como, por exemplo, da Análise. Portanto, somos de opinião que o corte para que se responda a questão deva ser de natureza semântica e não lógica.

Por outro lado, se tivermos como referência a rede de significações do Cálculo, responderemos que os conceitos fundamentais são a diferenciação e a integração. De fato, os problemas fundamentais do Cálculo - e, desse modo, já estamos antecipando a nossa resposta à primeira questão - de "variabilidade" e "multiplicidade" só se resolveram completamente através da construção das operações de diferenciação e integração, e da relação estabelecida entre elas através do Teorema Fundamental do Cálculo.

Quanto aos "problemas que motivaram a construção das idéias e dos conceitos básicos do Cálculo", acreditamos já ter respondido essa questão de forma exaustiva. Acrescentamos apenas o fato de que, apesar da dualidade contínuo/discreto ter sido essencial para o desenvolvimento de certos instrumentos do Cálculo - as séries, por exemplo -, somos de opinião que a solução desta dualidade é do âmbito da Análise. De fato, o ápice dessa discussão se localiza na construção dos números reais através dos cortes de Dedekind, em 1872, já em pleno desenvolvimento da Análise.

Isto posto, ficamos devendo "apenas" a resposta da questão principal: O que é o Cálculo? Mas, conforme já dissemos no início dessa seção, não há uma resposta "certa" que responda totalmente essa questão. Por outro lado, acreditamos que conseguimos atingir com essa 
discussão o que, para nós, representa a essência do Cálculo. Ainda que a nossa redação não tenha sido clara o suficiente para atingir a nossa meta, deixamos ao leitor, como último recurso, um mapa que simboliza, graficamente, a essência do Cálculo. Cabe ao leitor interpretá-lo, ou se preferir, construir outro mapa.

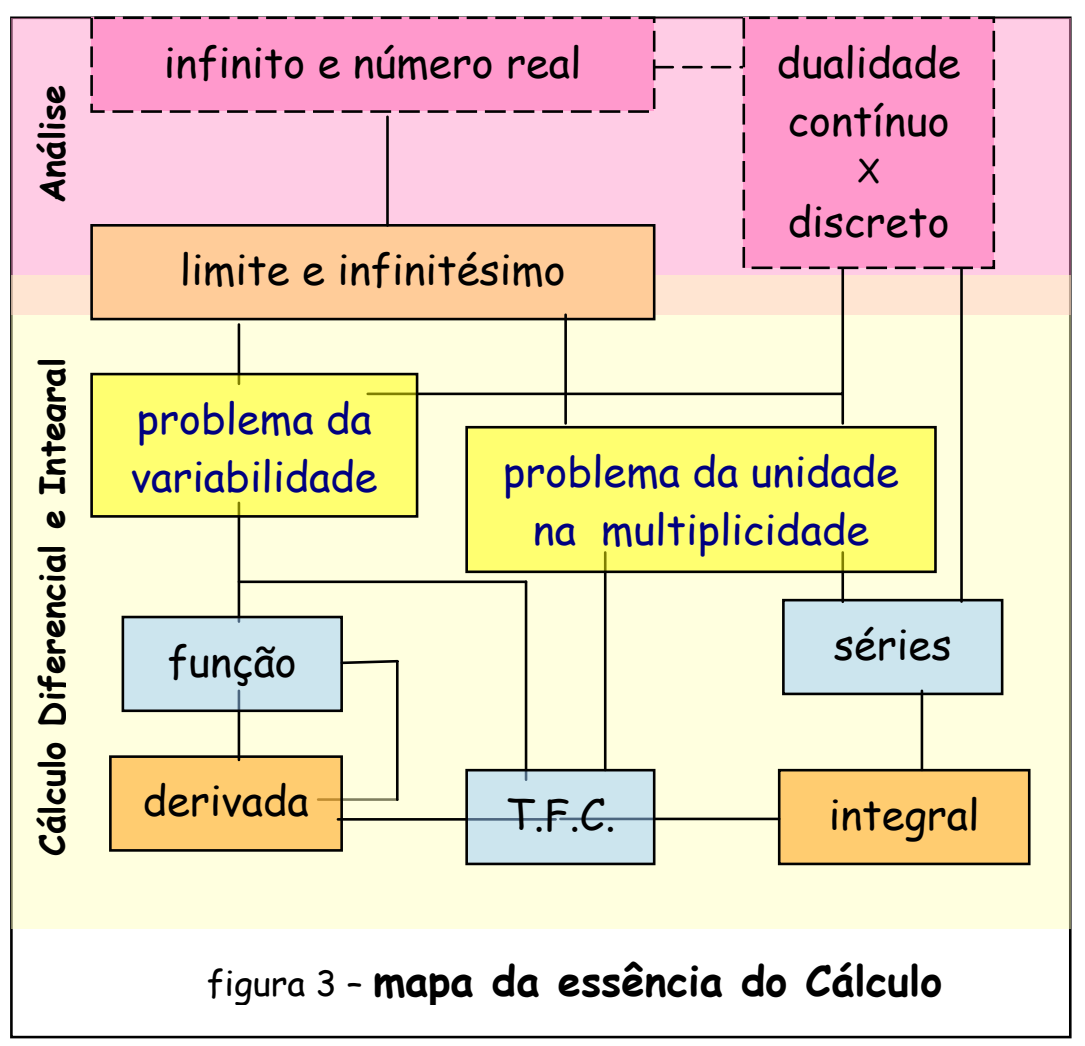


$\square$ Conceitos e resultados construtores e integradores do Cálculo

$\square$ Conceitos fundamentais do Cálculo

$\square$ Problemas essenciais e construtores do Cálculo

$\square$ Conceitos estruturais das idéias essenciais do Cálculo

$\square$ Conceitos e dualidades estruturais da Análise que motivaram, orientaram e participaram do desenvolvimento do Cálculo

$\square$ Domínio de significações da Análise

$\square$ Domínio de significações do Cálculo 


\subsection{A escala histórica: a evolução dos conceitos bási- cos do Cálculo.}

O conceito de infinito é, com efeito, o principal reagente das operações básicas do Cálculo, esteja ele relacionado à noção de limite ou à de infinitésimo. Assim, falar da história do Cálculo implica falar, em última instância, sobre a história do infinito, ou melhor, dos processos matemáticos infinitos: limites e quantidades infinitesimais (infinitésimos).

As noções de limite e infinitésimos sempre foram (e continuam sendo) dois nós fundamentais na grande rede do Cálculo. Podem ter suas estruturas e representações modificadas, ganhar mais ou menos importância no desenvolvimento das idéias básicas do Cálculo, de acordo com o momento histórico da própria produção matemática e científica em geral, mas, em qualquer etapa do desenvolvimento, estiveram sempre presentes na constituição daquilo que se chama Cálculo - área nobre e essencial do próprio conhecimento matemático. Assim, ao fazermos os nossos mapas históricos do Cálculo, daremos o merecido destaque ao desenvolvimento destes dois conceitos.

As idéias básicas do Cálculo têm origem na Grécia Antiga, mas é somente no século XVII que ele atinge o seu ápice, e ganha status de área do conhecimento matemático. Ao longo de sua história enfrenta duas grandes crises: uma logo no seu início, a partir dos paradoxos de Zenão, e outra, no século XVIII, provocada pelas questões de Berkeley. Para esta última crise são elaboradas então duas soluções: a análise real e a análise não-standard. A história do Cálculo, porém, não se 
encerra aí, seus conceitos - de natureza flexível, de fácil adaptação e com largo potencial de aplicações - continuam atualíssimos, ajustandose ${ }^{26}$ sempre a novas demandas sociais e científicas, e colaborando, cada vez mais, para o desenvolvimento da ciência e da própria matemática.

A história do Cálculo é longa demais para ser abreviada, e fecunda o suficiente para se fazer recortes superficiais, mas, mesmo assim, tentaremos fazer um "breve" relato da evolução histórica dos seus conceitos, sem comprometer, no entanto, o entendimento da epistemologia do Cálculo. Temos consciência da limitação deste nosso empreendimento, mas precisamos correr o risco. Um mapeamento conceitual do Cálculo ao longo do seu processo histórico de evolução, ainda que incipiente, se faz necessário para nossas futuras reflexões. Passemos então ao "breve" relato.

\footnotetext{
${ }^{26}$ Um clássico exemplo desse ajuste é o conceito de logaritmo que passa da condição de simples operador (e, neste contexto, o log na base dez era a principal referência) para a condição de uma das principais funções do Cálculo Diferencial e Integral (aqui, a base neperiana é que é a referência).
} 


\subsubsection{O prelúdio (do séc. VI a.C ao séc. III a.C)}

Algo de notável e assombroso aconteceu realmente na Grécia Antiga, no período helênico (de \pm 800-336 a.C). Segundo Eves (1995), a Grécia Helênica representou "uma das épocas mais notáveis da história em termos de realizações humanas". O Império Grego reunia, em seu extenso domínio territorial, cidades-Estado situadas em vários arquipélagos e regiões litorâneas do mar mediterrâneo - veja figura 4. Assim, além de concentrar os maiores cientistas do mundo antigo, a Grécia Antiga constituiu-se também no principal pólo intelectual da época. Grande parte do conhecimento humano teve sua origem neste período grego: a Medicina, a Física, a Lógica, a Matemática, o Direito, a Música, a Filosofia etc. As razões para o "fenômeno grego" são as mais diversas possíveis, mas um ponto parece consensual: o surgimento e 0 desenvolvimento da Filosofia. Segundo Eves (1995, p.94),

"Pela primeira vez na matemática, como em outros campos, o homem começou formular questões fundamentais como 'Por que os ângulos da base de um triângulo isósceles são iguais?' e 'Por que o diâmetro de um círculo divide esse círculo ao meio?'. Os processos empíricos do Oriente antigo, suficientes o bastante para responder questões na forma de como, não mais bastavam para as indagações mais científicas na forma de por quê". 


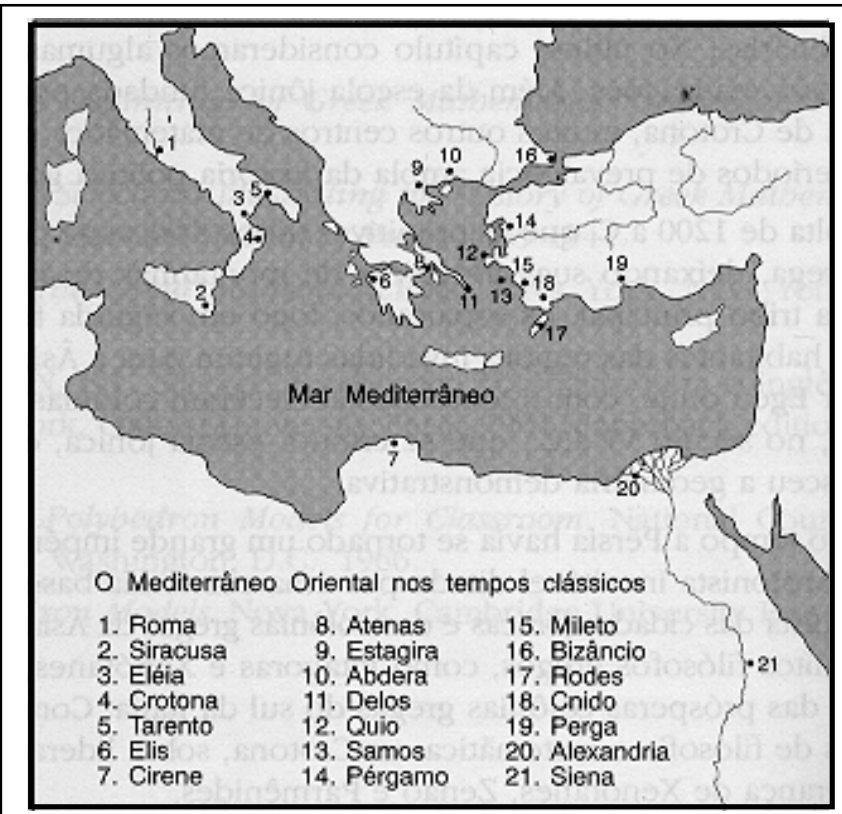

figura 4 - extraída de (Eves, 1995, p.130)

\section{Boyer ratifica a posição de Eves:}

As civilizações pré-helênica são freqüentemente consideradas como précientificas nas atitudes delas em relação à natureza, já que a elas faltaram claramente a confiança grega em sua racionalidade essencial, tanto como pelo sentimento de que sob a complexa heterogeneidade e o fluxo incessante de eventos seria achado elementos de uniformidade e permanência.

(Boyer, 1949, p. 14)

Ao fazer referência ao universo humano do período "préhelênico", Boyer inclui aí os Babilônios e os Egípcios; faz, no entanto, uma ressalva à importância desse conhecimento pré-científico produzido por essas civilizações para o desenvolvimento da própria ciência grega:

Nossa informação sobre a história da matemática no intervalo entre o melhor da matemática egípcia e babilônica e os trabalhos iniciais na Grécia é infelizmente fragmentada. Que estas civilizações orientais influenciaram a cultura grega está clara; mas a natureza e a extensão da contribuição delas são indeterminadas. Porém isso pode ter ocorrido como se desenrolou na Grécia: uma clara mudança no espírito da ciência e da matemática. A mente humana foi "descoberta" como algo 
diferente do próprio ambiente natural e capaz de discernir semelhanças em uma muliplicidade de eventos, de abstrair estas de seus cenários, generalizando-as, e deduzir disso outras relações consistentes com experiências ulteriores. É por esta razão que nós consideramos o método matemático e científico como originários com a civilização Helênica; mas dizer que matemática grega e ciência eram nativas seria esquecer da dívida de tema-assunto para o Egito e a Babilônia. É provável que a perspectiva nova dos Helenos era o resultado do fluxo de civilizações que ocorreram nesta época, isto imprime sobre o próspero crescimento grego o selo de numerosas culturas.

(Boyer, 1949, p.16)

Em consonância com o pensamento de Boyer, Barnes (1997) sugere uma localização mais precisa deste nascimento da ciência/pensamento científico:

Parece razoável concluir que Mileto, nos primórdios do século VI a.C., assistiu o nascimento da ciência e filosofia.

(Barnes, 1997, p.17)

Segundo Barnes, o nascimento da ciência e da filosofia teve o mesmo ponto de partida: os filósofos pré-socráticos.

Qual será, então, o fundamento da afirmativa de que os pré-socráticos foram defensores da razão e da racionalidade? O fundamento é o seguinte: eles apresentavam razões para suas opiniões e argumentavam em favor de suas doutrinas. Não omitiam pronunciamentos 'ex cathedra'. Isso talvez pareça um feito irrelevante. Não é. Ao contrário, é a realização mais relevante e mais digna de louvor dentre as três que relacionei. Os que duvidam do fato deveriam refletir sobre a máxima de George Berkeley, o filósofo irlandês do século XVIII: "Todo homem tem opiniões, mas poucos são os que pensam".

(Barnes, 1997, p.27)

É nesse período que se desenvolve a geometria grega, berço das idéias da ciência e do Cálculo. Boyer, concordando com a localização espaço-temporal definida por Barnes para o nascimento "da ciência e filosofia", se refere a Tales de Mileto ( 625-546 a.C.) como o grande precursor dessa "revolução intelectual": 
Tales é o primeiro grego mencionado com relação a esta "revolução intelectual", que produziu matemática elementar e que serviu para revelar essas dificuldades na concepção, no estudo e na resolução daquilo que foi produzido nos próximos vinte e cinco séculos e que hoje nós chamamos de cálculo.

(Boyer, 1949, p.16).

O autor acrescenta, no entanto, que Tales não construiu "um corpo de conhecimento matemático, nem aplicou seu método à análise do problema do contínuo". Essa tarefa veio a ser iniciada, segundo Boyer, por Pitágoras 27 - "o segundo matemático grego de quem nós temos informações substanciais".

De acordo com Proclus, Pitágoras "transformou o estudo da geometria em uma educação liberal, examinando os princípios da ciência do início e provando os teoremas de uma maneira imaterial e intelectual". Um resultado muito importante da pesquisa pitagórica sobre a unidade na natureza e geometria foi a "teoria de aplicação de áreas". Tal teoria irá influenciar posteriormente a construção de um método (o método de exaustão) que se tornará um procedimento padrão na matemática grega para o cálculo de áreas e volumes. Cabe ressaltar entretanto que os gregos não falavam de área de uma figura, mas de razão de superfícies. Tal fato deve-se ao problema da incomensurabilidade e à forma como desenvolveram o seu próprio conceito de número racional. Para comparar duas grandezas $A$ e $B$, escolhia-se uma terceira grandeza $C$, menor que as duas primeiras, e que coubesse em cada uma delas uma quantidade inteira de vezes. Assim, se $A=m . C$ e

\footnotetext{
${ }^{27}$ Há de se ressaltar que devido ao caráter hermético e místico da escola pitagórica, e pelo fato de muitos resultados, atribuídos a Pitágoras, terem se tornados públicos só depois de sua morte, não se sabem o que realmente pertencia a este personagem. Questiona-se inclusive sua existência humana. Heráclito, no entanto, garante que ele existiu, por volta do século VI a. C.. Contudo, a existência, ou não, de Pitágoras enquanto pessoa, não tira o mérito da grande contribuição de sua escola para o desenvolvimento da ciência, em particular a matemática.
} 
$B=n \cdot C$, diríamos que $\frac{A}{B}=\frac{m \cdot C}{n \cdot C}=\frac{m}{n}$, ou seja, que $A=\frac{m}{n} B$. A existência da quantidade $C$, escolhida como unidade comum para as duas grandezas, era assumida "intuitivamente", e poderia ser escolhida de modo que a razão fosse irredutível ${ }^{28}$.

O número desempenhou, sem dúvida, um papel central no desenvolvimento da escola pitagórica. Aristóteles observou inclusive que o número para os pitagóricos exercia o papel da matéria e da forma do universo.

Eles [os pitagóricos] chamavam um ponto de um, uma reta de dois, uma superfície de três e um sólido de quatro. O somatório de pontos gerava retas, o de retas, superfícies e o de superfícies, sólidos; com os seus um, dois, três e quatro eles poderiam construir o universo.

(apud Baron \& Bos, 1985, v.1, p.16)

Atribuindo "forma" aos números, os pitagóricos desenvolvem uma espécie de "aritmética geométrica". É neste contexto que surgem os números figurados ${ }^{29}$ : triangulares, quadrangulares, retangulares, etc.

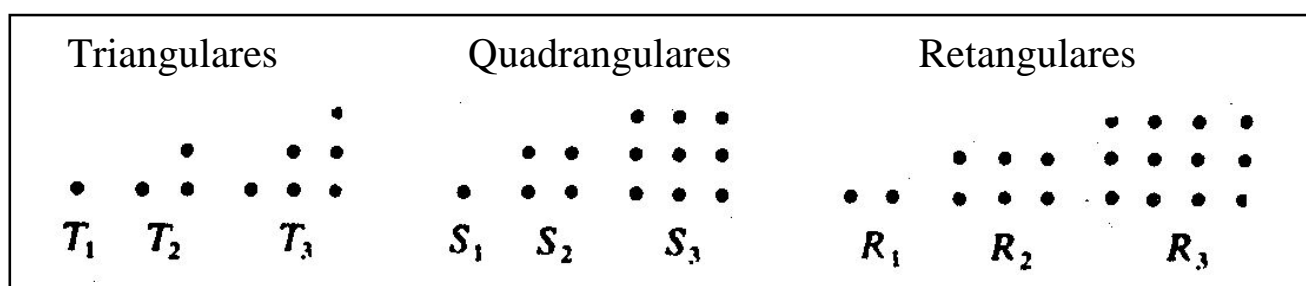

figura 5 - Números Figurados no Plano (Baron \& Boss, 1985, v.1, p.16)

\footnotetext{
${ }^{28}$ Para maiores detalhes consulte (Caraça, 1989).

${ }^{29}$ Os números figurados eram seqüências de números inteiros que obedeciam a uma determinada estrutura geométrica. - veja figuras 5 e 6.
} 

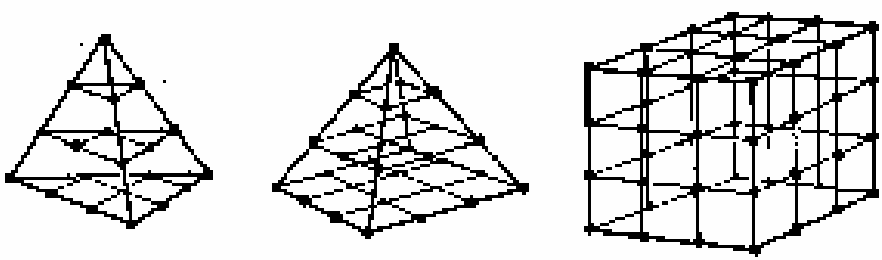

figura 6 - Numeros Figurados Espociais (Eoron $d$ Eoss. 1965, v.1 p.17)

Assim, a partir das propriedades geométricas das figuras, estabeleciam relações aritméticas. A figura a seguir ilustra, através do uso do gnomon ${ }^{30}$, uma relação entre a soma de números ímpares e os números quadrangulares e outra, entre a soma de números pares e números retangulares.

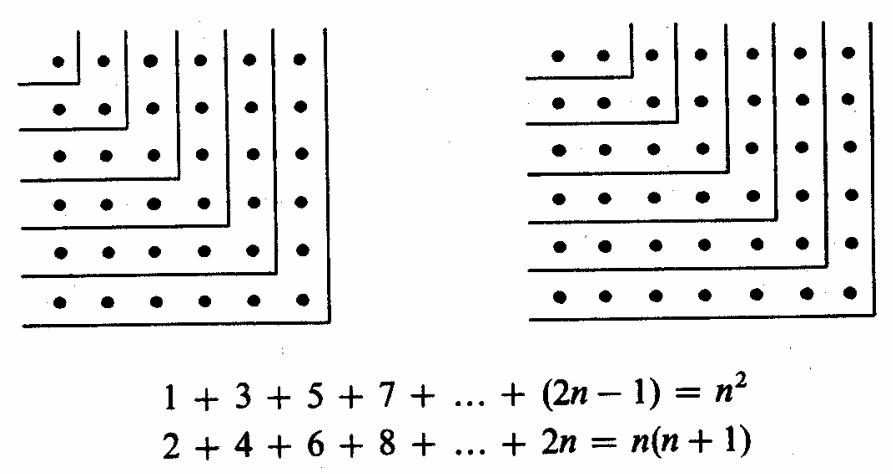

figura 7 - Baron \& Bos, 1985, v.1, p.17

A máxima "Tudo é número" é, com efeito, a grande referência que se tem da escola pitagórica. No entanto, nem "tudo" era "número" (número racional). No momento em que se descobre que não era possível "medir" a diagonal de um quadrado em relação ao seu lado ${ }^{31}$, a es-

\footnotetext{
${ }^{30}$ Uma espécie de esquadro de carpinteiro que era utilizado para traçar ângulos retos.

${ }^{31}$ Tal problema ficou conhecido historicamente como o "Dilema de Pitágoras" - para maiores detalhes verificar em (Caraça, 1989).
} 
cola pitagórica entra em crise. E esta crise irá, por certo, marcar o destino da própria matemática grega, de modo que esta tentativa de estabelecer pontes entre a geometria e a aritmética e, mais especificamente, entre grandezas contínuas e discretas, foi abandonada pelos matemáticos gregos que se seguiram. Cabe ressaltar, entretanto, que os números irracionais (segmentos incomensuráveis) ainda apareceram nos trabalhos de Platão e Euclides. Este último desenvolve inclusive em um dos livros de sua grande obra Os Elementos (mais especificamente, - livro $X$ ) uma "teoria dos números irracionais". Em tal teoria ${ }^{32}$, Euclides considera os números irracionais através de processos de aproximações por valores racionais, fazendo uso simultaneamente de sequiência de valores inferiores quanto de sequiência de valores superiores a medida do segmento incomensurável. Tal procedimento influenciou $R$. Dedekind (1872), conforme revelou o próprio matemático alemão, na elaboração de sua teoria dos números reais a partir de "cortes" de números racionais. É fascinante perceber que os gregos, há mais de 300 anos antes de Cristo, já haviam lançado no solo geométrico as sementes de conhecimento necessárias à fundamentação da Análise Real, que se iniciaria apenas no século XIX d.C..

Quanto às quantidades infinitesimais, não se sabe ao certo se os pitagóricos as utilizavam em suas pesquisas. Contudo, sabe-se que tais quantidades foram introduzidas no pensamento matemático através das explicações dos pré-socráticas para a natureza do mundo físico. Boyer (1949) localiza de forma mais precisa a origem dos infinitésimos. Segundo o autor, a doutrina materialista do atomismo físico, elaborada

\footnotetext{
${ }^{32}$ Segundo Heath (1956), é muito provável que esta teoria dos números irracionais tenha sido desenvolvido originariamente na própria escola pitagórica.
} 
no século $V$ a.C., em Abdera, foi a grande responsável por tal empreendimento. Esta doutrina sustentava que todas as coisas, mesmo a mente e a alma, eram feitas de átomos - partículas indivisiveis e imperceptíveis pelos sentidos por serem muito pequenas - que se moviam sobre o espaço vazio. A identificação destes pequeníssimos (mas finitos) elementos indivisíveis com a teoria pitagórica é bastante natural. O que não é tão natural assim, é a não aceitação desses indivisíveis na matemática por parte daquele que foi o maior representante da escola de Abdera: Demócrito ( 410 a.C.) - considerado por muitos historiadores da ciência e da filosofia o "pai da Física" e o "mais brilhante dos filósofos pré-socráticos". A fim de ilustrarmos tal atitude de Demócrito, citaremos um dilema proposto pelo pensador sobre seções paralelas de um cone, e que foi relatada pelo historiador e geógrafo Plutarco (46120 d.C.):
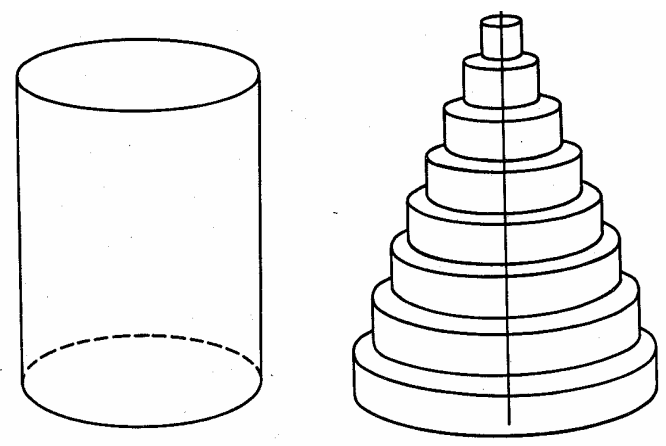

figura 8 - Baron \& Bos, 1985, vol. 1, p.20
Se cortarmos um cone por um plano paralelo à base [plano bem próximo à base], o que podemos dizer das superficies que formam as seções? Elas são iguais ou diferentes? Se elas são diferentes, elas tornarão o cone irregular, cheio de dentes, como degraus, e imparidades; mas se elas são iguais, a seções serão iguais, e parece que o cone terá a propriedade do cilindro de ser construído por círculos iguais e não diferentes: o que é um absurdo.

(apud Baron \& Bos, 1985, vol. 1, p.20) 
Por outro lado, sabe-se que Demócrito determinou o volume da pirâmide e do cone, os mesmos sólidos envolvidos no enunciado do seu dilema. Assim, é muito provável que o grande pensador tenha resolvido - problema usando quantidades infinitamente pequenas. Além disso, a grande influência que as pesquisas de Demócrito exerceu sobre os trabalhos de Platão e de Arquimedes ${ }^{33}$ é um forte indício dessa conjectura. É, no mínimo, curiosa, esta íntima relação entre os conceitos de indivisivel e infinitesimal na atitude de Demócrito. Apesar dos seus significados extremamente opostos (ou admite-se a existência do elemento indivisivel, ou a possibilidade de se dividir indefinidamente - infinitamente - uma quantidade, por menor que seja), os infinitesimais (ou indivisíveis matemáticos), na posição de Demócrito, parecem ser de um tipo especial. Os "indivisíveis matemáticos" podem ser divididos em partes menores (e de forma infinita), mas sem perder a propriedade essencial da substância da qual eles são elementos constitutivos. Ainda que sejam partidos, cada parte preserva a identidade do todo que 0 gerou. Talvez seja este processo mitótico que tornou possível Demócrito inferir dos indivisiveis o seu conceito de infinitesimal, afinal: os indivisíveis também são quantidades "infinitamente" (muito) pequenas.

As críticas feitas às quantidades infinitamente pequenas, introduzidas por Demócrito, foram tão severas quanto as que foram realizadas aos indivisíveis pitagóricos. A escola eleática, liderada por Parmênides (nascimento: 540/515 a.C.), é sem dúvida o principal exemplo dessa reação, ainda que sua doutrina tenha se servido da filosofia pitagórica para o seu próprio desenvolvimento. Mantendo-se frontal-

\footnotetext{
33 Em particular na obra sobre o "Método", onde o matemático cita Demócrito como autor do cálculo do volume do cone e desenvolve seus resultados baseado na noção de infinitésimo.
} 
mente contra a visão atomística, Parmênides defende a unidade $e$ invariabilidade do mundo:

\author{
(8.) Só ainda (0) mito de (uma) via \\ resta, que é; e sobre esta indícios existem, \\ bem muitos, de que ingênito sendo é também imperecível, \\ pois é todo inteiro, inabalável e sem fim: \\ nem jamais era nem será, pois é agora todo junto, \\ uno, contínuo; pois que geração procurarias dele? \\ Por onde, donde crescido? Nem de não ente permitirei \\ Que digas e pense; pois não dizível nem pensável \\ Eque não é; que necessidade o teria impelido \\ A depois ou antes, se do nada iniciado, nascer? \\ Assim ou totalmente é necessário ser ou não. \\ (...), e a decisão sobre isto está no seguinte: \\ é ou não é.(...)
}

Nem divisível é, pois é todo idêntico:

nem algo em uma parte mais, que o impedisse de conter-se, nem também algo menos, mas é todo cheio do que é, por isso é todo contínuo; pois ente a ente adere.

Por outro lado, imóvel em limite de grandes liames é em princípio e sem pausa, pois geração e perecimento bem longe afastaram-se, rechaçou-os fé verdadeira. O mesmo e no mesmo persistindo em si mesmo pousa. e assim firmado aí persiste; pois firme a Necessidade em liames (0) mantém, de limite que em volta o encerra, para ser lei que não sem termo seja o ente: pois é não carente; não sendo, de tudo careceria.

(apud Pré-Socráticos, 2000, p.123)

Assim, Parmênides desenvolve os seus três princípios explicativos básicos: o da identidade (o ser é... o não-ser não é), o da unidade e o da imutabilidade. No entanto, na produção matemática, existiam dois tipos diferentes de atividades: uma, de contagens de elementos discretos, separados e indivisíveis; e outra de medidas de quantidades "contínuas", infinitamente divisíveis - procedimento frontalmente contrário ao seu princípio de identidade: o ser é, o não-ser não é. Mas a crítica, 
tanto ao uso dos indivisíveis quanto ao dos infinitésimos, contextualizada na linguagem científica/matemática, foi realizada por seu mais brilhante (porém o não mais fiel) dos súditos: Zenão de Eléia (nascimento: 515/490 a.C.). Foi Zenão quem descobriu, com os seus paradoxos, uma anomalia em ambas as atividades "normais" da matemática na época. No paradoxo de Aquiles, Zenão "prova" que "se o espaço e o tempo são (infinitamente) divisíveis então o movimento é impossivel". Baron sintetiza de forma didática o seu argumento:

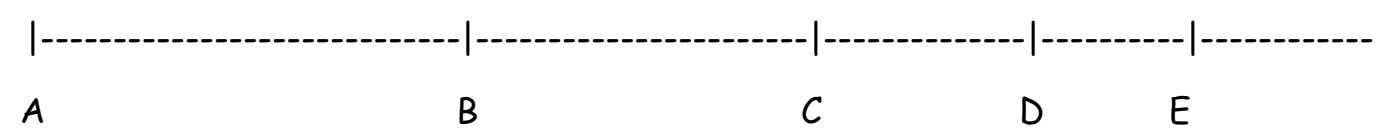

Se a tartaruga está em $B$ e Aquiles em $A$, Aquiles nunca pega a tartaruga, pois no momento em que Aquiles chega no ponto $B$ a tartaruga estará em algum ponto $C$ adiante, e quando Aquiles chega em $C$ a tartaruga estará em algum ponto $D$ adiante, e assim por diante ad infinitum: a tartaruga estará sempre na frente!

(apud Baron \& Bos, 1985, v.1, p.23)

Assim, como o movimento é possível (isto é, Aquiles não só alcança mas como também ultrapassa a tartaruga), Zenão conclui, a partir deste paradoxo, que o tempo não pode ser infinitamente divisível. 0 argumento parece logicamente convincente, mas note, no entanto, que "é falso afirmar que o que vai na frente não é alcançado: não é alcançado enquanto vai na frente, mas, não obstante, é efetivamente alcançado" ${ }^{34}$. A solução para o paradoxo é, com efeito, um problema fundamental do Cálculo Diferencial. Voltaremos a este assunto num momento mais oportuno; por ora, cabe ressaltar que Zenão desenvolveu um

\footnotetext{
${ }^{34}$ (Barnes, 1997, p.180).
} 
argumento parecido contra a divisão do espaço ad infinitum: o paradoxo A Dicotomia $^{35}$.

Contra o uso dos indivisíveis, Zenão desenvolveu dois paradoxos: A Flecha e $O$ Estádio. A descrição deste último é complexa e nos tomaria um tempo desnecessário, por isso optamos pela ilustração do paradoxo da Flecha. Neste paradoxo, Zenão "prova" que "se existem unidades de tempo e de espaço indivisíveis então o movimento é impossível". Vejamos o seu argumento nas palavras de Baron:

Considere uma flecha e assegure razoavelmente que a flecha deve estar num certo ponto num dado instante: como ela não pode estar em dois lugares no mesmo instante, não pode se mover nesse instante, se, por outro lado, está em repouso nesse instante, então, como o argumento se aplica para outros instantes, ela não pode se mover de jeito nenhum.

(Baron \& Bos, 1985, v.1, p.23)

Contudo, como o movimento da flecha é possível, Zenão conclui, a partir deste argumento, que o espaço e o tempo não possuem elementos indivisíveis. A solução deste paradoxo, assim como a dos outros três, está relacionada com o desenvolvimento de outros conceitos básicos do Cálculo, como os de infinito, continuidade, número real e derivada. No entanto, a impotência ${ }^{36}$ dos gregos de resolverem tais paradoxos, junto com a anomalia identificada pelos pitagóricos dos segmentos incomensuráveis, vai desencadear a primeira grande crise na matemática grega (e por que não dizer, do Cálculo). Uma crise que suscitará um outro conceito fundamental do Cálculo: a noção de limite. Vejamos então como foi que os matemáticos gregos "solucionaram" tal crise.

\footnotetext{
${ }^{35}$ Porfírio teria sustentado que o argumento da dicotomia pertencia a Parmênides - (apud Barnes, 1997, p.177).
} 
A falta de uma explanação quantitativa para os fenômenos de movimento e variabilidade foi, com efeito, uma das principais razões para as dificuldades implícitas nos argumentos de Zenão. Platão (428/7-348/7 a.C.) ${ }^{37}$, o grande filósofo de Atenas, já tinha percebido este abismo entre a geometria e a aritmética, e sugerido, por conseguinte, a construção de uma "ponte" através de uma construção axiomática do conceito de número, independente de qualquer base geométrica - assim, com uma antecedência de mais de 2000 anos, o grande mestre parecia adivinhar a discussão que se daria no final do século XIX.

Platão, no entanto, não dá uma resposta direta aos paradoxos de Zenão e ao problema da incomensurabilidade. Apesar de ter sido influenciado em seus pensamentos pelas escolas pitagórica e de Abdera, Platão rejeita a mônada pitagórica e o atomismo matemático de Demócrito, por estas teorias atribuírem uma espessura aos seus elementos "infinitamente pequenos". Tais conceitos apelavam por demais para a experiência sensivel para ser do agrado de Platão. O filósofo de Atenas preferiu interpretar o seu conceito de infinitesimal a partir do conceito altamente abstrato do apeíron ${ }^{38}$ ou indeterminado ilimitado. De acordo com Platão, o contínuo poderia ser melhor interpretado pelo "fluir do apeíron" do que através de um agregado infinito de elementos indivisíveis. Segundo Boyer (1949), esta visão platônica representa

\footnotetext{
${ }^{36}$ Os gregos possuíam apenas uma idéia intuitiva dos conceitos de continuidade e infinito, além do seu universo numérico estar restrito ao campo racional.

${ }^{37}$ Embora ele próprio não se considerasse um matemático, Platão deixou bem claro o seu interesse e habilidade na solução de problemas geométricos.

38 Segundo Mora (2000, p.37), o vocábulo apeíron, tal como emprega o filósofo Anaximandro, significa "sem fim” ou "sem limite”; costuma-se traduzir como "o infinito”, “o indefinido”, “o ilimitado” etc., e lhe foram dadas interpretações diversas entre os seus próprios discípulos. Também outros pré-socráticos, Platão (Filebo) e Aristóteles (Física, III, 203) utilizaram o termo.
} 
a fusão do contínuo e o discreto, bem próxima do Intuicionismo ${ }^{39}$ moderno de Brouwer. Assim, como observou Boyer, a noção de infinitamente pequeno está, com efeito, muito mais próximo do "infinitesimal generative" de Leibniz, ou mesmo da "magnitude infinitamente pequena intensiva" que apareceu na filosofia idealista do século XIX, do que do processo de subdivisão contínua de Demócrito. De fato, a noção de infinitesimal de Platão está presente nas variáveis infinitesimais do Cálculo de Newton quanto no Cálculo de Leibniz. Tal fato, acrescido da alusão à "ponte" aritmética-geometria, fez com que Boyer (1949) defendesse inclusive para Platão o legítimo título de um dos descobridores do Cálculo. Segundo o historiador, se à especulação metafísica Platão fosse acrescida uma concepção geral de número real e, conseqüentemente, de variável algébrica contínua, o Cálculo não precisaria esperar mais dois mil anos para ser "inventado". Infelizmente, os matemáticos gregos estavam muito mais preocupados em preservar a precisão lógica do que em investigar com mais profundidade esta dualidade essencial do Cálculo: o par discreto/contínuo. A dificuldade de sobrepor - obstáculo numérico provocado pela descoberta dos segmentos incomensuráveis foi também um dos principais inibidores dessa empreitada: a ponte platônica aritmética-geometria foi ignorada pelos matemáticos gregos. A construção de tal ponte teve que ser adiada para 0 longínquo final do século XIX.

\footnotetext{
${ }^{39}$ Concepção fundamental de L. Brouwer que afirma serem as entidades da Lógica Matemática livres criações do pensamento, independendo de origens empíricas, e sustentadas pela clareza que lhes confere seu caráter intuitivo - (Ferreira, 1999).
} 
Em sentido oposto ao pensamento de Platão, mas correspondendo às expectativas de precisão lógica dos matemáticos gregos, Aristóteles (387-322 a.C.), o grande filósofo grego, sugere que se expurgue toda noção de infinitamente grande ou infinitamente pequeno da ciência em geral. O que Aristóteles propõe, na verdade, é uma espécie de "exorcismo do conceito de infinito". A favor do seu pensamento argumenta que:

Na realidade, eles (os matemáticos) não precisam e nem usam o infinito. Eles apenas postulam que a linha reta pode ser estendida como quiserem. ${ }^{40}$

(apud Baron \& Bos, 1985, v.1, p.27)

E acrescenta que é desnecessário usar a idéia de infinitamente pequeno ou infinitamente grande pois:

Se adicionarmos continuamente a uma quantidade finita, excederemos qualquer grandeza dada e, do mesmo modo, se subtrairmos continuamente dela chegaremos a alguma coisa menor do que ela. ${ }^{41}$

(apud Baron \& Bos, 1985, v.1, p.27)

É desse modo, descartando e evitando o uso do conceito de infinito em suas ações, que os matemáticos gregos procuraram resolver a anomalia que Zenão havia identificado. Eudoxo (408-355 a.C.), membro da antiga escola de Pitágoras, desenvolve a teoria das proporções e 0 seu "método de exaustão" 42 , onde a teoria dos números é incorporada à estrutura geométrica e o conceito de infinito é evitado. Dois grandes matemáticos, Arquimedes e Euclides, assimilam, desenvolvem, e aplicam o método de exaustão de Eudoxo a problemas geométricos. Usam este método para manipular operações com limites sem invocar o

\footnotetext{
${ }^{40}$ Este é exatamente o teor do segundo postulado dos Elementos de Euclides.

${ }^{41} \mathrm{Tal}$ enunciado consiste basicamente no axioma de Eudoxo-Arquimedes, comumente usado na introdução de um curso inicial de Análise Real.
} 
conceito de infinito. Euclides explicita claramente em sua obra Elementos ${ }^{43}$ os princípios que norteiam tal método.

(Elementos $V$ - definições básicas da teoria das proporções de Eudoxo)

3. Uma razão é uma espécie de relação entre o tamanho de duas grandezas de mesma natureza.

4. Diz-se que duas grandezas de mesma natureza possuem uma mesma razão entre si quando, multiplicando-as, uma excede a outra.

(proposição 1, Elementos $X$ - a versão euclidiana do axioma de EudoxoArquimedes)

Considerando duas grandezas distintas, se subtrairmos da maior uma outra maior do que sua metade, e desta uma outra maior do que sua metade e assim por diante, obteremos finalmente alguma grandeza que será menor do que a menor grandeza considerada.

(apud Baron \& Bos, 1985, v.1, p.28)

A definição de razão (3, Elementos $V)$ como uma "espécie de relação" não parece muito esclarecedora. É, no entanto, na definição posterior, que Euclides deixa claro que não pode haver razões entre grandezas de espécies diferentes; ou seja, não pode haver razões entre superfícies (áreas) e retas (comprimentos), ou sólidos (volumes) e superfícies (áreas) e etc., o que é frontalmente contra a teoria matemática dos indivisíveis, desenvolvida pelos pitagóricos. Outro fato que deve ser aqui observado é que estas definições, agregadas ao corpo da teoria a que fazem parte - a teoria das proporções de Eudoxo -, é que vão suprir a carência grega de um conceito de número. O não enfrentamento do problema da incomensurabilidade fez que com que prevalecesse no "Cálculo grego" os procedimentos (indiretos) de comparação. Assim, para os gregos a questão que se coloca não é "Qual é a área de um círculo?", mas "Qual é a razão entre as áreas de dois círculos?", de

\footnotetext{
${ }^{42}$ O batismo do método desenvolvido por Eudoxo como "método de exaustão" será realizado apenas no século XVII, por Grégoire de Saint-Vicent.

${ }^{43} \mathrm{O}$ livro V dos Elementos de Euclides é uma exposição magistral da teoria das proporções de Eudoxo. No livro VI são apresentadas as aplicações da teoria eudoxiana das proporções à geometria plana.
} 
modo que, ainda que cada área seja incomensurável (irracional), é possível estabelecermos uma razão (racional) entre elas, e o problema da incomensurabilidade não se torna um obstáculo para o processo de comparação. Com isto, fica evidente que, por mais que a precisão e o rigor estejam nas metas da proposta paradigmática para a crise da matemática grega, a teoria das proporções, o alicerce dessa proposta, se fundamenta numa representação intuitiva e geométrica de número irracional.

A proposição (1, Elementos $X)$ é a versão euclidiana para o axioma de Eudoxo-Arquimedes - axioma fundamental para o desenvolvimento do "método de exaustão". Pode ser considerada também como a "célula mãe" daquilo que conhecemos hoje como a operação de limite. É o axioma que irá exorcizar de vez o conceito de infinito da matemática grega. Tal fato é, no mínimo, curioso, uma vez que este axioma, sendo a "célula mãe" da operação de limite, será usado para negar aquele que é o "regente básico" desta operação. Mas, afinal, em que consiste o "método de exaustão"?

M. Baron e H. Bos (1985) afirmam em seu livro que, para entendermos os gregos, é preciso que aprendamos a utilizar os seus instrumentos. Procuraremos, portanto, responder a tal questão, analisando um exemplo da aplicação deste método. Selecionamos um texto de Arquimedes (287-212 a.C.) por razões que justificaremos mais tarde.

(proposições 21, 22 - Sobre Conóides e Esferóides)

Qualquer segmento de um parabolóide de revolução é novamente metade do cone ou segmento de um cone que tem a mesma base e o mesmo eixo.

Suponha que a base do segmento é perpendicular ao plano do papel, e suponha que o plano do papel seja o plano que passa pelo eixo do parabolóide que corta a base do segmento em ângulos retos em $B C$ e torna seção parabólica $B A C$. 
Seja EF aquela tangente à parábola que é paralela a BC e seja $A$ o ponto de contato.

Então (1), se o plano da base do segmento é perpendicular ao eixo do parabolóide, este eixo é a reta $A D$ que bissecta $B C$ em ângulos retos em $D$.

(2) se o plano da base não é perpendicular ao eixo do parabolóide, trace AD paralelo ao eixo do parabolóide. $A D$ então bissecta $B C$, mas não em ângulos retos.

Trace por EF um plano paralelo à base do segmento. Este tocará o parabolóide em $A$, que será o vértice do segmento e $A D$ o seu eixo. A base do segmento será um círculo com diâmetro $B C$ ou uma elipse com eixo maior $B C$.

Pode-se encontrar um cilindro, ou tronco de um cilindro, passando pelo círculo ou elipse e tendo como eixo AD (proposição 9); do mesmo modo, pode-se traçar um cone ou um segmento de um cone, passando pelo círculo ou elipse tendo como vértice A e como eixo AD (proposição 8).

Seja $X$ um cone igual a $3 / 2$ (cone ou segmento de cone $A B C$ )

$O$ cone $X$ é portanto igual à metade do cilindro ou tronco de um cilindro EC (proposição 10).

Mostraremos que o volume do segmento do parabolóide é igual a X. Caso contrário, o segmento deve ser maior ou menor do que $X$.

Podemos então inscrever e circunscrever, como na última proposição, figuras constituídas de cilindros ou troncos de cilindros com mesma altura e tais que

(figura circunscrita) - (figura inscrita) $<($ segmento) $-X$

Seja o maior dos cilindros ou tronco formando a figura circunscrita aquele cuja base é o círculo ou a elipse ao longo de BC, com eixo OD, e seja o menor deles aquele cuja base é o círculo ou a elipse ao longo de PP' com eixo AL.

Seja o maior cilindro formando a figura inscrita aquele cuja base é o círculo ou a elipse ao longo de $R R^{\prime}$ com eixo OD, e o menor aquele cuja base é o círculo ou elipse ao longo de $P P^{\prime}$ em eixo LM.

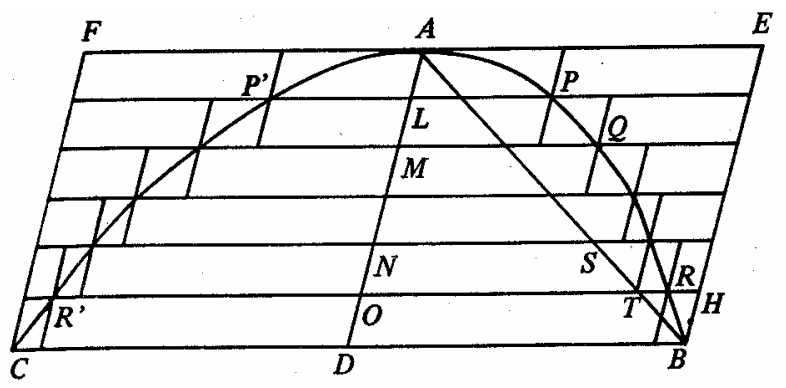

figura 9

Faça com que todos os planos das bases dos cilindros ou troncos interceptem a superfície do cilindro completo ou tronco EC.

(figura circunscrita) - (figura inscrita) < (segmento) - X 
Segue-se que

(figura inscrita) $>x$ $(\alpha)$

Agora, comparando sucessivamente os cilindros ou troncos com alturas iguais a $O D$ e formando respectivamente as partes do cilindro ou tronco EC e da figura inscrita, temos:

(primeiro cilindro ou tronco em EC): (primeira figura inscrita)

$$
\begin{aligned}
& =B D^{2}: R O^{2} \\
& =A D: A O \\
& =B D: T O, \text { onde } A B \text { intercepta } O R \text { em } T, \\
& e
\end{aligned}
$$

(segundo cilindro ou tronco em EC) : (segunda figura inscrita)

$=H O: S N$, da mesma maneira,

e assim por diante.

Então (proposição 1)

(cilindro ou tronco EC) : (figura inscrita)

$$
=(B D+H O+\ldots):(T O+S N+\ldots),
$$

onde $B D, H O, \ldots$ são todos iguais, e $B D, T O, S N, \ldots$ decrescem em progressão aritmética.

Mas [Lema que precede a proposição 1]

$$
B D+H O+\ldots>2(T O+S N+\ldots),
$$

Portanto (cilindro ou tronco EC) $>2$ (figura inscrita), ou $X>$ (figura inscrita); 0 que é impossivel por ( $\alpha$ ) acima.

Se, possivel seja o segmento menor do que $X$.

Neste caso inscrevemos e circunscrevemos figuras como antes, mas de tal modo que:

(figura circunscrita) - (figura inscrita) < X - (segmento),

e daí segue-se que:

(figura circunscrita) $<X$

E, comparando os cilindros ou troncos que constituem o cilindro completo ou tronco CE e a figura circunscrita respectivamente, temos:

(primeiro cilindro ou tronco CE): (primeiro na figura circunscrita) 
$=B D^{2}: B D^{2}$

$=B D: B D$

(segundo em CE) : (segundo na figura circunscrita)

$=H O^{2}: R O^{2}$

$=A D: A O$

$=H O: T O$

e assim sucessivamente.

Então (proposição 1)

(cilindro ou tronco CE): (figura circunscrita)

$=(B D+H O+\ldots):(B D+T O+\ldots)$,

< : 1, [Lema que precede proposição 1]

e daí segue-se que:

$x<$ (figura circunscrita);

isto é impossivel por ( $\beta$ ).

Assim, o segmento, não sendo nem menor nem maior do que $X$, tem que ser igual a ele e portanto a $3 / 2$ (cone ou segmento do cone $A B C$ ).

(apud Baron \& Bos, 1985, v.1, p.28)

Note inicialmente que a expressão "novamente metade do cone" quer dizer "metade do cilindro circunscrito" ou " $3 / 2$ do cone inscrito" ao parabolóide. Em sua demonstração, Arquimedes denomina de $X$ esta quantidade. Assim, o que ele quer provar é que o volume $C$ do parabolóide (isto é, do segmento) é igual a X. Isto posto, podemos enumerar os principais estágios do desenvolvimento do método de exaustão (na versão de Arquimedes): 
(1) Considere $I_{n}$ e $C_{n}$, respectivamente, sequiências de sólidos inscritos e circunscritos ao parabolóide do enunciado, de modo que $I_{1}<\ldots<I_{n}<I_{n+1}<C<\ldots<C_{n+1}<C_{n}<\ldots<C_{1} e$ $I_{1}<\ldots<I_{n}<I_{n+1}<X<\ldots<C_{n+1}<C_{n}<\ldots<C_{1}$.

(2) Suponha $C>X$

(3) Por escolha adequada de ' $n$ ', façamos $C_{n}-I_{n}<C-X$ (ax. de Eudoxo-Arquimedes - proposição 1, Elementos V) Note que a desigualdade anterior é equivalente a $C_{n}-C<I_{n}-X$

(4) Como $C_{n}>C$, temos que existe ' $n$ ' tal que $I_{n}>X$

(5) Por outro lado (usando resultados geométricos elementares), obtém-se $I_{n}<X$

(6) Isto é: $s e C>X$, então $I_{n}>X e I_{n}<X$. Logo, $C$ não pode ser maior que $X$.

(7) Suponha $C<X$

(8) Por escolha adequada de ' $n$ ', façamos $C_{n}-I_{n}<X-C$ (ax. de Eudoxo-Arquimedes - proposição 1, Elementos V)

(9) Como $C-I_{n}\left\langle X-C_{n}\right.$ e $\left.C\right\rangle I_{n}$, temos que existe ' $n$ ' tal que $X>C_{n}$

(10) Por outro lado (usando resultados geométricos elementares), obtém-se $X<C_{n}$

(11) Isto é: se $C<X$, então $C_{n}>X$ e $C_{n}<X$. Logo, $C$ não pode ser menor que $X$.

(12) Como $C$ não pode ser maior e nem menor que $X$, temos que $c=X$ 
Note, por exemplo, que se Arquimedes fizesse $n \rightarrow \infty$, nas duas desigualdades descritas em (1), obteria direto $C=X$. Não fez isto porque queria evitar, como sabemos, o uso do conceito de infinito. Por isso, para mostrar que $C=X$, mostrou que se considerássemos qualquer outra possibilidade além desta (isto é: $C>X$ ou $C<X$ ), chegaríamos, através do axioma de Arquimedes-Eudoxo e das propriedades geométricas das figuras construídas, a situações contraditórias. Assim, além do seu evidente desvio numérico, o método de exaustão é um processo indireto de demonstração que, em geral, não possibilita conhecer a origem real das descobertas dos resultados. Como será que Arquimedes descobriu o tal "cone" que serve como referência para a determinação do volume do parabolóide? Teria o grande matemático usado "a passagem direta ao limite" nas expressões dos sólidos inscritos e lou circunscritos ao parabolóide? Teria usado os infinitesimais? A resposta para este problema específico pode ser dada, usando as palavras do próprio Arquimedes que, em uma mensagem enviada a Eratóstenes ( 250 a.C.) nos diz que:

Vendo em você, como eu digo, um estudante sério, um homem de considerável eminência em filosofia e um admirador da matemática, pensei em escrever-lhe explicando em detalhes, no mesmo livro ${ }^{44}$, as peculiaridades de um certo método, pelo qual será possível iniciá-lo na investigação de alguns problemas de matemática, através da mecânica. Este procedimento é de muita utilidade, mesmo para as demonstrações dos teoremas; certas coisas tornam-se claras para mim, primeiro por um processo mecânico, embora eles tenham que ser demonstrados depois por arqumentos geométricos, pois a investigação pelo método citado não fornece uma demonstração. Uma visão antecipada, obtida pelo método, do teor das questões contribui para o processo de demonstração mais do que se não possuíssemos nenhum conhecimento prévio. (grifo nosso) 
Note, pelas palavras do próprio matemático, o destaque que ele dá ao método na busca de uma "visão antecipada" do "teor das questões" (essências dos resultados matemáticos). O grande mestre observa ainda o quanto "este procedimento [método] é de muita utilidade, mesmo para as demonstrações dos teoremas". Ressalta, entretanto, a necessidade da elaboração de uma demonstração mais rigorosa (o método de exaustão). Mas, afinal, em que consiste tal "método mecânico"?

Deixamos ao leitor a grata surpresa de descobrir, de uma só vez, as respostas para as duas questões ${ }^{45}$ aqui levantadas. $O$ texto, a seguir, apresenta uma outra solução para o problema do volume de um parabolóide, em que Arquimedes usou o tal método mecânico:

(Arquimedes, O Método, proposição 4)

Qualquer segmento de um conóide reto (isto é, um parabolóide de revolução) secionado por um plano perpendicular ao eixo é igual a $1 \frac{1}{2}$ vezes o cone que tem a mesma base e o mesmo eixo do segmento.

Isso pode ser investigado por nosso método como segue. Cortemos um parabolóide de revolução por um plano através do eixo obtendo a parábola $B A C$.

Corte também com um outro plano perpendicular ao eixo que intercepte o primeiro plano $B C$.

Seja $D A$ o eixo do segmento, prolongue-o até $H$ de tal modo que $H A=A D$.

Imagine que HD seja a haste de uma balança e A o seu ponto médio. A base do segmento sendo o círculo onde $B C$ é o diâmetro, e em um plano perpendicular a $A D$, ima-

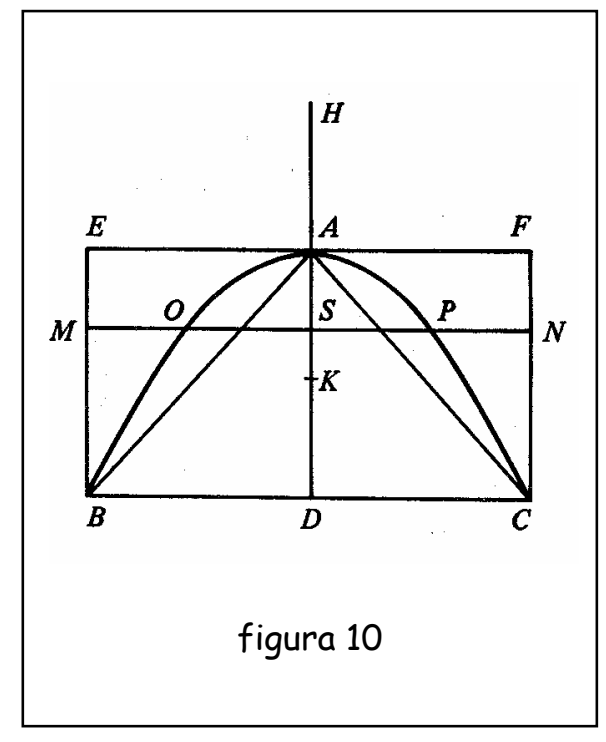

\footnotetext{
${ }^{44} \mathrm{O}$ livro a que se refere Arquimedes é a sua grande obra conhecida como “O Método", descoberto casualmente, em Constantinopla, somente no ano de 1906. É lamentável que esta obra não tenha sido descoberta antes.

45 Como será que Arquimedes descobriu o tal “cone” que serve como referência para a determinação do volume do parabolóide? Em que consiste tal "método mecânico”?
} 
gine (1) um cone obtido com o círculo em questão como base e A como vértice, e (2) um cilindro com o mesmo círculo como base e AD como eixo.

No paralelogramo EC tome qualquer reta MN paralela a BC, e por MN trace um plano perpendicular a AD; este plano cortará o cilindro em um círculo com diâmetro $M N$ e o parabolóide em um círculo com diâmetro $O P$.

Agora, BAC sendo uma parábola e BD, OS as ordenadas,

$D A: A S=B D^{2}: O S^{2}$

ou

$H A: A S=M S^{2}: S O^{2}$.

Portanto,

HA : AS = (círculo, raio MS) : (círculo, raio OS)

= (círculo no cilindro) : (círculo no parabolóide).

Logo, o círculo no cilindro, no lugar onde ele se localiza, estará em equilíbrio, em torno de A, com o círculo no parabolóide, se este último for colocado com seu centro de gravidade em $\mathrm{H}$.

Assim, como de costume, se considerarmos todos os círculos componentes do cilindro e o segmento inteiro e os tratarmos do mesmo modo, acharemos que o cilindro, no lugar onde está, estará em equilíbrio em torno de A com o segmento colocado com o seu centro de gravidade em $\mathrm{H}$.

Se Ké o ponto médio de AD, Ké o centro de gravidade do cilindro:

logo, $H A ́$ : $A K=$ (cilindro) (segmento)

logo, cilindro $=2$ (segmento), (Euclides, XII, 10)

e cilindro $=3$ (cone $A B C$ )

logo, segmento $=3$ (cone $a b c)$.

(apud Baron \& Bos, 1985, v.1, p.50-51)

Isto posto, fica evidente a introdução de conceitos provenientes da mecânica (princípio dos momentos) mas, conforme observou Baron (1985, v.1, p.52), "a coisa mais importante do método não é a idéia do peso e da balança e sim a idéia de considerar o parabolóide (conóide) e o cilindro como sendo construídos de seções circulares (sem espessura) que, na imaginação, podem ser transladados e acumulados em $\mathrm{H}^{\prime}$. Com efeito, são essas quantidades infinitamente pequenas (sem espessuras), o elemento fundamental do seu "método". Parece que voltamos a Demócrito. Ou será que já estamos no século XVII com Cavalieri? Bem, a influência que a "geometria dos indivisíveis" de Cavalieri possa porventura ter sofrido pelo método mecânico de Arquimedes é questi- 
onável, uma vez que a descoberta dos documentos originais da obra grega tenha se dado apenas no século XX. Mas, que o método mecânico tenha sofrido uma influência direta dos "indivisíveis matemáticos" de Demócrito parece bastante evidente, uma vez que Arquimedes era profundo conhecedor dos trabalhos do primeiro.

Assim, pode-se dizer que, em Arquimedes, tanto as quantidades infinitamente pequenas, como a célula-mãe da noção de limite, conviveram, não de forma muito harmoniosa, é verdade, mas cada qual com um papel bem definido no processo de construção do conhecimento matemático. Segundo o próprio matemático, coube à primeira a nobre tarefa de "construção" das idéias essenciais dos resultados matemáticos, enquanto que à segunda, coube a árdua tarefa de fornecer o "alicerce" para a busca de uma demonstração "mais" rigorosa. Mas, seriam esses mesmos os papéis reservados às noções de limite e infinitésimos na construção dos resultados do Cálculo? Estaria no procedimento infinitesimal a "essência" do pensamento do Cálculo Diferencial e Integral? E, seria, efetivamente, a noção de limite um sólido "alicerce" para os conceitos básicos do Cálculo?

Creio que ainda é muito cedo para discutirmos essa questão com mais profundidade. O contexto fornecido pelo Cálculo de Arquimedes não nos possibilita realizar uma reflexão mais profunda. Faltam, no seu Cálculo, dois ingredientes fundamentais: um bom conceito de número $e$ o conceito de variável (e, conseqüentemente, o conceito de função). Curiosamente, para avançarmos mais um pouco, e percebermos a real importância do conceito de variável para o desenvolvimento das idéias básicas do Cálculo, é preciso retroceder no tempo e recuperar o pensamento de Heráclito de Éfeso ( 500 a.C.), o "pai da dialética". 
O grande pensador pré-socrático, ao contrário de Parmênides, afirma que o universo é, ao mesmo tempo, divisível e indivisível, gerado e não-gerado, mortal e imortal, Palavra e Eternidade, Pai e Filho, Deus e Justiça. Faz do movimento o elemento fundamental de seus argumentos. A metafísica de Heráclito se caracteriza por três aspectos: sua noção da unidade dos contrários, seu conceito de relatividade e suas idéias sobre a impermanência ou o fluir.

Combinações - todo e não-todo, concorrentes diferentes, concordantes discordantes, de todas as coisas um e de um todas as coisas.

([B 10], apud Barnes, 1997, p.163)

É dessa forma que o "pai da dialética" explica a estrutura do universo. Segundo o pensador, o universo foi organizado por um pensamento de harmonia através da combinação dos princípios mais opostos. Se trouxermos esta reflexão de Heráclito para o "universo" do Cálculo, perceberemos que o Cálculo também foi construído através de alguns princípios opostos fundamentais: Discreto $x$ Contínuo; Local $x$ Global; Somas $\times$ Diferenças; Permanente Mudança $\times$ Imutabilidade. Mais: podemos dizer que para desenvolvermos o conceito de variável, o conceito de derivada, será preciso romper, num primeiro momento, com a característica estática da matemática grega e dar uma interpretação mais dinâmica às idéias básicas do Cálculo. E isto será feito na próxima etapa de desenvolvimento do Cálculo. Antes, porém, cabe destacar que na matemática grega, apenas os trabalhos de tangentes de Arquimedes e do sofista Híppias levavam em conta esses aspectos cinéticos. A espiral, por exemplo, fora definida por Arquimedes inicialmente em termos de movimento: 
Se resolvermos uma reta com uma das extremidades fixas num movimento uniforme em um plano até que ela retorne à posição inicial, e se, ao mesmo tempo em que resolvermos a reta, um ponto move-se ao longo da reta num movimento uniforme, começando da extremidade fixa, o ponto descreverá uma espiral no plano.

(apud Baron \& Bos, 1985, v.1, p.53)

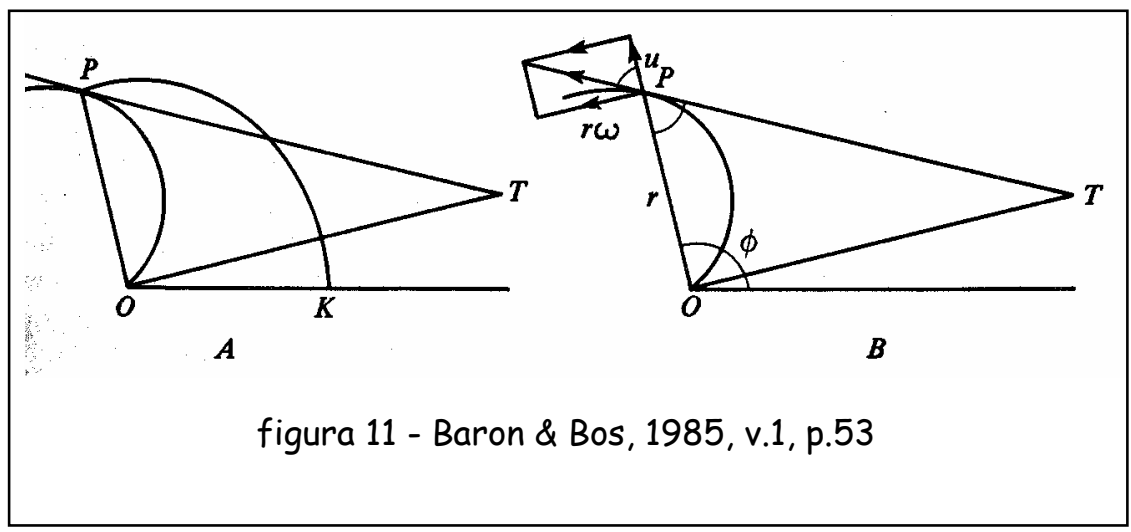

Assim, para determinar a tangente, era suficiente determinar 0 vetor velocidade, que por sua vez era determinado pela regra do "paralelogramo". Para as demais curvas (que no domínio grego eram em número bastante limitado) o método usado para determinar as tangentes era essencialmente geométrico. Além de Arquimedes, Euclides e Apolônio ${ }^{46}$ são exemplos de matemáticos gregos que resolveram (geométrica e estaticamente) tais tipos de problemas. Como os gregos tinham uma noção insatisfatória de ângulo e de tangente, além, é claro, de uma certa reticência em relação ao uso de interpretações cinéticas no desenvolvimento da matemática - o paradigma da época era o rigor lógico -, os "problemas de tangentes" não tiveram significativos avanços na matemática grega. Os sucessores de Arquimedes - Hiparco, Heron, Ptolomeu e outros - voltaram-se mais para o desenvolvimento das "ci-

\footnotetext{
${ }^{46}$ Apolônio determinou tangentes às cônicas - círculo, parábola, elipse e hipérbole - à moda euclidiana.
} 
ências matemáticas" tais como astronomia, mecânica e ótica. Como bem observou Boyer, para que houvesse um avanço significativo no "método geométrico grego", outros "avanços", em outras áreas do próprio conhecimento matemático precisariam ser efetivados: desenvolvimento de uma álgebra abstrata simbólica mais elaborada e introdução na álgebra e na geometria da noção de variação (variáveis e função).

De fato, os conceitos de função/variável, ou melhor, de funcionalidade/variabilidade constituem um eixo fundamental para o desenvolvimento do Cálculo. Enquanto que na filosofia grega pode-se perceber a idéia de movimento, tanto na filosofia peripatética ${ }^{47}$ de Aristóteles, quanto no conceito de "apeíron" de Anaximandro, que Platão invocou em sua filosofia $e$ indagações sobre a geometria, na matemática grega percebemos uma total ausência desse conceito de variabilidade/funcionalidade - exceto, como já observamos, no método de tangentes de Arquimedes. Na correlação de forças das idéias dessas duas correntes filosóficas para o desenvolvimento do conhecimento matemático, a filosofia aristotélica acabou prevalecendo sobre a atitude platônica. Um claro exemplo dessa supremacia pode ser observada na aritmética de Diofantes - que representa, aliás, o que se tem de mais refinado no pensamento algébrico grego. Segundo Boyer (1949, p.60), a base lógica da filosofia peripatética é muito mais forte que a concepção ontológica platônica da matemática na aritmética diofantina. Esta dificuldade de se apropriar e desenvolver a noção de variabilidade não é característica exclusiva dos matemáticos gregos: os matemáticos da

\footnotetext{
${ }^{47}$ Escola fundada por Aristóteles em Atenas, em 335 a.C.. Supõe-se que foi assim denominada por causa do peripatos, ou passeio coberto no jardim do Liceu, onde Aristóteles lecionava. Além de Aristóteles, seus membros mais importantes foram Teofrasto, Eudemo de rodes e Estratão de Lâmpsaco - (Blackburn, 1997, p.121)
} 
Europa medieval também terão as mesmas dificuldades. O grande portão de entrada deste conceito na matemática será, como veremos adiante, a filosofia dos escolásticos. 


\subsubsection{A transição para a Europa medieval}

Como se pode perceber pelos parágrafos anteriores, os conceitos de movimento não exerceram papel preponderante na estrutura formal da matemática grega. Apesar da frustrada tentativa de Platão e do caso isolado do método de tangentes de Arquimedes, o conceito de movimento $e$, conseqüentemente, o de variabilidade e funcionalidade, se desenvolveram, ainda que de modo incipiente, através da filosofia. E é na filosofia que ela permanecerá incubada até que se consiga o ingrediente fundamental para resgatá-la para o ambiente matemático. $O$ ingrediente de que falamos depende diretamente de um processo de "libertação" do pensamento algébrico do contexto geométrico. Segundo Boyer (1949, p. 61), o interesse dos hindus e árabes pelo desenvolvimento algébrico, e dos filósofos escolásticos pelos problemas do contínuo, são a base necessária para esse processo de transformação no paradigma da matemática.

Com efeito, os hindus se interessaram muito mais pelos aspectos aritmético e computacional da matemática do que pela característica geométrica e racional da matemática grega. O próprio nome atribuído por eles à matemática ("ganita" - que significa literalmente a "ciência do cálculo") caracteriza bem essa preferência. Ignoraram a criteriosa distinção grega entre a discretude do número e a continuidade da magnitude geométrica e, conseqüentemente, os paradoxos de Zenão e os questionamentos de Platão sobre o contínuo.

Por outro lado, apesar do grande interesse pelos números, tiveram dificuldades operacionais com o número zero. Brahmagupta (um dos mais notáveis matemáticos indianos da época) chegou, diante des- 
sas dificuldades, a considerar o zero como uma quantidade infinitesimal que na etapa final do cálculo se reduz a nada. Não consideraram, entretanto, as formas indeterminadas e procedimentos que envolviam a noção de limite ou mesmo de infinitesimais. $A$ construção do sistema de numeração foi, sem dúvida, a principal contribuição dos hindus, não só para o Cálculo, mas para a própria matemática.

Os números hindus alcançaram a Europa através da civilização árabe. A preservação e a transmissão da matemática grega para a Europa medieval também foram realizadas por este povo de natureza tão eclética. Os árabes tanto se interessaram pela álgebra e aritmética pragmática dos hindus quanto pela geometria estética e formal de Euclides, Arquimedes e companhia. Apesar do fascínio demonstrado pelo conhecimento científico produzido pelos povos hindus e gregos ${ }^{48}$, os árabes pouco acrescentaram ao desenvolvimento das idéias básicas do Cálculo.

No continente europeu a situação era menos motivante ainda. $O$ período que se estende da época da queda de Roma (455 d.C.) até o primeiro dos renascimentos intelectuais do Ocidente, sob o Papa Silvestre II (999-1003 d.C.), é tradicionalmente considerada como uma fase quase estéril da história da civilização européia, sendo denominada inclusive por muitos historiadores como as "idades obscuras" (Mason, 1962).

Para Bell (1987, p.95), no entanto, no caso específico da matemática, a decadência começou muito antes: no apogeu e esplendor do

\footnotetext{
${ }^{48}$ Os árabes construíram grandes "casas de sabedoria” para traduzir e estudar, principalmente, a obra científica dessas civilizações.
} 
próprio Império Romano. Segundo o historiador de matemática, a contribuição dos romanos é praticamente nula:

Além dos embaraçosos números romanos, aos quais se pode chamar criação matemática apenas por bondosa caridade, os romanos não criaram nada que se parecia com a matemática, nem de longe. Tomaram o pouco que necessitavam para a guerra, o levantamento de planos e a engenharia de força bruta dos gregos, aos quais haviam esmagado com o peso das armas, e se contentaram com isso. Quando Julio César reformou o calendário no ano de 46 a.C., não foi nenhum romano que propôs o ano bissexto com seu dia extra em fevereiro, mas Sosigenes de Alexandria. A contribuição dos romanos à civilização foi em direito, governo e paz na ponta de espada.

Em algumas linhas anteriores, o historiador chega a afirmar que "no campo matemático a mente romana era torpe". Há, no entanto, na literatura, opiniões menos severas a respeito dos romanos. Ronan (1987, p.130), por exemplo, cita em seu trabalho a admiração e o zelo que os romanos tinham pelas obras gregas, destacando inclusive o seu papel de grandes difusores do conhecimento grego:

Em geral diz-se que os romanos eram um povo prático e tecnológico, não muito dado à especulação inelectual; quanto ao pensamento abstrato, eles se voltavam aos grego sem busca de inspiração. Mesmo assim, considerando-se as complexas formulações do direito romano e o arrojo de sua arquitetura nos grandes arquedutos e basilicas, ainda é de admirar que eles realizassem tão poucos trabalhos científicos teóricos. Talvez seja menos surprendente o fato de que o trabalho realizado tendesse a ser um glossário das idéias gregas.

Um belo exemplo dessa dedicação ao estudo da filosofia e da ciência gregas é o de Boécio (480-524): "o último dos romanos e o primeiro dos escolásticos" 49 . É também considerado por alguns autores como um dos fundadores da Idade Média. Sua principal realização foi, sem dúvida, as suas sinteses em latim de obras gregas - que englobavam partes da aritmética e da geometria gregas e do sistema da lógica

\footnotetext{
${ }^{49}$ Citação de Martin Grabmann que aparece em (Reale \& Antiseri, vol.1, p.464). A nota de rodapé (52) traz o significado da expressão "escolástico".
} 
aristotélica - o que tornou possível a assimilação destas pelos latinos. Segundo Bell (1996, p.98):

Os livros de texto elementares de Boécio foram os que marcaram o passo da matemática na Europa da Idade Média. Retornando à síntese pitagórica, Boécio expunha um quadrívio desfigurado de aritmética, música, geometria e astronomia.

O quadrívio (Aritmética, Geometria, Música e Astronomia) foi, sem dúvida o paradigma de organização e transmissão do conhecimento durante grande parte da Idade Média.

Superadas essas contradições internas do Império Romano $e$, principalmente, a polêmica discussão acerca da origem precisa do período obscuro da ciência, resta-nos vencer outra dificuldade: identificar as razões para essa desaceleração brusca no desenvolvimento do conhecimento científico.

Mais uma vez aqui, não é explicitada nenhuma resposta direta e objetiva pela maioria dos historiadores da ciência e da matemática; no entanto, podemos elaborar duas conjecturas para justificar a ocorrência de tal fato histórico:

- a visão pragmática do conhecimento:

- a ascensão do cristianismo como religião oficial.

Com efeito, segundo Mason (1962, p.79), com a invasão do Império Romano - já em desagregação - pelos bárbaros teutônicos, algumas inovações técnicas e minudências foram trazidas pelos invasores, e estas constituíram, certamente, a base de um modo de vida materialmente superior ao da antiguidade clássica. O uso de calças em vez de toga, do estribo, para andar a cavalo, o consumo de manteiga, em lugar do azeite de oliveira, aperfeiçoamento dos métodos de fabricação do feltro, o esqui, a manutenção de barris e tinas, o desenvolvimento de no- 
vas culturas (do centeio, da aveia, do trigo, do lúpulo etc.) e, principalmente, o uso do pesado arado de rodas, que possibilitou o desenvolvimento do sistema dos três campos de cultura, sobre o qual se basearia a vida do solar medieval, são fatos que demonstram a sensível melhora na qualidade de vida produzida neste período. Assim, a forma respeitosa e contempladora que os romanos dispensavam à ciência grega foi substituída por uma visão mais pragmática do conhecimento científico.

Por outro lado, como já dissemos anteriormente, outro fato histórico também foi determinante para esse período obscuro do conhecimento científico: a ascensão do cristianismo.

Com a conversão de Constantino, o Grande, em 312 d.C., o cristianismo tornou-se a religião oficial de Roma. Assim, a partir do século IV d.C., os sacerdotes e bispos da igreja cristã ficaram investidos de uma autoridade e um poder nunca vistos anteriormente. Qual foi então a atitude dos representantes dessa nova religião em relação à ciência?

Segundo Ronan (1987, vol.2, p.135), as divergências entre os cristãos podem ser resumidas basicamente em duas atitudes:

Como é comum em assuntos dessa natureza, houve uma série de divergências entre os cristãos. Por um lado, podia-se dar uma boa razão para ignorar todos os estudos seculares - científicos ou outros - e concentrar toda a atenção no importante tema da salvação das almas. E, já que a ciência, no mínimo, significava voltar às fontes gregas, aos ensinamentos pagãos, seria pelo menos prudente deixá-la de lado para que a mente não ficasse contaminada de idéias perigosas, prejudicando as almas cristãs. Por outro lado, havia uma concepção diametralmente oposta. Se Deus fez o mundo, e viu que estava bom, então estudar o seu trabalho através da ciência só poderia provocar uma sensação de esplendor diante de tão divina sabedoria, e uma admiração por tais maravilhas que o criador permitia que o homem visse. Do lado da ciência, com a poderosa crença de que a contemplação das obras de Deus só poderia trazer um aumento da consciência em relação à onipotência e à sabedoria da divindade, estava Aurelius Augustinus, que mais tarde seria canonizado como Santo Agostinho. (grifo nosso) 
Sem dúvida, conforme bem disse Ronan, o cristianismo ocidental encontrou em Santo Agostinho (354-430) um paladino da ciência e da aprendizagem. Convém, no entanto, observar que, mesmo no pensamento de Santo Agostinho - por demais progressista para sua época -, o conhecimento científico era subjugado pela fé: o conhecimento era uma "dádiva divina" e, dessa forma, não poderia contradizer as palavras da Escritura Sagrada. Esta submissão do conhecimento à fé cristã submete também a filosofia à teologia e faz com que esta última seja então considerada pelos pensadores da época a "rainha das ciências".

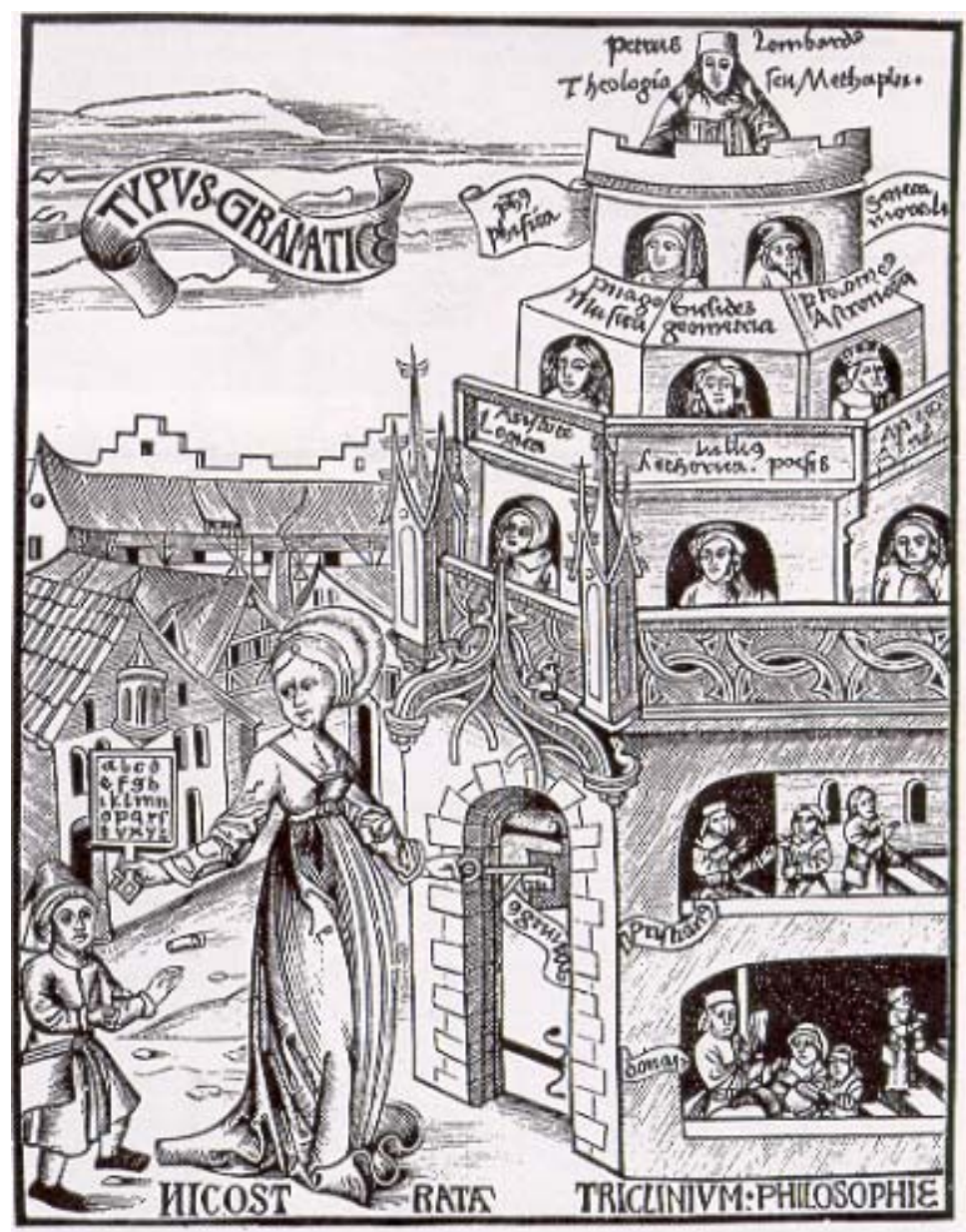

figura 12 - A torre da filosofia com a teologia, "a rainha das ciências" Da Margarita philosophica de George Reisch, 1508 - Ronan, 1987, v.2, p.152 
A teoria da natureza divina do conhecimento, de Santo Agostinho, dominou o pensamento ocidental durante gerações, sendo contestada apenas nas universidades de Oxford e de Paris - criadas no século XIII ${ }^{50}$-, à luz dos recém-descobertos ensinamentos de Aristóteles. Mas já era outra época.

De fato, nos séculos XII e XIII os trabalhos gregos começaram a ser traduzidos para o latim, como, por exemplo, a filosofia peripatética de Aristóteles. As considerações do filósofo grego sobre o infinito, o infinitesimal, a continuidade e outros tópicos relacionados à análise matemática despertaram o interesse e a curiosidade de parte dos filósofos escolásticos. Por outro lado, começa a surgir uma reação de grande parte dos teólogos cristãos contra essa intervenção "perigosa" da filosofia pagã nos domínios da ciência. O perigo estaria, na visão dos teólogos conservadores, na possibilidade de certos homens de talento científico tornarem-se heréticos sob essa influência pagã. Havia muitos aspectos na filosofia aristotélica que estavam em conflito com as Escrituras aceitas como autênticas pela Igreja cristã. Assim, não seria mais seguro privar esses homens de terem acesso aos documentos originais?

Não era dessa forma que pensava Santo Tomás de Aquino (12251274) - considerado, já na sua época, pela própria Igreja Católica ocidental, como seu mestre mais representativo. Segundo Ronan, Santo

\footnotetext{
${ }^{50}$ A universidade de Paris foi fundada por volta de 1170, como um desenvolvimento das escolas da Catedral de Notre-Dame, seguida de perto por Oxford, que também surgiu das escolas fundadas no século IX, pelo rei Alfredo. Paris tornou-se rapidamente um grande centro de teologia cristã ocidental e, por volta de 1220, as ordens mendicantes - dominicanos e franciscanos - começaram a ensinar ali. Em Oxford, entre os franciscanos, surgem dois grandes cientistas: Robert Grosseteste e seu aluno Roger Bacon, ambos muito versados na tradução das fontes árabes até então disponíveis.
} 
Tomás de Aquino, embora não fosse um cientista, se colocou do lado da razão e conseguiu uma síntese aceitável do cristianismo com o aristotelismo:

(...) Quase sozinho, foi capaz de fazer a faculdade teológica mudar de rumo e chegar a bons termos com o ensinamento aristotélico. Opôs-se tenazmente à noção de que todo conhecimento provém da iluminação divina; as coisas invisiveis de Deus podiam, assim pensava, ser vistas através de sua criação visivel. A razão podia trazer a verdade e a certeza. O mundo da natureza era um livro escrito por Deus. E tudo isso, junto com suas cuidadosas interpretaçôes teológicas da ciência grega, significa que os cristãos ortodoxos não precisavam ter nada a temer da filosofia pagã. Quando se tratava de ciência, os gregos revelavam o mundo de Deus: quando se tratava de assuntos da salvação, então a Igreja e as Escrituras eram a autoridade reveladora.

(Ronan, 1987, v.2, p.154).

Foi desse modo, com este argumento, que Santo Tomás de Aquino conseguiu abrir novamente as portas do conhecimento para a ciência. A importância do papel de Santo Tomás de Aquino para um novo despertar do conhecimento científico na Europa ocidental foi tanta que levou o historiador de matemática Bell $(1985$, p.96) a considerá-lo como o "Newton da teologia escolástica" 51.

A escola escolástica atende então ao chamado do seu grande mestre e começa a construir canais que possibilitem a harmoniosa convivência da doutrina cristã e da ciência (em particular, a ciência grega). Questões relacionadas principalmente às áreas de medicina e de física

\footnotetext{
${ }^{51}$ Segundo Mora (2000, vol.2, p.862) a escolástica é usualmente confundida com a filosofia medieval. É importante que se diga que esta última contém muitos elementos que não estão na primeira, entre eles as tendências místicas, que não podem ser identificadas precipidamente com a filosofia escolástica. Podem, dessa forma, existir num mesmo autor "tendências místicas" e "tendências escolásticas", mas nenhuma delas se reduz à outra. Por outro lado, a escolástica persistiu depois da filosofia medieval, no Renascimento, na época moderna e - sob a forma chamada "neoescolástica" - no final da época moderna e na idade contemporânea. Todavia, embora não se possa equiparar "filosofia medieval” e "filosofia escolástica", esta última constitui o ingrediente filosófico mais importante da idade média. O termo "escolástica” provém do vocábulo scholasticus ("escolástico”), isto é, aquele que ensina em uma escola. Mais especificamente, era chamado de scholasticus quem ensinava as artes liberais em uma escola monástica. Depois, "escolástico" designou o mestre que seguia certas orientações filosóficas e adotava certos métodos coerentes com elas.
} 
são retomadas e re-significadas em um novo contexto histórico e cultural. A produção do conhecimento científico continua, entretanto, sob a tutela da doutrina cristã.

Esse encorajamento à produção do conhecimento científico, ainda que condicionado a tutela do cristianismo, associado a uma visão mais pragmática do mesmo, irá porpocionar uma nova forma de se fazer ciência - bem diferente do modo dos antigos. Um dos maiores responsáveis por esta transformação foi Roger Bacon (1214-1292). De 1241 a 1246, Bacon lecionou em Paris. Em 1247 retornou a Oxford e tornou-se franciscano em 1254, o que the causou certas atribulações posteriores. Apesar de sua impopularidade entre as autoridades eclesiais, Bacon tornou-se uma figura importante no mundo da ciência por causa das virtudes positivas de sua perspectiva científica. Segundo Bacon, havia quatro obstáculos para se conseguir a verdade das coisas: i) autoridade fraca e inepta; ii) hábitos antigos; iii) opinião popular sem instrução; iv) encobrimento da ignorância de alguém por causa de uma aparência de sabedoria. Ele não classificou a autoridade das Escrituras em sua categoria (i), embora tenha declarado que essa autoridade devia ser informada pela razão, e que a razão, por seu lado, tinha de ser confirmada pela experiência. Essa experiência podia ser de dois tipos: (a) as obtidas por meio de experiências místicas interiores; (b) as obtidas por meio de causas exteriores, auxiliadas por instrumentos e com a precisão fornecida pelo uso da matemática ${ }^{52}$.

Para Bacon, tudo era parte do conhecimento do homem, revelado ou observado. Esta atitude, segundo o historiador Ronan, torna a perspectiva de Bacon muito mais "medieval" do que moderna. Desse modo, 
a scientia experimentalis de Bacon não era propriamente a nossa ciência experimental moderna; era mais o que se chamou, mais tarde, de magia naturalis, magia natural. Mas, ainda assim, era uma nova perspectiva científica e um longo passo na direção da ciência experimental.

A mudança na matemática foi, no entanto, um pouco mais lenta $e$ cautelosa. Enfatizando o papel que Roger Bacon teve para o desenvolvimento da nova maneira de pensar da ciência, Bell (1996, p.100) afirma:

Parece que a transição da antiga maneira de pensar para a moderna foi mais difícil na matemática do que na ciência. Não parece que haja um só exemplo claro de uma mente matemática que aparecera na Idade Média adiantando-se dois ou três séculos à sua época, como foi o caso de Roger Bacon (1214-1294) na ciência. Até Bacon, muito esperto na ciência, adormecia, todavia, na matemática, (...). Sua maneira de pensar era, todavia, a dos escolásticos aristotélicos, (...).

A descoberta e a re-significação da física aristotélica nesse período irá provocar, sem dúvida, sensíveis mudanças na produção do conhecimento matemático. Foi o que aconteceu: para dar conta dos novos modelos e interpretações dos fenômenos físicos, a matemática precisará se despojar, de modo paulatino, de sua característica estática, finita e rigorosa herdada dos antigos. Os conceitos de indivisiveis e de quantidades infinitamente pequenas retornam ao cenário matemático, tornando, pouco a pouco, os processos infinitos um instrumento normal da matemática da época: é a geometria euclidiana caminhando na direção da invenção do Cálculo. Para muitos historiadores da matemática, foi a escola escolástica o portão de entrada desses conceitos fundamentais do Cálculo na matemática. Mais uma vez, é a filosofia - o "amor à sabedoria" - que fornecerá novos caminhos para a matemática.

\footnotetext{
${ }^{52}$ Consultar (Ronan, 1987, v.2, p.141).
} 
Vejamos mais de perto essa contribuição dos escolásticos para o desenvolvimento do Cálculo.

Thomas Bradwardine - "doctor profundus", arcebispo de Canterbury e considerado por Boyer como o maior matemático inglês da época - desenvolveu dois trabalhos interessantes - Geometria Speculativa e Tractatus de Continuo - que irão retomar a discussão interrompida, e esquecida por longos séculos pelos matemáticos, sobre as quantidades infinitesimais. $O$ tempo ${ }^{53}$, segundo o arcebispo, era composto de elementos indivisíveis ${ }^{54}$. Pensava dessa forma porque não considerava o tempo contínuo. No entanto, ao tratar das grandezas contínuas, considerava-as como compostas de um número infinito de indivisíveis do "mesmo tipo" - contínua -, mas não feita de átomos ${ }^{55}$. 0 infinitesimal, para ele, tinha, assim como para Aristóteles, apenas existência potencial.

Uma atitude intermediária entre a posição de Bradwardine e a atomista é a defendida por William de Occam. Embora admita que nenhuma parte contínua é indivisivel, William sustenta que "a linha reta realmente consiste de pontos". No entanto, afirma, em outro momento, que "linhas e superfícies são puras negações, não tendo realidade no sentido de que um sólido é real" - (Boyer, 1949, p.67).

Segundo Boyer, a posição de Bradwardine tem sido associada mais com a de Brower e a dos intuicionistas modernos, que concebem o

\footnotetext{
${ }^{53}$ Esta concepção do tempo, devida a Bradwardine, foi influenciada provavelmente por Capella, Isidoro de Sevilha, Bede, e outros contemporâneos seus.

${ }^{54}$ Uma hora seria feita de 22560 desses instantes indivisíveis. Um cálculo aproximado desse “instante indivisível” fornece um valor em torno de 16 centésimos do segundo.

55 "Nullum continuum ex indivisibilibus infiitis integrari vel componi" - disse Bradwardine, usando pela primeira vez a palavra que Leibniz irá adotar, por sugestão dos irmãos Bernoulli, para designar no seu Cálculo a soma de um número infinito de infinitesimais: a integral. (apud Boyer, 1949, p.67)
} 
contínuo como feito de um número infinito de "partes infinitamente contínuas" (isto é, que podem ser subdivididas infinitamente e continuamente), enquanto que a de William corresponde àquela sustentada por Russell e os formalistas, que consideram o contínuo como um conjunto perfeito de pontos, denso em todo lugar.

Assim, priorizando o ponto de vista da "divisibilidade infinita" e "agregados infinitos", é que os filósofos medievais deram proseguimento aos seus estudos sobre o contínuo. Petrus Hispanus, que se tornou Papa João XXI, reconheceu em sua obra Summulae Logicalis dois tipos de infinito: infinito categoremático, no qual todos os termos são realmente realizados, e o infinito sincategoremático, que é limitado sempre pela potencialidade.

Albert de Saxony identifica a noção de continuidade com o processo de divisões infinitas: Infinitum continuum est divisible e Continuum est divisible in infinitum. Bradwardine procura explicitar melhor as diferenças entre o "infinito categoremático" e o "infinito sincategoremático". Segundo o filósofo inglês, o primeiro tipo é uma quantidade sem fim, enquanto o segundo é uma quantidade que não é tão grande mas que pode ser feita maior.

Concordando com Aristóteles, William de Occam nega que o infinito categoremático é sempre realizado. Richard Suiseth (1328) demonstrou muito mais interesse em "argumentos dialéticos" e sofismas sutis em relação ao infinito do que em uma definição propriamente dita dessa noção. Já Galileu considerou o infinito como uma grandeza e mostrou-se muito mais interessado na correspondência de agregados infinitos, do que na razão de grandezas finitas para grandezas infinitas. Esta concepção do infinito enquanto grandeza dissociada dos a- 
gregados infinitos que o geram é, sem dúvida, um dos principais obstáculos epistemológicos para a construção do seu próprio conceito. A correção desse desvio será feita pelo uso inicial de um maravilhoso instrumento inventado pelo Cálculo: as séries infinitas. Tal ferramenta se constitui, com efeito, num poderoso instrumento nessa passagem do discreto infinito para o contínuo. Nesse sentido, o "frutífero uso do infinito" nos trabalhos de Arquimedes possibilitou a passagem da "coleção infinita de linhas" em termos de séries - Boyer (1949, p.70). No entanto, essa mixagem entre os conceitos de contínuo e de infinito só vai ser bem decifrada com o desenvolvimento da Análise Matemática, no final do século XIX. Mas há de se ressaltar, entretanto, que a contribuição dos filósofos escolásticos no entrelaçamento inicial desses dois grandes nós (o infinito e o contínuo) do conhecimento do matemático foi de suma importância para o desenvolvimento do Cálculo.

Outra grande contribuição dessa escola foi a introdução e o desenvolvimento de ferramentas que permitissem uma análise mais quantitativa dos fenômenos físicos, com destaque para os fenômenos cinemáticos. Um notável exemplo dessa contribuição foi o significativo avanço que se deu neste período para a construção do conceito de derivada. É bem verdade, conforme nos relata Boyer (1949, p. 71), que tal contribuição se deu muito mais em termos da dialética do que como "método matemático", mas é neste período da história da matemática que irá se admitir, pela primeira vez, e de forma explícita, o conceito de variação.

Heráclito, Demócrito e Aristóteles realizaram algumas especulações metafísicas qualitativas sobre a idéia de movimento e certos geômetras gregos (Hippias, Arquimedes e outros) usaram essas espe- 
culações em seus pensamentos (mas não em suas provas). Platão chegou a vislumbrar o conceito de variável no "apeíron" de Anaximandro. No entanto, a idéia da representação da variação contínua por meio da grandeza geométrica ou do estudo dela em termos da discretude dos números racionais não foi certamente da alçada dos matemáticos gregos ${ }^{56}$. O estado embrionário dessas atitudes pode-se encontrar, sem dúvida, nas obras dos filósofos escolásticos e seus seguidores.

$\mathrm{Na}$ astronomia grega (assim como na física aristotélica) não existia o conceito de aceleração. Os movimentos eram todos uniformes (e daí eternos) e circulares. O movimento, conforme nos relata Boyer, era mais qualidade do que quantidade. Aristóteles se referiu à matemática como algo relacionado a "coisas que não envolvem movimento", e sustentou que os matemáticos estudam objetos "qua" contínuo, os físicos "qua" movendo, e a filosofia "qua" sendo.

A matemática grega foi muito mais o estudo da forma do que o da variabilidade. Mesmo as quantidades que aparecem nas equações diofantinas se comportam como constantes a determinar (incógnitas), do que como variáveis. Tal procedimento é continuado na Álgebra Hindu-Árabe.

Aristóteles, por sua vez, considerava o movimento uma qualidade que não cresce e nem decresce (como faz uma quantidade). Tal característica da física aristotélica predominou no pensamento das ciências naturais até o século XIII. Somente no século XIV, nos trabalhos de Jean Buridan, surge a idéia de "ímpeto", idéia precursora da noção mecânica de impulsão. Esta doutrina, atribuída a Buridan, é considerada

\footnotetext{
${ }^{56}$ Segundo Boyer (1949, p.71), a demanda pelo rigor no pensamento grego, que era congruente com a geometria, não permitiu que se estabelecesse na matemática nenhuma “confusão” do discre-
} 
por muitos historiadores como um prenúncio do famoso trabalho em dinâmica de Galileu. Surge também com os escolásticos a noção de velocidade instantânea (a física aristotélica só considerava a velocidade média), ainda que a esta não tenha sido dada uma definição precisa ${ }^{57}$. Um grande número de trabalhos, muito mais filosóficos, do que matemáticos, sobre a noção intuitiva de velocidade instantânea começa a ser discutido e apresentado em termos de "latitude das formas", ou melhor, de variabilidade de qualidades. A palavra "forma" aqui empregada está associada à idéia de "intensidade", e esta não é propriedade apenas da velocidade, mas pode estar referida a outras grandezas como, por exemplo, aceleração, densidade etc. A latitude de uma forma era a taxa de variação da forma, e a discussão se dava em termos do crescimento (intensão) ou decrescimento (remissão) da forma, isto é, em termos das alterações pelas quais a qualidade é adquirida ou perdida. Assim, ao contrário de Aristóteles, que só reconhecia dois tipos de movimento - uniforme e não-uniforme -, os escolásticos foram muito mais adiante. Eles não apenas distinguiram entre latitudo uniformis (movimento uniforme) e latitudo difformis (movimento não-uniforme), como subdividiram este último em outras categorias:

\footnotetext{
to com o contínuo.

${ }^{57}$ Podemos isentar os escolásticos desta responsabilidade pelo fato de não disporem de instrumentos necessário para uma tal definição de velocidade. Note que nem mesmo Galileu, tempos depois, realizou tal tarefa de definir precisamente velocidade instantânea.
} 


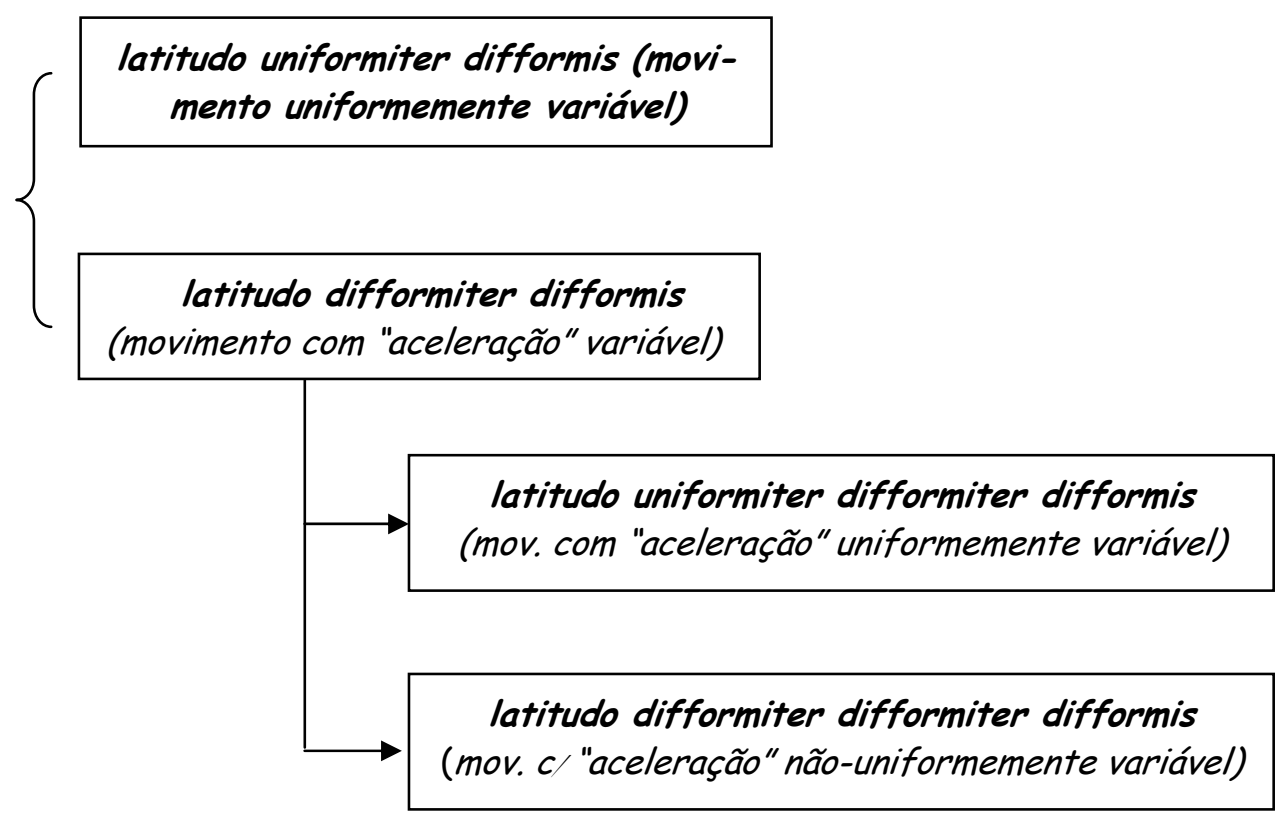

Henry Goethals foi um dos primeiros a usar o conceito de latitude em seus trabalhos, mas, como sugere Boyer (1949, p.74), foi Duns Scotus o primeiro a considerar o crescimento (intensão) e decrescimento (remissão) das formas. Muitos outros trabalhos sobre a variabilidade e latitude das formas apareceram na primeira metade do século XIV: Jean de Forli, Walter Burley, Albert de Saxônia.

"No século XIV o estuda da ciência matemática floresceu maravilhosamente em Oxford" ${ }^{58}$. Pode-se destacar inicialmente dois dos grandes trabalhos que floresceram nesta época em Oxford: o tratado sobre proporções, de Thomas Bradwardine, e o Líber calculationum, de Richard Suiseth (Calculator). O primeiro trabalho citado se dedicava mais à mecânica do que à aritmética, e, além disso, não fazia qualquer menção especial à teoria da latitude das formas. Já o segundo traba-

\footnotetext{
${ }^{58}$ Frase de Gunther, em Early Science in Oxford, II, 10 - apud Boyer, 1949, p.74.
} 
Iho, é considerado como o principal modelo de tais tratados sobre as latitudes de formas.

No capítulo inicial do seu Líber calculationum, Suiseth ("Calculator" ${ }^{59}$ ) desenvolve considerações gerais sobre a intensão e remissão de formas e a questão de como uma "latitude não-uniforme" corresponde ao seu máximo ou mínimo "gradus" ou intensidade. No capítulo seguinte, apresentou um resultado sobre intensidade média de uma forma cuja taxa de variação é constante em um certo intervalo de tempo:

"(...) a intensidade média de uma forma cuja taxa de variação é constante em um intervalo, ou de uma forma que é uniforme ao longo de cada metade do interva1o, é a média da sua primeira e da sua última intensidade".

(apud Boyer, 1949, p.75)

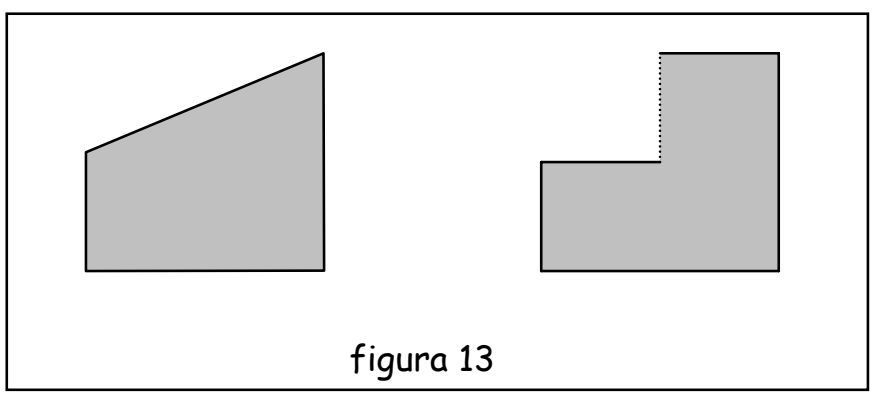

Para demonstrar o seu resultado, Calculator usou o contexto térmico e recorreu a um raciocínio dialético baseado em compensações $e$ "anulações" de taxas de variações opostas. Em síntese, o seu argumento pode ser descrito como segue:

"(...) se à maior intensidade fosse permitido decrescer uniformemente até 0 valor médio enquanto à menor fosse permitido crescer na mesma taxa até este valor médio, então o todo não cresceria e nem decresceria".

(apud Boyer, 1949, p.75).

\footnotetext{
${ }^{59}$ O apelido atribuído a Richard Suiseth - o "Calculista" - será preservado em inglês - "Calculator” - na redação deste trabalho, tal como foi citado por Boyer (1949), pelo fato de não conhecermos nenhuma literatura, em língua portuguesa, que se refira a este autor dessa forma.
} 
O método aqui descrito foi ampliado e aplicado pelo filósofo a questões relacionadas à densidade, à velocidade e à intensidade luminosa. A falta de precisão em suas definições e seus argumentos metafísicos levou Suiseth a situações dificultosas e paradoxais em relação ao conceito de infinito. Ele considerou, por exemplo, "uma raridade de grau zero como uma densidade de grau infinito". Calculator considerou, em geral, o infinito muito mais do ponto de vista de intensidade ou de grandeza, do que de agregados. Entretanto, no segundo livro de seu Liber calculationum, considerou o seguinte problema:

"se ao longo da metade de um intervalo de tempo a variação continua com uma certa intensidade, ao longo do próximo quarta parte do intervalo no dobro desta intensidade, ao longo da oitava parte seguinte no triplo desta, e assim ad infinitum; então a intensidade média para o intervalo todo será a intensidade da variação durante o segundo sub-intervalo (o dobro da intensidade inicial)"

(apud Boyer, 1949, p.76)

Considerando " $t$ ", o intervalo de tempo total, $e$ " $i$ ", a primeira intensidade, temos que o problema descrito acima é equivalente a mostrar que:

$$
\begin{aligned}
& i \frac{t}{2}+2 i \frac{t}{4}+3 i \frac{t}{8}+4 i \frac{t}{16}+\ldots+n i \frac{t}{2^{n}}+\ldots=2 i t \\
& \text { ou seja, } \frac{1}{2}+\frac{2}{4}+\frac{3}{8}+\frac{4}{16}+\ldots+\frac{n}{2^{n}}+\ldots=2 .
\end{aligned}
$$

No entanto, o filósofo deu uma verborrágica prova do seu resultado, apelando sempre para idéia intuitiva de taxa de variação uniforme. Seu pouco caso com a precisão dos conceitos que utilizava, sugere para muitos historiadores, conforme nos relata Boyer (1949, p.78), que seu interesse era muito mais em questões sofísticas sobre o assunto de variação do que uma séria tentativa de estabelecer em bases cientí- 
ficas o estudo do fenômeno de movimento e variabilidade. Apesar de assumir explicitamente a atitude peripatética, Calculator antecipou a necessidade de uma tradução aritmética (séries) desses problemas relacionados ao contínuo e ao infinito. Segundo Boyer,

"Seu denso estudo das variações de tais quantidades antecipou não apenas a elaboração científica destas, mas também prenunciou a introdução na matemática das noções de quantidade variável e derivada".

(Boyer, 1949, p.79)

Boyer observa ainda que as palavras "fluxão" e "fluentes" $60, \mathrm{u}-$ sadas por Newton em seu cálculo fluxional, também foram usadas exaustivas vezes por Calculator ${ }^{61}$. Antes porém, o trabalho de Suiseth irá influenciar um outro cientista natural: Nicolau de Oresme (132382).

Apesar sua doutrina ter sido influenciada pela de Calculator e de outros da escola de Oxford, Nicolau de Oresme apelou muito mais à intuição geométrica ${ }^{49}$ e ao uso efetivo de diagramas e sistemas de coordenadas, do que à dialética prolixa de seus mentores. Foram dois, os principais trabalhos de Nicolau de Oresme no assunto: Tractus de latitudinibus formarum e o Tractatus de figuratione potentiarum et mensurarum ${ }^{62}$.

Ao que parece, Nicolau de Oresme não foi o primeiro ${ }^{63}$ a usar a idéia de sistemas de coordenadas, mas o seu trabalho, no entanto, representa um marco no estudo da variação com a representação por co-

\footnotetext{
60 "Fluentes” significa quantidades que fluem, ou melhor, que variam. É o que Leibniz denominou por variável. E "fluxão" é tão somente a velocidade com que as quantidades "fluentes" variam.

${ }^{61}$ Este fato ratifica a seguinte "equação": "dialética de Calculator" + "intuição geométrica" = "solução dada pelo Cálculo para o problema da variabilidade".

${ }^{62}$ Segundo Boyer (1949, p.81) o primeiro aparenta ser uma "pobre imitação" do segundo, o que sugere que sua autoria deva pertencer a um estudante que certamente estava estudando a outra obra.

${ }^{63}$ Segundo Boyer (1949, p.82), os primeiros foram os geógrafos da Grécia Antiga.
} 
ordenadas. A "doutrina de configuração" de Nicolau de Oresme considera que a velocidade instantânea (intensão ${ }^{64}$ ) e o tempo (extensão) caracterizam formas tais como movimento. A quantidade de movimento é, então, a distância percorrida em um dado período de tempo. Movimento uniforme, variado (não uniforme) e uniformemente variado (uniformemente acelerado) eram todos distintos e representados pelos seguintes gráficos:

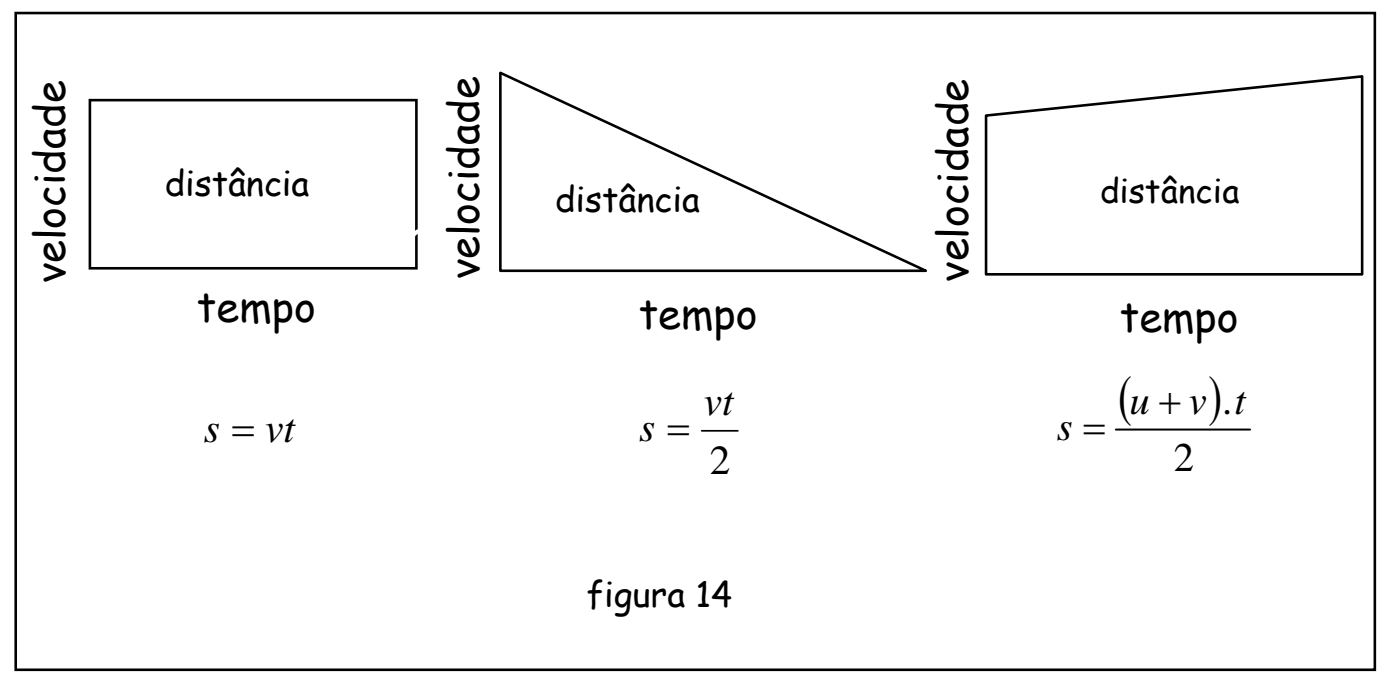

O matemático mostra que não só tinha uma clara concepção de aceleração ${ }^{65}$, mas também de aceleração uniforme:

"Se a 'velocitatio' (aceleração) é uniforme, então a 'velocitas' (velocidade) é 'uniformiter difformis' (uniformemente variável), mas se a 'velocitatio' (aceleração) é 'difformis' (não-uniforme), então as 'velocitas' (velocidade) é 'difformiter difformis' (não-uniformemente variável)".

(apud Boyer, 1949, p.83)

É também de sua autoria a seguinte proposição:

\footnotetext{
${ }^{64}$ Intensão - intensidade, aumento de tensão (Ferreira, 1999).

${ }^{65}$ Boyer (1949, p.82) ressalta o erro histórico que cometem aqueles que atribuem a Galileu a invenção do conceito de aceleração. Segundo o matemático, tal afirmação só demonstra, por parte destes, uma total ignorância da doutrina da latitude das formas.
} 
Proposição: A distância percorrida por um corpo partindo do repouso e movendo-se com aceleração uniforme (constante) é a mesma do que o corpo percorreria se ele se movesse no mesmo intervalo de tempo com uma velocidade uniforme (constante) que é a metade da velocidade final.

(apud Boyer, 1949, p.83).

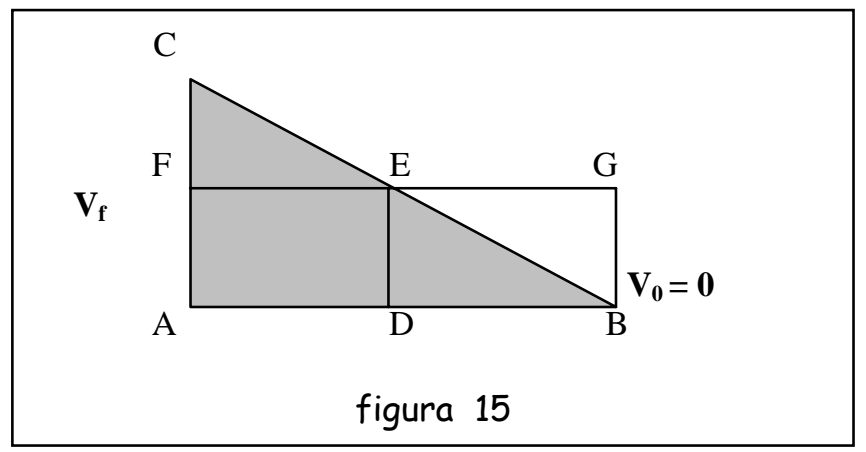

Nicolau de Oresme fez uma demonstração essencialmente geométrica. Não explicou o fato de que as áreas $A B C$ e $A B G F$ representam a distância percorrida. Mas usou o fato de que CFE e EBG representam a mesma distância ${ }^{66}$. Devido ao grande interesse demonstrado pelos escolásticos sobre a idéia de infinitesimal, é provável que Nicolau de Oresme tenha usado deste instrumento para tirar as suas interpretações da área sob a curva como a distância percorrida. Esta, talvez, tenha sido, como afirma Boyer (1949, p.84), a primeira vez que a área sob uma curva foi identificada como a medida de uma grandeza física 67. E, dessa forma, uma nova relação entre a física e a matemática se estabelece. A reticência à presença da idéia de movimento na matemática - como sugerira Aristóteles - estava com os seus dias contados. Os escolásticos permitiram de uma só vez a fusão do "qua" contínuo, da matemática, do "qua" movendo, da física, e do "qua" sendo, da filosofia, em uma doutrina admirável que irá, por certo, dar novos rumos à ma-

\footnotetext{
${ }^{66}$ Galileu fez uma demonstração similar à de Nicolau de Oresme para este resultado.
} 
temática e ao seu papel na construção do conhecimento científico. $O$ Cálculo, cabe ressaltar, não é só a parte beneficiada nesse maravilhoso empreendimento, mas, sobretudo, a condição de sua possibilidade. 0 pensamento aqui gerado já é, sem dúvida, um prenúncio daquilo que hoje chamamos Cálculo.

${ }^{67}$ Nesse caso específico, a área representa a distância percorrida pelo objeto. 


\subsubsection{Prenúncio do Cálculo}

Argumentos similares aos desenvolvidos por Nicolau de Oresme e Calculator apareceram também em trabalhos desenvolvidos por outros matemáticos da época no circuito Paris-Oxford. A expansão dessas idéias para o território italiano foi efetuada por Blasius de Parma (ou Biagio Pelicani) no século XV. Os princípios do movimento uniformemente acelerado parecem ter sido do domínio comum entre os escolásticos do século XIV ao século XVI e é bem provável que Galileu (1564-1642) tenha se apropriado desses ensinamentos. Indício desta suspeita foi o argumento e o diagrama usado por Galileu em um resultado do seu famoso trabalho Discorsi (de 1638), que estabelece uma equivalência (quanto à distância realizada) entre um movimento uniformemente acelerado e um movimento uniforme, de forma muito semeIhante ao desenvolvido por Nicolau de Oresme em seu Tractatus de figuratione potentiarum et mensurarum (p. 133, desta tese).

É inegável a contribuição dos escolásticos aos geômetras do século XVII. Os trabalhos de Nicolau de Oresme certamente influenciaram os trabalhos de Galileu e a Geometria de Descartes (1596-1650). Pode-se perceber ainda a importância dos trabalhos de Calculator nas obras do próprio Galileu, de Cardano (1501-76), de Newton (16421727), e de Leibniz (1646-1716). A importância do trabalho de Calculator impressionou Cardano de tal modo, que este chegou a considerá-lo como um dos maiores matemáticos que a humanidade até então já havia visto. Leibniz também fez citações a Calculator: observou o grande 
matemático que este último foi o primeiro a aplicar matemática à física e a introduzir a matemática na filosofia.

Apesar do prestígio de que os escolásticos gozavam entre os principais matemáticos do século XVII, Boyer (1949, p.88) pondera que a doutrina das latitudes das formas não representou uma "base de influência decisiva" no desenvolvimento dos métodos do Cálculo. Segundo o autor, o princípio guia desse desenvolvimento foi a geometria de Arquimedes, modificada pelas noções cinemáticas derivadas das discussões "quase-peripatéticas" dos escolásticos sobre o assunto de variabilidade. Um claro exemplo dessa saudável mistura - a filosofia escolástica ${ }^{68}$ e a geometria de Arquimedes - é a obra do Cardeal Nicolau de Cusa (1401-1464). Nicolau incorporou também em seus trabalhos elementos de um certo tipo de humanismo emergente na época, e que tinha raízes no misticismo platônico e pitagórico ${ }^{69}$. Assim, a introdução da filosofia platônica na matemática permitiu um livre uso de duas noções rejeitadas até então na matemática: o infinito e as quantidades infinitesimais.

Tal como Platão, Nicolau de Cusa considerava a matemática como a base de todo o seu sistema filosófico. "Para ele, a matemática não estava restrita, como para a Aristóteles, à ciência da quantidade, mas à forma necessária a uma interpretação do universo" - (Boyer, 1949, p.90). Nicolau reacendeu a "aritmologia ${ }^{70}$ platônica", associando as entidades da matemática com a realidade ontológica e restaurando para a matemática o status cosmológico que Pitágoras atribuía a ela. Para ele,

\footnotetext{
${ }^{68}$ É provável que a intermediação entre os escolásticos e o cardeal Nicolau de Cusa tenha sido realizada por Blasius de Parma (Boyer, 1949, p.89)

${ }^{69}$ Segundo Boyer (1949, p.89) a emergência do humanismo platônico deveu-se, principalmente, ao desgaste e declínio da própria filosofia escolástica.
} 
assim como para Platão, a matemática era estabelecida pelo intelecto e não por investigações empíricas.

Nicolau de Cusa introduziu em seus cálculos matemáticos tanto as "quantidades infinitamente pequenas" como as "infinitamente grandes". Definiu quantidade infinitamente pequena como "aquela que não pode ser feita menor", e a infinitamente grande como "aquela que não pode ser feita maior". Para demonstrar o resultado de Arquimedes para a quadratura do círculo usou explicitamente a idéia de infinitesimais:

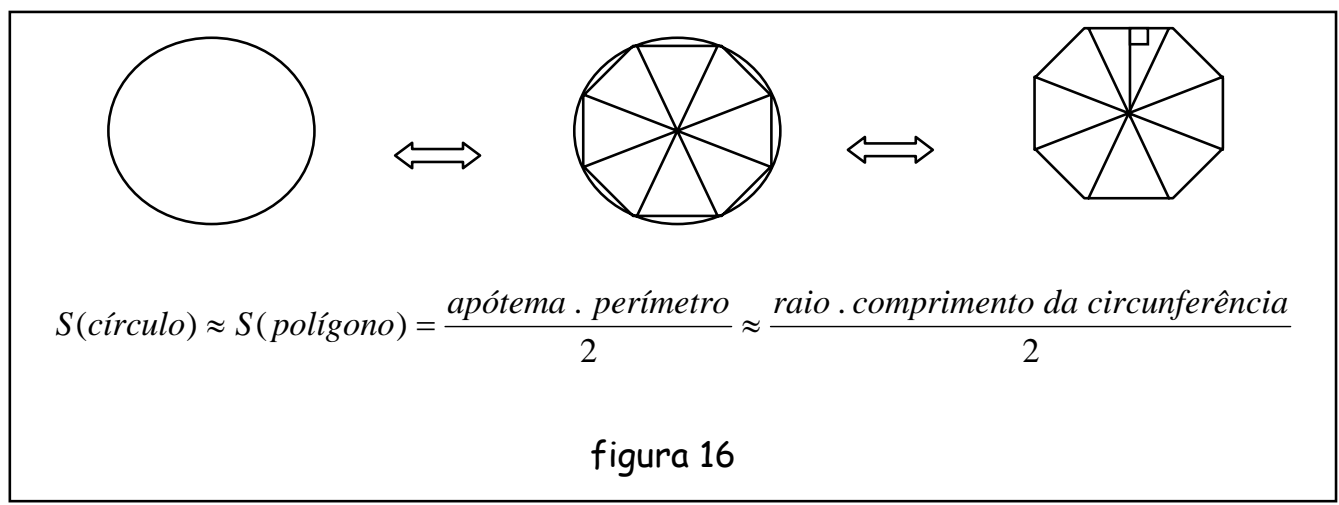

Esta idéia de descrever o círculo como um polígono de "número infinito" de lados, presente de forma marcante na demonstração de Nicolau de Cusa, aparece também nos trabalhos de M. Stifel (14861567) e de François Viète (1540-1603) - cerca de um século depois. Nicolau usou também o método de exaustão para "complementar" a sua demonstração. Leonardo da Vinci (1452-1519), que também tinha conhecimento dos trabalhos de Arquimedes, empregou métodos infinitesimais no desenvolvimento de seus trabalhos, tal como Nicolau usava-os

\footnotetext{
${ }^{70}$ Ciência que trata dos números e da medição das grandezas em geral - (Ferreira, 1999).
} 
nos seus. A influência da obra de Nicolau de Cusa nos trabalhos de Stifel e Da Vinci foi notadamente muito forte.

Simon Stevin (1548-1620), Kepler (1571-1630) e Galileu são exemplos de outros cientistas que conheciam o trabalho de Nicolau; só que estes abandonaram a segunda parte de seu método de demonstração (aquela que usa o método de exaustão). Embora Stevin mantivesse inicialmente o método de exaustão, aos poucos, o matemático foi substituindo o elemento de redução ao absurdo pela passagem direta ao limite. Voltaremos a este momento histórico do Cálculo ${ }^{71}$ oportunamente. Retornemos, por ora, à análise da influência dos escolásticos no desenvolvimento do Cálculo, da matemática e da própria ciência.

A transformação despertada nas ciências e na matemática pela filosofia escolástica começa a surtir efeitos. O interesse de Galileu pelo movimento irá provocar um desenvolvimento acentuado das propriedades das curvas geradas por movimento. Por conseguinte, uma nova gama de problemas começa a surgir: somas de séries, problemas de otimização etc., problemas estes que irão contribuir, conforme já observado neste trabalho, para a passagem do limite do seu estado embrionário, representado pelo método de exaustão, a esta nova etapa de sua construção, isto é, enquanto uma operação metafísica. A variável tempo passa a ter, então, um papel importante na construção do objeto matemático, o que reforça ainda mais a presença do infinito potencial nas atitudes relativas às idéias básicas do Cálculo.

No entanto, com o declínio da filosofia escolástica, começam a aparecer reações à influência desta escola, bem como do Aristotelis-

\footnotetext{
${ }^{71}$ Momento em que a noção de limite deixa de ser um elemento "camuflado” no método de exaustão para se tornar uma operação, ainda que metafísica, no contexto do Cálculo.
} 
mo, no desenvolvimento da ciência. Tal fato pode ser ilustrado, segundo Boyer $(1949$, p.96) pela atitude de Ramus. Curiosamente, foi no ápice dessa reação que os trabalhos de Arquimedes começam a aparecer em numerosas edições, despertando, além de interesse, uma profunda admiração por parte dos matemáticos da idade média. Outros fatos que permitiram um maior aprofundamento das obras de Arquimedes foram as traduções dos Elementos, de Euclides, e das Cônicas, de Apolônio, realizadas durante essa época.

Por outro lado, a introdução paulatina do simbolismo algébrico acentuou a diferença entre as demonstrações da geometria clássica "dos antigos" e os "novos métodos" a serem desenvolvidos no século XVII. A álgebra de Luca Paccioli (1445-1509) - Summa de arithmetica -, apesar de não significar um grande avanço em relação à de L. Fibonacci (1175-1250) ${ }^{72}$, foi estrategicamente fundamental para uma nova retomada do assunto na Itália do século XVI. Resoluções das equações do terceiro grau, por Nicolo "Tartaglia" (1499-1557) e G. Cardano (1501-76), e do quarto grau, por L. Ferrari (1522-65) e o livre uso dos números irracionais, negativos e imaginários, por Cardano, R. Bombelli (1526-73), Stifel e outros são exemplos notáveis desse desenvolvimento do pensamento algébrico. O desenvolvimento do "estilo algébrico" de pensar será, como veremos adiante, de importância fundamental para a criação e desenvolvimento da geometria analítica, que é propriamente o "espaço" geométrico que possibilitará a transformação e "invenção" do Cálculo.

Assim, a partir das leituras e dos estudos da matemática grega e da incorporação do modo algébrico de pensar, começam a surgir con- 
tribuições originais para o desenvolvimento do Cálculo grego conhecido. O cálculo do centro de gravidade do parabolóide de revolução, por $F$. Commandino (1509-75), é um belo exemplo disso ${ }^{73}$. Commandino foi, sem dúvida, mais fiel ao método de exaustão do que o próprio Arquimedes. Em verdade, foram Stevin e Luca Valério (1552-1618) ${ }^{74}$ os principais responsáveis por esta adaptação do método de exaustão "dos antigos" para o novo paradigma da matemática: o método das descobertas.

Simon Stevin, conforme já observado neste trabalho, substituiu gradativamente em seus trabalhos a redução ao absurdo, presente no método de Arquimedes, pela prova direta, baseada na passagem direta ao limite. Ao invés de considerar seqüências de figuras inscritas e circunscritas, o engenheiro de Bruges considerava apenas uma delas para a realização de seu cálculo. Um claro exemplo dessa significativa modificação no método dos antigos pode ser indicada pela proposição sobre o centro de gravidade. Referindo-se à demonstração dada por Commandino como "ingênua e sutil", Stevin inicia a sua própria:

\footnotetext{
${ }^{72}$ Também conhecido como Leonardo de Pisa.

${ }^{73}$ Apesar de o resultado já ter sido enunciado e demonstrado por Arquimedes, em seu trabalho o Método, os matemáticos dessa época não tinham tido acesso ainda a esta obra.

${ }^{74}$ Além de tradutores, foram profundos estudiosos das obras de Arquimedes.
} 


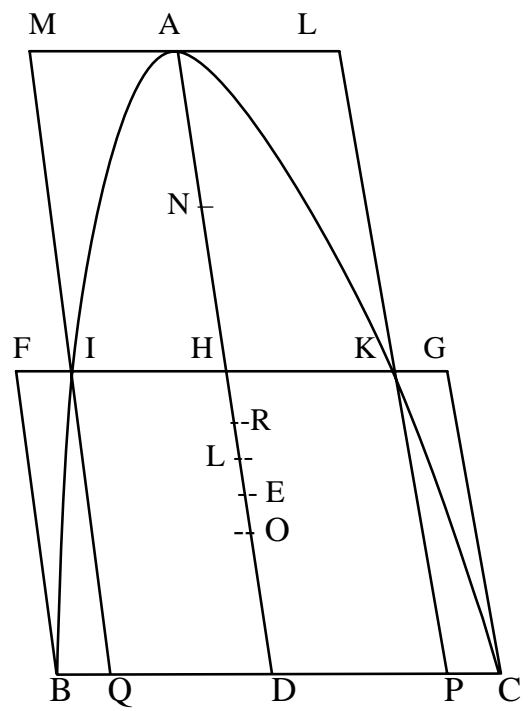

figura 17

Circunscreva sobre o segmento ABC dois segmentos cilindricos FGBC e MLIK como ilustrado (figura ao lado). Agora os centros de gravidade desses segmentos estão, pelo princípio de equilíbrio de figuras simétricas bilaterais, nos pontos médios, Ne $O$, de seus eixos, AH e HD, respectivamente; e o centro de gravidade da figura circunscrita formada está em $R$ de tal modo que $N R=2 R O$.

Seja $E$ o ponto tal que $A E=$ 2ED, pode ser mostrado então que $E R=\frac{1}{12} A D$. Se, agora, alguém similarmente circunscreve o segmento $A B C$ com quatro segmentos cilíndricos de mesma altura, o centro de gravidade desta figura circunscrita é determinado encontrando-se um ponto $L$ acima de $E$ de tal modo que $E L=\frac{1}{24} A D$.

Duplicando sucessivamente o número desses cilindros, o centro de gravidade da figura circunscrita permanece sempre acima de $E$, e diferirá de $E$ por $\frac{1}{48} A D, \frac{1}{96} A D$, e assim por diante. Então o centro de gravidade desce, aproximando-se de E cada vez mais (...).

(apud Boyer, 1949, p. 101-102)

Stevin finaliza sua demonstração considerando, de forma similar, uma sequiência de segmentos cilíndricos inscritos para chegar, enfim, ao resultado de que o ponto $E$ é, de fato, o centro de gravidade do parabolóide. Assim, através deste exemplo, pode-se perceber que o procedimento adotado pelo matemático flamengo caminha em direção 
ao conceito de limite. Stevin substitui a "redução ao absurdo" pela "passagem direta ao limite".

Luca Valério, em seu De centro gravitatis solidorum, de 1604, desenvolve um estudo sistemático do método de Arquimedes. Tendo mais compromisso com o rigor lógico do método de exaustão do que Stevin, Valério, no entanto, sugere que, uma vez que a diferença entre as áreas (ou volumes) das figuras circunscritas e inscritas pode ser feita sempre menor que qualquer área (ou volume) dada, não há necessidade de se considerar as duas seqüências: basta trabalhar com uma delas.

Johann Kepler (1571-1630), um ministro luterano, foi outro matemático que desenvolveu significativas modificações no método de Arquimedes. Inspirado e guiado pelas especulações de Nicolau de Cusa e Giordano Bruno (1548-1600), Kepler introduziu no método dos antigos os procedimentos infinitesimais. A Nova stereometria, que apareceu em 1615, continha três partes: uma parte inicial contendo a estereometria de Arquimedes junto com um suplemento de noventa e dois sólidos não considerados por Arquimedes; a segunda parte é sobre o problema dos tonéis de vinhos austríacos ${ }^{75}$ e a terceira sobre aplicações de sua teoria. Ao determinar a área do círculo, Kepler usou do mesmo expediente de Nicolau de Cusa, Stifel e Viète: considerou o círculo como um polígono de infinito número de lados. De modo análogo, considerou a esfera como sendo composta de infinitos cones infinitesimais, com vértice no centro da esfera, e cujas bases formam a superfície esférica - ele mostrou que o volume da esfera é igual a $\frac{1}{3}$ do

\footnotetext{
${ }^{75}$ Problema que tinha como objetivo determinar as “melhores” dimensões para um tonel de vinho.
} 
produto do raio pela área da superfície esférica. Kepler estendeu a aplicação de seu método infinitesimal ao cálculo de áreas de superfícies e volumes de sólidos, nunca antes tratados pelos matemáticos gregos. Baseando-se implicitamente numa espécie de "lei da continuidade" 76 para justificar essas aproximações infinitesimais. Segundo Boyer (1949, p.109), algumas somas infinitas de Kepler são notáveis antecipações daquilo que hoje chamamos de cálculo integral.

Uma outra categoria de problemas despertou o interesse de Kepler: os problemas de otimização. Na doliometria ${ }^{77}$, Kepler mostrou, entre outros resultados, que, dentre todos os paralelepípedos retos inscritos em uma esfera, o maior (o de maior volume) é o cubo. Resultados dessa natureza, isto é, valores máximos e mínimos de uma grandeza geométrica, foram obtidos pela construção de tabelas correlacionando as variáveis envolvidas nos problemas. A análise era feita com base na inspeção e comparação direta e induzida dos valores, ora selecionados e calculados. Assim, por esta inspeção direta de alguns valores predeterminados, Kepler pôde observar que no valor máximo, o volume começa a mudar a sua forma de comportamento, isto é: para valores menores da variável "independente", e próximos do ponto de máximo, o volume cresce até atingir o seu valor máximo, passa por ele e começa a decrescer a partir daí. Este fenômeno já tinha sido observado por Nicolau de Oresme, alguns séculos antes. Tal idéia irá aparecer novamente no pensamento de Fermat, na tentativa de resolver problemas de mesma natureza.

\footnotetext{
${ }^{76}$ A mesma "lei” será referida posteriormente por Newton e Leibniz no desenvolvimento de seus Cálculos.

${ }^{77}$ Doliometria - palavra latina derivada da palavra doliolum - pequeno barril, pipa . Assim, doliometria significa a área de estudo das medidas (de volume) de pipas e barris - (Ferreira, 1999).
} 
Vinte anos depois da publicação da Stereometria doliorum, de Kepler, surgiu na Itália um trabalho que iria se rivalizar em popularidade com o do grande astrônomo: o Geometria indivisibilibus de Bonaventura Cavalieri (1578-1647). Apesar da negação enfática de Cavalieri sobre a influência do pensamento de Kepler em seus trabalhos, temos que esta não só é notada de forma evidente, como pode ser justificada pelo vetor Galileu, que estabeleceu correspondências com os dois primeiros e, de certa forma, permitiu um trâmite indireto das idéias de Kepler até Cavalieri. Galileu não chegou, entretanto, a publicar nenhum trabalho específico sobre o uso dos infinitesimais.

As forças que influenciaram os trabalhos de Galileu e Cavalieri são as mesmas que sustentaram as de Kepler. Apesar de traírem as suas raízes escolásticas e não assumirem a herança da visão platônica da matemática, ambos os matemáticos atribuem a Valério um papel central no desenvolvimento de seus trabalhos. A admiração dos dois matemáticos pelos trabalhos de Valério levou os a atribuir-lhe o título de "o novo Arquimedes",

A influência do pensamento escolástico é claramente evidente no caso de Galileu. Traços dos trabalhos de Calculator e Hentisbery (1949, p.114), e da doutrina do ímpeto, de Buridan aparecem explicitamente nas citações de Galileu. Em seu trabalho Duas Novas Ciências, o físico, além de revelar os seus conhecimentos da discussão escolástica sobre o movimento, apresenta uma outra demonstração de um resultado já conhecido dos escolásticos Calculator. Hentisbery ${ }^{78}$ e Nicolau de Oresme, cujo enunciado é: a velocidade média de um corpo movendo com aceleração uniforme (constante) é dada por sua velocidade (ins- 
tantânea) no ponto médio do intervalo de tempo. A demonstração de Galileu muito se assemelha a dada por Nicolau de Oresme; vejamos:

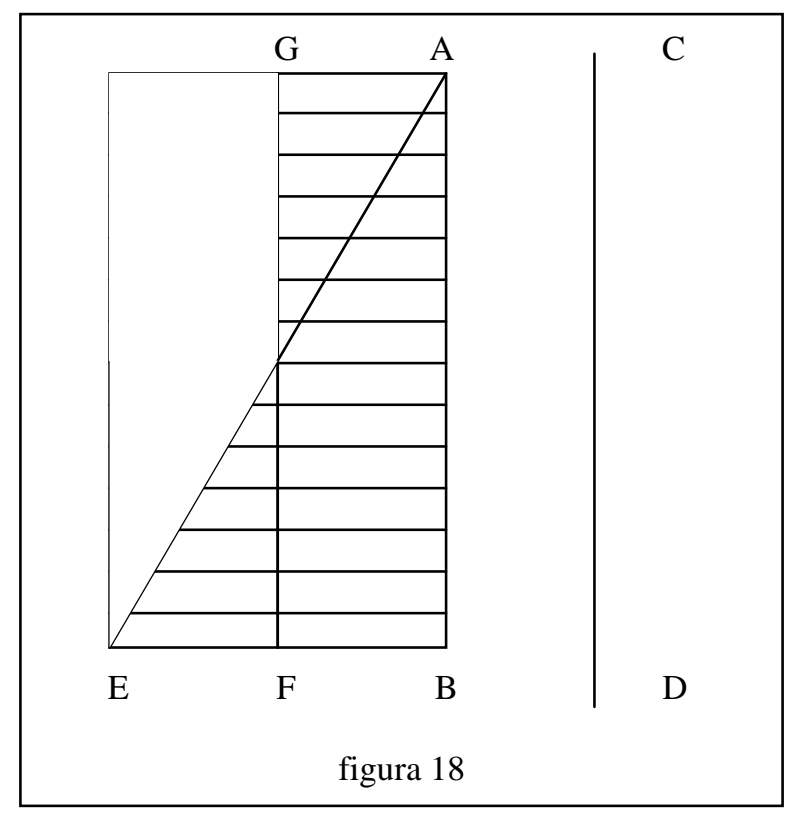

Seja AB (fig. 18) uma representação do tempo no qual o espaço CD é percorrido por um corpo que parte do repouso e é uniformemente acelerado. Seja a velocidade final representada por EB. Então as linhas desenhadas e paralelas a EB representarão as velocidades do corpo. Parece, então, que elas podem ser interpretadas também como os momentos, ou incrementos infinitesimais, nas distâncias percorridas pelo corpo em movimento. Então os momentos de um movimento uniformemente acelerado podem ser representados pelas paralelas do triângulo AEB, enquanto as paralelas do retângulo ABFG representam os momentos correspondentes de um corpo movendo-se uniformemente. Mas a soma de todas as paralelas contidas no quadrilátero ABFG é igual à soma daquelas (paralelas) contidas no triângulo AEB. Daí é claro que a distância percorrida pelos dois corpos são iguais, visto que o triângulo e retângulo são iguais em área se I é o ponto médio de FG.

(Boyer, 1949, p.113-114)

A demonstração de Galileu, bem como a de Nicolau de Oresme, parte da idéia de que a área sob uma "curva velocidade-tempo" representa a distância percorrida. Ambos usam em suas demonstrações as quantidades infinitesimais tal e como foram iniciadas por Demócrito e Platão, na Grécia antiga, e usadas por muitos outros filósofos e matemáticos na idade média.

\footnotetext{
${ }^{78}$ Hentisbery e Calculator demonstram este resultado dialeticamente.
} 
Galileu admitiu a possibilidade do infinito categoremático dos escolásticos na prática científica, mas, por outro lado, considerou que "o infinito e a indivisibilidade são de naturezas muito incompreensíveis para nós (os humanos)". O que levou o grande cientista a declarar esta limitação humana foram os numerosos paradoxos causados pelo uso dos próprios conceitos de infinito e indivisibilidade. Apesar de tudo, Galileu focou sua atenção, assim como Platão, sobre o infinito como multiplicidade ou agregado. Chegou inclusive a conjecturar a possibilidade de um terceiro tipo de agregado entre o "finito" e o "infinito". Não conseguiu, entretanto, nenhum resultado concreto a respeito de sua conjectura, mas, por outro lado, teve sensibilidade suficiente para perceber que tais dificuldades de compreensão do infinito, de indivisíveis e da noção de continuidade têm as mesmas raízes.

No que concerne às grandezas contínuas, Galileu acreditava que estas são feitas de elementos indivisíveis. Ao analisar os paradoxos de Zenão (o de Aquiles e o da Dicotomia), o matemático italiano percebe que a solução destes está associada a um outro tipo de questão "paradoxal": pode uma série infinita ter um resultado? ${ }^{79}$ Com essa questão, Galileu abre mais uma porta para a Análise. Mais uma vez, o grande pensador parece antecipar a essência do problema, mas sem propor uma solução para o mesmo. Tal questão a respeito da convergência, ou não, das séries só vai ser analisada, ainda que de um modo vago, e um pouco mais tarde, por Newton, em seus conceitos de primeira e última razão.

\footnotetext{
${ }^{79}$ Na linguagem atual esta questão se enunciaria da seguinte forma: pode uma série infinita ser convergente?
} 
No entanto, ignorando a perspectiva aritmética das questões fundamentais sobre a relação entre os conceitos de infinito e continuidade, colocadas por seu grande mestre, Bonaventura Cavalieri (15781647), aluno de Galileu, retoma os indivisíveis num contexto essencialmente geométrico. Cavalieri, em seu Geometria indivisibilibus continuorum nova quadam ratione promota (1635), transformou o uso de reta e superfície "indivisíveis" num conjunto poderoso de técnicas para comparar áreas e volumes. Tais resultados ficaram consagrados na literatura atual pelo nome de "princípio de Cavalieri". Para Cavalieri, um plano era constituído de um número infinito de retas paralelas eqüidistantes, e um sólido de um número infinito de planos paralelos. Uma reta (ou plano) chamada "regula" move-se paralelamente a si própria, gerando interseções (retas ou planos) em cada uma das figuras (plano ou sólido), até ela coincidir com suas bases. Estas interseções das figuras com a "regula" (que, em verdade, são segmentos de reta ou seções planas) constituem os elementos, ou indivisíveis, que compõem a totalidade das figuras.

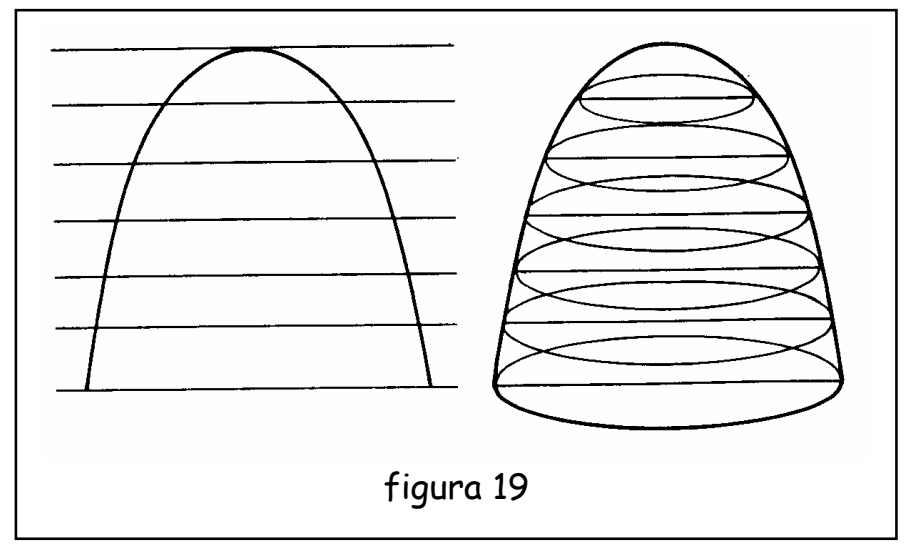


O método de Cavalieri foi empregado tendo como base os vários resultados já conhecidos sobre expansões binomiais. Para efeito de ilustração desse método vejamos um exemplo em que o matemático determina que a "soma dos cubos das linhas de um paralelogramo é quatro vezes a soma dos cubos das linhas de um dos triângulos constituintes".

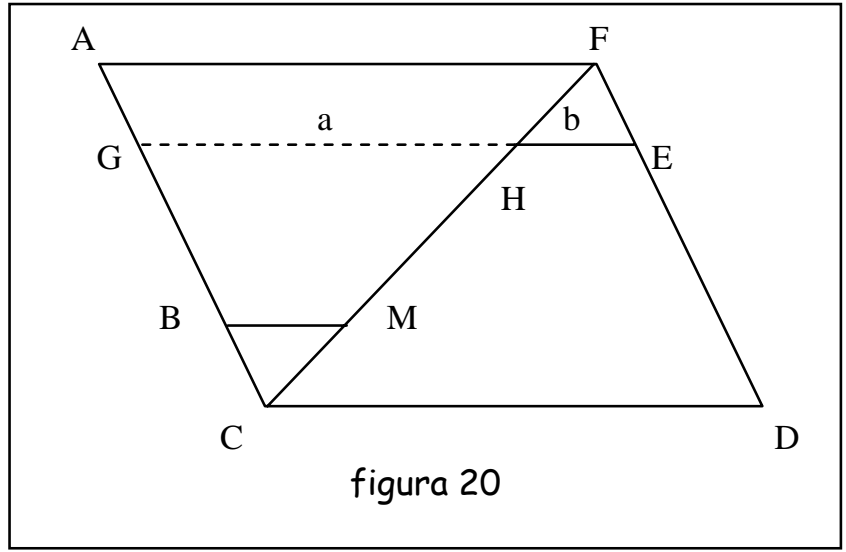

Seja $A F=c, G H=a, H E=b$, como na figura 20.

Nós temos

$$
\sum c^{3}=\sum a^{3}+3 \sum a^{2} b+3 \sum a b^{2}+\sum b^{3},
$$

onde as somas são tomadas sobre as linhas do paralelogramo e triângulos. Por simetria, esta soma pode ser escrita:

$$
\sum c^{3}=2 \sum a^{3}+6 \sum a^{2} b(1)
$$

Por outro lado,

$$
\sum c^{3}=c \sum c^{2}=c \sum(a+b)^{2}=c \sum a^{2}+2 c \sum a b+c \sum b^{2} .
$$

Mas, em proposições anteriores Cavalieri mostrou que

$$
\begin{aligned}
\sum a^{2}=\sum b^{2}=\frac{1}{3} \sum c^{2} . \text { Logo: } \\
\sum c^{3}=\frac{2}{3} c \sum c^{2}+2 c \sum a b=\frac{2}{3} \sum c^{3}+2(a+b) \sum a b= \\
=\frac{2}{3} \sum c^{3}+2 \sum a^{2} b+2 \sum a b^{2}=\frac{2}{3} \sum c^{3}+4 \sum a^{2} b \rightarrow \sum a^{2} b=\frac{1}{12} \sum c^{3}
\end{aligned}
$$

Substituindo (2) na equação (1), obtemos que

$$
\sum c^{3}=2 \sum a^{3}+6 \frac{1}{12} \sum c^{3}=>\sum c^{3}=4 \sum a^{3}
$$


Este resultado foi generalizado por Cavalieri, para um número ' $n$ ' natural qualquer ${ }^{80}$. Tal relação representa a antecipação de um resultado bastante conhecido do cálculo integral, isto é: $\int_{0}^{a} x^{n} d x=\frac{a^{n+1}}{n+1}$, onde ' $n$ 'é um número natural. A extensão do teorema para outros valores possíveis de $n$, além dos naturais, só será feito mais adiante, com outros matemáticos.

O Geometria indivisibilibus de Cavalieri alcançou popularidade quase que imediatamente, e se tornou, exceto para os trabalhos de Arquimedes, a mais cotada fonte para os matemáticos que desenvolviam trabalhos em geometria por meio de considerações infinitesimais. No entanto, as reações contrárias ao seu método infinitesimal não tardariam a aparecer. Paul Guldin, um jesuíta, foi um dos maiores críticos do método infinitesimal de Cavalieri. Guldin não fazia distinção entre o método de Cavalieri e o de Kepler; para ele ambos conduziam a falácias e situações paradoxais. Observou, por exemplo, que como o número de indivisíveis era infinito, estes não poderiam ser comparados entre si. Cavalieri tenta rebater o argumento do jesuíta ao afirmar que para as quantidades infinitas de indivisiveis serem comparadas elas precisam ser do "mesmo tipo". Com sua tentativa de explicação, Cavalieri complica-se ainda mais. Outro fato fundamental para a compreensão de seu método infinitesimal, e que Cavalieri não explica, diz respeito ao fato de como um conjunto de elementos sem espessura poderia formar uma área ou volume. O matemático italiano tenta recorrer, sem sucesso, à vaga relação entre as representações geométricas e a dinâmica de movimentos, pretendida por Platão, pelos escolásticos e por Galileu.

${ }^{80} \sum c^{n}=(n+1) \sum a^{n}$ 
Sugere então que áreas e volumes possam ser obtidos pelo fluir dos indivisíveis. Não desenvolveu e nem adaptou, entretanto, esta idéia ao seu método geométrico. Isto foi feito por seu amigo e sucessor Torricelli (1608-47).

Evangelista Torricelli, também aluno de Galileu, percebeu de forma mais completa as vantagens e desvantagens dos métodos de indivisíveis. Ao invés de ficar na retaguarda com respeito ao uso dos indivisíveis, partiu para o ataque: afirmou que os "antigos" (matemáticos gregos) deviam possuir, certamente, alguns desses métodos indivisíveis para descobrir teoremas difíceis, mas que eles não os revelavam "para esconder o segredo de seus métodos ou para não dar motivos para opositores invejosos" ${ }^{\prime 1}$. Torricelli, contudo, não ficava completamente satisfeito apenas com a demonstração dada pelo método dos indivisíveis. Ele, freqüentemente, complementava suas demonstrações com os estilos de demonstrações de Arquimedes e de Valério, a quem atribuiu também o título de "Arquimedes de nosso século". Superando Cavalieri em perspicácia e flexibilidade, Torricelli usou seu método de indivisiveis para fazer novas descobertas. Um intrigante resultado que obteve, em 1641, assegurava que o volume de um sólido infinitamente longo, obtido pela rotação de uma parte (infinita) da hipérbole sobre sua assíntota era finito. 


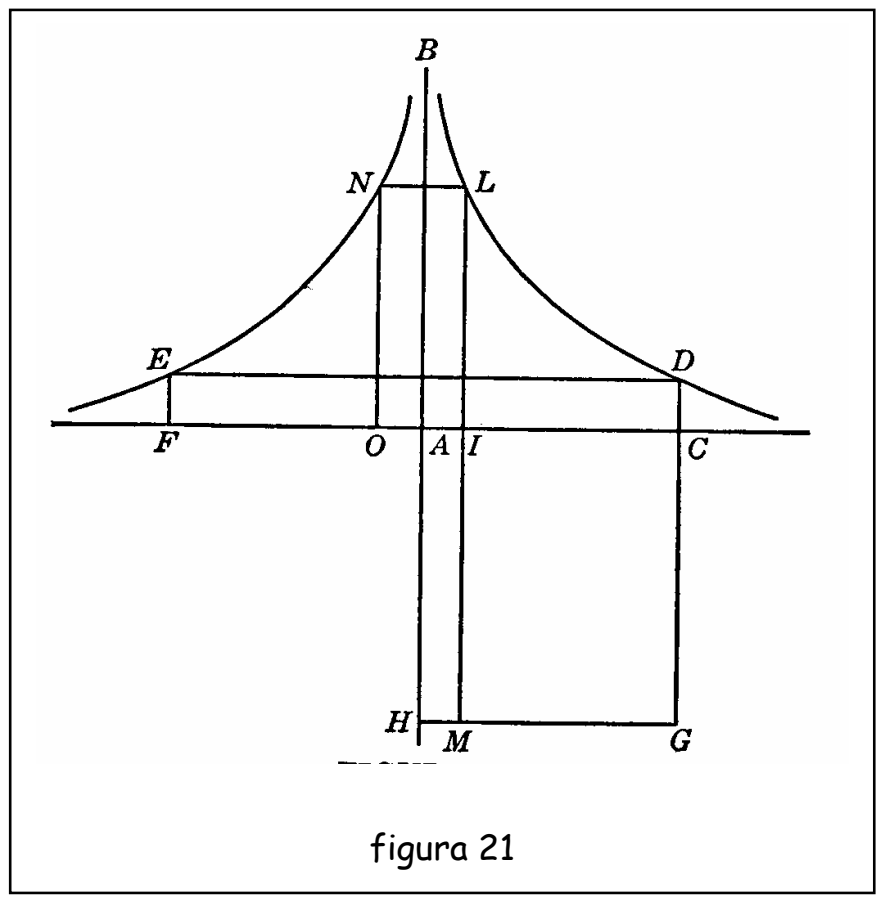

A demonstração dada por Torricelli consiste em provar que 0 volume do sólido de revolução infinito BEDB é igual ao volume do cilindro circular reto $A C G H$ de diâmetro $A H$ (que é tomado igual à distância do ponto $A$ à hipérbole que gera o sólido) e altura $A C$. Sua demonstração parte da decomposição do sólido de revolução em "anéis cilíndricos" - como, por exemplo, a superfície lateral do cilindro circular reto ILNO de diâmetro NL e altura IL - e por comparação dessas áreas com as áreas das seções retas do cilindro ACGH correspondentes - para 0 anel ILNO, a seção correspondente seria o círculo de diâmetro IM. Assim, demonstrando geometricamente que as áreas das regiões correspondentes são iguais, Torricelli chega ao seu resultado, uma vez que - volume do sólido é a "soma dos anéis cilíndricos", que, por sua vez, é igual à "soma das seções retas" do cilindro, o que, pelo princípio de Cavalieri, é igual ao volume do cilindro.

\footnotetext{
${ }^{81}$ apud (Boyer, 1949, p.127)
} 
Ao desenvolver a generalização do resultado do teorema de Cavalieri - $\int_{0}^{a} x^{n} d x=\frac{a^{n+1}}{n+1}, n$ um número natural - para valores de " $n$ " racionais, Torricelli fornece significativas contribuições ao desenvolvimento do cálculo diferencial. Algumas interpretações da sua demonstração acerca desse resultado sugerem que Torricelli considerou a tangente a uma curva $C$ num ponto $P$ como sendo determinada pelo movimento de uma secante PD - D outro ponto da curva - quando fazemos D se aproximar do ponto de tangência P. Boyer $(1949$, p129) assegura, no entanto, que "não há nada na linguagem de Torricelli para justificar tal conclusão"; muito pelo contrário, o conceito de tangente apresentado por Torricelli é baseado na definição estática dos antigos, segundo a qual, "esta é uma linha que toca a curva em apenas um ponto". Argumenta o historiador que a maior contribuição do matemático italiano foi o uso de uma concepção dinâmica de tangentes, baseada no uso de "paralelogramos de velocidades virtuais". Um exemplo da aplicação desse método é como segue:

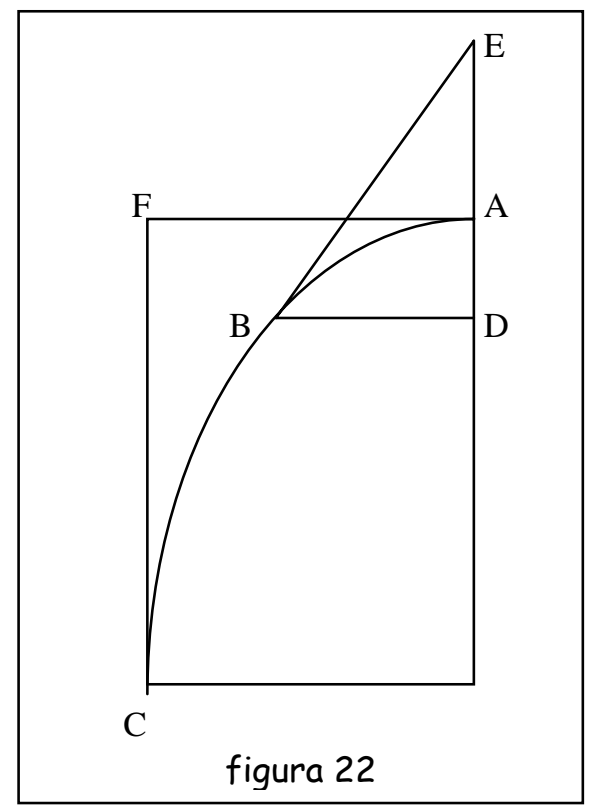

Seja a curva $A B C$ (fig.22), por exemplo, a parábola cúbica. Então se $E B$ é tangente à curva, nós teremos $E D=3 A D$. Isto é claro do fato que 0 ponto em movimento possuirá em $B$ um duplo ímpeto: um horizontal, dado pela distância BD: e o outro vertical, dado (pelas considerações anteriores) por três vezes a distância vertical $A D$. Então a direção do ponto $B$, pela decomposição dessas duas velocidades, será a linha $B E$, que é, conseqüentemente, a tangente.

(apud Boyer 1949, p. 132-133) 
Torricelli também aplicou o seu método das velocidades em espirais, as quais denominou de "espirais geométricas" para distingui-las das "espirais aritméticas" de Arquimedes. O matemático não deu, entretanto, um tratamento analítico a estas curvas.

Segundo Boyer (1949, p.133), o uso de representações cinemáticas na matemática pode ter sido antecipado pelos matemáticos franceses Roberval (1602-75) e Descartes (1596-1650), mas - acrescenta o historiador - foi sem dúvida através dos trabalhos de Torricelli que este conhecimento alcançou Barrow (1630-77), e, posteriormente, o seu aluno: sir Isaac Newton (1642-1727) - um dos "inventores" do Cálculo.

Junto com os seus métodos de exaustão, de indivisíveis e de composição de velocidades, além, é claro, dos inúmeros resultados sobre quadraturas, tangentes ou mesmo retificação de curvas, outro fato que torna Torricelli um dos principais antecipadores do Cálculo, é o conhecimento que este possuía de que o "problema de tangente é o inverso daquele de quadratura". Com efeito, talvez a única coisa que tenha faltado a Torricelli para que ele pudesse ter alcançado métodos e algoritmos mais universais, e aí ter se consagrado também como um dos inventores do Cálculo, foi o desenvolvimento de um tratamento analítico das curvas e figuras geométricas ${ }^{82}$. O seu Cálculo era essencialmente geométrico. Cabe destacar, entretanto, que a falta de uma definição precisa de velocidade instantânea e da falta de uma base sólida

\footnotetext{
${ }^{82}$ Este "tratamento analítico" foi iniciado por Fermat, Descartes e Barrow, culminando com os cálculos de Newton e de Leibniz.
} 
para os indivisíveis também contribuíram para a limitação de seus métodos.

Saindo da Itália para os Países Baixos, vamos encontrar o desenvolvimento de infinitesimais nos trabalhos de Grégoire de Saint Vicent (1584-1667). Com raízes em Arquimedes, e por meio de Stevin e Valerio, Grégoire constitui um outro eixo importante e independente no desenvolvimento dos indivisíveis na Europa do século XVII.

De Stevin e Valério, Grégoire aproveitou a versão direta do método de exaustão, evitando assim o método de redução ao absurdo. Entretanto, ao invés dos paralelogramos de Stevin e Valério, Grégoire usou em seu Opus geometricum (1625) uma "quantidade infinita de retângulos infinitamente finos", e quanto ao polígono de n-lados usado por Arquimedes, ele o substituiu por um polígono com número infinito de lados, tal e como foi feito por Nicolau de Cusa.

Segundo Boyer (1949, p.136), sua visão sobre a natureza dos indivisíveis, apesar de também não ser clara nem tampouco rigorosa, era menos ingênua que a de Cavalieri. Ele não considerava os infinitesimais sem espessura, como fez Cavalieri, mas com uma espessura bem pequena e que se tornava cada vez menor. Em uma de suas demonstrações, após inscrever em duas figuras de três dimensões muitos paralelepípedos finos, ele acrescentou que "esses paralelepípedos podem ser multiplicados então de tal modo que exaurirão o corpo no qual estão inscritos". É desta forma que Grégoire reedita o "método dos antigos" e atribui-lhe, de modo pioneiro, o seu consagrado nome de "método de exaustão". O sentido literal do nome de batismo dado ao método de Eudoxo, consagrado por Euclides e Arquimedes, tem muito mais a ver com o processo de subdivisão continua e infinita introduzida por Gré- 
goire do que com a hermética lógica dos gregos. Com esta nova interpretação do método de exaustão, a noção de limite passa, enfim, a incorporar o seu reagente básico: o conceito de infinito. É verdade que tanto Stevin, quanto Valério, deram suas valiosas contribuições nesse empreendimento, mas foi Grégoire quem fez talvez a primeira afirmação explícita de que uma série infinita define em si própria uma magnitude que pode ser chamada de o limite da série. Grégoire reconheceu também que a explicação do paradoxo de Aquilles pode ser feita em termos do limite de uma série infinita. Ele não conseguiu, entretanto, reconhecer que a questão fundamental do paradoxo de Zenão não estava em quando ou onde Aquilles ultrapassaria a tartaruga, mas muito mais em como ele poderia fazer isto.

Apesar de seu trabalho ter influenciado os de muitos outros matemáticos, Grégoire foi ignorado por seus contemporâneos, só tendo seu trabalho reconhecido posteriormente com Huygens (1629-95) e Leibniz (1646-1716) (o outro "inventor" do Cálculo). Como professor de várias escolas jesuítas, influenciou diretamente os trabalhos de Paul Guldin (1577-1642), André Tacquet e outros que também usavam considerações infinitesimais. O primeiro tornou-se o maior crítico da falta de rigor no uso de infinitesimais por Kepler e de indivisíveis por $\mathrm{Ca}$ valieri. O segundo, no entanto, desenvolveu trabalhos muito mais significativos com os métodos infinitesimais. Devido à variedade de métodos infinitesimais que empregou, Tacquet é comparado por Boyer (1949, p.139) ao seu contemporâneo Torricelli. Em seu Cylindricorum et annularium libri IV, Tacquet apresentou, por exemplo, quatro demonstrações da proposição que afirma que "o volume da esfera é igual 
à de uma cunha cilíndrica cuja base é a metade de um círculo máximo da esfera, e cuja altura é igual à circunferência da esfera".

Ao desenvolver os seus cálculos infinitesimais, André Tacquet, ao contrário de Cavalieri e Torricelli, considera que uma grandeza geométrica é feita apenas de partes homogêneas, isto é, os elementos infinitesimais são de mesma natureza do todo envolvido. Assim, um sólido é constituído de pequenos sólidos, uma área, de pequenas áreas, e uma linha, de pequenas linhas e, para se aproximar da grandeza procurada, usa a idéia de limite e o método de exaustão tal como sugeriu seu mestre Grégoire. Esta noção de limite irá aparecer com mais propriedade no trabalho Arithmetica infinitorum de John Wallis (16161703). Antes, porém, faz-se necessário que examinemos as contribuições de outros matemáticos franceses contemporâneos: Roberval (1602-75), Pascal (1623-62) e Fermat (1601-65) ${ }^{83}$ - tendo o segundo sofrido forte influência dos trabalhos de Tacquet.

Roberval admitia apenas os trabalhos de Arquimedes como sua única fonte de inspiração. No entanto, Boyer sugere que este possa ter sido influenciado também pelos trabalhos de Kepler, Stevin e Valério. Além disso, fica evidente sua familiaridade com os trabalhos de Cavalieri quando procura elaborar uma defesa do método de indivisíveis do matemático italiano. Roberval, no entanto, desenvolve sua teoria de indivisíveis em bases mais próximas das de Tacquet do que das de Cavalieri. Ele disse que não considerava em seu método "uma superfície como sendo realmente composta de linhas ou um sólido como feito de

\footnotetext{
${ }^{83}$ Cabe ressaltar que este trio de matemáticos franceses se interessou, além do Cálculo, por um campo emergente na matemática: a teoria dos números. Estes matemáticos serão, portanto, de importância fundamental para a introdução, ainda que de forma incipiente, de um viés mais aritmético no desenvolvimento do cálculo infinitesimal.
} 
superfícies, mas na realidade como sendo construídos de pequenos pedaços de superfícies e sólidos, respectivamente, sendo essas "infinitas coisas" consideradas "apenas como se elas fossem indivisiveis" ${ }^{84}$. Os seus cálculos de quadraturas e cubaturas foram desenvolvidos pelo processo de comparação entre as grandezas envolvidas. Apesar da confessa influência arquimediana, Roberval adotou a versão gregoriana do método de exaustão, mas sem formular explicitamente a operação de limite. Enquanto os matemáticos italianos, Cavalieri e Torricelli, procediam em bases puramente geométricas, Roberval - assim como Pascal e Fermat - desenvolveu o seu método infinitesimal com outro pano de fundo: o interesse pela teoria dos números. Influenciado pelas sugestões de Fermat, Roberval calculou a quadratura das "parábolas $x^{n \prime \prime}$ por procedimentos bem diferenciados dos de Cavalieri e Torricelli. Vejamos um fragmento desse raciocínio:

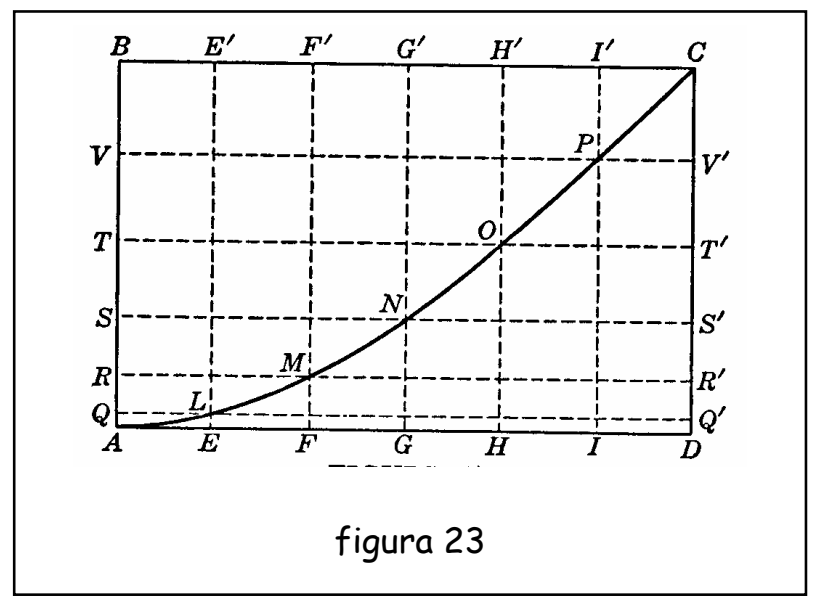

\footnotetext{
${ }^{84}$ apud Boyer (1949, p.141)
} 
Seja $A E=1, A F=2, A G=3, \ldots$ (fig.23).

Então da definição da parábola nós sabemos que $\frac{E L}{F M}=\frac{A E^{2}}{A F^{2}}$, e similarmente para os outros pontos de divisão.

Então

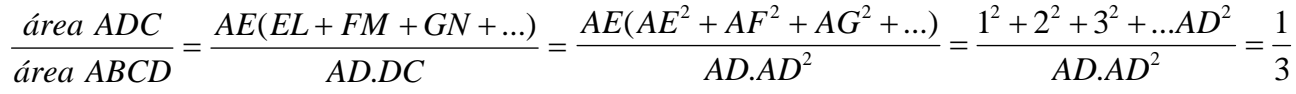

85

(apud Boyer, 1949, p.144-145)

Note que se considerássemos $A D=n A E$ na penúltima razão da demonstração de Roberval, e usássemos o resultado já conhecido desde os pitagóricos de que $\sum_{i=1}^{n} i^{2}=\frac{n^{3}}{3}+\frac{n^{2}}{2}+\frac{n}{6}$, o problema poderia ser resolvido do seguinte modo:

$$
\frac{\text { área } A D C}{\text { áreaABCD }}=\frac{1^{2}+2^{2}+3^{2}+\ldots n^{2}}{n^{3}}=\frac{\frac{n^{3}}{3}+\frac{n^{2}}{2}+\frac{n}{6}}{n^{3}}=\frac{1}{3}+\frac{1}{2 n}+\frac{1}{6 n^{2}}
$$

Assim, ao calcularmos o limite da última expressão, fazendo $n$ tender ao infinito, encontraríamos a razão procurada entre as áreas. É verdade que Roberval não explicitou tal operação em sua demonstração original, mas, também é verdade que ele a realizou, implicitamente, no ato de desprezar, para $n$ muito grande, quantidades muito pequenas em relação a quantidades constantes finitas.

Roberval tinha também conhecimento sobre os problemas do cálculo diferencial, mas a semelhança de seu método de tangentes com o de Torricelli levaram os matemáticos da época a suspeitarem da originalidade de seus métodos. Acusações de plágio a parte, Roberval considerou toda curva como o caminho de um ponto em movimento $e$ 
adotou como axioma, assim como Torricelli, que a direção do movimento é o mesmo do da tangente. Assim, determinou, aplicando a regra do paralelogramo das velocidades à parábola como o lugar geométrico dos pontos que eqüidistam do foco e da diretriz, a tangente a esta curva. Como neste caso específico, o paralelogramo é um losango, Roberval chegou à conclusão de que a tangente coincidia exatamente com a bissetriz do ângulo formado pelas distâncias ao foco e à diretriz.

Além de Fermat, Roberval manteve contato com Etienne Pascal, pai de Blaise Pascal. Assim, devido à amizade muito próxima de seu pai e Roberval, é provável que os trabalhos de Pascal tenham recebido fortes influências deste último. Segundo Boyer (1949, p.147), Blaise Pascal representa, em certo sentido, o ápice do desenvolvimento dos métodos infinitesimais realizado pelas tradições da geometria clássica. Pode-se perceber também um toque de misticismo em seus trabalhos consequiência, aliás, dos traços de sua própria personalidade.

Em seu trabalho Potestatum numericarum summa (1654), Pascal demonstra o teorema sobre a integral de $x^{n}$ fazendo uso apenas de proposições da geometria clássica e do exame dos números figurados a partir do triângulo aritmético ${ }^{86}$. O interesse de Pascal pelos números era notório. Desenvolveu inclusive um método aritmético geral para determinar a soma, não apenas no caso de termos que são potências integrais (do mesmo grau) dos n-primeiros números naturais, mas tam-

\footnotetext{
${ }^{85}$ Note que $\mathrm{AF}^{2}=(2 \mathrm{AE})^{2}=2^{2} \mathrm{AE}^{2}, \mathrm{AG}^{2}=(3 \mathrm{AE})^{2}=3^{2} \mathrm{AE}^{2}, \ldots$, e assim por diante.

${ }^{86} \mathrm{O}$ tal triângulo aritmético aqui referido é popularmente conhecido como triângulo de Pascal, mas, ao que tudo indica, sua descoberta deve-se ao matemático chinês Yang Hui (com publicações datadas de 1261 e 1275). No entanto, um estudo mais detalhado das propriedades do triângulo aritmético, que serviu como referência para outros trabalhos sobre este tema, é atribuído ao matemático alemão Michael Stifel (1486-1567).
} 
bém para potências (do mesmo grau) de alguns inteiros em progressão aritmética ${ }^{87}$. Explicitou essa relação na seguinte expressão: ${ }^{n+1} C_{1} d \sum^{(n)}{ }_{+}^{n+1} C_{2} d^{2} \sum^{(n-1)}+\ldots+{ }^{n+1} C_{n} d^{n} \sum^{(1)}=(a+N d)^{n+1}-a^{n+1}-N d^{n+1}$ em que a é o primeiro termo da progressão, $d$ a diferença comum (razão da PA), No número de termos, no grau da potência em questão, ${ }^{n+1} C_{i}$ o número na (i+1)-ézima coluna e na (n-i+2) linha no triângulo de Pascal, e $\sum^{(j)}$ a soma das j-ézimas potências dos termos da progressão.

Pascal usou o resultado acima para determinar áreas. Consideremos, por exemplo, a área sob a curva $y=x^{n}$. A superfície em questão pode ser considerada como a soma de ordenadas que são as n-ésimas potências das abscissas escolhidas em progressão aritmética (com primeiro termo nulo e com razão unitária), das quais existirão então infinitos termos. Assim, denominando b a última abscissa, e desprezando todos os termos de ordem inferior, a expressão se reduz $a(n+1) \sum^{(n)}=$ $b^{n+1}$, o que em notação atual poderíamos representar como: $\int_{0}^{b} x^{n} d x=\frac{b^{n+1}}{n+1}$.

Como se pode notar, o ponto essencial na demonstração de Pascal está na omissão dos termos de dimensão inferior. Pascal chegou a comparar os indivisíveis da geometria com o zero da aritmética, assim como fez Euler, tempos mais tarde, com as diferenciais do seu cálculo diferencial. Este ato de "desprezar as quantidades infinitesimais", encontradas originalmente nos trabalhos de Pascal, se constituirá um princípio básico no cálculo diferencial daqui por diante. É inegável a

\footnotetext{
${ }^{87}$ Isto é, Pascal desenvolveu os binômios $(1+2+3+\ldots+\mathrm{N})^{\mathrm{n}}$ e $(\mathrm{a}+\mathrm{Nd})^{\mathrm{n}}$, onde a $+\mathrm{Nd}$ é o termo geral da PA, tomando os coeficientes binomiais no triângulo aritmético.
} 
forte influência que a obra de Pascal exerceu no cálculo de Leibniz, que também adotou o fato fundamental de que as "diferenças" de ordem superior poderiam ser desprezadas. Newton também usou tal princípio fundamental no desenvolvimento do seu cálculo fluxional.

Ao contrário da escola peripatética, que só admitia a existência em potencial do infinitamente grande, Pascal adotou definitivamente as quantidades infinitamente pequenas como os elementos inversos dessas últimas ("para todo número enorme de grande como o 100000 existe um pequeno, o recíproco 0,00001, de modo que a existência do infinitamente grande implica a existência do infinitamente pequeno" - Boyer, 1949, p.151). Assim como Tacquet, Pascal foi favorável a uma teoria homogênea dos indivisíveis, isto é, os indivisíveis são de mesma natureza do todo da qual são partes constitutivas: são pequeníssimos comprimentos de um comprimento, pequeníssimas áreas de uma área ou pequeníssimos sólidos de um volume. Por outro lado, enquanto Pascal foi mais fiel ao uso das quantidades infinitesimais, Tacquet preferiu caminhar na direção da idéia de limite presente no método de exaustão de Grégoire de St. Vicent.

Apesar de Pascal ter antecipado outros resultados do Cálculo (técnicas de integração - por partes, por exemplo -, o uso do triângulo diferencial no cálculo de tangentes, etc.), o matemático subestimou a força das representações algébricas e analíticas, o que o impossibilitou de alcançar resultados mais gerais, como, por exemplo, a relação inversa entre os problemas de quadraturas e de tangentes. Esta preferência pelas técnicas da geometria clássica constituiu-se, sem dúvida, no principal obstáculo para uma antecipação da invenção do Cálculo por Pascal. 
Pierre de Fermat, amigo de Pascal, e, o maior matemático francês do século XVII, tinha um especial interesse na filologia grega e latina. O seu profundo conhecimento dessas línguas possibilitou-lhe uma leitura e estudo cuidadoso de obras clássicas da matemática, com destaque para os trabalhos de Arquimedes, Apolônio e Diofantes. A influência do primeiro foi, sem dúvida, tão fundamental para Fermat como o foi para os demais matemáticos da época, mas foram os trabaIhos dos dois últimos que forneceram os elementos essenciais do tratamento analítico de seu Cálculo.

Tanto os trabalhos de Apolônio e de Diofantes, quanto o desenvolvimento inicial da álgebra elementar pelos matemáticos italianos da idade média, encontraram eco nos trabalhos de dois outros grandes matemáticos franceses: Viète e Descartes. Viète, por exemplo, notou a grande força que tinha a representação e o raciocínio algébrico na solução de problemas geométricos. Ao propor, de modo inverso aos gregos, a redução dos problemas geométricos ao campo algébrico, Viète antecipava com seus trabalhos aquilo que hoje se constitui como geometria analítica. Mas foi o famoso trabalho Géométrie, de 1637, de René Descartes, que consolidou definitivamente a geometria analítica como um dos mais novos e poderosos instrumentos da matemática. Fermat, que também era familiar aos trabalhos de Viète, desenvolveu, paralelamente a Descartes, a sua geometria analítica. Assim, a rivalidade acadêmica entre Descartes e Fermat não vai se efetivar propriamente no terreno da geometria analítica, mas no uso desta para o desenvolvimento de soluções para os problemas do Cálculo. 
Descartes tinha familiaridade com a visão dos infinitesimais dos antigos, a dos medievais (escolásticos) e a de seus contemporâneos. $O$ matemático francês fez provavelmente uso inclusive desses infinitesimais - sem revelar, no entanto, o método que utilizava e sua fonte para calcular, a pedido de Mersenne, áreas, volumes e centros de gravidades de parábolas da forma $y^{n}=p x$. Entretanto, depois da publicação de seu famoso Géometrie, em 1637, o interesse de Descartes pelos métodos infinitesimais do Cálculo tende a diminuir e este se torna mais fiel à geometria analítica, ou melhor, ao seu "método algébrico". Argumentava que "somente através da álgebra é que podemos alcançar a precisão". O custo dessa fidelidade à precisão algébrica foi, sem dúvida, a limitação dos métodos cartesianos para a solução de problemas mais complexos do Cálculo.

O método algébrico de tangentes de Descartes consiste em passar através de dois pontos da curva um círculo com seu centro sobre o eixo $x$, e fazer os pontos de interseção coincidir. O centro do círculo torna-se então o ponto do eixo $x$ através do qual passa a reta normal à curva. Com isso, a reta tangente fica bem determinada. $O$ problema do seu método está na sua dificuldade de aplicação e resolução para curvas de naturezas mais complexas, uma vez que o seu método, com o objetivo de encontrar uma outra equação ${ }^{88}$ envolvendo a "subnormal" e a "subtangente" da curva para o ponto de tangência dado (fig. 24), usa propriedades geométricas bem específicas da curva envolvida na questão. Nem sempre é possível encontrar uma outra relação através da

\footnotetext{
${ }^{88}$ Uma equação era obtida pela semelhança dos triângulos retângulos que sempre aparecem na construção do método envolvendo a ordenada y do ponto, a subtangente e a subnormal:
} 
equação da curva ou de suas propriedades geométricas de modo que se possa resolver o problema algebricamente. E é esta limitação do método algébrico de Descartes, que, realmente, impossibilitou o matemático francês de construir um procedimento mais geral para os problemas de tangentes.

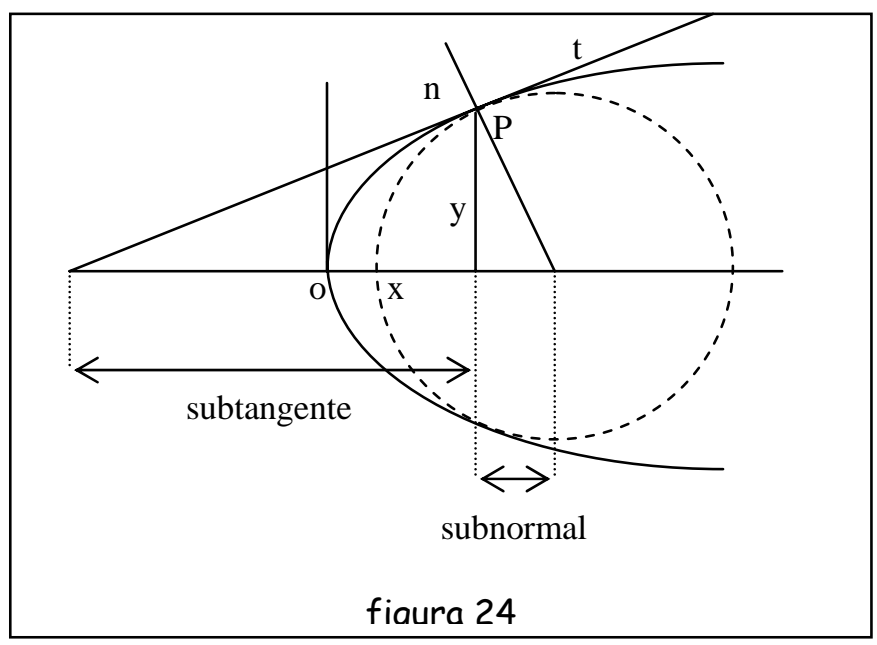

Já Fermat acrescenta às "propriedades específicas" (equações e definições analíticas) das curvas de sua geometria analítica o seu conhecimento acerca dos infinitesimais - obtido com o estudo das obras de Arquimedes, Kepler e Cavalieri -, criando, dessa forma, um instrumento infinitesimal analítico geral e poderoso para a resolução de problemas do Cálculo.

A primeira grande diferença, provocada pela introdução do simbolismo algébrico na geometria, ocorre no próprio conceito de infinitesimal. Enquanto quantidades infinitesimais estiveram associadas, ao longo da história, a linhas ou superfícies indivisíveis, ou mesmo números $\frac{\text { ordenada }}{\text { subtangente }}=\frac{\text { subnormal }}{\text { ordenada }}$. Esta proporção foi denominada por Descartes de gradiente da tangente 
infinitamente pequenos, com Fermat, as quantidades infinitesimais passam a ser uma "constante indeterminada", representada em geral pela letra "E", e que assume um papel mais próximo do nosso conceito de variável.

Em um artigo de 1638, Fermat publicou um método engenhoso para resolver problemas de "máximos e mínimos". O argumento deste método é como segue:

SOBRE UM MÉTODO PARA DETERMINAÇÃO DE MÁXIMO E MÍNIMO

Dividir o segmento $A C$ em $E$, de tal modo que o retângulo AE.EC possa ser máximo.

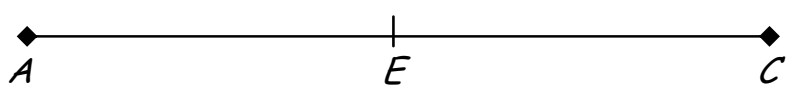

Seja a reta $A C$ dividida em $E$, de tal modo que o retângulo AE.EC possa ser máximo.

Seja $A C$ igual a $B$ e um dos segmentos igual a $A$ : o outro será $B-A$, e o retângulo, cujo máximo procuramos, será $B A-A q^{89}$. Agora seja $A+E$ a primeira parte de $B$, o resto será $B-A-E$ e o retângulo formado pelos segmentos será $B A-A q+B E-$ $2 A E-E q$, que consideramos ser aproximadamente igual a BA-Aq. Removendo termos comuns:

$B E \sim 2 A E+E q$

$e$ dividindo por $E, B \sim 2 A+E$.

Desprezando E, B é igual a 2A. Para resolver o problema devemos dividir a reta ao meio: é impossível existir um método mais geral.

(apud, Baron \& Bos, 1949, v.2, p.36).

Note, a partir do exemplo, que não há qualquer argumento que justifique se o ponto encontrado é de máximo ou de mínimo. Na verdade, não há sequer uma justificativa para a observação de Pappus, isto é, que o ponto de ótimo $x$ ocorre quando $f(x)=f(x+E)$. Apesar disso, 0 
procedimento usado pelo matemático é essencialmente analítico e facilmente estendido a outras situações-problemas.

Outro ponto que devemos observar no método de otimização de Fermat é que os procedimentos infinitesimais começam a ser desenvolvidos em termos de expressões analíticas. A variável área, no exemplo citado, foi explicitada em termos do comprimento $x$ e da quantidade infinitesimal E. O conceito de função começa, assim, a germinar e a ser introduzido de forma gradativa no desenvolvimento do Cálculo. E este - o conceito de função - é, sem dúvida uma das principais invenções do Cálculo.

Fermat também usa a sua quantidade infinitesimal $E$ no método de tangentes que desenvolveu. Vejamos através do exemplo da parábola uma aplicação de seu método.

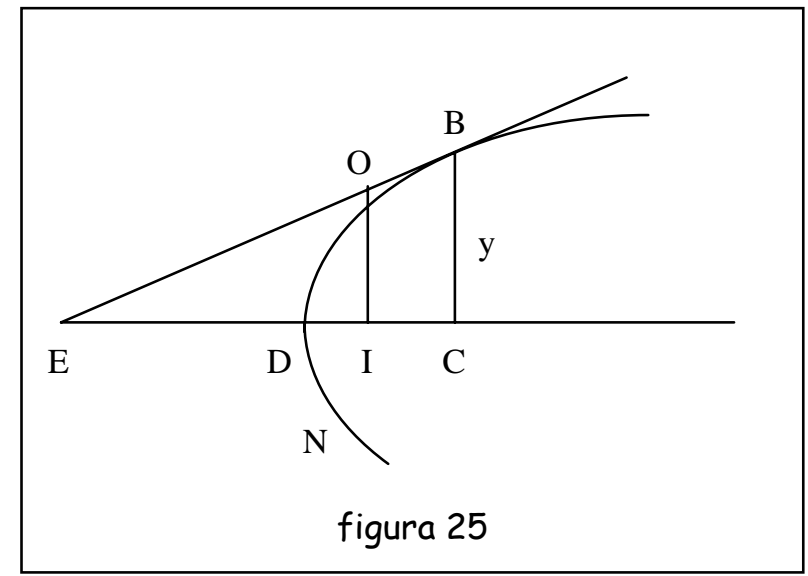

\footnotetext{
${ }^{89}$ Ao escrever uma letra q minúscula ao lado de uma quantidade qualquer, Fermat queria denotar o quadrado desta quantidade, assim, a expressão qBC significa (BC) $)^{2}$, Aq, representa $\mathrm{A}^{2}$, e assim por diante.
} 


\section{SOBRE AS TANGENTES A CURVAS}

Usamos o método acima para determinar a tangente a uma curva em um ponto. Tomemos, por exemplo, a parábola BDN com vértice $D$. Consideremos que a tangente à parábola passa por $B$ e encontra o diâmetro em $E$. Então, tome qualquer ponto $O$ sobre a reta $B E$ e trace a ordenada $B C$ no ponto $B$; temos então que $C D / D I$ será maior do que $q B C / q O I$, pois o ponto $O$ está fora da parábola; mas, $u$ sando triângulos semelhantes, $q B C / q O I=q C E / q I E ;$ segue-se dai que CD/DI é maior do que qCE/qIE. O ponto B é dado, logo conhecemos BC, o ponto C e CD; seja CD igual a D; seja CE igual a $A$ e CI igual a E; temos $\frac{D}{D-E}$ é maior do que $\frac{A q}{A q+E q-2 A E}$, e multiplicando os meios e extremos, D.Aq+D.Eq-2DAE é maior do que D.Aq-E.Aq.

Sejam então os termos aproximadamente iguais, de acordo com que estabelece 0 método; removendo termos comuns, temos,

$D$.Eq-2DAE -Aq.E, ou, o que dá no mesmo,

$D . E q+A q . E \sim 2 D A E$.

Dividindo por $E, D E+A q \sim 2 D A$.

Desprezando DE, vem Aq igual a 2DA, e A igual a $2 D$.

Assim, provamos que CE é igual ao dobro de CD, que é o resultado.

O método nunca falha; ele pode ser estendido a vários problemas; temos usado também para determinar centros de gravidades de figuras limitadas por retas e curvas assim com de sólidos. Ele une vários outros resultados que podemos descrever adiante se o tempo permitir.

(apud, Baron \& Bos, 1985, v.2, p.37).

Ao resolver o problema de calcular o centro de gravidade do parabolóide através de seu "método de máximo e mínimo" - ao invés de usar diretamente um método de quadratura, como fizeram seus antecessores: Arquimedes, Commandino, e outros -, Fermat reduziu um problema de retificação de arcos que envolviam tangentes a uma questão de quadraturas. Apesar da sua demonstração deste resultado sugerir que ele tivesse conhecimento da relação inversa entre os problemas de "somas" (áreas e volumes) e os de tangentes, tal fato, não foi, curiosamente, explicitado pelo grande matemático. Fermat, entretanto, desenvolve um método de quadratura que irá se assemelhar ao nos- 
so cálculo integral de hoje. Vejamos, por exemplo, como Fermat resolveu o problema da integral $\int_{0}^{a} x^{n} d x$, para " $n$ " um valor racional.

$O$ método de quadratura de Fermat pode ser considerado uma generalização daquele desenvolvido por Grégoire de Saint Vicent em seu Opus geometricum, ainda que este trabalho não tenha sido do conhecimento do matemático francês. Grégoire mostrou, por exemplo, que "se ao longo da assíntota horizontal de uma hipérbole retangular fossem marcados pontos cujas distâncias ao centro estão em proporção continuada ${ }^{90}$, e se nestes pontos as ordenadas são levantadas até à curva, então as áreas interceptadas entre estes são iguais" (apud Boyer, 1949, p.160). Fermat, por outro lado, modificou este processo de tal modo que ele pudesse ser aplicado tanto a hipérboles fracionárias quanto a parábolas. Para encontrar, por exemplo, a área sob a curva $y=x^{p / q}$, de 0 a $x$, ele considerou pontos $x, e x, e^{2} x, e^{3} x, \ldots$, com $e<1$, sobre o eixo das abscissas (fig. 26).

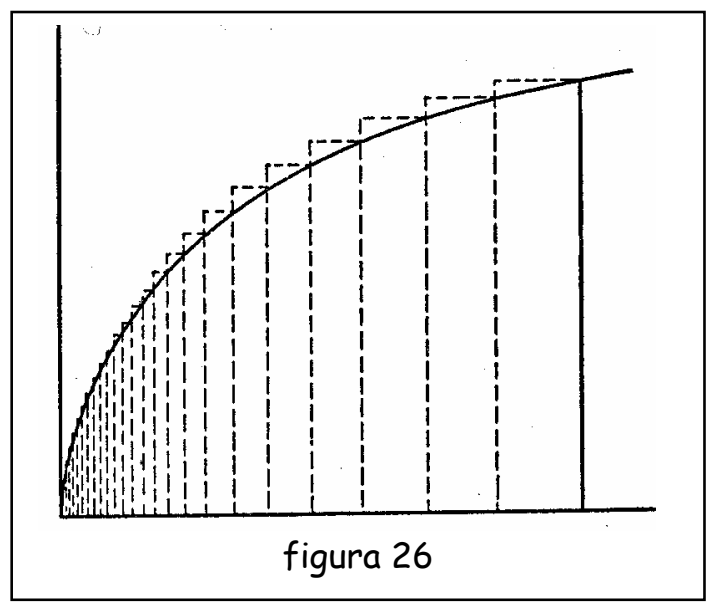

\footnotetext{
${ }^{90}$ Dizemos que a seqüência de números $\mathrm{a}_{1}, \mathrm{a}_{2}, \mathrm{a}_{3}, \mathrm{a}_{4}, \ldots, \mathrm{a}_{\mathrm{n}}, \ldots$ está em proporção continuada se $\frac{a_{1}}{a_{2}}=\frac{a_{2}}{a_{3}}=\frac{a_{3}}{a_{4}}=\ldots \frac{a_{n-1}}{a_{n}}=\frac{a_{n}}{a_{n+1}}=\ldots$, ou, de outro modo, se a seqüência ( $\left.\mathrm{a}_{\mathrm{n}}\right)$ forma uma progressão geométrica.
} 
Construindo então as ordenadas destes pontos, obteve uma quantidade infinita de retângulos cujas áreas estão em progressão geométrica. Assim como Grégoire de St. Vicent e Tacquet, Fermat encontrou a soma das áreas de tais retângulos como $x^{\frac{p+q}{q}}\left(\frac{1-e}{1-e^{\frac{p+q}{q}}}\right)$. Para encontrar a área sob a curva, Fermat percebeu que, quanto mais próximo de 1 a quantidade " $e$ " estiver, a quantidade de retângulos "aumenta" ${ }^{91}, e$ suas áreas ficam cada vez menores e mais próximas das regiões correspondentes da figura original. Antes, porém, Fermat fez a substituição $e=E^{q}$, para obter a soma dos retângulos como:

$$
x^{\frac{p+q}{q}}\left(\frac{1-e}{1-e^{\frac{p+q}{q}}}\right)=x^{\frac{p+q}{q}} \cdot \frac{(1-E)\left(1+E+E^{2}+\ldots+E^{q-1}\right)}{(1-E)\left(1+E+E^{2}+\ldots+E^{p+q-1}\right)} .
$$

Assim, fazendo e $\rightarrow 1$ na expressão anterior, Fermat obteve o seu re-

sultado, isto é, $\quad \int_{0}^{x} x^{\frac{p}{q}} d x=\frac{q}{p+q} x^{\frac{p+q}{q}}=\frac{x^{\frac{p}{q}+1}}{\frac{p}{q}+1}$.

É impressionante a antecipação de Fermat do conceito de integração como o limite de uma soma de retângulos. Ainda que Fermat não tenha dado a ênfase necessária à noção de limite, seu método de quadratura não deve nada ao método de integração desenvolvido por seu conterrâneo Cauchy, dois séculos depois. Segundo Boyer (1949, p.161), o que faltou a Fermat foi explicitar de forma clara a operação

\footnotetext{
${ }^{91}$ A palavra "aumenta” está sendo usada aqui de uma forma imprópria pelo autor, uma vez que a quantidade de retângulos é infinita. Entende-se, no entanto, que este abuso de linguagem serve para ilustrar de forma bem intuitiva o processo de refinamento da seqüência de retângulos desenvolvida por Fermat em sua demonstração.
} 
de limite e reconhecer nela mesma o elemento fundamental de seu método.

Fermat, assim como Pascal, também fez uso em seus métodos infinitesimais do triângulo diferencial, que se constituirá como um dos elementos fundamentais do Cálculo de Leibniz. Tais versatilidade e habilidade demonstradas por Fermat com respeito aos problemas básicos do Cálculo Diferencial e Integral, sua visão e capacidade de generalização, poderiam, com efeito, ter antecipado ao consagrado matemático francês o título de "inventor" do Cálculo, caso não fosse a sua surpreendente indiferença e ignorância em relação à questão fundamental sobre a relação inversa entre as operações de integração e diferenciação.

Segundo Boyer (1949, p.164), a influência de Fermat sobre os seus contemporâneos é muito difícil de precisar, visto que o grande matemático francês não tinha o hábito de publicar os seus trabalhos a maioria deles foi publicada postumamente, como, por exemplo, o Opera varia em 1679. Por outro lado, é notória, entretanto, a correspondência de Fermat com Roberval, Pascal e Mersenne. Quanto a Newton e Leibniz, no entanto, pode-se afirmar que, mesmo tendo as publicações dos métodos infinitesimais de Fermat se antecipado às dos outros dois, é muito pouco provável que o desenvolvimento do cálculo de Newton e do de Leibniz tenham recebido influências diretas dos trabalhos de Fermat.

No continente britânico, os novos métodos analíticos (a geometria analítica) inventados por Fermat e Descartes foram desenvolvidos

${ }^{92}$ Note que $\lim _{e \rightarrow 1} \frac{(1-E)\left(1+E+E^{2}+\ldots+E^{q-1}\right)}{(1-E)\left(1+E+E^{2}+\ldots+E^{p+q-1}\right)}=\lim _{e \rightarrow 1} \frac{\left(1+E+E^{2}+\ldots+E^{q-1}\right)}{\left(1+E+E^{2}+\ldots+E^{p+q-1}\right)}=\frac{q}{p+q}$. 
paralelamente pelo astrônomo inglês Thomas Harriot (1560-1621). Harriot é costumeiramente considerado o fundador da escola de algebristas ingleses. O seu grande trabalho é Artis analyticae praxisi, só publicado dez anos depois de sua morte e que trata, em grande parte, da teoria das equações. Grande parte desse material encontra-se nos trabalhos de Viète, mas o tratamento de Harriot é mais completo e mais sistematizado. Segundo Eves (1995, p.348), é incorreto, no entanto, atribuir também - como fazem, inclusive, alguns historiadores a Harriot o título de inventor da geometria analítica. $O$ historiador argumenta que há oito volumes de manuscritos de Harriot no Museu Britânico e que, além disso, outro historiador, D. E. Smith, mostrou que a parte da obra que lida com geometria analítica é uma interpolação feita por mãos posteriores. No entanto, um fato ninguém pode negar a respeito de Harriot: foi através dele que o pensamento algébrico desenvolvido no restante do continente europeu e no mundo hindu-árabe foi introduzido na matemática britânica.

John Wallis (1616-1703), por exemplo, foi apresentado aos métodos analíticos através dos trabalhos de Harriot. Na verdade, Wallis foi mais longe do que seu conterrâneo no desenvolvimento da álgebra: ele mostrou inicialmente que todos os teoremas do quinto volume dos Elementos de Euclides podem ser derivados exclusivamente da aritmética e de forma independente da geometria, e, desta forma, estabeleceu indubitavelmente a independência da álgebra da geometria. Apesar de querer aritmetizar os resultados da matemática em geral, Wallis não tinha grandes preocupações com o rigor. O matemático bri- 
tânico, por exemplo, usou livremente analogias e induções incompletas 93 em seus trabalhos.

Wallis assumiu explicitamente o conceito de infinito em seu Cálculo. Segundo Baron (1985, v.2, p.23), o matemático introduziu o símbolo $\infty$ para representar muitas linhas (ou paralelogramos) constituindo uma superfície plana. Assim, se B é a base de um triângulo e $A$ a sua altura, $\infty$ será o número de linhas na superfície. Com esta interpretação. O matemático desenvolve ingenuamente uma espécie de "álgebra do infinito" para, por exemplo, determinar a área de um triângulo. Neste caso, como o comprimento total das retas é $\infty \mathrm{B} / 2$ e a altura de cada paralelogramo é $A / \infty$, segue-se que a área dos triângulos é $(\infty B / 2) \cdot(A / \infty)=A \cdot B / 2$. Note que a concepção de Wallis sobre $0 \infty$ era dualista, ora funcionado como um número, ora com uma quantidade infinitamente grande.

Assim, pelo exemplo exposto no parágrafo anterior, já se pode perceber uma característica bem evidente nos trabalhos de Wallis na área específica do "Cálculo": o uso de métodos infinitesimais. O contato original com o método de indivisíveis de Cavalieri foi mediado por ninguém menos do que Torricelli. Mas, Wallis, sem abandonar a sua vocação aritmética, fez uma adaptação do método de indivisíveis de forma bem original: enquanto a abordagem de Cavalieri era essencialmente geométrica, Wallis, por outro lado, procedia aritmeticamente para abstrair da geometria dos indivisíveis, na etapa final do seu mé-

\footnotetext{
${ }^{93}$ Usa-se costumeiramente o termo incompleto para designar aqueles processos de indução em que se generaliza o valor verdade de uma proposição $\mathrm{P}(\mathrm{n})$ para todos os valores naturais de $\mathrm{n}$ a partir, apenas, da verificação desta proposição para uma quantidade finita destes valores. Para que a indução seja completa é necessário que se acrescente a hipótese indutiva, isto é: mostrar que a sentença “ $\mathrm{P}(\mathrm{k})$ verdadeira implica $\mathrm{P}(\mathrm{k}+1)$ verdadeira” é verdadeira qualquer que seja o valor natural de $\mathrm{k}$.
} 
todo, a noção aritmética de um limite. Segundo Boyer (1949, p.169), Wallis chegou mais próximo da operação de limite do que qualquer dos predecessores de Newton. Há de se ressaltar entretanto que Wallis foi recuperar a idéia de limite nos trabalhos dos matemáticos dos Países Baixos - Stevin, Grégoire de Saint Vicent e Tacquet.

Segundo Boyer (1949, p.171), pode-se identificar dois momentos distintos na obra de Wallis no que diz respeito ao desenvolvimento do seu método infinitesimal: uma primeira fase, dominada por uma espécie de álgebra do infinito - tal como ocorreu no exemplo supracitado - e que predomina no seu trabalho De sectionibus conicisi; e outra, marcada pelo seu famoso trabalho Arithmetica infinitorum, onde Wallis desenvolve o seu método infinitesimal com base na noção intuitiva de limite e de sua vocação aritmética. Vejamos como ilustração um velho resultado conhecido dos matemáticos: $\int_{0}^{a} x^{n} d x=\frac{a^{n+1}}{n+1}$.

Wallis alcançou este resultado observando inicialmente que:

$$
\frac{0+1}{1+1}=\frac{1}{2} ; \quad \frac{0+1+2}{2+2+2}=\frac{1}{2} ; \quad \frac{0+1+2+3}{3+3+3+3}=\frac{1}{2} ; \ldots ; \frac{0+1+2+3+\ldots+n}{n+n+n+n+\ldots+n}=\frac{1}{2} ; \ldots
$$

Como a razão é sempre igual a $\frac{1}{2}$, Wallis concluiu, com o auxílio da figura 27, que a área de um triângulo é a metade da área do paralelogramo de mesma base e mesma altura. 


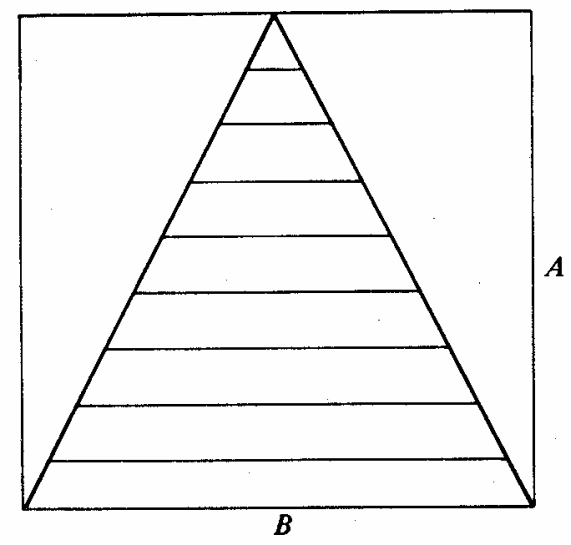

figura 27

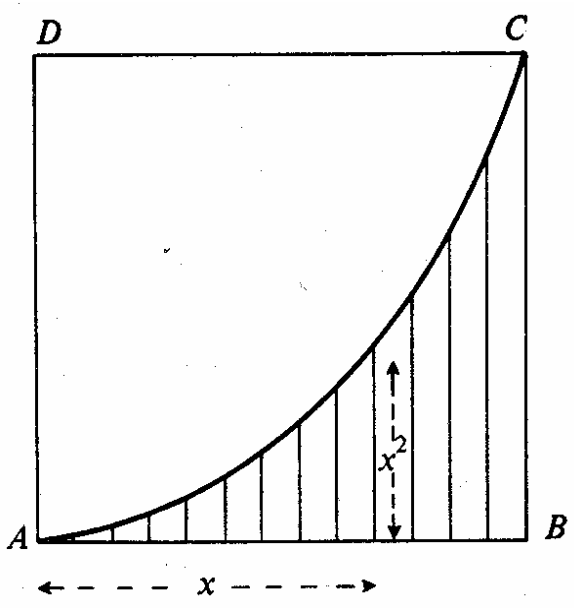

figura 28

De modo análogo, concluiu através da figura 28 e da igualdade

$$
\begin{gathered}
\frac{0+1}{1+1}=\frac{1}{3}+\frac{1}{6} ; \quad \frac{0+1+4}{4+4+4}=\frac{1}{3}+\frac{1}{12} ; \quad \frac{0+1+4+9}{9+9+9+9}=\frac{1}{3}+\frac{1}{18} ; \\
\ldots . . \quad \frac{0^{2}+1^{2}+2^{2}+3^{2}+\ldots+n^{2}}{n^{2}+n^{2}+n^{2}+n^{2}+\ldots+n^{2}}=\frac{1}{3}+\frac{1}{6 n} ; \ldots
\end{gathered}
$$

que a razão entre as áreas difere de $\frac{1}{3}$ por uma "grandeza desprezível" quando temos um número infinito de termos; em notação atual, poderíamos representar seu resultado por $\int_{0}^{1} x^{2} d x=\frac{1}{3}$.

Wallis observou, de modo similar, que razões análogas para a terceira, quarta, quinta potências são, respectivamente, $\frac{1}{4}, \frac{1}{5}, \frac{1}{6}$, e, por um processo de indução incompleta estendeu tal fórmula para potências inteiras superiores. Verificou ainda a validade da fórmula para mais alguns valores de $n$ negativos, racionais e inferiu, como no primeiro caso, que a fórmula continuaria válida para valores negativos, racionais e irracionais, exceto para $n=-1$.

Para Boyer (1949, p.173), a base para o conceito de integral definida pode ser considerada claramente estabelecida nos trabalhos de 
Fermat $e$ Wallis. Wallis confundiu seu trabalho com os infinitesimais, identificando retângulos infinitmente pequenos com linhas, e escrevendo $\frac{1}{\infty}=0$ - "idéia que conduzirá à concepção, encontrada em Leibniz, da integral como uma totalidade, e não como limite de uma soma" 94. Ressalta ainda o historiador que este conceito de integral, presente tanto em Wallis, quanto em Fermat, se tornará mais "confuso" posteriormente pela introdução das concepções de fluxões e diferenciais.

Com efeito, tanto Newton quanto Leibniz (os "inventores" do Cálculo), tendo ambos o conhecimento do Teorema Fundamental do Cálculo, preferiram atrelar o seu cálculo integral a uma aplicação simples e direta deste teorema em vez de investirem em uma definição mais precisa para o processo de integração. Esta é, efetivamente, a solução que foi dada pelo Cálculo para o problema da integração: integrar uma curva significa "antidiferenciar" a mesma, isto é, encontrar uma outra curva cuja "derivada" seja a curva dada. Em verdade, a definição precisa do conceito de integração (livre das "confusões" sugerida por Boyer), que será realizada em termos de limites de somas parciais (inicialmente com Cauchy, e depois com Riemann), é a solução da Análise. Deixemos por ora esta discussão e voltemos ao nosso relato histórico voltaremos a esse assunto num momento mais oportuno.

A tentativa de aritmetização dos resultados do Cálculo por Wallis repercute nos trabalhos de seu contemporâneo James Gregory (1638-75). Gregory unifica em seus trabalhos tanto a aritmética infinitesimal de Wallis quanto a de Roberval. Em seu artigo Vera circuli et hyperbolae quadratura, de 1667, Gregory vislumbrou a "passagem ao

\footnotetext{
${ }^{94}$ Boyer (1949, p.173)
} 
limite" como uma operação aritmética independente. Inscreveu e circunscreveu polígonos em círculos e em hipérboles, e mostrou, por duplicações do número de lados, que as séries obtidas a partir do perímetro dos polígonos eram convergentes, uma vez que as diferenças entre dois valores consecutivos se tornavam cada vez menores. Gregory afirmava, neste caso, que o limite era o "ultimo" polígono. E, para sinalizar que a série tinha uma soma, introduziu o termo "convergente", que ele trouxe da óptica ${ }^{95}$.

Gregory incorpora em seu método infinitesimal tanto a aritmética infinitesimal de Wallis e Roberval quanto a noção de limite presente nos trabalhos de Grégoire de Saint Vicent e de Tacquet. Faz isso sob a luz dos "novos" métodos analíticos desenvolvidos por Descartes. Como consequiência dessa maravilhosa combinação, obteve um poderoso método de tangentes, muito semelhante àquele desenvolvido por Fermat - a única diferença é, sem dúvida, a representação da quantidade infinitesimal: enquanto Fermat usava a letra maiúscula " $E$ ", Gregory usava o símbolo "o". Posteriormente, Newton irá adotar no desenvolvimento de seu Cálculo Fluxional tanto o símbolo "o" como parte substancial do método de tangentes desenvolvido por Gregory.

No entanto, este processo inicial de aritmetização do Cálculo irá encontrar a resistência de dois pensadores ingleses: o filósofo Thomas Hobbes (1588-1679) e o matemático e teólogo Isaac Barrow (163077).

\footnotetext{
95 O matemático britânico também desenvolveu "funções" em séries de potências, além de ter elucidado a relação inversa entre os métodos de tangentes e os de quadraturas.
} 
Hobbes caracterizou o Arithmetica infinitorum, de Wallis, como um "livro vil" 96 . Ele se referiu à aritmetização de Wallis como "absurda" e como "uma crosta de símbolos". Segundo Boyer (1949, p.176), "esta atitude em relação à álgebra e à geometria analítica foi provavelmente o resultado não apenas da predileção geral no século XVII por métodos geométricos do que por métodos aritméticos, mas também da visão exagerada de Hobbes da matemática como idealização da percepção sensória, muito mais do que como ramo da lógica formal abstrata". A visão de número de Hobbes estava bem próxima da dos pitagóricos. Ele interpretou número como uma coleção de unidades e razão apenas em termos de considerações geométricas. Este retorno à geometria euclidiana não só sacrifica a aritmética infinitesimal intuitiva de Wallis, Gregory e Roberval, mas adia, para um futuro não muito próximo, o desenvolvimento da noção de limite como a operação fundamental no desenvolvimento dos conceitos básicos do Cálculo Diferencial e Integral.

Isaac Barrow criticou tanto a aritmetização de Wallis quanto à geometria analítica de Descartes. Barrow manteve-se fiel à geometria euclidiana em todos os sentidos ${ }^{97}$. Barrow sustentou que os números matemáticos não têm existência real em si próprios e independem da quantidade geométrica contínua. Números como $0 \sqrt{3}$, por exemplo, não podem ser pensados isoladamente, sem referência a sua magnitude geométrica - assegurava Barrow. Acrescentou ainda o matemático bri-

\footnotetext{
96 Tradução do original, em inglês, "scurvy book".

${ }^{97}$ É de Isaac Barrow a primeira tradução dos Elementos de Euclides para o inglês. Foi através de sua tradução que seu brilhante aluno Isaac Newton teve acesso à matemática dos antigos.
} 
tânico que tais números "surdos" 98 eram "inexplicáveis" e que, portanto, deviam ser banidos da aritmética para uma outra "ciência" (que ainda não era ciência) vizinha: a álgebra. Barrow sustentou ainda que a aritmética era para ser introduzida na geometria, enquanto a álgebra era para ser incluída na lógica, mais do que na matemática. Esta atitude de Barrow certamente influenciou Newton - seu aluno - no desenvolvimento de seu Cálculo Fluxional. Newton, a fim de evitar a noção aritmética de limite, usa a idéia de variação contínua presente na idéia de movimento (velocidade) e em grandezas geométricas. Mas quanto ao novo método analítico, Newton contraria as orientações de seu mestre: ao invés de o lançar fora, muito pelo contrário, Newton incorporao na construção de seu Cálculo.

A forte influência dos Platonistas de Cambridge e a falta de um conceito de limite fizeram com que Barrow recuperasse em seus trabaIhos a noção de infinitesimal bem próxima de como Hobbes, Platão, Nicolau de Oresme e Galileu desenvolveram em seus trabalhos. Mas a falta da operação de limite, aliada a sua reticência em relação ao número irracional, fez com que Barrow se embaraçasse com os conceitos de velocidade instantânea e do contínuo. Para dar uma idéia deste último, Barrow procura associá-lo à experiência sensível de "movimento contínuo" sugerindo que uma grandeza contínua é aquela que "flui regularmente" por todos os valores "possíveis" 99 . Já para o conceito de velocidade instantânea usa o conceito de infinitesimal, tal como já havia

\footnotetext{
${ }^{98}$ Era dessa forma - como números “surdos” - que os matemáticos da época resistiam e se referiam aos números irracionais.

99 Os valores "possíveis” se referem ao conjunto universo que para Barrow se limitava ao campo dos racionais.
} 
feito Nicolau de Oresme em seus trabalhos, para assegurar a sua existência:

Para todo instante de tempo, ou partícula indefinidamente pequena de tempo, (eu digo instante ou partícula indefinida, mas, isto não faz diferença se nós supusermos uma linha por ser composta de pontos ou de segmentos indefinidamente pequenos; e então, da mesma maneira, se nós supusermos o tempo ser feito de instantes ou de intervalos indefinidamente pequenos); para todo instante de tempo, eu digo, existe algum grau de velocidade correspondente, que o corpo que se move é considerado possuir neste instante."

(apud Boyer, 1949, p.180)

Barrow assumiu então a concepção atomista de indivisível. Afirmou o matemático que as grandezas poderiam ser consideradas como constituídas pelos elementos indivisíveis ou pelo movimento contínuo de um instante ou um ponto, ou como um agregado de instantes ou de pontos. Contra o criticismo válido de Tacquet, Barrow defende o método de indivisíveis de Cavalieri.

Os trabalhos de Barrow incluem não apenas numerosos teoremas sobre quadraturas e tangentes, mas a mais clara referência sobre a relação inversa entre esses problemas. Tal relação inversa constitui o que se denomina nos dias de hoje "Teorema Fundamental do Cálculo". Mas, os registros históricos sobre o desenvolvimento do Cálculo apontam que dois outros matemáticos já haviam antecipado este resultado: os matemáticos e físicos Torricelli e James Gregory.

O primeiro, como já observamos neste trabalho, procurou relacionar tangentes e quadraturas diretamente através do conceito de movimento, generalizando e estendendo idéias já desenvolvidas por Galileu e Cavalieri. Usando a noção medieval do gráfico velocidadetempo, no qual a distância total percorrida é representada pela área sob a curva (veja p. 133 deste trabalho), e os resultados de quadraturas de curvas obtidos por Cavalieri, Torricelli percebeu esta relação 
inversa através dos problemas físicos (cinemáticos) inversos de: dada a equação horária do movimento, determinar uma expressão para a velocidade; $e$, dada a velocidade, encontrar a equação horária do movimento. Já Gregory, influenciado pela leitura direta que fez das obras de Torricelli, pôde enfim enunciar e publicar pela primeira vez uma demonstração do Teorema Fundamental do Cálculo, que certamente "influenciou" a demonstração de Barrow. A obra Lectiones geometricae, publicada por Barrow em 1670, e que continha a sua versão do Teorema Fundamental do Cálculo, era tão semelhante ao Geometriae, de Gregory, que a historiadora Baron (1985, v. 2, p.45) chega a questionar a originalidade do primeiro trabalho. O teorema de Barrow provado no texto suspeito é equivalente, em notação recente, a: $R y=\int_{0}^{x} z d x \Rightarrow R \frac{d y}{d x}=z$ - cópia 100 fiel do enunciado apresentado por Gregory -, onde R é uma constante (positiva) ${ }^{101}$ qualquer. Sua demonstração, com adaptação em algumas notações, é como segue:

\footnotetext{
${ }^{100}$ A única diferença é a letra usada para representar a constante: ao invés do $k$ de Gregory, Barrow usou $R$.

${ }^{101}$ A constante foi considerada positiva no enunciado do teorema por dois motivos históricos: primeiro porque sua demonstração é essencialmente geométrica e trabalha com áreas; o outro pode ser conseqüência do "sintoma de evitação" com respeito aos números relativos, atitude muito comum entre os matemáticos da época, que se recusavam a aceitar os números negativos como números e partes integrantes do próprio conhecimento matemático. Uma obra que descreve com clareza e profundidade a evolução histórica dos números relativos é (Glaeser, 1985)
} 

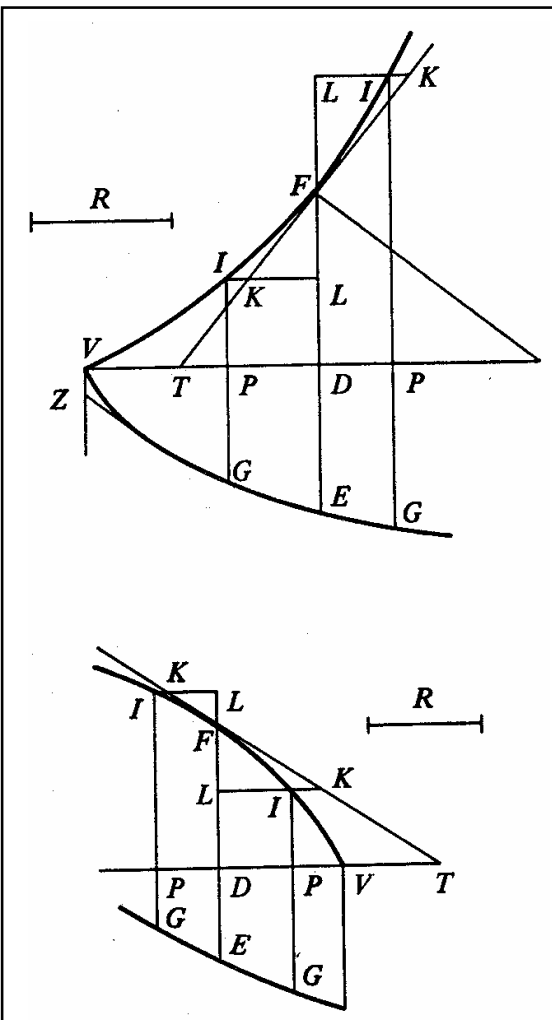

figura 29

Seja qualquer curva $Z G E$, com eixo VD; suponhamos primeiro que as ordenadas $V Z, P G$, $D E$ perpendiculares a $V D$, cresçam a partir do primeiro VZ. Seja a curva VIF tal que, traçando-se qualquer reta EDF perpendicular a VD (que corta as curvas nos pontos $E, F e$ $V D$ em $D)$, o retângulo sob $D F$ e qualquer reta dada $R$, pode ser respectivamente igual ao espaço interceptado VDEZ; faça agora $D E: D F:: R: D T$, e trace a reta TF: esta tocará a curva VIF.

Tome qualquer ponto I na curva VIF (primeiro acima do ponto $F$, em direção ao início $V$ ) $e$ através disto, trace as retas IG, KL paralela a VZ, VD (cortando a curva, como o esquema) então LF:LK::(DF:DT::)DE:R; então $\angle F X R=L K X D E$. Mas (por superposição) LFXR é igual ao espaço PDEG. Portanto LKX$D E=P D E G<D p \times D E$. Daí $L K<D P$, ou $L K<L L$.

Novamente tome qualquer ponto $I$, abaixo do ponto $F$, e faça o mesmo procedimento anterior. Então, por razoes semelhantes, parece que $\angle K \times D E=P D E G>D p \times D E$; portanto $L K>D P$, ou LI. Donde se conclui que a reta

inteira TKFK cai dentro (ou fora) da curva VIFI. As coisas continuam como antes se as ordenadas $V Z, P G, D E$ continuam a decrescer; a conclusão e o raciocínio serão os mesmos, com uma única diferença - é que a curva VIF é côncava com relação ao eixo VD.

(apud Baron \& Bos, 1985, v.2, p.45)

Barrow considera VD como o eixo $x$ - 0 eixo das abscissas. A curva ZGEG é então a função $z=f(x)$ sobre a qual se verificará a propriedade fundamental. Com efeito, note que as ordenadas y's da curva VIF se encontram definidas por $R y=\int_{0}^{x} z d x$ e que Barrow assegura que a reta FT é tangente à curva VIF em $F$, desde que $y / t=z / R$, isto é: $R(y / t)=z$, onde $t=D T$ é a subtangente. Note que a expressão derivada aqui é dada pela razão $(y / t)$. O resto da demonstração segue à moda dos antigos. 
Deixando de lado as controvérsias levantadas sobre o Teorema Fundamental do Cálculo, devemos destacar aqui uma das maiores contribuições de Barrow: o seu método de tangentes.

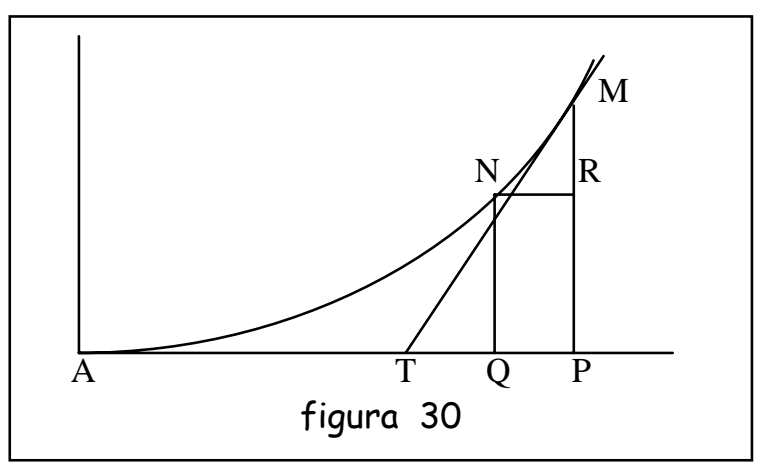

Seja AP, PM duas linhas retas dadas em posição, das quais PM corta uma curva dada em M, e seja MT suposta tocar a curva em M, e cortar a linha reta em $T$ (figura 30),

Para encontrar a quantidade da linha reta $P T$, eu considero um arco infinitamente pequeno, MN, da curva; em seguida eu desenho $N Q, N R$ paralelos a MP, AP [respectivamente]; eu faço $M P=\underline{m}, P T=\underline{t}, M R=\underline{a}, N R=\underline{e}$, e outras linhas retas, determinadas pela natureza especial da curva, úteis para o problema em questão, eu também designo pelo nome; eu também comparo MR, NR (e através delas, MP, PT) uma com a outra por meio de uma equação obtida por cálculo; nesse ínterim observando as seguintes regras.

Regra 1. No cálculo, eu omito todos os termos contendo uma potência de a ou e, ou produto destes (para estes termos não há valor).

Regra 2. Depois da equação ter sido formada, eu rejeito todos os termos consistindo de letras denotando quantidades conhecidas ou determinadas, ou termos que não contenham a ou $\underline{e}$ (para estes termos, convertidos para um lado da equação, serão sempre iguais a zero).

Regra 3. Eu substituo m (ou MP) por a , e $\underline{t}$ (ou PT) por e. Então o comprimento de PT é encontrado.

(apud Boyer, 1949, p.182-183)

Se trocarmos as letras $\underline{a}$ e $\underline{e}$ pelos símbolos $\Delta y$ e $\Delta x$, respectivamente, notaremos a proximidade do método de tangentes de Barrow com o atual conceito de derivada. Apesar de aparentemente não conhecer o método de tangentes de Fermat ${ }^{102}$, seu método é muito similar ao do matemático francês. É muito provável que o método de tan- 
gentes de Fermat tenha se tornado conhecido por Barrow através dos trabalhos de James Gregory e dos de Huygens (1628-95).

$O$ desejo de desenvolver novos algoritmos sobrepujava qualquer consideração de rigor na matemática normal da época. Os métodos dos antigos (dos gregos) eram rigorosos, mas muito pouco aplicáveis. Este era o paradigma que predominava na segunda metade do século XVII: a "intuição" e o "instinto" sobrepujavam a "razão". R. Courant e H. Robbins (1967, p. 409), além de ratificarem tal opinião, alertam-nos para o fato de que, se tal paradigma não estivesse sob domínio de "homens extremamente competentes", o risco de tal aventura teria sido muito maior:

Na análise matemática do século XVII e grande parte do XVIII pareceu haver-se abandonado por completo o ideal grego de raciocínio claro e rigoroso. $A$ "intuição" e o "instinto" substituíram a razão em numerosos casos importantes. Isto fomentou a fé sem discriminação no poder sobre-humano dos novos métodos. Se cria geralmente não só desnecessária, mas impossível, uma clara apresentação dos resultados do cálculo infinitesimal. Se não estivesse a nova ciência em mãos de um grupo restrito de homens extremamente competentes, teriam ocorridos sérios erros e até desastres. Estes cientistas se deixaram guiar por um sentido profundamente instintivo, que Ihes impedia de se perderem por completo.

Antes de prosseguirmos com nosso levantamento histórico, é importante que se registre as reais condições do "nascimento" do Cálculo: muita intuição e liberdade para pensar. Há de se ressaltar o importante papel que tiveram as quantidades infinitesimais nesse empreendimento de construção do Cálculo Diferencial e Integral: os infinitésimos se constituíram, a partir de então, como a fonte de "inspiração" e o ponto de partida das investigações e produções de todos os matemáticos que se aventuravam pelo domínio do Cálculo. Assim, o Cálculo

\footnotetext{
${ }^{102}$ Segundo o próprio Barrow, as fontes de suas idéias foram os trabalhos de Descartes, Huygens, Galileu, Cavalieri, Grégoire de Saint-Vicent, James Gregory e Wallis (apud Boyer, 1949, p.183).
} 
Diferencial e Integral, antes se tornar o que é hoje, precisou ser antes "Cálculo Infinitesimal". Isto antecipa uma questão de natureza epistemológica e fundamental tanto para o Cálculo quanto para o seu ensino - e que será discutida posteriormente neste trabalho: Seria a noção de infinitésimo a porta de entrada inevitável para a construção das idéias básicas do Cálculo? Do ponto de vista histórico já vimos que sim: a noção de infinitésimo foi o elemento estrutural inicial dos processos infinitos (procedimentos ad infinitum) que caracterizam a essência dos procedimentos do Cálculo.

Voltando ao século XVII, conforme ficou claro pelos parágrafos anteriores, os matemáticos da época tinham cada vez mais o interesse em substituir os métodos particulares por métodos mais gerais. Atendendo a essas expectativas, Huygens (1628-95), Hudde (1628-1704) e Heuraet (1633-60) introduziram um conjunto operacional de regras e fórmulas para a construção de tangentes e resolução de problemas de máximos e mínimos. Em verdade, estes matemáticos não desenvolveram idéias novas. Eles simplesmente formataram os diversos resultados já existentes, particularmente aqueles desenvolvidos por Fermate por Barrow, em fórmulas canônicas de caráter mais geral.

Neste momento da história do Cálculo, surge um outro tipo especial de problema: a retificação de arcos. Tal espécie de problema é de natureza mais difícil que os demais problemas surgidos até então no Cálculo, uma vez que, além de relacionar os conceitos de integração $e$ diferenciação, a função que surge no integrando da expressão ${ }^{103} \mathrm{tem}$, em geral, uma natureza bastante complexa para ser "integrada" pelos 
métodos existentes na época. Ao que parece, nenhum matemático anterior a Newton resolveu quadraturas dessas espécies de "curvas". Sabe-se que Willian Neil resolveu o problema do comprimento de arco da parábola semicúbica $a \cdot y^{2}=x^{3}$. No entanto foi Heuraet o primeiro a publicar um método para a retificação desta curva. Como o teor do método de Heuraet não é tão significativo para o desenvolvimento ulterior do Cálculo, nos reservamos o direito de não apresentá-lo neste espaço - uma apresentação simplificada deste método pode ser vista em Baron (1949, v.2, p.52). Cabe ressaltar, entretanto, que, com o entusiasmado interesse desses matemáticos por métodos mais gerais para a solução dos problemas do Cálculo, estava se configurando as condições necessárias para a realização de uma das maiores invenções matemática: o Cálculo Diferencial e Integral.

103 O comprimento de arco $\underline{s}$ de uma curva dada por $\mathrm{y}=\mathrm{f}(\mathrm{x})$ é determinado pela expressão: $s(x)=\int_{0}^{x} \sqrt{1+\left(f^{\prime}(t)\right)^{2}} d t$. 


\subsubsection{A "invenção" do Cálculo}

Newton (1642-1727) e G. W. Leibniz (1646-1716) são agraciados tradicionalmente por historiadores da matemática com os títulos de "inventores" do Cálculo Diferencial e Integral. A razão para que tenham recebido este título deve-se principalmente ao fato de que ambos desenvolveram procedimentos algorítmicos que deram origem posteriormente aos conceitos de derivada e integral, além, é claro, de usarem com regularidade o fato dessas operações serem inversas uma da outra para estabelecer os seus cálculos diferenciais e integrais ${ }^{104}$. No entanto, podemos assegurar que nenhuma "revolução" no pensamento matemático da época foi efetuada pelos dois cientistas, mas, que, muito pelo contrário, os seus trabalhos são uma contribuição relevante para os anseios da ciência normal da época - o que não tira, de modo algum, o mérito de suas obras.

Em verdade, não há quem mereça esse título - o de inventor do Cálculo Diferencial e Integral. Nem Newton, nem Leibniz, e muito menos qualquer outro matemático anterior ou posterior a esses dois grandes matemáticos. Nem mesmo Torricelli, Fermat e Barrow que anteciparam muitos procedimentos e resultados do Cálculo, ou mesmo Cauchy, que foi o primeiro a tornar efetivamente os conceitos de derivada e de integral conceitos básicos do Cálculo, fundamentando estes apenas no conceito de limite e de número real, mereceriam tal título. O Cálculo Diferencial e Integral foi uma construção coletiva em

\footnotetext{
104 Newton, por exemplo, interpretou freqüentemente a tarefa de integrar como sendo o ato de encontrar uma expressão (curva) cuja derivada (tangente) era a curva dada.
} 
que cada um deles deu sua valiosa contribuição, sendo Newton e Leibniz, certamente, uns de seus maiores contribuidores. Baron \& Bos (1985, v.3, p.5), ratificando esse ponto de vista, acrescentam que:

Ainda que o Cálculo não tenha nem começado e nem terminado com estes dois homens [Newton e Leibniz], cabe a eles um grande mérito. Newton estendeu e unificou os vários processos de cálculo e Leibniz ligou-os através de uma notação eficaz e de um novo cálculo operacional.

Uma outra simplificação da história do Cálculo, motivada inclusive pelas especificidades das teorias desenvolvidas por Newton e por Leibniz, nos é revelada por Boyer em (1949, p.188). Conforme nos revela o historiador, existe uma tendência em identificar no desenvolvimento do Cálculo dois tipos de percurso: o percurso cinemático, que começaria com Platão e Arquimedes, passaria por Galileu, Cavalieri e Barrow, e culminaria com Newton; e o percurso atomístico, que começaria com Demócrito, passaria por Kepler, Fermat, Pascal e Huygens, e atingiria o seu auge com Leibniz. Convém ressaltar entretanto que Galileu, Cavalieri e Barrow usavam tanto considerações cinemáticas quanto infinitesimais, além do que os trabalhos de Fermat, Pascal e Huygens também eram bastante familiares a Newton ${ }^{105}$. Assim, ao invés de procurarmos enquadrar (de forma reduzida) os pensamentos dos matemáticos anteriores nas interpretações e encaminhamentos dados por Newton e Leibniz para as questões do Cálculo, talvez fosse mais interessante enumerar e confrontar as características próprias de cada uma dessas preciosas obras. Comecemos por Newton, o "gigante dos gigantes" 106.

\footnotetext{
${ }^{105}$ Conferir em (Boyer, 1949, p.188-89).

106 Newton, humildemente, observou que se "conseguiu ver tão longe era porque estava sobre ombros de gigantes". Esqueceu de mencionar, no entanto, que se ele próprio não fosse um dos gigantes, isto é, "o gigante dos gigantes", não conseguiria ver tão longe.
} 


\section{O Cálculo de Newton}

Estudante da Universidade de Cambridge e aluno, em particular, de Barrow, Newton teve sua iniciação ao cálculo infinitesimal orientada por este último. Através dos ensinamentos de seu mestre teve acesso aos trabalhos de Cavalieri e aos dois tipos de indivisíveis. Segundo citações do próprio Newton, os textos que contribuíram para a sua iniciação no Cálculo foram:

- Schooten, F. van. Exercitationes mathematicae, Leyden, 1657 - (continha - Miscellanae, livro que lhe despertou um interesse especial)

- Descartes, R. Renati Descartes Geometria, editio secunda, Amsterdam, 1659 - (edição comentada e publicada por Schooten em 1659)

- Oughtred, w. Arithmeticae in numeris et speciebus institutio, Londres, 1631 - (tratado elementar sobre a aritmética e a álgebra; considerado a "chave" da matemática).

- Wallis, J. Arithmetica infinitorum, Oxford, 1656.

A partir da leitura da edição comentada do Geometria, de Descartes, Newton pôde assimilar uma discussão completa dos métodos das tangentes, as regras de Hudde, o método de Huygens para encontrar um ponto de inflexão, a retificação da parábola semicúbica segundo Heuraet e a notação de Descartes (Baron $\&$ Bos,1985, v.3, p.12).

No entanto, os recentes métodos analíticos desenvolvidos por Fermat e por Descartes também chegaram até Newton pelo trabalho Arithmetica infinitorum, de outro matemático britânico: John Wallis. O próprio Newton reconheceu publicamente que este texto serviu como fonte de inspiração para suas primeiras descobertas do cálculo 
fluxional. Segundo Boyer (1949, p.190), os princípios de indução e interpolação que Wallis empregou podem ter influenciado e levado Newton à descoberta do seu famoso teorema binomial, além, é claro, da apresentação de um problema clássico inacabado - a quadratura do círculo pela expansão de $\sqrt{1-x^{2}}$ em séries - que ele resolveria posteriormente e motivaria a construção de um dos pilares do seu cálculo integral: as séries. Baron \& Bos (1985, v.3, p.12) observam, além disso, que um relato completo do problema de quadratura foi assimilado por Newton através desta obra.

Outro fato notável da influência dos trabalhos de Wallis no pensamento de Newton diz respeito à própria concepção de número. Newton, assim como Wallis, e de modo diferente de Barrow, considerava o conceito de número como uma coleção de unidades. Tal interpretação numérica irá estimular a introdução e o desenvolvimento das séries infinitas como uma ferramenta auxiliar do seu cálculo infinitesimal. Assim, considerando que as bases do Cálculo de Newton são o seu método fluxional e o seu estudo das séries infinitas, pode-se notar que Wallis era certamente um dos gigantes aos quais o grande "inventor" do Cálculo se referiu em sua célebre frase em que afirmava que se conseguiu ver tão longe, era porque "estava sobre ombros de gigantes".

Sem nos alongarmos mais nas observações preliminares sobre os primeiros estudos de Newton sobre o Cálculo, vamos recorrer a um "fluxograma", esboçado por Whiteside, para apresentar de forma resumida as fontes através das quais Newton elaborou suas idéias iniciais: 


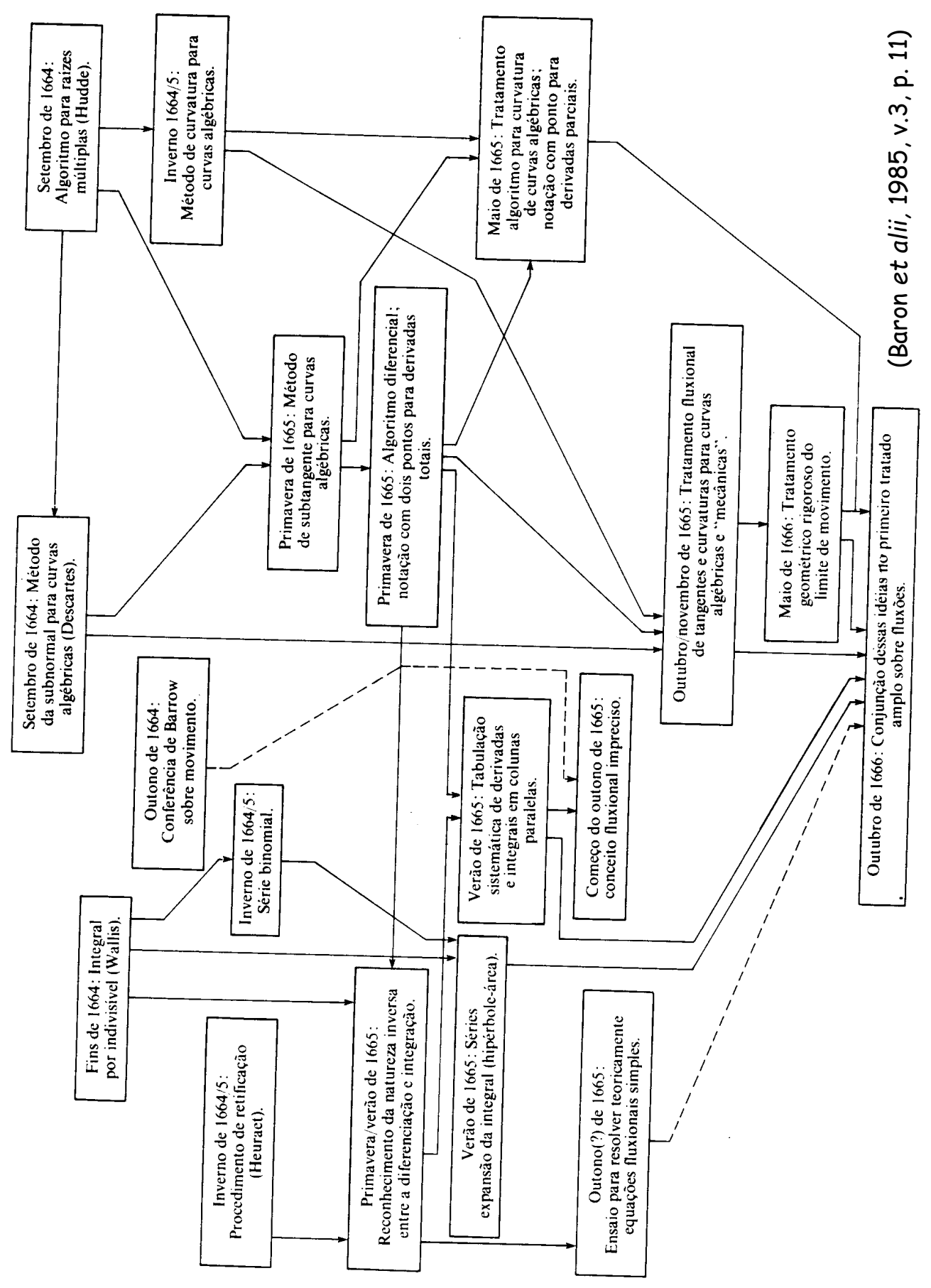


Os trabalhos de Newton sobre cálculo infinitesimal foram escritos de 1665 a 1676, mas nenhum deles foi publicado neste período. Segundo Boyer (1949, p.202), a razão para esse atraso talvez tenha sido a insatisfação pessoal de Newton com a fundamentação lógica de suas descobertas. Entre seus valiosos trabalhos podemos destacar: De analysi per aequationes numero terminorum infinitas (elaborado em 1669 e publicado em 1711) - o primeiro anúncio público do seu Cálculo: Methodus fluxionum et serierum infinitarum (escrito em 1671 e publicado em 1736) - sua segunda e mais extensa exposição do Cálculo; De quadratura curvarum (escrito em 1676 e publicado em 1704); Principia mathematica philosophiae naturalis (publicado em 1687) - a primeira publicação do seu Cálculo ${ }^{107}$.

Além desta confusão na ordem das publicações dos trabalhos de Newton (seu segundo trabalho sobre o Cálculo, por exemplo, foi o último, dos quatro destacados, a ser publicado), as idéias básicas perpassadas pelos seus trabalhos se modificam. O próprio Newton ofereceu, no Principia, três modos de interpretação de sua nova análise: uma em termos de infinitesimal (de modo semelhante ao modo como foi desenvolvido o seu primeiro trabalho De analysi); outra em termos de primeira e última razão, usando a idéia primitiva de limite (assim como foi feito no seu trabalho De quadratura curvarum); e uma terceira, em termos de fluxões (tal e como foi concebido o seu Methodus fluxionum et serierum infinitarum).

No seu trabalho inicial De analysi per aequationes numero terminorum infinitas, Newton não fazia uso ainda da idéia e notação

\footnotetext{
${ }^{107}$ Apesar do De analysi per aequationes numero terminorum infinitas ter sido elaborado e divulgado por Newton para o seu ciclo de amigos em 1669, sua publicação (em 1711) é posterior
} 
fluxionais. O seu conceito fundamental é o infinitamente pequeno tal como aparece nos trabalhos de Barrow e de Fermat. Newton, assim como os matemáticos posteriores a Torricelli, já tinha conhecimento do Teorema Fundamental do Cálculo e, portanto, soube usar de forma original tal resultado para calcular integrais, isto é: para determinar a quadratura de uma curva $y=y(x)$ era suficiente encontrar uma curva $z=z(x)$ de tal modo que a expressão de sua tangente fosse a curva original $y=y(x){ }^{108}$. É por esta razão, aliás, que alguns livros clássicos de Cálculo denominam o conceito de integral indefinida (ou antiderivada) por integral de Newton. Newton usou tal método para determinar a quadratura de inúmeras curvas tais como $y=x^{2}+x^{3 / 2} e$ $y=\frac{a^{2}}{b+x}$. Vejamos segundo as próprias palavras de Newton publicadas no De analysi - como o grande matemático usava tal resultado no cálculo de suas quadraturas:

SOBRE A ANÁLISE DE EQUAÇÕES

COM NÚMERO ILIMITADO DE TERMOS

O método que inventei há algum tempo atrás para medir a quantidade de curvas por uma série infinita de termos será apresentado a seguir com explicações concisas sem demonstrações profundas.

$A$ base $A B$ de uma curva $A D$ é perpendicular à ordenada $B D$. Chame $A B$ de $\times$ e $B D$ de $y$. Sejam ainda $a, b, c, \ldots$ quantidades dadas e sejam $m$ e $n$ inteiros [veja figura 30 a seguir]. Então

Regra 1: Se $a x^{m / n}=y$, então $[n a /(n+m)] x^{(m+n) / n}$ será igual à área $A B D$.

(...)

Regra 2: Caso o valor seja composto de vários termos daquela espécie, a área também será composta das áreas que resultam de cada um dos termos separadamente.

(apud Baron \& Bos, 1985, v.3, p.19-20)

ao do Principia mathematica philosophiae naturalis (1687).

${ }^{108}$ Determinar $\int y(x) d x$ significa encontrar $\mathrm{z}=\mathrm{z}(\mathrm{x})$ de tal modo que $\frac{d z}{d x}=y$ 
De forma didática, Newton resolve, posteriormente a cada regra, alguns exemplos para poder explicá-las. Só algumas páginas depois é que exibe uma demonstração para tais regras. A segunda regra é uma das propriedades básicas de integração (a "integral da soma de funções é a soma das integrais de cada função"), a primeira é aquela que explicita o que foi dito nos parágrafos anteriores: o teorema fundamental como instrumento de integração. Ao fazer sua demonstração, Newton a faz inicialmente para o caso particular de $x^{1 / 2}$ $=y$, para que se possa assimilar bem a estrutura de demonstração do caso geral. Apresentaremos diretamente o caso geral:

Preparação para demonstrar a primeira regra. $A$ quadratura de curvas simples segundo a regra 1. Seja então $A D \delta$ uma curva qualquer que tem a base $A B=x$, a ordenada perpendicular $B D=y$ e a área $A B D=z$, como antes. Simultaneamente seja $B \beta=0, B K=v$ e seja o retângulo $B \beta H K($ ov) igual ao espaço $B \beta \delta D$. Portanto, $A \beta=x+0$ e $A \delta \beta=z+0 v$. Com essas premissas procuro $y_{1}$ a partir de um relacionamento arbitrário entre $x$ e $z$ da seguinte maneira.

[segue o caso particular...]

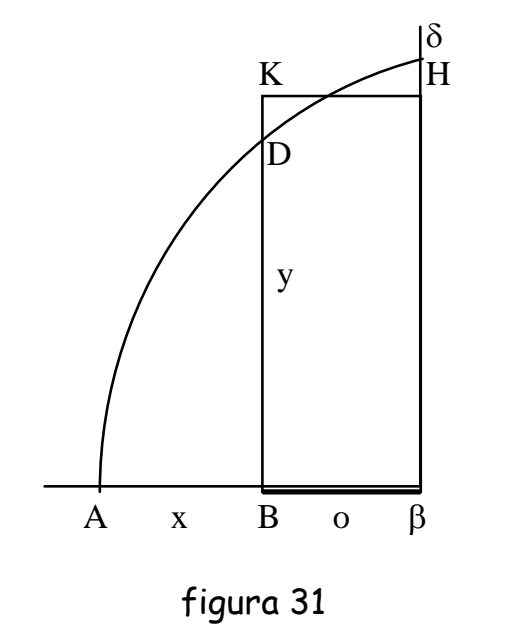

Ou em geral, se $[n /(m+n)] a x^{(m+n) / n}=z$, quer dizer, ao colocar $[n a /(m+n)]=c$ e $[m+n]=p$, se $c x^{p / n}=z$ ou $c^{n} x^{p}=z^{n}$, então, se $x+0$ for substituído no lugar de $x$ e z+ov (ou equivalentemente, $z+o u)$ for substituído no lugar de $z$, surgirá

$$
c^{n}\left(x^{p}+p o x^{p-1}+\ldots\right)=z^{n}+n o y z^{n-1}+\ldots,
$$

omitindo-se os outros termos, os quais foram desprezados, para sermos exatos. Agora eliminando-se os termos iguais $c^{n} x^{p} e z^{n} e$ dividindo-se 0 resto por 0 , vai sobrar $c^{n} p x^{p-1}=$ $n y z^{n-1}\left(=n y z^{n} / z\right)=n y c^{n} x^{p} / c x^{p / n}$. Quer dizer, ao dividir por $c^{n} x^{p}$, obtemos $p x^{-1}=n y / c x^{p / n}$ ou $p c x^{(p-}$ ${ }^{n) / n}=n y$; em outras palavras, pela restauração de $[n a /(m+n)]$ para $c e[m+n]$ para $p$, quer dizer, $m$ para $p-n$ e na para $p c$, teremos $a x^{m / n}=y$, então $[n /(m+n)] a x^{(m+n) / n}=z$. Como queríamos demonstrar.

(apud Baron \& Bos, 1985, v.3, p.23-24) 
A preocupação inicial de Newton ao desenvolver o seu método infinitesimal era muito mais facilitar a realização das operações do Cálculo do que clarificar as concepções das idéias básicas aí utilizadas. Em sua demonstração da área de $y=a x^{m / n}$ - confira o enunciado e a demonstração do resultado exposto nos parágrafos anteriores Newton interpreta a variável y como sendo a velocidade de crescimento de área ( $x$ é o tempo e $z$, a soma dos y's, a área procurada), isto é, como uma taxa de variação instantânea, mas não explica o significado de tal taxa, muito pelo contrário, considera que qualquer tentativa de definir tais "movimentos instantâneos" é tarefa da metafísica, da filosofia. Tal afirmação é no mínimo curiosa, uma vez que veio daquele que é considerado hoje um dos "inventores" do Cálculo Diferencial e Integral e fundadores da Física Clássica. Newton não define os "movimentos instantâneos" mas faz uso destes assim como o fizeram Nicolau de Oresme, Galileu e Descartes:

"Agora o produto da ordenada por um pequeno intervalo de base dará uma pequena porção de área, e a área total sob a curva é apenas a soma de todos estes momentos de área".

(De analysi, apud Boyer, 1949, p.195)

Numa carta enviada a Collins (em 10/12/1672), Newton revela ao seu amigo a fonte de inspiração para criação do seu método: os trabalhos de Fermat e de Gregory. Com efeito, o intervalo de tempo infinitesimal " 0 ", de Newton, além de ser efetivamente a mesma quantidade infinitamente pequena "o" de Gregory, é funcionalmente 
equivalente ao incremento infinitamente pequeno " $E$ " que Fermat usava em seus métodos infinitesimais ${ }^{109}$.

Apesar da confessa semelhança do seu método infinitesimal com os dos colegas matemáticos citados, duas características distinguem e garantem a originalidade do cálculo infinitesimal de Newton: o uso intenso do Teorema Fundamental do Cálculo como instrumento no cálculo de quadraturas (processo de integração); e o uso das séries infinitas como um algoritmo universal para estender a família de funções que se submetem ao seu método.

Neste seu trabalho, o De analysi, Newton concedeu um grande espaço ao "método das séries infinitas" e o seu uso na quadratura de curvas. Numa carta de Oldenburg (secretário da Sociedade Real de Londres) enviada a Leibniz (24 de outubro de 1676), Newton dá uma exposição das suas pesquisas na área das séries infinitas:

Ao iniciar os meus estudos matemáticos, tendo já conhecimento dos trabalhos do nosso célebre Wallis sobre a série por intercalação, cuja área do círculo e da hipérbole ele próprio enuncia, considerei o fato de que, na série de curvas cujo eixo ou base comum é $x$ e cujas ordenadas são $\left(1-x^{2}\right)^{0 / 2},\left(1-x^{2}\right)^{1 / 2},\left(1-x^{2}\right)^{2 / 2},(1-$ $\left.x^{2}\right)^{3 / 2},\left(1-x^{2}\right)^{4 / 2},\left(1-x^{2}\right)^{5 / 2}$ etc., se as áreas dos fatores intercalados, nominalmente $x, x-\frac{1}{3} x^{3}, x-\frac{2}{3} x^{3}+\frac{1}{5} x^{5}, x-\frac{3}{3} x^{3}+\frac{3}{5} x^{5}-\frac{1}{7} x^{7}$, etc., pudessem ser interpolados, deveríamos obter as áreas dos fatores intermediários das quais o primeiro $\left(1-x^{2}\right)$ é o círculo: de modo a interpolar essa série, notei que em todas elas o primeiro termo era $x$ e que os segundos termos $\frac{0}{3} x^{3}, \frac{1}{3} x^{3}, \frac{2}{3} x^{3}, \frac{3}{3} x^{3}$, etc. estavam numa progressão aritmética. Portanto, os primeiros dois termos das séries a serem intercaladas deveriam ser $x-\frac{1}{3}\left(\frac{1}{2} x^{3}\right), x-\frac{1}{3}\left(\frac{3}{2} x^{3}\right), x-\frac{1}{3}\left(\frac{5}{2} x^{3}\right)$, etc. Para intercalar 0 resto, comecei a refletir que os denominadores $1,3,5,7$, etc. estavam numa progressão aritmética de sorte que somente os coeficientes numéricos dos numeradores ainda necessitavam de uma investigação. Mas nas áreas dadas alternadamente, essas eram as potências do número 11 , a saber $11^{0}, 11^{1}, 11^{2}, 11^{3}$, $11^{4}$, quer dizer, primeiro 1, depois 1, 1; em terceiro 1, 2, 1; em quarto 1, 3, 3, 1; em

109 Ainda na mesma carta, Newton reconhece que o seu método é análogo às regras de diferenciação de Sluze e de Hudde, porém observa que o seu procedimento é mais geral que os dos dois matemáticos, que só consideravam funções algébricas racionais - assim como fizera Fermat. 
quinto 1, 4, 6, 4, 1, etc. Assim, comecei investigando com as figuras restantes nessas séries poderiam ser deduzidas das primeiras duas figuras dadas e achei que, colocando-se $m$ para a segunda figura, o resto seria produzido por multiplicação repetida dos termos dessa série,

$$
\frac{m-0}{1} \times \frac{m-1}{2} \times \frac{m-2}{3} \times \frac{m-3}{4} \times \frac{m-4}{5} \text {, etc. }
$$

Por exemplo, seja $m=4$ então $4 x(m-1) / 2$, igual a 6, será o terceiro termo; $6 \times(m-$ 2)/3, igual a 4, o quarto; $4 x(m-3) / 4$, igual a 1 , o quinto e $1 x(m-4) 5$, igual a 0,0 sexto termo, no qual a série termina. Em consequiência disso, apliquei esta regra para interpor série entre séries. Já que para o círculo o segundo termo era $\frac{1}{3}\left(\frac{1}{2} x^{3}\right)$, coloquei $m=1 / 2$ e surgiram os termos

$$
\frac{1}{2} x \frac{\frac{1}{2}-1}{2} \text { ou }-\frac{1}{8},-\frac{1}{8} x \frac{\frac{1}{2}-2}{3} \text { ou }+\frac{1}{16}, \frac{1}{16} x \frac{\frac{1}{2}-3}{4} \text { ou }-\frac{5}{128},
$$

e assim por diante ad infinitum. Daí cheguei a compreender que a área do segmento circular que queria era

$$
x-\frac{\frac{1}{2} x^{3}}{3}-\frac{\frac{1}{8} x^{5}}{5}-\frac{\frac{1}{16} x^{7}}{7}-\frac{\frac{5}{128} x^{9}}{9}, \text { etc. }
$$

E pelo mesmo raciocínio, as áreas das curvas restantes que deveriam ser inseridas podem ser obtidas igualmente: assim também a área da hipérbole e das outras curvas alternadas na série

$$
\left(1+x^{2}\right)^{0 / 2},\left(1+x^{2}\right)^{1 / 2},\left(1+x^{2}\right)^{2 / 2},\left(1+x^{2}\right)^{3 / 2}, \text { etc. }
$$

(apud Baron \& Bos, 1985, v.3, p.14-15)

Após determinar a quadratura do círculo $\left(y=\left(1-x^{2}\right)^{1 / 2}\right)$ e da hipérbole $\left(y=\left(1+x^{2}\right)^{1 / 2}\right)$, e de suas respectivas famílias de curvas, Newton observa que o método que gerou serve para "integrar" outros tipos de séries. Mais ainda, o matemático percebe, embutido no seu método de séries, o resultado que conhecemos hoje como o Teorema Binomial. Vejamos como Newton chega a este resultado na continuação do seu texto citado no parágrafo anterior:

A mesma teoria serve para intercalar outras séries por intervalos de dois ou mais termos, quando estiverem ausentes ao mesmo tempo. Essa foi a minha primeira nota sobre esses estudos. Teria certamente escapado da minha memória se não tivesse lançado um olhar retrospectivo a algumas anotações.

Mas quando examinei isso, comecei a perceber imediatamente que os termos

quer dizer,

$$
\left(1-x^{2}\right)^{0 / 2},\left(1-x^{2}\right)^{2 / 2},\left(1-x^{2}\right)^{4 / 2},\left(1-x^{2}\right)^{6 / 2} \text { etc. }
$$

$$
1,1-x^{2}, 1-2 x^{2}+x^{4}, 1-3 x^{2}+3 x^{4}-x^{6}, \text { etc. }
$$


poderiam ser interpoladas do mesmo modo como as áreas geradas por eles: e que nada foi requerido para essa finalidade a não ser a omissão dos denominadores 1 , $3,5,7$, etc., que estão nos termos que expressam as áreas; isto significa que os coeficientes dos termos da quantidade a ser intercalada, a saber, $\left(1-x^{2}\right)^{1 / 2}$, ou $\left(1-x^{2}\right)^{3 / 2}$, ou em geral $\left(1-x^{2}\right)^{m}$, surgem pela multiplicação repetida dos termos dessa série

$$
m \times \frac{m-1}{2} \times \frac{m-2}{3} \times \frac{m-3}{4} \times \frac{m-4}{5}, \text { etc., }
$$

tal que (por exemplo)

$$
\begin{gathered}
\left(1-x^{2}\right)^{1 / 2} \text { é o valor de } 1-\frac{1}{2} x^{2}-\frac{1}{8} x^{4}-\frac{1}{16} x^{6}, \text { etc., } \\
\left(1-x^{2}\right)^{3 / 2} \text { o de } 1-\frac{3}{2} x^{2}-\frac{3}{8} x^{4}-\frac{1}{16} x^{6}, \text { etc. }
\end{gathered}
$$

$e$

$$
\left(1-x^{2}\right)^{1 / 3} \text { o de } 1-\frac{1}{3} x^{2}-\frac{1}{9} x^{4}-\frac{5}{81} x^{6}, \text { etc. }
$$

Assim, a redução geral de radicais a séries infinitas, através da regra que expus no começo da minha carta anterior, chegou ao meu conhecimento antes que eu tivesse estado familiarizado com a extração de raízes. Mas uma vez conhecido isso, o outro não podia ficar oculto de mim por muito tempo.

(apud Baron \& Bos, 1985, v.3, p.15)

Não satisfeito com sua demonstração, Newton termina a carta "tirando a prova real" do seu resultado:

Pois para testar esses processos, multipliquei

$$
1-\frac{1}{2} x^{2}-\frac{1}{8} x^{4}-\frac{1}{16} x^{6}, \text { etc., }
$$

duas vezes por si mesmo; tornou-se 1- $x^{2}$ também. Com isso não obtive apenas a demonstração segura dessas conclusões, fui conduzido também a verificar se, reciprocamente, as séries assim formadas, que representavam as raízes da quantidade $1-x^{2}$, não poderiam ser extraídas dela aritmeticamente. E deu certo. Era essa forma de trabalhar com raízes quadradas.

$$
\begin{aligned}
& \frac{1-x^{2}\left(1-\frac{1}{2} x^{2}-\frac{1}{8} x^{4}-\frac{1}{16} x^{6}, \text { etc. }\right)}{\frac{1}{0-x^{2}}} \\
& \frac{-x^{2}+\frac{1}{4} x^{4}}{-\frac{1}{4} x^{4}} \\
& \frac{-\frac{1}{4} x^{4}+\frac{1}{8} x^{6}+\frac{1}{64} x^{8}}{0-\frac{1}{8} x^{6}-\frac{1}{64} x^{8}}
\end{aligned}
$$


Depois de ter esclarecido isso, abandonei totalmente a interpolação de séries e usava somente essas operações, pois davam fundamentações mais naturais. Tampouco existia um segredo qualquer acerca da redução pela divisão que, em todo caso, é um assunto mais fácil.

(apud Baron \& Bos, 1985, v.3, p.15-16)

Mesmo antes de escrever o De Analysi, Newton já havia experimentado outros tipos de demonstrações e notações. Mas foi, sem dúvida, a publicação do seu Methodus fluxionum et serierum infinitorum, em 1671, o marco de uma nova fase do seu pensamento sobre o Cálculo. Newton identifica aqui o que ele considera como os dois problemas básicos do seu Cálculo Diferencial e Integral:

Falta agora, como ilustração dessa arte analítica, explicitarmos alguns problemas típicos e tão especiais como a natureza de curvas que os representam. Mas sobretudo eu observaria que as dificuldades dessa espécie podem ser todas reduzidas a somente dois problemas que proporei com vista ao espaço percorrido por qualquer movimento local acelerado ou retardado:

1. Dado o comprimento do espaço percorrido continuamente (quer dizer, em cada [instante do] tempo), ache a velocidade do movimento num instante qualquer. 2. Dada continuamente a velocidade do movimento, ache o comprimento do espaço percorrido num instante qualquer.

(apud Baron \& Bos, 1985, v.3, p.26-27)

O Methodus fluxionum representa uma transformação substancial em sua concepção de infinitesimal: nele, Newton abandona a forma estática de Cavalieri em prol da interpretação dinâmica de Galileu e Hobbes.

Segundo Newton, esta mudança no seu procedimento infinitesimal serve apenas para remover a "aspereza" da doutrina dos indivisíveis. Assim, nesse seu segundo trabalho sobre o Cálculo, Newton, influenciado pelos trabalhos dos escolásticos, de Galileu, de Torricelli e de Barrow, assume a noção de velocidade como elemento 
fundamental do seu cálculo fluxional: uma quantidade variável se constitui, portanto, através do movimento contínuo de pontos, linhas e planos, e não como uma coleção de elementos infinitesimais. Newton considera "fluxão", tal como fizera Calculator, como a taxa de geração e "fluente" como a quantidade gerada. Vejamos essas idéias nas próprias palavras de Newton transcritas do texto citado acima:

Assim na equação $x^{2}=y$ se $y$ significa o comprimento do espaço percorrido num instante qualquer que é medido e representado por um segundo espaço $x$, que cresce com velocidade uniforme, então, $2 \times x$ designará a descrição da velocidade pela qual o espaço no mesmo momento de tempo está sendo percorrido. $E$, portanto, considerarei em seguida as quantidades como se fossem geradas por um aumento contínuo do espaço no qual um objeto se move descrevendo sua trajetória.

Não podemos ter, porém, uma estimativa do tempo, exceto no sentido de ser exposto e medido por um movimento local uniforme. Além disso, somente quantidades da mesma espécie $e$, do mesmo modo, as suas taxas de crescimento e decrescimento podem ser comparadas entre si. É por essas razões que no que se segue não considerarei o tempo como tal. Portanto, de uma das quantidades apresentadas que são da mesma espécie, suporei que elas aumentem num fluxo uniforme: a ela, e a todas as outras, podemos nos referir como se fosse o tempo. Assim, a palavra "tempo" não deve ser transferida erradamente a ela por simples analogia. Desta forma, se você encontrar em seguida a palavra "tempo" (como a tenho tratado no meu texto a fim de obter mais clareza e distinção) esse nome não deve ser entendido como tempo formalmente considerado, mas como sendo aquela outra quantidade cujo aumento ou fluxo uniforme interpreta e mede 0 tempo.

Mas, para distinguir as quantidades que considero perceptiveis, porém indefinidamente crescentes, das outras que em todo caso devem ser consideradas como conhecidas e determinadas e que são designadas pelas letras iniciais $a, b, c$, etc., chamarei as primeiras de fluentes e designá-las-ei pelas letras finais $v, x, y e$ z. As velocidades com as quais elas fluem e que aumentam pelo movimento gerador (que eu chamaria mais adequadamente de fluxões ou simplesmente de velocidade) designarei pelas letras ' $v, x, y$ e $z$; a saber para a velocidade da quantidade $v$ colocarei $v$ e para as velocidades das outras quantidades colocarei ' $x, y$ e $z$, respectivamente.

(apud Baron \& Bos, 1985, v.3, p.26-27) 
O matemático desenvolve ainda nesse trabalho algumas notações para os seus conceitos de diferenciação e integração:

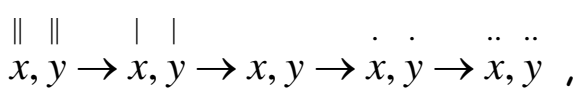

em que " $\rightarrow$ " determina o sentido da diferenciação, os pontos, conforme nos foi relatado no texto destacado acima, servem para indicar as fluxões (dois pontos significa uma fluxão de segunda ordem, isto é, a "velocidade de uma velocidade") e as barras para indicar as "integrais de Newton" (duas barras significa então a "integral de uma integral"). Vejamos então um exemplo de aplicação do seu cálculo fluxional para que possamos interpretá-lo de forma mais clara:

"Se o é um intervalo de tempo infinitamente pequeno, então $\dot{x} o$ e $\dot{y} o$ serão os incrementos infinitamente pequenos, ou momentos, das quantidades fluentes $x$ e $y$. Em $y=x n$ alguém então substitui $x$ por $x+\dot{x} o$ e y por $y+\dot{y} o$, expande como antes usando o teorema binomial, cancela os termos não contendo 0 , e divide tudo por o. Como, além disso, o foi assumido ser infinitamente pequeno, os termos contendo este - isto é, os momentos das quantidades - podem ser considerados como zero em comparação com os outros, e são para serem desprezados".

(apud Boyer, 1949, p.194)

Como se pode notar, Newton também fez uso das quantidades infinitesimais e de suas "propriedades" em seu método fluxional - o intervalo o era infinitamente pequeno. No entanto, o próprio Newton questiona, em um outro trabalho seu (o De quadratura), o processo de "desprezar" as quantidades infinitamente pequenas, argumentando em nome da "precisão" da matemática que "erros não são para serem desprezados em matemática" - não importando "quão pequeno seja" o seu valor (Boyer, 1949, p.201). Assim, com o seu "De quadratura", Newton inicia uma outra fase (a terceira) do seu pensamento sobre 0 Cálculo. 
Segundo Boyer (1949, p.195), no De quadratura, Newton teria removido todos os traços e vestígios do "infinitamente pequeno". Quantidades matemáticas não eram consideradas como constituídas de partes muito pequenas e de momentos, mas descritas pelo movimento contínuo:

A QUADRATURA DAS CURVAS,

Não considerarei aqui as quantidades matemáticas como sendo compostas de partes extremamente pequenas, mas como sendo geradas por um movimento contínuo. Linhas são descritas, e ao descrevê-las são geradas. Não por um alinhamento de partes, mas por um movimento contínuo de pontos. As superfícies são geradas pelo movimento contínuo de linhas, os sólidos pelo movimento de superfícies, os ângulos pela rotação dos seus lados, o tempo por

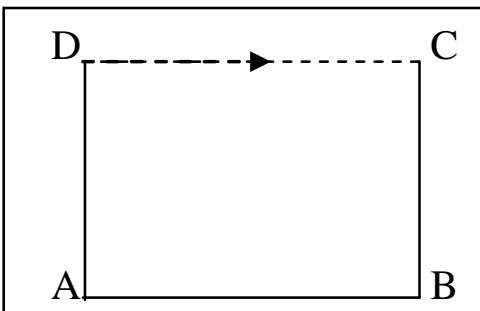

figura 32 um fluxo contínuo, etc.

Essa gênese está baseada na natureza e pode ser vista dia a dia no movimento dos corpos.

E desta maneira os antigos nos ensinaram a gerar retângulos justapondo-se linhas retas móveis ao longo de retas imóveis numa posição ou situação normal a elas.

(apud Baron \& Bos, 1985, v.3, p.31)

Em outro momento desse seu texto, Newton deixa clara a sua intenção de procurar evitar o uso de figuras infinitamente pequenas no seu novo método:

"Eu tenho procurado demonstrar que no método das fluxões não é necessário introduzir a geometria de figuras infinitamente pequenas"

(De quadratura, apud Boyer, 1949, p.202)

Assim como Stevin, Valério, Gregorie de St. Vicent, Tacquet e Wallis, Newton faz uso da idéia de limite (como um movimento 
contínuo) para justificar o seu cálculo infinitesimal 110, mais precisamente, o seu conceito de última razão:

"Últimas razões em que quantidades se anulam não são, estritamente falando, razões de quantidades últimas, mas limites para os quais as razões destas quantidades decrescem sem limite, aproximam, e que, embora eles possam ficar mais próximos do que qualquer diferença dada, seja o que for, eles não podem ultrapassar nem atingir antes que as quantidades diminuam indefinidamente".

(Principia, apud Boyer, 1949, p.198)

Assim, para calcular a última razão, Newton procedia de modo análogo ao que fizera no seu método fluxional, mas fazendo, entretanto, a seguinte alteração fundamental: a quantidade "o", antes um intervalo de tempo infinitamente pequeno, passava a ser um certo tipo de comprimento variável, isto é, um incremento $\Delta x$, inicialmente pequeno, mas "sempre" finito, e que irá se aproximar (continuamente) do número zero no final do seu procedimento. Tal modificação foi efetuada fazendo simplesmente $\dot{x}$ constante e igual à unidade ${ }^{111}$. Vejamos os passos do novo encaminhamento sugerido por Newton para o cálculo da última razão:

Suponhamos que a quantidade $x$ flua uniformemente. Encontre a fluxão de $x^{n}$. No mesmo intervalo de tempo em que a quantidade $x$ torna-se $x+o$ pelo fluxo, $a$ quantidade $x^{n}$ torna-se $x+o n\left[(x+0)^{n}\right]$, quer dizer, pelo método das séries infinitas $x^{n}+n o x^{n-1}+\frac{n n-n}{2} o_{0} x^{n-2}+, \ldots \quad e \quad$ os aumentos $0 e$ $n o x^{n-1}+\frac{n n-n}{2}$ oox $^{n-2}+, \ldots$ estão relacionado entre si como $1 e$ $n x^{n-1}+\frac{n n-n}{2} o x^{n-2}+, \ldots$ Agora faça aqueles aumentos desaparecerem e a sua última razão será de 1 a $n x^{n-1}$; portanto, a fluxão da quantidade $x$ está relacionada à fluxão da quantidade $x^{n}$ como 1 a $n x^{n-1}$.

(apudBaron \& Bos, 1985, v.3, p.34)

\footnotetext{
${ }^{110}$ Comparando com a noção de limite introduzida por Gregorie de St. Vicent no Cálculo, pode-se afirmar que a noção "terminus" deste último é análoga à idéia presente no conceito de "ultimate ratio" de Newton.
} 
Assim, o novo método fluxional pode ser sintetizado como segue:

- considera-se $y=y(x)$ (isto é, y como "função" de $x$ ) e o incremento inicial $\underline{0}$ de $x$;

- substitui-se $x$ por $x+0$ na expressão de $y(x)$ e subtrai-se, em seguida, este resultado pela própria expressão $y(x)$ para determinar a variação $\Delta y$ de $y$, motivada pela variação $\underline{o}$ de $x$;

- constrói-se a seguinte proporção: o está para $\Delta y$, assim como 1 está para $\Delta y / 0$;

- divide-se em seguida $\Delta y$ por $\underline{0}$, para encontrar o que se denominou por primeira razão:

- e, por último, faz-se o incremento o se aproximar continuamente de zero a fim de encontrar a última razão.

Tal procedimento se assemelha, a menos de certos desvios ${ }^{112}$, do conceito atual de derivada. Cabe ressaltar, entretanto, que, apesar de introduzir a noção de limite no conceito de derivada, Newton não pensava esta operação do ponto de vista aritmético. Trabalhava apenas com razão de comprimentos de quantidades geométricas. Segundo Boyer (1949, p.197), o matemático inglês nunca usou expressões dos tipos "últimos arcos", "últimas cordas", "últimos triângulos", "últimas tangentes", mas apenas última razão e última forma. No entanto, apesar de explicitar a idéia de limite, Newton abandonou esta abordagem do cálculo infinitesimal em função do uso dos infinitesimais. Tal fato pode ser justificado, em consonância com

\footnotetext{
${ }^{111}$ Note que se $x$ é igual a 1 , então o $=x \mathrm{o}=\Delta \mathrm{x}$.
} 
Boyer (1949, p.198), pela falta de uma clarificação aritmética da sua noção de limite e pelo caráter pragmático dos infinitesimais. Por outro lado, ninguém se aproximou mais da atual noção de derivada do que Newton.

A variabilidade de idéias presentes na obra de Newton, aliada à indefinição do próprio matemático em relação aos fundamentos dos conceitos básicos do seu cálculo infinitesimal, provocou certas distorções no emprego de seus conceitos básicos por seus seguidores. Segundo Boyer (1949, p.201), era muito comum entre os matemáticos da época interpretar as fluxões como quantidades infinitamente pequenas, equiparando-as inclusive com as diferenciais infinitamente pequenas de Leibniz.

No que tange ao conceito de integral, Newton usou, além do método das séries, o seu conhecimento sobre a relação inversa entre as duas operações básicas do Cálculo para desenvolver os seus cálculos integrais. Em essência, integrar, para Newton, era o mesmo que calcular a "antiderivada", isto é, a operação inversa de derivar ${ }^{113}$.

\footnotetext{
${ }^{112} \mathrm{Na}$ definição de derivada a razão encontra-se invertida (1: $\left.\Delta \mathrm{y} / \mathrm{o}\right)$; o tempo é considerado ainda como a variável independente universal, e o conceito de derivada é uma razão, e não propriamente um número.
} 


\section{O Cálculo de Leibniz}

Gottfried Wilhelm von Leibniz, "o mais versátil gênio do período" 114, foi, sobretudo, um autodidata. Doutor em direito, Leibniz interessou-se inicialmente por lógica e filosofia, áreas mais próximas à sua formação original. A aritmética e a mecânica foram os seus passos seguintes.

Incentivado por Huygens, Leibniz resolveu aprofundar os seus estudos em matemática. Numa viagem a Londres, em 1673, aprendeu muito sobre séries infinitas, comprou uma cópia do Lectures de Barrow e tomou conhecimento, através de Collins, do De Anaysi de Newton. Sua facilidade em assimilar as idéias matemáticas possibilitou-lhe estudar, ainda no ano de 1673, em Paris, os trabalhos matemáticos de Cavalieri, Torricelli, Gregorie de Saint Vicent, Roberval, Pascal, Descartes, Wren, Jean Gregory, Sluse, Hudde, e outros. Esses estudos representavam, na verdade, as primeiras leituras do matemático em geometria.

Seu primeiro trabalho publicado em matemática foi, no entanto, de análise combinatória. A partir de seus estudos iniciais sobre problemas de quadraturas, Leibniz publicou o seu Arithmetical tetragonism, que determinava a quadratura do círculo pela expressão 4. $\left(1-\frac{1}{3}+\frac{1}{5}-\frac{1}{7}+\ldots\right)$. Esta forte tendência para a aritmética foi, aliás, uma marca registrada dos trabalhos de Leibniz.

\footnotetext{
${ }^{113}$ É por esta razão inclusive que alguns livros de Cálculo fazem referência a antiderivada como "integral de Newton".

${ }^{114}$ Opinião expressa por Boyer (1949, p.202) e da qual também partilhamos. 
Leibniz percebeu que o problema de quadratura equivale a uma "soma de ordenadas eqüidistantes", ou retângulos infinitamente estreitos, para intervalos infinitesimais nas abscissas, e que a declividade da tangente dependia da razão das "diferenças consecutivas" das ordenadas e abscissas, quando estas se tornam infinitamente pequenas ${ }^{115}$. Assim, "se ela (a unidade diferencial "1") fosse escolhida infinitamente pequena, as aproximações (da área e do declive da tangente) tornar-se-iam exatas".

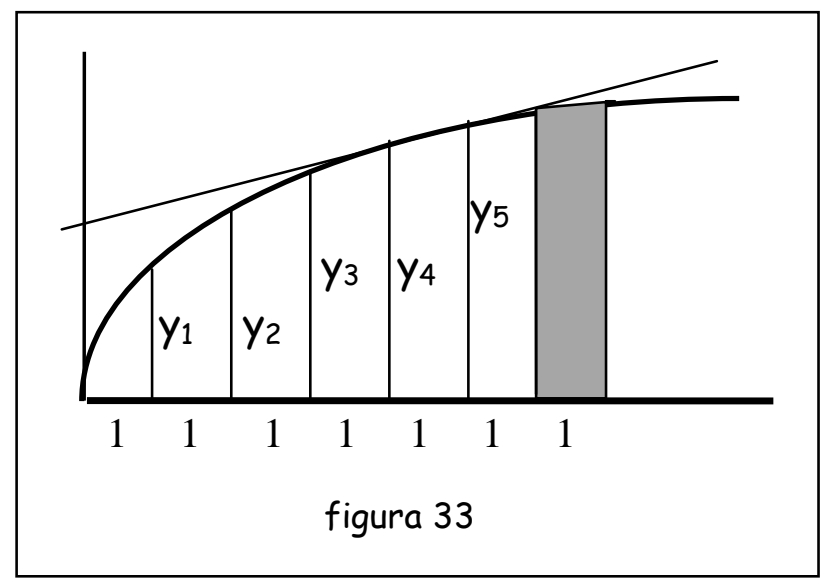

Assim, com outros matizes, Leibniz assume as "quantidades infinitamente pequenas" no seu conceito de "diferencial":

"a diferencial de uma variável y é a diferença infinitamente pequena entre dois valores consecutivos de $y^{\prime \prime}$

(Baron \& Bos, 1985, v.3, p.58)

Note que as diferenciais de Leibniz são quantidades infinitamente pequenas, mas, conforme afirma o próprio matemático, a razão entre elas (isto é, a derivada) é finita, e acrescenta que "para calculá-las devemos diferenciar a equação da curva e aplicar as regras

${ }^{115}$ Segundo o próprio Leibniz, o texto “Traité dês sinus du quart circle”, de Pascal, foi a grande 
do cálculo". E é a partir dessa noção de diferencial que Leibniz desenvolve o seu cálculo diferencial e integral.

No seu trabalho De geometria recôndita et analysi indivisibilium atque infinitorum ${ }^{116}$ - que foi efetivamente o primeiro tratado de Cálculo - Leibniz apresenta então um conjunto de "regras de cálculos para os símbolos", que constitui, em essência, as regras de diferenciação do seu cálculo diferencial e algumas aplicações a tangentes, problemas de máximo e mínimo e pontos de inflexão. No Acta eruditorum (1686), complementa o seu cálculo com técnicas relacionadas aos problemas de quadratura. Desenvolveu para este fim notações que são utilizadas até hoje em nossos cursos de Cálculo Diferencial e Integral ( $\left.d y, \frac{d y}{d x}, \int d x\right)^{117}$. Mas, o que significa "aplicar as regras do cálculo"? Para responder tal pergunta tomemos como exemplo as "regras de diferenciação" que o matemático desenvolveu.

Para começar, Leibniz observou que, como a razão das diferenciais é finita, então elas podem ser comparadas. Sugere então o seu postulado fundamental - e que se tornou a prática normal da época:

$$
x+d x=x
$$

Ou seja, as diferenciais podem ser comparadas entre si, mas, com respeito às quantidades finitas ordinárias, as diferenciais podem ser desprezadas. Era assim, desprezando as quantidades infinitesimais, que os matemáticos procediam, em geral, na etapa final de seus métodos infinitesimais.

\footnotetext{
fonte de inspiração para a sua concepção de derivada (Boyer, 1949, p.203).

${ }^{116}$ Publicado no “Acta eruditorum”, 1684, p. 292-300 (apud Boyer, 1949, p.208).

${ }^{117}$ Por esta razão, Cajori chamou Leibniz de "o construtor mestre das notações matemáticas".
} 
Leibniz observou ainda que o produto de diferenciais, ou diferenciais de segunda ordem, podiam ser desprezadas com respeito às próprias diferenciais. Assim:

$$
a d x+d y d x=a d x^{118}
$$

Feito isto, Leibniz enuncia as suas "regras do cálculo":

1. $d a=0$ se a é constante,

2. $d(u+v)=d u+d v$,

3. $d(u v)=u d v+v d u$,

4. $d(u / v)=(v d u-u d v) / v^{2}$,

5. $d\left(u^{n}\right)=n u^{n-1} d u$ (também se $n$ for uma fração ou negativo)

Para efeito de ilustração do pensamento diferencial de Leibniz, façamos uma demonstração da proposição 3 citada acima:

Dem.: Seja $z=u v ;$ logo $d z=d(u v)$ é o que queremos determinar.

Ora, ao provocarmos uma variação infinitesimal nas variáveis u e $v$, obteremos uma infinitesimal de $z$. Assim:

$z+d z=(u+d u)(v+d v)=u v+u d v+v d u+d u d v$.

Como $z=u v$, temos que:

$d z=u d v+v d u+d u d v$.

Note que $d z$, udv e vdu são todas quantidades infinitesimais de primeira ordem, menos dudv, que é um infinitésimo de segunda ordem e, portanto, pode ser desprezada em relação às demais. Isto posto, temos que:

$d(u v)=d z=u d v+v d u-$ como queríamos demonstrar. 
Assim como essa proposição, todas as demais regras de diferenciação de Leibniz são decorrentes apenas do seu postulado fundamental. Uma vez assumido o seu postulado fundamental, todo o resto é demonstrado de modo rigoroso. O maior obstáculo para Leibniz foi, sem dúvida, encontrar uma definição precisa do seu conceito de diferencial. O matemático sabia que a sua definição de diferencial em termos de quantidades infinitamente pequenas deixava o seu Cálculo um tanto quanto vulnerável. Assim, em seu artigo de 1684, Leibniz, tentanto dar mais rigor à definição deste conceito, define-o a partir de outra noção fundamental do seu Cálculo: o triângulo característico ${ }^{119}$. Vejamos então como o matemático tentou resolver tal questão.
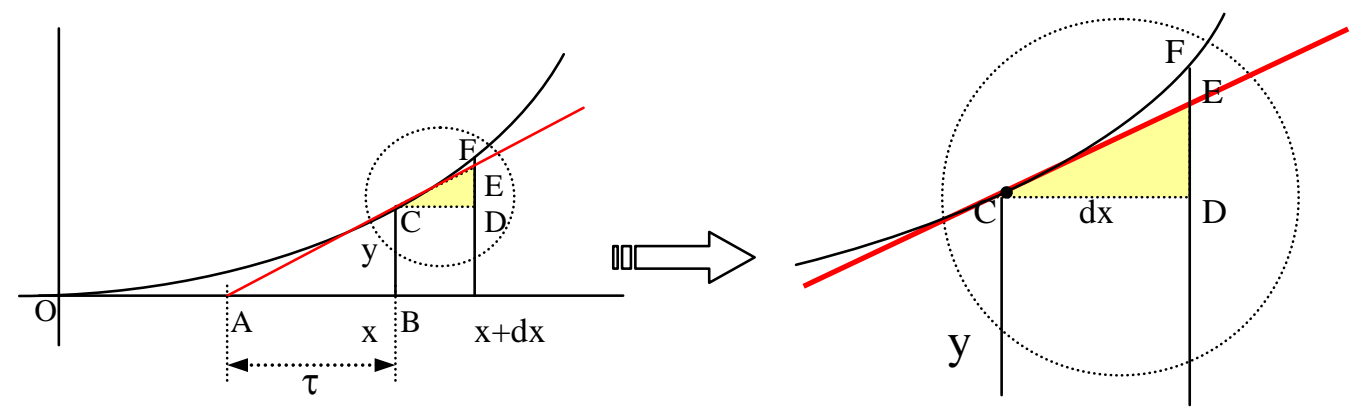

figura 34

Seja AE a tangente à curva OCE em $C$ conforme ilustra a figura acima. Considere $C D$ um segmento de comprimento arbitrário $\mathrm{dx}$. $O$ triângulo retângulo CDE é o "triângulo característico" relativo ao segmento dx. Assim, a partir da semelhança dos triângulos $A B C$ e $C D E$, Leibniz definiu a diferencial dy como sendo o segmento de reta DE que satisfaz a relação

\footnotetext{
${ }^{118}$ Tal resultado é conseqüência imediata do postulado fundamental. Com efeito, como a $+\mathrm{dy}=\mathrm{a}$, temos que $(\operatorname{adx}+d y d x)=(a+d y) d x=(a) d x$.
} 
$d y: d x=y: \tau$,

isto é: $d y=\frac{y}{\tau} d x$, em que y é a ordenada e $\tau$ é a subtangente ${ }^{120}$.

O matemático observou que, ainda que o valor de $\mathrm{d} x$ fosse infinitamente pequeno (e, por conseguinte, dy também), a razão $\frac{y}{\tau}=\frac{d y}{d x}$, que determina a inclinação da reta tangente, permaneceria constante. Tal razão corresponde ao conceito de derivada de Leibniz. Assim, a operação de derivar equivalia a determinar a razão entre as diferenciais.

Para denotar as novas diferenciais, Leibniz manteve o termo differentia (diferença), mas, não há como negar que o significado destas se modificou. De fato: na sua primeira versão do conceito de diferencial, esta corresponderia ao segmento DF, ao invés de DE, conforme nos mostra a figura anterior. A diferença entre estes segmentos, ainda que não nula, será desprezada posteriormente por Leibniz, que retornará a sua versão original. Do ponto de vista operacional, a primeira versão era muito mais aplicável que esta última - razão suficiente para fazer o matemático alemão desistir de vez da tentativa de justificar o uso das quantidades infinitamente pequenas "ao modo dos antigos". Leibniz assume de vez as quantidades infinitamente pequenas em seu Cálculo e afirma que este era para ser comparado com o "método de Arquimedes" 121 do mesmo modo que os trabalhos de Viète e Descartes tinham sido comparados com a

\footnotetext{
${ }^{119}$ Tal triângulo já havia aparecido nos trabalhos de Pascal.

${ }^{120}$ Define-se subtangente como sendo a projeção ortogonal do segmento de reta (parte da reta tangente), compreendido entre o ponto de tangência com a curva e o ponto de interseção com o eixo das abscissas, no eixo das abscissas.

${ }^{121}$ Leibniz está se referindo aqui ao método de exaustão desenvolvido por Arquimedes, e não, obviamente, aos métodos infinitesimais desenvolvidos no Método do matemático grego.
} 
geometria de Euclides. Segundo Boyer (1949, p.209), Leibniz foi menos enfático do que Newton nas justificações lógico-filosóficas dos seus procedimentos infinitesimais:

Ele [Leibniz] não fez realmente um esforço sério neste ponto, porque ele sentia que o Cálculo, como um modus operandi, trazia suas demonstrações com ele. Ele não desejava fazer do infinitamente pequeno um mistério (como fez Pascal); nem recorrer à intuição geométrica para clarificar; ele se prendeu muito mais à natureza algorítmica do método - por esta razão ele pode ser considerado como um dos fundadores do formalismo (como oposição ao intuicionismo) na matemática.

Leibniz também considerou as diferenciais de ordem superior. Definiu diferencial de ordem dois (ou de segunda ordem) como a "diferencial da diferencial de primeira ordem", a de ordem três como a "diferencial da diferencial de segunda ordem", e assim sucessivamente. Estendeu o seu postulado fundamental $\left(d^{(n)} x+d^{(n+1)} x=d^{(n)} x\right)$ a fim de poder comparar as diferencias de ordem superior.

No que tange ao conceito de integral, Leibniz recebeu forte influência dos trabalhos de Cavalieri no seu estudo inicial sobre problemas de quadraturas. Assim como Cavalieri, Leibniz escrevia "omn. $\ell$ " (abreviação de omnes $\ell$, "todos os $\ell$ ") para indicar a área de uma curva cujas ordenadas são $\ell$. Mais adiante, por sugestão dos irmãos Bernoulli, Leibniz adotará o símbolo que permanece até hoje como a notação universal da operação de integração: $\int y d x$. Esta mudança não representa apenas uma permuta de notação, mas de conceitos também. A "área da curva $y(x)$ " - isto é, a integral $\int y d x$ não é mais a soma das ordenadas, mas a soma de retângulos infinitamente pequenos $y . d x$. Leibniz, entretanto, não indica os extremos de integração, uma vez que os considera sempre como sendo a origem do sistema de coordenadas e a "última" abscissa " $x$ ". 


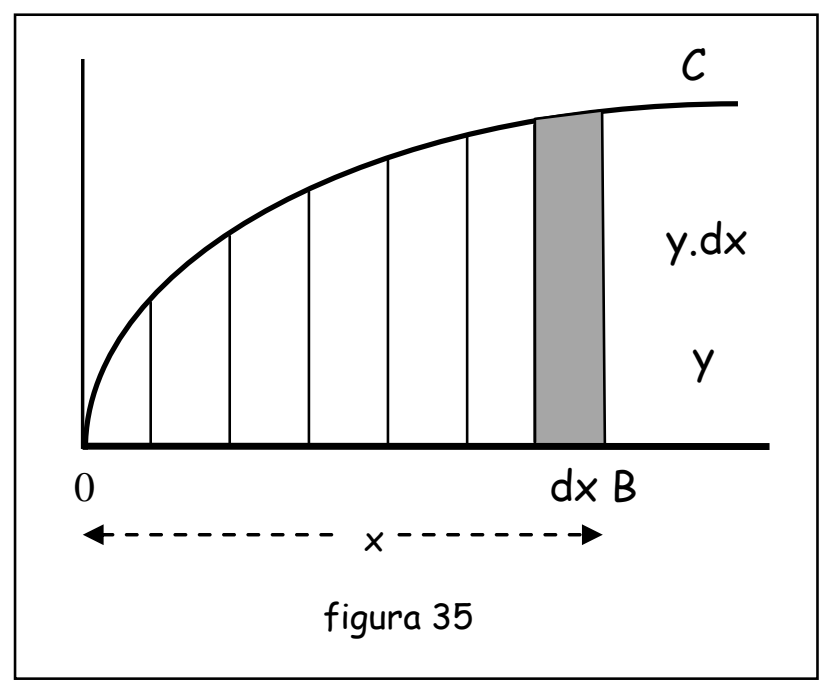

Leibniz percebeu ainda que as determinações de áreas e de tangentes também são operações inversas. Observou o matemático que "a diferença infinitamente pequena entre dois valores consecutivos da área $O C B$ é o último retângulo $y . d x "$ - figura 35 -; o que simbolicamente representou por: $d \int y d x=y d x$. Quanto ao "outro sentido" da relação inversa, Leibniz observou que este é consequiência imediata de sua definição de integral; assim, a soma de todos os dy's dará o próprio y - o que representou por $\int d y=y$.

Antes de prosseguirmos em nossa revisão histórica, seria interessante que fizéssemos uma pequena síntese comparativa dessas duas grandes criações da matemática: o Cálculo de Newton e o Cálculo de Leibniz. 


\begin{tabular}{|c|c|}
\hline Cálculo de Newton & Cálculo de Leibniz \\
\hline $\begin{array}{l}\text { As variáveis dependem do tempo } \\
\text { ("quantidades fluentes" é um conceito } \\
\text { cinemático). }\end{array}$ & $\begin{array}{l}\text { As variáveis "percorrem" sequiências de } \\
\text { valores "consecutivos" infinitamente } \\
\text { próximas. }\end{array}$ \\
\hline $\begin{array}{l}\text { É fundamentado no conceito cinemático } \\
\text { de fluxão (velocidade). }\end{array}$ & É fundamentado na noção de diferencial. \\
\hline $\begin{array}{l}\text { A operação de integração, para Newton, } \\
\text { se resume simplesmente à "tarefa de } \\
\text { determinar as quantidades fluentes para } \\
\text { as fluxões dadas". }\end{array}$ & $\begin{array}{l}\text { A operação de integração é, por } \\
\text { definição, um somatório de quantidades } \\
\text { infinitamente pequenas, mas, no contexto } \\
\text { prático, ela também é pensada como a } \\
\text { operação inversa da diferenciação. }\end{array}$ \\
\hline $\begin{array}{l}\text { Faz uso das quantidades infinitamente } \\
\text { pequenas (a variável "o" é uma quantidade } \\
\text { infinitesimal), mas, por outro lado, } \\
\text { preocupado com a sua fundamentação } \\
\text { lógica, assegura que o seu cálculo } \\
\text { independe delas e que pode ser dada uma } \\
\text { base rigorosa quanto ao seu conceito de } \\
\text { última razão; ressalta ainda que o seu } \\
\text { conceito de fluxão é uma velocidade } \\
\text { finita e não uma quantidade infinitamente } \\
\text { pequena. }\end{array}$ & $\begin{array}{l}\text { Assume incondicionalmente as } \\
\text { quantidades infinitamente pequenas em } \\
\text { seu Cálculo. }\end{array}$ \\
\hline $\begin{array}{l}\text { Dependia ainda das figuras e de } \\
\text { argumentos, em geral, físicos ou } \\
\text { geométricos, sobre elas. }\end{array}$ & $\begin{array}{l}\text { O sistema de notação de Leibniz é muito } \\
\text { mais poderoso do que o de Newton. O } \\
\text { cálculo de Leibniz "superou as figuras", } \\
\text { traduzindo todos os seus argumentos na } \\
\text { linguagem de símbolos e de fórmulas. }\end{array}$ \\
\hline $\begin{array}{l}\text { A noção de limite se realiza na ação de } \\
\text { desprezar os termos da "primeira razão" } \\
\text { que ainda contenham o seu "aumento } \\
\text { ínfimo" ("o"). }\end{array}$ & $\begin{array}{l}\text { A noção de limite está associada } \\
\text { diretamente à atitude de desprezar as } \\
\text { quantidades infinitesimais em relação às } \\
\text { quantidades finitas, ou de quantidades } \\
\text { infinitesimais de ordem superior com } \\
\text { respeito a outras de ordem inferior. }\end{array}$ \\
\hline
\end{tabular}

Assim, por sua simplicidade e praticidade, o Cálculo leibniziano se difundiu mais rapidamente pelo continente europeu do que o Cálculo newtoniano. Na Suíça, por exemplo, Johann e Jakob Bernoulli foram os primeiros a produzir um pequeno tratado de cálculo diferencial (169192) - Johann tinha maior originalidade e imaginação, mas Jakob foi superior em seu potencial de crítica. Na França, Marquês de L'Hospital (1661-1704), discípulo francês de Leibniz, publicou em 1696 o seu 
Analyse des infiniments petits pour l'intelligence des lignes courbes baseado no trabalho de Johann Bernoulli, de quem foi aluno. A matemática francesa da época teve influência direta do próprio Leibniz e de Johann Bernoulli. Na Alemanha, o Cálculo de Leibniz foi assimilado pelo trabalho filosófico de Cristian Wolff e também pelos trabalhos dos irmãos Bernoulli. Na Itália, Guido Grandi - que mantinha correspondências com Leibniz - foi o principal responsável por sua difusão.

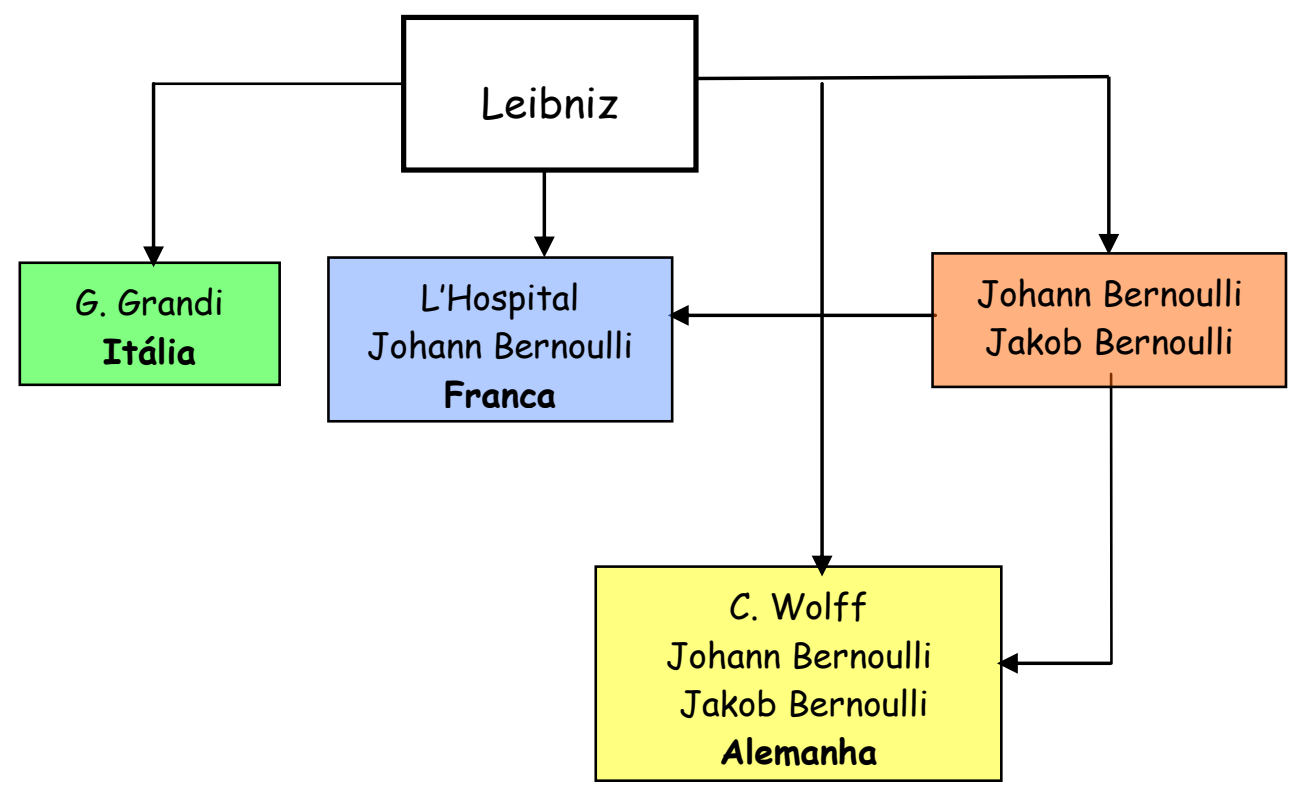

figura 36 - Mapa da expansão do Cálculo de Leibniz no continente europeu

O pequeno volume de Johann Bernoulli sobre o cálculo diferencial começa com o postulado paradoxal de que se uma quantidade é diminuída ou acrescida por uma quantidade infinitamente pequena ela não é, efetivamente, diminuída e nem aumentada. Já quanto à integral, ele preferiu defini-la como a operação inversa da diferenciação. Ao contrário do irmão, que abraçou os infinitesimais 
sem pestanejar, Jakob procurou divulgar o trabalho de Leibniz com mais prudência. Tentou evitar o pseudo-infinitesimal e afirmou que "uma menor quantidade do que qualquer grandeza dada" é o número zero. Por outro lado, ele afirmou que o axioma de Euclides "se coisas iguais são tiradas de coisas iguais, o resultado é igual" não precisava ser absolutamente verdadeiro quando quantidades incomparavelmente pequenas estão envolvidas. Por isso, ele avisou que no Cálculo as quantidades infinitamente pequenas devem ser usadas com cautela para evitar paralogismos.

Wolff seguiu as modificações de Jakob Bernoulli. Ele pensou o infinitamente grande $e \quad 0$ infinitamente pequeno como ficções geométricas convenientes (impossíveis). Já Grandi defendeu a existência do absolutamente infinito e de grandezas infinitesimais de várias ordens. É dele - e com o aval de Leibniz - o resultado paradoxal: $1-1+1-1+1-1+\ldots=0+0+0+\ldots=\frac{1}{2}$. Comparou este resultado com o mistério da religião Cristã e com a criação do mundo pelo qual uma força absolutamente infinita criou alguma coisa de absolutamente nada.

No entanto, começam a aparecer algumas resistências aos recém-criados métodos infinitesimais. Em 1700, por exemplo, inicia-se uma discussão sobre a validade do método infinitesimal. Rolle afirmava, por um lado, que os novos métodos levavam a paralogismos enquanto Johann Bernoulli sustentava que este não havia compreendido - Cálculo. Pierre Varignon, amigo de Bernoulli, tentou clarificar e apaziguar a situação mostrando indiretamente que o método infinitesimal poderia ser reconciliado com a geometria de Euclides. Em 1727, Bernard Fontenelle - amigo de Varignon - pensou que, com a publicação do seu trabalho Élements de la géometrie de l'infini, 
chegaria a um consenso e harmonia na escola francesa. Afirmou que a geometria é inteiramente intelectual e que independe da descrição real da figura. Desenvolveu, por outro lado, uma espécie de álgebra do infinito similar à de Wallis. Em um de seus cálculos, por exemplo, usou o fato de que $\infty \cdot \infty^{\infty-1}=\infty^{\infty}$. Fontenelle e Johann Bernoulli, assim como Wallis, tentaram, sem sucesso, aritmetizar as quantidades infinitas: procuraram definir o infinitamente pequeno como o recíproco do infinitamente grande. É salutar tal pretensão, mas, a forma como procederam, comprometeu ainda mais a credibilidade das quantidades infinitamente pequenas.

Mas afinal, o que são quantidades infinitamente pequenas / quantidades evanescentes? Poderia o Cálculo sobreviver sendo, como disse Voltaire a seu respeito, "a Arte de enumerar e medir uma Coisa cuja Existência não pode ser concebida"?

Antes, porém, de analisarmos os desdobramentos da polêmica acerca da existência das quantidades infinitamente pequenas, cabe-nos registrar que Newton e Leibniz foram mais prudentes que os seus seguidores. Tanto Newton, com o seu conceito de última razão, quanto Leibniz, com o seu conceito de diferencial, observaram algumas questões básicas que foram simplesmente ignoradas pelos seus seguidores. 


\subsubsection{O período de indecisão}

\subsubsection{A revisão crítica dos métodos infinitesimais}

Apesar da potência dos métodos infinitesimais na solução de problemas de máximo e mínimo, de tangentes e de quadraturas, alguns matemáticos hesitavam em usá-lo devido, principalmente, à falta de uma definição clara a respeito do significado das quantidades infinitamente pequenas. Huygens, por exemplo, que tanto incentivara os estudos de Leibniz, não os aceitava prontamente, ainda que não fizesse nenhum tipo de oposição a estes. Outros, no entanto, começam a questionar tais procedimentos infinitesimais. Dois desses críticos merecem a nossa atenção: o físico e geômetra holandês Bernard Nieuwentijdt (1695) ${ }^{122}$ e o filósofo britânico George Berkeley (1683-1753).

Nieuwentijdt considerava as "quantidades evanescentes" de Newton um conceito muito vago: como podia algo inicialmente ter um valor aproximado e depois se tornar igual? O que o físico holandês não compreendia, na verdade, era o significado da operação de limite. Outra questão interessante levantada por ele é "como podia a soma de infinitesimais de Leibniz ser uma quantidade finita?". Vejamos então como foram as réplicas das partes citadas.

\footnotetext{
${ }^{122}$ Como não se conseguiu obter em nenhuma fonte as respectivas datas de nascimento e de falecimento de Nieuwentijdt, mencionamos apenas o ano em que o geômetra iniciou as suas críticas ao cálculo infinitesimal.
} 
Em um artigo publicado no Acta eruditum (1695), Leibniz apresenta a defesa do seu cálculo infinitesimal. Segundo o matemático, para compreender o seu método era necessário que se abdicasse do "escrúpulo excessivo" que transbordava nas mentes de certos matemáticos. Sustentava que, em verdade, seu método diferia do método de Arquimedes apenas nas expressões usadas, sendo, nesse sentido, melhor adaptado e mais direto na arte da descoberta. Referindo-se explicitamente ao axioma de Arquimedes-Eudoxo, Leibniz afirmou que "quantidades que não diferiam por uma quantidade dada eram de fato iguais". Eis aí o cerne da idéia de limite. Além disso, o matemático afirmou que alguém poderia usar este procedimento como ferramenta, do mesmo modo que "os algebristas usavam as raízes imaginárias com grande proveito" (Boyer, 1949, p.215).

No final de sua argumentação o matemático surpreende ao afirmar que "infinito e infinitesimal não significam nada", mas que são apenas quantidades que alguém pode tornar tão grandes ou tão pequenas quanto se queira para mostrar que um erro é menor do que qualquer coisa ${ }^{123}$ estabelecida - isto é, que não existe erro. Leibniz sugere então que, se alguém quiser rejeitar a idéia da quantidade tão pequena quanto se queira, poderia assumir o infinitésimo como sendo a quantidade (positiva e não nula) que é menor do que qualquer grandeza (positiva) dada.

Em seu texto "Historia et origo calculi differentialis", Leibniz insiste no caráter "anfíbio" dos infinitésimos: existem e não-existem, assim como os números imaginários (Boyer, 1969, p.215). Ao se referir mais especificamente à sua noção de diferencial, ele a considera "como 
um tipo de ficção", observando que uma distinção entre a quantidade infinitesimal dy e a quantidade finita $d(y)$ - sua segunda versão do conceito de diferencial - não se faz tão necessário, uma vez que "depois de tudo, dy: $d x$ pode ser sempre reduzido a uma razão $d(y): d(x)$ entre quantidades que são, sem qualquer dúvida, reais e estabelecidas" (apud Boyer, 1969, p.216).

Para justificar a transição do finito para as quantidades infinitamente pequenas, Leibniz recorreu a um princípio conhecido como a "lei da continuidade" ${ }^{124}$. Tal princípio foi expresso pelo matemático em uma carta enviada a um amigo (em 1687) como segue:

Em qualquer transição suposta, terminando em algum termo, é permitido instituir um raciocínio geral, no qual o termo final pode também ser incluído.

(apud Boyer, 1969, p.217)

Em outra ocasião, o matemático alemão afirmou que "a diferença não é assumida ser nula até o cálculo ser depurado tanto quanto possível pelas legítimas omissões, e reduzidas a razões de quantidades não-evanescentes, e nós chegarmos finalmente ao ponto onde aplicamos nosso resultado ao último caso" (apud Boyer, 1969, p.217-218). Assim, pode-se perceber na sua argumentação que a idéia de limite estava invocada implicitamente no seu método infinitesimal.

Já a resposta de Newton às críticas ao seu trabalho foi menos enfática do que a de Leibniz. O matemático inglês considerou que o significado do seu método se encontrava na razão de fluxões e não nas quantidades evanescentes em si mesmas. Para explicar os conceitos de "quantidades evanescentes" e de "primeira e última razão", Newton deprecia a dificuldade dessa questão:

\footnotetext{
${ }^{123}$ Qualquer coisa aqui quer dizer uma grandeza (número) positiva.

${ }^{124}$ Kepler e Nicolau de Cusa também usaram este princípio.
} 
Mas a resposta é fácil: por última velocidade é entendida como aquela com qual o corpo é movido, não antes dele alcançar seu último lugar, quando o movimento cessa, nem depois; mas no exato instante em que ele alcança.... E, de igual modo, a última razão de quantidades evanescentes é para ser entendida como a razão das quantidades, não antes de se anularem, nem depois, mas aquela [razão] com as quais elas [as quantidades] se anulam.

(apud Boyer, 1969, p.216)

A última razão é, com efeito, o conceito de derivada de Newton. Embora tenha afirmado que a última razão não seja a razão das "últimas quantidades", mas sim, o limite para o qual as razões de quantidades que, "decrescendo sem terminar", convergem, o matemático inglês considerou, na realização de fato do seu cálculo fluxional, tal quantidade como razão de infinitesimais.

Outra crítica contundente ao Cálculo Infinitesimal, mas sem direito a réplicas - pois ambos os matemáticos já haviam falecido na época -, foi o elegante texto The Analyst (1734) ${ }^{125}$, do filósofo e bispo britânico George Berkeley (1683-1753).

Em seu texto, Berkeley mostrou que os princípios utilizados no Cálculo pelos "grandes cientistas" 126 necessitavam de maior clareza $e$ segurança. Em sua crítica aos fundamentos da ciência, e contraatacando as críticas que alguns cientistas faziam à religião, Berkeley põe em dúvida, inicialmente, a "certeza" da ciência:

(...) Esses homens, que só têm tratado de pontos claros, dificilmente admitiriam que alguns pontos obscuros podem não parecer totalmente ilógicos. Mas, aquele que consegue digerir uma segunda ou terceira fluxão, uma segunda ou terceira diferença, não precisa, creio, melindrar-se com nenhum ponto de divindade.

(apud Baron \& Bos, 1985, v.4, p.19)

\footnotetext{
${ }^{125}$ O título completo da obra é "O analista; ou um Discurso dirigido a um matemático infiel. Onde se discute a questão se o objeto, princípios e inferências da análise moderna são concebidos mais distintamente ou deduzidos mais logicamente que os mistérios e pontos de fé religiosos". O matemático infiel, embora não identificado por Berkeley, era provavelmente o astrônomo inglês Edmund Halley (1656-1742).

${ }^{126}$ Apesar da crítica também servir para o trabalho de Leibniz, Berkeley se pauta nos trabalhos de Newton e seus seguidores.
} 
Berkeley descreveu a falta de clareza nos conceitos de "fluxões" e de "fluxões de ordem superior":

Agora, como nosso juízo está esgotado e intrigado pela percepção de objetos extremamente minúsculos, até mesmo a imaginação, faculdade que deriva do Juízo, está bastante intrigada e esgotada para formar idéias claras sobre as menores partículas de tempo, ou sobre os menores incrementos aí gerados: e tanto mais, para compreender os momentos, ou aqueles incrementos das quantidades fluentes em statu nascente, em sua origem primeira ou princípio de existência, antes que elas se tornem partículas finitas. E parece ainda mais difícil conceber as velocidades abstraídas de tais entidades nascentes imperfeitas. Mas as velocidades das velocidades, a segunda, terceira, quarta e quinta velocidades, etc., ultrapassam, se não estou errado, toda compreensão humana. Quanto mais o cérebro analisa e persegue essas idéias fugitivas mais ele se perde e se confunde; os objetos, primeiramente velozes e diminutos, logo desaparecem de vista. Certamente, para qualquer Razão, uma segunda ou terceira fluxão parece um mistério obscuro. A Celeridade incipiente de uma Celeridade incipiente; 0 aumento nascente, ou seja, algo que não tem magnitude: não importa a forma como isso seja considerado, será impossível ter uma concepção clara a respeito. Se não estou errado, chamo a atenção de todos os leitores pensantes para julgarem essa questão. E, se uma segunda fluxão for inconcebível, o que devemos pensar de terceiras, quartas e quintas fluxões, etc.?

(apud Baron \& Bos, 1985, v.4, p.19-20)

Criticou ainda a dedução da fluxão de $x^{n}$ baseado no comportamento contraditório da quantidade infinitamente pequena "o", que, primeiro, é diferente de zero (para dividir) e, depois, igual a zero (para que desapareçam os termos com potências de "o"). Mostra, portanto, que a existência de "o" é inconcebível do ponto de vista lógico.

O grande autor do método de fluxões sentiu essa dificuldade e, portanto, cedeu a essas abstrações agradáveis e à metafísica geométrica, sem as quais ele sabia que nada poderia ser feito sobre os princípios recebidos, e o leitor julgará o que ele fez com tais princípios em demonstrações. Sem dúvida deve ser reconhecido o fato de que ele usou as fluxões como os andaimes de um edifício, como coisas a serem deixadas de lado ou desprezadas tão logo se descobrissem linhas finitas que fossem proporcionais a elas. Mas esses expoentes finitos são determinados com a ajuda de fluxões. Portanto, o que quer que seja obtido por meio de tais expoentes e proporções é atribuído às fluxões, que devem, portanto, ser entendidas previamente. E o que são tais fluxões? Velocidades de incrementos evanescentes? E o que são esses incrementos evanescentes? Eles 
não são nem quantidades finitas, nem quantidades infinitamente pequenas, nem coisa não-existente. Será que não podemos chamá-las fantasmas de quantidades desaparecidas?

Para Berkeley, apesar do cálculo não estar fundamentado, ele nos conduz a resultados verdadeiros por uma compensação dupla de erros ${ }^{127}$ :

- primeiro erro - o triângulo característico não é semelhante ao triângulo da ordenada;

- segundo erro - o desprezo dos produtos das diferenciais nas demonstrações das regras.

Berkeley questionou ainda a existência real de uma velocidade instantânea, pois, neste caso, para que se pudesse conceber tal velocidade, o intervalo de tempo deveria ser nulo. Em razão disto, Berkeley sugeriu que seria melhor, no Cálculo, considerar incrementos ao invés de velocidades. Curiosamente, o filósofo britânico aceitou os indivisíveis de Cavalieri, mas insistiu que eles eram em número finito. Segundo Berkeley, a divisibilidade infinita é apenas uma ficção e as grandezas infinitamente pequenas são inconcebíveis pelo fato destas serem "imperceptíveis pela mente através dos sentidos". Para Berkeley, mesmo a matemática deveria estar relacionada com o mundo "real" da percepção sensorial.

Apesar da atitude realista ingênua de Berkeley em relação à matemática, suas críticas aos métodos infinitesimais foram convincentes e contundentes. Como resultado, apareceram nos sete

\footnotetext{
${ }^{127}$ Esta interpretação da validade dos resultados do Cálculo, como devido a uma compensação de erros, nós encontraremos mais adiante em Euler, Lagrange, e Carnot.
} 
anos seguintes cerca de trinta artigos com a tentativa de responder ou remediar suas críticas.

Benjamin Robins (1707-51), conterrâneo de Newton e Berkeley, em seu trabalho "A Discourse Concerning the Nature and Certainty of Sir Isaac Newton's Methods of Fluxions and of Prime and Ulimate Ratios", reconheceu, por exemplo, que a frase "the ultimate ratio of vanishing quantities" era uma expressão figurativa, referindo-se não à última razão, mas a uma "quantidade fixa que alguma quantidade variando, por um aumento ou diminuição contínua, se aproximará perpetuamente (...) desde que a quantidade que varia possa diferir dela em sua aproximação por menos do que qualquer quantidade dada, por menor que seja (...) embora ela nunca possa ser absolutamente igual a ela" (apud Boyer, 1949, p.230). Esta última observação do matemático - de que a quantidade variável nunca pode ser igual ao valor do qual se aproxima - gerou muita controvérsia entre os próprios defensores do Cálculo de Newton.

James Jurin (1734), por exemplo, insistiu no fato de que existem variáveis que alcançam os seus limites, contrariando e se opondo a Robins. Jurin tem a seu favor o próprio texto de Newton, mas - que ele, como Newton, não conseguiu, foi justificar o significado da expressão indeterminada 0/0. A intenção de Robins em não permitir que a variável atingisse o seu valor limite era, com certeza, evitar o aparecimento dessa situação de indeterminação. Todavia, a controvérsia Jurin-Robins não superou os anseios dos matemáticos britânicos na busca de respostas para as questões de Berkeley. $\mathrm{Na}$ verdade, os matemáticos ainda não estavam satisfeitos com o método 
de limite $e$, embora a discussão sobre infinitesimais tenha desencorajado o seu próprio uso, eles não baniram esta idéia.

Colin Maclaurin (1698-1746), em seu Treatise of Fluxions (1742), considerou o infinitamente pequeno como "sendo um postulado muito audacioso para uma ciência como a geometria" (Boyer, 1949, p.233). Se, por um lado, não conseguia conceber a existência do infinitamente pequeno, por outro, Maclaurin admitiu, assim como Robins, introduzir na geometria a idéia de velocidade instantânea. Definiu velocidade na mesma linha de Nicolau de Oresme:

A velocidade de um movimento variável em algum instante dado não é para ser medido pelo espaço que é realmente descrito depois do instante de tempo dado, mas pelo espaço que teria sido descrito se o movimento fosse uniformemente continuado daquele instante.

(apud Boyer, 1949, p.233)

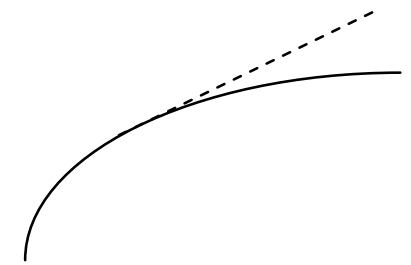

figura 37

Maclaurin fracassou, no entanto, em não perceber a velocidade instantânea como o limite da velocidade média.

Brook Taylor (1685-1731) reconheceu a importância da exposição do Cálculo em termos de diferenças finitas $e$ limites $e$ escreveu um livro sobre o assunto: Methodus incrementorum directa et inversa. Enquanto Robins e Maclaurin enfatizaram a interpretação em termos de fluxões, Taylor afirmou que Newton fundou seu método sobre a primeira e última razões ${ }^{128}$. Assim, ao contrário de Robins e

\footnotetext{
${ }^{128}$ Newton, por exemplo, reconheceu que o limite da razão de momentos era o mesmo que a razão das velocidades e fluxões correspondentes.
} 
Maclaurin, que assumiram que qualquer pessoa tinha uma idéia clara de velocidade instantânea, Taylor sentiu que era mais fácil conceber os momentos e obter as razões das fluxões a partir destes. Para determinar a relação de fluxões, ele trabalhou fazendo uso das diferenças finitas. No entanto, Taylor, assim como Leibniz, não foi claro com respeito à transição das diferenças finitas para as fluxões: ele interpretou isto pelo simples fato de escrever zero para as quantidades evanescentes. Para ele, última razão é aquela na qual as quantidades já evanesceram e são feitas zero, uma atitude que foi aparecer no Continente, no trabalho de Euler.

John Landen (1758) desenvolveu seus trabalhos na mesma linha do seu conterrâneo Taylor, isto é, em termos de diferenças finitas. Ao invés de calcular o quociente de fluxões, ou de diferenciais, Landen calculava "o valor do quociente de um residual dividido por um outro". Era entendido por um residual uma expressão da forma $x-v$, ou $x^{n}-v^{n}$. Por exemplo, a fluxão, ou quociente residual, de $x^{m / n}$ ele encontrou escrevendo:

$$
\frac{x^{\frac{m}{n}}-v^{\frac{m}{n}}}{x-v}=x^{\frac{m}{n}-1}\left\{\frac{1+\frac{v}{x}+\left(\frac{v}{x}\right)^{2}+\left(\frac{v}{x}\right)^{3}+\ldots}{1+\left(\frac{v}{x}\right)^{\frac{m}{n}}+\left(\frac{v}{x}\right)^{\frac{2 m}{n}}+\left(\frac{v}{x}\right)^{\frac{3 m}{n}}+\ldots}\right\},
$$

e fazendo, em seguida, $v=x$.

Apesar do significativo avanço que este matemático deu com sua "Análise Residual" na direção da construção do conceito de derivada, seu trabalho não teve eco no continente britânico. Faltava aqui, assim como no trabalho de Taylor, introduzir e explicitar nas idéias já 
pensadas dois ingredientes fundamentais do Cálculo: a operação de limite e a noção de função.

O conceito de função foi, com efeito, um dos principais elementos na construção e fundamentação das idéias básicas do Cálculo. Nesta época, encontraremos no continente uma tendência crescente em relacionar o Cálculo com o conceito formal de função, ao invés da concepção institucional de geometria. Tal iniciativa irá marcar uma nova fase no desenvolvimento do Cálculo: é o período de libertação do Cálculo das amarras da geometria, mais precisamente, da geometria analítica, em prol de uma abordagem mais analítica, em termos de função. Passemos então a esta análise.

\subsubsection{A passagem do Cálculo para a Análise Real}

Entre todos os matemáticos da época, Leonhard Euler (17071783) foi, sem dúvida, aquele que mais promoveu essa nova análise, organizando-a, e colocando-a sobre uma base formal. A maioria dos seus predecessores considerou o cálculo diferencial tendo ligação estrita com a geometria, mas Euler fez do tema uma teoria formal de funções que não precisava recorrer a digramas ou a concepções geométricas.

Embora Leibniz já tivesse feito menção à palavra função, num sentido bem próximo ao atual, foi Euler o primeiro a dar proeminência a este conceito e fazer um estudo e classificação sistemática de todas 
as funções elementares, junto com o seu cálculo diferencial e integral. Há de se ressaltar, entretanto, que sua terminologia a respeito de funções difere da atual: o que para Euler era função "contínua" hoje é uma função "diferenciável", uma "função descontínua" equivale hoje a uma função contínua que deixa de ser diferenciável em alguns pontos. Em verdade, Euler usava a palavra "contínua" para adjetivar a "variação da função". A expressão "contínua" do matemático está associada ao movimento da tangente ao gráfico de f. Assim, "função contínua" deve ser interpretada então como uma "função que tem variação contínua", ou, de outro modo, aquela cuja reta tangente varia continuamente ao longo do gráfico de $f$.

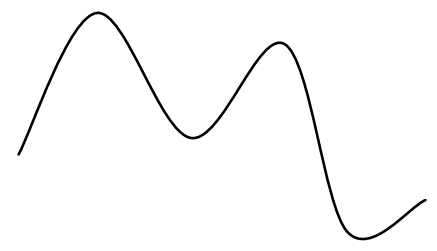

Euler: função contínua

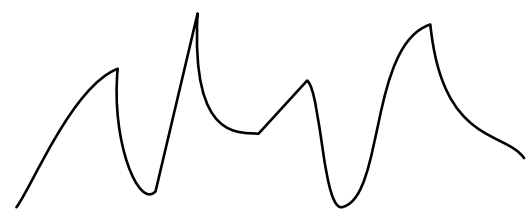

Euler: função descontínua

figura 38

Como Euler restringiu o seu estudo às funções bem comportadas, ele não se envolveu em grandes dificuldades relacionadas às noções de infinito e de continuidade.

No que tange às quantidades infinitamente pequenas, sua visão sobre o assunto foi muito simples, assemelhando-se de algum modo às de Wallis, Taylor, Johann Bernoulli, e Fontenelle. Para ele, um infinitamente pequeno ou uma quantidade evanescente era simplesmente alguma coisa que será zero. Esta visão poderia ter servido como base para uma interpretação em termos de limite, na qual as diferenciais são simples variáveis que se aproximam de zero como 
um limite; Euler, entretanto, não procedeu desta maneira. Para Euler, as diferenciais eram simplesmente zero. Embora ele tenha admitido a existência de um número infinito de infinitesimais - como aqueles encontrados nas diferenciais de ordem superiores - ele afirmou que estes eram todos zeros. O conceito de derivada era simplesmente a determinação da razão de incrementos evanescentes - um procedimento heurístico para encontrar o valor da expressão 0/0. Vejamos então, através de um exemplo, como Euler calculava a razão de quantidades evanescentes.

Para calcular a razão de evanescentes (derivada) de $x^{2}$, Euler permitiu a variável independente $x$ tornar-se $x+\omega$. Desse modo, a razão de incrementos em $x$ e $x^{2}$ era então $1:(2 x+\omega)$. Segundo o matemático, esta razão é sempre diferente da razão 1:2x a menos que $\omega$ se anule. Euler substitui então $\omega$ por zero para obter a razão evanescente: $\frac{d x^{2}}{d x}=\frac{2 x}{1}$ do mesmo modo que Taylor determinou a fluxão de $x^{2}$.

Cabe ressaltar, entretanto, que, em algumas ocasiões, ele usou cálculo de diferenças finitas como um instrumento alternativo ao cálculo diferencial, mas não justificou a relação existente entre eles. Já com relação ao infinito, Euler adotou as visões de Wallis e Fontenelle, usando expressões do tipo $\frac{a}{0}=\infty, \frac{a}{d x}=\infty$ etc. Considerou, além disso, tal como fez para os infinitésimos, quantidades infinitamente grandes de ordens superiores. A quantidade infinita $\frac{a}{d x^{2}}$, por exemplo, seria de segunda ordem, $\frac{a}{d x^{3}}$ seria de terceira ordem e assim por diante. 
A falta de cuidado com as operações infinitas levou Euler a incorrer em erros tais como $1-2+3-4+5-\ldots=1 / 4$ ou $1-3+5-7+\ldots=0{ }^{129}$.

O trabalho de Euler recebeu duras críticas de Robins em 1739. Segundo este último, a "grosseira" concepção de infinitesimal era consequiência dos ensinamentos que Euler teria recebido do "calculista deselegante" (Jhoann Bernoulli). Por outro lado, D'Alembert (1717-83), seu contemporâneo, estava promulgando a doutrina que, em pouco tempo, irá predominar nas teorias de fundamentação do Cálculo.

Segundo Boyer (1949, p.247), D'Alembert foi conduzido provavelmente por dois trabalhos anteriores a considerar o método de limites como fundamental no Cálculo: De quadratura curvarum (Newton, 1704) e Instituições de geometria (De la Chapelle, 1746 - texto que apresentou as idéias iniciais de limites de Stevin, Gregorie de St. Vicent, e outros). D'Alembert interpretou a expressão de Newton "primeira e última razão" não literalmente, como uma primeira ou última razão de duas quantidades surgindo repentinamente, mas como um limite.

D'Alembert foi, na verdade, o primeiro matemático a dar uma definição para esta operação: ele chamou uma quantidade de limite da outra se a segunda pode aproximar-se da primeira indefinidamente, ou então, que a diferença entre elas é absolutamente indeterminável. Assim como Robins, ele afirmou, entretanto, que a quantidade variável nunca coincide, ou é igual, ao seu limite. Deixando esta polêmica de lado, cabe ressaltar que a grande contribuição de D'Alembert não foi efetivamente a definição de limite, mas o fato de ter percebido que a

\footnotetext{
${ }^{129}$ Euler calculou essas somas infinitas a partir do resultado de Leibniz para a série de Grandi $(1-1+1-1+1-1+1-1+\ldots=1 / 2)$
} 
base do cálculo diferencial (a noção de derivada), assim como o método de fluxões, era para ser fundamentado na idéia de limite. "A diferenciação de equações" - disse ele - "consiste simplesmente em encontrar os limites da razão de diferenças finitas de duas variáveis incluídas na equação" (Boyer, 1949, p.247). Segundo D'Alembert, esta era, com efeito, a verdadeira metafísica do Cálculo.

D'Alembert rejeitou veementemente a interpretação do infinitesimal como uma quantidade fixa, como um estado intermediário entre as quantidades positivas e o nada. Segundo o matemático, se uma quantidade é alguma coisa, ela ainda não desapareceu; se ela é nada, ela literalmente desapareceu. Para D'Alembert a palavra infinitesimal significa "indefinidamente pequeno", e procurou definir este conceito em termos de limites. Assim como Euler, ele afirmou que poderia existir ordem de quantidades infinitamente grande do mesmo modo que foi feito para os infinitesimais.

Outro conceito que incomodava os matemáticos desde o período grego, e que o matemático francês tentou clarificar, foi o de infinito. Contrário à visão de Fontenelle, D'Alembert afirmou que a noção de infinito é apenas uma abreviação conveniente para a interpretação em termos de limites e que o seu significado está associado tão somente à idéia de "indefinidamente grande". A interpretação de D'Alembert foi feita muito mais em termos de geometria do que em termos de concepções aritméticas ${ }^{130}$. Baseado na sua concepção geométrica do infinito, D'Alembert não via a necessidade de se supor a existência do

\footnotetext{
130 Embora no mapa esquemático da divisão do conhecimento, no prefácio da Enciclopédia, infinitesimais são consideradas pelo matemático no domínio da álgebra, e não no da geometria.
} 
infinito real em matemática, relegando esta questão sobre a sua existência ou não ao domínio da filosofia.

Foi desse modo, com D'Alembert, que a noção de limite foi colocada definitivamente no circuito do Cálculo. No entanto, vai demorar mais algum tempo para que esta operação se torne o elemento unificador de todos os conceitos básicos do Cálculo Diferencial e Integral. Com efeito, a influência das explicações de Leibniz ainda preponderam no século XVIII no continente europeu: das 28 publicações que apareceram de 1754 a 1784, 15 interpretaram o cálculo em terminologia Leibniziana, 6 em termos de limites, quatro em termos de zeros de Euler e uma em termos de um método (de Lagrange) que passaremos a analisar agora.

Joseph Louis Lagrange (1736-1813) ecoou Berkeley na sua crítica aos infinitesimais e teve uma atitude cética em relação ao limite pelo fato deste estar envolvido com dificuldades metafísicas. Ele afirmou que a definição de D'Alembert de tangente como limite de uma secante estava insatisfatória, visto que depois que a secante se torna tangente nada a impede de continuar o movimento e se tornar secante do outro lado. Não aceitava as fluxões por não considerar a idéia de movimento necessária e rejeitou a divisão de zeros de Euler por não ter clara a idéia da razão de dois termos que se tornam zeros. Por outro lado, escreveu a Euler afirmando que teria descoberto com seu método a verdadeira metafísica do Cálculo Diferencial e Integral.

Seu método ${ }^{131}$ - acreditava o matemático - era essencialmente algébrico. Lagrange se inspirou no cálculo que Leibniz realizou das

\footnotetext{
${ }^{131}$ Publicado no artigo Sur une nouvelle espèce de calcul relatif à la différentiation et à l'intégration dês quantités variables em 1772.
} 
diferenciais de todas as ordens do produto de duas variáveis e nas potências da mesma ordem de um binomial nessas variáveis. Ele notou que a mesma correspondência ocorria entre as potências negativas e as integrais. Seguindo esse caminho, ele fez uso de uma analogia similar com as séries de Taylor $e$, assumindo que toda função pode ser representada e escrita através de uma série dessa, concluiu que:

$$
f(x+h)=f(x)+f^{\prime}(x) h+f^{\prime \prime}(x) \frac{h^{2}}{2 !}+\ldots,
$$

em que os coeficientes das potências de $h$ representam as razões de diferenciais, ou de fluxões.

A independência, no entanto, de seu método, da noção de limite, ou dos infinitesimais, é apenas ilusória, uma vez que é preciso garantir, além da existência, a convergência da série encontrada. No que tange ao conceito de integral, nada de novo foi acrescentado: este era tratado basicamente como operação inversa da derivação.

Ao comparar o trabalho de Lagrange com o de Euler, Boyer (1949, p.253) afirma que o primeiro tem uma vantagem em relação ao último: tornar fundamental o formalismo da teoria das funções, mais do que as preconcepções em geometria, mecânica ou filosofia. Lagrange fez também do conceito de derivada o conceito central do Cálculo, dando a esta o seu nome de batismo (derivada / função derivada) e uma notação muito próxima da que usamos hoje: $f^{\prime} x$.

$O$ método de Lagrange foi, no entanto, pouco reconhecido ${ }^{132}$ talvez, segundo Boyer (1949, p.235), pelo seu caráter inovador (tanto na forma como na notação empregada). Outros métodos diferenciais

${ }^{132}$ Embora outros matemáticos - Cordocet, Arbogast e Servois, por exemplo - tenham desenvolvido métodos similares ao de Lagrange na tentativa de elaborarem métodos alternativos aos infinitesimais e aqueles em termos de limites. 
foram desenvolvidos, mas, de certo modo, recaíam ou se assemelhavam a qualquer um dos quatro que aqui foram apresentados: o das razões de diferenciais de Leibniz; o da divisão de zeros de Euler; o do limite do quociente de diferenças finitas de D'Alembert $e$ o das séries de Lagrange. Assim, diante da insatisfação dos matemáticos da época com esta "babel diferencial", e percebendo que todos os métodos mesmo o de Lagrange - estavam, de certo modo, intimamente relacionados com a noção de infinito, a Academia de Berlim, da qual o próprio Lagrange era presidente, ofereceu um prêmio (em 1784) para a melhor exposição de uma teoria clara e precisa do infinito matemático. Quem ganhou o prêmio foi Simon L'Huilier com o trabalho intitulado "Exposition élémentaire dês principles dês calculs supérieurs". Neste trabalho, L'Huilier propôs mostrar que o método dos antigos conhecido como método de exaustão - convenientemente estendido em termos de limites, era suficiente para estabelecer indubitavelmente os princípios do novo cálculo integral. Fazendo do conceito de limite o conceito básico de sua exposição, L'Huilier concordou com D'Alembert que "no cálculo diferencial não foi necessário pronunciar o nome quantidade diferencial". Ele manteve o nome "quociente diferencial" e - símbolo $\frac{d y}{d x}$ para representar esta quantidade, mas insistiu, entretanto, que o último não era nada, mas um símbolo que era para ser interpretado como um único número. $O$ quociente diferencial de L'Huilier era um único número ou função, equivalente à função derivada de Lagrange, e representava essencialmente a presente concepção de derivada. 
O matemático fracassou, no entanto, ao dar uma definição da noção de limite:

Dada uma quantidade variável sempre menor ou maior do que uma quantidade constante proposta; mas que pode diferir da última por menos do que qualquer quantidade pequena proposta; esta quantidade constante é chamada o limite em grandiosidade ou pequenez da quantidade variável.

(apud Boyer, 1949, p.256)

L'Huilier afirmou - ainda sobre limites - que "se uma quantidade goza em todos os estágios de uma certa propriedade, seu limite gozará desta mesma propriedade". Tal proposição é falsa: para verificar tal fato, basta observar que todo número irracional é o limite de uma sequiência de números racionais, no entanto, esses possuem propriedades diferenciadas. Outro exemplo: o círculo como o limite de uma sequiência de polígonos.

O trabalho de L'Hulier, apesar de significar um grande avanço para a fundamentação das idéias básicas do Cálculo, não foi amplamente difundido. Já o trabalho de L.N.M. Carnot - (soldado) a quem a Assembléia Francesa deu o título de "o organizador da vitória" - foi mais popular e publicado em várias línguas. Tinha como meta conhecer em que consistia "o verdadeiro espírito da Análise Infinitesimal". Sua escolha, no entanto, do princípio unificador, foi desastrosa. Ele concluiu que o verdadeiro princípio metafísico da Análise Infinitesimal era, apesar de tudo, o "princípio da compensação de erros" tal como Berkeley e Lagrange já haviam sugerido.

Carnot considerou o Cálculo como a "arte" de comparar "quantidades que desaparecem". Para explicar se as quantidades desaparecidas são nulas ou não, Carnot usou o mesmo argumento de Leibniz: a lei de continuidade. Afirmou que alguém poderia substituir 
qualquer quantidade por uma outra que diferisse dela por uma quantidade infinitesimal e que, dessa forma, as "quantidades inapreciáveis" são meramente quantidades auxiliares que são introduzidas, tais como os números imaginários, apenas para facilitar a computação, e que são eliminados ao se alcançar o resultado final. Observou então que as diferenciais eram para ser definidas em termos de variáveis, antecipando desse modo a visão de Cauchy sobre este conceito. Carnot defendeu ainda que todos os métodos do Cálculo estavam relacionados. Tal posição será compartilhada por dois outros matemáticos: Lacroix (1765-1843) e Laplace (1749-1827).

Em 1797, por exemplo, foi publicado o primeiro volume do mais famoso e ambicioso livro sobre Cálculo Diferencial e Integral de sua época: oTraité du calcul differentiel et du calcul integral - de Lacroix. Com efeito, este trabalho representa uma mixagem das diversas correntes existentes. Nele, o matemático interpretou o método das séries de Lagrange em termos de limites de D'Alembert e L'Huilier. Embora tenha aceitado a metafísica de Lagrange, adotou também a notação diferencial de Leibniz. Considerou ainda, assim como Euler, o coeficiente diferencial como um quociente de zeros.

Laplace aplaudiu a atitude de Lacroix, afirmando que uma tal reaproximação dos métodos serviria para se chegar a uma clarificação mútua de todos os métodos, o que possibilitaria encontrar posteriormente, no que eles teriam em comum, a verdadeira metafísica do Cálculo Diferencial e Integral.

Em seu trabalho mais popular - Traité élémentaire (1802) Lacroix omitiu o método de Lagrange e fez sua explanação em termos de limites. Este texto, segundo Boyer (1949, p.265), foi um dos 
maiores responsáveis pela difusão da notação de Leibniz e da doutrina de limites no continente. A tradução inglesa simplificada do seu trabalho, publicada no ano de 1816, estende a influência do trabalho de Lacroix para o continente britânico. 


\subsubsection{O desenvolvimento da Análise (Real): a solução standard da fundamentação do Cálculo Diferencial e Integral}

A crítica contundente de Berkeley feriu os brios dos matemáticos da época, que, motivados, começaram a trabalhar na busca de soluções para as questões levantadas pelo pensador britânico. O século XVIII é, como sabemos, marcado então por um período de controvérsias e tentativas de explicações. No entanto, a fundamentação dos conceitos do Cálculo se efetivará apenas no século XIX. A solução para este problema consistiu em:

- primeiro, considerar as variáveis como funções de uma variável independente;

- introduzir a função derivada como um conceito fundamental do Cálculo;

- explicitar o conceito de derivada (de uma função em relação a sua variável independente) em termos de uma noção, ainda que intuitiva, de limite.

Desta forma, paulatinamente, as "quantidades variáveis" são substituídas pelo conceito de função, o de "últimas razões" e "razões de diferenciais" pelo de função derivada, e os "infinitesimais" pela noção de limite. Foi um processo bastante intricado e que pode ser considerado completo nos textos de Bolzano (1781-1845) e Cauchy (1789-1857), mas, que começa e se desenvolve na mesma medida em 
que o conceito de função evolui, e se constitui num instrumento fundamental para o Cálculo.

Leibniz usa, por exemplo, a palavra "função" pela primeira vez para representar as quantidades geométricas variáveis relacionadas a uma curva (tais como coordenadas, tangentes etc.). Johann Bernoulli identificava funções com expressões analíticas (fórmulas), que envolviam apenas uma variável. Euler (1707-1783) definiu função também como expressões analíticas, mas deu a este conceito um lugar central no desenvolvimento do Cálculo. Em seu trabalho, por exemplo, não usa termos geométricos (como curvas, áreas, retas etc.), mas sim fórmulas e as relações entre elas. Foi o uso intenso do seu conceito de função que permitiu a Euler dar um tratamento mais analítico ao Cálculo. Lagrange, por sua vez, faz do conceito de função derivada o elemento fundamental do seu cálculo diferencial.

Assim, paralelamente à evolução do Cálculo, o conceito de função foi se desenvolvendo ${ }^{133}$ e a passagem do Cálculo em variáveis para o Cálculo de funções foi se efetivando gradativamente, até que, por volta de 1800, todas as disciplinas da matemática que tratavam de processos infinitos (limites, séries, diferenciação e integração) fossem reunidas sob o nome de Análise.

A transição do Cálculo para a Análise, no século XVIII, não foi somente uma questão de crescimento e divisão em subcampos: foi uma mudança substancial do paradigma da ciência normal praticada na época. O Cálculo era orientado por um estilo geométrico; a Análise era um estudo e manipulação de fórmulas. O Cálculo empregava símbolos

\footnotetext{
${ }^{133}$ Para maiores informações sobre a evolução histórica do conceito de função, ver (Rüthing, 1984).
} 
algébricos (abscissas e ordenadas); a Análise introduziu o conceito de função, o que possibilitou a passagem da figura para a fórmula. Dois dos maiores responsáveis por esta mudança de atitude no Cálculo foram, conforme já mencionamos, os matemáticos Bolzano e L. A. Cauchy, sendo que os trabalhos do primeiro foram descobertos tardiamente ${ }^{134}$ e não chegaram a influenciar decisivamente a construção inicial da Análise. Vejamos como tal história se sucedeu.

Os trabalhos de D'Alembert, L'Huilier e Lacroix formaram, com efeito, a base do trabalho de Cauchy. O conceito de derivada de Cauchy é praticamente o mesmo de L'Huilier. A grande contribuição de Cauchy foi, no entanto, a "arrumação lógica" que realizou na estrutura das idéias do Cálculo. Ao contrário dos matemáticos que desenvolviam - seu "cálculo diferencial" a partir da noção de diferencial, Cauchy fez do seu conceito de derivada, alicerçada na operação de limite, a idéia fundamental do seu cálculo diferencial:

Se a função $y=f(x)$ for contínua entre dois limites dados da variável $x$, então, para qualquer valor de $x$ dentro dos limites, um aumento infinitamente pequeno da variável produzirá um aumento infinitamente pequeno da própria função. Portanto, se dissermos que $\Delta x=i$, os dois termos da razão das diferenças:

$$
\frac{\Delta y}{\Delta x}=\frac{f(x+i)-f(x)}{i}
$$

serão quantidades infinitamente pequenas. Mas, enquanto que esses dois termos aproximar-se-ão indefinidamente de zero, sua razão poderá convergir para algum outro limite positivo ou negativo. Esse limite, quando existe, tem um valor definido para cada valor específico de $x$, mas varia com $x$. Portanto, se, por exemplo, tomarmos $f(x)=x^{m}$, onde $m$ é um número inteiro, a razão entre as diferenças infinitamente pequenas será:

$$
\frac{(x+i)^{m}-x^{m}}{i}=m x^{m-1}+\frac{m(m-1)}{1.2} x^{m-2} i+\ldots+i^{m-1}
$$

e seu limite será a quantidade $m x^{m-1}$, que é uma nova função da variável $x$. Isso será verdadeiro em geral, mas a forma da nova função que serve como limite da

\footnotetext{
${ }^{134}$ Foi Herman Hankel quem descobriu e divulgou inicialmente os trabalhos de Bolzano.
} 
razão $\frac{f(x+i)-f(x)}{i}$ dependerá da forma da função inicial $y=f(x)$. Indicamos a dependência chamando essa nova função de "função derivada", designando-a pelo uso de um apóstrofo na notação: $y^{\prime}$ ou $f^{\prime}(x)$.

(Cauchy, Resume des leçons données a l'École Polytechnique sur le Calcul Infinitesimal, apud Baron \& Bos, 1985, v.4, p.48 e 49)

$O$ conceito de derivada de Cauchy, representado por $f^{\prime}(x)$ ou $y^{\prime}$, é, com efeito, o quociente diferencial de L'Huilier aplicado ao conceito de função de Euler e Lagrange. A definição de Cauchy não representa nenhuma grande invenção, mas é apenas uma clarificação, com o auxílio do conceito de função, de uma idéia que teve origem em D'Alembert. Cauchy define assim o conceito de derivada de forma independente do conceito de diferencial. Ao contrário do que se pensava até então, Cauchy condiciona a existência deste último à existência da derivada e define a diferencial de uma função em termos de limite:

Seja $y=f(x)$ novamente um função da variável independente $x$.

Seja $i$ uma quantidade infinitamente pequena e $h$ uma quantidade finita. Se dissermos que $i=\alpha h, \alpha$ será, novamente, uma quantidade infinitamente pequena, e teremos a identidade:

$$
\frac{f(x+i)-f(x)}{i}=\frac{f(x+\alpha h)-f(x)}{\alpha h}
$$

da qual deduzimos que

$$
\frac{f(x+\alpha h)-f(x)}{\alpha}=\frac{f(x+i)-f(x)}{i} h
$$

O limite para o qual converge o lado esquerdo da equação (1) à medida que se aproxima indefinidamente de zero $e \mathrm{~h}$ permanece constante é chamado "diferencial" da função $y=f(x)$. A diferencial é indicada pelo d característico: dy ou $d f(x)$.

Seu valor pode ser facilmente determinado se soubermos o valor da função derivada $y^{\prime}$ ou $f^{\prime}(x)$. De fato, se tomarmos os limites de ambos os lados da equação (1), acharemos o resultado geral:

No caso especial $f(x)=x$, a equação (2) se reduz a

$$
d f(x)=h f^{\prime}(x)
$$

$$
d x=h \text {. }
$$


Assim, a diferencial da variável independente $x$ é precisamente a constante finita h. Dado isso, a equação (2) torna-se:

ou, equivalentemente,

$$
d f(x)=f^{\prime}(x) d x
$$

$$
d y=y^{\prime} d x
$$

Essas últimas equações mostram que a derivada $y^{\prime}=f^{\prime}(x)$ de qualquer função $y=f(x)$ é precisamente igual a $\frac{d y}{d x}$, isto é, a razão entre a diferencial da função e a diferencial da variável ou, se quisermos, ao coeficiente pelo qual devemos multiplicar a segunda diferencial a fim de obtermos a primeira. É por isso que a derivada é chamada às vezes de 'coeficiente diferencial'.

(Cauchy, Resume des leçons données a l'École Polytechnique sur le Calcul Infinitesimal. apud Baron \& Bos, 1985, v.4, p.49 e 50)

Cauchy generaliza a relação que existe entre as diferenciais e a noção de derivada para diferenciais de ordens superiores, encontrando assim a fórmula: $d^{n} f(x)=f^{(n)}(x) d x^{n}$ (ou, equivalentemente, $d^{n} y=y^{(n)}$ $\left.d x^{n}\right)$, em que $f^{(n)}(x)$ significa a derivada de ordem ' $n$ ' de $f$.

Apesar de ter feito demonstrações - sempre que possivel - dos seus resultados, o Cálculo de Cauchy não pode ser considerado um primor de rigor. Sua definição de limite, por exemplo, foi essencialmente a mesma ${ }^{135}$ que a de D'Alembert (1717-83) e a de B. Robins (1707-51):

Quando os valores sucessivos atribuídos a uma variável aproximam-se indefinidamente de um valor fixado por uma diferença dele tão pequena quanto se queira, este último é então chamado o limite de todos os outros. - (definição de limite de Cauchy)

(Cauchy, Resume des leçons données a l'École Polytechnique sur le Calcul Infinitesimal, apud Baron \& Bos, 1985, v.4, p.46)

Nos trabalhos de Cauchy o limite é muito mais uma operação aritmética do que geométrica. No entanto, engana-se quem pensa que 
com a fundamentação das idéias básicas do Cálculo na noção de limite, Cauchy queria banir de vez os infinitesimais; muito pelo contrário, o matemático francês revela-nos em seu texto que o seu principal objetivo era "reconciliar o rigor" com a "simplicidade" das quantidades infinitamente pequenas:

Meu principal objetivo é reconciliar o rigor, que foi o princípio-guia de meu curso de análise [Cours d'analyse] com a simplicidade alcançada ao considerarmos diretamente as quantidades infinitamente pequenas.

(Cauchy, Resume des leçons données a l'École Polytechnique sur le Calcul Infinitesimal, apud Baron \& Bos, 1985, v.4, p.46)

E, a partir da noção de limite, Cauchy apresenta uma definição de infinitesimal:

"(...) quando os valores numéricos sucessivos de uma variável diminuem indefinidamente de modo a tornarem-se menores que qualquer número ${ }^{136}$ dado, dizemos que a variável se torna "infinitamente pequena" ou uma quantidade infinitamente pequena. O limite de tal quantidade é zero".

(Cauchy, Resume des leçons données a l'École Polytechnique sur le Calcul Infinitesimal, apud Baron \& Bos, 1985, v.4, p.46)

Segundo Cauchy, uma quantidade infinitamente pequena não é zero e nem uma quantidade constante (positiva) menor do que qualquer quantidade finita, mas é uma variável que se aproxima de zero. Note que, enquanto para Cauchy, a noção de "infinitamente pequena" decorria da noção de limite, para os seus antecessores, ela era, ao contrário, o elemento metafísico necessário para que o processo de limite se realizasse e que, como tal, precisava ser esclarecida.

\footnotetext{
${ }^{135}$ Ao contrário dos outros matemáticos citados, Cauchy admitiu a possibilidade da variável atingir seu limite.

${ }^{136}$ Quer dizer: número positivo dado - As dificuldades de natureza epistemológica dos números relativos não haviam sido superadas.
} 
A partir desta idéia de infinitesimal, Cauchy define continuidade de uma função real:

Suponha $f(x)$ equivalente e finita qualquer que seja o valor de $\underline{x}$ entre dois limites dados; então se $f(x+i)-f(x)$ for sempre infinitamente pequena entre esses limites $[f(x+i)$ e $f(x)]$, dizemos que $f(x)$ é uma função contínua da variável $\underline{x}$ entre os limites em questão.

(Cauchy, Resume des leçons données a l'École Polytechnique sur le Calcul Infinitesimal, apud Baron \& Bos, 1985, v.4, p.48)

Bolzano também definiu continuidade de modo similar. 0 matemático tcheco, aliás, também definiu os conceitos básicos do Cálculo Diferencial e Integral em termos de limite - como fez Cauchy - mas foi além em relação ao conceito de infinito. Apesar do seu isolamento em Praga, o trabalho de Bolzano era mais próximo da Análise atual do que o de Cauchy. Enquanto este último considerou apenas 0 infinito potencial em sua análise - o infinito como o indefinidamente grande -, Bolzano considerou esta noção no nível de conjuntos, vislumbrando inclusive a existência do infinito atual.

Além disso, ao contrário de Cauchy, que assumiu e tentou demonstrar, sem sucesso, a conjectura de que "toda função contínua deixava de ser diferenciável apenas em uma quantidade enumerável de pontos isolados" 137 , Bolzano apresentou um contra-exemplo para tal resultado, isto é, o matemático exibiu a construção de uma função contínua, que não é diferenciável em nenhum de seus pontos:

Seja $P Q$ um segmento linear inclinado para a horizontal. Seja ele [PQ] dividido em duas partes iguais pelo ponto $M$, e subdivida os segmentos $P M$ e $M Q$ em quatro partes iguais, sendo os pontos de divisão $P_{1}, P_{2}, P_{3}$ e $Q_{1}, Q_{2}, Q_{3}$ [veja fig. 39]. Seja $P_{3}{ }^{\prime}$ a reflexão de $P_{3}$ em relação à [reta] horizontal que passa por $M, e$

\footnotetext{
${ }^{137}$ A nomenclatura "enumerável" e "ponto isolado" não era própria da época - foi usada aqui apenas para simplificar o enunciado da conjectura.
} 
seja $Q_{3}{ }^{\prime}$ a reflexão de $Q_{3}$ em relação à [reta] horizontal que passa por $Q$. Forme a linha quebrada $P P_{3}{ }^{\prime} M Q_{3}{ }^{\prime} Q$. Aplique agora a cada um dos quatro segmentos desta linha quebrada a operação fundamental como descrita acima, obtendo deste modo uma linha quebrada de $4^{2}$ segmentos. Continuando este processo indefinidamente, a figura da linha quebrada convergirá para uma curva que representa uma função contínua, mas que não é diferenciável em nenhum ponto.

(apud Boyer, 1949, p. 269-70)

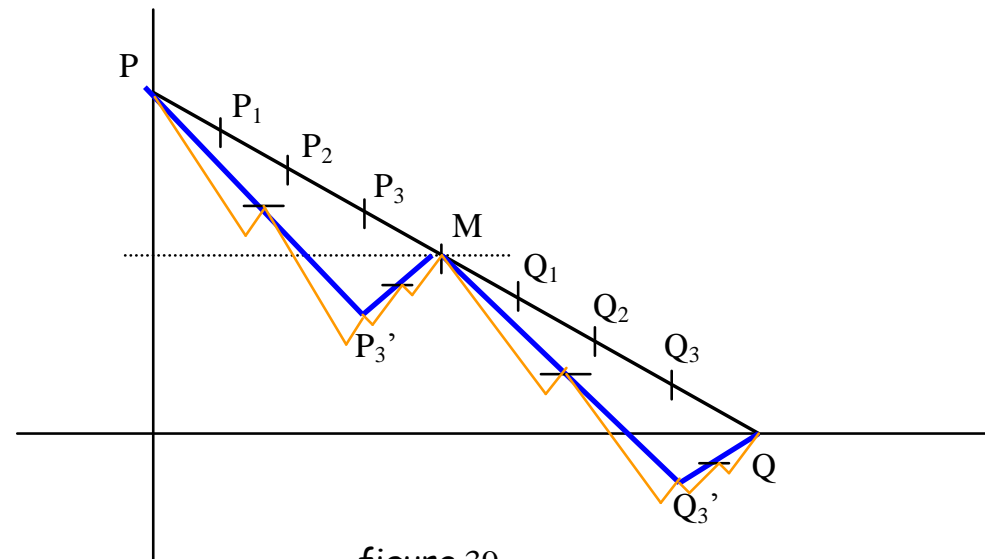

figura 39

Apesar da beleza do exemplo dado por Bolzano em 1834, este não teve influência direta no desenvolvimento da Análise no continente. Tal conjectura persistiu até 1872, quando Weierstrass apresentou o seu contra-exemplo: $f(x)=\sum_{n=0}^{\infty} b^{n} \cos \left(a^{n} \pi x\right)$, em que ' $x$ ' é uma variável real, ' $a$ ' um inteiro ímpar, e 'b' uma constante positiva menor do que a unidade tal que $a b>1+\frac{3 \pi}{2}$.

No que tange ao conceito de integração, pode-se dizer que, depois da descoberta pelos matemáticos - desde Barrow, Newton e Leibniz - da relação inversa entre as operações de integração $e$ diferenciação, o cálculo integral foi desenvolvido como uma espécie de cálculo antidiferencial, isto é, para integrar determinada curva ou função, o que se procurava era tão somente a curva ou função cuja derivada era a curva ou função dada. Cauchy, entretanto, distinguiu 
dois tipos de integração: a 'integral definida' e a 'integral indefinida' de uma função. Para a primeira elaborou uma definição em termos de limite de uma sequiência de somas ${ }^{138}$ :

Suponhamos que a função $y=f(x)$ seja contínua com relação à variável $x$ entre os limites finitos $x=x_{0}$ e $x=X$. Marquemos por $x_{1}, x_{2}, \ldots, x_{n-1}$ novos valores de $x$ entre esses limites, valores eses que supomos variar do primeiro limite ao segundo. Podemos usar esses valores para dividir a diferença $X-x_{0}$ em elementos:

$$
x_{1}-x_{0}, x_{2}-x_{1}, x_{3}-x_{2}, \ldots, X-x_{n-1}
$$

que terão sempre o mesmo sinal. Consideremos agora o efeito de multiplicarmos cada um desses elementos pelo valor de $f(x)$ correspondente à origem do mesmo elemento: assim, multiplicamos o elemento $x_{1}-x_{0}$ por $f\left(x_{0}\right)$, o elemento $x_{2}-x_{1}$ por $f\left(x_{1}\right), \ldots$, finalmente, o elemento $X-x_{n-1}$ por $f\left(x_{n-1}\right)$. Seja

$$
S=\left(x_{1}-x_{0}\right) f\left(x_{0}\right)+\left(x_{2}-x_{1}\right) f\left(x_{1}\right)+\ldots+\left(X-x_{n-1}\right) f\left(x_{n-1}\right)
$$

a soma dos produtos obtidos dessa maneira. $A$ quantidade $S$ claramente dependerá : 1) de $n$, o número de elementos nos quais a diferença $X-x_{0}$ foi dividida, $e, 2)$ dos valores reais desses elementos, $e$, portanto, da maneira como foi feita a divisão.

Deve ser observado agora que, se os valores numéricos dos elementos se tornarem muito pequenos e se o número $n$ tornar-se muito grande, a maneira de divisão terá apenas um efeito desprezível sobre o valor de S. Isso pode ser provado, como segue.

(Cauchy, Resume des leçons données a l'École Polytechnique sur le Calcul Infinitesimal, apud Baron \& Bos, 1985, v.4, p.50-51)

Cauchy observou ainda que, se a divisão do segmento $\left(X-X_{0}\right)$ for refinada, $S$ aproximar-se-ia de um limite, independentemente do modo como as divisões fossem escolhidas.

Assim, quando os elementos da diferença $X-x_{0}$ se tornarem infinitamente pequenos, o modo de divisão terá apenas um efeito desprezível sobre o valor de $S$, $e$, se diminuirmos os valores numéricos desse elementos, indefinidamente, enquanto aumentamos o seu número, o valor de $S$ torna-se-á, finalmente, uma constante, ou, em outras palavras, o valor de $S$ alcançará um certo limite, que depende somente da função $f(x)$ e dos valores extremos, $x_{0}$ eX da variável $x$. Esse limite é chamado integral definida.

(Cauchy, Resume des leçons données a l'École Polytechnique sur le Calcul Infinitesimal apud Baron \& Bos, 1985, v.4, p.51)

\footnotetext{
${ }^{138}$ Leibniz e outros matemáticos dos séculos XVII e XVIII também pensavam o conceito de integral como uma soma infinita, mas preferiram em seus cálculos usar os seus conhecimentos do
} 
$O$ argumento de Cauchy não é inteiramente concludente e seria aperfeiçoado posteriormente por B. Riemann (1826-66). Cabe registrar, entretanto, que Cauchy estendeu a sua definição de integral definida para funções descontínuas em um ponto do intervalo como segue:

$\int_{x_{0}}^{X} f(x) d x=\int_{x_{x}}^{X_{0}-\varepsilon} f(x) d x+\int_{X_{0}+\varepsilon}^{X} f(x) d x$, em que $\mathbf{X}_{0}$ é $\mathbf{o}$ único ponto de descontinuidade de $f$ no intervalo $\left[x_{0}, X\right]$ e $\varepsilon$ é indefinidamente pequeno.

Isto posto, Cauchy deu ainda uma demonstração para o Teorema Fundamental do Cálculo:

Se um dos dois limites da integral definida $\int_{x_{O}}^{X} f(x) d x$, digamos, a quantidade $X$, puder variar, a própria integral variará com esta quantidade. $E$, se substituirmos o limite $X$, que se tornou variável, por $x$, teremos uma nova função de $x$, que é chamada de uma integral da origem $x=x_{0}$. Seja:

$$
F(x)=\int_{x_{o}}^{x} f(x) d x \quad \text { essa nova função. }
$$

(...) $F(x+\alpha)-F(x)=\int_{x_{o}}^{x+\alpha} f(x) d x-\int_{x_{o}}^{x} f(x) d x=\int_{x}^{x+\alpha} f(x) d x=\alpha f(x+\theta \alpha)$

[onde a última igualdade é obtida pelo teorema do valor médio para integral ${ }^{139}$ ]. (...) - [e conclui como segue:] Assim, se a função $f(x)$ é finita e contínua, de $x=x_{0}$ a $x=X$, o mesmo podemos dizer da função $F(X)$. Além disso, se dividirmos ambos os lados de (2) por $\alpha$ e tomarmos os limites, obteremos $F^{\prime}(x)=f(x)$. Assim, a integral (1), considerada como função de $x$, tem como derivada a função $f(x)$, que está sob o sinal $\int$ na integral.

(Cauchy, Resume des leçons données a l'École Polytechnique sur le Calcul Infinitesimal, apud Baron \& Bos, 1985, v.4, p.52-53)

A expressão de $F(x)$ construída no resultado acima é denominada então integral indefinida da função $f(x)$. O resultado demonstrado 
significa, grosso modo, que a derivada da integral indefinida de uma função contínua f é a própria função f. Este é, em essência, o Teorema Fundamental do Cálculo. Mas, por outro lado, foi a definição de integral definida dada por Cauchy que abriu espaço para um aprofundamento posterior do próprio processo de integração, além, é claro, deste conceito suscitar questões relativas à convergência ou não das séries.

Varignon, no início, e Lagrange, no final do século XVIII, chamaram a atenção para o fato de que o uso das séries só era seguro se pudéssemos investigar a convergência do seu resto. $O$ uso inadequado deste instrumento chegou a provocar situações constrangedoras mesmo a matemáticos do porte de Leonhard Euler. Abel (1802-29), Bolzano, Fourier (1768-1830), Cauchy e Gauss (17771855) sentiram, no entanto, a necessidade de definir com precisão a convergência de séries infinitas e de construir testes que permitissem avaliar tal convergência. Mas foi Cauchy - segundo Grattan-Guinness (1980, p.117) - "quem explorou a definição de convergência e suas consequiências para um novo nível de detalhes". Em seu Cours d'analyse, Cauchy afirmou que:

(...) se, para valores sempre crescentes de $n$, a [n-ésima parcial] soma $S_{n}$ chega indefinidamente próximo de um certo limite $S$, a série será dita convergente, e 0 limite em questão será chamado a soma da série. Por outro lado, se a soma $S_{n}$ não se aproxima de algum limite fixo enquanto $n$ cresce indefinidamente, a série será divergente, e não poderá ter mais uma soma.

(apud Grattan-Guinness, 1980, p.117)

139 Se f é contínua em [a,b], então existe um valor $\xi$ no intervalo, tal que $\int_{a}^{b} f(x) d x=(b-a) f(\xi)$ 
No mesmo texto, Cauchy apresenta um notável teorema que, segundo ele, fornece a condição necessária e suficiente para a convergência de uma série:

(...) para uma série ser convergente 'é necessário e suficiente que, para valores infinitamente grandes do número $n$, as somas

$S_{n}, S_{n+1}, S_{n+2}$, etc....

difiram do limite $S e$, conseqüentemente, entre elas próprias, por quantidades infinitamente pequenas'.

(apud Grattan-Guinness, 1980, p.117)

A condição necessária é consequiência imediata da definição dada pelo matemático, mas a condição suficiente compreende uma dificuldade ainda não superada pelos matemáticos: a existência do número $S$ que é o limite da série. $O$ que garante a existência do número $S$ - que representaria a soma - para uma série que "converge dentro de si mesma" (isto é, $\forall \varepsilon>0, \exists p>0 ;\left|S_{m}-S_{n}\right|<\varepsilon, \forall m, n>p$ )? A existência de tal número suscita questões relativas à idéia de continuidade - fato que não pode ser mais ignorado pelos matemáticos.

Cauchy, entretanto, ignorando a dificuldade intrínseca ao seu teorema, definiu, em seguida, os números irracionais como limites de sequiências ou séries convergentes de números racionais, assentando, desse modo, o significado da noção de número irracional na noção de limite. Por outro lado, ao elaborar a sua definição de limite, Cauchy precisou admitir a priori e implicitamente a existência de tal número irracional - questão que passou despercebida pelo matemático em seu teorema "sobre convergência das séries".

Cauchy não percebeu a circularidade do seu raciocínio (limite $\rightarrow$ número irracional $\rightarrow$ limite), assumindo tacitamente que toda seqüência que "converge dentro de si mesma" tem um limite. Apesar desse fato- 
e de outros deslizes históricos -, o matemático francês é considerado pela maioria dos matemáticos como o "fundador" do Cálculo Diferencial no sentido moderno.

Com efeito, pelos parágrafos anteriores, podemos perceber que a contribuição de Cauchy foi além da combinação dos conceitos de função e de limites nos fundamentos do Cálculo. Com Cauchy, os conceitos do Cálculo receberam uma formulação rigorosa. Pode-se afirmar ainda que o rigor de suas argumentações formou o princípioguia para grande parte do desenvolvimento da Análise do século XIX. Há de se ressaltar, entretanto, que em seu valioso trabalho sobre Cálculo e Análise aparecem algumas expressões que precisariam de explicações posteriores. "Aproximar indefinidamente", "tão pequeno quanto se queira", "última razão de incrementos infinitamente pequenos" são exemplos dessas expressões. Essas idéias foram depuradas posteriormente, com destaque para os matemáticos da escola matemática alemã.

$O$ processo de aritmetização, que se iniciou gradualmente por volta de 1700, e que culminou com a separação da Análise de qualquer base geométrica, é chamado pelos historiadores de matemática de "Aritmetização da Análise". A partir do seu desfecho, a operação de limite, livre das idéias de movimento, de quantidades geométricas, de quantidades infinitamente pequenas ou de quaisquer pressupostos metafísicos, se tornou o instrumento básico do novo paradigma da Análise. 
K. Weierstrass (1815-97) ${ }^{140}$ foi, sem dúvida, um dos principais articuladores desse processo de aritmetização da Análise. Foi ele quem, efetivamente, construiu uma base puramente formal independente da intuição geométrica e de qualquer idéia de movimento - para a Análise.

Ao propor a sua "teoria estática do conceito de variável", Weierstrass criticou o apelo à intuição de movimento contínuo presente na expressão de Cauchy: "que a variável aproxima-se de um limite". Ao contrário do matemático francês, ele interpretou a variável " $x$ " simplesmente como uma letra designando qualquer número de uma coleção de valores numéricos. Uma variável contínua foi igualmente definida em termos de considerações estáticas:

Se para qualquer valor $x_{0}$ do conjunto e para qualquer seqüência de números positivos $\delta_{1}, \delta_{2}, \ldots, \delta_{n}$, entretanto pequenos, existem nos intervalos $\left(x_{0}-\delta_{i}, x_{0}+\delta_{i}\right)$ outros [elementos] do conjunto, este [conjunto] é [então] chamado contínuo.

(apud Rezende, 1994, p.74)

E, a partir dessa idéia, elaborou a definição formal de limite:

(Dizemos que) Lé o limite de $f(x)$ para $x=$ a se dado $\varepsilon>0$ existe $\delta>0$ tal que para todo valor de $x$ diferindo de a por menos do que $\delta$, o valor de $f(x)$ irá diferir de L por menos do que $\varepsilon$.

(apud Rezende, 1994, p.74)

Note que nessa definição não existe nenhuma referência a qualquer tipo de infinitesimal. Foi no simbolismo inequívoco de Weierstrass que a idéia do infinitesimal foi novamente banido do Cálculo. Na teoria de limites de Weierstrass o conceito de limite não está associado a qualquer idéia de movimento contínuo, mas, ao

\footnotetext{
${ }^{140}$ Fato curioso - revelado por Boyer (1949, p.285) - é que Weierstrass não apresentou seus trabalhos sobre os elementos do Cálculo em artigos. Seus trabalhos ficaram conhecidos
} 
contrário, é definido a partir de uma relação lógica entre duas desigualdades. O seu conceito de variável não representa uma passagem progressiva através de todos os valores de um intervalo, mas a suposição disjuntiva de qualquer um dos valores do intervalo. Portanto, não faz sentido perguntar na teoria de limites de Weierstrass "se uma variável alcança, ou não, o seu valor limite", mesmo porque a questão que se coloca agora é "se o limite de uma função é, ou não, igual a L". O conceito de limite de Weierstrass não envolve a idéia de aproximação, mas é tão somente um estado de coisas estáticas.

Weierstrass pretendia estabelecer a Análise com base apenas no conceito de número. Para isto, precisou dar uma definição de número irracional independente da noção de limite. Weierstrass "resolveu" a questão da circularidade presente na definição de número real identificando o número com a própria sequiência que "converge" para ele. Assim, $\sqrt{2}$ não é definido como o limite da sequiência (1; 1,4; $1,41 ; 1,414 ; \ldots)$, mas como sendo a própria sequiência que converge. Tal atitude foi, com efeito, a primeira solução normal para a anomalia apresentada na definição de número real.

H. E. Heine (1821-81) e G. Cantor (1845-1918) também adotaram - mesmo procedimento. Consideraram o número real " $S$ " não como "determinado" pela série, mas como "definida" pela própria. Entretanto, assim como Weierstrass, precisaram modificar a definição de convergência de Cauchy, usando a idéia de "convergência dentro de si mesma" - do próprio Cauchy - como a própria definição de

publicamente pelas leituras e citações de seus alunos. 
convergência para a série. Ou de outro modo, uma série é dita ser convergente se $\lim _{n \rightarrow \infty} S_{n+p}-S_{n}=0$, sendo $\mathrm{p}$ uma quantidade arbitrária e $S_{n}$ a n-ésima soma parcial da série.

A fundamentação dos conceitos da Análise trouxe de volta, então, os problemas de Zenão com respeito aos conceitos de infinito e continuidade. Para muitos matemáticos esses dois conceitos eram assim como a própria operação de limite foi um dia - conceitos metafísicos, e se encontravam além da definição matemática. Por tal razão, suas definições eram muito mais objeto da Filosofia do que da Matemática. Mais uma vez, os matemáticos estavam enganados...

A noção de continuidade, por exemplo, sempre esteve associada, em boa parte de sua história, às percepções sensíveis da realidade física. Galileu, por exemplo, interpretou o conceito de continuidade como "uma variação que se faz por gradações insensíveis" ${ }^{141}$. Essa idéia de movimento (variação por gradações insensíveis) pode ser percebida tanto em Newton (implicitamente) quanto em Leibniz (explicitamente). O primeiro apela em seus trabalhos para as idéias intuitivas de "movimentos contínuos", enquanto o segundo apela para o seu "postulado de continuidade". Leibniz, por outro lado, procurou dar também uma interpretação da noção de continuidade em termos de agregados. Para Leibniz, um conjunto forma um continuum "se entre quaisquer dois elementos existe sempre um outro elemento do conjunto" (apud Boyer, 1949, p.291). A definição de Leibniz tem mais a ver com a noção de densidade do que propriamente com a de

\footnotetext{
${ }^{141}$ Galileu se inspirou em uma situação empírica em que se deixava um líquido viscoso escorrer sobre uma placa suficientemente inclinada. O grande físico atribuiu ao movimento realizado pelo líquido a propriedade de ser contínuo.
} 
continuidade.

Já Bolzano e Cauchy, ao contrário de Newton e Leibniz, definem o conceito de continuidade para funções por intermédio da operação de limite. No entanto, o que se buscava nesse momento histórico da matemática é uma definição de conjuntos e agregados contínuos que não dependesse da noção de limite. Nesse sentido, pode-se afirmar que a construção do conjunto dos números reais de modo independente da noção de limite foi, ao mesmo tempo, a substância e a fonte de inspiração desse empreendimento. Foi o matemático alemão $R$. Dedekind (1831-1916), apenas no final do século XIX, quem vislumbrou inicialmente uma solução para a construção simultânea da idéia de continuidade e dos números reais de modo independente da noção de limite.

R. Dedekind foi buscar na geometria o elemento básico da idéia de continuidade. Perguntou-se o matemático se existia na "magnitude geométrica contínua" algo que resolvesse essa dificuldade, visto que a aritmética havia aparentemente fracassado. Depois de "pensar nisso sem resultado por muito tempo", descobre o matemático, a "essência" do conceito de continuidade. Mais precisamente, em 1872, no seu trabalho "Continuidade e Números Irracionais", Dedekind enuncia a sua grande "descoberta":

(...) nós atribuímos à reta a qualidade de ser completa, sem lacunas, ou seja, contínua. Mas esta continuidade, em que consiste? A resposta a esta pergunta deve compreender em si tudo, e somente ela permitirá desenvolver em bases científicas o estudo de todos os campos contínuos. Naturalmente, não se consegue nada quando, para explicar a continuidade, se fala, de um modo vago, de uma conexão ininterrupta nas suas partes mais pequenas; o que se procura é formular uma propriedade característica e precisa da continuidade que possa servir de base a deduções verdadeiras e próprias.

Pensei nisso sem resultado por muito tempo, mas, finalmente achei o que procurava. O meu resultado será talvez julgado, por várias pessoas, de vários 
modos, mas a maior parte, creio, será concorde em considerá-la bastante banal. Consiste ela na consideração seguinte:

Verificou-se que todo ponto da reta determina uma decomposição da mesma em duas partes, de tal natureza que todo ponto de uma delas está à esquerda de todo ponto da outra. Ora, eu vejo a essência da continuidade na inversão desta propriedade e, portanto, no princípio seguinte: se uma repartição de todo os pontos da reta em duas classes é de tal natureza que todo ponto de uma das classes está à esquerda de todo os pontos da outra, então existe um e um só ponto pelo qual é produzida esta repartição de todos os pontos em duas classes, ou esta decomposição da reta em duas partes.

Como já disse, creio não errar admitindo que toda gente reconhecerá imediatamente a exatidão do princípio enunciado. A maior parte dos meus leitores terá uma grande desilusão ao aprender que é esta banalidade que deve revelar 0 mistério da continuidade. A este propósito observo o que segue. Que cada um ache 0 princípio enunciado tão evidente e tão concordante com a sua própria representação da reta, isso satisfaz-me ao máximo grau, porque nem a mim nem a ninguém é possível dar deste uma demonstração qualquer. A propriedade da reta expressa por este princípio não é mais que um axioma, e é sob a forma deste axioma que pensamos a continuidade da reta, que reconhecemos à reta a sua continuidade.

(apud Caraça, 1989, p.59-60)

Em resumo, Dedekind caracteriza a continuidade da reta pela afirmação de que todo "corte" da reta é produzido por um ponto dela mesma, isto é, qualquer que seja o corte $(A, B)$, gerado pelos conjuntos $A$ e $B$, existe sempre um ponto da reta que "separa" as duas classes ( $A)$ e (B). Esta afirmação, da qual "nem a mim nem a ninguém é possível dar uma demonstração qualquer", tornou-se conhecida desde então como o postulado da continuidade de Dedekind. Os números reais são obtidos, a partir deste postulado, por uma extensão dos racionais para um domínio contínuo:

(...) chamo número real ao elemento de separação das duas classes dum corte qualquer no conjunto dos números racionais; se existe um número racional a separar as duas classes, o número real coincidirá com esse número racional; se não existe tal número, o número racional dir-se-á irracional.

(apud Caraça, 1989, p.62)

O número real de Dedekind é uma criação da mente humana, livre das intuições de espaço e tempo, fruto da imaginação material de 
um cientista no exercício de fazer ciência. Irônica e curiosamente foi a própria geometria que forneceu o elemento básico para a transposição geométrica do conceito de continuidade. A geometria sugeriu o caminho para uma definição sutil de continuidade, e foi, no final do processo, excluída da definição formal e aritmética deste conceito. Agora o "teorema fundamental sobre limites" 142 poderia ser provado rigorosamente e sem se recorrer à geometria.

O axioma de Dedekind possui outras formas de apresentação equivalentes - talvez a mais conhecida (e mais usada também no campo pedagógico) delas seja a de Cantor, em que é postulada a existência de uma correspondência biunívoca entre o conjunto dos números reais e a reta. Talvez seja por esta razão que alguns textos didáticos de Análise adotam o termo "axioma de Dedekind-Cantor" para significar qualquer uma das versões desse axioma.

A definição de número real dada por Dedekind é equivalente às definições de número real dadas por Weierstrass, Méray, Heine e Cantor, mas possui características bem diferenciadas. Para Dedekind, o número real é o elemento de separação de cortes racionais enquanto que para os demais ele é um agregado de números racionais (formado de elementos de uma série de racionais convergente dentro de si mesma). Assim, numa tentativa de harmonizar a definição de Dedekind em termos de cortes com a visão de número como agregado, Bertrand Russell (1872-1970) elabora uma outra definição de número real. Russell sugeriu que um número real fosse definido não como o elemento

\footnotetext{
${ }^{142}$ Diz-se que uma seqüência $\mathrm{x}_{\mathrm{n}}$ é de Cauchy se, dado $\varepsilon>0$, existe um inteiro positivo $\mathrm{n}_{\mathrm{o}}$ tal que $\left|\mathrm{x}_{\mathrm{n}}-\mathrm{x}_{\mathrm{m}}\right|<\varepsilon$, quaisquer que sejam $\mathrm{n}, \mathrm{m}>\mathrm{n}_{\mathrm{o}}$. Isto posto, temos que o "teorema fundamental sobre limites" nos diz que: Toda seqüência de Cauchy, de números racionais, converge para um (único) número real.
} 
de separação, mas como sendo um (o "menor" deles) dos "segmentos" de números racionais determinados pelo corte. Nesse sentido, o número real irracional $\sqrt{2}$, por exemplo, seria definido como um agregado formado pela união do conjunto dos números racionais negativos com o conjunto de todos os números racionais cujos quadrados são menores que 2.

Antes de prosseguirmos seria interessante observar que Dedekind e Russell construíram o conceito de número real a partir apenas da noção de classes ordenadas. A propriedade essencial do número real 2, por exemplo, não é a sua magnitude, mas o seu lugar no conjunto ordenado dos números reais. Cabe lembrar ainda que os esforços dessas tentativas em construir os números reais tinham como meta dar a estes uma definição lógica e formal que fosse independente das intuições geométricas e que evitasse o "círculo vicioso" de Cauchy. Feito isto, a Análise - agora Análise Real - foi consolidada e edificada sobre dois alicerces fundamentais: os conceitos de número real e de continuidade. Resta, portanto, nessa perspectiva standard da fundamentação das idéias do Cálculo, apenas um obstáculo para ser vencido: a clarificação $e$ inserção definitiva do infinito atual nos procedimentos da Análise.

Não há como provar a existência ou não de conjuntos infinitos no sentido físico, tampouco há a possibilidade de execução de uma operação com um número infinito de etapas. Galileu vislumbrou esta última dificuldade: como pode - disse o pensador italiano - uma soma infinita ter um resultado finito? Segundo Boyer (1949, p.295), a ciência não pode responder este ponto: a questão da existência ou não do infinito deve ser posta em termos hipotético na matemática. 
No entanto, mesmo na matemática, a construção da noção de infinito atual só foi possível tardiamente. Até meados do século XIX, a idéia de infinito que predominou na matemática - salvo algumas exceções como, por exemplo, o infinito categoremático medieval - foi o infinito potencial de Aristóteles: infinito como algo indefinidamente grande. Tal significação do infinito esteve presente mesmo na fundamentação da Análise desenvolvida por Weierstrass.

Com efeito, Weierstrass em sua Análise considera apenas o infinito potencial. A construção do infinito atual começa pela conscientização de uma anomalia típica dos conjuntos infinitos: no universo dos conjuntos infinitos é possível que a "parte seja igual ao todo"; isto é, é possivel encontrar um subconjunto do conjunto infinito que pode ser posto em correspondência biunívoca com o próprio conjunto.

Esta anomalia essencial dos conjuntos infinitos foi percebida por Bolzano e também por Cauchy, o que fez inclusive com que este último rejeitasse a possibilidade da existência do infinito atual. Por outro lado, Dedekind e Cantor - que mantinham correspondências entre si souberam tirar proveito desse comportamento paradoxal dos conjuntos infinitos, explicitado inicialmente por Bolzano, para definir conjuntos infinitos. Segundo Dedekind:

Um sistema $S$ é dito ser infinito quando ele é similar a uma parte de si próprio; em caso contrário $S$ é dito ser um sistema finito.

(apud Boyer, 1949, p.296)

Com esta definição, os conjuntos infinitos passam a existir como um conceito logicamente autoconsistente, totalmente integrado ao conhecimento matemático. Cantor, no entanto, vai além: procura 
realizar uma "tipificação" da noção de infinito em uma série de papers, em que revisava a história do infinito de Demócrito a Dedekind. Partindo do infinito categoremático, desenvolvido pelos escolásticos, Cantor desenvolveu a sua doutrina do infinito.

Desde a época de Wallis, o símbolo $\infty$ foi usado pelos matemáticos para representar o infinito em diversos contextos e com significados bem diferenciados. Ora foi usado para representar "o maior inteiro positivo" (como fez Fontenele, por exemplo), ora para significar o crescimento indefinido de uma variável (como sugeriu Weierstrass ao escrever a expressão $f(\infty)=b$ ), etc. Assim, para evitar este tipo de confusão de significados com respeito ao mesmo símbolo, Cantor criou a sua própria forma de representação. Para representar todos os elementos do conjunto dos números inteiros positivos usou o símbolo $\omega$. Cantor mostrou que o conjunto dos números racionais pode ser colocado em correspondência biunívoca com - conjunto dos números inteiros positivos, e, por esta razão, essas duas classes de números têm a mesma potência. Esse fato não ocorre com o conjunto dos números reais, o que faz com este último conjunto tenha uma potência superior, que foi representada pelo símbolo $C$. Esses "números", que representam as potências do infinito, são chamados números transfinitos. Assim, w é um número transfinito, $C$ é um número transfinito, $e \omega<C$. Já se conhecem exemplos de números transfinitos maiores que $C$, mas não se tem exemplos desses números entre $\omega$ e $C$. No entanto, cabe ressaltar que a definição de variável contínua, e, por conseguinte, de todos os conceitos básicos do Cálculo, requerem apenas os infinitos do tipo $\omega$ e $C$ de Cantor. 


\title{
4.2.7. A análise não-standard de Robinson: a solução não-standard da fundamentação do Cálculo Infinitesimal
}

\author{
É curioso que ninguém tenha feito qualquer objeção a $\sqrt{-1}$ \\ como tendo alguma contradição, \\ nem as quantidades infinitamente grandes, \\ desde Cantor, foram questionadas, \\ mas ainda permanece o preconceito contra \\ as quantidades infinitamente pequenas. \\ C. S. Peirce em "The New Elements of Mathematics"
}

A Análise de Cauchy-Weierstrass - agora Análise Real - foi consolidada $e$ edificada sobre dois alicerces fundamentais: os conceitos de número real e de infinito - tendo na operação de limite, tal como Weierstrass a definiu, sua operação fundamental. Assim, observando que o conjunto dos números reais IR satisfaz ao axioma de Arquimedes (que estabelece que dados dois números positivos $a, b$ com $a<b$, é sempre possivel ultrapassar o segundo por adição sucessiva de termos iguais ao primeiro ${ }^{143}$ ) pode-se perceber porque os infinitesimais não foram bem vindos a essa "nova análise" e banidos temporariamente do mundo acadêmico da matemática.

Com efeito. Suponha a existência do número infinitesimal $d x$. Pelo axioma de Arquimedes, existe $n \in N$, suficientemente grande, tal que $n . d x>1$, ou seja, existe um número real racional positivo $1 / n<d x, 0$ que contradiz a própria definição do infinitesimal $\mathrm{d} x$, a menos que ele o infinitesimal - fosse o próprio número real zero. Isto posto, percebe-se que, dada a estrutura arquimediana da reta real, uma

\footnotetext{
${ }^{143}$ Dito de outro modo, existe sempre um número natural $\mathrm{n}$ para o qual se verifica a relação $a+a+\ldots+a(n-v e z e s)>b$.
} 
quantidade infinitesimal é necessariamente nula; sendo o contínuo divisível sem resto até o infinito, não poderiam aí existir nem "átomos" indivisíveis fazendo parar o processo de divisão, nem infinitamente pequenos que o excedam (Petitot, 1985b, p.210).

Desde então, todos os elementos estranhos ao conjunto $R$ foram banidos dos textos de análise matemática em geral, embora a referência a infinitésimos tenha persistido até os dias de hoje em textos de outras disciplinas científicas que fazem uso do cálculo, como é o caso da física, da matemática aplicada e das ciências tecnológicas. Nestas áreas do conhecimento, os infinitesimais continuam sendo uma importante ferramenta para a criação e o estudo de novos modelos matemáticos. Mas, e o tal rigor matemático, como é que fica? São, os infinitésimos, abordagens ingênuas e inconsistentes da matemática?

Para os físicos e engenheiros este rigor é bem menos necessário $e$ importante do que para o matemático aplicado e o educador matemático. A "pressão ideológica" da escola formalista é muito maior nestes dois últimos. Entretanto, para que se alcançasse a formalização do conceito de infinitesimal, foi preciso reconstruir a Análise. Não se trata de destruir o que já havia sido construído - a Análise Real -, mas, sim, de estender as suas definições e os seus resultados para um domínio mais geral em que a noção de infinitesimal pudesse ser fundamentada de forma rigorosa. Tal fato só se tornou possível com a evolução da lógica matemática no início do século $X X$, mais precisamente com o desenvolvimento da teoria dos modelos que "analisa as relações existentes entre uma estrutura matemática concreta e a sua teoria, no sentido formal do termo". É nesse 
contexto que surge aquela que seria a redenção das quantidades infinitesimais: a Análise Não-Standard.

A Análise Não-Standard foi desenvolvida pelo matemático Abraham Robinson (1918-1974) em pleno século XX, há menos de quarenta anos. Segundo Pinto (2000, p.28), o seu aparecimento pode talvez se situar, oficialmente, na data de publicação do artigo Nonstandard Analysis, Proc. Roy. Acad. Sci., Amsterdam (A), 64 (1961), p.437-440, em que A. Robinson, pela primeira vez, usou um modelo nãostandard da reta numérica para elaborar um desenvolvimento do Cálculo Infinitesimal que segue muito de perto o estilo dos seus criadores no século XVII, particularmente o de Leibniz. Cinco anos depois, no já célebre livro texto Nonstandard Analysis, North Holand (1966) Robinson consolida o prestígio de sua análise mostrando como se podem aplicar, com vantagem, os seus métodos a muitas áreas distintas da Matemática. Mas foi, contudo, o estudo e o desenvolvimento do cálculo elementar que despertaram o maior interesse da comunidade científica. Vejamos agora como se realizou esta nova etapa de desenvolvimento das quantidades infinitesimais. 


\section{Reconstruindo os infinitesimais}

Segundo Petitot (1985b, p.210-11) a história das quantidades infinitesimais pode dividir-se de modo aproximado em três períodos:

(...) o primeiro, de Leibniz a Cauchy, passando por Euler, é o da elaboração do cálculo diferencial e integral (no estilo leibniziano). 0 segundo, que conduz diretamente à análise contemporânea, começa, com Cauchy e Weierstrass, por uma crise de rigor, pela eviç̧ão dos infinitesimais leibnizianos e sua substituição por um cálculo de limites. Este novo cálculo, sintática e semanticamente consistente, revelou-se de uma tal eficácia que a questão inicial do estatuto lógico-conceitual dos infinitesimais se encontrou pouco a pouco sedimentada, relegada, apagada, recalcada e, em qualquer caso, uma curiosidade para filósofos (se bem que certos matemáticos como C.S. Peirce lhe atribuissem ainda uma grande importância). Só nos anos 60 ela será reativada pela análise não-standard, e de um modo bastante estranho, à primeira vista.

Em seguida o autor complementa que a temporalidade própria da história lógico-conceitual dos infinitesimais é uma temporalidade ramificada e recorrente que pode ser esquematizada - segundo ele -, grosso modo, por intermédio da figura seguinte.

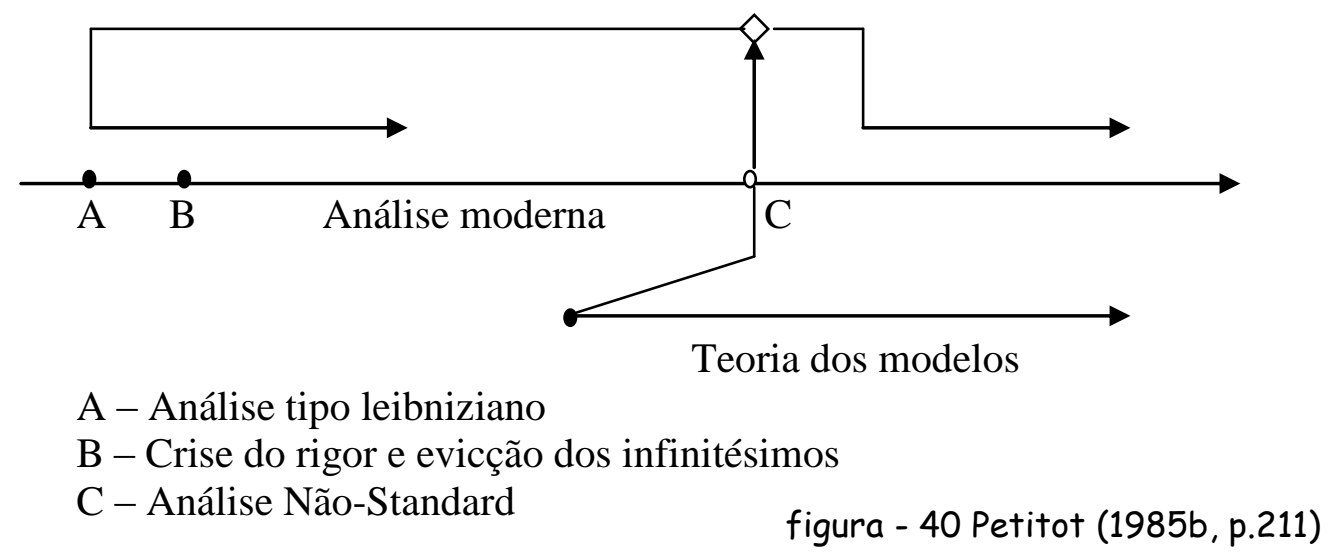

Segundo Pinto (2000, p.14-15), a Análise Não-Standard constitui, de certo modo, um regresso a Leibniz. O autor apresenta dois argumentos muito fortes para a sua afirmação: 
Em primeiro lugar, porque Leibniz advogava abertamente o uso de números infinitos e infinitesimais para o desenvolvimento do Cálculo. Em segundo lugar, porque sendo Leibniz um precursor da lógica matemática, está, por esse fato, na origem do instrumento que viria a servir para justificar plenamente a legitimidade do uso daquele tipo de quantidades - a teoria dos modelos.

Com efeito, Leibniz preconizava para o estudo do Cálculo Infinitesimal a adoção de um sistema numérico mais amplo que o dos números reais que incluísse, para além destes, números "ideais" infinitos e infinitesimais e no qual continuassem a verificar-se as leis usuais dos números ordinários. A construção de tal sistema, nas condições propostas por Leibniz, é - conforme já vimos - impossível!

Contudo, a utilização de números infinitos e infinitesimais persistiu durante todo o século XVIII e parte do seguinte. Euler, os Bernoulli, Lagrange, D'Alembert, Bolzano e Cauchy, por exemplo, não só obtiveram excelentes resultados usando números infinitos $e$ infinitesimais, como ainda se empenharam, sem, contudo, conseguir, na busca de sua fundamentação lógica. Apesar dos sucessos obtidos, a noção de "infinitésimo" - segundo Pinto (2000, p.27) - nunca foi devidamente clarificada e o seu uso imoderado conduziu o desenvolvimento do Cálculo a sérias inconsistências e dificuldades que não puderam ser superadas senão em meados do século $X X$.

Em 1958, baseado em uma generalização da construção de Cantor dos números reais, C. Schmieden e D. Laugwitz (1958) apresentaram o sistema dos números reais estendidos, que continham os números infinitamente pequenos e os infinitamente grandes. Completamente independente do trabalho de Schmieden e Laugwitz, Abraham Robinson descobriu um novo método de interpretar $e$ resolver o duplo problema do cálculo infinitesimal levantado por 
Berkeley: a "existência dos infinitesimais" e o de como "operar com eles [os infinitesimais]" (caso eles existam). Tendo observado que os infinitesimais não podem existir como números "ordinários", Robinson sugeriu um "alargamento" do sistema de números reais - o conjunto dos números hiper-reais ${ }^{*} R$; um conjunto contendo tanto os números infinitesimais quanto infinitos, e que contém um subconjunto isomorfo ao conjunto dos números reais.

Os princípios básicos e leis que governam esses novos números são descritos pelo princípio da transferência (que é, em essência, equivalente ao princípio de continuidade de Leibniz):

Qualquer coisa que possamos dizer que seja uma proposição verdadeira sobre os números reais será também verdadeira sobre os números hiper-reais.

(apud Oliveira, 1993, p.53)

Ora, tal como está enunciado, o princípio de transferência precisa ser passado a limpo, uma vez que sabemos que a extensão pretendida - e que contém, sobretudo, os "números infinitesimais" não pode satisfazer à propriedade arquimediana do conjunto dos números reais. Assim, para desfazer essa situação paradoxal, Robinson restringe a afirmação "as mesmas propriedades" a uma coleção específica de proposições que podem ser formuladas em uma linguagem formal especificada, com a interpretação apropriada em $R e$ em * $R$, e na qual o teorema clássico de isomorfismo para o sistema de números reais não possa ser formulado.

Usando a teoria dos modelos, Robinson garante a existência de um sistema de números que se ajusta às metas traçadas. Há, no entanto, vários modos de construir o conjunto dos hiper-reais. Como já falamos no corpo desta tese da construção dos reais a partir dos 
racionais, daremos preferência à construção dos hiper-reais que é realizada por analogia a esta primeira. Pouparemos o leitor aqui dos detalhes técnicos dessa construção - como, por exemplo, o das demonstrações de certos resultados -, de modo que se possa ter uma idéia geral de todo o processo. O leitor que quiser elaborar um estudo mais detalhado dessa teoria poderá encontrar um vasto material a respeito em (Oliveira, 1993), (Stroyan \& Luxemburg, 1976) e (Cutland, 1988), por exemplo.

\section{A construção de ${ }^{*} R$}

Se $C$ for o conjunto de todas as sequiências de Cauchy de racionais e se $\equiv$ for a relação de equivalência sobre $\mathcal{C}$ definida por:

$\left\{a_{n}\right\} \equiv\left\{b_{n}\right\}$ se e somente se $\lim _{n \rightarrow \infty}\left(a_{n}-b_{n}\right)=0$,

então os reais são precisamente $\operatorname{IR}=(C / \equiv)$, o conjunto de todas as classes de equivalências.

Para definir as operações algébricas sobre IR, indicamos por $\left\langle a_{n}\right\rangle$ a classe de equivalência da sequiência $\left\{a_{n}\right\}$ e definimos a adição e a multiplicação componente a componente por:

$$
\left\langle a_{n}\right\rangle+\left\langle b_{n}\right\rangle=\left\langle a_{n}+b_{n}\right\rangle \text { e }\left\langle a_{n}\right\rangle \cdot\left\langle b_{n}\right\rangle=\left\langle a_{n} \cdot b_{n}\right\rangle
$$

A ordem em IR é definida por:

$$
\left\langle a_{n}\right\rangle\left\langle\left\langle b_{n}\right\rangle \text { se existe } \varepsilon \in Q_{+} \text {tal que } a_{n}<b_{n}-\varepsilon\right.
$$

para todo $n$ suficientemente grande. Além disso, podemos identificar os racionais como um subconjunto de IR, por meio da imersão: $a \rightarrow\langle a, a, a, \ldots\rangle$. 
A construção de ${ }^{*} R$ segue a mesma estratégia. Considere $S O$ conjunto de todas as seqüências de números reais. Introduzimos uma relação de equivalência $\sim$ sobre $S$ e definimos então ${ }^{*} R$ como $(S / \sim)$ o conjunto de todas as classes de equivalência. Mas, se na construção de $I R$, os elementos das classes de equivalência $\left\langle a_{n}\right\rangle$ eram identificados apenas pelo ponto limite, independente de suas "velocidades" de convergência - ou seja, $\{1 / n\}$ e $\left\{1 / n^{2}\right\}$, neste caso, pertenciam à mesma classe -, na relação de equivalência que age sobre $S$ leva-se em conta também o modo de convergência - assim, $\langle 1 / n\rangle$ e $\left\langle 1 / n^{2}\right\rangle$ representam classes distintas, e são, portanto, números hiper-reais diferentes. A fim de definir rigorosamente a relação de equivalência " " faz-se necessário a construção de uma linguagem mais específica ${ }^{144}$. No entanto, podemos abreviar este percurso, sem perda substancial da idéia de sua construção, utilizando uma linguagem mais acessivel e intuitiva.

Definição. Seja " " a relação de equivalência sobre o conjunto $S$ de todas as sequiências de números reais dada por:

$\left\{a_{n}\right\} \sim\left\{b_{n}\right\}$ se e somente se $\left\{a_{n}\right\}$ for igual $a\left\{b_{n}\right\}$ quase em toda parte.

A fim de prosseguir em nossa construção simplificada dos hiperreais, o leitor poderá assumir a expressão "quase em toda parte" como sendo equivalente ao fato das sequiências envolvidas apresentarem termos correspondentes diferentes apenas para uma quantidade finita destes, isto é, $a_{n}$ deixa de ser igual a $b_{n}$ para uma quantidade finita de

\footnotetext{
144 Faz parte dessa linguagem a definição de conceitos tais como medida, filtro, ultrafiltro, utrafilltro livre etc e um breve estudo de algumas de suas propriedades básicas.
} 
valores $n \in N$. Isto posto, define-se o conjunto dos reais nãostandard ou dos hiper-reais por ${ }^{*} R=(S / \sim)$. Para representarmos um número hiper-real utilizaremos um elemento de sua própria classe: $\left\langle a_{n}\right\rangle$. Podemos então definir a adição e multiplicação em * $R$ por

$$
\left\langle a_{n}\right\rangle+\left\langle b_{n}\right\rangle=\left\langle a_{n}+b_{n}\right\rangle \text { e }\left\langle a_{n}\right\rangle .\left\langle b_{n}\right\rangle=\left\langle a_{n} \cdot b_{n}\right\rangle,
$$

onde $a_{n}+b_{n}$ e $a_{n} \cdot b_{n}$ representam a soma e o produto (termo a termo), respectivamente, em IR.

A ordem em ${ }^{*} R$ é definida por:

$$
\left\langle a_{n}\right\rangle\left\langle\langle b _ { n } \rangle \text { se e somente se } a _ { n } \left\langle b_{n}\right.\right. \text { quase em toda parte. }
$$

É evidente que todas as definições independem dos elementos representantes escolhidos (provar isso é um bom exercício de Análise Real!). Além disso, com tais definições, $\left({ }^{\star} R,+,.\right)$ é um corpo ordenado cujo elemento zero é $0=\langle 0,0,0, \ldots>$ e cujo elemento unidade é $1=\langle 1,1,1$, ...>. Além disso, podemos identificar os reais IR como um subconjunto de ${ }^{\star} R$, por meio do homomorfismo injetor: $a \rightarrow\langle a, a, a, \ldots\rangle$. Desse modo, todos os números reais são elementos de ${ }^{\star} R$. Mas onde estão (e o que são?) os números infinitesimais e os números infinitos?

\section{Definição:}

i) Um elemento $x \in{ }^{\star} R$ é infinitesimal se $-a<x<$ a para todo número real positivo a.

ii) Um elemento $x \in{ }^{\star} R$ é finito se $-a<x<$ a para algum número real positivo a.

iii) Um elemento de ${ }^{\star} R$ que não seja finito é chamado infinito. 
$\delta_{1}=\langle 1 / n\rangle, \delta_{2}=\left\langle 1 / n^{2}\right\rangle$ e $0=\langle 0,0,0, \ldots\rangle$ são exemplos de números infinitesimais, sendo o zero o único número real infinitesimal. Por outro lado, $\langle n\rangle$ e $\left\langle-n^{2}\right\rangle$ são exemplos de números infinitos, sendo o primeiro deles, positivo, e o último, negativo. Note, a partir das definições, que todo número infinitesimal é finito, que a soma e o produto de infinitesimais é ainda um número infinitesimal e que o produto de um número finito e um número infinitesimal é um número infinitesimal. Note ainda que o inverso de um número infinito é um número infinitesimal.

Podemos, além disso, caracterizar os números hiper-reais finitos a partir dos números infinitesimais e números reais como segue:

Proposição: Qualquer $x \in{ }^{\star} R$ finito pode ser escrito de modo único como uma soma $x=a+\varepsilon$, onde $a \in \mathbb{I R} e \varepsilon$ é um infinitesimal.

Por se tratar de um resultado fundamental que relaciona as duas estruturas algébricas (IR $e^{\star} R$ ) que dão o suporte numérico às duas abordagens da análise (análise real e a análise não-standard), realizaremos a demonstração deste resultado.

\section{Demonstração:}

Com efeito. Suponha que existam duas representações para o número hiper-real finito $x: \quad x=a_{1}+\varepsilon_{1}=a_{2}+\varepsilon_{2}$, onde $a_{1} e a_{2} \in \mathbb{R}$, e $\varepsilon_{1}$ e $\varepsilon_{2}$ são números infinitesimais. Assim, $a_{1}-a_{2}=\varepsilon_{2}-\varepsilon_{1}$. Como essa quantidade é simultaneamente real e infinitesimal, temos que esta deve ser o número real zero. Logo $a_{1}=a_{2} e \quad \varepsilon_{2}=\varepsilon_{1}$. 
Para mostrar a existência, considere o número real $a=\sup \{b \in I R ; b<x\}{ }^{145}$. Como $x$ é um número hiper-real finito, o conjunto citado é limitado superiormente, o que nos permite, através do axioma de Dedekind-Cantor em IR, garantir a existência do número real a. Assim, para construir a decomposição, considere $\varepsilon=x-a$; devemos mostrar então que $\varepsilon$ é um número infinitesimal. De fato. Suponha que $\varepsilon$ não seja um infinitesimal; então existe um número real $r$ tal que $0<r<|x-a|$ (o valor absoluto em ${ }^{\star} R$ é definido do mesmo modo que em IR). Se $x-a>0$, isso implica $a+r<x$, contrariando a escolha de $a$. Por outro lado, se $x$-a< 0 , implica que $x<a-r$, o que também contraria a escolha de a, o que prova o resultado.

A partir do resultado acima, pode-se afirmar que um número hiper-real finito é, em essência, composto de duas partes distintas, uma real, e outra infinitesimal. Por isso, o único número real a que identifica a parte real do número finito $x$ é em geral denominado a parte standard de $x$ e é denotado por ${ }^{\circ} x$ ou st( $x$. Por outro lado, associado a um número real $a$, temos uma infinidade de números hiperreais $x$. Assim, ao conjunto dos números hiper-reais $x$ tais que ${ }^{\circ} x=a$ chamamos de mônoda de a.

De um ponto de vista bem informal, uma forma de visualizar esses conceitos "geometricamente" é como segue:

\footnotetext{
${ }^{145} \mathrm{O}$ supremo de um subconjunto A de IR é (caso exista) o número real $\alpha$ tal que: (a) $\forall \mathrm{x} \in \mathrm{A}$, $\mathrm{x}\langle\alpha$; (b) $\forall \beta \in \mathrm{IR}$ tal que $\beta>\mathrm{x} \forall \mathrm{x} \in \mathrm{A} \Rightarrow \beta>\alpha$. O supremo de um conjunto é efetivamente a "menor cota superior" do conjunto dado. Em IR, uma condição necessária e suficiente para a
} 


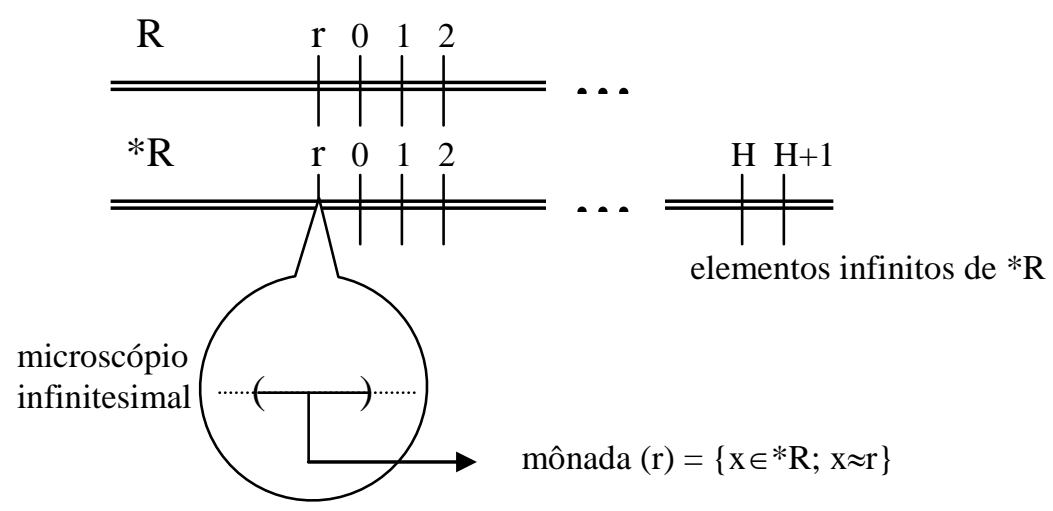

em que $x \approx r$ indica que $x$ e $r$ estão infinitamente próximos, isto é, que $x-r$ é infinitesimal.

Isto posto, pode-se afirmar que * $R$ é um corpo ordenado, embora não completo; a mônoda do zero, por exemplo, que é o conjunto dos infinitésimos, é limitada mas não possui supremo e nem ínfimo. É precisamente nesse novo sistema numérico que se fundamenta não só a definição de infinitesimal, bem como todos os procedimentos infinitesimais do Cálculo e da Análise. Surge assim a Análise NãoStandard, uma Análise que não nega a Análise Real; mas, que, ao contrário, é uma extensão desta última.

No entanto, ao invés de prosseguirmos com a construção dos elementos fundamentais da Análise Não-Standard, optamos por retornar à do Cálculo Infinitesimal, com o objetivo de "corrigir" as "imperfeições" dos procedimentos infinitesimais clássicos, desenvolvidos e difundidos por Leibniz e seus seguidores. A fundamentação da Análise Não-Standard foge ao escopo desta tese. Por outro lado, a justificação e a re-significação dos métodos infinitesimais desenvolvidos no Cálculo sob o ponto de vista não- 
standard, estas sim, são de nosso interesse. A apresentação simplificada da construção dos números hiper-reais foi realizada aqui tão somente com o objetivo de fornecer uma linguagem básica (e mínima) para que pudéssemos realizar a nossa meta de reinterpretar os métodos infinitesimais. Cabe ressaltar, entretanto, que continuaremos a adotar aqui a nossa atitude moderada com relação às justificações lógicas dos resultados matemáticos ora apresentados; o nosso compromisso é com a fundamentação e o entendimento do Cálculo Infinitesimal, e não com a fundamentação da Análise NãoStandard ou mesmo da Análise Real. A relação entre estas duas últimas representa ainda um vasto e maravilhoso campo de investigação recente em Matemática, mas isto é assunto para outras teses... Por ora, voltemos ao Cálculo Infinitesimal, só que agora - conforme já dissemos - através de uma abordagem não-standard. Cabe ainda ressaltar que, apesar do método infinitesimal que se expõe a seguir não ter o formalismo da análise não-standard, seus procedimentos são todos justificáveis por esta última.

\section{O Cálculo Não-Standard}

Nós nos ocuparemos aqui da análise não-satandard dos dois problemas fundamentais do Cálculo Diferencial e Integral: o problema da tangente e o problema de cálculo de áreas. 


\section{$O$ problema da tangente}

No desenvolvimento histórico do Cálculo, verificam-se dois modos de intuir uma tangente: um "dinâmico" e outro "estático". Cada um origina um código escritural específico, conforme nos revela Petito† (1985b, p. 214-15).

1) Na intuição dinâmica, a reta $\tau_{f}\left(x_{0}\right)$ é o limite das secantes $M_{0} M_{1}$ de (C) para o ponto $M_{1}$ que tende para o ponto $M_{0}$.

Esta intuição "passa" facilmente à escrita. $M_{1}$ é o ponto de coordenadas $\left(x_{0}+\Delta x, f\left(x_{0}+\Delta x\right)\right)$ em que $\Delta x$ é um incremento de $x$ tendendo para zero. O coeficiente angular da reta $M_{0} M_{1}$ é então $\Delta f / \Delta x$ onde $\Delta f$ é 0 incremento $f\left(x_{0}+\Delta x\right)-f\left(x_{0}\right)$ de $f$ correspondente a $\Delta x$. A tangente $\tau_{f}\left(x_{0}\right)$ de (C) em $M_{0} e$ é, por consequiência, a reta passando em $M_{0}$ e tendo por coeficiente angular o limite - que se escreve $f^{\prime}\left(x_{0}\right)$ e se denomina derivada da função $f(x)$ em $x_{0}$ - da relação $\Delta f / \Delta x$ quando $\Delta x$ tende para zero.

2) Na intuição "estática" a tangente não é definida por um processo (passagem ao limite), mas por uma posição. A tangente $\tau_{f}\left(x_{0}\right)$ é a reta que corta (C) em $M_{0}$ em dois pontos infinitamente vizinhos. É a reta que - numa vizinhança infinitesimal de $M_{0}$ - se identifica com (C). Para fazer "passar" à escrita esta intuição é necessário:
a. Introduzir a noção de incremento infinitesimal $d x$ de $x$;
b. Definir o incremento infinitesimal $d f=f\left(x_{0}+d x\right)-f\left(x_{0}\right)$ de $f$ em $x_{0}$ correspondente a $d x$;
c. Construir a hipótese de que a relação $d f / d x$ seja definida e constante para todo o dx (é esta constância que codifica a intuição que (C) é localmente indiscernivel da sua tangente):
d. Definir a derivada (coeficiente angular da tangente) $f^{\prime}\left(x_{0}\right)$ de $f$ em $x_{0}$ como igual a esta relação constante.

A abordagem dinâmica do problema foi a perspectiva de Newton (pelo menos em parte), depois de D'Alembert, e enfim, de Cauchy e sobretudo de Weierstrass, culminando com a construção do conceito de derivada definida pelos dois últimos.

Por outro lado, foi Leibniz quem imortalizou a definição "estática" de tangente - ainda que de forma problemática e 
ambivalente. As críticas sofridas, já as conhecemos. Vejamos agora como justificá-las do ponto de vista não-standard.

Seja $\Gamma$ a curva plana de equação $y=f(x)$ que passa pelo ponto $M_{0}$ de coordenadas $\left(x_{0}, y_{0}\right)$ : define-se a tangente a $\Gamma$ em $M_{0}$ como sendo reta $\tau_{f}\left(x_{0}\right)$ que melhor aproxima $\Gamma$ numa vizinhança adequada de $M_{0}$. $\mathrm{Na}$ intuição geométrica estática, defendida por Leibniz e seus seguidores, a tangente $\tau_{f}\left(x_{0}\right)$ é a reta que corta $\Gamma$ em dois pontos infinitamente próximos (pertencentes a uma mesma vizinhança infinitesimal de $M_{0}$ ), ou seja, é a reta que, numa vizinhança infinitesimal de $M_{0}$ e a menos de um infinitésimo, se identifica com $\Gamma$. Não existe nenhuma outra reta com a propriedade local de, passando por Mo, se situar entre $\Gamma$ e $\tau_{f}\left(x_{0}\right)$. Para uma melhor ilustração de nossa explicação, consideremos $\Gamma$ como sendo a parábola $y=x^{2}$ e $M_{0}=$ $(1,1)$.

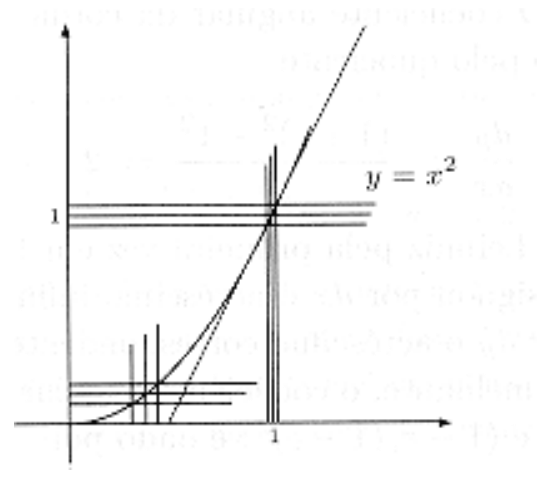

figura 41 - extraída de (Pinto, 2000, p.17)

Considere então, na linha $y=x^{2}$, um outro ponto $M_{1}$ infinitamente próximo de $(1,1)$. Assim, $M_{1}$ tem coordenadas $\left(1+\varepsilon,(1+\varepsilon)^{2}\right)$, em que $\varepsilon$ é um número infinitesimal. O coeficiente angular da corda que passa por estes dois pontos é dado pelo quociente 


$$
\frac{d y}{d x}=\frac{(1+\varepsilon)^{2}-1^{2}}{\varepsilon}=2+\varepsilon
$$

onde, tal como fez Leibniz pela primeira vez em 1684 se designou por dx o acréscimo infinitesimal da variável independente e por dy o acréscimo correspondente da variável dependente. De modo semelhante, o coeficiente angular da corda que passa pelos pontos $\left(1,1^{2}\right)$ e $\left(1-\varepsilon,(1-\varepsilon)^{2}\right)$ é dado por

$$
\frac{d y}{d x}=\frac{1^{2}-(1-\varepsilon)^{2}}{\varepsilon}=2-\varepsilon .
$$

Ora os cálculos efetuados no sistema ampliado indicam que o coeficiente angular (real) da tangente à parábola no ponto $(1,1)$ deve estar compreendido entre $2-\varepsilon$ e 2+c. Como o único número real compreendido entre esses dois elementos é 2, temos, por conseguinte, que o coeficiente angular da tangente à parábola $y=x^{2}$ no ponto $(1,1)$ é igual a 2. Então $y=2 x-1$ será a equação da tangente, $\tau_{x^{2}}(1)$, a $\Gamma$ no ponto $M_{0} \equiv(1,1)$

A solução encontrada cumpre efetivamente o prometido, isto é, coincide com $\Gamma$ numa vizinhança infinitesimal de $M_{0}=(1,1)$, a menos de uma quantidade infinitesimal. Basta observar que:

i) para $x=1$ temos $y=1$ na parábola e $y=1$ na reta tangente, $\tau_{x^{2}}(1)$;

ii) para $x=1+\varepsilon$ temos $y=1+2 \varepsilon+\varepsilon^{2}$ na parábola e $y=2(1+\varepsilon)-1$ na reta tangente, $\tau_{x^{2}}(1)$;

iii) e, finalmente, que a distância entre os dois pontos é dada por $\left|1+2 \varepsilon+\varepsilon^{2}-(1+2 \varepsilon)\right|=\varepsilon^{2}$ que é, com efeito, uma quantidade infinitesimal. 
Nessa nova abordagem infinitesimal do problema da tangente, não existem contradições e situações paradoxais. $O$ papel semanticamente inconsistente do incremento infinitesimal $\mathrm{dx}$ (de que $d x$ é e não é zero), que aparecia nos argumentos infinitesimais standards dos séculos XVII e XVIII, é substituído então por uma interpretação do problema em um sistema ampliado (dos números hiper-reais) que contém, de certo modo, o sistema inicial (dos números reais). Nesse sentido, define-se, grosso modo ${ }^{146}$, a derivada $f^{\prime}\left(x_{0}\right)$ por

$$
f^{\prime}\left(x_{0}\right)=s t\left(\frac{f\left(x_{0}+d x\right)-f\left(x_{0}\right)}{d x}\right)
$$

em que st $\left(^{*}\right)$ significa a parte standard de $\left(^{*}\right)$.

\section{Cálculo de áreas planas}

De modo análogo, podemos enfrentar o outro problema fundamental do Cálculo Diferencial e Integral: o cálculo de áreas.

Seja $\Gamma$ a curva de equação $y=f(x)$ representada na figura 42 e denote-se por $A$ a área da porção do plano limitada lateralmente pelas linhas $x=a$ e $x=b$ e superior $e$ inferiormente pelas linhas de equações $y=f(x)$ e $y=0$ para $a \leq x \leq b$, respectivamente. $O$ cálculo da área $A$ pode ser feito de uma forma muito simples, conforme nos revela Pinto (2000, p.19):

\footnotetext{
${ }^{146}$ Como $\mathrm{x}=\mathrm{x}_{0}+\mathrm{dx}$ é um número hiper-real, o símbolo $f$ que aparece no quociente representa, na verdade, uma extensão não-standard da própria função real original $f$, e, portanto, deveria ser denotado por $f^{*}$. Optamos, no entanto, pela própria expressão de $f$, uma vez que, além de não termos apresentado aqui como tal extensão não standard de $f$ é efetuada, tecnicamente falando, o procedimento rigoroso resume-se, em última instância, ao que adotamos.
} 
(...) substitui-se A por outra figura plana constituída por um número infinito de retângulos de base infinitesimal justapostos, como se indica na figura. (Entendese aqui por número infinito um número maior que todo número natural, número este cuja existência, novamente, ao modo de Leibniz, é assegurada.)

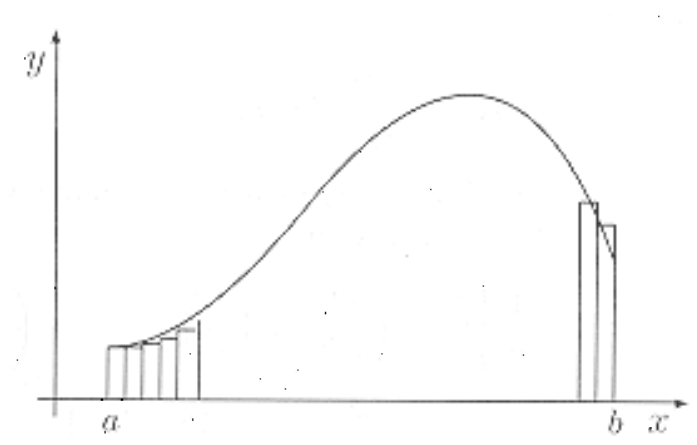

figura 42 - extraída de (Pinto, 2000, p.19)

Mais concretamente, prossegue o autor, sendo $v$ um número infinito positivo, tem-se que o comprimento infinitesimal da base comum dos retângulos é dado por

$$
d x=\frac{(b-a)}{v} .
$$

Além disso, as alturas de cada um dos retângulos infinitesimais são dados por $f(a+j d x), j=0,1,2, \ldots, v-1$.

Assim, obtém-se uma primeira aproximação para a área procurada, através da soma (infinita)

$$
f(a) d x+f(a+d x)+\ldots+f(a+(v-1) d x) d x \equiv \sum_{j=0}^{v-1} f(a+j d x) d x
$$

constituída por $v$ parcelas.

Tendo em conta a desigualdade

$$
\sum_{j=0}^{\nu-1} f(a+j d x) d x \leq\left\{\max _{a \leq x \leq b} f(x)\right) \sum_{j=0}^{\nu-1} d x \equiv(b-a)\left\{\max _{a \leq x \leq b} f(x)\right\}^{147},
$$

\footnotetext{
147 Optamos mais uma vez aqui pela simplificação da linguagem, identificando operações e conceitos básicos dos sistemas real, IR, e hiper-real, *R.
} 
pode-se afirmar que a soma estimada é finita, isto é, um número hiperreal finito, podendo expressar-se então na forma $A+\delta$, em que $\delta$ é um número infinitesimal e $A$ é o número real cujo valor se pretende calcular. Usando a moderna notação de integral (também devida a Leibniz), pode-se escrever que

$$
A=\int_{a}^{b} f(x) d x=s t\left(\sum_{j=0}^{\nu-1} f(a+j d x) d x\right) .
$$

A título de ilustração, calculemos $\int_{0}^{1} x^{2} d x$.

Considerando $\mathrm{d} x=v^{-1}$ onde $v$ é um "número hiper-real inteiro infinito positivo", temos que

$$
\begin{aligned}
& \sum_{j=0}^{v-1} f(0+j / v) \frac{1}{v}=\frac{1}{v}\left\{0^{2}+\left(\frac{1}{v}\right)^{2}+\left(\frac{2}{v}\right)^{2}+\ldots+\left(\frac{v-1}{v}\right)^{2}\right\}= \\
& =\frac{1}{v}\left\{\frac{1}{v^{2}}+\frac{2^{2}}{v^{2}}+\ldots+\frac{(v-1)^{2}}{v^{2}}\right\}=\frac{1}{v^{3}} \sum_{j=0}^{v-1} j^{2}=\frac{1}{v^{3}} \frac{v(v-1)(2 v+1)}{6}=\frac{1}{3}-\frac{1}{6 v}\left(1+\frac{1}{v}\right) \\
& \text { Como } \frac{1}{6 v}\left(1+\frac{1}{v}\right) \text { é um número infinitesimal, temos que } \\
& \mathrm{A}=\int_{0}^{1} x^{2} d x=\frac{1}{3} .
\end{aligned}
$$

Isto posto, não há como continuar afirmando que os infinitesimais "são abordagens ingênuas e inconsistentes" da análise. A Análise Não-Standard é, sem sombra de dúvida, a redenção do Cálculo Infinitesimal. A pedra angular do entendimento e do emprego algébrico coerente dos infinitesimais se encontrava - conforme nos revela o próprio criador da Análise Não-Standard - no fato de se 
introduzir sobre uma extensão ${ }^{*} R$ de $I R$ uma relação de equivalência (ser infinitamente vizinho) que fosse mais fraca que a relação de igualdade, mas que coincidia com a igualdade quando fosse restrita a IR. Foi necessário então um aparato formal e conceitual de que não se dispunha na época. Como observou o próprio Robinson:

"Na realidade, o que então faltava era uma linguagem formal que tornasse possível dar uma formulação precisa e uma delimitação das leis [...] que se supunham aplicar igualmente aos números finitos e aos sistemas extensos que incluíam quer números infinitamente pequenos, quer números infinitamente grandes"

(Robinson, 1966, p.266).

Hoje, para nossa felicidade, dispomos de duas abordagens possíveis para o Cálculo Diferencial e Integral, uma em termos de limite (com raízes em Newton-D'Alembert-Cauchy) e outra em termos de infinitesimais (motivada pelo cálculo infinitesimal de Leibniz) e, para cada uma delas, um tipo de Análise que fornece a devida sustentação lógica. De modo resumido, pode-se afirmar que a Análise Real de Cauchy-Weierstrass está para o Cálculo Diferencial e Integral Standard, assim como a Análise Não-Standard de Robinson esta' para 0 Cálculo Infinitesimal de Leibniz. Há quem diga ainda que a Análise Não-Standard globaliza a Análise Real Standard. Nesse sentido, há ainda muito que se aprender a respeito dos procedimentos infinitesimais. Talvez seja isto que Baldino queira nos dizer quando nos apresenta o seguinte título ${ }^{148}$ :

\section{Infinitésimos: Passado ou Futuro?}

\footnotetext{
${ }^{148}$ Titulo da palestra apresentada pelo professor no V ENEM - São Leopoldo/RS, em 1998.
} 
Assim, com o advento da Análise Não-Standard, poderíamos dizer que o Cálculo Infinitesimal deixa de ser passado, não, para ser "futuro", mas para se fazer presente e tornar-se, sobretudo, uma boa opção didática para o ensino de Cálculo. 


\subsection{A escala filosófica: os mapas conceituais do Cálculo}

Concluída a revisão histórica da evolução dos conceitos básicos do Cálculo, temos como resultado um universo imenso de informações todas relevantes - acerca do tema, mas que precisam ser mapeadas e re-significadas em outras escalas. Este conhecimento, produzido ao longo das quase 200 páginas ${ }^{149}$ de revisão, propicia, sem dúvida, a construção de um grande número de mapas. As possibilidades de mapas são muitas, realmente. Cabe então ao pesquisador saber discernir e construir aqueles que serão úteis ao desenvolvimento do seu trabalho.

Nesse sentido, optamos pela construção de "mapas conceituais" do Cálculo, procurando mapear a evolução dos conceitos que participaram efetivamente da origem, construção e desenvolvimento do Cálculo. São eles: a noção de variável (mapa 2); a de função (mapa 3); 0 conceito de derivada (mapa 4); o de integral (mapa 5); a noção de infinitésimo (mapa 6); o conceito de limite (mapa 6); o de infinito (mapa 7); e, o de número real (mapa 8$)^{150}$.

O primeiro mapa, que não trata de nenhum conceito em especial, é, em verdade, uma apresentação panorâmica das origens das idéias

\footnotetext{
${ }^{149}$ A despeito do número de páginas ser extenso, a priori, para uma revisão histórica do Cálculo, o autor do trabalho, que teve semelhante estado de perplexidade ao encerrar o seu relato (o autor temia que tal procedimento pudesse descompassar os capítulos de sua tese e desfocar os reais objetivos do seu trabalho), não viu maneiras de reduzi-la, uma vez que algumas informações, apesar não de servirem diretamente às suas sínteses, são essenciais para o perfeito entendimento do texto histórico.

${ }^{150}$ Há de se ressaltar ainda que outros mapas já foram antecipados no corpo deste trabalho, como, por exemplo, o mapa da Essência do Cálculo (p.67), o da Difusão do Cálculo de Leibniz (p.181) etc.
} 
básicas do Cálculo. A sua construção se justifica pelo simples fato de ser ele o ponto de partida de todos os demais mapas. Todos os conceitos aqui citados estão relacionados com ele. Aliás, a construção dos outros mapas também merece uma breve justificativa de nossa parte. Passemos a ela então.

As noções de variável e função - mapas (2) e (3) - constituem o que chamamos de conceitos construtores do Cálculo. Com efeito, com - advento da geometria analítica no século XVII, o cálculo diferencial e integral é estabelecido então sobre curvas definidas implicitamente através de equações envolvendo quantidades variáveis: diferenciam-se variáveis, integram-se variáveis. Com o desenvolvimento do conceito de função, o Cálculo passa a ser realizado em termos de funções reais. Além disso, como veremos no capítulo seguinte, estes dois conceitos, tal como são apresentados no ensino médio de matemática, constituem verdadeiras fontes de obstáculos epistemológicos para o conceito de derivada. Assim, entender a participação desses dois conceitos na construção das idéias do Cálculo Diferencial e Integral ajudará a, primeiro, compreender, para depois, vencer os tais obstáculos.

A construção dos mapas dos conceitos de derivada e de integral (mapas 4 e 5, respectivamente) se justifica pelo que eles representam para o prório Cálculo: são efetivamente os conceitos fundamentais do Cálculo Diferencial e Integral.

Ora, por outro lado, os procedimentos do Cálculo sempre foram estruturados a partir de duas idéias básicas: a noção de infinitesimal e/ou a noção de limite. Assim uma síntese comparada da evolução histórica desses dois conceitos estruturais do Cálculo Diferencial e 
Integral torna-se imprescindível. Tal fato é consolidado então na realização do sexto mapa.

Já o sétimo mapa trata daquele que é o reagente básico dos procedimentos que caracterizam o Cálculo Diferencial e Integral: o conceito de infinito. De fato, o Cálculo Diferencial e Integral trata em geral de processos que se realizam ad infinitum, estejam estes caracterizados nos processos infinitesimais que the deram origem ou nas operações de limites que foi a solução standard para o seu problema de fundamentação. Assim, apesar da história do infinito transcender a história do próprio Cálculo, um mapeamento deste conceito estrutural da Análise é fundamental para a compreensão do próprio Cálculo. Além disso, as operações e os procedimentos infinitos constituem, efetivamente, um dos principais obstáculos de aprendizagem no ensino de Cálculo.

Além do infinito, outro conceito estrutural da Análise Real que mereceu a nossa atenção especial foi o conceito de número real. Um mapa deste conceito (mapa 8) retrata, em essência, a história da dualidade discreto/contínuo, que também participou ativamente da construção dos objetos e instrumentos do Cálculo. Além disso, as dificuldades de aprendizagem oriundas da interpretação ingênua dos estudantes deste conceito serão objeto de estudo do próximo capítulo desta tese.

Assim, como se pode notar, a escolha dos temas dos mapas tem a ver não só com o estudo da evolução histórica das idéias básicas do Cálculo, mas também com as dificuldades de aprendizagens dos estudantes em relação a determinados tópicos desse conhecimento que são tratados no ensino de matemática, principalmente numa disciplina 
inicial de Cálculo Diferencial e Integral. Portanto, pode-se afirmar que esta seção representa de certo modo uma antecipação das questões que serão discutidas no próximo capítulo.

Outro ponto que devemos salientar diz respeito à escala que utilizamos na construção dos mapas. Tendo como meta atingir uma visão mais simples e global dos mapas conceituais, procuramos reduzir ao mínimo possivel suas escalas. No entanto, este processo de redução foi feito, em cada mapa, dentro de um limite mínimo de definição, de modo que os elementos essenciais de cada um deles fossem preservados. Assim, por exemplo, em alguns mapas veremos o nó "escolásticos" para representar as contribuições dessa escola filosófica sem, contudo, especificar precisamente o modo pelo qual tal fato se sucedeu no interior deste nó. Para conhecermos efetivamente - feixe de relações que realiza a contribuição dos escolásticos, precisaríamos ampliar esse nó do mapa conceitual. No entanto, se tal ampliação fosse feita no mesmo mapa, correríamos o risco de desfocar e desvirtuar o real motivo de sua construção: o que interessa então é tão somente o quanto de concreto a filosofia escolástica contribuiu para o desenvolvimento do conceito em questão; além disso, os pormenores dessa contribuição o leitor pode, caso se interesse, encontrar no texto histórico que desenvolvemos na seção anterior. Por outro lado, em alguns mapas, foi nececessário que nos referissemos especificamente a alguns dos filósofos escolásticos em especial - isto ocorreu, por exemplo, quando a participação desses filósofos foi muito mais decisiva para a construção do conceito em questão do que a de seus colegas. 
Outro aspecto que deve ser destacado para uma boa compreensão dos mapas diz respeito à simbolização utilizada nas suas construções.

A fim de facilitar a visualização dos mapas, foram utilizadas legendas e cores. Notas numeradas também foram acrescentadas para complementar e auxiliar a leitura dos mapas (veja figura a seguir). A ordem da numeração das notas serve inclusive como um guia de orientação para a leitura do mapa.

Os nós dos mapas estão representados, em geral, pelos nomes de pensadores, ou de grupos de pensadores, ou de civilizações inteiras, ou mesmo de conceitos matemáticos. O conteúdo dos nós pode ser assimilado pelo contexto oferecido pelas notas de apoio que os contém.

Os feixes de relações entre os nós estão representados por setas que indicam o sentido do fluxo do conhecimento ou apenas por linhas, quando o sentido não está bem determinado. Em alguns casos, usaremos linhas ou setas "pontilhadas" para indicar uma relação mais fraca ou o caráter indicial de sua provável existência. 


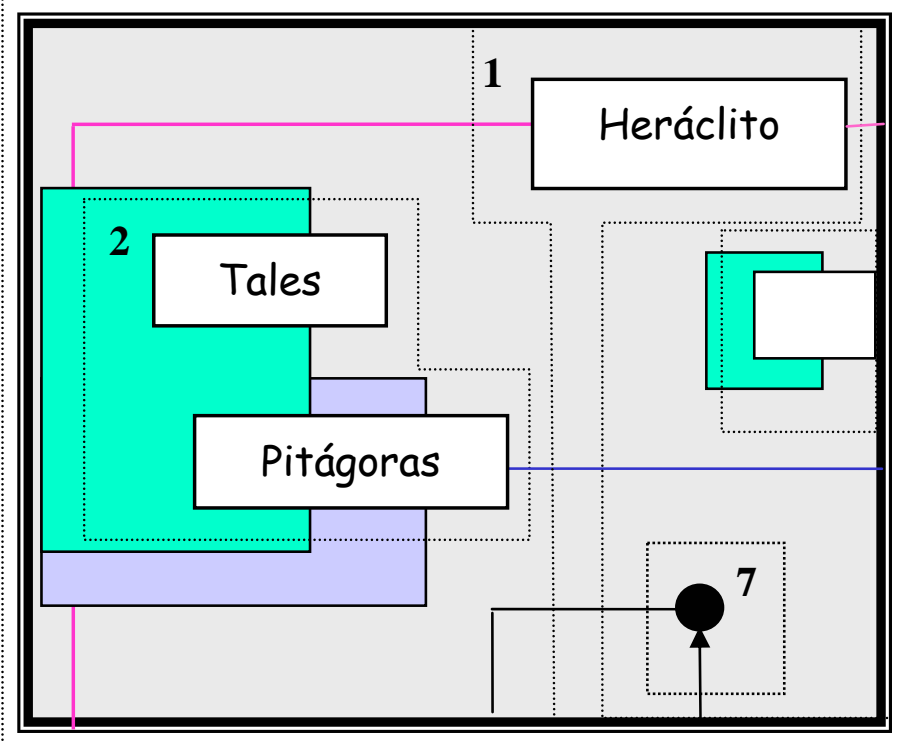

Fragmento

do mapa 1

1. A origem da dualidade variabilidade/permanência, essencial para o desenvolvimento do Cálculo, se dá na filosofia pré-socrática, na dialética de Heráclito e na perseguição da "unidade e a invariabilidade do mundo" da filosofia eleática, cujo maiores representantes são Parmênides e Zenão. Heráclito, Parmênides e Zenão, através de suas metafísicas, forneceram o patamar base das discussões posteriores acerca desta dualidade essencial.

2. O surgimento e o desenvolvimento da geometria grega irá fornecer dois outros problemas fundamentais do Cálculo: a determinação de tangentes a curvas e o cálculo de áreas e volumes. A máxima pitagórica "tudo é número", bem como a teoria dos números figurados, representa efetivamente a primeira inserção dos indivisíveis na matemática: o indivisível “atômico”.

\section{figura 43}

Outro ponto que devemos salientar diz respeito ao inevitável - $e$, algumas vezes indesejável - cruzamento entre as linhas ou setas dos mapas. Tal fato ocorre principalmente devido à limitação geométrica (plana) de nossa representação diante da riqueza de entrelaçamentos possíveis entre os diversos nós dos mapas. Assim, para indicar um cruzamento de fato entre duas linhas do mapa usaremos um ponto conforme descreve a figura a seguir. Caso tal ponto não esteja simbolizado, o leitor não deve interpretar a interseção das linhas como um cruzamento de fato, mas, conforme já dissemos, como uma limitação da forma de representação utilizada. 


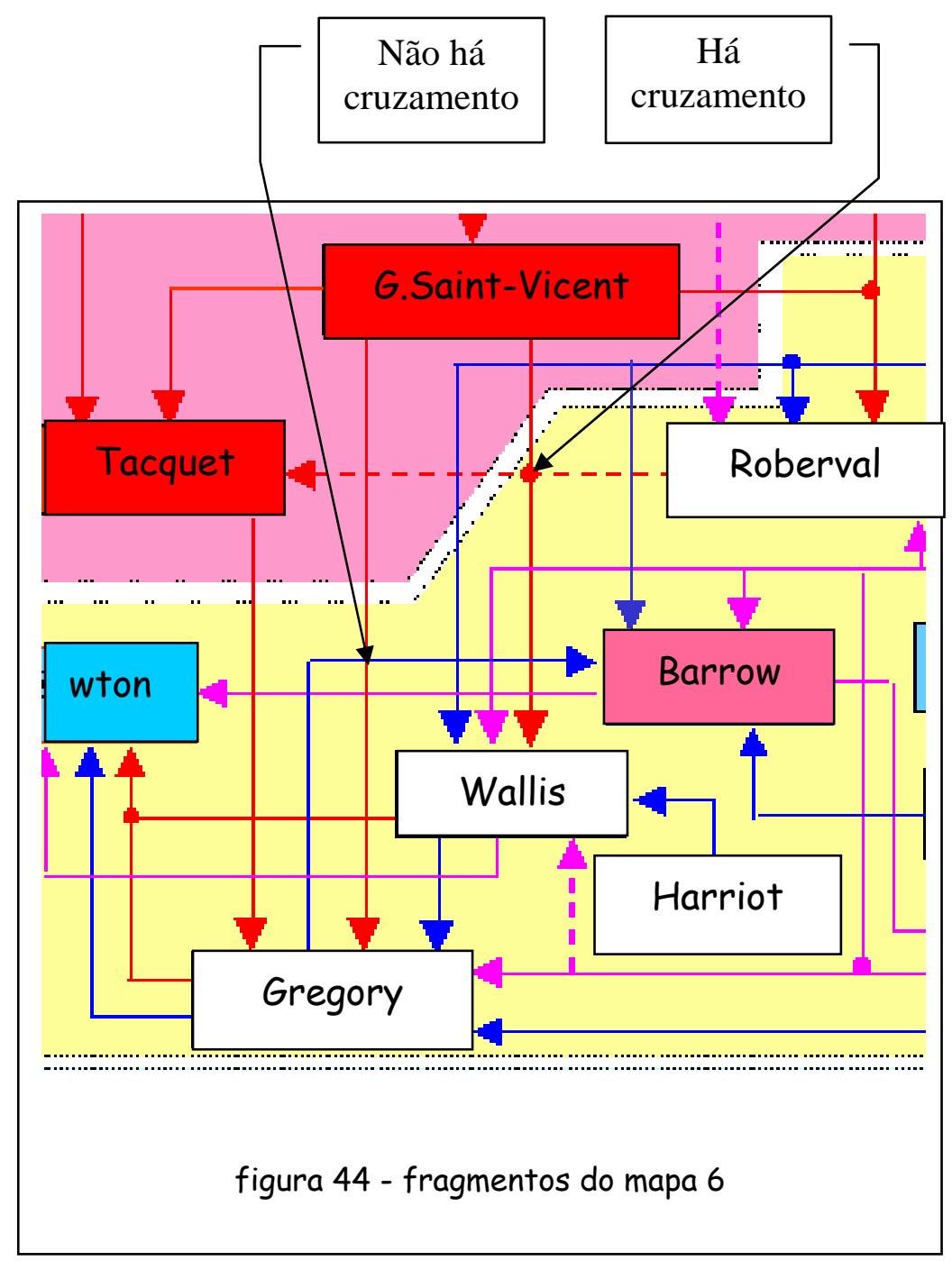

Passemos então à apresentação dos mapas. 
figura 45 - Mapa da formação das idéias básicas do Cálculo na Grécia antiga (600-200 a.c.)

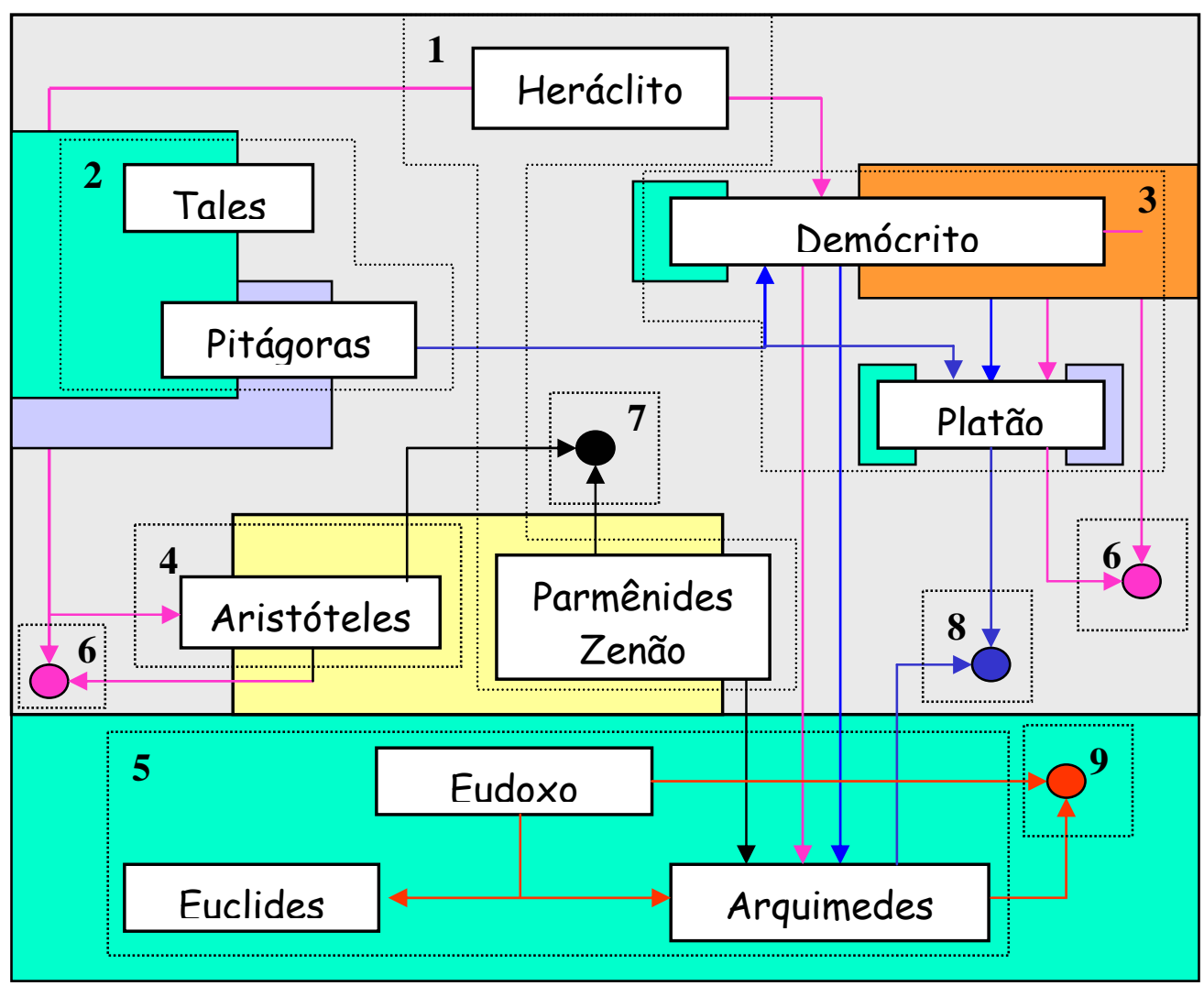

Domínio da Aritmética

Fluxo da noção de infinito

Domínio da Lógica

Fluxo da noção de infinitesimal

Domínio da Filosofia

Fluxo da idéia de movimento

Domínio da Geometria / Álgebra Geométrica

Fluxo da noção de limite

Domínio da "Física"

o Ponto de culminância de uma idéia e de conexão com outras redes de significações 
1. A origem da dualidade variabilidade/permanência, essencial para o desenvolvimento do Cálculo, se dá na filosofia pré-socrática, na dialética de Heráclito e na perseguição da "unidade e a invariabilidade do mundo" da filosofia eleática, cujos maiores representantes são Parmênides e Zenão. Heráclito, Parmênides e Zenão, através de suas metafísicas, forneceram o patamar base das discussões posteriores acerca desta dualidade essencial.

2. O surgimento e o desenvolvimento da geometria grega irá fornecer dois outros problemas fundamentais do Cálculo: a determinação de tangentes a curvas e o cálculo de áreas e volumes. A máxima pitagórica “tudo é número", bem como a teoria dos números figurados, representa efetivamente a primeira inserção dos indivisíveis na matemática: o indivisível "atômico”.

3. O conceito de indivisível “atômico” será depurado tanto por Demócrito quanto por Platão. Demócrito “percebe” que o indivisível matemático era de outra natureza, uma vez que este poderia ser divisível ad infinitum. Já Platão preferiu interpretar o seu conceito de infinitesimal a partir do conceito altamente abstrato do apeíron - ou indeterminado ilimitado -, do filósofo Anaximandro. De acordo com Platão, o contínuo poderia ser melhor interpretado pelo "fluir do apeíron” do que através de um agregado infinito de elementos indivisíveis.

4. Aristóteles representa um marco no desenvolvimento da lógica. No entanto, apesar de ser considerado um dos precursores da lógica dialética, o filósofo grego não distingue na sua "física” os tipos de movimentos que os corpos podem realizar: limita-se apenas a reconhecer os estados em que há ou que não há movimento. Além disso, ao sugerir o “exorcismo” da noção de infinito da ciência em geral, o filósofo grego está se opondo, na verdade, àquelas que se constituirão o ingrediente básico dos procedimentos do Cálculo: as quantidades infinitamente pequenas.

5. Para muitos historiadores de matemática o método de exaustão, criado por Eudoxo, representa o estado embrionário da noção de limite. Pode-se afirmar ainda que o desenvolvimento de tal método realiza, efetivamente, os anseios dos matemáticos gregos da época de tornar esta ciência um modelo de precisão e rigor. Euclides e Arquimedes foram, sem dúvida, os principais difusores desse engenhoso método de calcular quadraturas e cubaturas. Sabe-se, entretanto, que Arquimedes usava de outros métodos - métodos infinitesimais - para "descobrir" os seus resultados. O grande sábio de Siracusa usava o método de exaustão “apenas para demonstrar”.

6. A matemática grega é essencialmente estática, desprovida de qualquer idéia de movimento - o uso de idéias de cinéticas que aparece, por exemplo, em um método de tangentes desenvolvido por Arquimedes, representa exceção. No conhecimento grego em geral, a filosofia platônica e a física aristotélica são exemplos da resistência à idéia de movimento, ainda que esta última tenha tratado essa noção de forma incipiente. Tanto os resultados da filosofia platônica quanto da "física” de Aristóteles serão retomados e estudados na idade média pelos escolásticos.

7. A convivência harmoniosa da noção de infinito com a lógica formal só foi possível na matemática, no final do século XIX, com Dedekind e Cantor. Até esse momento, a matemática teve que conviver de modo atribulado com a presença desses importantes elementos de suas redes de significações, ou fazer a opção por uma delas. A matemática grega fez opção pelo rigor e precisão da lógica formal.

8. A noção de infinitesimal resiste nos escritos de Platão e Demócrito e, clandestinamente, na obra de Arquimedes. O desenvolvimento do conceito de variável tanto no contexto algébrico (pelos hindus e árabes) quanto no sentido metafísico (pelos escolásticos, que retomam os estudos da filosofia platônica em oposição à filosofia peripatética de Aristóteles) serão incorporados posteriormente às idéias iniciais de Demócrito e Platão para a construção de uma nova concepção de infinitesimal, que será fundamental para a “invenção” e o desenvolvimento do Cálculo.

9. Se, por um lado, o método de exaustão de Eudoxo representa, efetivamente, a origem da noção de limite, por outro, o axioma de Arquimedes (dados a, b $\in I R, a>>b, \exists n \in N, n$ suficientemente grande, tal que $\mathrm{nb}>\mathrm{a}$ ) constitui-se, associado ao método indireto de demonstração por exaustão, um artifício para evitar os processos ad infinitum, tão característicos das "passagens diretas ao limite”. Entretanto, no início do século XVII, os matemáticos irão preferir os procedimentos de “passagens diretas ao limite”. 
figura 46 - Mapa do conceito de variável

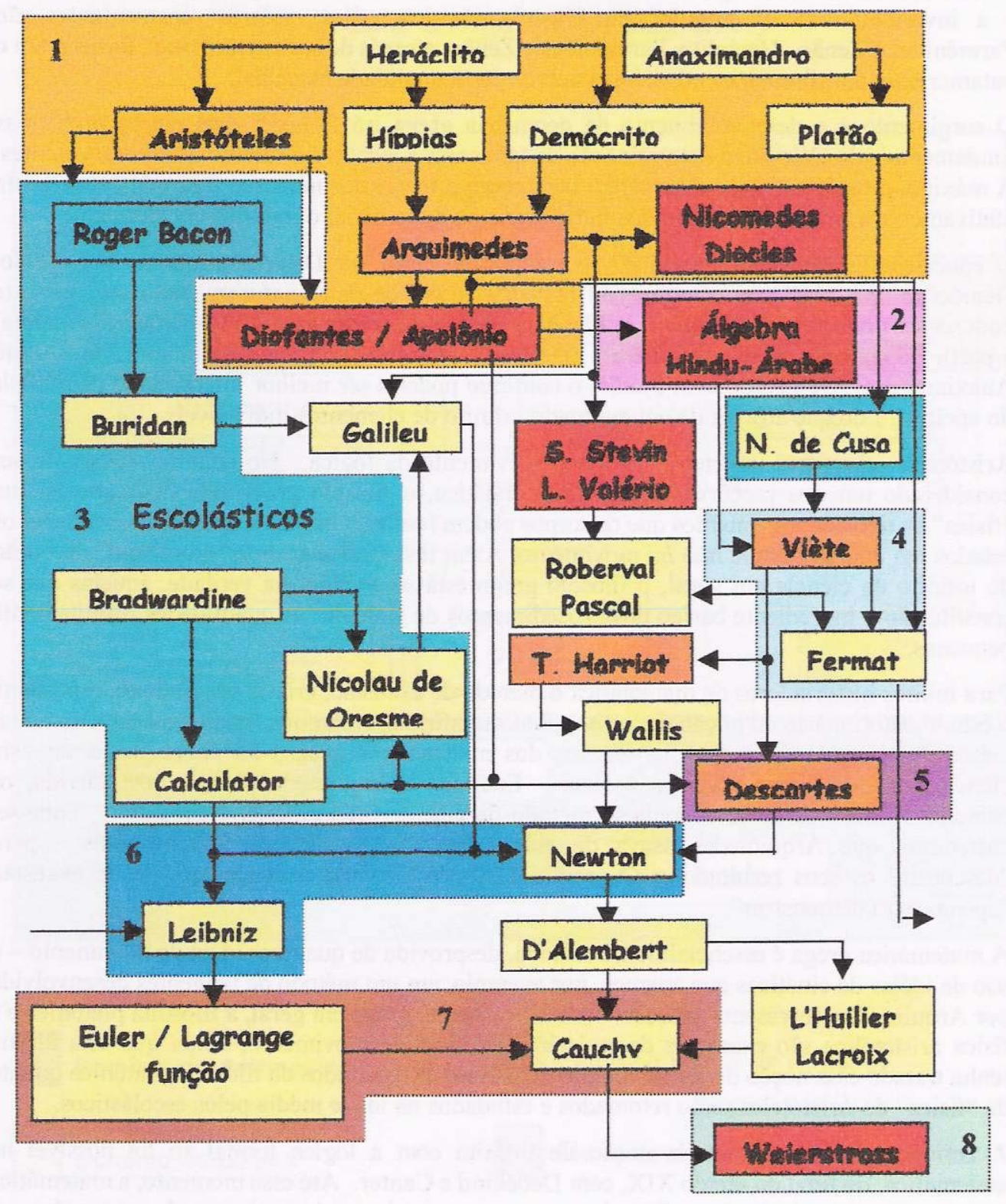

\begin{tabular}{ll}
\hline Estático / algébrico & $\square$ Domínio da filosofia \\
\hline Dinâmico / analítico & $\square$ Desenvolvimento do método analítico \\
\hline Presença das duas idéias & $\begin{array}{l}\text { Desenvolvimento da Geometria } \\
\text { Domínio da matemática grega }\end{array}$ \\
$\begin{array}{l}\text { Domínio da matemática hindu- } \\
\text { árabe }\end{array}$ & $\begin{array}{l}\text { A "invenção" do Cálculo } \\
\text { A evolução do conceito de função }\end{array}$ \\
& A teoria estática da variável
\end{tabular}


1. A noção de variabilidade na matemática grega está associada basicamente a duas situações distintas, a saber: o valor indeterminado de uma grandeza geométrica; ou o "fluir" de uma grandeza geométrica. A primeira atitude, que está presente majoritariamente na geometria grega, consolida o estilo grego da "álgebra geométrica" (isto é, de se fazer demonstrações geométricas de resultados genuinamente algébricos), que será desenvolvida posteriormente por Diofantes numa tentativa de dar um tratamento mais algébrico à noção de variável. Já a segunda atitude, presente no método cinético das tangentes, desenvolvido por Hippias e no método mecânico, de Arquimedes, representa uma re-significação do "fluir do apeíron", de Anaximandro, citado por Platão em sua filosofia para idealizar o continuum.

2. A partir de traduções das obras de Apolônio e de Diofantes, a civilização hindu-árabe toma contato com o método dedutivo e o estilo geométrico da álgebra grega. Sendo exímios calculistas - uma vez que a atividade comercial era uma das principais atividades econômicas dessas civilizações -, os estudiosos e tradutores hindu-árabes realizam uma miscigenação do estilo dedutivo da geometria grega com o seu habitual modo aritmético-algébrico de pensar. A associação direta da variável com o valor numérico desconhecido de uma equação representa, efetivamente, a primeira tentativa de libertação da noção de variável do contexto geométrico.

3. Com o advento do cristianismo e a projeção do seu domínio a quase todo o continente europeu, a produção intelectual fica mais restrita a representantes e seguidores dessa doutrina. Surge, assim, a filosofia escolástica. Os escolásticos realizam então uma tradução "tutelada" - pela própria doutrina cristã - das obras gregas. As obras de Aristóteles e de Platão são então estudadas e reinterpretadas. São realizadas então um aprofundamento e uma "matematização" do problema da variabilidade. São identificados outros tipos de movimento - movimentos uniformemente variados, movimentos com variação uniformemente variada etc -, estes são modelados e estudados a partir de gráficos que relacionam as quantidades variáveis envolvidas - a relação funcional entre as quantidades variáveis é estabelecida então pelo desenho de uma curva. A "doutrina do ímpeto" de Buridan, a "teoria das fluxões" de Calculator e a "doutrina de configuração" de Nicolau de Oresme são exemplos de resultados dessas investigações.

4. A introdução da filosofia platônica no âmbito da filosofia natural, realizada pelos escolásticos, permitiu um livre uso de duas noções rejeitadas até então na matemática: o infinito e as quantidades infinitesimais. A fusão do simbolismo algébrico com a re-significaçao dos infinitesimais realizada por Nicolau de Cusa deu origem ao desenvolvimento dos métodos infinitesimais criados por Viète e Fermat. Estes dois últimos foram, de fato, os principais articuladores e realizadores desse método nesse estado embrionário do Cálculo. O incremento infinitesimal "E", que aparece em todos os métodos infinitesimais desenvolvidos por Fermat, representa, em geral, uma variação infinitesimal da abscissa x.

5. Em outro contexto, muito mais próximo da álgebra do que da análise, Descartes desenvolve métodos essencialmente algébricos para resolver os problemas do Cálculo. Seu método, porém, é bastante limitado, mas o expediente geométrico que criou - a geometria analítica fornecerá o novo ambiente em que serão tratadas as questões pertinentes ao Cálculo. As variáveis se apresentam relacionadas a partir da equação da curva.

6. Tanto o Cálculo de Newton quanto o de Leibniz não realizam mudança substancial no conceito de variável. Variável é um conceito dinâmico, e implicitamente determinado pela relação funcional com outras variáveis. Esta relação funcional implícita é dada, em geral, pela equação de uma curva. Há de se ressaltar, entretanto, que o Cálculo de Leibniz é muito menos dependente da geometria analítica do que o de Newton.

7. A introdução do conceito de função no âmago do Cálculo, realizado por Euler e Lagrange, possibilitará, mais adiante, com a evolução deste conceito, uma reinterpretação do conceito de variável. Confira o mapa 3 (figura 47).

8. A inserção da noção de conjunto na matemática, a interpretação do conceito de função e da noção de infinito neste novo contexto, possibilitará a Weierstrass desenvolver sua teoria estática de variável. Nesse sentido, a variável "x" é simplesmente uma letra designando qualquer número de uma coleção de valores numéricos. Esse contexto é, com efeito, o contexto da Análise. 
figura 47 - Mapa do conceito de função

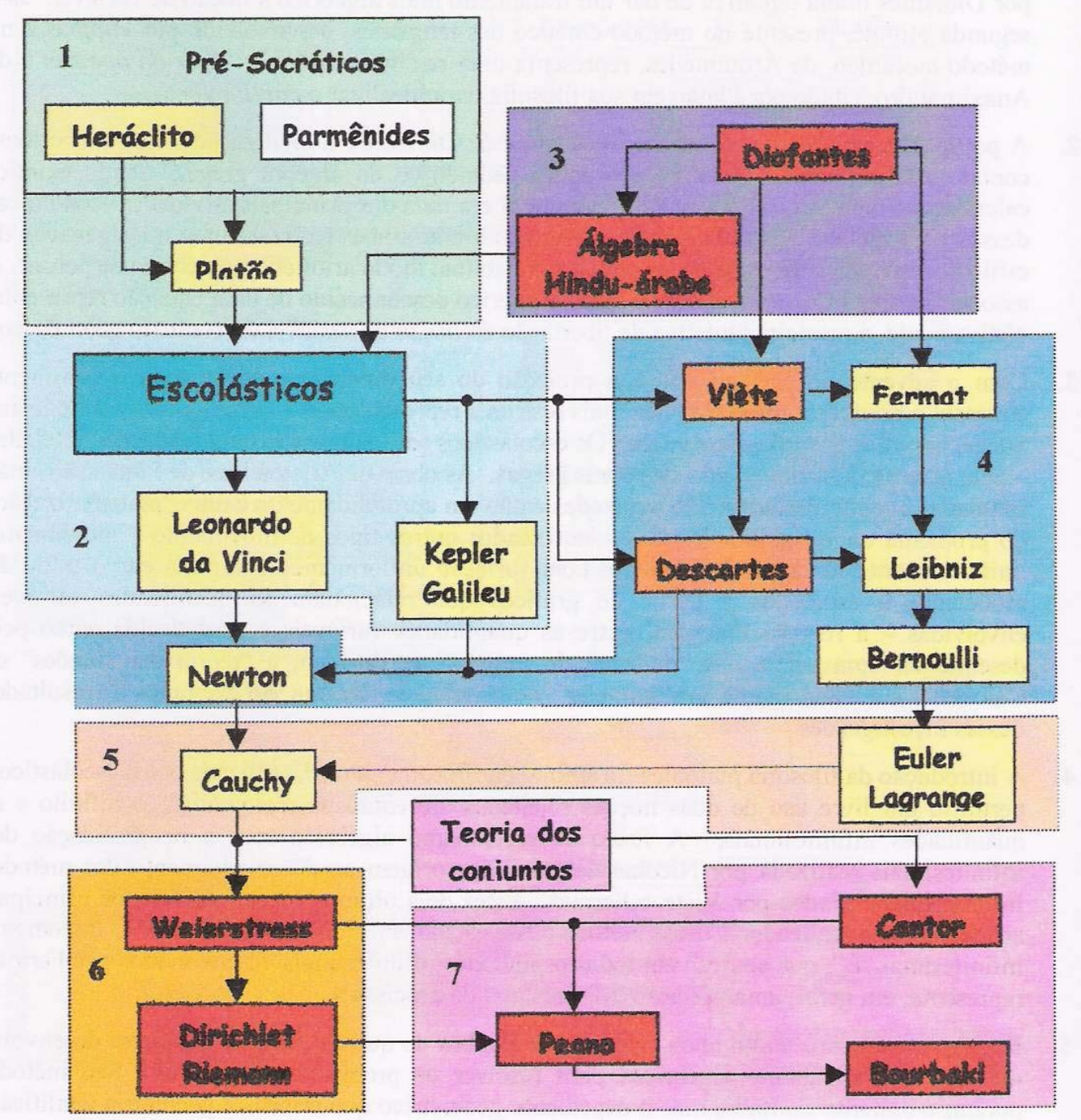

Estático / algébrico

A abordagem da Geometria Analítica

Dinâmico / analítico

Presença das duas idéias

Domínio da filosofia grega

Desenvolvimento da álgebra elementar

Origem das quantidades fluentes

Função como expressão analítica

Interpretação estática do conceito de variável

A formalização do conceito de função a partir da teoria dos conjuntos 
1. A explicação pré-socrática dos fenômenos da natureza através da interdependência das coisas (grandezas) simboliza, sem sombra de dúvida, a idéia essencial do conceito de função. O devir heracliteano, por sua vez, representa a origem da idéia de variabilidade, outro pilar conceitual da idéia de função. A filosofia de Platão soube preservar essas características essenciais da idéia de função: a idéia de fluência e a de interdependência das coisas.

2. A inserção das idéias platônicas nos problemas da filosofia natural realizada pelos escolásticos provocará uma revisão crítica da física aristotélica. Surge a idéia de aceleração e, o estudo do movimento / variação torna-se um dos problemas centrais da filosofia natural. Kepler e Galileu dão profundas contribuições para esta mudança de paradigma no domínio da física. Por outro lado, com um século de antecedência, Leonardo da Vinci usa em seus trabalhos a idéia de fluentes, que será aproveitada mais adiante por Newton em seu cálculo fluxional.

3. A tradução hindu-árabe da álgebra geométrica grega possibilitará o desenvolvimento de técnicas algébricas elementares. O conceito de variável é então uma extensão algébrica da noção de número (um número desconhecido, simbolizado por uma letra, com a qual realizamos as operações do mesmo modo que realizamos com os números).

4. Com a inserção do simbolismo algébrico na geometria, surge a geometria analítica (Descartes). Os métodos infinitesimais do Cálculo são desenvolvidos então a partir das equações das curvas $\mathrm{F}(\mathrm{x}, \mathrm{y})=0$ - inicialmente, por Viète e Fermat, e, por último, por Newton e Leibniz. Assim, é a equação da curva que estabelece a relação de interdependência entre as variáveis. E é exatamente esta relação de interdependência entre as variáveis que Leibniz chamou de função. A definição de função dada por Jhoann Bernoulli representa, em essência, a idéia de Leibniz.

5. Euler e Lagrange, ao introduzir o conceito de função no núcleo operacional do Cálculo, passam a identificar o conceito de função com a expressão analítica que a define. Cauchy, que faz da noção de limite em termos de funções, o conceito fundamental de sua Análise, não acrescenta nada de substancial em relação às versões iniciais de Euler e Lagrange.

6. O desenvolvimento inicial da Teoria dos Conjuntos propicia a Weierstrass os elementos necessários para que realizasse a sua teoria estática do conceito de variável. O exemplo clássico da função de Dirichlet (para x racional $\rightarrow \mathrm{y}=0$; e, para $\mathrm{x}$ irracional $\rightarrow \mathrm{y}=1$ ) e o estudo que Riemann realizou sobre a convergência das séries de Fourier, fez com que estes matemáticos estabelecessem o conceito de função em termos de "uma livre correspondência entre duas variáveis representativas de conjuntos de números".

7. Com o desenvolvimento da Teoria dos Conjuntos e sua inserção na linguagem matemática, o conceito de função é definido formalmente então em termos de relação entre conjuntos. Nesse contexto, função é conjunto: conjunto de pares ordenados ou de n-uplas ordenadas que obedecem a propriedades especiais. 


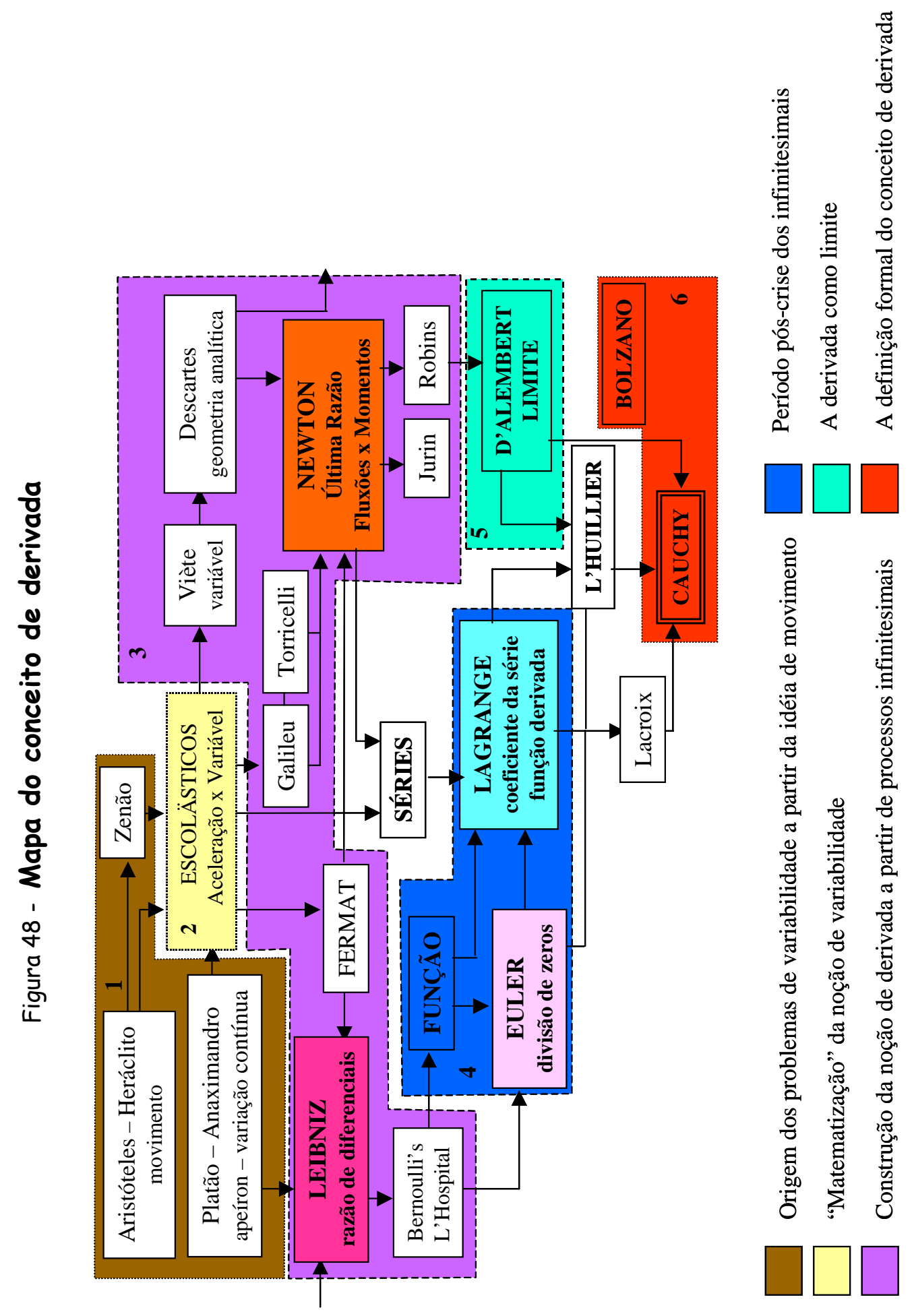


1. Os problemas relacionados à idéia de movimento constituem, desde o início da história da matemática, o principal pólo de significações da noção de derivada. Os paradoxos de Zenão evidenciam, no entanto, a grande dificuldade que os gregos tiveram no tratamento de questões relacionadas à noção de movimento. Tal fato deve-se, principalmente, à falta de compreensão dos matemáticos gregos de duas noções fundamentais: o conceito de infinito e a idéia do continuum. Para assimilar a idéia deste último, Platão sugeriu que seria necessário realizar uma ponte entre a geometria e a aritmética - mas a sugestão de Platão só teve eco no final do século XIX. Já o problema de se determinar reta tangente é tratado na matemática grega exclusivamente no contexto geométrico.

2. O primeiro passo para a "matematização" do problema da variabilidade foi dado pelos escolásticos, na idade média. Os conceitos de velocidade instantânea e de aceleração começam a ser estudados e considerados a partir da análise mais detalhada que estes filósofos fizeram dos problemas de movimento. Incorporaram as séries e, conseqüentemente, a noção de infinito no tratamento desses tipos de problemas.

3. Com o desenvolvimento da geometria analítica por Descartes, os problemas de calcular velocidades instantâneas e de determinar retas tangentes a curvas estabelecem uma relação muito mais próxima e fecunda entre si. Tal associação possibilitará não só a consolidação do Cálculo Diferencial, como permitirá uma primeira interpretação do TFC por Torricelli, no contexto cinemático. Os métodos infinitesimais desenvolvidos por Viète e Fermat se constituíram no paradigma normal do Cálculo no século XVII. O aperfeiçoamento e as generalizações desses métodos infinitesimais culminaram com o desenvolvimento do Cálculo por Leibniz e por Newton. O primeiro interpretou a derivada como a razão de diferenciais ( $\frac{d y}{d x}=d y: d x$ ), enquanto o último interpretou a derivada como razão de fluxões (que eram, por sua vez, determinadas a partir do conceito de última razão do seu método fluxional) - neste caso, $\frac{d y}{d x}=\frac{y}{\dot{x}}$, em que $\dot{y}$ e $\dot{x}$ representam as fluxões (velocidades) das variáveis y e $\mathrm{x}$, respectivamente.

4. O período seguinte às críticas aos métodos infinitesimais é marcado pela diversificação de caminhos e buscas de soluções para as situações paradoxais provocadas pelo uso das quantidades infinitesimais. Euler continua fiel aos métodos infinitesimais e interpreta a derivada a partir da divisão de zeros (infinitesimais). Lagrange faz uso das séries e de um instrumento recém introduzido no âmbito do Cálculo Diferencial e Integral: o conceito de função. O matemático francês assume que toda função pode ser escrita como uma série infinita de potências de $x$ (ou de $(x-a)$ ). Isto posto, Lagrange define a derivada da função $f$ no ponto “ $a$ ” (isto é, f'a) como sendo o coeficiente do termo $(x-a)$ da série.

5. D’Alembert identifica a operação de limite como sendo o elemento unificador dos conceitos básicos do Cálculo e propõe então a definição de derivada a partir desta noção: $\frac{d y}{d x}=\lim _{\Delta x \rightarrow 0} \frac{\Delta y}{\Delta x}$.

6. A fundamentação do conceito de derivada é concluída com Cauchy no final do século XIX. A definição de Cauchy é, em essência, a mesma de D’Alembert, incorporando apenas o conceito de função - Cauchy definiu derivada de uma função $f$ em $x_{0}$ por $f^{\prime}\left(x_{0}\right)=\lim _{i \rightarrow 0} \frac{f\left(x_{0}+i\right)-f\left(x_{0}\right)}{i}$. De modo independente - e mesmo antes - de Cauchy, o matemático tcheco Bolzano já havia realizado esse feito. Mas, o tardio conhecimento de seu trabalho fez com que este não interferisse diretamente no processo histórico de evolução do conceito de derivada. 


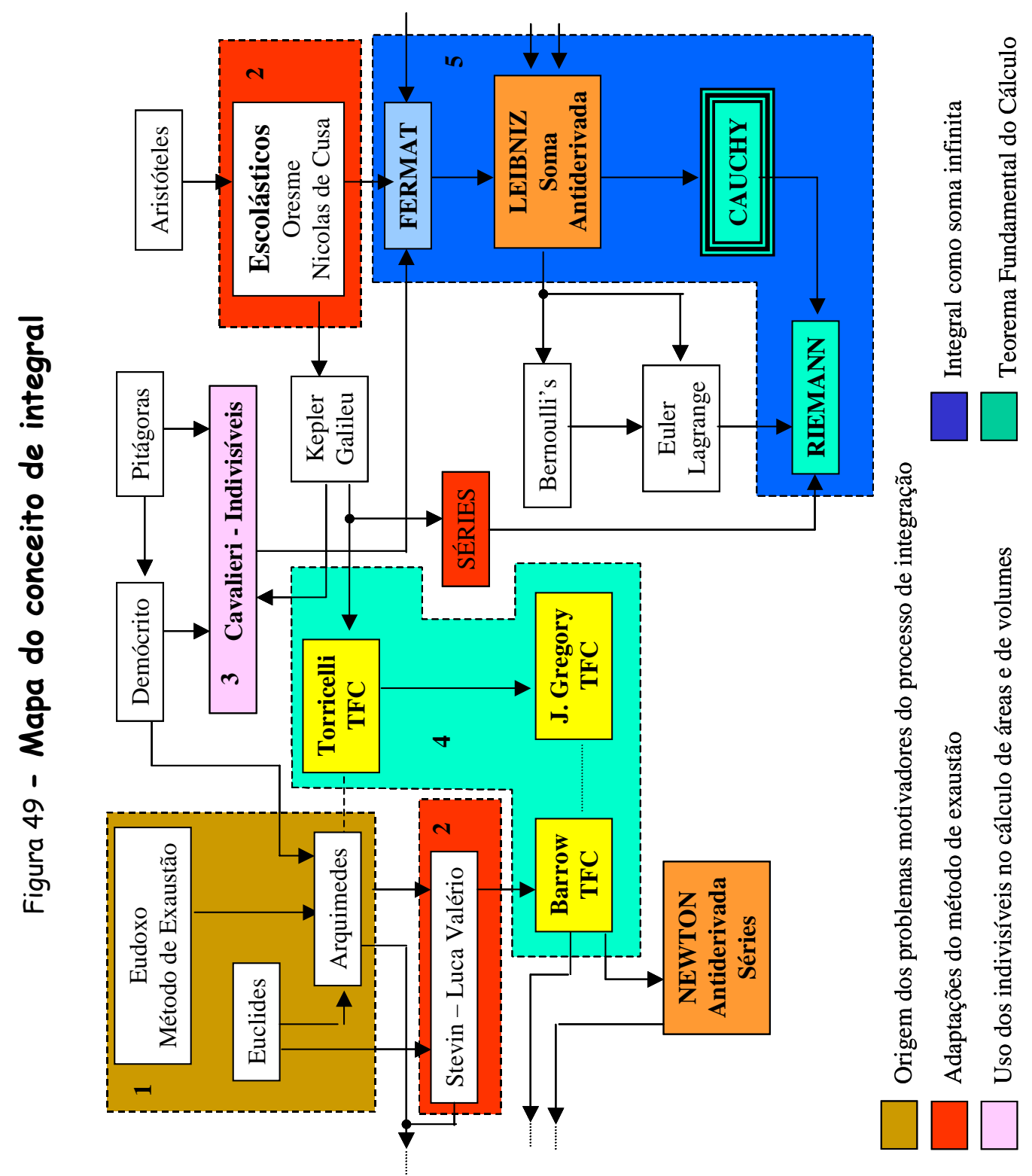


1. O método de exaustão criado por Eudoxo e o uso dos indivisíveis matemáticos de Demócrito representam efetivamente os primeiros processos de integração que se conhece na história da matemática. O primeiro se tornou instrumento padrão da matemática grega para os cálculos de áreas e de volumes, tendo em Euclides e Arquimedes seus maiores usuários e difusores. Já os indivisíveis matemáticos de Demócrito, apesar de serem usados informalmente por Arquimedes para a realização de suas descobertas - para demonstrar o matemático de Siracusa usava oficialmente o método de exaustão, - são colocados de lado na matemática grega. No entanto, o estudo dos indivisíveis será retomado mais adiante pelos matemáticos dos séculos XVI e XVII.

2. Os escolásticos foram os primeiros a realizarem adaptações do método de exaustão dos gregos. Nicolau de Cusa, por exemplo, interpretou o círculo como sendo um polígono de infinitos lados, formado por uma infinidade de triângulos infinitesimais. Stevin e Luca Valério foram mais prudentes em suas adaptações, substituindo de modo gradativo o método indireto de demonstração pela "passagem direta ao limite”.

3. Cavalieri faz ressurgir na literatura matemática a noção de "indivisível heterogêneo", outrora utilizado pelos pitagóricos e pela escola de Abdera (em que Demócrito foi o seu mais ilustre representante). Para Cavalieri, uma área era determinada por uma soma infinita de elementos indivisíveis de comprimentos, e o volume por uma soma infinita de elementos indivisíveis de áreas.

4. A descoberta inicial do Teorema Fundamental do Cálculo vinculou de forma marcante o conceito de integração ao conceito de antidiferenciação: integrar uma curva significava encontrar uma curva cuja derivada era a curva dada inicialmente.

5. Dando seqüência às adaptações do método de exaustão iniciadas por Stevin e Valério, Fermat propõe um método de quadratura baseado tanto na noção de infinitesimal quanto na noção intuitiva de limite: calcular a área de uma região plana limitada por uma curva significava calcular a soma infinita de retângulos infinitesimais inscritos nessa região. Fermat rejeita totalmente os indivisíveis de Cavalieri por estes não serem de mesma natureza daquilo que se quer encontrar: determinamos áreas somando áreas; por outro lado, quando somamos comprimentos, encontramos comprimentos. Leibniz e Newton assumem a mesma idéia de integração de Fermat. No entanto, como os “inventores” do Cálculo já tinham conhecimento do TFC, adotaram, na prática, este resultado no cálculo de suas integrais. A definição de integração só tem alguma mudança significativa no século XIX, com Cauchy. O matemático francês define a integral definida de uma função contínua pelo limite de uma soma parcial finita de retângulos, que aproximam inicialmente a região dada, e cujas bases vão tendendo a zero à medida que aumentamos o número de retângulos da nossa soma parcial. Tal conceito foi aperfeiçoado posteriormente por Riemann. 
figura 50 - Mapa dos conceitos estruturais do Cálculo

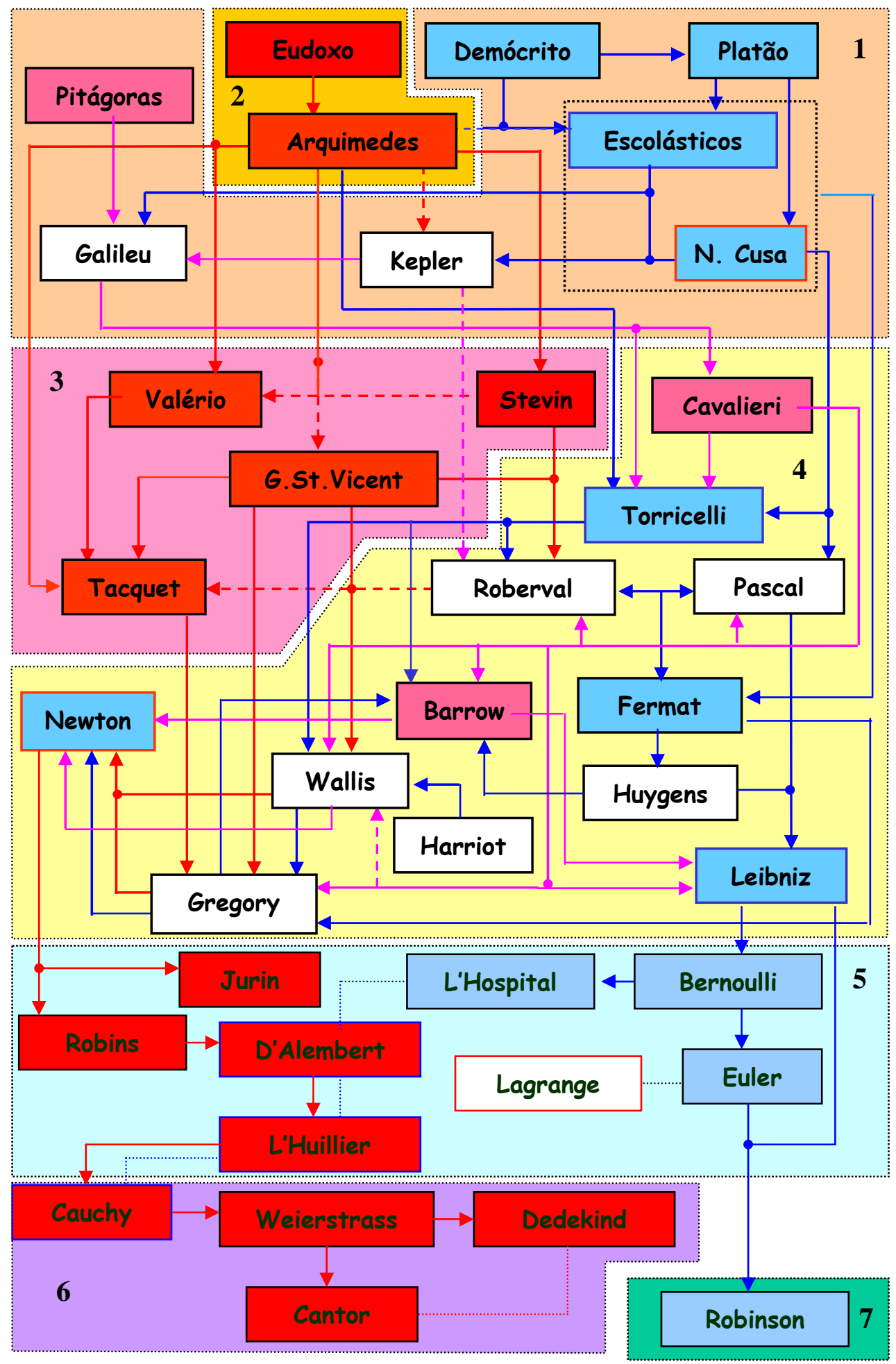

Fluxo da noção de indivisivel atômico / heterogêneo

Fluxo da noção de limite

Fluxo da noção de indivisível homogêneo / infinitésimo

Situação de indefinição do autor citado / falta de dados conclusivos 
1. A origem das quantidades infinitamente pequenas se dá na Grécia antiga através de duas perspectivas: uma atomística e a outra infinitesimal. Na primeira, o indivisível, como o próprio nome já diz, é a menor parte constitutiva das “coisas" e, portanto, não pode ser dividida. Foi assim na escola pitagórica e na fase inicial da escola de Abdera. No entanto, o próprio Demócrito - representante maior da escola de Abdera - reconheceu uma propriedade especial nos indivisíveis "matemáticos": estes - disse o filósofo - poderiam ser divididos ad infinitum. Surge assim a primeira representação do infinitésimo (ou "indivisível homogêneo" conforme foi denominado historicamente durante uma certa época). Essa perspectiva infinitesimal, iniciada por Demócrito, será retomada por Platão, ainda na Grécia antiga, e pelos filósofos escolásticos, já na Idade Média.

2. Por outro lado, com a crítica realizada por Zenão, tanto aos indivisíveis quanto aos processos infinitesimais, os matemáticos preferiram, na sua grande maioria, abandonar essas idéias e adotar o "método de exaustão" - criado por Eudoxo e, desenvolvido e difundido principalmente por Euclides e Arquimedes - como o paradigma. Arquimedes, no entanto, não abandonou as quantidades infinitamente pequenas totalmente. O método criado por Eudoxo é, com efeito, o estágio embrionário da noção de limite.

3. As adaptações sucessivas do método de exaustão realizadas por Stevin e Valério, no final do século XVI, e Gregorie de Saint-Vicent, início do XVII, aproximam a idéia de limite à do seu princípio reagente básico: a noção de infinito. Gregorie foi responsável pela denominação "método de exaustão" ao método dos antigos criado por Eudoxo.

4. Entretanto, no período que antecede à “invenção” do Cálculo, os procedimentos infinitesimais já dominam os novos métodos matemáticos. Os indivisíveis atômicos, retomados e desenvolvidos nesse período por Cavalieri - e presentes também nos trabalhos de Pascal, Roberval, Barrow e Wallis -, são criticados e substituídos definitivamente pela noção de infinitésimo. O maior responsável por esse processo de exclusão dos indivisíveis atômicos foi o matemático Fermat, por sua vez, um dos principais criadores dos métodos infinitesimais. Tais procedimentos infinitesimais constituem, em essência, o Cálculo de Newton e o de Leibniz.

5. Após as críticas de Nieuwentijdt e de Berkeley aos métodos infinitesimais, o Cálculo passa por um período de reflexão. São três as atitudes que marcaram este período de indecisão do Cálculo: uma positiva em relação aos infinitésimos que teve em Eüler o seu maior expoente, e que procura minimizar a crise em torno dos problemas de fundamentação por uma compensação em termos de resultados conseguidos a partir deste; uma negativa, que propõe a substituição dos infinitésimos por uma noção intuitiva de limite, e que teve em D’Alembert o seu principal articulador; uma terceira, minoritária e defendida por Lagrange, que acreditava que a solução dos fundamentos do Cálculo estava na Álgebra.

6. Ao término desse período de indecisão da história da matemática, a operação de limite surge como o único paradigma para os novos procedimentos do Cálculo. Cauchy foi o principal articulador desse novo paradigma. Há de se ressaltar que o matemático francês não descartou de vez os infinitesimais: seu duplo projeto era conciliar a leveza e a praticidade dos infinitesimais com o rigor da noção de limite. A definição formal de limite dada por Weierstrass e a construção dos números reais realizada por Dedekind culminam com a criação da Análise Real e, por conseguinte, com uma nova exclusão dos infinitésimos da Matemática.

7. No entanto, em 1961, Robinson, usando a teoria dos modelos, descobriu um novo método de interpretar e resolver o duplo problema do cálculo infinitesimal levantado por Berkeley: a “existência dos infinitesimais” e o de como “operar com eles [os infinitesimais]”. Tendo observado que os infinitesimais não podem existir como números "ordinários”, Robinson sugeriu um "alargamento" do sistema de números reais - o conjunto dos números hiper-reais *R; um conjunto contendo tanto os números infinitesimais quanto infinitos, e que contém um subconjunto isomorfo ao conjunto dos números reais. Surge então a Análise Não-Standard: a redenção dos infinitesimais. 


\section{figura 51 - Mapa do conceito de infinito}

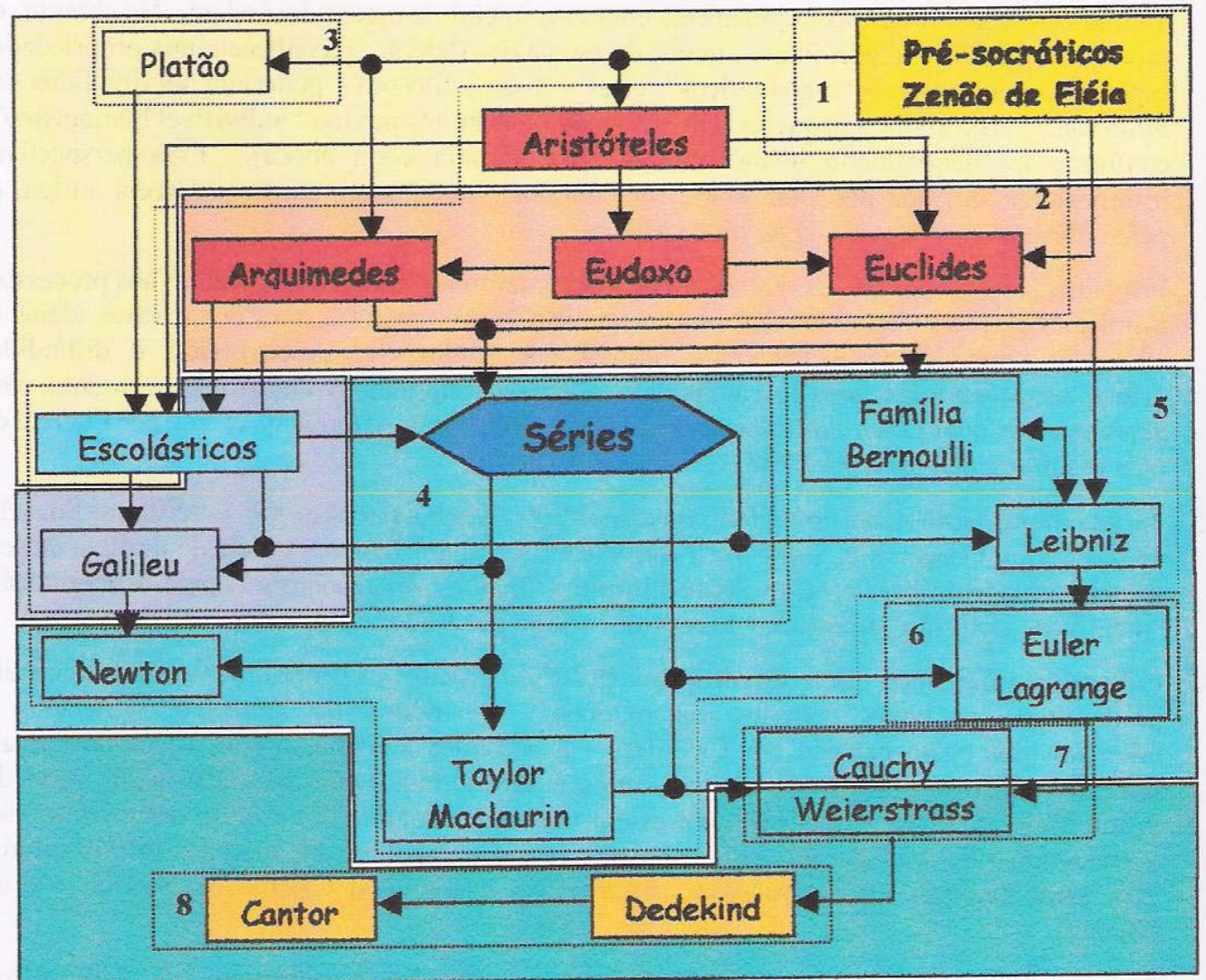

Início das questões relacionadas ao infinito

Reticência à noção de infinito

Introdução da noção de infinito no domínio da matemática

Instrumento construtor e difusor da noção de infinito

Domínio da filosofia

Domínio da Geometria grega Domínio da Física

Domínio do Cálculo

Domínio da Análise

Etapa de formalização 
1. Alguns historiadores consideram o período da filosofia pré-socrática como o marco inicial das discussões sobre a idéia do infinito no domínio da ciência, ou, pelo menos, da pré-ciência. De fato, a introdução de questões dessa natureza no âmbito da matemática é atribuída a Zenão de Eléia que, com seus paradoxos, suscita problemas interessantes relacionados ao movimento de corpos e ao uso das idéias de elementos indivisíveis e infinitesimais.

2. As situações contraditórias presentes nos paradoxos de Zenão e provocadas pelo uso das quantidades infinitamente pequenas e/ou indivisíveis fizeram com que Aristóteles propusesse o extermínio destas, e, é claro, da própria noção de infinito, da ciência grega. Atendendo à solicitação do filósofo, Eudoxo desenvolve, junto com a sua teoria das proporções, aquele que será tomado como procedimento padrão na matemática grega: o método de exaustão. Este método, difundido posteriormente por Euclides e Arquimedes, consistia de um método de prova indireto, que procurava através da negação da tese e do truncamento das seqüências de aproximação chegar a resultados contraditórios. No entanto, é sabido que Arquimedes, para chegar aos seus resultados, fazia uso das quantidades infinitamente pequenas, comprovando, assim, a não funcionalidade do método de exaustão para a descoberta dos resultados: tal método era tão somente um método de prova. Desse modo, pode-se afirmar que apesar da noção de infinito ter sido afastada do modelo de prova da matemática grega, ela subsiste, de modo marginalizado, nas idéias infinitesimais como elemento de descoberta dos resultados matemáticos. Foi assim, por exemplo, com Arquimedes.

3. Na filosofia grega, a noção de infinito encontra refúgio nas idéias de Platão. O filósofo de Atenas interpretou o seu conceito de infinitesimal a partir do conceito do apeíron ou indeterminado ilimitado. Para Platão, o contínuo poderia ser melhor interpretado pelo "fluir do apeíron” do que através de um agregado infinito de elementos indivisíveis.

4. Esta associação platônica do infinito com a idéia de movimento será recuperada na idade média, na Europa, pela filosofia escolástica. Os escolásticos não só re-introduzem a noção de infinito no âmbito da ciência como são os principais responsáveis pela tipificação e matematização da variedade de movimentos. As séries, nesse sentido, começam a desempenhar um papel fundamental na tradução e interpretação do infinito contínuo pelo infinito discreto. A tipificação dos movimentos - incluído aí o desenvolvimento do conceito de aceleração - junto com os processos infinitos - com destaque para as séries - são incorporados à física de Galileu. O físico italiano traz a tona problemas motivados pelos paradoxos de Zenão: como pode uma soma infinita ser limitada?

5. Newton, depois Taylor e Maclaurin, fazem uso das séries em diversos tipos de problemas do Cálculo. Leibniz também faz uso deste valioso instrumento em seu Cálculo - é verdade, que com bem menos intensidade do que Newton.

6. Euler e Lagrange, com a introdução do conceito de função, tornam a série infinita um instrumento fundamental no desenvolvimento do Cálculo: funções passam ser estudadas e interpretadas analiticamente a partir de séries infinitas; números irracionais são definidos a partir de série de números racionais etc.

7. Já no âmbito da Análise, Cauchy e Weierstrass dão uma contribuição fundamental para as questões aqui levantadas: a noção de convergência desenvolvida a partir da noção de limite.

8. A construção dos números reais é, ao mesmo tempo, causa e efeito do desenvolvimento da noção de infinito. Se, por um lado, as séries infinitas serviram como suporte para as primeiras caracterizações aritméticas dos números irracionais, por outro, o conjunto dos números reais se constitui como referência nas tipificações matemáticas do conceito de infinito. Dedekind e Cantor fecham então com chave de ouro a construção dos números e a história do infinito no âmbito da matemática. 
Figura 52 - Mapa da construção do conceito de número real

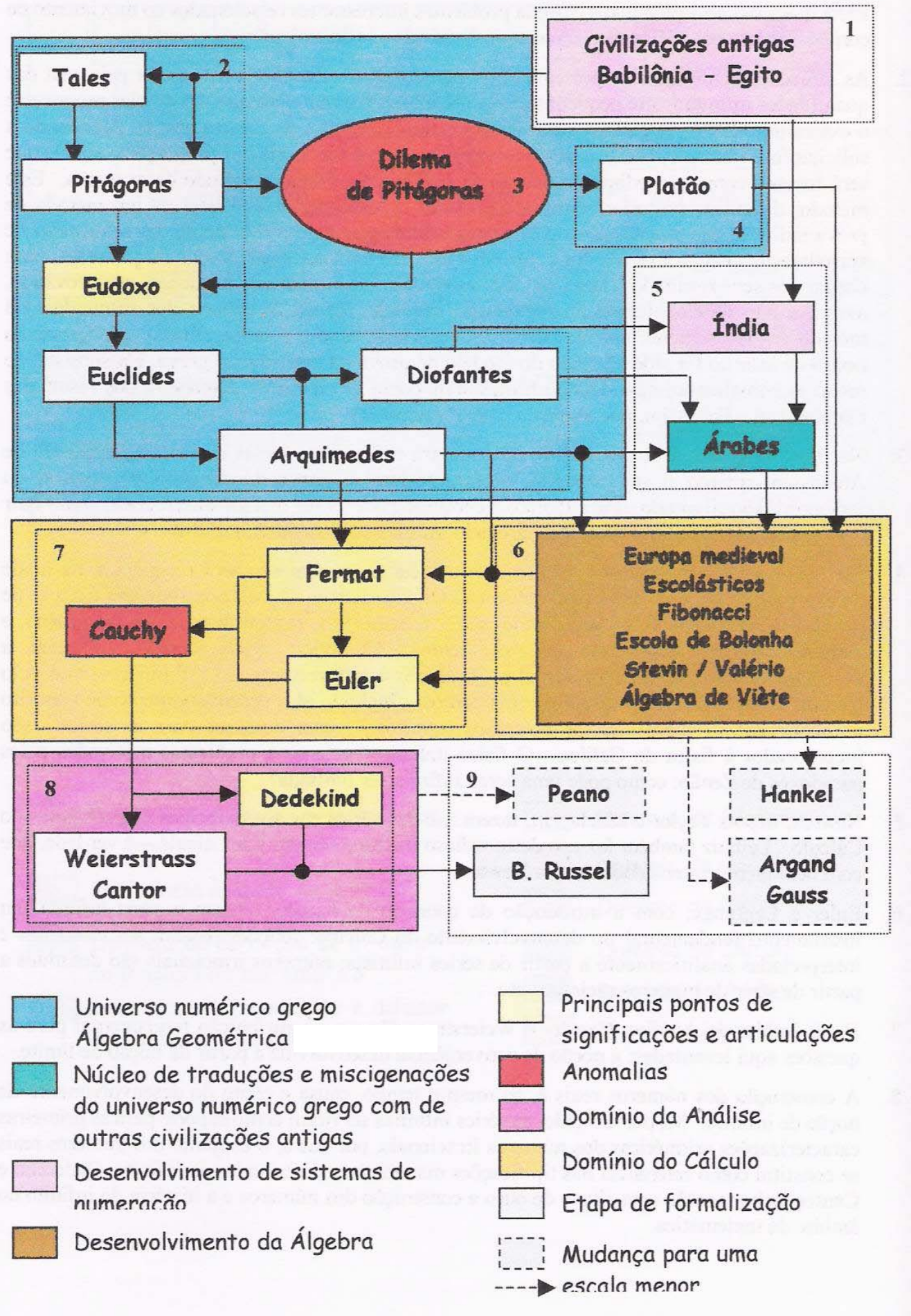


1. É neste momento histórico que se dá a construção dos primeiros sistemas de numeração, motivados pelos problemas de contagem (números naturais) e de medida (números racionais).

2. O domínio numérico da matemática grega está subordinado basicamente ao problema de medidas de grandezas geométricas. Os números figurados da escola pitagórica e a teoria das proporções desenvolvida por Eudoxo - e relatada no livro V dos Elementos de Euclides caracterizam bem o universo numérico da matemática grega que não ultrapassou o campo dos racionais positivos.

3. Os matemáticos gregos tomaram conhecimento, entretanto, da existência de segmentos incomensuráveis na geometria - como a diagonal do quadrado, por exemplo. A existência de tais segmentos causou um certo desconforto entre os geômetras gregos conhecido, historicamente, como o dilema de Pitágoras.

4. Uma possível solução para a anomalia da incomensurabilidade e dos paradoxos de Zenão foi vislumbrada por Platão. O filósofo ateniense percebeu, mais de 2000 anos atrás, que a solução do problema da medida das "quantidades incomensuráveis" seria alcançada através de uma construção axiomática do conceito de número, independente de qualquer base geométrica. Platão sugere então que se faça um esforço nessa libertação da aritmética da geometria.

5. A matemática hindu recebe influências tanto da matemática grega quanto da matemática desenvolvida na mesopotâmia. A construção de sistemas de numeração que deram origem ao nosso atual sistema e o desenvolvimento de procedimentos algébricos mais independentes da geometria foram as principais contribuições dos matemáticos hindus para o desenvolvimento da matemática e, mais especificamente, para o processo de libertação da aritmética e da álgebra da geometria. $\mathrm{O}$ culto à sabedoria realizada pela civilização árabe fez com que esta se tornasse efetivamente um centro de estudos e "miscigenações" do conhecimento científico. A forma grega de pensar (o raciocínio dedutivo) e o procedimento algébrico e aritmético desenvolvido pelos hindus (liberto do domínio geométrico) convivem com certa harmonia na matemática árabe.

6. Este convívio harmonioso - presente na matemática árabe - entre o pensamento algébrico, a aritmética - libertos da geometria - e o raciocínio dedutivo presente na geometria euclidiana, associado à assimilação por parte dos filósofos escolásticos da conjectura de Platão acerca do problema da incomensurabilidade possibilitará, na idade média, o surgimento de quatro instrumentos fundamentais para o desenvolvimento do Cálculo: o conceito de variável, a noção de infinitesimal, as séries e a noção intuitiva de limite. Stevin, Valério e Gregorie de Saint-Vicent são os principais responsáveis pela mutação da noção de limite presente no método de exaustão. Já Kepler, Cavalieri, Torricelli e Fermat constituem a via do desenvolvimento da noção de infinitesimal.

7. Viète e Fermat foram, sem dúvida, os principais responsáveis pelo desenvolvimento do método analítico e a introdução deste nos procedimentos do Cálculo. Fermat, além disso, se dedicou com entusiasmo ao desenvolvimento da teoria dos números. Outro grande matemático que, tendo já o conhecimento do Cálculo Infinitesimal de Newton e de Leibniz e do conceito de função, desenvolveu resultados importantes no âmbito da teoria dos números, foi o suiço Euler. O príncipe da matemática - como era chamado - aplicou o seu conhecimento de Cálculo para caracterizar e representar algumas quantidades irracionais, sem falar ainda, do desenvolvimento de parte substancial da teoria dos números complexos ${ }^{151}$. A proposta de construção dos números irracionais a partir de séries convergentes de racionais foi efetuada por Cauchy. No entanto, como a sua noção de limite estava fundamentada num conceito a priori de número real, sua proposta apresentava uma característica paradoxal.

8. Weierstrass "resolveu" a questão da circularidade presente no raciocínio de Cauchy identificando o número com a própria seqüência que "converge" para ele. Entretanto, a solução definitiva para a construção dos números reais de forma independente da noção de limite veio com Dedekind. Com o seu postulado de continuidade, e a partir da noção algébrica de corte, Dedekind constrói formalmente o conjunto dos números reais. Cantor e B. Russell desenvolvem também outras caracterizações dos números reais.

${ }^{151}$ A famosa expressão $e^{i \pi}+1=0$ foi demonstrada por Euler. 
9. A construção axiomática dos números reais que predomina atualmente na literatura de Análise se aproxima mais da caracterização de B. Russell. Por outro lado, a construção axiomática dos números naturais foi elaborada por Peano fazendo uso da teoria dos conjuntos. Já Hankel, algumas décadas antes de Peano, justifica os procedimentos operatórios dos números inteiros relativos, dando a estes a dignidade numérica, enquanto a dupla Argand - Gauss, um pouco mais cedo, desenvolvem os principais resultados acerca da teoria dos números complexos. 


\section{Uma cartografia simbólica do ensino de Cálculo}

5.1. Algumas visões preliminares sobre o ensino de Cálculo

Se a pergunta "o que é Cálculo?" fosse feita a um professor ou um estudante "medianos", recém saídos de uma aula de Cálculo, certamente a resposta que se ouviria seria posta em termos dos conteúdos didáticos usualmente ensinados nesse curso: limites, derivada, integral e algumas de suas aplicações. Esta simplificação excessiva da questão levantada é conseqüência imediata da influência de uma vivência didática, nem sempre crítica, de um curso "normal" 152 de Cálculo - ainda que este esteja maquiado com o uso de novas tecnologias (computadores) e de novos instrumentos de ensino (softwares matemáticos: maple, matlab etc.). Mas, seria realmente esta sequiência didática - a mesma proposta por Cauchy na sua apresentação do Cálculo no início do século XIX - a forma de apresentação legítima do que deveria ser o ensino de Cálculo?

Bem, a resposta para essa questão está intimamente relacionada com o que se pensa sobre o Cálculo e com o que se pretende com o seu ensino. Se nós imaginamos o Cálculo como uma espécie de Pré-Análise, e estamos preocupados apenas com o treinamento algébrico e sintático

\footnotetext{
${ }^{152}$ Ver significado de curso “normal” na nota de rodapé 17.
} 
de seus resultados, subordinando os objetivos de seu ensino aos da disciplina de Análise Real, podemos dizer que estamos no caminho certo. Mas, por outro lado, se com o ensino de Cálculo pretendermos que o aluno apreenda suas idéias básicas, suas redes de significações e relações com o conhecimento científico e outros domínios da matemática, se estivermos mais interessados no sentido dos resultados do Cálculo do que com a sua sintaxe lógica ${ }^{153}$, a resposta será negativa.

No entanto, ignorando as raízes de suas posições epistemológicas frente ao ensino de Cálculo, alguns professores assumem a tal sequiência didática e insistem no fato de que a diferença do Cálculo para a Análise estaria "apenas" no "modo de apresentação" dos conteúdos programáticos e na "dosagem do rigor" empregada em cada uma das disciplinas. Assim, em um curso de Análise "provam-se" os "resultados matemáticos" usados no Cálculo, enquanto que num curso de Cálculo faz-se apenas "contas", ou seja, "cálculos", e "aplicam-se os resultados".

Mas, que "resultados"? Quem é que determina esses "resultados": o Cálculo ou a Análise? Ao que parece, isto é, da forma como estão estruturadas estas disciplinas no ensino superior, é a Análise que traça as diretrizes para o ensino de Cálculo. Surge assim, no campo pedagógico, uma contradição em relação à origem histórica da própria Análise. Pior para o ensino de Cálculo, que não consegue ter como referência outro ponto além desta visão "pré-analítica" do próprio Cálculo.

\footnotetext{
153 Seria interessante, talvez, retomar a leitura da discussão que realizamos no capítulo anterior deste trabalho sobre o Cálculo e a sua essência.
} 
Esse confronto entre os domínios das disciplinas de Cálculo e de Análise é inevitável quando procuramos discutir acerca de quais seriam os elementos pedagógicos e os conteúdos essenciais de qualquer uma delas. E, a partir desse confronto, surge uma outra discussão, de natureza epistemológica, que diz respeito à tensão entre dois elementos essenciais na construção do conhecimento matemático como um todo: o rigor e a intuição. Um recorte desta relação entre as disciplinas de Cálculo e Análise, tomando como referência esses dois elementos construtores do conhecimento matemático, é discutido em (Reis, 2001). Façamos uma breve revisão crítica dos principais pontos da análise de Reis.

A revisão de alguns pontos centrais da tese de Reis nos ajudará a situar, a partir do confronto com a Análise, alguns elementos inerentes ao domínio de uma disciplina de Cálculo. De início, pode-se adiantar que não existe uma opinião consensual no meio acadêmico nem dos autores de livros didáticos entrevistados pelo autor, nem de quaisquer outros professores e pesquisadores do ensino de Cálculo - a respeito do que deveria ser uma disciplina inicial de Cálculo. O que se busca aqui com essa discussão é tão somente fornecer ao leitor um panorama contextual da crise de identidade dessa disciplina, até para que se possa justificar certos procedimentos que adotaremos quando realizarmos, na próxima seção, o mapeamento das dificuldades de aprendizagem no ensino de Cálculo.

Em sua tese de doutorado $A$ tensão entre rigor e intuição no ensino de Cálculo e Análise, Reis realizou entrevistas com alguns dos 
principais autores ${ }^{154}$ (nacionais) de livros didáticos de Cálculo e de Análise a respeito do tema. Uma das poucas atitudes consensuais entre os professores entrevistados foi a rejeição da forma de rigor que fundamenta o ensino de Cálculo no conceito weierstrassiano de limites e continuidade, com épsilons e deltas. No mais, os quatro autores apresentaram posições divergentes, bastante diferenciadas em relação às questões levantadas pelo autor da tese.

No que tange à correlação de forças entre a intuição e o rigor no ensino de Cálculo - questão norteadora da referida tese - as atitudes ficaram bem divididas, algumas vezes não muito bem definidas. Dois deles, entretanto, explicitaram claramente sua opção por uma abordagem mais intuitiva do Cálculo: o professor Ávila e o professor Baldino, este último, por sinal, já citado diversas vezes no desenvolvimento deste trabalho.

O professor Ávila, baseado em sua experiência com ensino, relata que:

Então, depois de toda essa minha experiência com ensino, eu acordei para esta realidade de que o ensino rigorizado desde o início não é a melhor coisa. A gente tem de lembrar que o intelecto não é só racional, não é só lógica, mas tem a intuição, a visualização geométrica, que muito ajudam no aprendizado.

(Entrevista com Ávila - nov/98, apudReis, 2001, p.109)

Ávila destaca ainda que, apesar do Cálculo ser, atualmente, um instrumento para físicos, engenheiros, químicos, biólogos, estatísticos, economistas e cientistas sociais: "seus conceitos fundamentais são profundos e sutis, e desafiaram os melhores matemáticos por cerca de

\footnotetext{
154 São eles: Djairo Guedes de Figueiredo, Geraldo Severo de Souza Ávila, Elon Lages Lima e Roberto Ribeiro Baldino - que na época da entrevista (1998) eram, respectivamente, professores da UNICAMP, UFG-GO, IMPA e UNESP/Rio Claro.
} 
século e meio. A devida apreciação desses conceitos só pode ser adquirida gradualmente e por via intuitiva". E prossegue dizendo que:

O Cálculo deve ser apresentado com um mínimo de formalismo, com apelo à intuição e aos problemas de Física e Geometria que Ihe deram origem.

(apud Reis, 2001, p.111)

A posição do professor Baldino em relação a esta problemática já foi apresentada no início deste nosso trabalho, mas segundo outras fontes. Gostaríamos, entretanto, de lançar mais luz sobre a sua opção por uma abordagem intuitiva do Cálculo, transcrevendo aqui 0 fragmento de um diálogo do professor com o entrevistador, quando, na ocasião, relata a este último algumas de suas experiências didáticas:

Baldino: Olha, o Teorema do Valor Intermediário uma vez eu tentei numa aula de Física, quando eu estava discutindo isso, eu tentei dizer pros caras "Olha, aqui, como é que você vai cercar esse número real aqui, vai ser o limite de uma seqüência, etc". E um cara disse: "Mas, pra que, se a curva passa de cima pra baixo tem que cortar num ponto. Isso não tem sentido". Eles não aceitaram a problematização que eu tava querendo pôr, atinge o valor intermediário, vai cortar e acabou. O Teorema do Valor Médio, por exemplo, quer dizer, o que que aquilo é. Tem aí num artigo desses que eu escrevi. Quer dizer, o cara faz uma aplicação: a derivada, agora, a aplicação do teorema do Valor Médio, se a derivada é zero então a função é constante, olha aqui, porque existe um ponto intermediário, etc. Ai o aluno da física diz assim: "Mas quer dizer então, que um automóvel com velocidade nula fica parado?" 155. É, no fundo é isso. Não precisa demonstrar. Não tem sentido demonstrar isso. É evidente, velocidade nula, vai ficar parado. Se a derivada tem derivada nula ela é constante, demonstrar o quê? Que problemática é essa? Ele vai pensar em quê? Não é um problema dele. Quer dizer, você tá querendo que o sujeito pense num problema que não é dele. Ora ele vai decorar. Não tem sentido pra ele.

Reis: Com certeza, então quer dizer, a própria intuição levou à aquisição daquele conhecimento sem a necessidade dele ser formalizado a nível de demonstração, com épsilons e deltas...

Baldino: Sem a menor dúvida. Ele ta demonstrado a nível da turma, porque o que que é demonstrar? Demonstrar, no fundo, é justificar. Ele ta justificado, ele tem justificações. O aluno fala, ele mostra com um gesto que se a derivada é nula a função não se mexe, é constante. Então isso pra ele é uma demonstração. Agora pro matemático não é, mas é outro contexto, é outro campo semântico. Num campo semântico de um curso de Cálculo, isso aí ta mais do que demonstrado,

\footnotetext{
${ }^{155} \mathrm{O}$ exemplo que o professor Baldino apresenta já foi citado no nosso trabalho (p.12) e pode ser encontrado também na referência bibliográfica (Baldino, 1998).
} 
não tem o que fazer mais, não tem o que duvidar. Você só vai duvidar disso quando você entra no: "O que que é, afinal, um número real onde a curva corta o eixo, 0 que que é esse número real?". Aí, o próprio Bolzano errou, o próprio Cauchy não tinha essa demonstração. Ele não tinha o conceito de número real. Então você vai cobrar do aluno uma coisa que os matemáticos do passado não foram capazes de fazer (...).

(apud Reis, 2001, p.232)

Já o professor Djairo não se define por nenhuma das duas linhas de pensamento. Chega a se posicionar na linha formalista de Hilbert, por oposição ao intuicionismo de Brouwer, mas acaba concluindo que no processo de criação de matemática, o "cara" acaba usando mesmo a intuição:

Então, é uma questão de ,, novamente eu sou mais Hilbert. Hilbert teve uma grande polêmica, você deve saber, com Brower, no início do século, sobre o negócio de construtividade e numa determinada hora o Hilbert disse: "Olha, eu prefiro fazer matemática com as duas mãos em vez de fazer com uma amarrada nas costas". Ele considerava que você começando a... tira o axioma da escolha, tira isso, tira aquilo, você tá se limitando no tipo de matemática que você vai fazer. Mas então é tudo uma questão de onde você começa. Você ter... sobre esse método dedutivo e sobre o rigor. Você tem as suas bases, os seus axiomas, suas definições, e dai em diante você prossegue honestamente. Eu acho que rigor é isso, não tem "aconchambração". "Como é que você demonstra isso? Tá aqui. Onde é que você usou o axioma da escolha, onde é que o Sr. usou o postulado de Dedekind? Eu usei aqui". Então, com isso, você educa o aluno. Eu acho que é por aí. Você não pode... bom isso é na demonstração. Agora tem outra coisa sobre o rigor, uma coisa também que eu falei que é o seguinte: a questão de como é que 0 fulano faz matemática. O sujeito tem a impressão de que o matemático quando tá criando, ele tá extremamente cuidadoso em fazer uma coisa e usar o método dedutivo no processo de criação da matemática. Isso não é verdade. No processo de criação de matemática, o cara usa intuição, tentativa, faz de conta que isso vai funcionar. Uma vez que ta tudo... que ele chegou à conclusão: "Ah, de fato, este negócio deve ser verdade". Aí sim, aí ele tem que sentar e na hora de escrever o artigo, o artigo tem que ser escrito com rigor. Mas o processo de criação não é assim.

(apud Reis, 2001, p.273)

No seu argumento, Djairo reserva à intuição o papel da descoberta dos resultados matemáticos, cabendo ao método dedutivo dar a validade do pensamento até então intuitivo: é assim que se "faz 
matemática" - disse o professor. A questão que se coloca então, a partir dessa afirmação, é: em que medida queremos que o nosso aluno faça matemática? Fazer o aluno compreender a estrutura de uma demonstração ajuda a "educar o aluno"? Educar em quê? É preciso que se diga. É inegável que o ato de demonstrar tem a sua importância fundamental para aquilo que chamamos de "fazer matemática" principalmente quando é o aluno que faz a demonstração ${ }^{156}$. O que precisamos definir é a intensidade e o papel da demonstração na construção dos conceitos básicos no ensino de Cálculo.

Reis (2001, p.67) conta-nos em sua tese, por exemplo, um fato pitoresco de um matemático não muito conhecido, Pierpont (1899), que vivenciou, no final do século XIX, os três projetos considerados mais importantes da Matemática naquela época: a Aritmetização da Análise, segundo Weierstrasss; a Fundamentação da Teoria dos Conjuntos, segundo Cantor; e a Filosofia do Formalismo, segundo Frege (18481925). Segundo o pesquisador, Pierpont não resistia à "visão de rigor total" oferecida pelos três e pronunciou a célebre frase: "O que pode ser provado deve ser provado!". Por outro lado, em oposição a Pierpont, pode-se afirmar, em consonância com os professores Ávila e Baldino, que "o que tem significado para o aluno não precisa ser provado!". Tudo é uma questão de prioridade, de atitudes procedimentais. Diante disto, cabe-nos perguntar qual é, afinal, a atitude do estudante que se quer efetivamente quando ensinamos matemática? Qual deve ser o elemento motivador do processo de ensino: o problema que é a fonte do resultado que se quer intuir ou o

\footnotetext{
${ }^{156}$ Cabe aqui lembrar a proposta do professor Baldino, apresentada no início desta tese, de que o professor deve falar menos e ouvir mais e, o aluno, ouvir menos, e falar mais.
} 
resultado, já finalizado e enunciado em forma de teorema? Quer dizer, o que deve ser priorizado é o processo "intuitivo" da criação ou o processo "educativo" de vigilância do rigor, na busca da compreensão de uma demonstração?

Outra questão que se impõe ainda, relacionada diretamente à natureza da disciplina que se vai ensinar, é se a atitude do estudante desejada deve ser flexibilizada em relação à disciplina a ser ensinada? Isto é: a atitude que se espera do aluno num curso de Cálculo é diferente daquela num curso de Análise? Voltamos então ao começo de nossa discussão: caberia então ao Cálculo uma abordagem mais intuitiva e à Análise uma abordagem mais rigorosa?

O professor Elon - o quarto entrevistado por Reis - apresenta em sua argumentação um tripé de ações que ele considera como sendo os três componentes fundamentais do ensino de matemática em geral: a conceituação, a manipulação e as aplicações. No que diz respeito à polêmica entre o Cálculo e a Análise, o professor sustenta que a diferença entre eles é "meramente didática", cabendo à primeira uma abordagem com ênfase nas aplicações e nas manipulações, e à segunda, com ênfase no raciocínio, no método dedutivo:

Bom, primeira coisa. Esta questão, esta pergunta que você fez: a diferença entre Cálculo e Análise. A diferença entre Cálculo e Análise é meramente didática. Quer dizer, se você ensinar com ênfase nas aplicações e nas manipulações, então você vai ensinar Cálculo. Agora, se você quer pôr ênfase no raciocínio, no método dedutivo, na organização da matemática, da Análise Matemática como ciência dedutiva, então é Análise. Éa diferença entre o livro do Heron e o livro do Euclides. O Heron era um cara aplicado, os livros dele eram voltados para as aplicações da matemática, enquanto que o livro de Euclides era um livro que tinha por objetivo sistematizar, embora ambos fossem didáticos, sistematizar o conhecimento matemático de forma a mais rigorosa possivel dentro dos padrões da época. Então, essa diferença de Cálculo e Análise é uma diferença meramente didática que eu acho, eu insisto que é um ponto de vista generalizado, que o Cálculo deve preceder a Análise por motivos de maturidade intelectual.

(apud Reis, 2001, p.297) 
No que diz respeito à problemática do rigor, o professor rejeita a idéia de um rigor absoluto:

(...) Quer dizer, então essas coisas, o rigor ele evolui passo a passo. E dependendo da atitude das pessoas, você nunca atende um rigor absoluto. 0 absoluto é uma coisa terrível para a matemática, tornaria a matemática impalatável, difícil de engolir. Eu acho que você tem que responder à questão do rigor sempre com honestidade, eu acho que demonstrar é convencer as outras pessoas. Na medida que seus interlocutores estão convencidos, você não precisa demonstrar. Por exemplo, você está dando aula no ginásio. Daí você pega três pontos sobre uma circunferência. Você não vai provar para os seus alunos que três pontos distintos sobre uma circunferência nunca estão numa mesma reta, nunca são colineares. Todo mundo aceita isso. Então, para que que você vai provar isso? Mas, na verdade, isso aí precisa ser provado, a partir da definição de circunferência. Mas então, eu costumo dizer que para os meus alunos que rigor e exigência de precisão em matemática é muito parecido, quando você dá aula, é muito parecido com ensinar educação sexual para uma criança. Você vai até o ponto em que ela fica satisfeita. Mais tarde, quando ela for amadurecendo, você vai mais longe. E mais tarde quando ela for amadurecendo mesmo, não precisa mais de você, ela já sabe. A mesma coisa é em matemática. Você não deve ir além do que os alunos necessitam, se eles estão satisfeitos com sua explicação... desde que não seja uma mentira. Você não vai dizer para o seu filho que as crianças vieram com a cegonha, por exemplo, que depois você vai ter de desdizer mais tarde. Éa mesma coisa em matemática. Você não vai fazer uma coisa dizendo que $a+b$ ao quadrado é igual $a^{2}+b^{2}$ porque depois você vai ser pego na mentira. Mas, respeitando esse princípio de que você sempre deve dizer a verdade, mas não necessariamente toda a verdade, eu acho que aí está um dos pontos de equilíbrio do ensino.

(apud Reis, 2001, p.292)

A flexibilização do rigor parece ser, com efeito, um outro ponto consensual entre os professores entrevistados. Curioso também é a definição não "rigorosa" de demonstração (demonstrar é convencer outras pessoas) feita pelo professor Elon, (cuja produção acadêmica se dá no âmbito da matemática pura) em sua argumentação. O professor Baldino também concorda com essa definição: para ele "demonstrar, no fundo, é justificar". Interessante também é o princípio da honestidade de que nos fala Elon: "você deve sempre dizer a verdade, 
mas não necessariamente toda a verdade". E no que diz respeito mais diretamente ao ensino de Cálculo ele conclui que:

(...) você deve ensinar Cálculo como você deve ensinar matemática sempre de forma honesta. Você pode não exagerar na conceituação, mas sempre você deve se colocar numa posição defensável do ponto de vista lógico. ... Você pode não dizer toda a verdade, mas sempre dizer a verdade. (grifo nosso)

(apud Reis, 2001, p.286)

Este argumento do autor deixa transparecer uma certa dúvida com relação ao primeiro elemento do seu tripé fundamental do ensino de matemática: a conceituação. $O$ que o autor quer dizer com a expressão "não exagerar na conceituação"? Ou melhor, o que ele quer dizer com "conceituação"? Estaria o professor se referindo apenas à justificação lógica dos resultados matemáticos? Seria este então o significado de conceituar para o autor? Por outro lado, se conceituar significa construir significados, estabelecer feixes de relações entre os significados envolvidos no processo de ensino, um exagero dessas atitudes no ensino de Cálculo até que seria bem vindo, uma vez que tal ensino tem sofrido ultimamente uma quase total abstinência de significações - quando essas existem, restringem-se, em geral, ao domínio da justificação lógica dos resultados matemáticos. Acreditamos, desse modo, que não se deva reduzir o nível de conceituação, mas, sim diversificar os meios para que se possa atingir um nível de significação mais apropriado para o ensino de Cálculo. Nesse sentido, conceituar assume uma dimensão mais ampla: a de "estabelecer relação entre significados", em que a justificação lógica a demonstração - passa então a ser apenas uma das possibilidades. 
O professor Ávila, defendendo a "transmissão de idéias" como o principal procedimento de conceituação, faz um alerta para 0 despropósito de uma exposição carregada de formalismo e rigor:

Qualquer curso, seja de Cálculo, Análise ou outra disciplina matemática, deve, antes de tudo, transmitir idéias. E isto nem sempre é possivel numa exposição carregada de formalismo e rigor. Até mesmo em cursos mais avançados, a insistência excessiva nesses elementos da apresentação freqüentemente dificulta a transmissão das idéias e o próprio aprendizado.

(apud Reis, 2001, p.119)

Morris Kline, no prefácio do seu texto "Cálculo: uma aproximação intuitiva e física", é muito mais incisivo em suas críticas a uma apresentação rigorosa de um curso inicial de Cálculo. Segundo o professor, além de tal abordagem ser muito difícil para o estudante que está tendo um primeiro contato com este assunto, esta camufla, sobretudo, o verdadeiro espírito de criação em matemática: a abordagem formal causa a falsa impressão de que o matemático realiza seus trabalhos "dedutivamente". Complementando sua crítica, o professor cita duas célebres frases que demonstram a limitação do método dedutivo na criação e construção dos significados em matemática:

Um primeiro curso rigoroso em Cálculo lembra algumas das palavras de Samuel Johnson; "Eu encontrei um argumento pra você, mas eu não sou obrigado a encontrar para você o entendimento". Ainda que o material rigoroso seja compreendido, seu valor é limitado. Como Henri Lebesgue chamou atenção: "Lógica nos faz rejeitar certos argumentos, mas ela não pode fazer-nos acreditar em algum argumento."

(Kline, 1998, prefácio)

Concordando com os professores Ávila e Kline, acreditamos que a posição do professor de Cálculo deve ser muito mais ousada, deve sair da "retranca", da "posição defensável do ponto de vista lógico", e optar pela busca a todo o momento pela "transmissão de idéias", isto é, 
pela construção dos significados - esta, aliás, deve ser, efetivamente, a meta não só do ensino de Cálculo como da própria matemática em geral ${ }^{157}$. Cabe aqui, entretanto, uma ressalva a esse debate polêmico que se trava entre os elementos do par rigor/intuição: estes não são termos mutuamente excludentes.

Com efeito, é muito comum os matemáticos sugerirem que uma "explanação intuitiva" é aquela em que, necessariamente, "falta rigor". Bicudo (1992, p.64), no entanto, contrariando esta concepção dicotômica entre intuição e rigor, apresenta nos uma relação de simbiose entre eles no processo de construção do conhecimento matemático:

É por essa tensão dialética entre intuição e rigor que se sobe na espiral do conhecimento matemático. Mesmo que não percebamos, a intuição está impregnada do rigor que colaborou na possibilidade de sua criação. Éo equilíbrio das tendências de diferenciação (intuição) e unificação (rigor). Não há avanço de uma sem a outra.

Kline (1998, prefácio) complementa a observação de Bicudo afirmando que:

O rigor refina indubitavelmente a intuição, mas não a suplanta.

Isto posto, o que se percebe mais uma vez é que não existe um rigor absoluto, nem tampouco uma intuição absoluta. Não é à toa que a metáfora utilizada por Reis (2001, p. 203) para escalonar os diversos níveis de rigor e intuição é um intervalo aberto: não tem máximo, não tem mínimo. O que existe, em verdade, são níveis de rigor. Aliás, a própria história da matemática nos fornece elementos suficientes para

\footnotetext{
${ }^{157}$ Poderíamos afirmar que tal meta se estende para o ensino de qualquer conhecimento em geral; preferimos, no entanto, não polemizar com as outras áreas do conhecimento.
} 
- nosso convencimento a respeito da existência desses diferentes níveis de rigor.

Com efeito, a "intuição geométrica" e a teoria das grandezas incomensuráveis de Eudoxo, por exemplo, foram fundamentais para a formalização do conceito de continuidade de Dedekind. Outro exemplo notável é a própria história do Cálculo, que apresentamos no capítulo 4 deste trabalho. O desenvolvimento propriamente do Cálculo se deu em três níveis, a saber:

- no período inicial, o de invenção dos procedimentos infinitesimais, por Fermat, Newton e Leibniz, o Cálculo foi fundamentado na idéia intuitiva de quantidades infinitamente pequenas; ser rigoroso aqui era saber justificar os seus argumentos com base na teoria desenvolvida acerca das quantidades infinitesimais:

- após a crise da inconsistência lógica das quantidades infinitesimais, segue um período de indecisão em que coexistiram mais de uma abordagem para o Cálculo: uma em termos de limite, defendida por D'Alembert, outra em termos de infinitésimos, liderada por Euler, e outra, minoritária, liderada por Lagrange, que foi baseada numa crença ingênua de que a álgebra poderia dar conta dos processos infinitos que permeiam tanto a abordagem infinitesimal e como aquela em termos de limites;

- com a fundamentação das idéias básicas do Cálculo realizada por Cauchy, a noção intuitiva de limite passa ser o paradigma de rigor para a demonstração dos resultados do Cálculo; 
- só depois, com a definição formal de limite e o processo de aritmetização da Análise iniciada por Weierstrass, é que surge o padrão epsilônico de limites para a demonstração dos resultados do Cálculo. Mas, isto já é Análise, e não Cálculo 158.

Inúmeros outros exemplos poderiam ser citados aqui; preferimos, no entanto, aproveitar a potencialidade deste último exemplo a respeito dos diferentes níveis de rigor no desenvolvimento histórico do Cálculo. O historiador inglês Grattan-Guiness (1997), por exemplo, destacou a importância desse mapeamento histórico do rigor do conhecimento com finalidades didáticas:

(...) a história da matemática ensina muito claramente que, de fato, o rigor se dá em niveis, os quais, portanto, devem ser especificados antes de se avaliar o trabalho matemático do estudante.

(Grattan-Guiness, 1997, p.81)

Com efeito, estes níveis históricos do rigor, se não podem funcionar propriamente como paradigma, servem, sem dúvida, como parâmetros para que possamos encontrar e balizar o nosso paradigma de rigor no ensino de Cálculo. Grosso modo, pode-se afirmar, com base nas observações de especialistas ${ }^{159}$, que o paradigma de rigor propriamente daquilo que se costuma chamar de Cálculo situa-se a partir de Newton e Leibniz, momento de sua invenção, até a primeira fase de Cauchy: a partir do processo de aritmetização da Análise - do

\footnotetext{
${ }^{158}$ Segundo o professor Baldino, Análise (Real) é a teoria de Weierstrass aplicada às questões fundamentais do Cálculo (apud Reis, 2001, p.232).

${ }^{159}$ Historiadores de matemática, pesquisadores da área temática do ensino de Cálculo, professores de Cálculo, autores de livros didáticos de Cálculo etc.
} 
qual Cauchy também participou em sua fase inicial - já se pode considerar como domínio da própria Análise.

Por outro lado, é importante que se diga que o paradigma de rigor para o ensino de Cálculo, se é que existe, depende de outras variáveis do campo pedagógico: muitas destas se encontram inclusive fora do foco e do alcance desta nossa pesquisa. A busca desse paradigma é, sem dúvida, um dos maiores desafios para o professor de Cálculo. Assim, considerando a metáfora do ponto de equilíbrio, Reis conclui que o ponto de equilíbrio entre a intuição e o rigor seria o ponto ideal do procedimento didático:

Talvez a melhor metáfora, que agora se nos apresenta, seja o de uma reta com dupla seta, onde, numa extremidade pode-se representar o rigor e, na outra, a intuição:

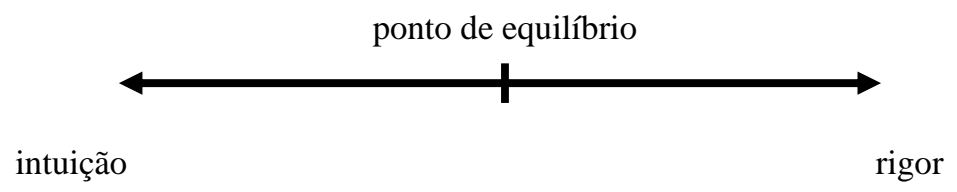

É claro que o ponto ideal é o de equilibrio, mas este ponto, na verdade, é difícil de ser conseguido no ensino. O trabalho do professor pode situar-se em qualquer um dos pontos dessa reta contínua. $O$ professor tem autonomia para deslocar-se para qualquer ponto dessa reta. Se o deslocamento tenderá a ser, com mais frequiência, para a esquerda, (intuição), isso pode denotar uma preocupação pedagógica mais voltada à produção de sentidos e significados e à formação de conceitos. Se o deslocamento for, com mais freqüência, para a direita (rigor), isso poderá significar uma preocupação e uma ação pedagógica mais sintáticoprocedimental.

(Reis, 2001, p.202)

Antes de prosseguirmos gostaríamos de tecer alguns comentários sobre a metáfora de Reis. Primeiro, é preciso que se entenda que o ponto de equilíbrio - que o professor considera como o ponto ideal - é um marco ideológico e varia de professor para professor - o que ele (Reis) considera como ponto de equilíbrio não é o 
mesmo que, por exemplo, Baldino considera. Não existe posição consensual a respeito do que seja um ponto de equilíbrio - a própria tese de Reis demonstra isso. Outra observação que deve ser feita é que o ponto ideal não depende apenas da intenção / expectativa do professor: este varia de acordo com o contexto oferecido pelo grupo real de alunos que está cursando a disciplina de Cálculo. O professor precisa ser perspicaz e flexível o suficiente para, na realização do próprio curso, chegar o mais próximo possivel do ponto ideal. Esse ponto é, na verdade, uma utopia pedagógica que se ajusta a cada momento novo do processo ensino-aprendizagem.

Por outro lado, é importante que se diga também que a metáfora que o autor construiu é uma bela tentativa de se buscar uma resposta para uma questão de natureza bastante complexa: o ponto ideal entre rigor e intuição no ensino de Cálculo. Sua tese, junto com as opiniões dos seus entrevistados, ofereceu-nos um maravilhoso painel do que pode e deve ser uma disciplina inicial de Cálculo. Com base nessa revisão ${ }^{160}$, tiramos alguns indicadores do que deveria ser, em nossa opinião, um curso inicial de Cálculo. Não se trata de uma opinião consensual, nem tão pouco de uma verdade absoluta, é apenas a "nossa verdade" em busca de uma identidade para o curso superior de Cálculo, diante das circunstâncias aqui apresentadas pelos autores supracitados. São eles: 
- O conteúdo do Cálculo não se resume na sequiência limitecontinuidade-derivada-integral; ao contrário, podemos situar este conteúdo dentro do intervalo histórico que vai de Leibniz à primeira fase de Cauchy; definição formal de limite $e$ os resultados frutos do processo de aritmetização desenvolvido por Weierstrass é Análise, Análise Real.

- Os conceitos básicos do Cálculo são as operações de diferenciação, de integração e o Teorema Fundamental do Cálculo, sejam estes conceitos e resultados desenvolvidos a partir da noção de limite ou de infinitesimal. A fundamentação da operação de limite é do âmbito da Análise Real, e a da noção de infinitesimal, da Análise Não-Standard. Cálculo é Cálculo! E não, Análise.

- Concordamos com os professores Ávila e Baldino: o significado, o sentido dos resultados deve prevalecer sobre a sua justificação lógica. A discussão de idéias vale muito mais que a apresentação / reprodução da demonstração de um resultado matemático: "é assim que se faz matemática" disse o professor Djairo.

- A relação do Cálculo com outras áreas do conhecimento não deve ser realizada apenas em termos de aplicações e no final do processo de construção de seus conceitos básicos; tal relação deve ser antecipada, ser o carro-chefe das idéias geradoras dos conceitos básicos do Cálculo. A noção de velocidade, por exemplo, não é meramente uma aplicação do

${ }^{160}$ da tese de Reis e da opinião de outros autores. 
conceito de derivada; velocidade é, isto sim, um dos principais elementos do núcleo semântico do conceito de derivada.

Assim, com esta revisão preliminar, acreditamos que chegamos a extrapolar, em alguns momentos, a nossa meta de "fornecer ao leitor um panorama contextual da crise de identidade da disciplina de Cálculo". Acreditamos, entretanto, que cumprimos nossa meta inicial. No entanto, alguns pontos discutidos aqui serão retomados na seção seguinte, só que agora no contexto das dificuldades de aprendizagem de natureza epistemológica dos estudantes no ensino de Cálculo - nosso principal objeto de análise. 


\subsection{Dificuldades de natureza epistemológica do ensino de Cálculo}

As dificuldades do ensino de Cálculo são a confirmação mais verdadeira das dificuldades do ensino de matemática em sentido amplo. Com efeito, no ensino médio e fundamental de matemática consegue-se, em geral, dissimular as dificuldades de aprendizagem através da assimilação das "regras do jogo" pelo aluno. Mas no ensino superior de Cálculo a continuidade do jogo deixa de ser possível, uma vez que não existe qualquer tipo de preparação para isso: os conteúdos que fazem parte da rede de significações do Cálculo ou são ignorados ou se encontram camuflados sob outras idéias no ensino básico de matemática. Dessa forma, por exemplo, que a "transformação das dízimas periódicas em frações" é uma regra da "aritmética", a "área do círculo" é apenas uma "fórmula geométrica", a "definição dos números irracionais" é "puramente algébrica" (costuma-se dizer que "número irracional é aquele que não pode ser escrito como uma razão de inteiros..." - aquele "o quê?") etc.

Assim, com a camuflagem dos problemas e das idéias básicas do Cálculo no ensino de matemática, o estudante desenvolve sua aprendizagem em matemática nos níveis fundamental e médio ignorando completamente aquilo que ficou escondido. Com isso, as dificuldades de aprendizagem no ensino superior de Cálculo logo aparecem, uma vez que o professor insiste em ensinar as "regras do jogo" sem que os elementos fundamentais e que dão significado ao jogo ainda façam parte das redes de significações dos estudantes. 
As dificuldades de aprendizagem que os alunos apresentam em geral num curso inicial de Cálculo no ensino superior são bem diversificadas e se encontram distribuídas ao longo de todo o processo didático. Vão desde de "problemas de fundo emocional", como, por exemplo, o temor pela possivel reprovação, aos "problemas de base" na formação matemática do estudante. Cabe ressaltar, entretanto, conforme já enunciamos no início desta tese, que o foco desta pesquisa está nas dificuldades de natureza epistemológica e específica do ensino de Cálculo. Um mapeamento dessas dificuldades é o principal objetivo desta seção. Antes, porém, de iniciarmos o tão pretendido mapeamento, algumas observações são pertinentes.

A primeira delas diz respeito à escala a ser utilizada. $O$ procedimento que adotaremos partirá sempre de escalas menores, onde procuraremos determinar os macro-espaços de natureza epistemológica, aumentando em seguida as escalas para que se possa ver com mais detalhes, em cada um deles, as redes de dificuldades e os seus entrelaçamentos. Será inevitável em nossas análises retornar a escalas menores, ou estabelecer conexões com outros mapas, de outros domínios do conhecimento, e outros contextos diferentes, com o objetivo de esclarecer o nosso ponto de vista. O confronto das dificuldades de aprendizagem dos estudantes com os obstáculos epistemológicos que os matemáticos tiveram que superar para efetivarem a construção dos conceitos básicos do Cálculo foi, por exemplo, um recurso muito utilizado por nós para refletirmos e compreendermos algumas destas dificuldades. Isto, por si só, já justificaria a revisão histórica que fizemos da evolução das idéias básicas do Cálculo. 
O procedimento de escolha das escalas não é linear, muito pelo contrário, envolve múltiplas dimensões. A opção de começar pela menor escala possivel ${ }^{161}$ tem implicações tanto de natureza filosófica quanto organizacional. Em verdade, o que observamos a priori são as dificuldades dos alunos e não os macro-espaços. No entanto, cabe ressaltar que o ato de construir a "menor" escala é um exercício de grande intensidade intelectual no terreno da epistemologia do Cálculo e do seu ensino.

A configuração global dos macro-espaços é desse modo o resultado desse esforço que, de certa forma, já tinha se iniciado na discussão feita no capítulo anterior sobre a essência do Cálculo. Com efeito, os obstáculos epistemológicos originados em determinados conceitos do Cálculo antecipam, de certo modo, algumas das dificuldades encontradas pelos nossos estudantes. Assim, para identificarmos os nossos macro-espaços fizemos uso de cinco dualidades essenciais do Cálculo e de seu ensino: discreto/ contínuo: finito/infinito; variabilidade/permanência; local/global; sistematização/construção. As três primeiras, conforme observamos, foram introduzidas no mapeamento que fizemos do Cálculo. As duas últimas são outras duas dualidades fundamentais para a discussão da problemática do ensino do Cálculo, sendo que a última, no entanto, não é de caráter específico do Cálculo. A presença da dualidade local/global é justificada aqui pelo belo texto de Petitot (1985, p.1171), publicado no volume 4 da enciclopédia Einaudi sobre este tema. Já

\footnotetext{
${ }^{161}$ Esta foi a menor escala possível que encontramos no período de realização do trabalho; pode ser, entretanto, que o leitor consiga vislumbrar outra ainda menor.
} 
a última dualidade traduz as dificuldades produzidas no seio da relação essencial entre epistemologia e didática.

Passemos agora ao mapeamento realizado segundo a sua subdivisão nos macro-espaços aqui citados. 


\subsubsection{O macro-espaço da dualidade discreto/contínuo}

\section{Na escala histórica}

$\mathrm{Na}$ escala histórica este macro-espaço se constitui pelas discussões em torno do problema histórico e fundamental da medida das grandezas geométricas, intuitivamente contínuas, através de processos aritméticos discretos. A dificuldade dessa dualidade discreto/contínuo se materializou historicamente e pode ser percebida originalmente nos paradoxos de Zenão e no problema da incomensurabilidade de certos segmentos geométricos, este último, vivenciado pela escola pitagórica, que floresceu no século VI a.C., é conhecido por "dilema de Pitágoras". No entanto, foi o filósofo Platão - primeiro a vislumbrar uma possível solução para o problema através da construção de uma "ponte" entre a geometria e a aritmética, mas que só se concretizaria vinte séculos depois na construção dos números reais por cortes de Dedekind.

Cabe ressaltar, entretanto, a retomada dessa questão pelos escolásticos na idade média. Após um longo período de completa dormência dessa questão, os sábios filósofos interpretaram $e$ desenvolveram os problemas pertinentes à dualidade discreto/contínuo associando-os a outras questões relacionadas ao problema da variabilidade de grandezas físicas. Assim, a partir dos resultados desses estudos surgem dois conceitos fundamentais para o desenlace dessa dualidade: as séries infinitas e a noção de variável. 
No auge da invenção do Cálculo, Newton, Leibniz e seus parceiros intelectuais procuram interpretar a idéia de continuidade através da intuição de "movimentos contínuos" e "variáveis contínuas". Assim, a continuidade é um conceito cinemático e/ou metafísico. Nesse contexto, o uso indiscriminado do Teorema Fundamental do Cálculo como o instrumento mais usado nos cálculos de integrais pode representar também um sintoma de evitação das questões pertinentes à dualidade discreto/contínuo, presente no âmago do conceito de integral de Riemann, tal como hoje nos é apresentado em um curso inicial de Análise.

Dois outros grandes matemáticos, além do próprio Newton, irão retomar a valiosa contribuição deixada pelos escolásticos: as séries. Euler e Lagrange incluem definitivamente esta poderosa ferramenta do Cálculo no seu núcleo de atividades.

Já no século XIX, a escola matemática francesa, tendo em Cauchy o seu maior representante, resolve o problema de fundamentação das idéias básicas do Cálculo Diferencial e Integral, mas não o da dualidade discreto/contínuo. E daí para frente, já entramos no âmbito da Análise. Mais detalhes da evolução e solução do problema da continuidade podem ser visualizados nos mapas 7 e 8 (páginas 300 e 302 deste trabalho).

\section{$\mathrm{Na}$ escala pedagógica}

Já no processo pedagógico, a dualidade discreto/contínuo é completamente ignorada desde os níveis mais elementares do ensino de matemática. A consequiência disso mais imediata é o hiato estabelecido entre a aritmética e a geometria, com o sacrifício da primeira. 
Interessante que o hiato ocorre não por falta de oportunidade: os estudo das dízimas periódicas e das progressões aritméticas e geométricas são excelentes ocasiões para se fazer a aproximação dessas áreas do conhecimento matemático.

O prejuízo da aritmética de que falamos pode ser sentido naquela que é a sua noção fundamental: o número. Excetuando os números naturais, que são construídos a partir do problema histórico da contagem, os demais (inteiros, racionais e irracionais) estão associados à "construção da reta numérica". Os números reais são dessa forma uma "medida" na reta numérica, e as suas representações decimais ou são finitas ou são "aproximadas": $\pi=3,14 ; \sqrt{2}=1,4$ etc. Assim, os números irracionais continuam no processo pedagógico, tal como em seus tempos de outrora, "nebulosos", "surdos", números que "não dizem nadd" e que não possuem uma posição na reta numérica "estão sempre andando na retd". Sua existência é assumida apenas potencialmente no universo da "matemática abstrata" (como se pudesse haver uma matemática não-abstrata).

Assim, pode-se afirmar que o cenário pedagógico que se apresenta em torno do número irracional não é diferente daquele desenvolvido pelos matemáticos do Renascimento. Os matemáticos europeus dessa época, apesar de terem descoberto - com o auxílio de um sistema de numeração posicional herdado das civilizações hinduárabe - que os números irracionais eram identificáveis a números decimais sem fim, cujos algarismos após a vírgula nunca se reproduzem na mesma ordem, não conseguiram identificá-los na reta numérica. Por isso, tais números foram denominados "nebulosos" ou "surdos" pelos 
próprios matemáticos. Vale dizer ainda que apesar da denominação de "números surdos" ser contestada por Stevin, ela ainda persistiu nos trabalhos de Wallis. Assim, desprovidos de um suporte geométrico que Thes garantissem uma "dignidade numérica", os números irracionais permanecerão até o século XVIII na clandestinidade. Os elementos que permitirão transpor historicamente este obstáculo epistemológico são o estudo das séries numéricas e a fundamentação da noção de continuidade - processos, iniciados no século XVIII e, concluídos no século XIX.

Isto posto, torna-se compreensível o caráter "nebuloso" do número irracional no processo pedagógico. Assim como os matemáticos renascentistas, os nossos alunos também são privados durante todo o ensino básico dos instrumentos que possibilitariam uma superação desse estado nebuloso do número irracional. Em verdade, a privação a que se submetem nossos estudantes é muito maior: escondem deles inclusive os problemas motivadores $e$ as dificuldades intrínsecas à construção do significado do número irracional. É assim, por exemplo, quando, no ensino fundamental, ensina-se, por meio de uma regra prática, que a dízima periódica $0,333 \ldots$ é a representação decimal da fração 1/3; ou quando, no ensino médio, ensina-se que a soma infinita de uma progressão geométrica $\left(a_{n}\right)$ de razão $q(0<|q|<1)$ é dada pela fórmula algébrica $a_{1} /(1-q)$.

Assim, a dízima periódica, uma denominação aritmética para as séries geométricas, é camuflada e "resolvida" aritmeticamente. E, com esta camuflagem, as séries são relegadas a um segundo plano no ensino básico de matemática. $E$, desse modo, torna-se inevitável no campo pedagógico o hiato entre a representação decimal de um número 
irracional (discreto) e a sua representação geométrica (contínua). Nesse sentido, seriam interessantes que se realizassem algumas antecipações do binômio séries/limites no ensino básico para que houvesse uma problematização inicial das dificuldades de representação e definição dos números irracionais. Não se pretende com isso antecipar a construção formal dos números reais para o ensino básico ${ }^{162}$. O que se quer é oferecer ao estudante um cenário real das dificuldades da significação deste conceito, ao passo que, com esta apresentação, alguns elementos essenciais do "pensamento diferencial" - como a noção intuitiva de limite e as séries - já pudessem ser iniciadas. Além disso, o aluno poderia vislumbrar, com essa antecipação, outros processos de aproximações possiveis para alguns números irracionais notáveis. Assim, em vez de identificar $\pi$ simplesmente com o valor racional 3,14, o aluno poderia desenvolver outros procedimentos de aproximação ${ }^{163}$, percebendo, através destes, as dificuldades intrínsecas a problemática do número irracional.

No entanto, esta interface entre a representação decimal de um número irracional e a sua representação geométrica não é realizada em momento do ensino de matemática. Ao contrário, pode-se dizer que no processo didático coexistem "duas" definições de número irracional completamente dissociadas uma da outra:

\footnotetext{
${ }^{162}$ Tal empreendimento não seria nem mesmo do âmbito de um curso superior e inicial de Cálculo - isto é tarefa para o ensino de Análise Real.

${ }^{163}$ A história da matemática fornece, a propósito, um grande número de exemplos notáveis a esse respeito.
} 
- número irracional é aquele que não pode ser escrito na forma de uma razão irredutível entre números inteiros:

- número irracional é um número decimal infinito que não possui parte periódica.

Como consequiência disso surgem entre os alunos outras representações do número irracional. Em nossa dissertação de mestrado (Rezende, 1994) pudemos observar as seguintes atitudes em relação aos números irracionais:

\footnotetext{
I- "São os reais menos os racionais".

II- "É um número que não é racional".

III- "É uma sequiência de termos indefinidos".
}

(Rezende, 1994, p.121)

Pode-se dizer que as duas primeiras posições representam, em geral, a idéia que predomina na hora de definir, mas, que, por outro lado, grande parte dos alunos admite no nível de suas explicações o número irracional como números "confusos", ou "dificeis de entender a sua estrutura", quer dizer: "sem uma lógica definida". Assim, a partir desta significação de número irracional, alguns estudantes abandonavam as definições usuais e classificavam ${ }^{164}$, por exemplo, os números $0,1010010001 \ldots$ e 0,12345678910111213... em racionais, uma vez que ambos possuem uma "seqüência lógica" definida.

Já no que toca a definição de número real, pode-se dizer que as atitudes dos alunos subentendem uma idéia de totalidade:

\footnotetext{
${ }^{164}$ Em verdade a definição que é abandonada aqui é a segunda - aquela em termos de números decimais -, uma vez que a primeira, por não ser usada em termos práticos, já foi abandonada há muito tempo.
} 
I- $\quad$ "São todos os números existentes, excluindo os complexos".

II- "NUZUQUI - União dos naturais, inteiros, racionais e irracionais".

III- "QUI- União dos racionais e irracionais".

(Rezende, 1994, p.122)

Assim, outro fato que merece nossa atenção diz respeito à "circularidade" do conceito de número real. Tal como ocorreu no raciocínio de Cauchy - que realizou a construção do número real a partir da operação de limite, e esta, por sua vez, a partir da noção de número real -, as definições de números real e irracional apresentam no campo pedagógico uma relação similar de circularidade. De fato. No processo pedagógico, define-se, em geral, um número irracional por exclusão, isto é, como sendo o número real que não é racional; mas, por outro lado, o conjunto dos números reais é definido pela reunião dos conjuntos dos números racionais e irracionais.

Isto posto, percebe-se que o universo numérico dos estudantes que entram - $e$, também, daqueles que se formam em um curso superior 165 - é, em geral, o conjunto dos números racionais acrescido de um conjunto enumerável de números irracionais notáveis, dos quais se conhecem apenas os seus valores aproximados. A noção de continuidade como o ingrediente fundamental na extensão do conjunto dos números racionais para o dos números reais é completamente ignorada.

Já no ensino normal de Cálculo, a noção de continuidade é estabelecida, não em termos de agregados, mas, em termos de função. A continuidade de uma função é definida localmente através da noção

\footnotetext{
${ }^{165}$ Essa circularidade presente na noção de números reais foi verificada inclusive em alunos egressos de um curso de Análise Real (Rezende, 1994) - o que, sem dúvida, é muito mais preocupante.
} 
de limite: diz-se que uma função $f$ é contínua em um ponto $x_{0}$ do seu domínio se $\lim _{x \rightarrow x_{0}} f(x)=f\left(x_{0}\right)$. E, a partir da extensão dessa propriedade local para todos os pontos do seu domínio, o conceito de continuidade é então "globalizado"; assim, diz-se que a função $f$ é contínua se ela for contínua em cada ponto do seu domínio. No entanto, esta passagem do conceito local de continuidade para o seu formato global, apesar de ser "bastante natural" ${ }^{166}$, não acrescenta muito em termos de significações para o seu estado global. Esta extensão do conceito de continuidade não possibilita sequer ao aluno dar exemplos de funções contínuas. Assim, para criar as condições didáticas necessárias para a realização desta tarefa, o professor usa, em geral, do mesmo recurso que Ëuler usou a mais de dois séculos atrás: associa-se, apelando para a intuição geométrica, a noção de continuidade de uma função ao traçado do seu gráfico - "uma função contínua é aquela que ao desenharmos o seu gráfico não tiramos o lápis do papel". O professor que nunca cometeu esse pecado que atire a primeira pedra...

Guardando a pedra no bolso, reconhecemos, entretanto, os desvios conceituais que tal procedimento pode provocar. Afinal: a função $f(x)=1 / x, x \in \mathbb{R}-\{0\}$, é contínua ou não é? Do ponto de vista topológico não há dúvida: é contínua - "a imagem inversa de um aberto é sempre um aberto" -, ainda que esta não obedeça aos parâmetros de Euler. Entretanto, esta sutileza topológica não compromete, no âmbito do Cálculo, o nível de significação de continuidade proposto pela alegoria geométrica do "esboço contínuo do gráfico" de uma função. 0

\footnotetext{
${ }^{166}$ Pode-se dizer que a extensão é muito mais lógica do que natural.
} 
que importa mesmo, do ponto de vista do Cálculo, é que a função $f(x)=$ $1 / x$ é contínua pra $x>0$, é contínua para $x<0$ e, que não existe um modo de defini-la em $x=0$ de modo a torná-la contínua neste ponto.

Nesse sentido, acreditamos que o uso desse expediente, além de não causar prejuízos ao bom desenvolvimento de um curso de Cálculo, é uma boa alegoria para a noção global de continuidade de uma função real. Newton, por exemplo, unificou as noções de continuidade $e$ diferenciabilidade na idéia de "variação contínua", sem fazer qualquer distinção entre elas, e tal fato não impediu que ele vislumbrasse os métodos analíticos que constituíram efetivamente o seu Cálculo Diferencial e Integral. A significação de continuidade não é efetivamente do âmbito do Cálculo: tal problemática só foi resolvida historicamente, e de modo definitivo, no âmbito da Topologia. Mas, por outro lado, isto não significa dizer que o par discreto/contínuo não possa ser iniciado no ensino de Cálculo. Uma oportunidade ótima para isto se suceder se encontra no próprio conceito de integração.

Com efeito, fazer estimativas de áreas de regiões planas curvilíneas através de aproximações sucessivas de áreas de regiões poligonais induz o próprio conceito de integral. Foi assim com Arquimedes, no estágio embrionário do Cálculo; foi assim com Fermat, na iminência do Cálculo; e, foi assim com Riemann, na fundamentação da Análise. Esta idéia associada ao instrumento de séries é a realização do próprio significado de integração. No entanto, no ensino superior de Cálculo, apesar da idéia de integral definida de uma função $f$ ser introduzida através do problema motivador de cálculo de áreas e definida formalmente em termos de limite da soma de Riemann de $f$, a oportunidade de se estabelecer tal relação discreto/contínuo, ainda 
que num nível inicial, é, geralmente, desperdiçada. O uso exclusivo do Teorema Fundamental do Cálculo e o exaustivo treinamento realizado através de listas de exercícios de "técnicas de integração" levam o aluno a identificar o conceito de integral definida com 0 de antiderivada: "a integral é a inversa da derivada".

Assim, esta identificação induzida da integral definida com a antiderivada de uma função representa a própria reedição pedagógica do sintoma de evitação da dualidade discreto/contínuo desenvolvido pelos próprios "inventores" do Cálculo. Newton, por exemplo, preferiu assumir explicitamente a operação de integração como a operação inversa da diferenciação. Segundo o matemático, a operação de integração corresponde original que diferenciada fornece a equação das velocidades" ${ }^{167}$. Isto posto, pode-se afirmar que, no ensino de Cálculo, a dualidade discreto/contínuo permanece embutida tacitamente na definição formal da integral de Riemann.

Outra confusão bastante comum em relação ao conceito de continuidade que pode ser notada no ensino superior de matemática diz respeito a sua associação com a noção de densidade. 0 próprio Leibniz, ao dar uma interpretação da noção de continuidade em termos de conjuntos, identificou as duas noções. Para Leibniz, um conjunto forma um continuum "se entre quaisquer dois elementos existe sempre um outro elemento do conjunto" (apud Boyer, 1949, p.291). Assim, é natural que os estudantes de um curso de Cálculo não façam distinção entre as duas noções, até porque estas sequer foram apresentadas a eles no ensino médio, nem no próprio curso de Cálculo. Mas, por outro

\footnotetext{
${ }^{167}$ É por esta razão inclusive que a antiderivada é denominada por alguns textos didáticos de Cálculo por integral de Newton.
} 
lado, é lamentável que tal fato ocorra entre os estudantes que já fizeram um curso inicial de Análise. Isto dá evidências de que o curso de Análise também não tem cumprido o seu papel no ensino superior de matemática. Mas isto é assunto para uma outra tese. Voltemos às atitudes dos estudantes em relação a este tema.

Em nossa dissertação de mestrado (Rezende, 1994, p.124), por exemplo, foram identificadas quatro idéias básicas relativas aos conceitos de densidade e continuidade:

\section{Densidade:}

I- "[Um conjunto é denso] quando entre dois [de seus elementos] tem sempre outro [de seus elementos]"

\section{Continuidade:}

I- $\quad$ "Um conjunto] é contínuo quando está um do lado do outro"

II- "Uma seqüência, por exemplo, 1,999... se aproxima continuamente para 2"

III- "[Um conjunto] é contínuo, quando não tem buraco"

É interessante observar que quando os nossos alunos se deparam com as dificuldades de explicitar a idéia de continuidade, eles acabam, sem qualquer pressão do jogo didático, revivendo etapas históricas relevantes para a construção do conceito matemático em questão. Foi - que ocorreu exatamente aqui com o conceito de continuidade. A primeira posição é similar, por exemplo, à definição que Galileu deu para o conceito de continuidade. Na segunda posição a idéia de continuidade se apresenta de forma intuitiva no processo de uma variável aproximar-se continuamente do seu valor limite, tal como fizeram D'Alembert e Cauchy em suas definições de limites. Já a terceira posição representa, historicamente, um avanço em relação às duas anteriores, mas, no entanto, está longe ainda de ser efetivamente o conceito de continuidade formalizado por Dedekind e Cantor. 
Isto posto, podemos concluir, com base no mapeamento que fizemos desse primeiro macro-espaço epistemológico, que:

- a dualidade discreto/contínuo é ignorada no ensino de matemática, inclusive num curso de Análise - o seu habitat epistemológico;

- os sintomas de evitação desta dualidade e do seu campo semântico estão presentes em todas as fases do ensino de matemática; a prevalência das "técnicas de integração" sobre o significado de integral definida, motivada pela identificação desta com o conceito de antiderivada, é um exemplo destes sintomas de evitação; a pouca ênfase dada ao estudo das séries é o outro lado desta moeda;

- o hiato entre os campos da aritmética e da geometria é uma das principais consequiências da ignorância da dualidade discreto/contínuo;

- o domínio numérico da totalidade de nossos alunos se restringe aos racionais. Já com respeito aos números reais (irracionais), podemos dizer, com certas restrições, que apenas a "técnica operatória" é dominada por eles. Não sabem responder o que um número real é, efetivamente. Isto ocorre, como diria Caraça (1989), porque não conhecem o reagente básico (o conceito de continuidade) que motiva 0 processo de extensão do conjunto dos números racionais para o conjunto dos números reais. 
O mapa a seguir sintetiza o cenário que aqui foi apresentado acerca das dificuldades de aprendizagem situadas no macro-espaço de natureza epistemológica relativa à dualidade discreto/contínuo.

figura 53 - Mapa do macro-espaço da dualidade discreto/contínuo

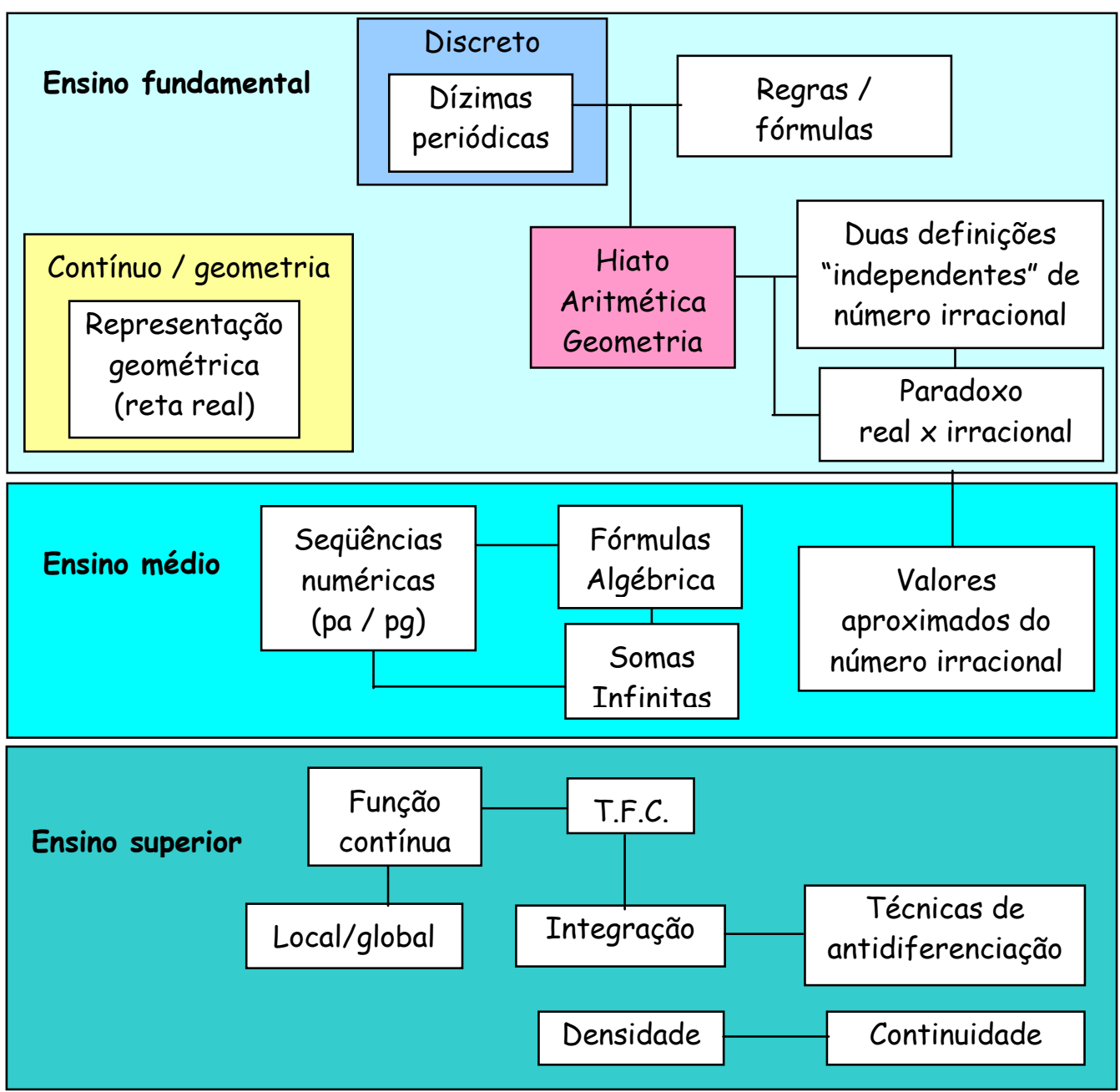




\subsubsection{O macro-espaço da dualidade variabilidade/permanência}

\section{Na escala histórica}

A origem dessa dualidade essencial para o desenvolvimento do Cálculo se dá na filosofia pré-socrática, na dialética de Heráclito e na perseguição da "unidade e a invariabilidade do mundo" da filosofia eleática. Heráclito, Parmênides e Zenão, através de suas metafísicas, forneceram o patamar base das discussões posteriores acerca desta dualidade essencial.

No entanto, o estudo quantitativo de variabilidade só veio a ser desenvolvido pelos escolásticos no século XIV através da teoria das "latitudes" das formas. A noção escolástica de latitude é, com efeito, a forma embrionária do conceito de derivada. Essas noções penetram no universo matemático através da cinemática desenvolvida por Galileu e Torricelli.

Por outro lado, paralelamente a esta aproximação da matemática com a cinemática, desenvolve-se a forma algébrica de pensar. Tendo como marco a álgebra geométrica de Diofantes e de Apolônio, o desenvolvimento do modo algébrico de pensar passou pelo crivo das interpretações e interferências dos matemáticos hindus e árabes, chegando à escola matemática francesa dos séculos XVI e XVII, com destaque para Viète, Descartes e Fermat. Enquanto o primeiro foi o idealizador do raciocínio algébrico propriamente dito - Viète, ao contrário dos gregos, resolvia problemas geométricos através de 
procedimentos puramente algébricos -, os dois últimos desenvolveram dois instrumentos fundamentais para o desenvolvimento da forma analítica de pensar do Cálculo: a geometria analítica, de Descartes, e os métodos analíticos, de Fermat.

Assim, dispondo desses instrumentos, Newton e Leibniz, cada um a seu modo, resolvem o problema da variabilidade desenvolvendo, respectivamente, as suas noções de "última razão" e "diferencial". No entanto, para se chegar ao conceito chave do Cálculo para este problema - o conceito de derivada - foi necessário o desenvolvimento de um outro conceito fundamental: o conceito de função.

Euler e Lagrange são os principais responsáveis pela introdução deste conceito no cenário do Cálculo Diferencial e Integral. No entanto, a abstração e a definição formal do conceito de derivada só foi sacramentada com Cauchy, no século XIX. Mais informações históricas a respeito do problema de variabilidade podem ser obtidas nos mapas dos conceitos de variáveis (p.290-291), de função (p.292293) e de derivada (p.294-295).

Já a outra questão fundamental, o da permanência ou "invariabilidade das coisas", aliada às idéias relacionadas ao conceito de variabilidade, irá permitir o desenvolvimento de outro conceito fundamental do Cálculo: a integral. Em verdade, o conceito de integração se desenvolve a partir da "matematização" do problema da "unidade na multiplicidade". A versão escolástica do método de exaustão grego é, com efeito, o embrião do processo de integração.

Os escolásticos não contribuíram apenas com a idéia, mas, também com a inserção das séries como elemento fundamental na construção da noção de integração. Cabe ressaltar, entretanto, que 
desde as séries desenvolvidas pelos escolásticos, no século XIV, até a soma de Riemann, no século XIX, foi necessário o desenvolvimento da noção de limite no seio da dualidade discreto/contínuo. Entretanto, diante das dificuldades intrínsecas do próprio conceito, a operação de integração esteve associada, por meio da descoberta do Teorema Fundamental do Cálculo por Torricelli, Gregory e Barrow, à noção de antiderivada, isto é, a operação de integração é interpretada como operação inversa da diferenciação. Mais detalhes a respeito pode ser obtido através das consultas aos mapas dos conceitos de integral (p.296) e de número real (p.302).

\section{$\mathrm{Na}$ escala pedagógica}

A partir da revisão histórica que fizemos no capítulo anterior, procuramos tornar evidente que o desenvolvimento do Cálculo Diferencial e Integral se deu através de uma relação de simbiose deste, principalmente, com a geometria, a física e a filosofia. A álgebra participa do processo com a sua forma abstrata de pensar, com o seu simbolismo, tendo uma fundamental participação no desenvolvimento da noção de variável, que possibilitará a construção daquele que é, sem dúvida, um dos conceitos básicos do Cálculo e da própria matemática: o conceito de função. É exatamente nesse contexto histórico que "nasce" o conceito de função, isto é, a noção se estabelece a partir de

uma relação funcional implícita entre as quantidades variáveis. 0 cumprimento de certas exigências por parte dessa relação funcional é consequiência de um processo de depuração histórica e matemática. Mas o que interessa para o Cálculo é, essencialmente, essa relação de interdependência entre as quantidades variáveis. É exatamente a 
partir dela que resolveremos o problema da variabilidade, isto é, da "medida" da taxa de variação de uma das variáveis em relação à outra.

É verdade, no entanto, que o conceito de função "evoluiu" no processo histórico de construção do conhecimento matemático: sai do âmbito do Cálculo, enquanto relação entre quantidades variáveis, para o âmbito da Teoria dos Conjuntos, como uma operação especial entre conjuntos. Neste último contexto, função é conjunto de pares (ou ternos, quadras, etc., dependendo do seu número de variáveis) ordenados, que satisfazem determinadas propriedades algébricas, mas, efetivamente, não é essa idéia de função que foi essencial para o desenvolvimento do Cálculo. Afinal, não derivamos "conjuntos", nem tampouco os integramos, e nem fazemos uso dessa definição formal de função em qualquer momento de um curso normal do Cálculo, ou mesmo de Análise. Em verdade, a definição formal de função é tão abstrata, quanto estéril, uma vez que pouco contribuiu para o desenvolvimento do conhecimento matemático de um modo geral.

Por outro lado, a forma como este conceito é trabalhado em geral no ensino médio e fundamental provoca sérios desvios de natureza epistemológica no ensino de Cálculo e da própria matemática. Apesar de muitos desses alunos já terem sido apresentados à definição formal de função, cabe-nos ressaltar, entretanto, que também não é essa a representação de função que caracteriza as atitudes dos estudantes. Estas, como podem ser vistas em (Cabral, 1998, p.151) e (Neto, 1998, p.31-38), se caracterizam, em geral, e são identificadas pelos estudantes por suas expressões analíticas. Assim a função é a expressão $\operatorname{sen} x$, ou $x^{2}$ etc. 
De fato, uma função, para a grande maioria de nossos estudantes recém ingressos no curso superior, se resume à expressão analítica que a define, como se ela (a expressão analítica) por si só definisse a relação funcional. Tal fato ocorre, talvez, porque os alunos assumem tacitamente a variável " $x$ " como a "variável independente universal". Cabe, entretanto, ressaltar que a idéia de função é estabelecida pelos alunos, não no contexto da "variabilidade", mas, em termos de uma correspondência estática entre os valores das variáveis " $x$ " e " $y$ ". O gráfico da função é, em geral, "plotado" através de uma tabela em que os valores "notáveis" são escolhidos pelo professor. A curvatura das curvas que compõem o gráfico da função é, em geral, induzida pelo professor que tenta convencer o aluno, pelo acréscimo de mais pontos, ou mesmo através de um sofisticado programa computacional, que a única possibilidade é a dele - professor.

Esta noção majoritária, bem como suas propriedades $e$ elementos principais, são estáticos e de natureza algébrica. Fala-se, por exemplo, em injetividade ou sobrejetividade, mas não em crescimento ou decrescimento da função, ou melhor, em quanto e como cresce/decresce o valor de uma função em relação à sua variável independente. Discutem-se (caso existam) os zeros e o período da função, mas não os seus pontos críticos, que são, em verdade, os elementos de articulação do esboço do gráfico de uma função real de uma variável (também real). Assim, a função, agora também identificada pelo seu gráfico, surge da "plotagem" dos pares $(x, f(x))$ no plano cartesiano $x y$. E é assim, em termos da correspondência $(x, f(x))$ que se estabelece a representação que o nosso estudante tem de função. Note que, neste caso, a função (a expressão analítica) é dada 
e sua representação é construída através de um procedimento estático, estético e induzido por propriedades algébricas da função. Esta idéia de função não está errada conceitualmente, ao contrário, ela representa a forma como Dirichlet (1837) conceituou a noção de função: "Uma função $y(x)$ é dada se temos qualquer regra que associe um valor definido y a cada $x$ em um certo conjunto de pontos" - (apud Rüthing, 1984). Por outro lado, tal idéia de função, caracterizada pelo seu formato algébrico, se encontra na contra-mão da história do Cálculo.

Com efeito, tal interpretação, além de não ter participado historicamente da solução do problema da variabilidade dada pelo Cálculo, constitui efetivamente um dos maiores obstáculos epistemológicos àquela noção de interdependência entre quantidades variáveis, tão essencial para o desenvolvimento do Cálculo. Senão vejamos.

Alguns dos principais obstáculos de aprendizagem para os alunos de um curso de Cálculo são os ditos "problemas de taxas relacionadas" e os "problemas de otimização". A dificuldade que encontram é tanta que em certas instituições existe um acordo tácito entre os professores de "bom senso" e "boa alma" de não cobrarem ambos os temas numa mesma prova. E, além disso, a fim de amenizar o desastre provocado pela inserção da única questão, procura-se apresentar situações problemas simples para esta - de preferência, dentro do próprio contexto da matemática: problemas geométricos ou algébricos, nada de física ou outras áreas "estranhas" ao aluno. Mas em que consiste essa dificuldade? 
Cabral (1998, p.153-154), analisando, por exemplo, o universo de respostas dadas pelos estudantes a alguns "problemas de taxas relacionadas", identifica quatro níveis de respostas: o aritmético, o algébrico, o funcional e o diferencial, identificando entre eles uma hierarquia de natureza "epistemológica". Façamos aqui um recorte de um de seus exemplos para o melhor entendimento da classificação efetuada pela autora:

Situação-Problema B

Uma pessoa que solta um papagaio segura a corda a $1,5 \mathrm{~m}$ do solo; a corda é liberada à razão de $0,6 \mathrm{~m} / \mathrm{s}$ na medida em que o papagaio se move horizontalmente a uma altura de $33,5 \mathrm{~m}$. Supondo que a corda fique sempre tensa, determine a taxa à qual o papagaio está se movendo no instante em que foram liberados $38 \mathrm{~m}$ de corda ${ }^{168}$.
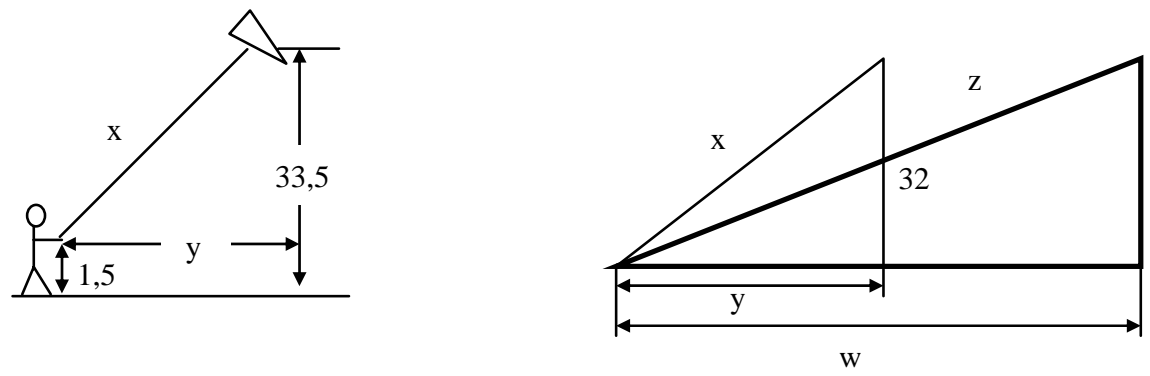

figura 54 - Figuras que acompanham o enunciado do problema

10 significado: aritmético $->\sqrt{38^{2}+32^{2}}$

$2^{\circ}$ significado: algébrico $\rightarrow 38^{2}=32^{2}+y^{2}$

$3^{\circ}$ significado: funcional $\rightarrow x^{2}=32^{2}+y^{2}$

$4^{\circ}$ significado: diferencial -> $y \frac{d y}{d t}=x \frac{d x}{d t}$

\footnotetext{
${ }^{168}$ Cabe ressaltar que a descrição da experiência de "soltar papagaio" feita no enunciado da questão, além de ser uma simplificação da situação real - o fato da corda estar tensa não garante que esta tenha a forma de um segmento de reta -, evita o enfrentamento direto de uma questão interessante do âmbito do Cálculo: qual é de fato a curva que descreve a forma da corda amarrada à pipa?
} 
Segundo a professora, em situações como estas, os dois primeiros níveis de significação são os mais comuns. Este resultado justifica, com efeito, por que os alunos temem tanto os problemas dessa natureza: não conseguem definitivamente "enxergar" as quantidades variáveis envolvidas no problema nem tampouco a relação funcional entre elas: "o difícil mesmo é encontrar a função" 169 .... Isso mesmo, como exigir agora desse aluno que "enxergue" o conceito de função, se até o momento, a função sempre foi dada "pronta" para ele? Como pode ele "enxergar" as "variáveis" do problema, se até agora estas eram apenas "letras" ( $x$ e $y$, de modo geral) que representavam números que se relacionavam segundo uma lei de correspondência explicitada a prior? Identificar o que varia, e em função de que varia é, sem dúvida, o primeiro passo para a resolução da questão.

Além disso, não foi surpresa nenhuma para nós que os dois últimos significados são encontrados com menos frequiência nas respostas dos alunos. A pesquisadora acrescenta, entretanto, dois fatos que consideramos relevantes para a nossa discussão: que os dois últimos níveis de significação são produzidos simultaneamente; e, que a elaboração do terceiro não leva o aluno a entrar no campo diferencial. A autora sustenta ainda a tese de que "é o trabalho que ocorre sobre 0 quarto significado que auxilia a organização do anterior".

De fato, entrar no quarto nível de significação implica muito mais do que encontrar a relação funcional: o aluno precisa interpretar a derivada como taxa de variação, traduzir então para a linguagem diferencial os dados do problema, identificar a variável do problema

\footnotetext{
${ }^{169}$ Frase dita por um aluno entrevistado por Cabral e que representa, efetivamente, a dificuldade encontrada pela maioria dos nossos alunos de Cálculo quando têm de resolver problemas dessa
} 
em relação a qual irá diferenciar a equação $e$, claro, chegar à equação, envolvendo as taxas de variações presentes no enunciado do problema 170

Por outro lado, para se chegar à relação funcional, para identificar as variáveis do problema, é preciso que se identifique e interprete o que está variando, como está variando e em relação a que está variando. Assim, para entrar no nível de "significação funcional" é preciso que o aluno já tenha vivenciado certas experiências cognitivas, ainda que em patamares mais elementares, com alguns dos elementos componentes do contexto de significações do campo diferencial. A relação entre os dois últimos níveis é essencialmente dialética e de cumplicidade. Talvez seja esse o sentido que Cabral quis dar quando nos falou "que os dois últimos níveis de significação são produzidos simultaneamente". Em verdade, a tese que sustenta posteriormente às suas afirmações é premissa fundamental para que se possa garantir a primeira delas, isto é, a produção simultânea dos dois últimos níveis de significação.

Ainda no que tange aos níveis de significação sugeridos por Cabral, cabe ressaltar que a hierarquia estabelecida pela autora entre eles segue, de certo modo, a ordem histórica: os problemas foram tratados inicialmente através de procedimentos aritméticos e geométricos; com o desenvolvimento da forma algébrica de pensar surge o conceito de variável; e, pela introdução do simbolismo algébrico na geometria, desenvolve-se a geometria analítica $e$, por conseguinte, a

\footnotetext{
natureza.

${ }^{170}$ Em problemas de maior complexidade é preciso em geral encontrar mais de uma relação funcional entre as quantidades variáveis, obtendo, desse modo, mais equações envolvendo as taxas de variações - tantas quanto forem necessárias.
} 
relação funcional entre quantidades variáveis determinadas implicitamente pela equação da curva que as relacionam; na "invenção" do Cálculo, o desenvolvimento do "pensamento diferencial" foi efetivado em termos da relação funcional estabelecida pela geometria analítica.

Quanto aos "problemas de otimização" a situação é similar. Apesar da presença de outros elementos complicadores no campo diferencial - como, por exemplo, a natureza topológica do domínio da função a ser otimizada - as dificuldades dos alunos se encontram, majoritariamente, tal como na classe de "problemas de taxas relacionadas", nos dois primeiros níveis de significação.

Assim, pode-se assegurar pelo que foi exposto anteriormente, que a razão principal para as dificuldades de aprendizagem na resolução de problemas de taxas relacionadas e de otimização é, efetivamente, esse desvio epistemológico do conceito de função, realizado desde cedo nos ensinos médio e fundamental de matemática, de modo viesado para o campo algébrico. O pior de tudo isso é que os professores de Cálculo (e alguns autores de textos didáticos da área), em geral, reforçam ainda mais esse viés algébrico do conceito de função quando fazem uma "breve revisão" deste conceito.

Além disso, pode-se afirmar que esse viés algébrico também se faz presente nos dois conceitos fundamentais do Cálculo Diferencial e Integral, e, em particular, da dualidade variabilidade/permanência: no conceito de derivada e no de integral definida.

Com efeito, com o descolamento da dualidade discreto/contínuo do conceito de integral, estimulado principalmente pelo uso do Teorema Fundamental do Cálculo, o ato de integrar é identificado pelo 
aluno ao ato de encontrar a antiderivada da função do integrando. É salutar que o aluno saiba interpretar e usar o T.F.C. para realizar os seus cálculos de integrais. No entanto, não se pode dizer o mesmo do exaustivo treinamento em "técnicas de integração" que levam o aluno, entre outras coisas, a ignorar o significado do conceito de integral e a encará-la como um procedimento algébrico. Para se apreender o significado de integração é preciso que se explore mais as tramas e urdiduras da sua malha de significações. Calcular uma integral através de processos numéricos aproximados, ou mesmo usando determinados tipos de séries - como fizeram Newton, Euler e outros - também são exercícios que contribuem para o processo de tecedura da noção de integral. A noção deve ser explorada então na sua totalidade, e não reduzida simplesmente ao ato algébrico de encontrar uma antiderivada da função através das "técnicas de integração".

Já no que toca ao conceito de derivada o problema é muito mais sério. Calcular exaustivamente derivadas de funções através das regras usuais de derivação não leva o aluno a construir efetivamente o significado desta operação. Interpretá-la tão somente como "coeficiente angular da reta tangente" significa ignorar o problema histórico essencial da "medida" instantânea da variabilidade de uma grandeza - esse foi, inclusive, o grande problema perseguido inicialmente pelos filósofos escolásticos.

Com efeito, derivada, na sua relação com as diversas áreas do conhecimento, é, sobretudo, taxa de variação instantânea. A interpretação geométrica não esgota completamente a idéia essencial de derivada; existe todo um campo de significações importante para a tecedura da noção de derivada: pensar velocidade instantânea como 
coeficiente angular da reta tangente ao gráfico de $s=s(t)$ é consequiência, e não causa, da ação de interpretá-la como limite de velocidades médias, quando fazemos $\Delta t$ cada vez mais próximo de zero. $\mathrm{Na}$ verdade, ambas as interpretações se complementam e contribuem para a significação do conceito de derivada. Eximir a interpretação dinâmica do conceito de derivada é, além de um contra-senso histórico, um atentado ao seu próprio significado.

Não se trata apenas de reinterpretar apenas a sua definição, mas também os diversos contextos de que participa. A interpretação da regra da cadeia, pensando derivada como taxa de variação instantânea, e usando a notação de Leibniz, torna o significado dessa regra muito mais transparente:

$$
z \stackrel{z(y)}{\longleftarrow} y \stackrel{y(x)}{\longleftarrow} x \Rightarrow \frac{d z}{d x}=\frac{d z}{d y} \cdot \frac{d y}{d x}
$$

A generalização de tal regra para cadeias maiores torna-se bem natural, e é feita sem dificuldades pelo aluno.

Ajudaria bastante o desenvolvimento e o fortalecimento das redes de significações construídas pelo aluno se os resultados matemáticos pudessem ser interpretados em outros contextos, além do lógico-formal. É preciso interpretar, por exemplo, o Teorema do Valor Médio para derivadas, tanto geométrica, quanto fisicamente. Não só ele, como todo e qualquer resultado, sempre que possível, mesmo que se "perca tempo" com isso. Conforme já observamos no início desta tese, faz muito mais sentido para o aluno interpretar que "a velocidade de um corpo que não se move é nula" (ou que a reta tangente ao gráfico de uma função constante é o próprio gráfico, que tem inclinação nula) do que o contexto lógico-formal da demonstração 
usual da derivada da função constante. Além de "não se perder tempo", ganha-se em significação.

No entanto, não é isso que é feito em geral num curso "normal" de Cálculo. Muito pelo contrário, dá-se ênfase exagerada às técnicas de derivação e integração, tornando o ensino de Cálculo um arcabouço de técnicas algébricas associadas a estas operações. Não é a toa que um dos maiores obstáculos encontrados pelos estudantes no ato de "integrar" se encontra nas suas próprias dificuldades com os procedimentos algébricos, como se pode perceber nos exemplos que Cabral (1998) destaca em sua tese, e que são muito peculiares para qualquer professor de Cálculo:

a) Ao calcular a antiderivada $\int \frac{\sqrt{x}}{1+\sqrt[3]{x}} d x$ no quadro de giz para os seus colegas, um aluno procede, usando o método de substituição simples, do seguinte modo:

$u^{2}=x, \int \frac{\sqrt{x}}{1+\sqrt[3]{x}} d x=\int \frac{u 2 u}{1+u^{2 / 3}} d u=\int u\left(1+u^{-2 / 3}\right) 2 u d u$... momento em que é interrompido pelo professor para que reflita sobre o erro que cometeu.

(Cabral, 1998, p.161-162)

b) $\int\left(x^{2}+1\right)^{15} x d x=\int\left(x^{3}+x\right)^{15} d x$

(Cabral, 1992, p.169-170)

c) Ao derivar $e^{x^{2}}$ o aluno não "enxerga" a composição de funções e responde que $\frac{d e^{x^{2}}}{d x}=e^{x^{2}}$

(Cabral, 1992, p. 180) 
A regra da cadeia para a derivação, evidenciada no último item selecionado da dissertação de Cabral (1992), é, sem dúvida, uma das principais barreiras para os cálculos de derivadas pelos alunos. A dificuldade em identificar e operar com a composição de funções é aqui, com efeito, o maior elemento complicador. É muito comum observarmos nas "provas" de Cálculo de nossos alunos erros como:

$$
\begin{aligned}
& \frac{d \operatorname{sen}^{2} x}{d x}=2 x \cos x \\
& \frac{d \cos \sqrt{x}}{d x}=-\operatorname{sen} x \cdot \frac{1}{2 \sqrt{x}}
\end{aligned}
$$

(dados obtidos da segunda prova parcial de Cálculo I, do curso de Matemática da UFF, $2^{\circ}$.sem/ 1998)

Os erros cometidos nos exemplos anteriores são de mesma natureza: o aluno "esquece" de fazer a composição da derivada da função mais externa, com a função mais interna $\left[(f \circ g)^{\prime}(x)=f^{\prime}(g(x)) \cdot g^{\prime}(x)\right]$.

Acrescente $a$ isto os inúmeros cálculos de limites, que exigem muito mais habilidades algébricas do aluno do que a compreensão do próprio significado da operação pelo mesmo. Mas isto é assunto para o próximo tópico. 


\section{figura 53 - Mapa do macro-espaço da dualidade variabilidade/permanência}

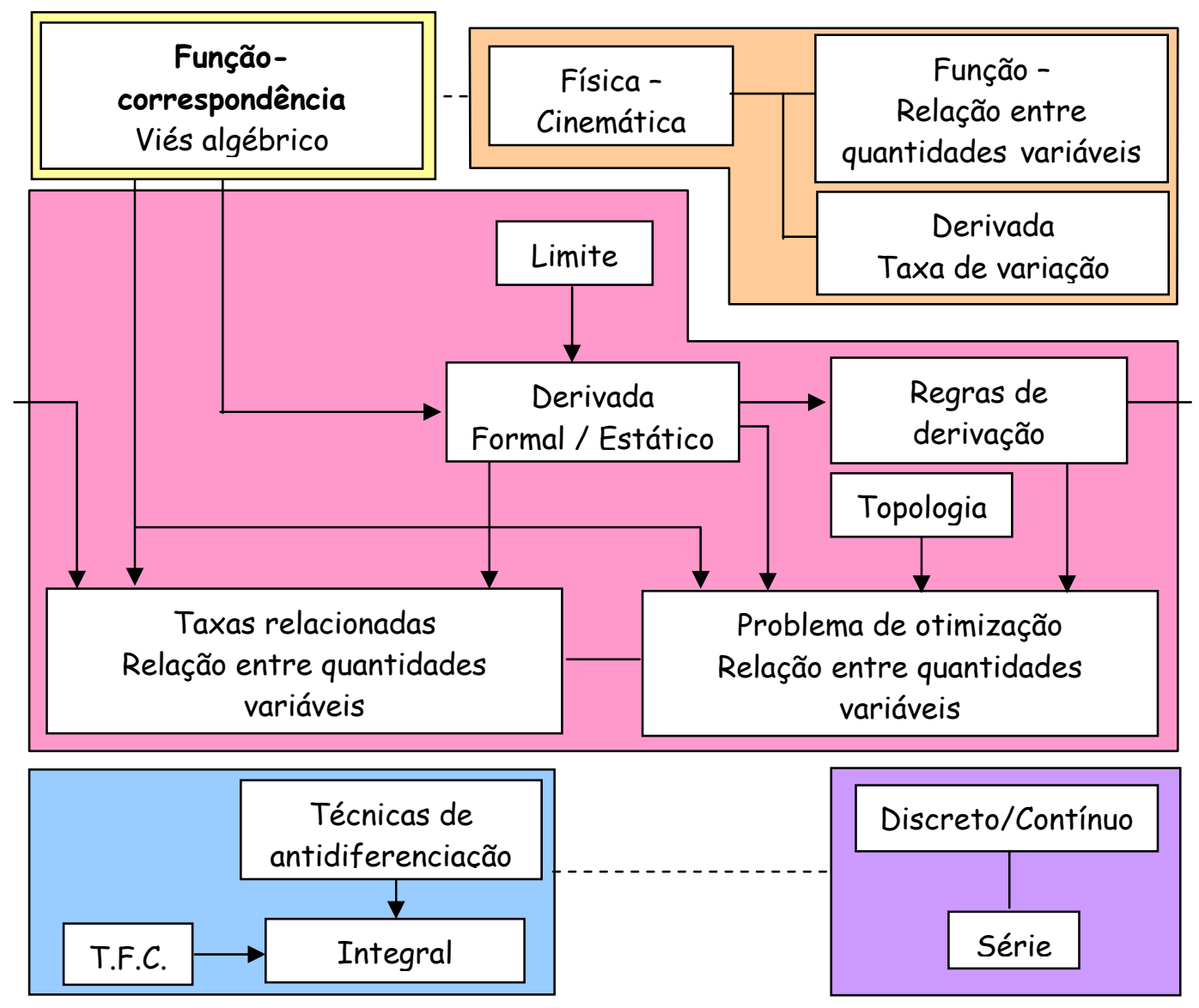

\section{Ensino médio}

Idéias fundamentais do problema da variabilidade que não participam efetivamente do processo didático do Cálculo

Abordagem didática clássica do problema da variabilidade

Abordagem didática clássica do problema do cálculo integral

Idéias fundamentais do cálculo integral que não participam efetivamente do processo didático 


\subsubsection{O macro-espaço da dualidade finito/infinito}

\section{Na escala histórica}

Ao analisar os paradoxos de Zenão (o de Aquiles e o da Dicotomia), Galileu percebe e explicita uma questão "paradoxal" mas de importância fundamental para o desenvolvimento do Cálculo e da Análise: "pode uma série infinita ter um resultado [finito]?". Responder essa questão hoje em dia, para nós, pode ser simples, mas não foi assim durante séculos e séculos de construção do conhecimento matemático.

Falar sobre a história do infinito implica falar da história do Cálculo, para não dizer, sem nenhum exagero, da própria Matemática. $O$ infinito é um dos ingredientes fundamentais para a construção da ponte discreto/contínuo. É sabido que todo número real é uma quantidade finita de uma soma discreta infinita, que a integral definida e a derivada de uma função são processos infinitos, ou que ao aproximarmos uma curva por uma linha poligonal - ou a área de uma região plana pela área de uma região poligonal - devemos realizar o tal processo ad infinitum para que possamos encontrar o "verdadeiro" valor do comprimento - ou área - da figura dada. E são exatamente esses procedimentos ad infinitum que caracterizam as idéias $e$ as operações básicas do Cálculo.

Segundo Morris (1997) a história do infinito tem início há aproximadamente 25 séculos, quando Zenão de Eléia, muito antes de 
Galileu, propõe com os seus paradoxos um dos problemas mais duradouros e enigmáticos da ciência: como definir o infinito?

Os matemáticos e filósofos gregos, ao invés de enfrentarem o problema, procuram evitá-lo, considerando a existência do infinito potencialmente. Aristóteles chega a propor uma espécie de "exorcismo" da idéia de infinito, tomando como base para as suas argumentações os procedimentos matemáticos adotados pelos geômetras que não precisavam, por exemplo, que "a reta fosse infinita", bastando que ela pudesse ser prolongada até o tamanho necessário para que se fizesse a demonstração. Assim, atendendo ao chamado de Aristóteles, a matemática é posta em bases lógicas e a noção de infinito é expulsa dos seus procedimentos "normais". Há de se ressaltar, entretanto, que houve uma certa resistência a esse expurgo do infinito das idéias matemáticas na ciência e filosofia gregas. Platão e Demócrito - da escola de Abdera - resistiram, cada qual com as armas que tinha: Platão com a idéia de apeíron (que é a palavra grega para infinidade; etimologicamente tal vocábulo significa "sem limites") e Demócrito com o seu indivisível matemático (o infinitesimal). Arquimedes - apesar de fazê-lo de forma velada também fez uso das quantidades infinitamente pequenas nos seus processos de descobertas.

No entanto, a inserção definitiva do infinito no contexto matemático se dá na idade média, novamente com os escolásticos. Gregorie de Saint-Vicent faz então uma adaptação do método de exaustão de Eudoxo, tornando este um processo de aproximação infinita. Procedimentos infinitesimais e/ou baseados na noção intuitiva de limite começam a serem usados como ferramentas "normais" da 
matemática da época. E é dessa forma que a noção de infinito participa e contribui para a "invenção" e o desenvolvimento do Cálculo.

Do Cálculo de Newton e Leibniz ao Cálculo de Cauchy, a noção de infinito só mudou de corpo, ora se encontrando travestido de infinitesimal, ora de limite. No entanto, é apenas no início do século passado, com a reaproximação da Matemática com a Lógica e o desenvolvimento da Teoria dos Conjuntos, que a noção de infinito se integra definitivamente como conceito fundamental do "edifício" lógico-matemático. Tal façanha se realiza na escola alemã, com destaque para Dedekind e Cantor.

\section{$\mathrm{Na}$ escala pedagógica}

"O infinito e a indivisibilidade são de naturezas muito incompreensíveis para nós (os humanos)" - já dizia Galileu. O grande mestre da física tinha consciência das dificuldades inerentes à noção de infinito, ainda que sua morte antecedesse à "invenção" do Cálculo em aproximadamente trinta anos. Assim, apesar da complexidade do conceito de infinito, é, no mínimo, curioso que nossos estudantes não tenham sequer consciência das dificuldades referentes à noção de infinito, mesmo tendo eles já realizado um curso de Cálculo ou mesmo de Análise. Isso nos leva a concluir que cursar ou não cursar as referidas disciplinas, tal como se encontram organizadas nos dias de hoje, não faz diferença alguma para a instrução do aluno nesse assunto. Evidências do que aqui afirmamos podem ser encontradas, por exemplo, em Sierpinska (1987) e Rezende (1994). 
Em sua pesquisa sobre obstáculos epistemológicos relativos à operação de limite, Sierpinska (1987) verificou a hegemonia de posições finitistas ou do infinito potencial nas atitudes dos estudantes. Em nossa dissertação de mestrado, em 1994, mostramos que os resultados não são diferentes dos da pesquisadora polonesa, mesmo tendo o nosso grupo piloto a participação de alunos tanto de Cálculo quanto de Análise. Encontramos nas atitudes dos estudantes as seguintes interpretações do conceito de infinito:

I- "O infinito transmite a idéia de uma coisa distante, mas que existe. Ou uma coisa muito grande, ou muito pequena, mas que também existe. Quando dizemos que duas retas se encontram no infinito, significa que elas se cruzam em algum lugar". (4) ${ }^{171}$

II- "Infinito é o conjunto onde não existe um limite máximo e um limite mínimo". (2 e 3)

III- "É alguma coisa sem fim, ou a idéia de que podemos encontrar tantos elementos quanto queiramos num espaço delimitado". (1 e 2)

IV- "O infinito é uma forma indeterminada. Não existe. Os tipos são: $+\infty$ e $-\infty "$. (4)

V- "Infinito é muito vago, você não consegue defini-lo, mas você pode dizer que existem infinitas estrelas no céu e infinitos grãos de areia na praia; pois você não consegue contá-los, mas você sabe que existem muitos". (2)

VI- "Não tem fim; não pode ser contado". (1 e 2)

VII- "Não tem fim, mas pode ter limite; existe, como um número infinitamente grande" (1)

VIII- "O infinito é uma quantidade muito grande de elementos com o qual não conseguimos uma representação concreta (associação). Os tipos são + $\infty$ e - $\infty$. Não existe. Só o universo é infinito". (2 ?)

IX- "Infinito é diferente de indeterminação; não tem valor; não podemos dizer que não existe. Existe. Não sei dizer como". (?)

\footnotetext{
${ }^{171}$ Os números entre parênteses indicam a(s) “classe(s)” de interpretação da noção de infinito, mediante a classificação que foi feita posteriormente das atitudes dos estudantes com respeito a este conceito. As quatro classes determinadas são apresentadas a seguir.
} 
X- "Estamos sempre acostumados a resolver problemas de um modo geral que estão ligados a realidade $e$, de repente quando nos enfrentamos com outros do tipo que envolvem a noção de infinito, ficamos com dificuldade. Por exemplo, $\lim _{n \rightarrow \infty} e^{n}=e^{\infty}=\infty$ é um exemplo difícil de entender, mas que com a prática se torna mais fácil". (?)

XI- "O infinito existe como uma ferramenta "quebra-galho", não é praticamente nada, não é um número, valor ou propriedade, apenas um símbolo. Este símbolo não é definido... Os tipos são; $+\infty$, para indicar algo extremamente grande; - $\infty$, para indicar algo extremamente pequeno, e $\infty$ para indicar que não existe limite". (4)

(Rezende 1994, p.102)

Diante da riqueza das atitudes espontâneas dos estudantes acerca da noção de infinito, somos levados a compartilhar as idéias do escritor Jorge Luis Borges que nos fala do estado alucinógeno que o confronto com esta noção pode provocar em nossas mentes (Morris, 1997, p.13). As atitudes dos estudantes são híbridas e transcendem, muitas vezes, o próprio contexto matemático (pensam, por exemplo, a questão no universo físico). Algumas só conseguem traduzir em palavras a angústia de quem "não consegue dar um significado" para a noção de infinito (as posições IX e X, por exemplo). Assim, procurando reinterpretar as atitudes dos estudantes a partir do contexto histórico da evolução matemática deste conceito, podemos encontrar quatro posições definidas: 
1. Infinito como "algo que não tem fim": posições III, VI e VII.

2. Infinito como "algo incontável": posições II, III, V, VI e VIII(?).

3. Infinito como "algo ilimitado": posição II.

4. Infinito como "forma indeterminada": posições I, IV e XI.

Esses quatros níveis de significação da noção de infinito obtidos a partir das respostas dos estudantes não representam de forma alguma uma classificação. Os níveis não são excludentes e a distinção entre alguns deles pode passar despercebida. Por isso, alguns esclarecimentos se fazem necessários. Por exemplo, a distinção que fizemos entre (1) - "algo que não tem fim" - e (3) - "algo ilimitado" pode ser explicada pelo paradoxo de Galileu ("pode uma série infinita ter um resultado [finito]?"), aqui representado pela posição VII: para este estudante o infinito "não tem fim" mas pode ser limitado ${ }^{172}$. Tal fato, como observou Sierpinska (1987), pode levar o aluno a fazer distinção entre "algo que não tem fim" e "algo ilimitado" (posição infinitista), ou pode levá-lo a simplesmente identificá-los (posição finitista). Por isso tivemos o cuidado de fazer esta distinção. $O$ mesmo ocorre em relação à posição (2) - "infinito como algo incontável" - e essas duas posições anteriores. Observe, por exemplo, que em $V$ podemos ter "infinitos" grãos de areia em uma praia mesmo que essa quantidade seja limitada: "infinitos" porque a tarefa de contá-los um a um é impossivel. Um representante notável desta atitude em relação

\footnotetext{
${ }^{172}$ Um exemplo simples desse fato é qualquer intervalo aberto e limitado (a,b) da reta real: é um conjunto infinito, não tem fim, mas é limitado.
} 
ao conceito de infinito foi a do matemático suíço Johann Bernoulli que, baseado nessa impossibilidade de medir e quantificar determinadas grandezas físicas, afirmou que o infinitamente grande podia ser entendido através das grandes distâncias astronômicas que não podiam ser medidas ou calculadas. Já o último grupo de significação (4 "infinito como forma indeterminada") representa um afastamento da noção para o terreno simbólico: o infinito é apenas um símbolo que serve para representar situações de indeterminação. Esta atitude é consequiência imediata do próprio processo didático que induz o estudante a identificar os símbolos $\pm \infty$ com os casos de séries $e$ sequiências divergentes.

Interessante observar que alguns estudantes fazem menção à noção de limite quando tentam apresentar a sua interpretação do infinito. Por outro lado, quando se referem aos "tipos" de infinito, fazem distinção apenas do ponto de vista algébrico: existe o "infinito positivo", o "negativo" e o "sem sinal", que serve para representar apenas que o limite não existe. Note que a dualidade discreto/contínuo passa longe do campo de significações dos estudantes - e o que é pior, alguns deles já tinham feito um curso de Análise.

Outro aspecto que pode ser observado é a ingenuidade com que os estudantes lidam com as operações infinitas. Em nossa dissertação de mestrado (Rezende, 1994) tivemos oportunidade de investigar $e$ identificar algumas dessas ingenuidades: 
a série harmônica: $1+\frac{1}{2}+\frac{1}{3}+\frac{1}{4}+\ldots$ (Rezende, 1994, p.115-116)

O contato inicial com este formato ${ }^{173}$ da série harmônica faz com que os estudantes sugiram o número " 2 " como o "valor limite" da série. Ao serem estimulados a calcular a soma dos quatro primeiros termos da série (que é igual a $\frac{25}{12}=2 \frac{1}{12}$ ), mudam imediatamente a estimativa do "valor limite" para "3". Quando são novamente incentivados a calcular a soma dos onze termos iniciais, duas atitudes se verificam: alguns desistem de somar até o décimo primeiro termo da série e permanecem com o valor "3" como "valor limite"; no entanto, aqueles que realizam a tarefa até o final, percebem que ao somar 0 décimo primeiro termo a soma ultrapassa o valor 3 , e que a série, portanto, não convergiria para este valor, mas, certamente, convergiria para um outro valor maior que 3. Assim, tirando a "preguiça" do primeiro grupo de estudantes, as duas posições se identificam e têm uma mesma certeza: a série harmônica é convergente. A justificativa para isto é "lógica": as frações que vão sendo acrescentadas "vão se tornando cada vez menores, desprezíveis em relação ao número maior a ser alcançado". Contudo, quando a série é identificada pelo nome ou pela sua representação formal, alguns estudantes recordam da informação que algum dia obtiveram que a série harmônica era divergente, mas confessam, por outro lado, que "não tinham aceitado esta idéia muito bem"na ocasião em que receberam tal informação.

\footnotetext{
173 A representação formal da série harmônica $\sum_{n=1}^{\infty} \frac{1}{n}$ lembra a alguns alunos a informação já conhecida - e memorizada em outro momento de sua vivência didática - do seu comportamento divergente.
} 
Note, pelo exemplo exposto, que dois fatos se tornam evidentes: de imediato, percebe-se na justificativa dos estudantes uma inversão do sentido lógico do resultado: se $\Sigma a_{n}$ converge $\Rightarrow \lim a_{n}=0$ - aliás, 0 argumento invertido dos estudantes (isto é, se $\lim a_{n}=0 \Rightarrow \Sigma a_{n}$ converge) foi usado com muita frequiência por grandes matemáticos, sem qualquer tipo de contestação, até o século XVIII; além disso, percebe-se que apesar de construírem outra rede de significações em relação à série harmônica (todos foram unânimes em afirmá-la convergente), os alunos que já fizeram um curso de Análise, entretanto, demonstraram continuar obedientes à informação ensinada no tal curso.

a série de Grandi: 1-1+1-1+1-1+... (Rezende, 1994, p.111-114)

Duas atitudes são observadas inicialmente: uma majoritária, em que o estudante afirma que o resultado de tal soma é nula, uma vez que $1-1+1-1+1-1+\ldots=(1-1)+(1-1)+(1-1)+\ldots=0+0+0+\ldots=0 ;$ outra, cujo raciocínio é similar à anterior, em que o aluno afirma que tal soma é 1 , pois $1-1+1-1+1-1+\ldots=1+(-1+1)+(-1+1)+(-1+1)+\ldots=1+0+0+0+\ldots=1$.

Note que ambos os argumentos fazem uso da propriedade associativa para calcular o resultado da série de forma bastante ingênua: a convergência ou não da série sequer é questionada. Motivado por essa atitude unânime (apesar de apresentarem dois resultados) dos estudantes, foi sugerido aos alunos os seguintes desenvolvimentos: 
$1-1+1-1+1-1+\ldots=1+1-1+1-1+1-1+\ldots$ (propriedade comutativa)

$1+1-1+1-1+1-1+\ldots=1+1+(-1+1)+(-1+1)+(-1+1) \ldots$ (propriedade associativa)

$1+1+(-1+1)+(-1+1)+(-1+1) \ldots=2+0+0+0+\ldots=2$.

Diante desse comportamento estranho da série, os alunos percebem que ela pode "convergir" para 3, ou para 4, ou -1, ou qualquer outro valor inteiro. Instaura-se dessa forma o caos total nas atitudes dos estudantes. Apesar de não entenderem o porquê da confusão, os estudantes afirmam que os resultados obtidos são verdadeiros por que partem de "raciocínios lógicos" e de propriedades bastante bem conhecidas por eles: será?

Isto posto, foi apresentado aos estudantes a solução de Leibniz para o problema:

$S=1+x+x^{2}+x^{3}+\ldots$

Multiplicando a expressão acima por $x$, obtém-se

$x S=x+x^{2}+x^{3}+\ldots$

Fazendo, em seguida, (b) - (a), obtém-se

$(1-x) s=1 \Rightarrow s=\frac{1}{1-x}$

Assim, fazendo $x=(-1)$ simultaneamente em (a) e (c) obtém-se:

$1-1+1-1+1-1+\ldots=\frac{1}{1-(-1)}=\frac{1}{2}$.

A atitude dos estudantes em relação à solução dada por Leibniz foi, diante de suas próprias fragilidades conceituais, de surpresa e de submissão: não ousam questionar o raciocínio daquele que foi considerado um dos inventores do Cálculo. Esse sentimento de impotência por parte dos estudantes é fruto mais uma vez da formação matemática passiva que receberam. Obedecem aos "rituais 
consagrados"e às "convenções matemáticas" estabelecidas no processo pedagógico, aprendem a "jogar o jogo sintático" do ensino da matemática - se $A$ então $B$ - e ignoram o significado daquilo que fazem ou "aprendem". Em geral, é isso que aprendem em um curso de Análise: - jogo sintático da arte de demonstrar em matemática.

Em verdade, o que fez falta aos estudantes era o mesmo que faltava a Leibniz: a compreensão da noção de convergência de uma soma infinita e a ausência de critérios que permitissem avaliar em que medida as propriedades algébricas de uma soma finita podem ser estendidas "naturalmente" para uma soma infinita.

$>$ as indeterminações matemáticas (Rezende, 1994, p.125-129)

É muito comum observarmos os seguintes procedimentos nos cálculos de limites realizados por nossos estudantes:
a) $\lim _{x \rightarrow \infty}\left(1+\frac{1}{x}\right)^{x}=1^{\infty}=1$
b) $\lim _{x \rightarrow \infty}\left(\sqrt{x^{2}+x}-x\right)=\infty-\infty=0$
c) $\lim _{x \rightarrow \infty} x \operatorname{sen}\left(\frac{1}{x}\right)=\infty \cdot 0=0$

Os argumentos para esses procedimentos são, em geral, como seguem:

a) quando $x \rightarrow \infty, \frac{1}{x} \rightarrow 0 e\left(1+\frac{1}{x}\right) \rightarrow 1 ; \log \left(1+\frac{1}{x}\right)^{x} \rightarrow 1^{\infty}=1.1 .1 \ldots$ (infinitas vezes)

= 1, uma vez que 1 "vezes" 1 é sempre igual a 1;

b) quando $x \rightarrow \infty, \sqrt{x^{2}+x} \rightarrow \infty$; logo $\sqrt{x^{2}+x}-x \rightarrow \infty-\infty=0$; 
c) quando $x \rightarrow \infty, \frac{1}{x} \rightarrow 0$ e, portanto, $\operatorname{sen}\left(\frac{1}{x}\right) \rightarrow 0$; logo $x \operatorname{sen}\left(\frac{1}{x}\right) \rightarrow \infty .0=0$, pois o produto de zero por qualquer número, por maior que seja esse número, é sempre igual a zero.

Assim, pode-se perceber nas atitudes dos estudantes uma simplificação ingênua do cálculo dos limites. Não reconhecem as situações de indeterminação presentes em cada um dos limites e procuram traduzir e "resolver" as indeterminações através de uma espécie de álgebra do infinito. O interessante é que o infinito, que "não é nada", ou "é apenas um símbolo matemático", passa a se comportar agora como número.

Essa atitude dos estudantes de construir, por conta própria, uma espécie de álgebra do infinito pode ser justificada pela própria evolução histórica do Cálculo. Não foram poucos os matemáticos que, desprovidos de conhecimentos que permitissem tratar os processos infinitos com mais clareza, usaram desse mesmo expediente em relação a noção de infinito usado pelos nossos estudantes de Cálculo: Cavalieri, Wallis e Fontenelle, entre tantos outros, são exemplos do que estamos afirmando. Fontenelle, ao defender os indivisiveis de Cavalieri, considerou que o $\infty$ era o último termo da seqüiência $0,1,2,3, \ldots$. Em seguida, definiu o "infinitamente pequeno" pelo inverso algébrico do

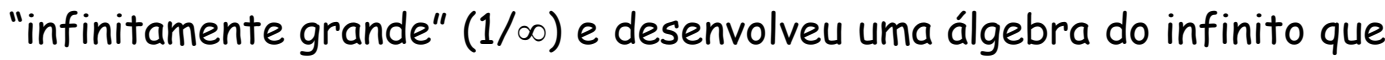
deixaria qualquer professor atual de Cálculo 1 pasmado. Fontenelle afirmou, por exemplo, que $\infty . \infty^{\infty-1}=\infty^{\infty}=\infty$.

Cabe ressaltar, entretanto, que foi justamente esse comportamento "estranho" da inserção do $\infty$ em cálculos algébricos que 
fez com que D'Alembert rejeitasse a idéia da existência do infinito atual ${ }^{174}$ (Boyer, 1949, p.257). Assim, pode-se afirmar que essas tentativas iniciais da construção de uma álgebra do infinito (realizadas por Cavalieri, Wallis, Fontenelle) constituíram, de certo modo, um obstáculo epistemológico para a construção do infinito atual. Por outro lado, é notório que foi a partir das reflexões a respeito desses procedimentos ingênuos relacionados às indeterminações matemáticas que se iniciou o processo de construção da operação de limite. Cabe lembrar ainda que foi o próprio D'Alembert que fez sobressair a operação de limite no caso da indeterminação 0/0 e que culminou com a definição atual de derivada.

Em um curso inicial de Cálculo outras indeterminações costumam aparecer: $0^{0}, \pm \infty / \pm \infty, \infty^{0}$, etc., e são igualmente ignoradas e "resolvidas" ingenuamente, com exceção de uma delas, que apesar de não ser resolvida, em geral, pelos estudantes, é pelo menos reconhecida como uma situação de indeterminação: a expressão 0/0. Mas o que é que há de especial com a expressão 0/0 que condena o seu aspecto indeterminado, e que as outras não têm?

Para início de conversa, 0/0 é indeterminação essencial do cálculo diferencial. A noção de derivada decorre de uma expressão indeterminada dessa natureza. Seja na razão de diferenças infinitamente pequenas - como em Leibniz e Euler ${ }^{175}$-, seja no limite de razões de incrementos que tendem a zero simultaneamente - como

\footnotetext{
${ }^{174}$ Um dos argumentos do matemático francês contra o uso do infinito em cálculos algébricos era como segue: ora, se $(\infty+n)=\infty$ e $(\infty-n)=\infty$, então $(\infty+n)=(\infty-n)$, o que implica que $n=-n$, o que é um contra-senso.

${ }^{175}$ Euler afirmou, por exemplo, que o problema central da definição de derivada estava em estabelecer uma definição para a divisão de zeros.
} 
em D'Alembert e Cauchy ${ }^{176}$. No entanto, não é essa informação ${ }^{177}$ que faz nosso aluno reconhecer tal expressão como indeterminada. 0 início da história é um pouco mais distante.

Certamente, em algum momento do ensino fundamental de matemática o estudante tem contato com situações algébricas do seguinte tipo: $0 \cdot x=0$. Seja na resolução de equações ou sistemas de equações lineares do primeiro grau. $E$, assim, o professor tem - e sabe aproveitar - a oportunidade para trabalhar com os estudantes que 0/0 é uma expressão indeterminada, pois a equação $0 . x=0$ tem uma infinidade de soluções $(1.0=0,2.0=0$, etc. $)$.

No entanto, o mesmo não é feito com outros "tipos" de indeterminações. Um fato curioso, e que merece o nosso destaque, acontece em relação à indeterminação $0^{0}$. É usualmente ensinado aos estudantes que "todo número elevado a zero é igual a um". Um argumento usado para justificar tal afirmação é como segue:

$1=\frac{x^{n}}{x^{n}}=x^{n-n}=x^{0}$, onde $x$ é um número real qualquer...

Logo, para $x=0$ temos $0^{0}=1$.

O curioso, é que, em geral, o professor não percebe que se o seu raciocínio fosse verdadeiro, ele teria "provado" também que 0/0 = 1 . De fato, se podemos fazer $x=0$ na expressão desenvolvida pelo professor, temos então que:

$$
\frac{0}{0}=\frac{0^{n}}{0^{n}}=0^{n-n}=0^{0}=1
$$

${ }^{176}$ Se $\mathrm{f}$ é diferenciável em $\mathrm{x}$, f é contínua em $\mathrm{x}$, isto é, $\lim _{h \rightarrow 0} f(x+h)-f(x)=0$; logo,

$$
\begin{aligned}
& f^{\prime}(x)=\lim _{h \rightarrow 0} \frac{f(x+h)-f(x)}{h}=\frac{0}{0} \text {. } \\
& { }^{177} \text { Em geral, tal informação sequer faz parte do banco de dados de nossos estudantes. }
\end{aligned}
$$


Assim, se $0^{0}=1,0 / 0$ também deveria ter o mesmo valor para salvaguardar o seu argumento. Essa discussão sobre a indeterminação ou não da expressão $0^{0}$ ainda gera polêmica entre os docentes de matemática do ensino médio e fundamental nos dias de hoje. Basta ver os artigos publicados pelo professor Elon nas revistas RPM ${ }^{178}$ números 1 (Lima, 1982, p.5-8) e 7 (Lima, 1985, p.17-20). O último artigo coloca um ponto final nesta polêmica.

Isto posto, fica evidente que a idéia de infinito não participa e nem contribui de forma significativa na construção das redes de significações estabelecidas num curso usual de Cálculo. As atitudes ingênuas dos estudantes em relação às operações infinitas e às indeterminações matemáticas são fatos evidentes disso. O infinito é um elemento estranho para o nosso aluno do ensino médio $e$, por conseguinte, para o nosso aluno de Cálculo. Mas continua estranho para - estudante, mesmo após um curso de Análise. Alguns desses estudantes agora são professores de matemática, lecionam nos ensinos médio e fundamental, e o conceito de infinito continua estranho para a maioria deles. Com isso, reproduzem o ciclo que eles próprios vivenciaram.

Assim, pode-se concluir a partir do que foi exposto acima que:

- a posição predominante entre os estudantes com relação à noção de infinito é a atitude potencialista, isto é, aquela em que o infinito existe apenas potencialmente, uma vez que os processos infinitos não se realizam efetivamente;

\footnotetext{
${ }^{178}$ RPM - Revista do Professor de Matemática - é uma revista editada periodicamente pela Sociedade Brasileira de Matemática.
} 
- representar uma situação de indeterminação é uma das principais atribuições do infinito. Segundo os estudantes, o estado de indeterminação é conseqüência da impossibilidade das operações infinitas de se realizarem.

- os estudantes não realizam suas interpretações $e$ tipificações do infinito no contexto da dualidade discreto/contínuo; não reconhecem as especificidades do infinito matemático contínuo;

- os alunos adotam atitudes bastante ingênuas nos processos e operações infinitas; transferem, por exemplo, as propriedades que conhecem acerca da soma finita para as somas infinitas;

- como as operações infinitas não se realizam, o que se obtém então são apenas valores aproximados; o "limite da sequiência é" significa que a sequiência "tende" a um valor que é a "melhor aproximação" para ela; a noção de limite se constitui assim como um processo de aproximação;

- as indeterminações matemáticas - exceto a expressão 0/0 em alguns casos - são ignoradas pelos estudantes $e$ substituídas por uma espécie de álgebra do infinito;

- o "ciclo da ignorância da noção de infinito" é alimentado pela ausência de conhecimentos básicos a respeito dos estudos matemáticos de Dedekind e Cantor sobre esta noção na formação do professor de matemática do ensino médio $e$ fundamental, o que inviabiliza qualquer possibilidade de reação ao ciclo. 
figura 55 - Mapa do macro-espaço da dualidade finito/infinito

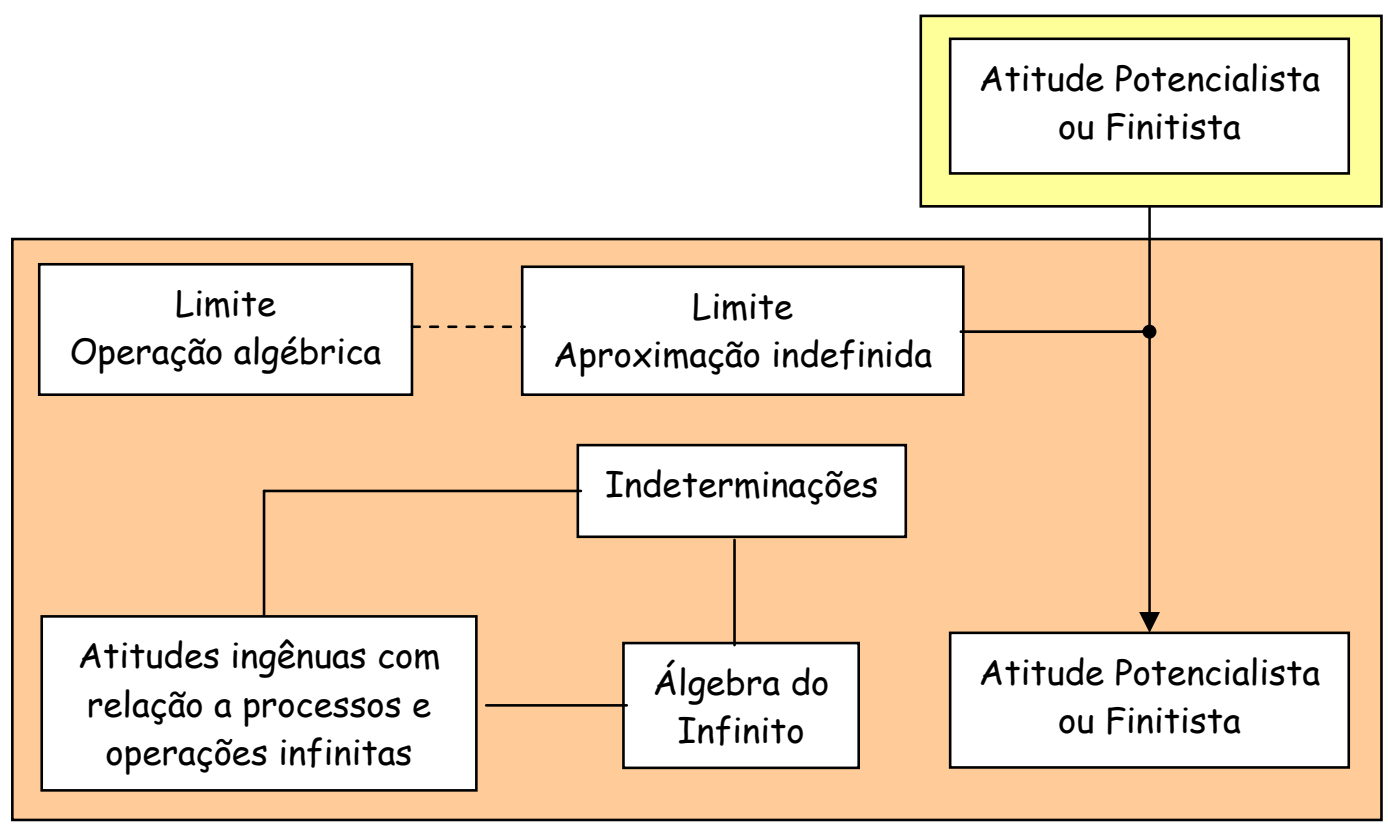

Ensino médio

Abordagem do infinito no ensino superior 


\subsubsection{O macro-espaço da dualidade local/global}

\section{Na escala histórica}

Ao contrário das dualidades discutidas até agora (discreto/contínuo, variabilidade/permanência e finito/infinito) neste trabalho, a história da oposição local/global é recente, podendo ser datada, segundo Petitot (1985, p.11), de meados do século XIX, aproximadamente.

"Fundada originariamente na intuição espacial", a oposição local/global invadiu o campo matemático e estabeleceu com este uma relação de simbiose que the rendeu um arcabouço de conhecimentos que possibilitaram, nestes últimos anos, o desenvolvimento de novas interpretações e significações no campo da epistemologia. Segundo Petitot (1985a, p.11), tal simbiose permitiu "reformular alguns dos problemas 'dialéticos' mais críticos, colocados pela estrutura lógicosintático-semântica das línguas naturais". Com efeito, o pesquisador francês, a partir de algumas observações genéticas sobre a semântica, atravessou o universo dos vários aspectos matemáticos da oposição local/global, para concluir, enfim, sobre as dificuldades inerentes à esquematização das formas lingüísticas. E, além disso, Petitot, com base no "percurso epistemológico" que realizou, vislumbrou um novo cenário epistemológico para a oposição local/global: 
Em nossa opinião, a possibilidade de percursos epistemológicos deste tipo é a premissa de um novo tipo de implicação fenomenológica da matemática que permitirá talvez transformar substancialmente a nossa relação com a ciência. Mas, seja qual for o futuro, doravante a oposição local/global deve ser considerada como uma das categorias fundamentais da razão pura.

(Petitot, 1985a, p.70-71)

É inegável a contribuição de natureza epistemológica da oposição local/global sugerida pelo autor, mas o valor superestimado dessa contribuição, alicerçada por teorias e modelos matemáticos, é questionável e criticada por alguns autores. Tal atitude é considerada por estes como uma interpretação "neopositivista" das questões epistemológicas. Uma discussão aprofundada desse tema, neste momento da nossa dissertação, nos obrigaria a mudar de escala, e buscar outros cenários não imaginados inicialmente, o que, de certa forma, comprometeria a nossa investigação sobre "o quê" da oposição local/global realmente interessa para o nosso trabalho.

Assim, aumentando a escala, e buscando os entrelaçamentos possíveis entre a oposição local/global e a matemática, poderíamos afirmar, em consonância com Petitot (1985a, p.12), que a dualidade local/global está "matematicamente correlacionada" com os seguintes temas: "colagem de modelos locais em objetos globais, passagem do local ao global e análise de suas obstruções, métodos de análise das estruturas locais elou globais não triviais, etc.". Ou de forma sintética, que "a oposição local/global recorre à análise das múltiplas relações dialéticas que ligam os aspectos locais aos globais, ela recorre também à análise das estruturas locais como tais e às estruturas globais como tais". 
Outro aspecto abordado por Petitot em estudo sobre a oposição local/global diz respeito às interconexões que esta dualidade estabelece com outras "oposições", a saber: centrado/acentrado; singular/universal; particular/geral; espaço/função; discreto/ contínuo - sendo, todas elas, sem exceção, de interesse para o nosso trabalho. A última delas, por exemplo, constitui, conforme já observamos, o universo de um dos macro-espaços das dificuldades de natureza epistemológica do ensino de Cálculo já citados. Ocupar-nos-emos, agora, da "oposição" espaço/função, citada por Petitot.

A oposição local/global é, sem dúvida, a priori, um produto de nossa percepção do espaço, mas, evidentemente, não se esgota nela. Com efeito, a simulação euclidiana do espaço, apreendida pela percepção humana, é tão somente uma aproximação local do que ele efetivamente é ${ }^{179}$. E o pensamento de que sua condição global é uma extensão natural de sua situação local é por demais ingênua. Petitot, tomando a representação espacial de Riemann como exemplo, ratifica o que afirmamos:

Notemos simplesmente que ela (a idéia de Riemann) subverte totalmente a nossa intuição espontânea do espaço, porquanto destrói "a evidência" que a estrutura global do espaço se obtém por extensão direta da sua estrutura local. Com Riemann, o problema da passagem do local ao global separa-se de toda a intuição e torna-se uma problemática matemática fundamental.

(Petitot, 1985a, p.22)

Além disso, no que se refere às origens da própria geometria euclidiana - nosso paradigma perceptual de simulação do espaço -, Petitot chega inclusive a levantar suspeitas de que esta tenha se

\footnotetext{
${ }^{179}$ Podemos aproximar localmente uma superfície esférica (o espaço real) pelo seu plano tangente (a simulação do espaço). Tal resultado pode ser estendido para um domínio maior de superfícies: as superfícies/variedades regulares.
} 
inspirado originalmente na estrutura do espaço físico: para o pesquisador, tal inspiração poderia estar relacionada diretamente com a formalização dos processos de construção geométrica. Mas isto, segundo o autor, não impede que a geometria euclidiana "constitua um dos principais centros motores da "retificação" generalizada do simbólico que desde então governou a história"(Petitot, 1985a, p.20).

E é no desenvolvimento histórico da geometria, que Petitot localiza a contribuição essencial do Cálculo para o surgimento das primeiras relações solidárias entre o local e o global:

Até o fim do século XIX, a geometria reduz-se essencialmente ao estudo de objetos geométricos imersos num espaço bi- ou tridimensional. Os métodos utilizados são, por um lado, os métodos sintéticos herdados da tradição euclidiana $e$, por outro lado, os métodos analíticos e algébricos fundados no uso de coordenadas. Com a introdução do cálculo infinitesimal, as coordenadas permitem a análise das propriedades diferenciais dos objetos (equação das tangentes, das normais, estruturas dos pontos singulares, etc.). Assim aparecem os primeiros teoremas gerais sobre as curvas algébricas e a "solidariedade" que existe entre a sua estrutura local e a global.

(Petitot, 1985a, p.21)

Assim, com base na datação histórica do surgimento da oposição local/global, pode-se concluir que esta dualidade não participou efetivamente da "invenção" do Cálculo. Com efeito, tanto Newton quanto Leibniz não faziam distinção e sequer relacionavam os conceitos locais $e$ as propriedades globais das "curvas" que diferenciavam $e$ integravam. No Cálculo de Newton, por exemplo, os conceitos de continuidade e diferenciabilidade - conforme já foi dito neste trabalho - se identificavam e eram definidos a partir do comportamento global das curvas. Assim, para o matemático inglês a curva da figura 56 era o desenho de duas curvas diferenciáveis, e não o de apenas uma curva, que deixa de ser diferenciável em apenas um ponto. A noção de diferenciabilidade é, portanto, uma característica global da curva. 


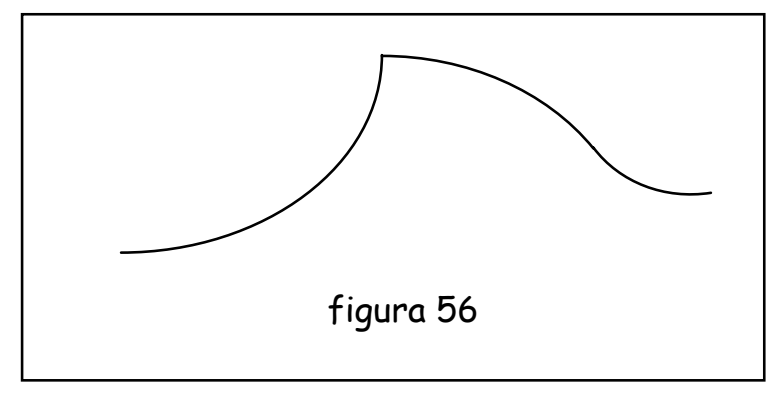

Leibniz, assim como Newton, também considerava a noção de diferenciabilidade de uma curva no nível global. Em verdade, tanto Newtom quanto Leibniz não explicitaram 0 conceito de diferenciabilidade localmente, apesar de efetuarem os seus cálculos em certas ocasiões no nível local. Dois fatores justificam a ausência de considerações locais nestas duas versões iniciais do Cálculo:

- Uma primeira relacionada ao "bom" comportamento das curvas freqüentemente utilizadas nos cálculos de Newton e Leibniz; tais curvas eram, em geral, "bem comportadas" (no mínimo, diferenciáveis) e, por causa disso, tal comportamento não suscitava questões de natureza local. Para a determinação local da tangente (da derivada) a propriedade de diferenciabilidade era assumida implicitamente pela característica global da curva.

- Faltavam aos matemáticos dois conceitos fundamentais para que pudessem vislumbrar a íntima relação da dualidade local/global com o Cálculo que acabavam de "inventar": a noção de limite e o conceito de função. 
De fato, o conceito de função, introduzido no núcleo semântico do Cálculo por Euler e Lagrange, vai constituir, junto com a noção de limite, a urdidura da nova estrutura do Cálculo. O Cálculo começa, a partir de então, a se preocupar com questões essenciais da dualidade local/global, tornando-se, por sua vez, e cada vez mais, uma rede de significações e correlações entre os pólos dessa dualidade. Esta nova versão, impregnada de conceitos e resultados que estabelecem correlações entre níveis locais e globais, constitui e representa parte substancial do conteúdo programático de um curso inicial de Cálculo normalmente ensinado em nossas universidades. Tais correlações inerentes à dualidade local/global, bem como as relações de significações estabelecidas em cada um dos níveis, originam algumas das maiores dificuldades de aprendizagem dos alunos de Cálculo, em geral. Um mapeamento destas dificuldades constitui aqui, portanto, 0 objeto premente de nossa investigação. Antes porém de passarmos ao nosso mapeamento, convém encerrarmos nossa "revisão histórica" acerca da dualidade local/global falando de suas correlações com a matemática moderna.

A matemática moderna é, no que diz respeito à sua criatividade, dominada por um tipo de passagem do local ao global similar à organização de uma Enciclopédia. Tal analogia, estabelecida por Petitot (1985a, p.17) em seu artigo, suscita um sentido positivo para a matemática moderna: ela representa, segundo ele, a reinstauração do global no universo matemático.

Assim, para alcançar a "intertextualidade" matemática generalizada, a matemática moderna precisou introduzir uma série de conceitos translocais e praticar uma intensa atividade analógica de 
tradução parcial das diversas teorias entre si. Segundo Petitot (1985a, p.18),

Esta "intertextualidade" generalizada cresceu a um ponto tal que a rede léxico-semântica da matemática moderna se tornou bastante próxima da de uma língua natural: a complexidade global da língua matemática atual assemelha-se à de uma língua natural, mas com a diferença absolutamente crucial de que o sentido se torna aí explicitamente construído e as analogias demonstráveis.

Entretanto, isso não significa, segundo o próprio autor, que a "essência" da matemática ${ }^{180}$ seja a de uma língua formal reduzida aos seus automatismos geradores. Petitot observa que não existe "estado de base" das "matemáticas modernas" ainda que elas - as "matemáticas modernas" - sejam unitárias; o seu argumento é como segue:

(...) se as matemáticas modernas são ainda unitárias, isto não se verifica, como na física, por um imperialismo do local, mas pelo fato de elas não possuírem uma estrutura global canônica, sendo os seus únicos estados globais, estados "excitados", irrepresentáveis, obtidos por analogias translocais.

(Petitot, 1985a, p.18)

Isto posto, o pesquisador francês identifica quatro consequiências dessa situação "excitada" das matemáticas modernas.

I) A nivel cultural, a dissolução aparente dos objetos matemáticos concretos numa intertextualidade generalizada torna as características da criatividade matemática incompreensiveis aos não iniciados, isto é, "isotéricas". Esta disjunção da matemática do contexto cultural é dramática, na medida em que a matemática constitui doravante o único lugar onde uma reinstauração do global compativel com a redução metodológica do global ao local típico é ainda verdadeiramente pensável. Ora, sublinhamos mais acima as consequiências desastrosas do defeito de reinstauração do global, a menor das quais não é a apropriação generalizada pelo Capital da instrumentação científica e, através dela, do que, para as nossas culturas, é a verdade.

II) A nível pedagógico, a inexistência de uma estrutura global canônica conduz a sobrevalorizar a redução categorial elou lógico-sintático ao local, isto é, as tendências axiomáticas e logicistas formais.

${ }^{180}$ O autor está se referindo aqui à “matemática pura”. 
III) A nível da sociologia da matemática, a noção de "grande" matemático descende diretamente do fato de, para além das suas garantias de coerência, a matemática ser a expressão de um sujeito de enunciação. É "grande" matemático todo matemático que, para resolver um problema local considerado crucial, gerou um "estado" excitado global, isto é, em definitivo, um estilo.

IV) Mas a grande conseqüência desta afinidade das matemáticas modernas com uma língua natural poderia ser a de romper a aliança histórica da matemática com as ciências exatas, deixando às tecnologias informáticas o cuidado de assegurar tal função, e inflectir a sua finalidade com vista a uma refundição das relações com a realidade. Atualmente, este novo tipo de compromisso ontológico é representado pela idéia fundamental de Thom, segundo a qual a intertextualidade matemática informada pela intuição espacial atingiu uma maturidade suficiente para poder visar uma geometrização do sentido e, através dela, o retornar em bases radicalmente novas dos problemas clássicos da Característica Universal, da relação entre categorias de pensamento e categorias da língua, assim como uma elucidação dialética da regulação biológica e do tempo como princípio morfogênico: numa palavra, das aporias que animavam até aqui o cerne especulativo de conceito.

(Petitot, 1985a, p.18-19)

A quarta consequiência enumerada pelo autor - considerada pelo próprio como a "grande consequiência" - é, sem dúvida, uma apologia à teoria das catástrofes, desenvolvida por René Thom, da qual o autor não consegue esconder a sua simpatia. No entanto, aquela que mais chamou nossa atenção foi a segunda citação do autor, que estabelece uma conseqüência desse "estado excitado das matemáticas modernas" no nível pedagógico. Com efeito, as tendências axiomáticas e logicistas formais predominantes no ensino superior de matemática são, sem dúvida, consequiências inoportunas do desenvolvimento da matemática moderna no processo pedagógico. E o ensino de Cálculo, conforme já foi observado, padece do mesmo mal - tal fato será discutido com mais detalhes neste trabalho, no momento em que estivermos dissertando sobre o quinto e último macro-espaço das dificuldades do ensino de Cálculo, consolidado no contexto da dualidade 
sistematização/construção. Vislumbramos, assim, nesta última dualidade - sistematização/construção - mais uma possibilidade de correlação com a oposição local/global. Antes porém, devemos enfrentar a tarefa primeira de mapear as dificuldades de naturezas epistemológicas do ensino de Cálculo no contexto da dualidade local/global. Mudemos portanto de escala.

\section{$\mathrm{Na}$ escala pedagógica}

Vimos nos parágrafos anteriores que a dualidade local/global participa de forma tardia da história do Cálculo (datada como século XIX por Petitot). No ensino de matemática, a participação dessa dualidade é retardada ao máximo. Excetuando os tópicos referentes a "conjuntos" e "noções de lógica", a oposição local/global passa desapercebida pelos alunos e seus professores de matemática dos ensinos médio e fundamental. O que não faltariam são oportunidades. Polinômios, função exponencial, assim como outros tópicos do ensino de matemática, poderiam ser explorados sob a luz da oposição local/global. No entanto, ao ingressar no curso superior $e$ fazer um curso inicial de Cálculo, o estudante se depara com diversas situações do contexto dessa dualidade. Esta imersão tardia em questões de natureza local/global suscita nos alunos algumas dificuldades de interpretação dos conceitos e resultados "normalmente" apresentados num curso de Cálculo.

Com efeito, os conceitos do Cálculo são definidos, na sua maioria, localmente - continuidade num ponto, diferenciabilidade num ponto, etc. - e estendidos, em geral, de forma "natural" para o seu estado 
global - a função é diferenciável se ela o for em cada ponto do seu domínio, etc., mas, por outro lado, muitos dos seus resultados são de natureza global - "se f'>0 em um intervalo I, então f é crescente em I", o Teorema Fundamental do Cálculo, etc. -, o que exige do aluno uma habilidade de ir e vir aos dois pólos - local e global - de significações do tema abordado. Assim, para assimilar a estrutura do resultado matemático, o aluno precisa saber propriamente as condições locais elou globais de suas hipóteses, do seu resultado (tese) propriamente dito e das correlações entre eles. Se tal habilidade não foi trabalhada com o aluno em fases anteriores de sua aprendizagem escolar, as consequiências são, em geral, catastróficas: os resultados do Cálculo são deformados ou enfraquecidos pelos estudantes.

Um exemplo do que acabamos de afirmar é o que ocorre por exemplo com o Teorema da Função Inversa. Existe na literatura didática de Cálculo mais de uma versão desse teorema:

Teorema: Sejam $a, b$ dois números, $a<b$. Seja $f$ uma função derivável no intervalo $a<x<b$ e tal que $f^{\prime}(x)>0$ para todo $x$ nesse intervalo aberto. Então a função inversa $x=g(y)$ existe, e temos

$$
g^{\prime}(y)=\frac{1}{f^{\prime}(x)}=\frac{1}{f^{\prime}(g(y))}
$$

Teorema: Seja $f$ diferenciável em uma vizinhança de $x_{0}, x_{0} \varepsilon$ dom $(f)$. Se $f^{\prime}$ é contínua em $x_{0}$ e $f^{\prime}\left(x_{0}\right) \neq 0$, então:

a) $f$ é inversivel em uma vizinhança de $x_{0}$ :

b) $\left(f^{-1}\right)^{\prime}\left(y_{0}\right)=\frac{1}{f^{\prime}\left(x_{0}\right)}=\frac{1}{f^{\prime}\left(f^{-1}\left(y_{0}\right)\right)}$, em que $y_{0}=f\left(x_{0}\right)$.

Parte substancial da primeira versão também é usada para estudar o crescimento/decrescimento de funções reais. Já a segunda 
versão tem sua composição mais próxima do contexto da Análise do que do próprio Cálculo. No entanto, as duas versões são apresentadas, em geral, aos alunos, sendo a última delas alvo de algumas simplificações dos estudantes. É muito comum, o aluno pensar que, para garantir a existência da função inversa, é suficiente verificar que $f^{\prime}\left(x_{0}\right) \neq 0$, "esquecendo-se" de verificar as demais hipóteses. Tal "esquecimento" pode ser justificado, em geral, pelo fato do aluno não "perceber" a importância das demais hipóteses para a sustentação da tese do resultado. E por que será que tal fato passa despercebido pelo aluno? O problema é que o professor remete usualmente o valor de "importância" das hipóteses para o momento da demonstração do resultado, coisa que para o aluno não tem "importância" - pois, em geral, demonstrações desse gênero não caem na prova - e muito menos significado. Associe-se a isto o fato de que, em muitas demonstrações, a utilização de uma hipótese pode ser feita de forma bastante sutil. Assim, as "simplificações" errôneas aparecem com bastante freqüência.

Ainda nesse contexto, outro ponto que gostaríamos de observar diz respeito ao uso indiscriminado das regras de derivação. Um exercício deste tópico do conteúdo programático de Cálculo e que nenhum dos alunos de uma das turmas da disciplina de Cálculo Diferencial e Integral I do curso de Matemática $\left(2^{\circ}\right.$ semestre de 1998) conseguiu resolver foi proposto com o seguinte enunciado:

Seja f uma função real de variável real definida por $f(x)=\left\{\begin{array}{cc}x^{2} \operatorname{sen}\left(\frac{1}{x}\right), & \text { se } x \neq 0 \\ 0, & \text { se } x=0\end{array}\right.$ Verifique se fé diferenciável e determine a função derivada de $f$. 
O procedimento predominante - quase consensual - dos alunos foi o seguinte:

$$
f^{\prime}(x)=x^{2} \cos \left(\frac{1}{x}\right) \cdot\left(\frac{-1}{x^{2}}\right)+2 x \operatorname{sen}\left(\frac{1}{x}\right)=-\cos \left(\frac{1}{x}\right)+2 x \operatorname{sen}\left(\frac{1}{x}\right)
$$

Os que conseguiam chegar até aí, apresentavam, posteriormente, as seguintes atitudes:

1) paravam aí e davam a expressão encontrada como resposta;

2) ou, testavam o valor zero na expressão encontrada e

a. concluíam que derivada de $f$ não existia no ponto $x=0$

b. concluíam que a derivada de $f$ neste ponto $(x=0)$ era zero, uma vez que "0. $\pm \infty . \pm \infty+0 . \pm \infty=0+0=0 "$

Em qualquer das soluções apresentadas, o aluno ignorou o fato de que não podia usar a regra da cadeia para $x=0$. A solução em termos da definição formal da derivada sequer foi cogitada por algum dos alunos. Muito pelo contrário, alguns alunos, ao tomarem ciência da solução da questão, que também apresentava o valor " 0 " para $f^{\prime}(0)$, procuraram argumentar a favor de sua resposta. O fato da função ter o valor " 0 " no ponto $x=0$ parece não ter nenhuma importância para o aluno: $f(0)$ podia ser 5 , ou -5 , e nada mudaria no seu "processo" de diferenciação propriamente dito. $O$ conceito de derivada é dessa forma identificado com a sua "†écnica" de derivação: primeiro deriva-se a função "globalmente" - isto é, nos pontos em que ela está definida por alguma expressão analítica - depois, verifica-se a existência de restrições. Em nenhum momento, o tratamento local da questão é considerado - note que, para o aluno, a $f^{\prime}$ já foi determinada na primeira parte de sua solução, o que ele faz, em seguida, é tão somente determinar o valor de 
f'. Assim, pode-se dizer que, através da aplicação indiscriminada da "técnica" de derivação, a derivada passa a ter para o aluno uma natureza "global". Esta é a "regra": para saber a derivada, primeiro "deriva-se" a expressão (ou expressões) de $f$, usando as regras de derivações, para depois excluir as restrições de f'. Surge, assim, de forma camuflada, o seguinte dilema do curso normal de Cálculo: a derivada é um conceito local ou global?

Em verdade, o grande dilema não é este. Acreditamos que o aluno compreende a natureza local do conceito de derivada, bem como o de sua extensão "natural" para o domínio global. A dificuldade se encontra na passagem de um para o outro. Esta passagem não é tão "natural" assim, e, neste caso específico, as regras de derivação acabam assumindo de forma equivocada o papel principal na correlação dos níveis local e global do processo de diferenciação.

Assim, pode-se dizer que a significação do conceito de derivada em um curso normal de Cálculo se estabelece em dois caminhos distintos: um inicial, estabelecida no nível teórico pelo professor, que parte da definição local de derivada para estendê-la de forma "natural" para o seu estado global; o outro, influenciado pelas técnicas de derivação, que realiza o caminho inverso. Esta dicotomia entre "o que o aluno diz que é" e "o que ele faz ser" é um campo rico de investigações. Mas fixemos nossa atenção por agora apenas na dicotomia local/global e suas correlações com as dificuldades de aprendizagem no ensino de Cálculo, ou melhor, na correlação estabelecida entre a oposição local/global e a oposição variabilidade/permanência. 
Com efeito, a reação dos estudantes ao estudo do crescimento/decrescimento de funções reais - que representam um desdobramento da dualidade variabilidade/permanência no ensino de Cálculo - suscita alguns resultados interessantes de serem investigados sob o prisma da oposição local/global.

Alguns estudantes, por exemplo, ignoram o fato de que apesar de - estudo do crescimento/decrescimento de funções reais diferenciáveis ser realizado no nível local, ele não é pontual. Não são raros os casos em que o aluno, por exemplo, afirma que a derivada de uma função num ponto $x_{0}$ é zero porque "para $x_{0}$ o valor da função é constante". Segundo tal raciocínio, se $f(1)=3$, então teríamos $f^{\prime}(1)=0$, pois $f(1)$ é constante. O aluno descobre deste modo o óbvio e ululante: que em cada ponto do domínio, a função assume um único valor. É evidente que o aluno já sabia disso, o que ele ainda não percebeu é que para se concluir o estado de permanência (constância) de uma função é necessário que se compare, assim como no caso do crescimento/decrescimento, os valores de $f$ numa vizinhança de $x_{0}$. Não faz sentido dizer que uma função é crescente, ou decrescente, ou mesmo constante num ponto (veja figuras 57a, 57b, 57c e 57d), tal propriedade só se estabelece em termos de intervalos (ou de subconjuntos) do domínio da função.

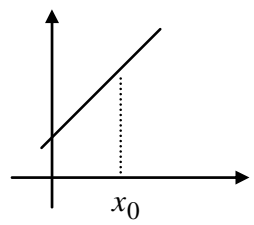

figura $57 a$

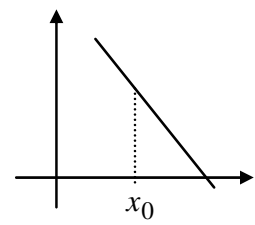

figura $57 b$

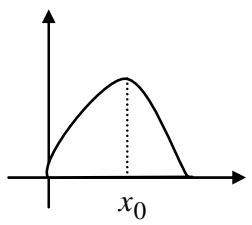

figura $57 c$

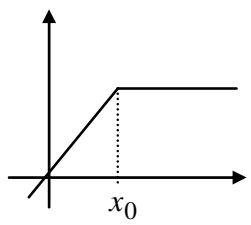

figura $57 d$ 
Isto posto, fica faltando apenas, para finalizar o nosso mapeamento, investigar as dificuldades de aprendizagem no ensino de Cálculo sob a luz da dualidade que apresenta o seu espaço de significações mais próximo do contexto pedagógico: a oposição sistematização/construção.

figura 58 - Mapa do macro-espaço da dualidade local/global
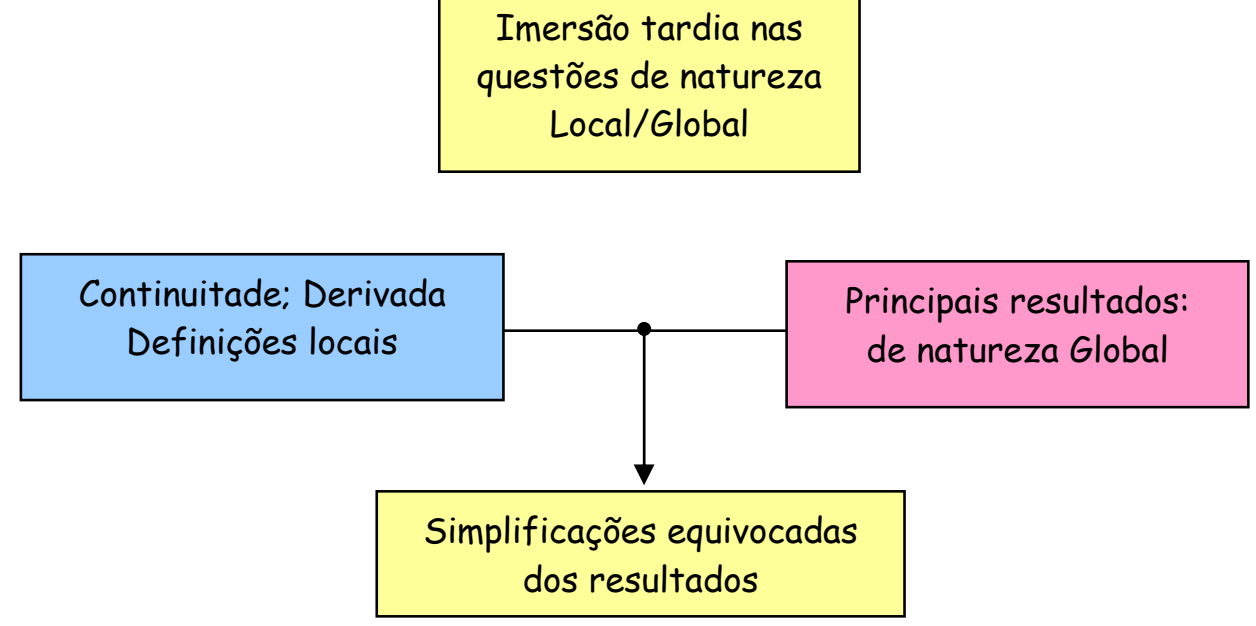

Conceituação de derivada: Local $\rightarrow$ Global 


\subsubsection{O macro-espaço da dualidade sistematização/construção}

\section{$\mathrm{Na}$ escala filosófica}

O termo "sistematização" tem raízes no campo semântico de "sistema", que, por sua vez, está substancialmente relacionado com algumas noções fundamentais do conhecimento matemático. Uma definição geral e concisa de "sistemas" pode ser vista em Mora (2000, v.4, p.2703):

Uma definição muito geral de "sistema" é: "Conjunto de elementos relacionados entre si funcionalmente, de modo que cada elemento do sistema é função de algum outro elemento, não havendo nenhum elemento isolado". O termo "elemento" é tomado num sentido neutro; pode-se entender por ele uma entidade, uma coisa, um processo etc. (caso em que cabe falar de "sistema real") ou pode-se entender por ele algum conceito, termo, enunciado etc. (caso em que cabe falar em "sistema conceitual", "sistema lingüistico" etc.).

Essa distinção feita pelo autor entre sistemas "real" $e$ "conceitual", permite-nos diferenciar as atitudes de natureza epistemológica das principais tendências filosóficas. Segundo Mora (2000, v.4, p.2704), existem três formas de relação entre sistema real e sistema conceitual:

1) o sistema conceitual deriva do real, de modo que o primeiro é um reflexo do segundo, 2) o sistema real é "produto" de uma ordem imposta pelo sistema conceitual, 3) sistema real e sistema conceitual são paralelos (sendo isomórficos se a cada determinado "ponto" de um corresponde um determinado "ponto" do outro). A forma de relação 1) é admitida geralmente por autores de orientação realista em epistemologia. A forma de relação 2) é admitida por autores de tendência kantiana. A forma de relação 3) pode ser ontologicamente neutra, mas também pode ser interpretada como derivada do pressuposto de que se 0 conhecimento é possível, só o é em virtude da correspondência necessária entre sistema real e sistema conceitual. 
No âmbito do conhecimento matemático, a idéia de sistematização está diretamente associada ao surgimento de duas escolas filosóficas muito influentes no seu processo de interpretação e "construção": o formalismo e o logicismo. Em ambas as escolas, a matemática está intimamente relacionada com a lógica formal, tendo esta última um papel fundamental em suas significações e construções. No formalismo, pretende-se alcançar um estado global unitário da matemática, usando-se a lógica formal como o seu principal instrumento de significações. No logicismo, a relação entre a matemática e a lógica é extremada ao nível de subordinação. A matemática, neste contexto, é interpretada como um prolongamento da lógica: todos os seus conceitos e resultados podem ser reduzidos a esta última ciência.

No entanto, com o fracasso das escolas formalista e logicista, que esbarraram nos seus próprios problemas constitutivos, e a "popularização" acadêmica da ação de construir, abre-se espaço para o surgimento de uma tendência oposta - o "construtivismo matemático" defendida por Poincaré e pelos intuicionistas ${ }^{181}$. Segundo Mora:

Num sentido mais amplo, o construtivismo matemático, e metamatemático, é uma tendência que se opõe ao logicismo. Segundo o construtivismo, uma "entidade matemática" existe - ou seja, "é demonstrável" - tão somente na medida em que se pode proporcionar uma regra ou técnica de construção dessa entidade.

(Mora, 2000, v.1, p.564)

Mas o que significa "construtivismo", ou ser "construtivista"?

Em seu dicionário de filosofia, Mora faz a seguinte referência ao termo "construtivismo":

\footnotetext{
181 Outra grande escola filosófica da matemática, que sugere em seu paradigma um outro instrumento de construção do conhecimento matemático: a intuição.
} 
CONSTRUTIVISMO. Este termo, assim como "construcionismo" e "construcionalismo", é empregado para caracterizar tendências filosóficas nas quais a noção de construção - e a noção correlata de "constituição" - desempenha um papel importante.

(Mora, 2000, v.1, p.563)

Tal definição, além de concisa, é bem abrangente $e$, por conta disso, torna-se difícil encontrar nos dias de hoje alguém que não seja "construtivista" no sentido colocado pelo autor. Em verdade, a distinção que se deve fazer hoje não é em "ser" ou "não ser" construtivista, mas sim do "tipo" de construtivismo que se está praticando e defendendo. O próprio Mora ratifica essa posição citando um texto de Javier Lorenzo (La filosofia de la matemática de Poincaré, 1974, p.3, 356-357) em seu dicionário:

"(...) quase todas as formulações realizadas depois do aparecimento das antinomias, praticamente, recorrem, de uma maneira mais ou menos explícita, ao construtivismo; os próprios realistas platônicos que sustentavam taxativamente 0 logicismo primitivo, depois das restrições a seus excessos platônicos produzidas pelas limitações formalistas (...), aceitaram métodos que qualificam de construtivos".

(apud Mora, 2000, v.1, p.564)

Assim, pode-se afirmar que o par sistematização/construção não constitui propriamente uma dualidade no sentido filosófico: não existe sistematização sem construção, nem construção sem sistematização.

No entanto, as interpretações relativas ao processo de "construção" do conhecimento continuam sendo diferenciadas pelo termômetro ideológico do par sistematização/construção. $E$ é precisamente essa diferenciação das atitudes epistemológicas balizadas pelo termômetro ideológico sistematização/construção que constitui o cerne da dualidade que dá sustentação ao nosso quinto 
macro-espaço das dificuldades de aprendizagem de natureza epistemológica do Cálculo.

\section{$\mathrm{Na}$ escala pedagógica}

Apesar de podermos usar o tal termômetro ideológico sistematização/construção em diversas áreas do conhecimento, limitaremos aqui o seu uso ao âmbito do Cálculo e de seu representante pedagógico - a primeira disciplina de Cálculo oferecida em um curso superior. No entanto, as imersões de tal termômetro em áreas de conhecimento e disciplinares correlatas não estão aqui proibidas.

"Sistematização", conforme já foi observado, não é oposição de "construção", muito pelo contrário, é parte constitutiva do processo de construção do conhecimento em geral. No desenvolvimento histórico do Cálculo (capítulo 4 desta tese), por exemplo, pode-se dizer que houve mais de um momento em que tal conhecimento foi sistematizado: uma sistematização inicial foi realizada no século XVII por seus "inventores", Newton e Leibniz, em termos de quantidades infinitesimais; outra, já no século XIX, foi realizada por Cauchy $e$ Weierstrass, em termos de limite; e, mais recentemente, em meados do século XX, por Robinson, novamente, em termos de infinitesimais.

Por via de regra, a realização didática do ensino de Cálculo e os seus livros-texto seguem basicamente o mesmo princípio e padrão de sistematização propostos por Cauchy-Weierstrass (limite continuidade - derivada - diferencial - integral). Em ambos os níveis, por exemplo, os conceitos são definidos formalmente e os resultados são demonstrados passo a passo segundo um modelo axiomático que 
parte da definição formal de limite $e$ de alguns "postulados fundamentais" oriundos da Álgebra Moderna e da Análise Matemática, tais como: o conjunto dos números reais ser um corpo ordenado, propriedades relativas à ordem de $R$, o postulado de continuidade de Dedekind-Cantor, etc.. Cabe ressaltar, entretanto, que outros resultados 182 são acrescidos e assumidos tacitamente como "postulados" durante o processo de execução do modelo.

Exercícios de cálculos e fixação são acrescentados ao final de cada tópico do conteúdo programático para que o treinamento possa ser realizado. Nesta etapa, a influência das técnicas algébricas é facilmente evidenciada: fatorar polinômios, por exemplo, torna-se imprescindivel para que se efetuem os cálculos de limites.

A significação dos conceitos e dos resultados é realizada no âmbito da justificação lógica formal das "definições" dos conceitos básicos e das "demonstrações" dos teoremas. Primeiro define-se 0 conceito, depois, apresentam-se os exemplos, como se estes nada tivessem a ver com a origem histórica do conceito definido. Assim, com essa sistematização exacerbada, surge um dos grandes obstáculos de natureza epistemológica do ensino normal de Cálculo: a "desmaterialização" dos seus resultados e conceitos básicos.

Com efeito, a definição formal de derivada, por exemplo, não terá sentido algum para o aluno, se não for consubstanciada com as redes de significações deste conceito com a geometria e com a física. Não são as idéias de velocidade e coeficiente angular, interpretações do conceito de derivada, mas, ao contrário, são elas, efetivamente, as

\footnotetext{
${ }^{182}$ É o caso, por exemplo, do teorema do valor intermediário, da integrabilidade inata das funções contínuas em intervalos fechados, etc.
} 
idéias geradoras e construtoras do campo semântico da noção de derivada. Do mesmo modo, não é "simplesmente" demonstrando um teorema/proposição - ou o que é pior: apenas assistindo a sua demonstração - que se constrói a sua rede de significações. Muitas vezes a simples interpretação do resultado faz muito mais sentido para - aluno do que a sua demonstração. Vamos a um exemplo do que afirmamos:

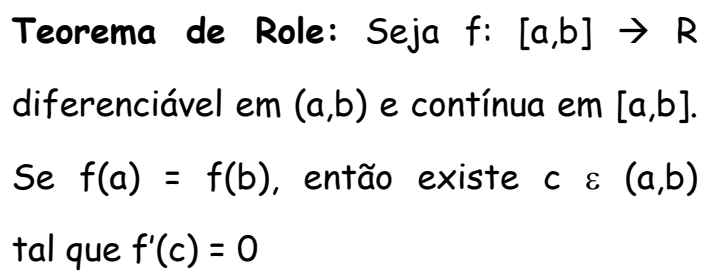

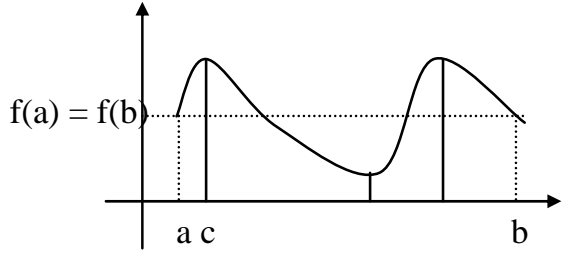

figura 59

Argumento intuitivo: Ora, se $f$ é constante no intervalo [a,b], teríamos uma infinidade de pontos onde $f^{\prime}$ é nulo - o que está de acordo com o resultado do teorema. Por outro lado, se $f$ começa a crescer a partir de " $a$ ", em algum momento os valores de $f$ terão que começar a decrescer para que $f$ possa retornar ao valor $f(a)$ (este é um possível valor para o " $c$ " procurado). O ponto em que ocorre essa "mudança" de comportamento constitui um ponto de máximo relativo para $f$. Como a função é diferenciável em todo o intervalo $(a, b), 0$ gráfico de fé uma curva suave (isto é, não tem "bicos"), e, assim, a derivada da função nesse ponto de retorno deve ser nulo. Por outro lado, se $f$ começa a decrescer a partir de " $a$ ", em algum momento os valores de $f$ terão que aumentar, para que $f$ possa retornar ao valor $f(a)$. O resto do raciocínio é análoao ao do caso anterior.

Assim, para se recuperar o "real" nível de significação dos conceitos e resultados do Cálculo é preciso que se inverta a polaridade da dualidade sistematização/construção; isto é, ao invés de se construir as significações no nível do conhecimento já sistematizado, deveríamos é construir os campos de significações dos resultados e idéias básicas do Cálculo para, num momento posterior, buscar a sistematização desses elementos. 
No entanto, para que se inicie a inversão de tal polaridade é preciso trazer à tona essa discussão fundamental acerca da oposição entre o "conhecimento sistematizado" (o dos livros didáticos e notas de aulas do professor) e o "conhecimento real" ${ }^{183}$ (o que traz consigo a sua história e o seu campo de significações) do Cálculo, sem o receio ou timidez de explicitar o que se pensa e pretende com um curso inicial de Cálculo. Tal questão precisa ser analisada e discutida pelos professores de Cálculo, em caráter emergencial, para que se possa minimizar efetivamente, nesse nível de ensino, os problemas de aprendizagem relativos a essa disciplina. Contudo, para resolver o problema do ensino de Cálculo, no entanto, é preciso muito mais: é preciso fazer o conhecimento do Cálculo emergir do "esconderijo forçado" a que foi submetido pelos atuais ensinos médio e fundamental de matemática. Ao se promover tal emersão, o Cálculo não estará ajudando apenas a si próprio, mas, sobretudo ao próprio ensino de matemática como um todo. Mantendo-se o Cálculo em cativeiro, alguns dos problemas fundamentais da geometria e da aritmética continuarão a ser "mal resolvidos" através de "fórmulas" e "regras" mágicas, e "convenções" unilaterais. Como já afirmamos em outro momento desta tese, não se trata de se antecipar a disciplina de Cálculo para o ensino médio - como, inclusive, já sugeriram alguns autores -, mas, sobretudo, de se iniciar, desde cedo, uma preparação para o Cálculo.

\footnotetext{
${ }^{183}$ Alguns autores construtivistas se referem a esse "tipo" de conhecimento como "conhecimento verdadeiro”. No entanto, a expressão "verdadeiro” também é do domínio da lógica formal - por isso preferimos adotar uma outra forma de denominação.
} 
Com efeito, não se aprende geometria em uma única "disciplina de geometria", nem "álgebra", nem mesmo "aritmética", e muito menos "Cálculo". Em verdade, tendo como referência o processo histórico de construção do conhecimento matemático, poderíamos dizer mais: por exemplo, nem a Geometria euclidiana, nem a Álgebra e a Teoria dos Números se constituíram sem a participação efetiva das idéias básicas do Cálculo.

Por outro lado, é preciso fazer, no âmbito da própria disciplina de Cálculo, algumas correções de natureza epistemológica das articulações entre os seus conceitos básicos, observando, como uma boa referência, o próprio processo histórico de construção. Devemos, no entanto, ter o cuidado de não cair na atitude ingênua de imaginar que "percurso histórico" da construção do conhecimento seja o caminho "mais natural" e/ou "mais simples" de ser realizado pelo sujeito aprendiz.

Tal pensamento - que constitui a essência do princípio genético: "a ontogênese recapitula a filogênese" - suscita uma série de paradoxos e inverdades no terreno da epistemologia. Muitas vezes, na história do conhecimento matemático, a mudança no seu curso foi motivada mais por questões exteriores à própria matemática do que por seus problemas internos. O desenvolvimento da Álgebra no oriente médio, ou da Teoria dos Números na época das grandes guerras mundiais, são exemplos do que acabamos de afirmar. Não se pode ignorar, portanto, os contextos históricos, políticos, sociais, econômicos e culturais no processo de construção do conhecimento científico. 
Por outro lado, as teorias psicológicas de aprendizagem fazem o mesmo tipo de ponderação com relação ao nível ontogenético. Outro elemento diferenciador evidente dos níveis ontogenético e histórico são as condições psicológicas de quem produz o conhecimento. As condições psico-cognitivas e emocionais do cientista, no seu ato íntimo de investigação científica, são muito diferentes daquelas que um aluno do ensino "normal" possui para desenvolver o seu processo e aprendizagem. Por mais que o professor pretenda reproduzir tal circunstância histórica da produção do conhecimento científico em sua sala de aula, sempre esbarrará nesses obstáculos de natureza psicológica.

Além do que foi exposto acima, não podemos perder de vista a temporalidade da ação educativa, que se executa no presente, mas se projeta para o futuro. Como observou D'Ambrósio (1997, p.30), muito das teorias e práticas que foram criadas no passado para resolver os problemas de ontem pouco nos ajudaria para resolver os problemas de hoje. Vejamos um exemplo específico na matemática: o logaritmo.

Com efeito, "tábuas de logaritmos" e "mantissas" já não fazem parte do atual campo semântico do conceito de logaritmo com a mesma intensidade de épocas atrás. Com o desenvolvimento das tecnologias computacionais e da aplicação da expansão polinomial de Taylor nessas tecnologias, novos elementos passam a integrar e dominar a teia semântica desse conceito matemático.

E para encerrar esta seção, gostaríamos de citar um poema de Dschuang Dsi, divulgado por René Thom e reproduzido por D'Ambrósio em seu livro: 


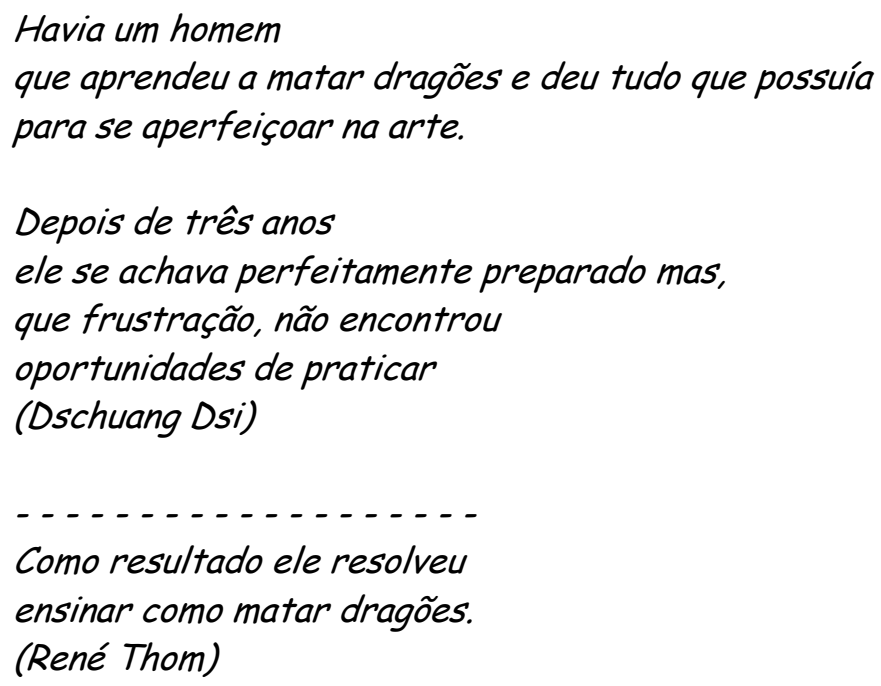

Isto posto, resta-nos parar de formar guerreiros para matar dragões. 


\section{figura 60 - Mapa do macro-espaço da dualidade sistematização/construção}

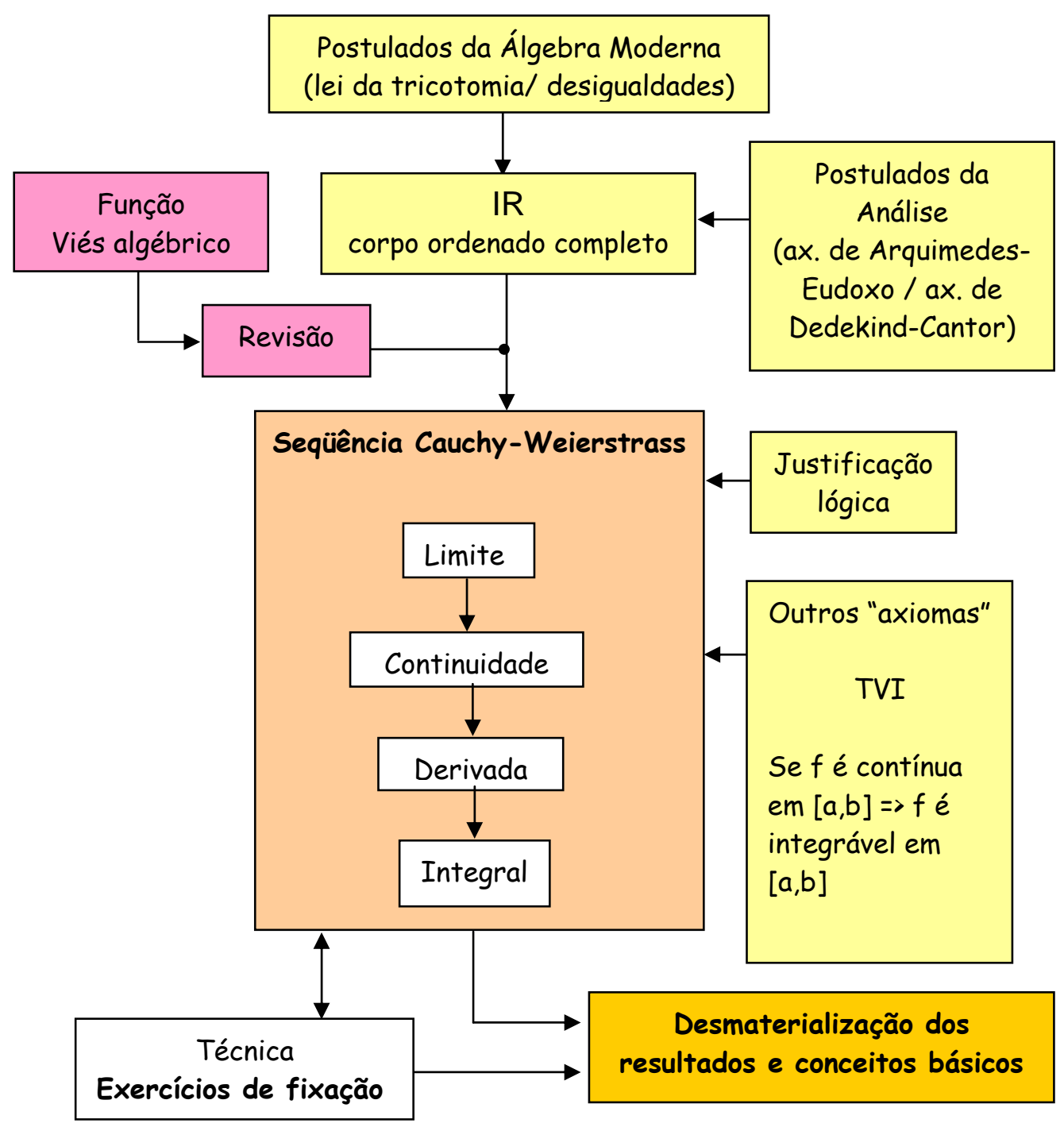




\subsection{Mapa espectral das dificuldades de natureza epistemológica do ensino de Cálculo}

Antes de passarmos às nossas considerações finais convém mudar de escala outra vez para observar que os macro-espaços determinados não são estanques e nem constituem fronteiras bem definidas, ao contrário, eles se entrelaçam e se inter-relacionam plenamente, sem hierarquias de valores ou graus de subordinação. A própria história do Cálculo nos dá uma infinidade de exemplos dessa natureza. Um problema clássico do Cálculo como a quadratura do círculo, por exemplo, está diretamente relacionado à dualidade variabilidade/permanência, mas também tem raízes nas dualidades discreto/contínuo e finito/infinito - a solução desse problema passa necessariamente pelo contexto dessas três dualidades.

Se levarmos em conta ainda que este problema foi resolvido, historicamente, tanto em termos de limite quanto em termos de infinitésimos, e que ao introduzi-lo no processo pedagógico pode-se fazer da forma mais variada possível (pode-se simplesmente "definir" a área do círculo pela fórmula $\pi r^{2}$, como é feito usualmente no ensino básico de matemática), temos que este problema também apresenta implicações na dualidade sistematização/construção. 


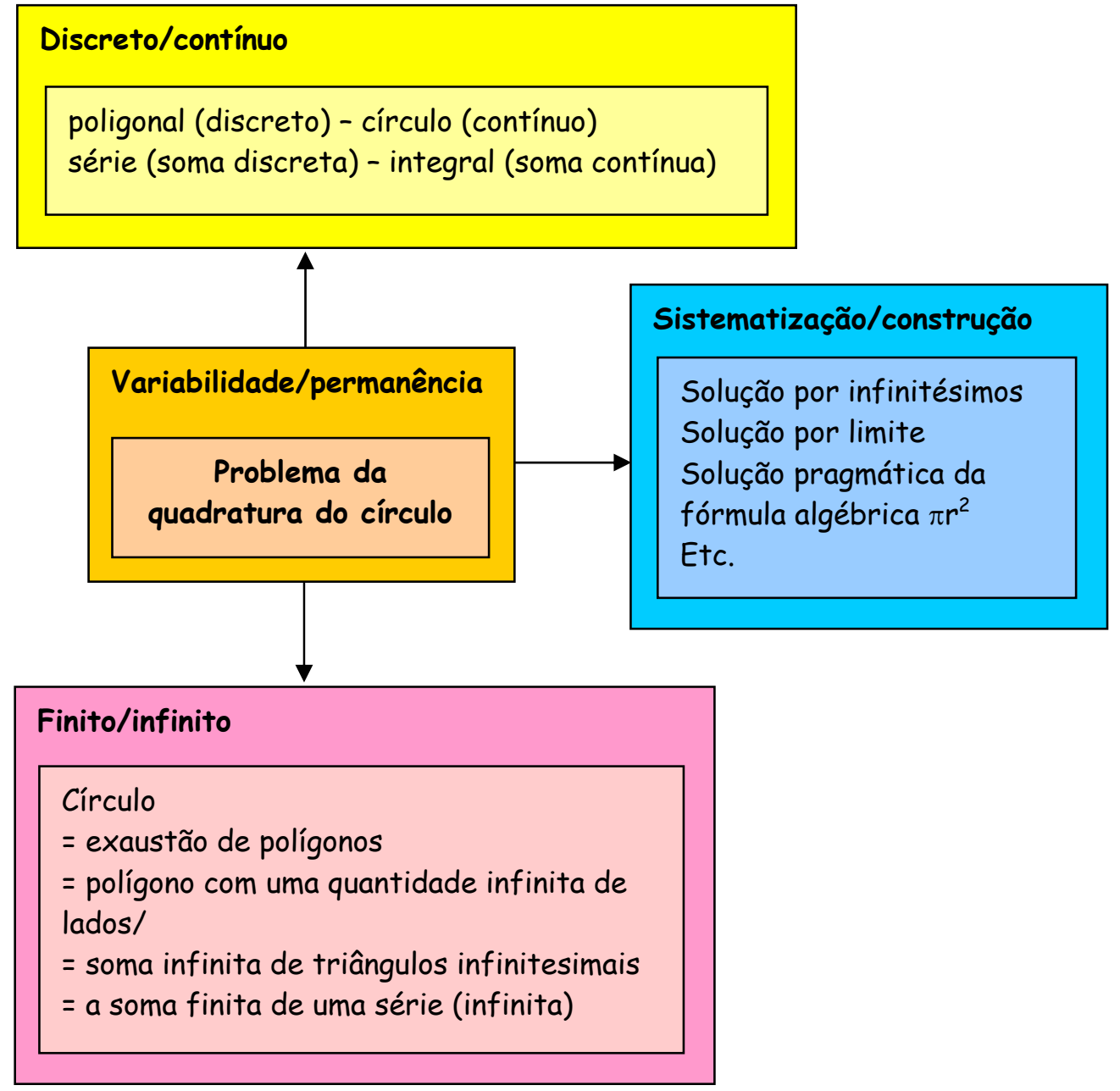

figura -61

Assim, ao se ensinar o problema da quadratura do círculo, as dificuldades de aprendizagem que irão surgir poderão estar relacionadas com algumas dessas dualidades, ou outras, que por ventura não tenham sido avaliadas neste nosso trabalho. Todavia, tendo como referência o mapeamento que realizamos, pode-se afirmar que grande parte das dificuldades de aprendizagem de natureza epistemológica do ensino de Cálculo aqui levantadas se encontra, muitas vezes, nos entremeios de dois ou mais macro-espaços aqui 
identificados. Desse modo, ao diminuirmos ainda mais a escala na nossa ação de mapear, observaremos um espectro formado por um feixe de relações que interligam os diversos elementos que constituem os cinco macro-espaços aqui determinados.

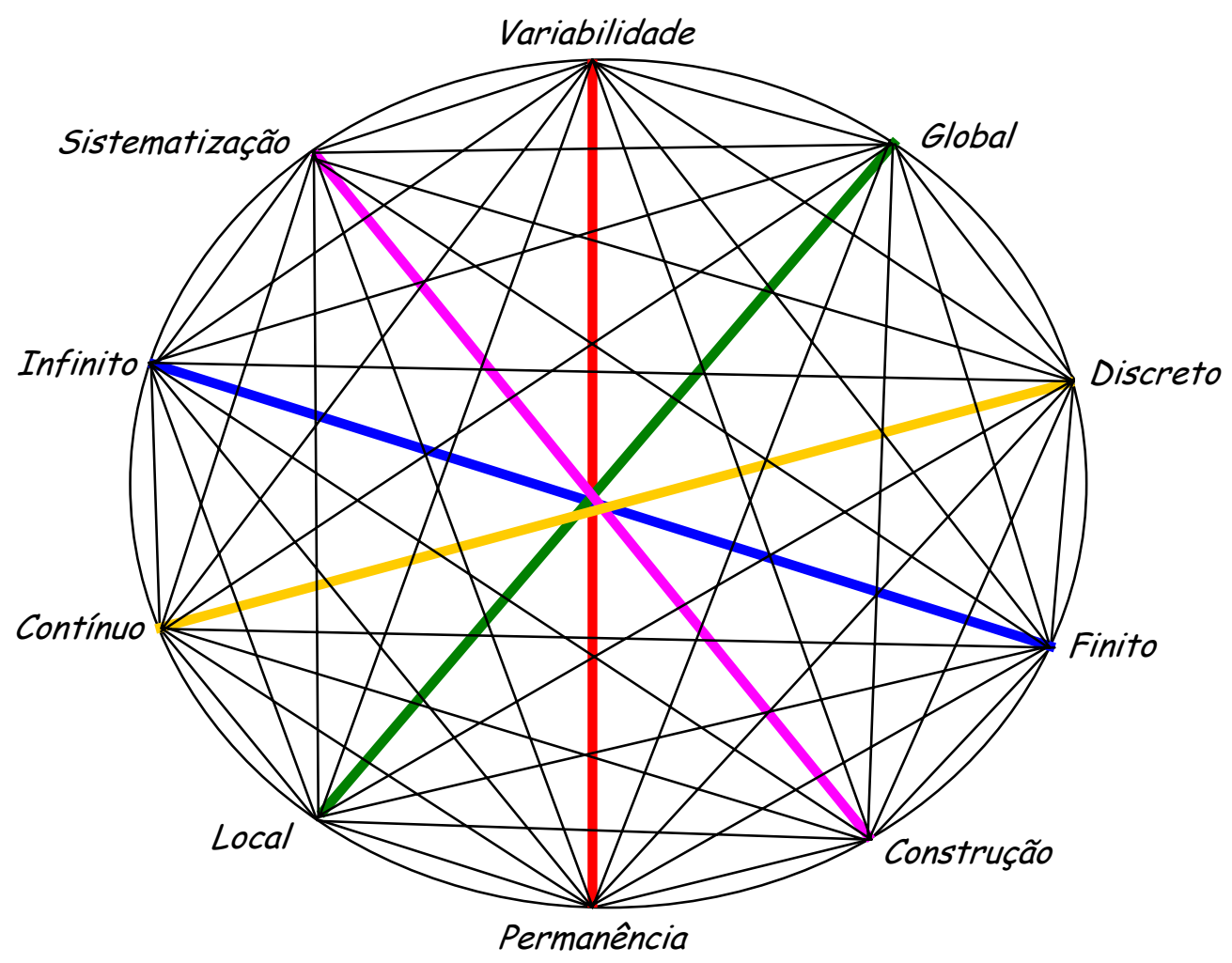

figura 62 - Mapa espectral dos macro-espaços de dificuldades do ensino de Cálculo 


\section{Considerações finais}

O mapeamento das dificuldades de aprendizagem de natureza epistemológica do ensino de Cálculo realizado, em pequena escala, no capítulo 5 desta tese, representa, efetivamente, o cumprimento da principal meta desta pesquisa.

Para a realização desse empreendimento foi necessário um conhecimento a priori das dificuldades de aprendizagem dos estudantes (dados obtidos pela revisão bibliográfica realizada pelo autor e pela sua própria experiência didática como professor da referida disciplina) e outro relacionado à compreensão dos obstáculos epistemológicos e da evolução histórica das idéias básicas e procedimentos do próprio Cálculo (capítulo 4 desta tese). Assim, a partir do entrelaçamento dos fatos históricos e pedagógicos, e tendo como pano de fundo as dualidades essenciais e os mapas conceituais ${ }^{184}$ do Cálculo, foram consolidados e consubstanciados os macro-espaços de dificuldades de aprendizagem de natureza epistemológica do ensino de Cálculo.

Esses macro-espaços foram identificados pelas cinco dualidades fundamentais do Cálculo e do seu ensino:

- discreto/contínuo; variabilidade/permanência; finito/infinito; local/global; sistematização/construção.

\footnotetext{
${ }^{184}$ Cabe ressaltar que a construção dos mapas históricos conceituais do Cálculo (seção 4.3 desta tese), bem como a produção de todo o texto da revisão histórica do Cálculo, foi de importância fundamental para a compreensão das dificuldades de aprendizagem dos estudantes, além de representar, de certo modo, uma antecipação do esforço filosófico realizado na determinação dos macro-espaços de dificuldades de aprendizagem supracitados.
} 
Ao mapearmos as dificuldades de aprendizagem dos estudantes, foram estabelecidas relações entre os macro-espaços determinados e os mapas históricos e conceituais do Cálculo, e destes com o ensino de Matemática em sentido amplo. Os resultados obtidos com o mapeamento aqui realizado encontram-se sintetizados no capítulo anterior; cabe-nos agora, portanto, analisar mais diretamente as implicações destes no processo pedagógico.

A partir do mapeamento realizado foi observado, em essência, um único lugar-matriz das dificuldades de aprendizagem de natureza epistemológica do ensino de Cálculo: o da omissão/evitação das idéias básicas e dos problemas construtores do Cálculo no ensino de Matemática em sentido amplo.

De fato, a ausência das idéias e problemas essenciais do Cálculo no ensino básico de matemática, além de ser um contra-senso do ponto de vista da evolução histórica do conhecimento matemático, é, sem dúvida, a principal fonte dos obstáculos epistemológicos que surgem no ensino superior de Cálculo. Assim, fazer emergir o conhecimento do Cálculo do "esconderijo forçado" a que este está submetido no ensino básico é, sem dúvida, o primeiro grande passo para resolvermos efetivamente os problemas de aprendizagem no ensino superior de Cálculo.

Ora, mas no próprio ensino superior de Cálculo também sentimos falta de certas idéias e problemas construtores do Cálculo. As significações e interpretações das noções de derivada e de integral definida - e de seus resultados - no contexto da mecânica são um exemplo dessa ausência. Em verdade, este esvaziamento semântico da 
disciplina de Cálculo é, ao mesmo tempo, causa e efeito da crise de identidade pela qual passa o ensino superior de Cálculo.

Isto posto, percebe-se que o lugar-matriz das dificuldades de aprendizagem do ensino de Cálculo está presente em ambos os níveis de ensino. Assim, procuraremos fazer a caracterização do lugarmatriz em dois tempos: primeiro, abordaremos os aspectos do lugarmatriz no âmbito do ensino básico de matemática; por último, cuidaremos dos aspectos do lugar-matriz relacionados a tal crise de identidade do ensino superior de Cálculo.

Passemos então à caracterização desse lugar-matriz.

\section{- O lugar-matriz no ensino básico de matemática}

Antes de tudo cabe destacar que a maior parte do território do lugar-matriz das dificuldades de aprendizagem do ensino superior de Cálculo encontra-se no ensino básico. A evitação/ausência das idéias e problemas construtores do Cálculo no ensino básico de matemática constitui, efetivamente, o maior obstáculo de natureza epistemológica do ensino de Cálculo, e porque não dizer do próprio ensino de matemática. É incompreensivel que o Cálculo, conhecimento tão importante para a construção e evolução do próprio conhecimento matemático, não participe do ensino de matemática. O Cálculo é, metaforicamente falando, a espinha dorsal do conhecimento matemático. 
No corpo desta tese já foram enunciadas outras razões que justificam uma participação mais efetiva do Cálculo no ensino básico de matemática. Algumas de caráter social como, por exemplo, a imprescindibilidade de algumas de suas idéias para o exercício pleno da cidadania numa sociedade cada vez mais complexa. No entanto, o contexto que está sendo proposto aqui para a análise do lugar-matriz das dificuldades de aprendizagem do ensino de Cálculo se situa no terreno da epistemologia. Isto é, procuraremos justificar a emersão das idéias do Cálculo estritamente do ponto de vista epistemológico, tendo em vista as dificuldades que foram mapeadas.

É muito usual afirmar-se no meio acadêmico que o ensino básico de matemática é (ou pelo menos deveria ser) processado em três vias: a via da aritmética, a via da geometria e a via da álgebra. Uma pergunta que surge naturalmente dessa questão é "cadê a via do Cálculo?". No entanto, pode-se dizer que o que se quer aqui está muito além de simplesmente construir a quarta via: a via do Cálculo. O que se quer, isto sim, é possibilitar ao Cálculo exercer no ensino básico de matemática o mesmo papel epistemológico que ele realizou no processo de construção do conhecimento matemático no âmbito científico. Só que para que isto ocorra será também necessária uma articulação do ensino de matemática com outras áreas do conhecimento como, por exemplo, a física, mais precisamente, a mecânica. Desse modo, as três vias - a da aritmética (número), a da geometria (medida) e a da álgebra (variável) - juntas com a via da mecânica (movimento), devem ser articuladas e tecidas a partir das idéias e problemas construtores do Cálculo em benefício, não só de uma preparação de natureza epistemológica para um futuro ensino superior de Cálculo, mas, 
sobretudo, para a consolidação e construção das significações propostas no ensino básico tanto de matemática quanto de física.

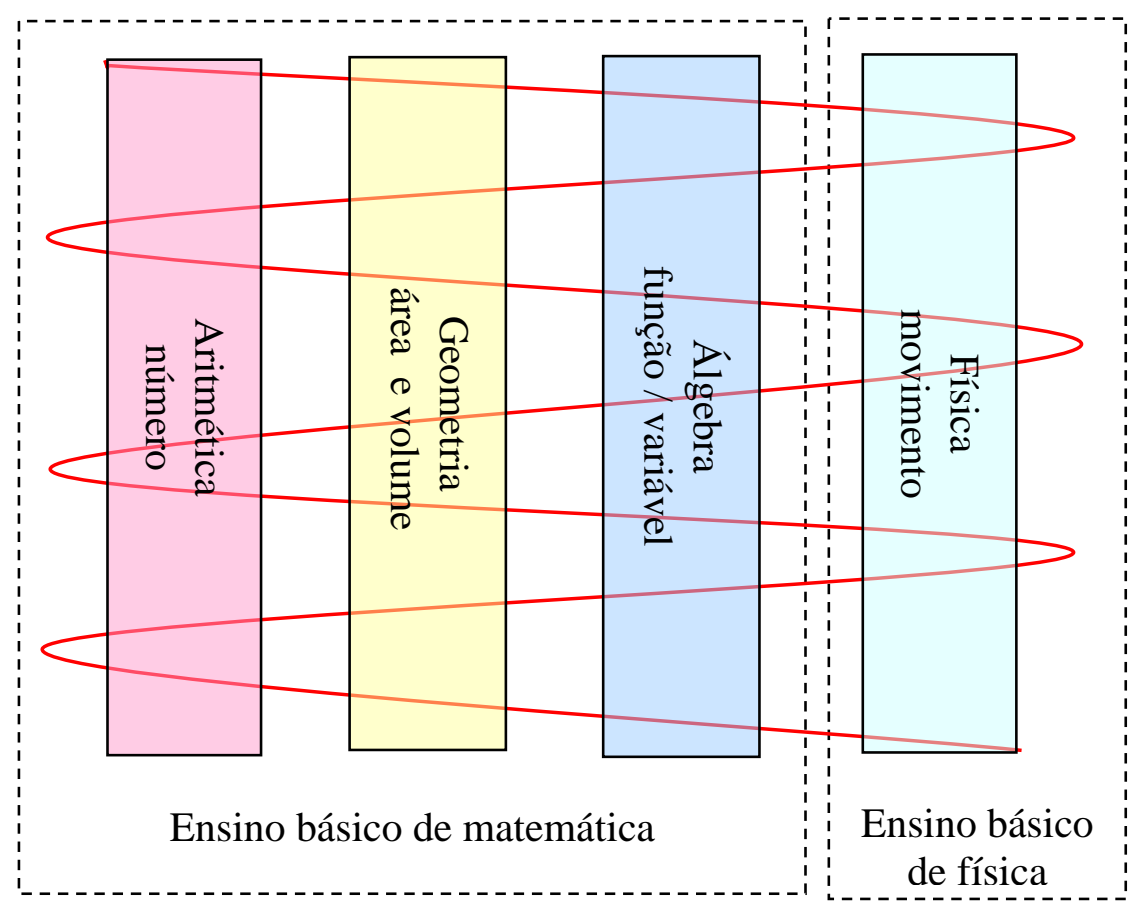

figura 63

Por outro lado, é notório que estão presentes alguns resultados do Cálculo no ensino básico de matemática: cálculo de áreas de círculos $e$ de volumes de sólidos de revolução, soma de uma progressão geométrica infinita, representação decimal dos números reais etc. $O$ que não está presente é o Cálculo. As idéias e as soluções dos problemas do Cálculo estão, como já afirmamos, submersas, escondidas, e os seus resultados são na maioria das vezes ensinados de forma camuflada: a área do círculo e a soma de uma progressão geométrica infinita tornam-se simplesmente fórmulas algébricas, a transformação das dízimas periódicas em frações é realizada por uma regra da aritmética etc. 
Assim, para essa emersão e preparação do Cálculo no ensino básico, duas linhas diretrizes se constituem naturalmente: o problema da variabilidade e o problema da medida - que são, efetivamente, as questões fundamentais do Cálculo. Há de se ressaltar, entretanto, que no problema da medida existem propriamente dois problemas distintos $e$ intrinsecamente relacionados: o processo geométrico da medida (procedimento de cálculo de áreas e volumes) e o processo aritmético da medida (o valor numérico da medida, o número real). Antes de analisarmos o conteúdo próprio de cada uma dessas linhas de inserção do Cálculo no ensino básico, convém observar que a apresentação das idéias do Cálculo deverá ser feita gradualmente e em forma helicoidal 185, quer dizer, a aprendizagem de uma idéia não se esgota em um único momento do ensino: precisará ser retomada em outros contextos e articulada com outras idéias, de modo a prosseguir no seu caminho de significações.

\section{O problema da variabilidade.}

A idéia de variação é tão básica e natural que pode (e deve) ser trabalhada na escola desde as séries iniciais. A variação da altura do pé-de-feijão plantado num chumaço de algodão (uma das primeiras experiências escolares) é percebida em geral por toda criança, assim como a variação das medidas do seu próprio corpo que "cresce" com o avançar do tempo. No entanto, para passar da percepção sensível da variação para uma compreensão mais sistêmica do processo de

\footnotetext{
${ }^{185}$ Alguns educadores matemáticos usam a expressão “espiral” - preferimos, no entanto, a imagem da hélice, em razão dos diferentes níveis de abordagem.
} 
variação, um conceito fundamental da matemática torna-se imprescindível: o conceito de função.

Do ponto de vista histórico, o conceito de função entrou no âmbito do conhecimento matemático por dois notáveis caminhos: o da filosofia natural (dos escolásticos) e o algébrico, da geometria analítica (de Descartes). Neste último caminho, o conceito se estabelece a partir da relação implícita entre as variáveis da equação que determina a curva. Trata-se, portanto, de uma noção estática motivada única e exclusivamente pela descrição algébrica (equação) da curva. Neste caso, a equação da curva ou mesmo a expressão analítica que define a função são dadas a priori. Já no primeiro caminho, a relação funcional era explicitada diretamente pela curva (gráfico) que era usada especificamente para indicar como uma determinada grandeza y variava em relação à outra - $x$. Nesta representação dinâmica do conceito de função, o que motiva a construção da curva é justamente o fato de ela descrever a variação de uma grandeza em relação a outra ${ }^{186}$. A expressão analítica que define a função é, neste caso, conseqüência do modo como se dá a variação entre as quantidades variáveis. $O$ modo como as grandezas variam é que é o ponto de partida para se construir o conceito de função.

Ambas as representações fizeram parte da construção do Cálculo, mas não há como negar a importância fundamental que teve a representação dinâmica do conceito de função na significação do conceito de derivada como taxa de variação instantânea. No entanto, no ensino básico de matemática, dá-se pouca ênfase a este processo

\footnotetext{
${ }^{186}$ É exatamente esta a idéia de função que está por de trás do fenômeno de crescimento do pé-defeijão.
} 
dinâmico da construção do conceito de função. A idéia de função é estabelecida, em geral, não no contexto da "variabilidade", mas em termos de uma correspondência estática entre os valores das variáveis " $x$ " e " $y$ ". A expressão analítica, que representa a regra de correspondência, é dada desde o início do processo de construção. $O$ gráfico da função é "plotado" então com o auxílio de uma tabela de valores "notáveis", e o traçado da curva que representa o gráfico da função é realizado por um processo indutivo. Em seguida, é estudada uma série de propriedades algébricas da função (imagem, raízes, injetividade, periodicidade, variação do sinal etc.), subordinando o seu significado ao exercício e desenvolvimento de técnicas algébricas: resolução de equações $e$ inequações algébricas, exponenciais $e$ trigonométricas - como se essa fosse a principal razão para se estudar funções.

Este monopólio da representação algébrica do conceito de função é claramente um sintoma de evitação das idéias básicas do Cálculo e constitui-se, conforme observamos no mapeamento que realizamos no capítulo anterior, na principal fonte de obstáculos de natureza epistemológica para a resolução de problemas de taxas relacionadas e de otimização: "o difícil é encontrar a função!". Só que para encontrar a função - no caso específico dos problemas de taxas relacionadas - é necessário primeiro saber interpretar o problema: identificar as variáveis que fazem parte do cenário do problema, como elas variam entre si, quais as taxas de variação são conhecidas e qual é a taxa de variação que está sendo pedida. 
Assim, para que se possa romper com essa caracterização algébrica do conceito de função e devolver este conceito ao Cálculo, será preciso construir suas significações a partir do problema fundamental da variabilidade. Isto é, caracterizar as funções reais usualmente estudadas no ensino básico a partir do estudo de suas variações. Desse modo, $a$ função afim $y=a x+b$, por exemplo, é aquela cuja variação de uma variável é proporcional 'a variação da outra: $\Delta y=a \Delta x$ (figura 64), ou de outro modo: que a taxa de variação $\frac{\Delta y}{\Delta x}=a$ é constante. Já a função quadrática $y=a x^{2}+b x+c$ pode ser caracterizada como a função cuja taxa de variação da taxa de variação da quantidade y em relação a x é constante, ou de outro modo:

$$
\frac{\Delta y}{\Delta x}=(2 a x+b)+a \Delta x \cong 2 a x+b=T \Rightarrow \frac{\Delta T}{\Delta x}=2 a
$$

- o que equivale dizer que a variação da inclinação da reta tangente ao gráfico é constante (figura 65).

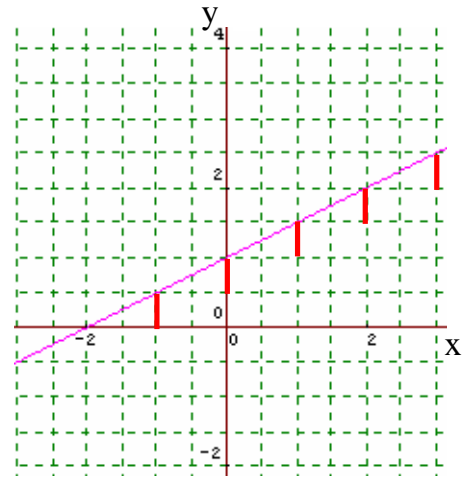

figura 64

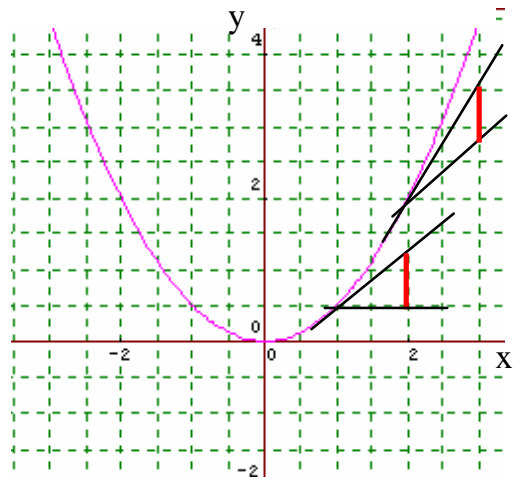

figura 65

No entanto, para que haja a consolidação efetiva dessas idéias é necessário que estas propriedades das funções afins e quadráticas sejam estabelecidas a partir de situações-problema, seja do cotidiano 
ou mesmo de outras áreas do conhecimento. Cabe lembrar, recordando a própria história do Cálculo (e o que foi dito em alguns parágrafos anteriores), que a física oferece condições apropriadas para emersão das idéias do Cálculo - aliás, foi assim, através do entrelaçamento das idéias físicas, do infinitésimo e da geometria analítica, que Newton construiu o seu Cálculo. $E$, dentre as idéias físicas, o conceito de velocidade instantânea representa um nó vital para a construção das significações do conceito de derivada como taxa de variação instantânea. Aproveitando o próprio cenário cinemático dos movimentos uniforme e uniformemente variado, o conceito de velocidade podia ser introduzido a partir da noção intuitiva de limite (como fez D'Alembert), interpretando-a geometricamente como o coeficiente angular da reta tangente ao gráfico da função $s=s(t)$ que descreve a posição do objeto (figura 66).

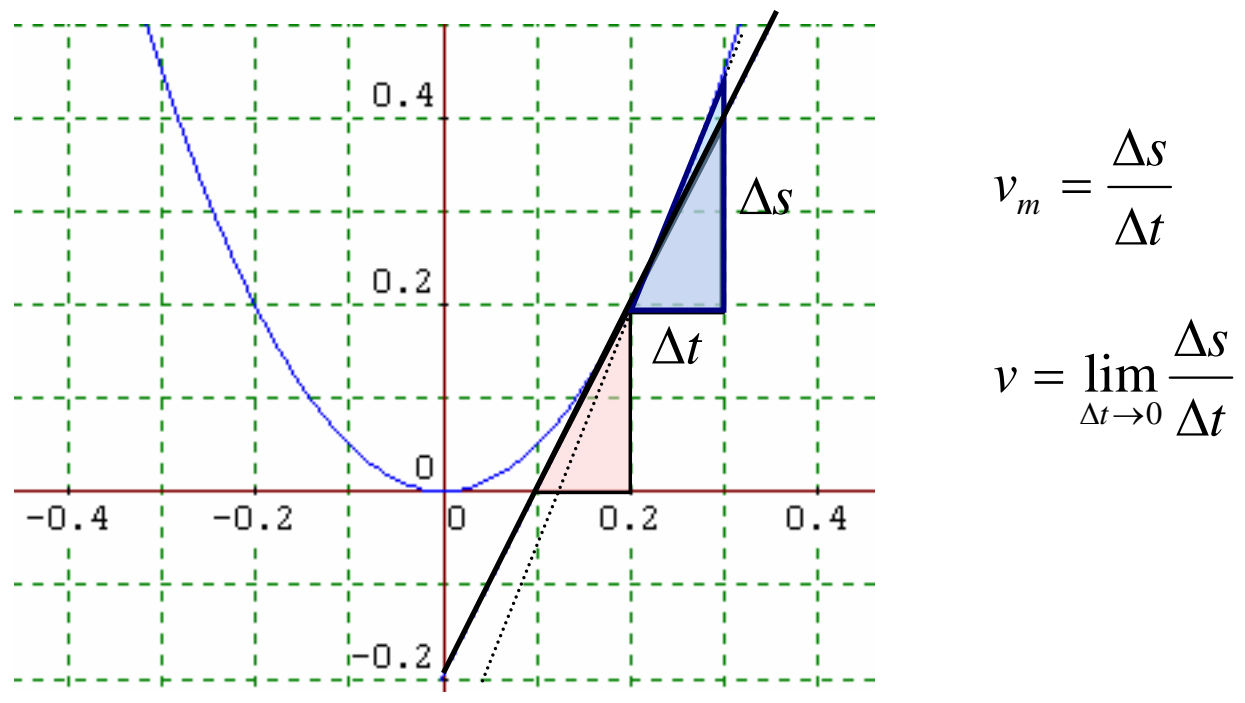

figura 66

Vivenciar outras situações concretas desta natureza seria necessário para que se pudesse consolidar o significado de derivada 
como taxa de variação instantânea. Feito isto, seria interessante retomar o estudo das funções afins e quadráticas para tecer novas urdiduras, determinando as suas funções derivadas, e restabelecendo suas caracterizações a partir do conceito de derivada:

$$
y=a x+b \Rightarrow \frac{d y}{d x}=a, \text { e } y=a x^{2}+b x+c \Rightarrow \frac{d y}{d x}=2 a x+b \Rightarrow \frac{d^{2} y}{d x^{2}}=2 a .
$$

Isto posto, novas imersões na física seriam interessantes para realizar, com detalhes, o estudo das equações horárias dos movimentos uniforme e uniformemente variável. A apresentação de como Galileu chegou à equação horária de um corpo em queda livre, $s=g t^{2} / 2$, seria por demais interessante para o aluno. A apresentação dos gráficos sxt, $v \times t$ e axt ${ }^{187}$, nesse caso, ajudariam a consolidar as relações entre essas grandezas a partir da noção de função derivada: $v(t)=\frac{d s}{d t}$ e $a(t)=\frac{d v}{d t}$.

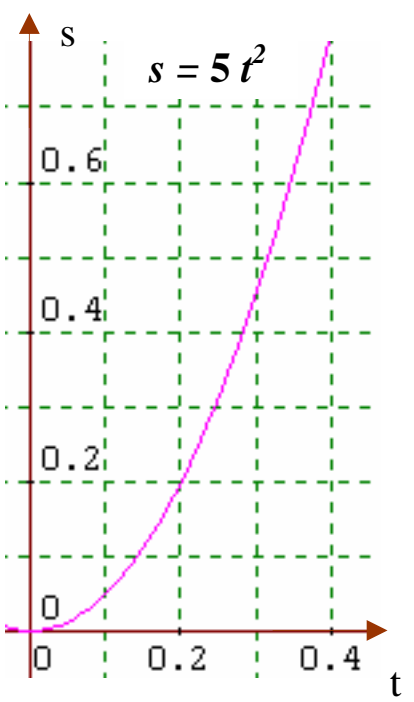

figura 67

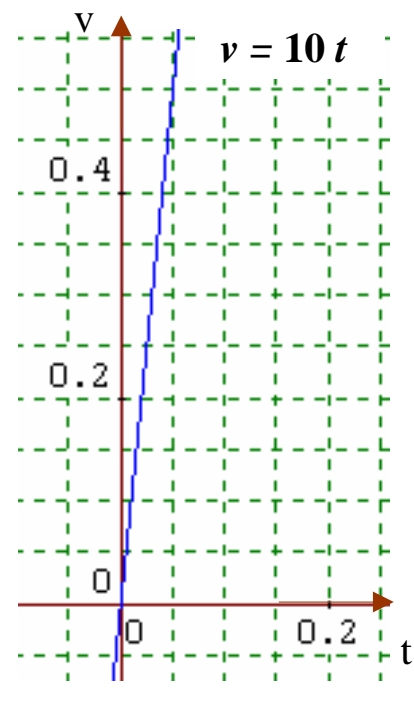

figura 68

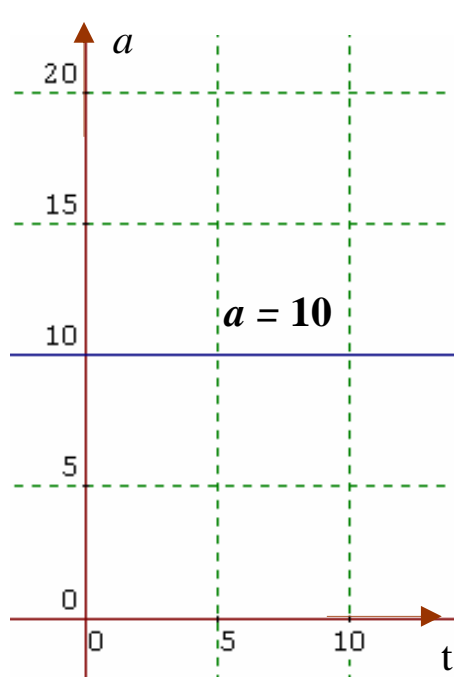

figura 69

Assim, tendo como ponto de partida o cenário físico ora apresentado, poder-se-iam estudar em seguida - e de modo mais 
genérico - algumas relações gráficas entre a função quadrática $s=s(t)$ que descreve o movimento uniformemente variável de um corpo $e$ as suas funções derivadas: $v=v(t)$ e $a=a(t)$.
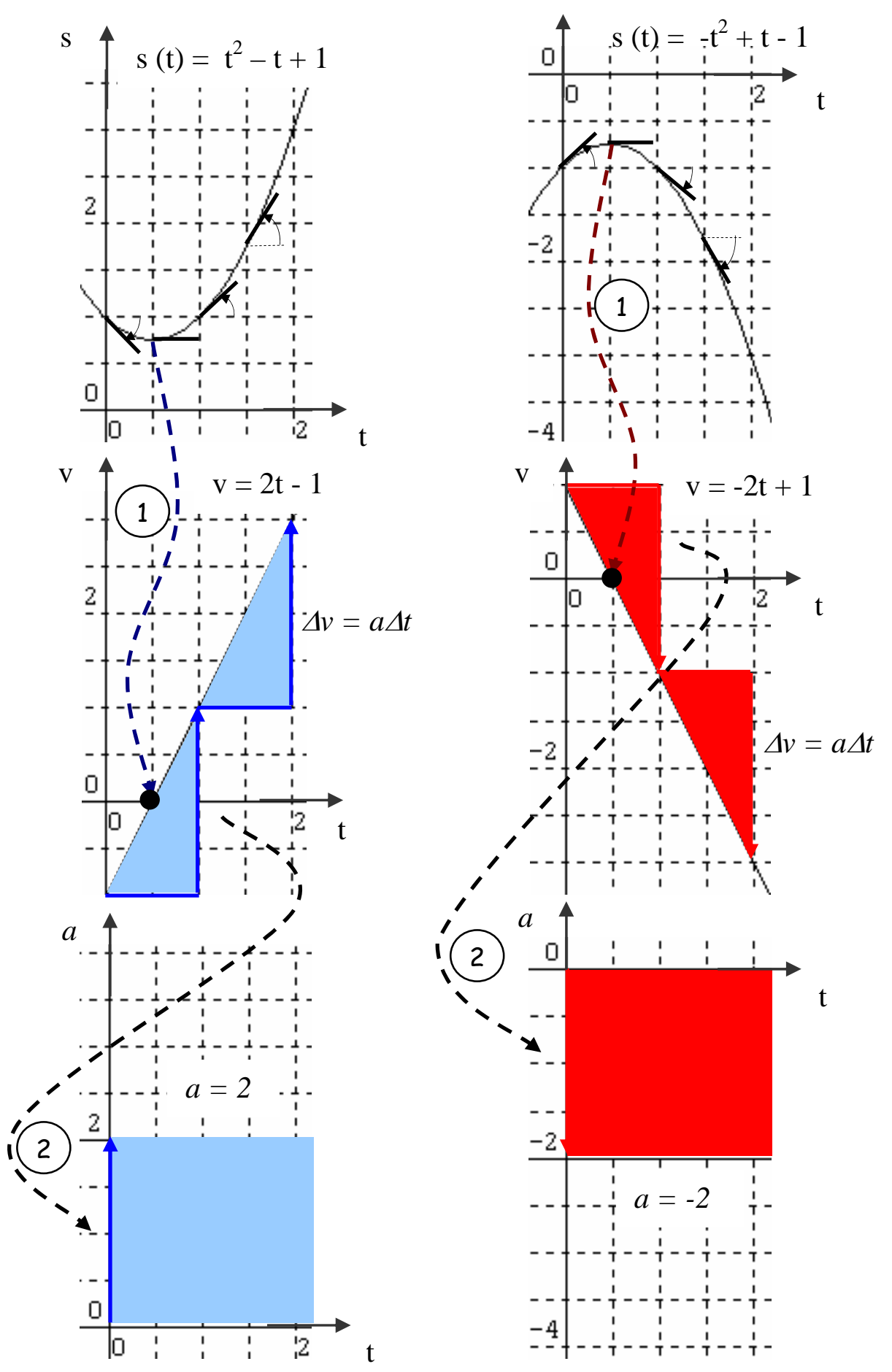

figura -70

\footnotetext{
${ }^{187}$ Nas figuras 67, 68 e 69 são apresentados os respectivos gráficos considerando a=g=10m/s .
} 
$\mathrm{Na}$ construção e análise dos gráficos esboçados na figura anterior podem ser explorados os seguintes pontos:

- o estudo da variação da função derivada de $s=s(t)$ a partir da interpretação geométrica e pontual de derivada $-v=\frac{d s}{d t}-$ como coeficiente angular da reta tangente ao gráfico da função $s=s(t)$ - observe o fluxo indicado pelas setas de número 1 na figura anterior.

- a partir do estudo da variação da função afim $v=v(t)$ podese observar que a aceleração $a=a(t)$, que neste caso é constante, fica determinada pela variação $\Delta v$ de $v$ quando fazemos $\Delta t=1$ no gráfico vxt; de fato, $a=\Delta v / \Delta t=\Delta v / 1=\Delta v-$ observe o fluxo indicado pelas setas de número 2 na figura anterior.

Feito isto, as regras da soma e produto de derivadas poderiam ser apresentadas, a partir da abordagem diferencial de Leibniz, tendo como objetivo primeiro o cálculo das derivadas de qualquer função polinomial. As outras regras de derivação poderiam ser apresentadas à medida que novas funções reais - e com elas, uma nova gama de problemas - fossem sendo apresentadas. O objetivo aqui não é o treinamento nas regras de derivação, mas sim, o de dar significado ao estudo efetivo das funções reais do ponto de vista de sua variabilidade.

Nesse sentido, a apresentação das funções exponenciais $e$ logarítmicas logo em seguida ao estudo das funções polinomiais seria um caminho bem interessante do ponto de vista da construção de novos 
feixes de relações com outros tópicos do ensino de matemática, da física e de outras áreas do conhecimento, e do próprio Cálculo. Uma articulação natural, por exemplo, seria com o estudo das progressões geométricas. Problemas de juros, de crescimento de população, de tempo de meia vida, pH etc., forneceriam ótimos contextos para a construção das funções exponenciais e logarítmicas a partir do problema da variabilidade. No cálculo de suas derivadas apareceria um outro elemento interessante: a construção do número irracional $e$ (o número de Euler). Um saída razoável do ponto de vista semântico para a construção do significado deste número seria defini-lo como o próprio limite da sequiência $\left(1+\frac{1}{n}\right)^{n}$, quando $n \rightarrow \infty$. Construir uma tabela de valores da seqüência nesse caso ajudaria o aluno a perceber - comportamento da representação decimal do número. Sua irracionalidade e transcendência é conversa para um outro momento.

Uma outra articulação interessante seria com a equação diferencial $\frac{d y}{d x}=k y$. Poder-se-ia mostrar que a função exponencial $y(x)=e^{k x}$ é a única função real que satisfaz a equação diferencial destacada e interpretar, a partir deste resultado, uma propriedade fundamental desta modalidade de função, isto é: a rapidez com que uma função exponencial $y(x)$ cresce/decresce é proporcional ao próprio valor da função $y(x)$ em cada ponto. Tal propriedade, além de caracterizar a própria função exponencial, justifica o fato desse tipo de função ser adequado à descrição de fenômenos nas mais diversas áreas do conhecimento científico, como os relacionados com o crescimento de populações, a radiotividade, juros compostos e etc. 
Assim, a resolução em seguida de alguns desses problemas seria de fundamental importância para a consolidação da rede de significações da função exponencial.

Isto posto, as derivadas das funções trigonométricas poderiam ser calculadas, mas sem que se fizesse em torno dessas os costumeiros exageros de cálculos. Acreditamos que os cálculos de suas derivadas seriam muito mais úteis na resolução de determinados problemas de taxas de variação que envolvessem alguma relação direta com a sua expressão.

Em resumo: pode-se dizer que a principal proposta elaborada aqui no âmbito do problema da variabilidade é desenvolver, desde cedo, e gradativamente, o estudo de funções reais a partir de situaçõesproblema do cotidiano ou de outras áreas do conhecimento (com destaque para o entrelaçamento possivel e fundamental com o ensino de física) a partir do problema fundamental da variabilidade. Construir o campo semântico do conceito de derivada (velocidade; taxa de variação instantânea; reta tangente; coeficiente angular da reta tangente; propriedades operatórias etc.) deve ser outra meta fundamental.

\section{O problema geométrico da medida}

O cálculo de áreas de regiões planas limitadas por curvas não retilíneas e de volumes de sólidos "arredondados" é, com efeito, um problema de natureza geométrica, mas cuja solução passa pelo domínio do Cálculo. Arquimedes e Euclides desenvolveram e resolveram alguns desses problemas. O cálculo da área do círculo, por exemplo, foi um desses maravilhosos problemas - e também um dos mais difíceis. As 
soluções apresentadas pelos geômetras, no entanto, são parciais e remetem a outros problemas do âmbito do Cálculo: Euclides mostra, de certo modo, que a área do círculo é proporcional ao quadrado do seu diâmetro - mas não determina a constante de proporcionalidade; a solução de Arquimedes estabelece a área do círculo em termos do seu comprimento - que, no caso, também foi determinado de modo parcial pelo próprio matemático ${ }^{188}$. O que fica escondido em ambas as soluções - e daí o seu caráter parcial - é o número irracional $\pi$. Isto justifica a complexidade do problema da quadratura do círculo: a sua medida envolve a construção de um número irracional transcendente.

Diante da dificuldade de medir a área do círculo, temos que a solução desse problema será sempre incompleta enquanto o número $\pi$ não for efetivamente apresentado ao estudante. Acreditamos, no entanto, que a solução do problema da área e do comprimento do círculo pode, e deve, ser apresentada num primeiro momento de modo parcial no ensino fundamental de matemática. Dois procedimentos didáticos bem razoáveis para a apresentação de uma solução parcial de cada um desses problemas nesse nível de ensino são como segue:

\footnotetext{
188 Para determinar o comprimento do círculo, Arquimedes considerou duas seqüências de polígonos inscritos e circunscritos. Determinou em seguida os perímetros dos polígonos construídos por meio de uma fórmula de recorrência que relacionava as seqüências dos perímetros dos polígonos inscritos e circunscritos. Desse modo, o matemático conseguiu determinar o perímetro do círculo de forma aproximada: usando n=96 (em que n é o número de lados dos polígonos inscrito e circunscrito), o comprimento $\mathrm{L}$ do círculo foi estimado entre: $3 \frac{10}{70} d<L<3 \frac{10}{71} d$ (onde d é o diâmetro do círculo), o que sugere um valor aproximado para $\pi$ de 3,14 - (Dörrie, 1965).
} 
- para o cálculo do comprimento do círculo

Verificar empiricamente que o comprimento $C$ do círculo é diretamente proporcional ao seu diâmetro $D$ através das medidas dessas grandezas geométricas de uma grande quantidade de círculos. Cada aluno da turma poderia realizar, por exemplo, três medidas distintas e registrar os valores que encontrou em uma tabela de valores CXD. O valor aproximado da constante de proporcionalidade seria então o valor médio de todas as constantes encontradas. O importante é fazer com que o aluno perceba que quanto maior for o número de círculos medidos, melhor será a aproximação da constante de proporcionalidade. Deve-se enfatizar, entretanto, que tal constante é um número irracional e que o que obtemos foi tão somente um valor aproximado dessa constante.

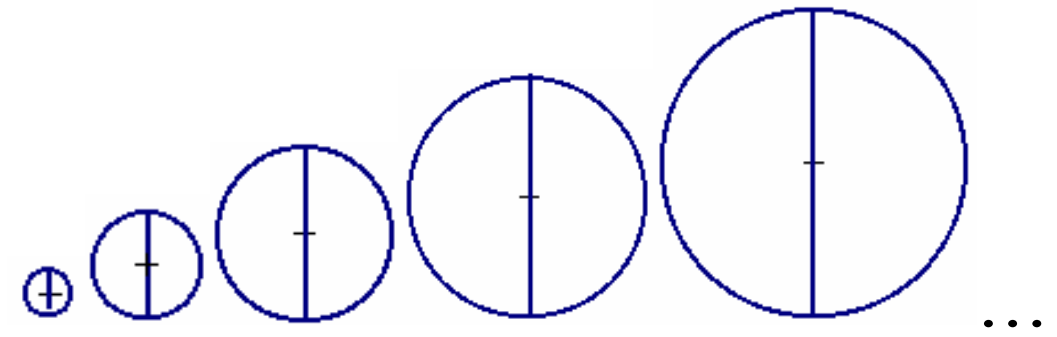

figura 71

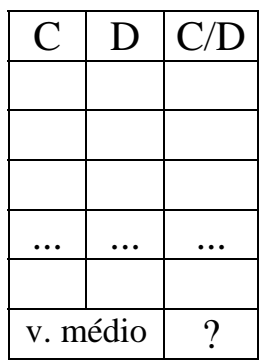

- para o cálculo da área do círculo

Uma adaptação da solução arquimediana poderia ser proposta aqui de forma bem simples. Para isto seriam necessários alguns instrumentos básicos de geometria (régua, compasso, transferidor), tesoura e cola. 


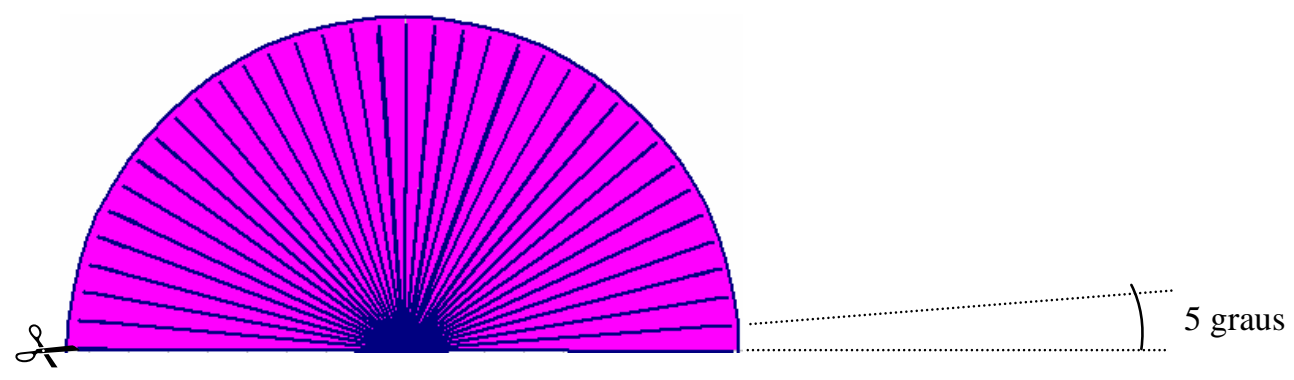

cortar apenas sobre as linhas azuis

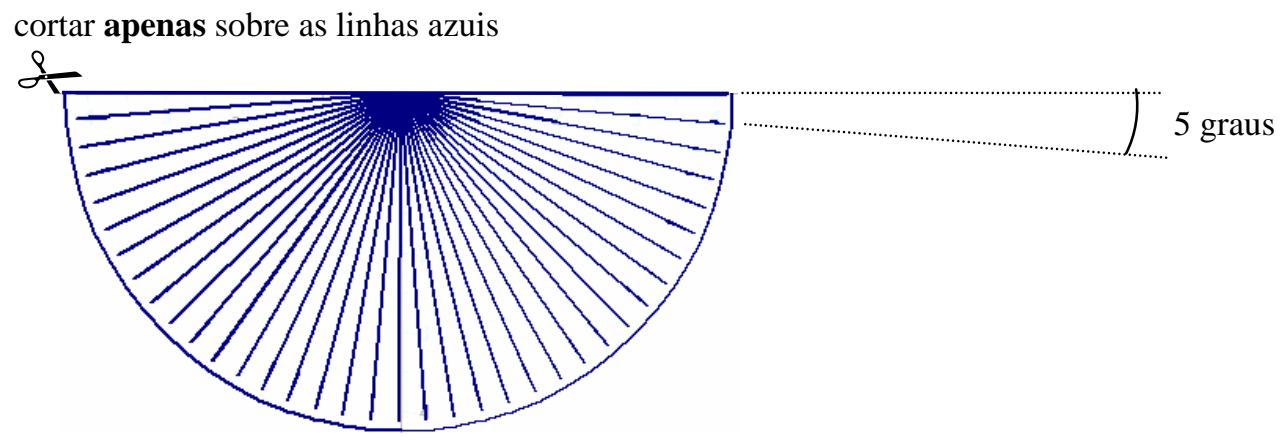

figura 72

Recortada as figuras, o próximo passo consiste na construção, pelo processo de colagem, do seguinte "retângulo":

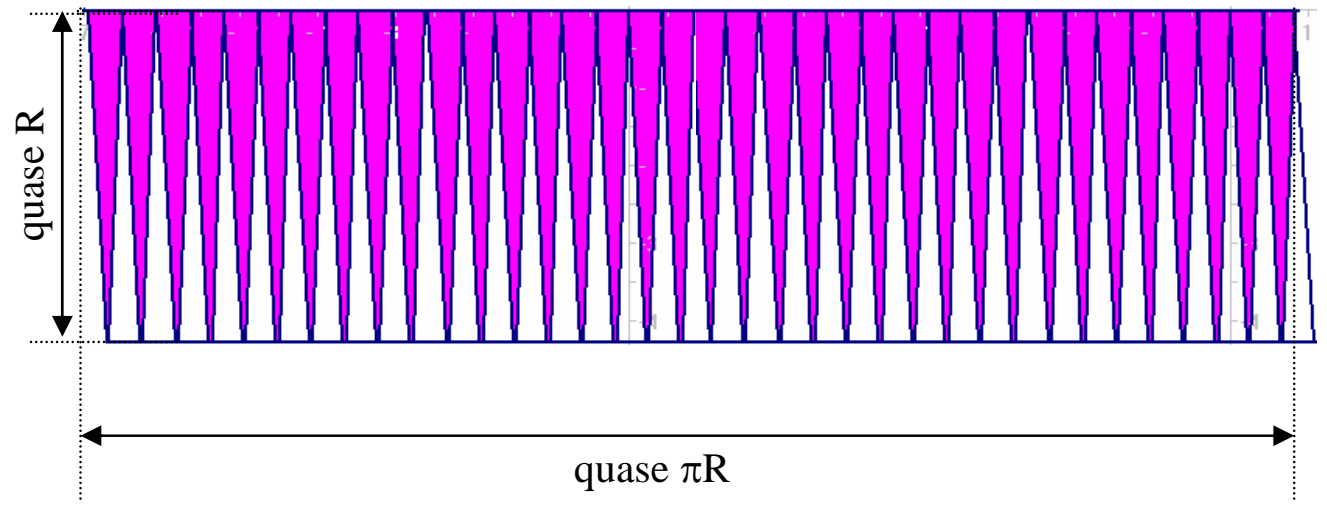

figura 73

A área do círculo pode ser determinada então, de modo aproximado, pela área do "retângulo" construído. 
Cabe destacar aqui que ambas as atividades destacadas não são tão distantes da realidade do ambiente didático do ensino fundamental de matemática, tendo sido usadas por diversos educadores matemáticos em suas atividades de ensino. Deve-se, contudo, enfatizar para o aluno que os valores exatos do comprimento $(C=2 \pi R)$ e da área $\left(A=\pi R^{2}\right)$ do círculo são determinados através de um processo infinito de exaustão e estão diretamente relacionados ao estudo do número irracional $\pi$. Não se deve ter receio de informar ao aluno 0 caráter parcial da solução apresentada; isto serve, sobretudo, para mostrar as dificuldades intrínsecas do problema e que, num momento futuro, precisarão ser enfrentadas com o uso de outros instrumentos.

Acreditamos, no entanto, que com o desenvolvimento dos estudos em geometria euclidiana e das funções trigonométricas básicas, o estudante poderia ser apresentado a uma outra forma de resolver o problema. Usando a noção intuitiva de limite poder-se-ia apresentar uma adaptação das soluções arquimedianas. Para a dedução das fórmulas do comprimento da área do círculo seria necessário que se fizesse o cálculo do limite fundamental

$$
\lim _{n \rightarrow \infty} \frac{\operatorname{sen}\left(\frac{\pi}{n}\right)}{\frac{\pi}{n}}=1 .
$$

O cálculo de tal limite pode ser feito de modo intuitivo e graficamente por comparação: 


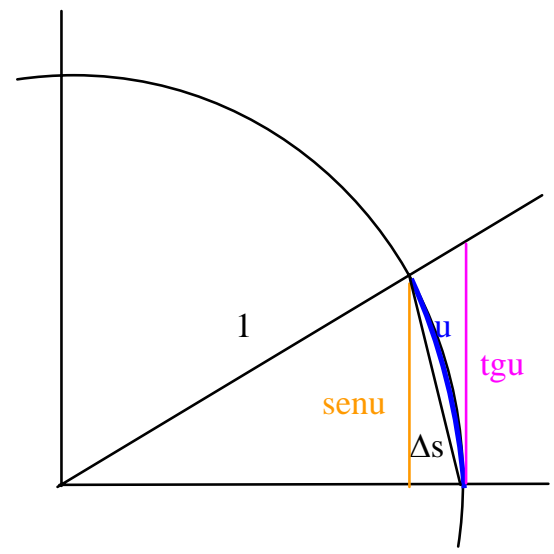

figura 74

\section{Caso $u \rightarrow 0^{ \pm}$}

Considerando $u=\pi / n$, temos que

$n \rightarrow \infty \Leftrightarrow u \rightarrow 0$

Por comparação, obtém-se, geometricamente, que $\operatorname{sen} u \leq \Delta s \leq \operatorname{tg} u$

considerando que $\Delta s \sim u$ quando $u \rightarrow 0$, tem-se

que $\operatorname{sen} u \leq u \leq \operatorname{tg} u \Rightarrow 1 \geq \frac{\operatorname{sen} u}{u} \geq \cos u$

Assim, quando $u \rightarrow 0,1 \rightarrow 1$ e $\cos u \rightarrow 1$,

o que implica que $\frac{\operatorname{sen} u}{u} \rightarrow 1$.

O caso $u \rightarrow 0=$ se faz de modo análogo.

Esta abordagem do problema da área do círculo representa efetivamente uma antecipação do conceito de integral de Riemann e poderia ser o portão de entrada do conceito de integração no ensino médio. Achamos, no entanto, que o conceito de integral poderia ser introduzido por uma outra via paralela ao ensino de funções e através de cálculos de áreas de regiões planas que oferecessem menos dificuldade de cálculos. Considerando regiões limitadas pelas curvas do tipo $x=a, x=b, y=0$ e $y=f(x), f(x)>0$ (figura 80), a área seria definida pela expressão:

$$
A=\lim _{n \rightarrow \infty} \sum_{i=1}^{n} f\left(x_{i-1}\right) \Delta x_{i}=\int_{a}^{b} f(x) d x,
$$

em que $\Delta x_{i}=x_{i}-x_{i-1}$. O que importa neste primeiro momento é o aluno apreender intuitivamente o significado da integral definida como sendo - "limite" da soma de pequenos retângulos, isto é, fazer o aluno ver que uma forma de interpretar a variação de uma determinada grandeza é raciocinar como se ela fosse constante por partes, em intervalos "infinitamente pequenos". Assim, estaremos recuperando, a partir da 
solução parmenidiana para o problema da dualidade variabilidade/permanência, a essência do conceito de integração.

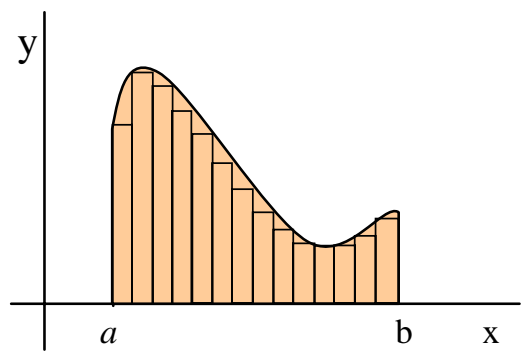

figura 75

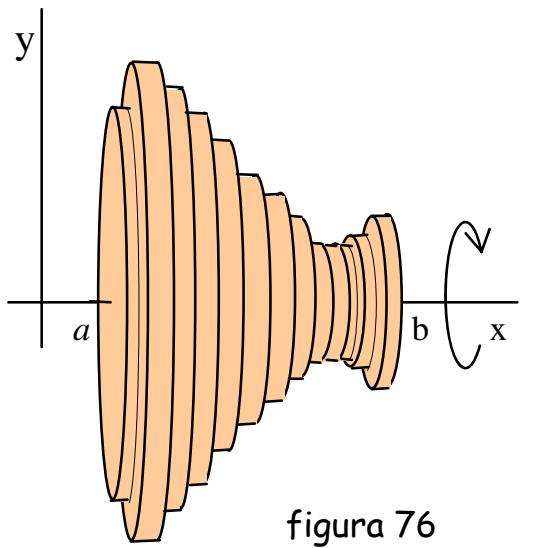

figura 76

Alguns cálculos aproximados de certas áreas e volumes (isto é, fixando um valor para $n$, e calculando a soma finita) poderiam ser efetuados. Para algumas regiões particulares, o cálculo da área pela definição de integral poderia ser realizado: o caso da parábola $y=x^{2}, x$ variando no intervalo $[0,1]$, por exemplo, é um desses casos possíveis o desenvolvimento da integral $\int_{0}^{1} x^{2} d x$ implica, inicialmente, no cálculo da soma dos $n$ primeiros números quadrados que pode ser obtida usando os números figurados da escola pitagórica $\left(\sum_{i=1}^{n} i^{2}=\frac{n(n+1)(2 n+1)}{6}\right) .{ }^{189}$

Com o desenvolvimento do estudo das funções trigonométricas e a conseqüente solução dos problemas clássicos do comprimento e da área do círculo, poder-se-ia introduzir no âmbito da geometria espacial o cálculo de volumes de sólidos de revolução obtidos pela rotação de regiões planas, do mesmo tipo daquela que foi usada anteriormente

\footnotetext{
189 Este número figurado pode ser estudado ainda no triângulo de Pascal - ver (Enzensberger, 1997).
} 
para o cálculo das áreas, em torno do eixo das abscissas Ox (figura 81). Nesse caso o volume poderia ser calculado pela expressão

$$
V=\lim _{n \rightarrow \infty} \sum_{i=1}^{n} \pi f^{2}\left(x_{i-1}\right) \Delta x_{i}=\int_{a}^{b} \pi f^{2}(x) d x
$$

em que $\Delta x_{i}=x_{i}-x_{i-1}$. Desse modo, o volume do cilindro, do cone e da esfera poderiam ser calculados considerando, respectivamente, as funções $f(x)=c, f(x)=x$ e $f(x)=\sqrt{R^{2}-x^{2}}$, em domínios apropriados.
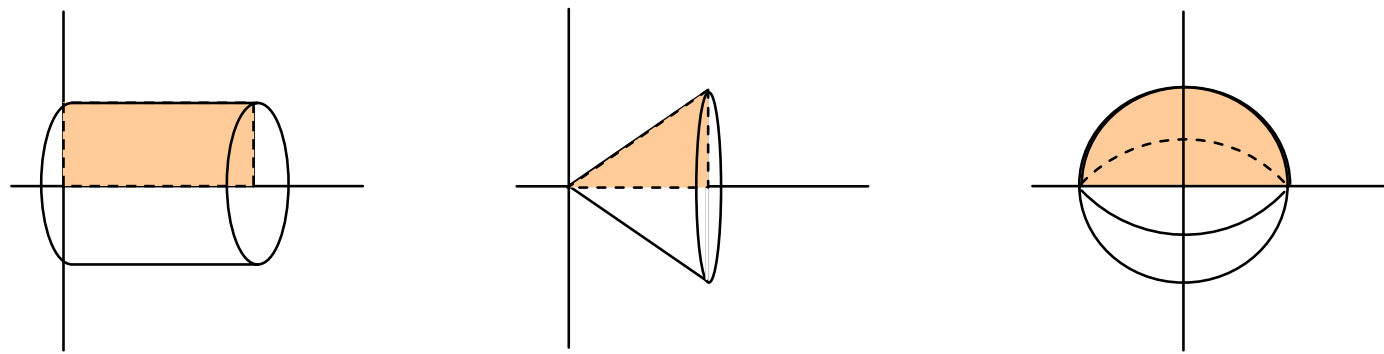

figura 77

Ainda nesse contexto, poderiam ser recuperados aqui os teoremas (princípios) de Cavalieri a partir de uma adaptação de seus resultados para o contexto do Cálculo atual.

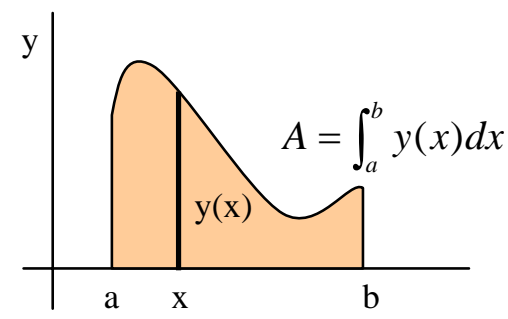

figura 78

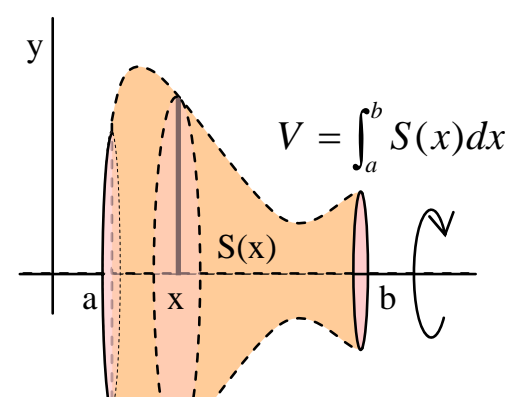

figura 79

A contextualização da integral definida em outras situações físicas ajudaria a consolidar a idéia de integral como uma "soma contínua". A articulação entre os elementos dos ternos 
massa/densidade/volume e trabalho/força/deslocamento, por exemplo, são algumas dessas possibilidades.

Poder-se-ia apresentar em seguida as propriedades básicas de integração: $\int_{a}^{b}(f \pm g)(x) d x=\int_{a}^{b} f(x) d x \pm \int_{a}^{b} g(x) d x \quad e \int_{a}^{b}(c f)(x) d x=c \int_{a}^{b} f(x) d x$, $c \in \mathbb{R}$, sem o exagero do exercício da técnica. O mais interessante, seria retomar o contexto cinemático com o objetivo de construir o enunciado do Teorema Fundamental do Cálculo, isto é, construir o seu resultado no mesmo contexto cinemático apresentado por Torricelli e Newton:
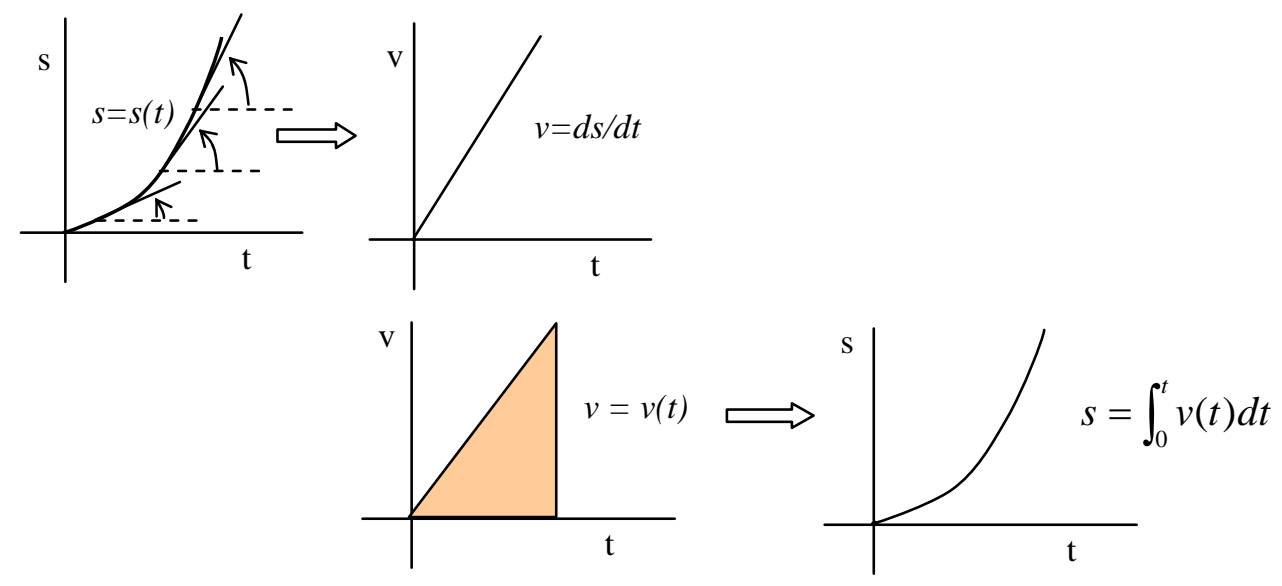

figura 80

Assim, temos, a partir das relações gráficas, que $s(t)=\int_{0}^{t} v(t) d t=\int_{0}^{t} \frac{d s}{d t} d t$ e $v(t)=\frac{d s}{d t}=\frac{d}{d t}\left(\int_{0}^{t} v(t) d t\right)$. Isto posto, uma versão mais fraca do enunciado de Cauchy do Teorema Fundamental poderia ser construído com os estudantes, isto é:

$$
\begin{gathered}
\frac{d s}{d t}=v(t), v(t) \text { uma função cujo gráfico é uma curva contínua } \\
\qquad \int_{a}^{b} v(t) d t=s(b)-s(a)
\end{gathered}
$$


Feito isto, novos cálculos de integrais, usando agora o Teorema Fundamental, poderiam ser realizados. Contextualizar estes cálculos em outras situações físicas (massa/densidade/volume $e$ trabalho/força/deslocamento, etc), seria interessante para que se pudesse dar outras dimensões do uso do Teorema Fundamental do Cálculo.

\section{O problema aritmético da medida}

O problema aritmético da medida está diretamente associado à construção dos números reais e foi resolvido fundamentalmente através do entrelaçamento de diversos elementos constitutivos das dualidades finito/infinito e discreto/contínuo. $O$ despertar para 0 problema é bem antigo: data do momento em que a escola pitagórica teve contato inicial com essa dificuldade: o conhecido "dilema de Pitágoras". Antes disso, acreditava-se que os números racionais eram suficientes para representar e quantificar as medidas das grandezas geométricas, e de tudo o mais: afinal, tudo era número (número racional)! Foi nessas condições históricas que surgiu a primeira grande crise do problema da medida.

Com essa incapacidade dos racionais para solucionar tal problema, abre-se na aritmética um novo campo de estudo, para o qual o desenvolvimento das ferramentas do Cálculo será imprescindível. No entanto, a segunda crise do problema da medida surge antes da "invenção" do Cálculo por Newton e Leibniz, sendo identificada pela histórica questão de Galileu: "pode uma soma infinita dar um resultado finito?". A resposta a essa questão só será dada com o desenvolvimento da noção de convergência e de alguns critérios 
(teoremas) para se decidir a convergência ou não de séries números reais. Mas isto já acontece no portão de entrada da Análise. Cabe, no entanto, ressaltar que, ainda no âmbito do Cálculo, através do estudo das séries, foram realizadas algumas caracterizações importantes de certos números irracionais notáveis como, por exemplo, do número de Euler, $e, e$ do $\pi$.

Já a terceira crise ocorreu no período de desenvolvimento da Análise, motivada essencialmente pelo raciocínio circular presente na definição de número real de Cauchy: a definição formal de limite estava fundamentada na noção de número real, e a deste último na existência do limite. A solução se deu em duas etapas: a primeira solução, e mais imediata - dada por Weierstrass -, consistiu de um ajuste lógico na própria definição de número real; a segunda, e decisiva - a de Dedekind -, elaborou uma construção do número real de modo independente da operação de limite.

Como se pode ver pelo histórico acima, o problema da medida precisou de mais de 2000 anos para ser resolvido plenamente, tendo sido o processo de solução realizado em etapas: a primeira etapa consistiu do reconhecimento da insuficiência dos números racionais; na etapa seguinte, houve a conscientização de que a representação de uma grandeza incomensurável estava associada diretamente 'a noção de infinito; isto posto, a próxima etapa foi marcada pela busca paciente de uma resposta para a questão de Galileu - a principal contribuição desse período consistiu, sem dúvida, na definição formal de limite, e, em particular, da convergência (e critérios de convergências) das séries numéricas; a última etapa só se encerrou através da construção axiomática dos números reais, de forma independente da noção de 
limite, e a partir do postulado de continuidade de Dedekind-Cantor. Desse modo, fica evidente, pela própria complexidade da solução do problema da medida, que esta deverá ser realizada no processo didático em etapas e adaptada para uma abordagem mais intuitiva dos seus problemas internos.

Acreditamos, por exemplo, que o conteúdo da primeira crise do problema da medida pode ser abordado no próprio contexto do ensino de geometria, quando do ensino do teorema de Pitágoras. $O$ argumento de que a medida da diagonal do quadrado de lado unitário não pode ser um número racional pode ser apresentado e demonstrado com a participação de todos os alunos. Para isto o aluno precisa ter em mente a caracterização do número racional como uma classe de equivalência, isto é, que o número racional $\frac{1}{2}$, por exemplo, representa todas as razões $a / b$, a e b números inteiros, tal que $\frac{a}{b}=\frac{1}{2} ; e$, diante disto, que é sempre possível (pelo processo de simplificação) encontrar uma razão irredutível que representa o número racional.

Verificada a insuficiência dos números racionais para o problema da medida, suscitaria nos estudantes o sentimento de se criar novos números os números irracionais. Cálculos aproximados da $\sqrt{2}$, bem como de outros números irracionais algébricos $-\sqrt{3}, \sqrt{5}$ etc. - podem (e devem) ser apresentados simultaneamente de modo $a$, desde cedo, se considerar as questões fundamentais do par discreto/contínuo e das dificuldades inerentes a essa dualidade. Ter consciência das dificuldades é educativo. Escamotear essas dificuldades é que é imperdoável! Os processos de aproximação devem apresentar uma estimativa racional do número em si, mas, sobretudo, induzir nos alunos 
- pensamento de que tais números (irracionais) apresentam uma representação decimal infinita, que não possui parte periódica.

Isto posto, voltar-se-ia ao campo dos números racionais para estudar a sua representação decimal, isto é, verificar que todo número racional ou tem uma representação decimal finita ou tem uma representação decimal infinita que possui uma parte periódica. Para isto, basta que o aluno conheça o algoritmo de divisão de inteiros (figura 81). O conhecimento desse resultado auxiliaria, aliás, na caracterização dos números irracionais como uma decimal infinita e não periódica, mas que é finito. Para garantir a finitude desses "primeiros" números irracionais pode ser usado o poder de convencimento da percepção geométrica - ou será que algum aluno da classe duvidaria de que, apesar da representação decimal infinita, a diagonal de um quadrado de lado 1 é, naturalmente, finita?

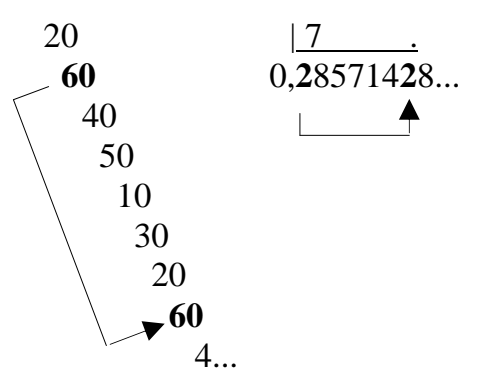

figura 81

Sendo assim, a construção dos reais seria estabelecida a partir de sua representação decimal do seguinte modo:

IR $\left\{\begin{aligned} \text { racional }\left\{\begin{aligned} & \rightarrow \text { Decimal finita } \\ & \text { irracional } \rightarrow \text { Decimais infinitas e não periódicas }\end{aligned}\right.\end{aligned}\right.$ 
A "construção" dos números reais iniciada aqui é inspirada na própria atitude de Weierstrass que assumiu a convergência das séries e definiu os números irracionais pela própria série. A substituição paulatina da expressão "representação decimal/dízima" por "série" é legítima e, associada à noção intuitiva de limite, torna-se fundamental para que se possa num momento posterior discutir sobre a convergência ou não de tais "expressões decimais". Acreditamos que no ensino básico pode-se antecipar a convergência de algumas séries: as séries geométricas, por exemplo, representam algumas dessas possibilidades. Não acreditamos, entretanto, que o ensino básico de matemática seja o lugar adequado para se estudar os critérios de convergência das séries. Nem sempre essa tarefa é tão simples como no caso das séries geométricas, e, além disso, este estudo teórico sobre a convergência das séries é propriamente uma tarefa para um curso de Análise Real.

A representação decimal dos números $\pi$ e $e$, bem como suas histórias, poderia ser realizad(o)a no ensino médio, em momento oportuno, a partir da introdução do estudo das funções reais (trigonométricas e exponenciais). No entanto, a convergência dessas séries é assunto para outra hora. Podemos fazer, por exemplo, como fez Euler: assumir implícita e intuitivamente a convergência delas. Cabe ressaltar que o objetivo aqui não é formalizar e nem desenvolver critérios de convergência de séries, mas, sim, apresentar e caracterizar alguns números irracionais importantes para o ensino de matemática em sentido amplo. $O$ foco do ensino das idéias básicas do Cálculo deve estar sempre voltado para as idéias e suas significações. 
Isto posto, a alegoria do hotel infinito de Cantor poderia ser apresentada para dar ao estudante a noção de enumerabilidade do conjunto dos números racionais e de seus subconjuntos. Tal fato, associado à informação da não-enumerabilidade do conjunto dos números reais (e somente informação!), revelaria ao estudante a importância dos números irracionais para o completamento da "reta real". A apresentação de fatos curiosos da matemática em forma de enigmas está longe de criar problemas para os estudantes; ao contrário, tem servido muitas vezes para chamar a atenção do próprio aluno para o misterioso mundo da matemática $e$ de suas potencialidades.

Assim, pode-se afirmar de forma sintética que é possivel superar no ensino básico de matemática, ainda que parcialmente, as três crises históricas do problema da medida. O que mais interessa realmente neste período é ambientar o aluno, desde cedo, com as significações próprias da dualidade discreto/contínuo, de modo a consolidar a construção dos números reais a partir de uma abordagem intuitiva delas.

- O lugar-matriz e a crise de identidade do ensino superior de Cálculo

A disciplina inicial de Cálculo, tal como está estruturada, se encontra, semanticamente, muito mais próxima da Análise do que do próprio Cálculo. Não é à toa que esta disciplina é considerada por um grande número de professores como uma pré-Análise, ou, mais 
especificamente, como uma abordagem "mais intuitiva" da Análise de Cauchy-Weierstrass em que se põe evidência nas técnicas de calcular limites, derivadas e integrais. Essa atitude predominante no ensino de Cálculo é caracterizada então por uma posição híbrida: por um lado, dáse ênfase à organização e à justificação lógica dos resultados do Cálculo, e, por outro, realiza-se um treinamento exacerbado nas técnicas de integração, no cálculo de derivadas e de limites. Esta formatação analítica e algébrica da disciplina de Cálculo no ensino superior é, sem dúvida, uma das principais fontes da crise de identidade que mencionamos no início desta conclusão. No entanto, a principal fonte mesmo de obstáculos de aprendizagem é a carência de algumas idéias e problemas construtores do Cálculo. Tal fato pôde ser percebido inclusive no mapeamento que aqui foi realizado (capítulo 5) das dificuldades de aprendizagem dos alunos. Senão vejamos.

Podem-se enumerar, a partir do mapeamento realizado, as seguintes ausências:

- a pouca ênfase dada à derivada como uma taxa de variação instantânea (um dos principais obstáculos epistemológicos à resolução de problemas de otimização e de taxas relacionada); o conceito de velocidade não participa efetivamente da construção do campo semântico do conceito de derivada - ele é meramente uma das interpretações possíveis:

- a falta de uma caracterização clara dos números reais - o problema da circularidade da definição do número real continua mal resolvido, mesmo depois de um curso de Cálculo; a caracterização dos números irracionais $\pi$ e e em termos de 
séries de números racionais é ignorada;

- configura-se uma participação isolada da noção de infinito tal atitude se revela apenas (e de modo ingênuo) nos cálculos de limites;

- as indeterminações matemáticas são pressupostas; sequer é enfatizado o fato da derivada ser, por definição, uma situação de indeterminação - "uma divisão de zeros", como Euler sugeriu alguns séculos atrás;

- os problemas de áreas são tratados exclusivamente através do uso do TFC e das técnicas de integração - não é explorada a caracterização da integral de Riemann a partir das séries infinitas;

- as séries, que constituem um dos principais elementos na passagem da soma discreta para a soma contínua, são desprestigiadas até mesmo no momento em que se estuda o encaminhamento sugerido por Lagrange para o estudo das derivadas (os polinômios de Taylor): considera-se quando muito o caso linear:

- nota-se a falta de uma contextualização mais dinâmica no estudo das funções reais: "encontrar a função" que vai ser otimizada é sempre a tarefa mais difícil para o aluno na resolução dos problemas de otimização.

Assim, diante dessa crise de identidade do ensino de Cálculo, faz-se urgente redimensionar o paradigma de ensino de Cálculo: nem a preparação para um ensino posterior de Análise e nem a "calculeira 
desenfreada" 190 servem como meta para um curso inicial de Cálculo; precisa-se voltar o ensino do Cálculo para o próprio Cálculo, os seus significados, os seus problemas construtores e suas potencialidades. Tão importante quanto saber usar as regras de derivação e as técnicas de integração, é saber os seus significados, as suas múltiplas interpretações, sua utilidade em outros campos da matemática e em outras áreas do conhecimento.

Diante disso, é preciso "re-calibrar" a disciplina de Cálculo em relação ao par técnica/significado. Mas também é preciso "recalibrar" a disciplina de Cálculo, conforme já foi dito no capítulo anterior desta tese, em relação ao par sistematização/construção. Isto é, em vez de se construir os resultados e conceitos do Cálculo no nível do conhecimento já sistematizado, deve-se ter em mente a construção das redes de significações das idéias básicas para, num momento posterior, buscar a sistematização dos elementos dessa rede. "Não são as idéias de velocidade e coeficiente angular, interpretações do conceito de derivada, mas, ao contrário, são elas, efetivamente, as idéias geradoras e construtoras do campo semântico da noção de derivada" - já havíamos afirmado antes.

Ora, mas quais são (ou devem ser?) então as idéias básicas do ensino superior do Cálculo? Como devemos sistematizá-las? Qual o nivel de rigor pretendido no processo de sistematização?

Comecemos pela última questão.

Com base na discussão que realizamos sobre algumas visões preliminares do ensino de Cálculo (seção 5.1 desta tese), podemos

\footnotetext{
${ }^{190}$ Com "calculeira desenfreada” queremos dizer: a excessiva ênfase dada às técnicas de cálculos de limites, de derivadas e de antiderivadas.
} 
assumir que o fluxo de conhecimento daquilo que se costuma chamar de Cálculo propriamente situa-se, historicamente, a partir de Newton e Leibniz, momento de sua invenção, até a primeira fase de Cauchy, momento em que o Cálculo é estruturado em termos de uma noção intuitiva de limite. No entanto, para se definir o paradigma de rigor para o ensino de Cálculo, se é que isto seja possível, o problema é mais complexo e depende de outras variáveis do campo pedagógico. A busca desse paradigma é, sem dúvida, um dos maiores desafios para o professor de Cálculo. O ponto de equilíbrio - o ponto ideal - é, na verdade, uma utopia pedagógica que se ajusta a cada novo momento do processo ensino-aprendizagem. O professor, conforme já foi dito neste trabalho, precisa ser perspicaz e flexível o suficiente para, na realização do próprio curso, chegar o mais próximo possível do ponto ideal. Para que isso ocorra o professor precisará enfrentar a polarização usualmente feita no meio acadêmico entre os ensinos de Cálculo e de Análise, cortar o cordão umbilical que submete o ensino de Cálculo ao ensino de Análise, e procurar no próprio Cálculo as metas do seu ensino e o nível de rigor possível e desejado.

No que diz respeito às idéias básicas do Cálculo pode-se afirmar, com base no seu desenvolvimento histórico, que o Cálculo se constituiu a partir de dois procedimentos fundamentais, inversos e que se entrelaçam na busca de soluções de problemas da aritmética (do número), da geometria (da medida do espaço) e da física (do movimento), e que de forma inevitável estão associados a processos infinitos. São eles os processos de diferenciação e integração, correlacionados entre si pelo Teorema Fundamental do Cálculo. Newton, por exemplo, percebia dois tipos de problemas no Cálculo: um, 
em que dada a posição do objeto, pedia-se para determinar as velocidades (diferenciação), e o problema inverso, dadas as velocidades $e$ as condições iniciais do movimento, determinar a posição do objeto (integração). Leibniz, por sua vez, também identificou duas categorias de problemas no Cálculo: o problema fundamental de determinar as diferenças infinitamente pequenas de uma seqüência de valores (diferenciação), e o problema inverso de determinar a soma infinita dos termos de uma sequiência de valores (integração). Assim, desde Newton e Leibniz, e por caminhos diferentes, os processos de diferenciação e integração, consolidadas no Teorema Fundamental do Cálculo, sempre foram as duas linhas mestras do Cálculo e devem constituir, portanto, os grandes núcleos semânticos do ensino superior de um curso inicial de Cálculo. Assim, grosso modo, poder-se-ia dizer que os conceitos de derivada e de integral devem ser, interligados pelo Teorema Fundamental do Cálculo, os dois núcleos semânticos do ensino de Cálculo.

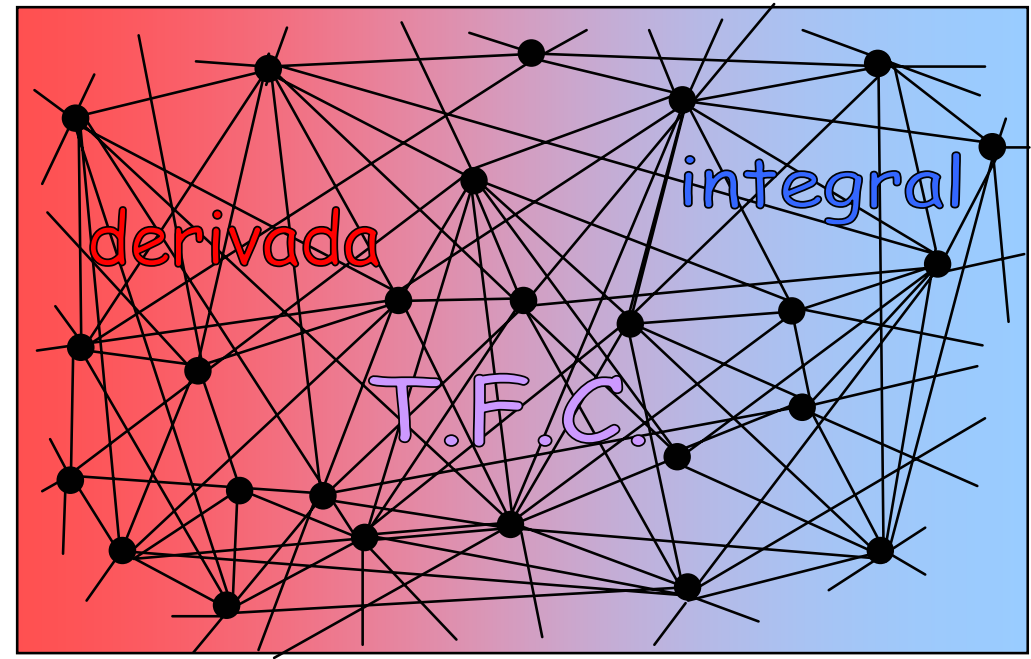

figura 82 
Por outro lado, não há como negar a importância de dois outros conceitos no desenvolvimento do Cálculo: as noções de limite e de infinitésimo. Estes conceitos sempre desempenharam o importante papel de elementos construtores das significações das idéias básicas do Cálculo, funcionando como o grande alicerce que dava sustentação aos procedimentos usuais do Cálculo. No entanto, devemos ter em mente que estes conceitos não devem ser, eles próprios, objetos de estudo e aprofundamento em um curso de Cálculo: a fundamentação da operação de limite é do âmbito da Análise Real, e a da noção de infinitesimal, da Análise Não-Standard. A participação efetiva destes conceitos no processo de ensino de Cálculo deve ser no nível intuitivo, e não no nível formal, da construção das idéias fundamentais do Cálculo. Assim, pode-se afirmar que tanto a definição formal de limite, de Weierstrass, em termos de e's e $\delta$ 's, quanto à construção rigorosa do infinitésimo elaborada por Robinson em sua Análise Não-Standard não são (e nem devem ser) efetivamente os elementos construtores dos conceitos e resultados do Cálculo numa disciplina inicial num curso superior de Cálculo. Acreditamos que a noção intuitiva de limite de Cauchy e os infinitesimais de Leibniz e Euler serviriam com mais presteza aos reais objetivos de um curso inicial de Cálculo no ensino superior.

No entanto, diante disso surge uma questão natural em relação a esses dois elementos construtores do Cálculo: qual deve ser o elemento construtor das idéias básicas no ensino superior de Cálculo: limite ou infinitésimo?

Reconhecemos o mérito dessa questão e sua relevância para o ensino superior de Cálculo. No entanto, convém observar que nossa 
pesquisa não se realizou com esse objetivo - o de avaliar qual deve ser - elemento construtor das idéias básicas a serem desenvolvidas no ensino superior de Cálculo - e que, por esse motivo, não possui elementos de análise que permitam chegar a uma conclusão efetiva dessa questão em toda sua especificidade. Não foi feito aqui nenhum estudo comparativo das abordagens propostas em termos de limites ou de infinitésimos que possibilitasse chegar a alguma conclusão a esse respeito.

Em verdade, as fontes bibliográficas e as experiências didáticas aludidas pelo autor desta tese para a realização do mapeamento das dificuldades de aprendizagem dos alunos tiveram por base o modelo usual do ensino de Cálculo em termos de limite. No entanto, o papel reservado para a operação de limite nesse modelo de ensino está completamente equivocado: apesar de comprometer quase a terça parte do tempo didático da disciplina de Cálculo, a operação de limite é muito mais uma operação (técnica) algébrica do que propriamente aquela "idéia metafísica" - como diria Newton - que mais tarde foi interpretada por D'Alembert e Cauchy como a "verdadeira metafísica" do Cálculo.

Por outro lado, os textos que elaboravam propostas de uma abordagem infinitesimal para o ensino de Cálculo - (Baldino, 1998 e 1999) e (Oliveira, 1993) - e que foram considerados na realização dessa pesquisa não forneceram elementos de análise convincentes para que pudéssemos decidir de modo favorável à implementação didática de uma proposta estritamente infinitesimal. O texto de Oliveira (1993) cumpre efetivamente o que promete: faz uma apologia ao ensino da Análise Não-Standard. Quanto a isso já nos posicionamos 
frontalmente contra: apresentar a Análise Não-Standard de Robinson como modelo de sistematização para o ensino de Cálculo é um equívoco da mesma estirpe que aquela que adota a abordagem do Cálculo em termos da definição formal de limite, de Weierstrass, em termos de E's e d's. Já a proposta de Baldino (1998) parece-nos mais próxima do que deveria ser efetivamente o ensino de Cálculo. No entanto, ela faz uso das duas noções construtoras (ver ficha de trabalho número 16 Derivada - da referência citada) e a noção de infinitésimo apresentada pelo autor apresenta um duplo sentido: ora funciona como o infinitésimo no sentido de Cauchy, ora faz alusão ao infinitésimo de Robinson. Além disso, há de se ressaltar que em nenhuma das duas propostas obtemos dados concretos sobre a eficácia ou não de cada uma delas na correspondente implementação didática.

Cabe lembrar ainda que a aposta que se faz com a nossa pesquisa transcende o espaço local do ensino superior de Cálculo. Não acreditamos que se resolvam efetivamente os problemas de aprendizagem do ensino de Cálculo em uma única dose no ensino superior, sem que haja, de fato, um enfrentamento do seu principal adversário: o esvaziamento semântico de suas idéias do ensino de matemática em seu sentido amplo (inclusive no próprio ensino superior de Cálculo). No entanto, é possível acenar com algumas contribuições a respeito da questão proposta a partir do estudo de natureza epistemológica que fizemos do Cálculo e das dificuldades de aprendizagem do seu ensino.

Para começar, se levarmos em conta o nível de participação de cada um destes conceitos no processo de construção do Cálculo, a quantidade infinitesimal leva uma grande vantagem. Com efeito, o 
Cálculo surge e se desenvolve a partir das quantidades infinitamente pequenas. Até mesmo Cauchy, que fundamentou o seu Cálculo na noção de limite, não ignorou a idéia de infinitesimal; ao contrário, definiu-a em termos de limite, isto é, como uma quantidade variável que tende a zero. Assim, do ponto de vista histórico e epistemológico não há como negar: a noção de infinitesimal é, com efeito, o portão de entrada das idéias básicas do Cálculo.

Outro ponto favorável à noção de infinitesimal é o seu caráter intuitivo, que faz dela um elemento bastante usual (desde a invenção do Cálculo até os dias de hoje) nos procedimentos dos físicos, dos engenheiros e dos matemáticos aplicados. Há de se ressaltar ainda, a seu favor, o fato de que muitos textos clássicos de Cálculo, apesar de adotarem a fundamentação das idéias básicas em termos de limite, fazem uso também das concepções infinitesimais, embora de modo não declarado, acerca de aplicações da integral definida - é muito comum, por exemplo, o aparecimento de elementos diferenciais (infinitesimais) de comprimento, $d s$, de área, $d A$, e de volume, $d V$, no desenvolvimento dos resultados de comprimentos, áreas e volumes de figuras geométricas "arredondadas" 191.

E a favor da noção de limite, o que é que se tem?

Ora, a operação de limite foi efetivamente a primeira solução (a solução standard) para a crise de fundamentação do Cálculo Infinitesimal provocada pelas críticas de Berkeley - a outra, que apareceu apenas em meados do século XX, é a solução apresentada pela

\footnotetext{
${ }^{191}$ Tal fato pode ser justificado pela complexidade da operação de limite que aparece na definição usual da integral definida em termos da soma de Riemann: é muito mais simples e intuitivo, por exemplo, fatiar um sólido de revolução em anéis cilíndricos concêntricos de pequena espessura $\mathrm{dx}$ e determinar o volume do sólido a partir da soma contínua do volume de todos os anéis.
} 
Análise Não-Standard de Robinson. Assim, a favor da operação de limite como elemento construtor das idéias básicas do ensino de Cálculo tem-se a cômoda e majoritária posição que defende o seu uso tendo em vista a existência de uma Análise (Análise Real) bem estruturada e consolidada, enquanto, por outro lado, a Análise NãoStandard, que é quem daria o devido suporte ao uso dos infinitésimos, continua pouco conhecida (e por isso mesmo, pouco usada) pela grande maioria de matemáticos. No entanto este argumento pode ser facilmente refutado, senão vejamos.

Primeiramente, a grande maioria dos estudantes universitários (os alunos de cursos de serviço) que fazem um curso de Cálculo sequer farão um curso posterior de Análise Real ou mesmo de Análise NãoStandard. Além disso, se fizermos uma análise mais criteriosa para avaliar o quê da noção de limite é essencial para o desenvolvimento das idéias básicas do ensino de Cálculo verificaremos que o que realmente importa está presente na noção de infinitésimo de Cauchy. Com efeito, examinemos, por exemplo, o caso da derivada.

Note que na definição da derivada em termos de limite $f^{\prime}(x)=\lim _{\Delta x \rightarrow 0} \frac{f(x+\Delta x)-f(x)}{\Delta x}$ - que é a mesma de Cauchy - a expressão $\Delta x$ é em essência o infinitesimal de Cauchy. Assim, poderíamos simplesmente reescrever a definição da derivada em termos dessa quantidade infinitesimal do seguinte modo:

$$
f^{\prime}(x)=\left(\frac{f(x+d x)-f(x)}{d x}\right), \quad \text { onde } d x \quad \text { é uma quantidade }
$$

infinitesimal no sentido de Cauchy, isto é, uma quantidade variável que tende a zero. 
Assim, pode-se dizer que a idéia de limite que aparece nas definições de derivada e de integral de Cauchy representa, em verdade, uma versão standard da idéia de infinitesimal. Portanto, acreditamos - parafraseando D'Alembert - que a "verdadeira metafísica" do Cálculo traduz-se em assumir quantidades (variáveis) indefinidamente 192 pequenas a priori e fazê-las, através de um processo infinito, aproximá-las de zero. Como explicar e justificar esse processo infinito, conforme já foi dito, é tarefa para a Análise Real e para a Análise Não-Standard.

\section{As últimas palavras e um manifesto...}

Isto posto, pode-se dizer que a análise do lugar-matriz das dificuldades de aprendizagem de natureza epistemológica do ensino de Cálculo foi realizada tendo em vista duas situações pedagógicas distintas: no ensino superior, onde, mal ou bem, as idéias do Cálculo são apresentadas, e no ensino básico, onde essas idéias são escamoteadas.

A análise realizada no contexto do ensino superior foi desenvolvida a partir de três eixos temáticos configurados a partir dos pares: técnica/significado; construção de significados/justificação lógica; e limite/infinitésimo. A partir dessa discussão ficou evidenciada a existência de uma crise de identidade no ensino superior de Cálculo, caracterizada basicamente pela subordinação do ensino de Cálculo a uma espécie de preparação para a Análise e pela excessiva caracterização algébrica de suas idéias fundamentais. A primeira é a principal responsável pelo uso de demonstrações evasivas $e$

\footnotetext{
192 Talvez seja essa a razão pela qual Korzybski (2000) tenha demonstrado explicitamente sua preferência pelo termo "indefinitesimal” em vez de "infinitesimal".
} 
desnecessárias, que monopolizam os processos de significações das idéias e resultados do ensino de Cálculo. A última, por outro lado, constitui-se pelo exagero da técnica que desvirtua, sem dúvida, os significados das idéias básicas do Cálculo. Para superar esta crise é necessário rediscutir o papel do ensino de Cálculo no ensino superior. No entanto, o sucesso do ensino superior de Cálculo está condicionado a uma preparação das idéias básicas do Cálculo no ensino básico de matemática. Mas esta já é a outra face do lugar-matriz dos problemas de aprendizagem do ensino de Cálculo.

No contexto do ensino básico de matemática, foram explicitadas algumas possibilidades de emersões e de articulações das idéias básicas do Cálculo com o conteúdo programático das disciplinas de matemática e de física. As articulações foram realizadas segundo três linhas diretrizes: a do problema da variabilidade (variável/movimento); a do problema geométrico da medida (processos de medida/cálculos de áreas e volumes); e da expressão numérica de uma medida (número). Pretende-se com esta emersão das idéias do Cálculo no ensino básico de matemática possibilitar ao Cálculo que ele possa desempenhar, desde cedo, o seu papel histórico na construção do conhecimento matemático. Esta preparação para o Cálculo beneficiará não só o ensino superior de Cálculo, mas, sobretudo, o próprio ensino de matemática.

Para finalizar este trabalho gostaríamos de fazer um manifesto público em prol de uma reflexão de natureza epistemológica sobre o ensino básico de matemática. A formatação algébrica a que está submetido este ensino é uma herança de uma visão estruturalista da matemática, inspirada no fenômeno da matemática moderna. Engana- 
se quem pensa que este modo de ver a matemática e o seu ensino tenha ficado no passado e que o movimento construtivista veio romper essas barreiras. Muito pelo contrário, o construtivismo, de certo modo, também tem raízes no estruturalismo. Trata-se de uma interpretação psicológica das questões epistemológicas que não consegue por si só, e de modo efetivo, entrelaçar as significações do conhecimento matemático. A tecedura do construtivismo é realizada, em geral, na superfície do conhecimento matemático, não consegue responder às questões epistemológicas de natureza mais profunda, no âmbito das significações da própria matemática. É preciso compreender a natureza do conhecimento matemático, de suas construções e justificativas. Em outras palavras, é preciso construir uma epistemologia da matemática. E assim sendo, perceber-se-á que o Cálculo constitui, com efeito, um dos principais e fundamentais elementos da urdidura do conhecimento matemático em seu sentido amplo. $O$ que esta tese propõe sobremaneira é que se permita às idéias básicas do Cálculo participar efetivamente dessa tecedura do conhecimento matemático do ensino básico. Feito isto, acreditamos, as dificuldades do ensino superior de Cálculo serão em grande parte superadas, tanto quanto as do próprio ensino de matemática, e perceber-se-á, conforme nos disse certa vez Edgard Allan Poe, que "É apenas por faltar algum degrau aqui e ali, por descuido, em nosso caminho para o Cálculo Diferencial [e Integral], que este último não é coisa tão simples quanto um soneto de Mr. Solomon Seesaw". 


\section{Bibliografia}

ANDRÉ, M. E. D. A. de. Etnografia da prática escolar. Campinas: Editora Papirus, 1995.

BACHELARD, G. O direito de sonhar. Rio de Janeiro: Editora Bertrand Brasil S.A., 1991.

A formação do espírito científico. Tradução Estela dos Santos Abreu. Rio de Janeiro: Contraponto Editora, 1996.

BALDINO, R. R. Desenvolvimento de essências de Cálculo Infinitesimal. Rio de Janeiro: MEM/USU, 1998.

- Cálculo em Assimilação Solidária. Apostila do mini-curso apresentado no II EEMAT. Macaé: SBEM-RJ, 1999.

BARNES, J. Filósofos Pré-Socráticos. São Paulo: Martins Fontes, 1997.

BARON, M. E. E e BOS, H. J. M. Curso de História da Matemática: origens e desenvolvimento do Cálculo. Brasília: Editora Universidade de Brasília, volumes 1, 2, 3, 4 e 5, 1985.

BARUFI, M. C. B. A construção/negociação de significados no curso universitário inicial de Cálculo Diferencial e Integral. Tese de Doutorado. São Paulo: FE-USP, 1999.

BELL, E. T. Historia de las Matematicas. $2^{a}$ edição em espanhol. México: Fondo de Cultura Económica, 1996.

BICUDO, I. Análise Não-Standard. Boletim de Educação Matemática BOLEMA. Vol.8, p. 60-67. 1992. 
BLACKBURN, S. Dicionário Oxford de Filosofia. Rio de Janeiro: Jorge Zahar Editor, 1997.

BORGES, J. L. El Hacedor. $2^{a}{ }^{a}$ edição. Madrid: Alianza Editorial, 1999.

BOYER, C. B. The History of the Calculus and its Conceptual Development. New York: Dover Publications Inc., 1949.

CABRAL, T. C. B. Vicissitudes da Aprendizagem em um Curso de Cálculo. Dissertação de Mestrado. Rio Claro: UNESP, 1992. Contribuições da Psicanálise à Educação Matemática: A Lógica da Intervenção nos Processos de Aprendizagem. Tese de Doutorado. São Paulo: USP, 1998.

CARAÇA, B. de Jesus. Conceitos Fundamentais da Matemática. 9a edição. Lisboa: Livraria Sá da Costa Editora, 1989.

COURANT, R. e ROBBINS, H. O que é a Matemática? Rio de Janeiro: Editora Ciência Moderna LTDA, 2000.

CORNU, B. Aprentissage de la Notion de Limits: Conceptions et Obstacles, Tese de Doutorado. Grenoble: L'Universite Scientifique et Medicale de Grenoble, 1983.

CUTLAND, N. Nonstandard Analysis and its Applications. Cambridge: Cambridge University Press, 1988.

D'AMBRÓSIO, U. Educaşão Matemática: da teoria à prática. $2^{a}$. ed. Campinas: Papirus, 1997.

DAVIS, R. B., e VINNER, S. The Notion of Limits: Some Seemingly Unavoidable Misconception Stages. Journal of Mathematical Behavior, 5, 1986. 
DEWEY, J. Como Pensamos. São Paulo: Nacional, 1979.

DÖRRIE, H. 100 Great Problems of Elementary Mathematics. Their History and Solution. New York: Editora Dover, 1965.

ENZENSBERGER, H. M. O Diabo dos Números. Tradução SérgioTelarole. São Paulo: Editora Cia Das Letras, 1997.

EVES, H. Uma Introdução à História da Matemática. São Paulo: Editora da Unicamp, 1995.

FERREIRA, A. B. H. Novo Dicionário Aurélio. Século XXI. São Paulo: Editora Nova Fronteira, 1999.

FREGE, G. Lógica e Filosofia da Linguagem. São Paulo: Editora Cultrix \& Editora da USP, 1978.

GIORELLO, G. e MONDADORI, M. Cálculo. Enciclopédia Einaudi, vol. 42, Sistemática. Lisboa: Imprensa Nacional-Casa da Moeda, 2000.

GLAESER, G. Epistemologia dos números relativos. Rio de Janeiro: Boletim do GEPEM, 17, p. 29-124, 1985.

GRATTAN-GUINESS, I. The Development of the Foundations of Mathematical Analysis from Euler to Riemann. Massachusetts: The Colonial Press Inc., 1970. . From the Calculus to Set Theory. An Introductory History. New Jersey: Princeton University Press, 1980. . O que foi e o que deveria ser o Cálculo? Campinas: Zetetiké, 5 (7), p. 69-94, 1997.

GREENSPAN, H. P e BENNEY, D. J. Calculus. An Introduction to Applied Mathemathics. Tokyo: McGraw-Hill Kogakusha Ltd., 1973. 
HEATH, Sir T. L. Euclid. The Thirteen Books of The Elements. New Jersey: Editora Dover, 1956.

HEGEL, G.F.W. Fenomenologia do Espírito. Tradução de Paulo Menezes. Petrópolis: Editora Vozes, 1992.

KUHN, T. S. A Estrutura das Revoluções Científicas. $3^{a}$ edição. São Paulo: Editora Perspectiva S.A., 1989.

KLINE, M. Matemáticas para los Estudiantes de Humanidades. México: Fondo de Cultura Económica, 1998.

Mathematics and the Physical World. New York: Editora Dover, 1981. Calculus: An Intuitive and Physical Approach. $2^{\underline{a}}$ edição. New York: Editora Dover, 1998.

KORZYBSKI, A. Science and Sanity. An Introduction to NonAristotelian Systems and General Semantics. 5a edição. New York: Institute of General Semantics, 2000.

LAUGWITZ, D. e SCHMIEDEN, C. Eine Erweiterung de Infinitesimalrechnung; Math. Z. 69; p. 1-39; 1958.

LÉVY, P. As Tecnologias da Inteligência: o Futuro do Pensamento na Era da Informática. Rio de Janeiro: Editora 34, 1993.

LIMA, E. L. Conceitos e controvérsias. Revista do Professor de Matemática, vol.I, no 1, p.5-8. Rio de Janeiro: SBM, 1982. Novamente $0^{\circ}$. Revista do Professor de Matemática, no 7, p.1720. Rio de Janeiro: SBM, 1985. 
MACHADO, N. J. Epistemologia e Didática. As Concepções de Conhecimento, Inteligência e a Prática Docente. São Paulo: Editora Cortez, 1995. A Matemática e a Língua Materna: Uma Impregnação Mútua. São Paulo: Editora Cortez, 1997. Matemática e Realidade. São Paulo, Editora Cortez: 1994. Noções de Cálculo. Coleção Matemática por Assunto. Vol. 9. São Paulo: Editora Scipione. 1988.

MASON, S. F. História da Ciência. Edição brasileira. Porto Alegre: Editora Globo, 1962.

MONMONIER, M. Maps. Distortion and Meaning. Washington: Association of American Geographers, 1981.

MORA, J. F. Dicionário de Filosofia. São Paulo: Edições Loyola, volumes I-IV, 2000.

MORRIS, R. Uma Breve História do Infinito. Dos Paradoxos de Zenão ao Universo Quântico. Rio de Janeiro: Jorge Zahar Editor, 1997.

NETO, T. A. de Q. F. e REZENDE, W. M. Interpretações do conceito de função. Caderno de Licenciatura / PADCT-UFF, v.1, p. 31-38, Rio de Janeiro: IMUFF, 1998.

OLIVEIRA, T. A. de. Análise Não-Standard: Uma Apologia ao seu Ensino. Dissertação de Mestrado. Rio Claro: IGCE/UNESP, 1993.

PETITOT, J. Local/Global. Enciclopédia Einaudi, vol. 4, Local/Global, p. 11-75. Lisboa: Imprensa Nacional-Casa da Moeda, 1985a. 
Infinitesimal. Enciclopédia Einaudi, vol. 4, Local/Global, p.209-

86. Lisboa: Imprensa Nacional-Casa da Moeda, 1985b.

PINTO, J. J. M. S. Métodos infinitesimais de Análise Matemática. Lisboa: Fundação Calouste Gulbenkian, 2000.

PRÉ-SOCRÁTICOS. Vida e obra. Pensadores. São Paulo: Editora Nova Cultural Ltda, 2000.

RACINE, J. B. et al. Escala e Acção. Contribuições para uma Intrpretação do Mecanismo de Escala na Prática de Geografia. Revista Brasileira de Geografia, 45, 1982.

REIS, F. da S. A Tensão entre o Rigor e Intuição no Ensino de Cálculo e Análise: A Visão de Professores-Pesquisadores e Autores de Livros Didáticos. Tese de Doutorado em Educação. Campinas: UNICAMP, 2001.

REZENDE, W. M. Uma Análise Histórica-Epistêmica da Operação de Limite. Dissertação de Mestrado. Rio de Janeiro: IEM-USU, 1994.

ROBINSON, A. Non-Standard Analysis, Proc. Roy. Acad. Amsterdam Ser. A.64; p. 432-440; 1961.

Non-Standard Analysis. Amsterdam: North-Holland, 1966.

RONAN, A. Colin. História Ilustrada da Ciência. Edição brasileira. Rio de Janeiro: Jorge Zahar Editor Ltda, volumes 1, 2, 3 e 4, 1987.

RÜTHING, D. Some Definitions of the Concept of Function from J. Bernoulli to N. Bourbaki. The Mathematical Intelligencer, vol. 6, $n^{\circ} 4,1984$. 
SANTO AGOSTINHO. Vida e obra. Pensadores. São Paulo: Editora Nova Cultural Ltda, 1999.

SANTOS, B. de S. Para um Novo Senso Comum: a Ciência, o Direito e a Política na Transição Paradigmática, V.1 A Crítica da Razão Indolente: Contra o Desperdício da Experiência. São Paulo: Editora Cortez, 2000.

SIERPINSKA, A. Humanities Students and Epistemological Obstacles Related to Limits. Educational Studies in Mathematics, 18, 1987.

SILVEIRA, J. P. Cálculo Infinitesimal. Web-page http: www.mat.ufrgs.br/ portosil/calculo.html, 1999.

SRTROYAN, K. D., e LUXEMBURG, W. A. J. Introduction to the Theory of Infinitesimals. New York: Academis Press, 1976.

TALL, D. e VINNER, S. Concept Image and Concept Definition in Mathematics with Particular Reference to Limits and Continuity. Educational Studies in Mathematics, 12, p. 151-169.1976.

THOM, R. Parábolas e Catástrofes. Lisboa: Publicações Dom Quixote, 1985.

WILLCOX, A. B. et alii. Introduction to Calculus. Vol. 1. New York, Houghton Mifflin Company, 1971. 


\section{Anexos}

\begin{tabular}{|c|c|c|c|c|c|c|c|}
\hline$\sqrt{\text { USP }}$ & 90 & $\overline{91}$ & 92 & 993 & $\overline{994}$ & 95 & \\
\hline \multirow{2}{*}{$\begin{array}{l}\text { Escola } \\
\text { Politécnica }\end{array}$} & 24,5 & 23,1 & 22,8 * & 21,9 & 13,7 & 28,8 & 22,5 \\
\hline & 54,1 & 79 & 75,5 & 50,6 & 46,9 & 35,9 & 57,0 \\
\hline \multirow[t]{2}{*}{ Arquitetura } & 3,7 & 11,7 & 76,2 & \multirow[t]{2}{*}{46,8} & \multirow[t]{2}{*}{38,9} & \multirow[t]{2}{*}{20,8} & 33,0 \\
\hline & 22,4 & 19,9 & 45,7 * & & & & 29,3 \\
\hline \multirow[t]{3}{*}{ IME } & 72,2 & 72,2 & 62,7 & \multirow[t]{2}{*}{69,3 * } & \multirow[t]{2}{*}{51,9 * } & \multirow[t]{2}{*}{53,8} & 64,0 \\
\hline & 78,7 & 70,7 & 69,4 & & & & 72,9 \\
\hline & & & & 72,8 * & 44,7 * & 66,9 & 61,5 \\
\hline
\end{tabular}

\begin{tabular}{|l|l|l|l|l|l|l|l|}
\hline UFF /96.1 & Matric. & Des. Ini. & Perm. & Ap. & Rep & I. Ñ-Ap. & I.Rep.2 \\
\hline \hline Cálculo 1 & 259 & 77 & 124 & 75 & 49 & $71 \%$ & $39,5 \%$ \\
\hline Cálc. Ap.1 & 318 & 48 & 224 & 137 & 87 & $56,9 \%$ & $38,8 \%$ \\
\hline Cálc.11 & 109 & 52 & 32 & 15 & 17 & $86,2 \%$ & $53,1 \%$ \\
\hline Cálc.5 & 160 & 41 & 89 & 48 & 41 & $70 \%$ * & $46,1 \%$ \\
\hline
\end{tabular}

\begin{tabular}{|l|l|l|l|l|l|l|l|}
\hline UFF /00.1 & Matric. & Des.Ini & Perm. & Ap. & Rep & I. Ñ-Ap & I.Rep.2 \\
\hline \hline Cálc.DI 1 & 36 & 17 & 13 & 8 & 5 & $77,8 \%$ & $38,5 \%$ \\
\hline Cálc. Ap.1 & 342 & 45 & 227 & 171 & 56 & $50 \%$ & $24,7 \%$ \\
\hline Cálc.1(Mat) & 109 & 36 & 49 & 18 & 31 & $83,5 \%$ & $63,3 \%$ \\
\hline Cálc.DI 5 & 44 & 9 & 26 & 22 & 4 & $50 \%$ * & $15,4 \%$ \\
\hline
\end{tabular}

